Historic, Archive Document

Do not assume content reflects current scientific knowledge, policies, or practices. 



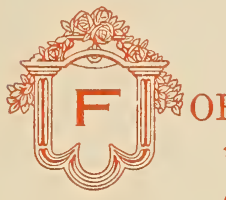

RR FIFTY-SIX YEARS we have been supplying our customers Seeds of the finest quality obtainable, and Implements the most perfect mechanical genius can devise, and we take the opportunity through this Catalogue to again thank our many friends for their generous patronage, and to assure them that we will do all in our power to merit a continuance of their business.

It is our aim to please you; let us have your order again for the coming season, and we will try to fill it to your complete satisfaction.

\section{NO ORDER TOO LARGE}

\section{NO ORDER TOO SMALL}

It is important that orders be sent to us as soon after receipt of Catalogue as convenient, that we may be able to give the quickest possible shipments, and we would suggest that anyone failing to receive prompt shipments should inform us, as it frequently happens that orders reach us without a signature, so please give your Name, Post Office, County and State in full, as plainly as possible, your name especially written very distinctly.

We urge customers to inform us promptly on the arrival of orders if anything proves otherwise than expected. Mail orders receive the same careful attention that customers do over our counters, but if errors occur, we are willing and anxious to correct them.

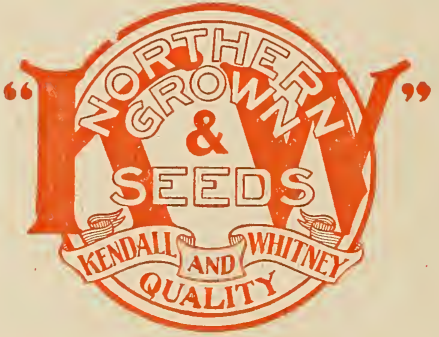

Market Gardeners, and others requiring large quantities of seeds, are invited to write us for quotations. :

Greenhouse plants furnished at short notice.

Seeds forwarded by Mail, Express or Freight, as the purchaser may wish.

In shipping we make no charge for delivery to railroads or express companies.

Bags charged at cost.

Prices quoted in our Catalogue are subject to change without notice.

All sums to the amount of one dollar and upwards may be sent at our risk if forwarded according to the following directions, viz.: by Post Office Money Orders, Bank Drafts or Cash sent in a Registered Letter.

\section{ALL CORRESPONDENCE ANSWERED PROMPTLY}

While we exercise the greatest care to have all seeds pure and reliable, we do not give any warranty, Expressed or Implied. If the purchaser does not accept the Seeds on these conditions they must be returned at once.-K. \& $W$.

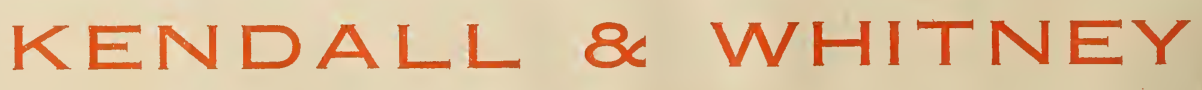



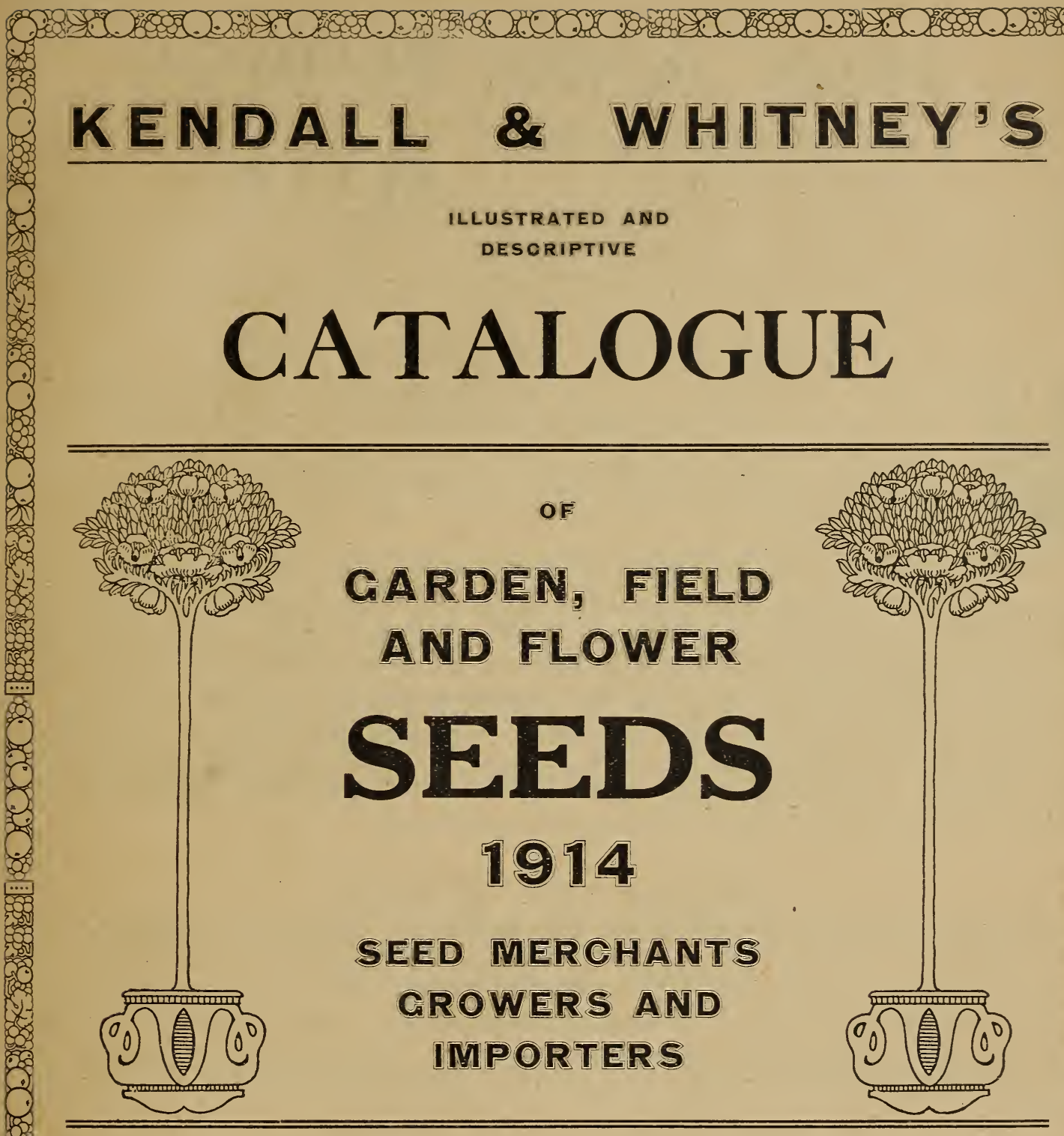

AND DEALERS IN

Agricultural and Horticultural Implements, Insecticides, Fertilizers, Poultry and Dairy Supplies, Wooden Ware, Galvanized Iron Ware, Brooms, Brushes, Cordage, Etc.

\section{KENDALL \& WHITNEY}

FEDERAL AND TEMPLE STREETS, PORTLAND, MAINE 


\section{BRIEF HINTS FLOWER

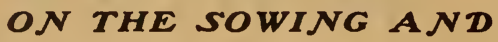 \\ CULTIVATION OF \\ SEEDS

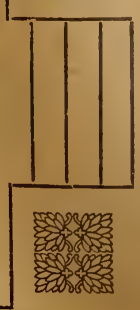

\section{THE SOIL AND ITS PREPARATION}

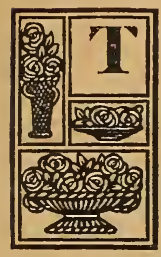

$\mathrm{HE}$ best soil for annuals and for most flowering plants is a light, rich loam. In such they grow readily and attain to great perfection of bloom with but little care. Deep and thorough trenching in the autumn, if possible, and the application of very old or decayed manure or leaf mold, will give the amateur a well prepared and suitable soil.

Where the soil is too light, a thin layer of clay, if to be had, should be spread over the surface in the autumn, and dug in-after being pulverized by the winter frosts-in the spring. This, with the use of old manure, will keep the garden in good condition. No unvarying rules can be given; much must be left to the judgment of the amateur. He must understand that the soil of a good garden should be deep, well pulverized, friable and rich.

Where the flower garden is a specialty, then more pains ought to be taken, and those who are about to do this, if they have not the requisite information, will consult something more than a catalogue. Our hints are intended for the mass of the people who love flowers, and do not wish to incur great expense in the gratification of their taste.

\section{PERIOD FOR SOWING}

This must depend much upon the season as well as the locality. As a general rule for New England, the proper time to commence sowing is about the last of April, though a few sorts may be planted as soon as the ground can be got ready; and for a succession the sowing should be continued until June. To avoid all danger of injury, the sowing may be deferred, but when a little labor is of no consideration the sowing may be made earlier, and, in case of failure or injury from frost or wet, another sowing may be made when the weather is more favorable.

It is the great error to cover too deeply, and the cause of more than half of the complaints against seedmen of selling old and worthless seeds comes from inexperience and want of judgment in sowing. No rule can be given in this respect, but, as a general guide, all large seeds may be sown half an inch deep; smaller, less, and for the smallest, a covering of one-sixteenth of an inch will suffice. If sown too deeply they are longer in germinating, and are liable to decay. Avoid the general error of sowing the seeds too thickly, as it causes an elongated and feeble growth, which no subsequent thinning will entirely remedy.

As soon as the seedlings have made three or four leaves, and are an inch high, they should be thinned out. If they are kinds which will bear removal, they may be replanted in vacant spaces. Stir the soil around the plants from time to time, and, if they appear crowded, a second thinning will be of great benefit to those that remain. If the growth is not strong from the nature of the soil, apply occasionally a small amount of phosphate or bone fertilizer.

Transplanting should, if possible, always be done in cloudy weather. If the soil is dry the plants will require a light watering, to settle the earth around the roots, and if warm, sunny days succeed the operation, they will root all the better to have shade for a day or two. 


\section{GARDEN REQUISITES}

There are several aids to the economical management of the garden, which are almost indispensable; one of these is the hot-bed frame for the forwarding of plants for early plantinga frame made of various sizes, according to the size of the garden, from four sashes upward. The length of sash is generally six feet, by three wide, the size of glass six by eight inches. The frame should have a southern or a southeastern exposure; should be made up of fresh horse manture, and a few leaves mixed with it ; this must be laid in a heap preparatory to being used, and when in a proper state of fermentation, prepared for the reception of the frame. A few inches of rich, loamy soil must be spread over the manure; then cover the frame with the sashes, and after standing a few days, to allow the rank heat and steam to pass off, the seed can be sown. Where the ground is well drained, a better plan is to dig out a space the size of the frame, one or two feet deep, according to the season and the heat required, in which the manure is placed, care being taken to pack firmly and evenly.

\section{SEEDS IN PACKETS OR OUNCES}

The following may be selected from our Catalogue, at the prices named, and will be forwarded, postage free, to any part of the United States:

Purchasers remitting $\$ 1.00$ may select seeds (in PACKETS OR OUNCES only) at Catalogue prices, amounting to $\$ 1.25$.

Purchasers remitting $\$ 2.00$ may select seeds (in PACKETS OR OUNCES only) at Catalogue prices, amounting to $\$ 2.50$.

Purchasers remitting $\$ 3.00$ may select seeds (in PACKETS OR OUNCES only) at Catalogue prices, amounting to $\$ 4.00$.

Purchasers remitting $\$ 4.00$ may select seeds (in PACKETS OR OUNCES only) at Catalogue prices, amounting to $\$ 5.50$.

Purchasers remitting $\$ 5.00$ may select seeds (in PACKETS OR OUNCES only) at Catalogue prices, amounting to $\$ 7.00$.

Seeds when ordered in LARGER AMOUNTS than the above (as quarts or pounds) WILL NOT BE INCLUDED, NOR PLANTS OR BULBS.

\section{Condensed Information Concerning the Parcel Post}

It does not have any effect on seeds, bulbs or plants. These are sent the same as in the past, at the rate of 8 cents per pound regardless of distance. Parcel Post does include, however, all merchandise usually sent by mail or express; this is sent as 4 th class.

RATES OF POSTAGE FOR 4TH CLASS MERCHANDISE ZONE DISTANCES.

Portland and rural delivery

First Pound. $\$ 0.05$

Within 50 miles

50 to 150 miles

150 to 300 miles

300 to 600 miles

600 to 1,000 miles

1,000 to 1,400 miles

1,400 to 1,800 miles

* 1,800 miles and over

1st Zone
2nd 66
3rd 66
4th 6
5th 66
6th 66
7th 66
8th 66

\section{RESTRICTIONS}

Size limit, 72 inches in length and girth combined.

Four onces or under, 1 cent per ounce.

Over four ounces considered one pound.

Fractional pounds considered pounds.

Weight limit up to and including second zone, $20 \mathrm{lbs}$; ; beyond that, 11 pounds.

\section{SPECIAL}

Seeds and bulbs do not come under 4th class matter, but will be permitted in the parcel post mails under regulations as to size and weight applicable to other parcel post packages, but at the rate of postage of one cent for two ounces or fraction thereof, regardless of distance.

Classification excludes matter of a character perishable within a period reasonably required to transport and deliver, and parcels of form and kind likely to injure postal employees or equipment or other mail matter. 


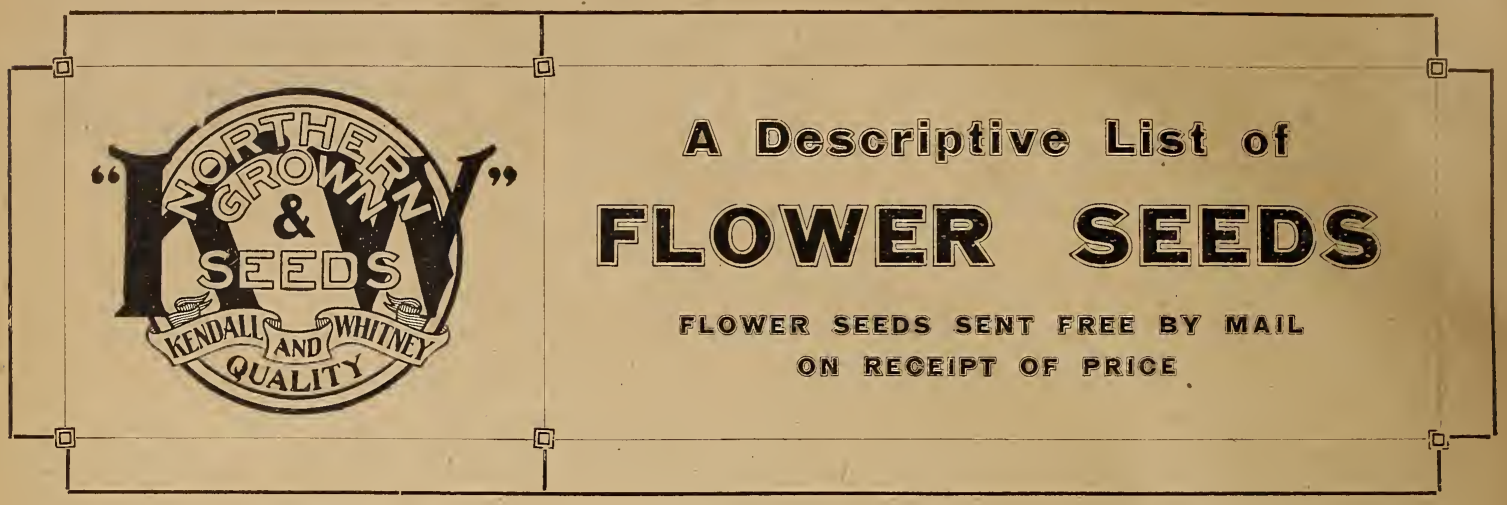

ABRONIA UMBELLATA.

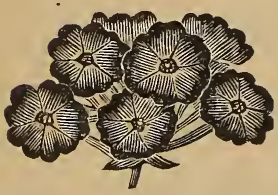

Handsome, trailing annuals with clusters of sweet-scented flowers resembling the verbena. Fine for baskets or for the garden. Blooms from August until October $\ldots \ldots \ldots \ldots \ldots \ldots \ldots \ldots$

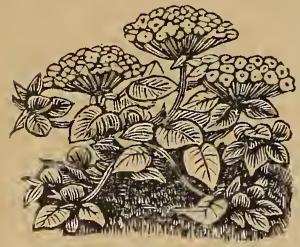

\section{ACROLINIUM.}

An elegant, half-hardy annual, producing beautiful everlasting flowers. Grows about one foot high.

Album. Pure white .......... 5 Roseum. Bright rose color..... . 5 ABRoNia UmbelLATA. MIXed ......................

\section{ADONIS.} A hardy annual, with very pretty foliage, producing bright
red flowers. Grows about one foot high and blooms for a long time...............................................

\section{AGERATUM.}

$\mathrm{H}$ a $1 \mathrm{f}$-hardy, free-flowering annuals, blooming throughout the season. Fine for beds or borders.

Fine Mixed. $1 \mathrm{ft} . \ldots \ldots \ldots \ldots$

Imperial Dwarf Blue. 8 in. Perfection Dark Blue. $1 \mathrm{ft} .5$

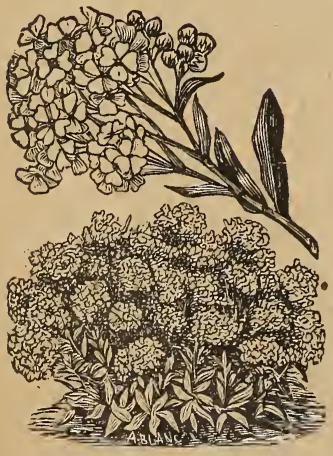

Alyssum.

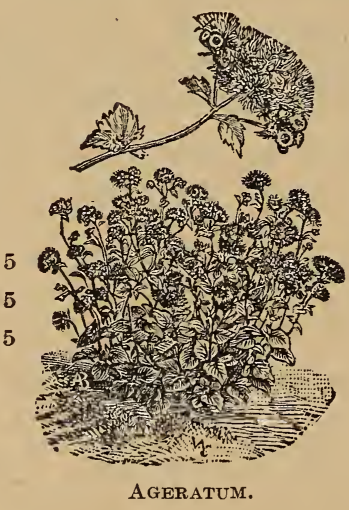

ALYSSUM.

A hardy annual, about eight inches high, with clusters of small, fragrant flowers. Fine for bedding and bouquets.

SwEet. White; $1 \mathrm{ft} . \ldots \ldots \ldots$.... 5

Saxatile Compacta. Yellow,

$3 / 4 \mathrm{ft}$. ; hardy perennial ......

Tом Тнимв. Very dwarf; white..................
ANTIRRHINIUM. (SNap Dragon.)

\section{GIANT VARIETIES.}

Per Pkt.

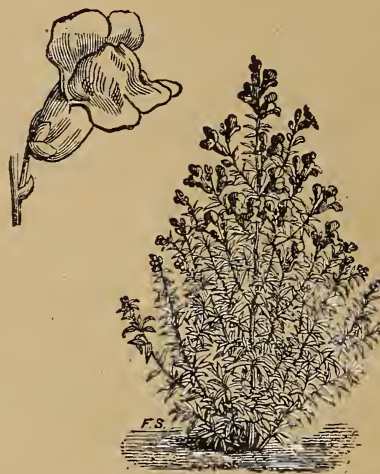

ANTIRRHINIUM.
A very showy and halfhardy perennial, about three feet high, flowering we ll the first season. Sow the seeds early, in pots or under glass. An improvement over the o 1 d variety, producing longer spikes and larger flowers.

Rose .............. 5

SCARLET ............. 5 SCARLET. White throat. 5 White............. 5 YeLlOW ............. 5 Yellow AND ORANGE... 5 Mixed ............... 5

HALF DIVARF. Fine for bedding, about eighteen inches high.

Mixed ................

\section{AMARANTHUS.}

Half-hardy annuals, about two feet high, with finely variegated foliage. They are most brilliant on poor soil and in dry seasons.

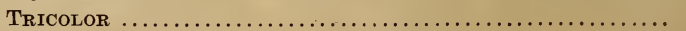

\section{AMMOBIUM ALATUM.}

A useful everlasting for making dried winter bouquets and showy border plant, growing freely in any garden soil. Hardy annual.

WHITE. $2 \mathrm{ft}$. .

\section{AMPELOPSIS-Veitchii. (Boston Ivy•)}

Popular, rapid-growing, hardy vine. Adheres firmly to stone or brick, foliage turning very brilliant in the autumn.

\section{ANAGALRIS.}

Beảutiful, trailing, hardy annuals, about six inches high and very desirable for small beds, edgings, baskets, etc.

Mixnd

\section{ASPERURA.}

A most profuse-blooming, hardy annual, attaining an average growth of one foot, the flowers of which are a beautiful light blue, are very sweet scented, and last a long while

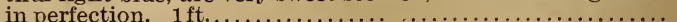

\section{ASTER.}

Very beautiful and popular half-hardy annuals, growing from ten to eighteen inches high. For profusion of flowers and richness of display, the asters are unrivalled. Sow the seed early in the spring, under glass or in pots in the house, and transplant into rich soil, about one foot apart. 


\section{ASTER-Continued.}

DWARF VARIETIES.

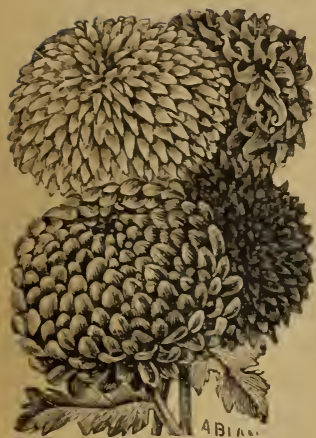

QUilled Aster.

IV I IR PYIRAMIDAL If when well grown, form a whicn well grown, form a complete bouquct of flowers
of splendid nixed colors; 1 ft. . ....... 10

I) I IR CHIRYSA NTHEMUM FLOWERED. A free bloomer, with large free bloomer, wi th 1 a rge 10

T R I U M P H. Decp scarlet. A rich, brilliant color. Eacli plant bears thirty to forty flowers of great beauty; 8 in. 10

SEMI-DUA RE VARIETIES. COMET. A variety of great beauty. Grows in pyranidal form thirteen to fifteen inclies ligh, covered with large double flowers with long curled petals. C'hoicest long curled petals. Clioicest 10

CARTER'S WHITE PLUME. One of the most magnificent white asters yet produced; height about fifteen

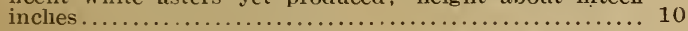

HERCULES. Petals very long, flowers attaining the enormous diameter of six inches. Excellent
for pot culture. Mixed colors.................. 25 for pot culture. Mixed colors..................... witli florists.

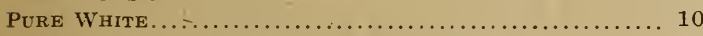

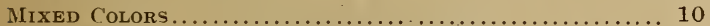

GERMAN QUILLED. Perfectly double quilled flowers of beautiful mixed colors ............................ 5

QUEEN OF THE MARKET. Finest mixed; very early 10 VICTORIA. Very large, of perfectly double form.

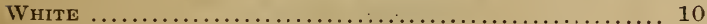

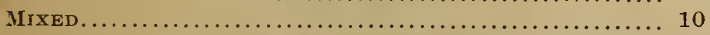

COCA R D E A U

OR C ROW N.

OR C R O W N.
The flowers of

this variety have

large white cen-

ters b ord e r ed

with scarlet, car-

$\mathrm{mine}$, violet or

blue; attractive

and beautiful; 2

ft. .......... 10

JEWEL. A beautiful class obtained from the well-known large flowered Peon Perfection. The Perfection. The double, and the petals so symmetrically incurved as to resemble a perfect ball. Iixed colors ${ }^{\circ}$... 10

ROSF: FLO WVERED. A fine variety; flowmixed; 2 ft...... 10

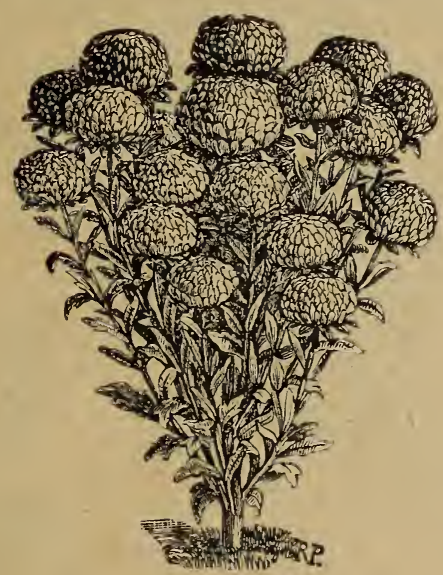

JEWEL ASTER.

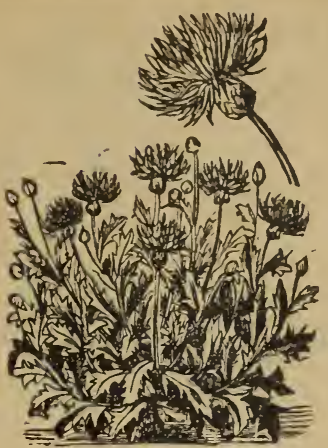

BACHELOR'S BUTTON.

BALSAM.

Most magnificent, proular, lalf-liardy anuals, from one and one-half to two feet in lieight. Sow the seeds early in frames. and transplant to a well enriched border one foot apart.

Fine Double. Mixed.... 5

ROSE-FLOWERED ......... 5

Camelia-Flowered. Finest mixed.

\section{BACHELOR'S}

BUTTON.

Per Pkt.

A showy, hardy annual, about two feet high, succeeding well in any soil. Set six inches apart.

Finest Mixed...

EMPEROR William. Deep blue

Double BLUE.

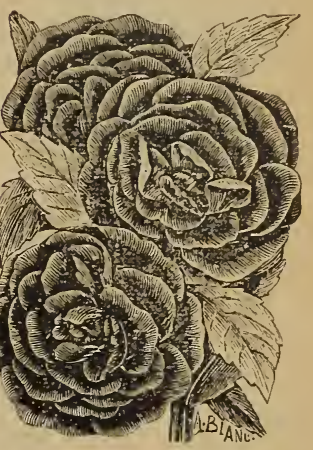

Double BaLsAM.

BARTONIA AUREA.

A showy, half-hardy annual, growing about two feet high, bearing very brilliant yellow flowers. Thin plants to six inches apart...............

BEANS. (Flowering.)

See list of beans with vegetable seeds.

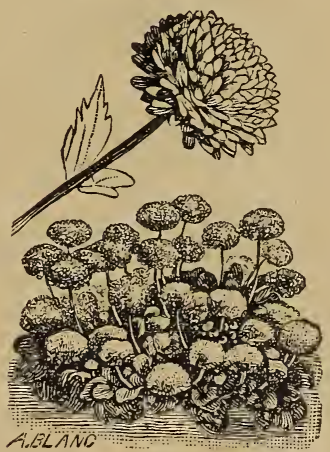

Double Daisy.

\section{BRACHYCOME} IBERIDIFOLIA. (Swan River Daisy.)

Very pretty, free-flowering, dwarf-growing annual; well adapted to edgings, rustic baskets, or pot culture.

Mixed Blue AND White.

$1 / 2 \mathrm{ft} . \ldots \ldots \ldots \ldots \ldots \ldots \ldots$.
BELLIS PERENNIS.

\section{(Double Daisy.)}

A favorite perennial for the border or for pot culture. Set plants six inches apart.

RED. Double; very fine.. 10 SNowball. White; large 10 Finest Mixed. Double:. 10

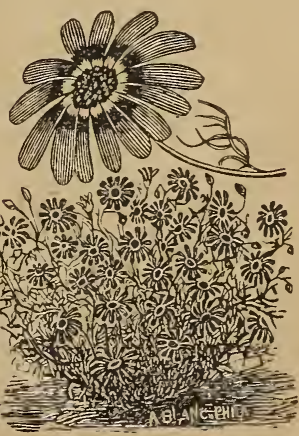

SWAN RIVER DAISY.

CHINESE. Common variety $; \operatorname{mixed} \ldots \ldots \ldots \ldots \ldots \ldots .5$ 


\section{BROWALLIA.}

Per Pkt.

Handsome, profuse-blooming annual, covered with beautiful flowers during the summer and autumn months.

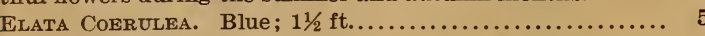

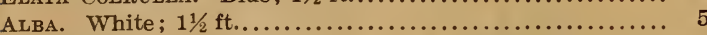

Fine MIXED $\ldots \ldots \ldots \ldots \ldots \ldots \ldots \ldots \ldots \ldots \ldots \ldots \ldots \ldots \ldots \ldots, \quad 5$

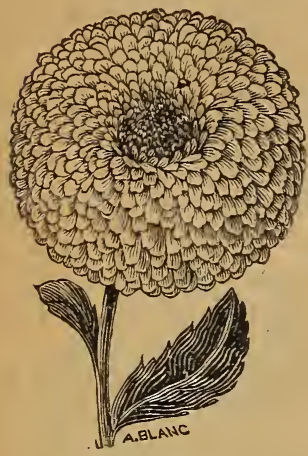

\section{CALENDULA.}

Free-flowering, hardy annual, growing in any good garden soil, producing a fine effect in beds or mixed borders. 1 to $1 \frac{1}{2} \mathrm{ft}$.

M E T E o R. Double; yellow striped orange ............... Prince of Orange. Double; dark orange............... 5 Finest Double Mixed...... 5

Calendula.

\section{CALCEOLARIA.}

Indispensable for the greenhouse or the flower garden. They succeed in any light, rich soil. Half-hardy perennials.

Choice Mixed Varieties.... 25

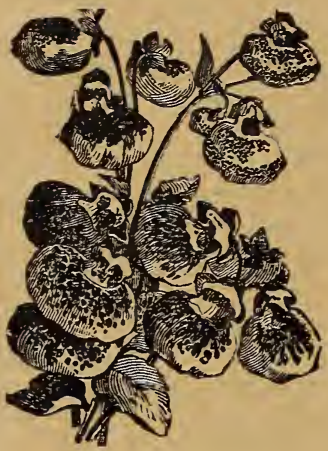

Calceolaria.

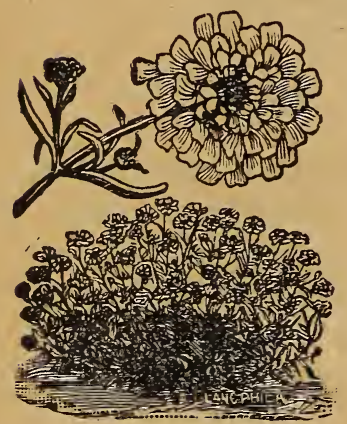

CANDYTUFT.

\section{CANDYTUFT.}

A well-known, hardy annual, very useful for bedding and bouquets, and also for pot culture.

EMPREss. Large trusses of pure white flowers; very handsome. Us ed for forcing. Ounce 40c..

Littile Prince. Large heads of pure"white flowers. Plants about six inches high. Ounce 40c: 5 Crimson. Ounce 25c...... 5 PURPle. Ounce 25c...... 5 WHITE. Ounce $25 \mathrm{c} . . . \ldots$. . 5

TALL. Finest mixed. Ounce $25 \mathrm{c} . \ldots \ldots \ldots \ldots \ldots \ldots \ldots \ldots \ldots \ldots, 5$ Rocket. Pure white, long spikes. Ounce $25 \mathrm{c} . \ldots \ldots \ldots \ldots \ldots$..... 5

\section{CANARY BIRD FLOWER.}

A rapid-growing, delicate climber, reaching a height of from ten to fifteen feet. B rig h t yellow, fringed; exceedingly beautiful foliage. Half-hardy annual.

\section{CANNA.}

Per Pkt.

Handsome foliage plants, growing from three to eight feet high. Highly ornamental on the lawn.-- Soak the seed in warm water for about twelve hours. Seeds should be sown early in a strong, moist heat. Half-hardy"perennials.

Finest Mixed

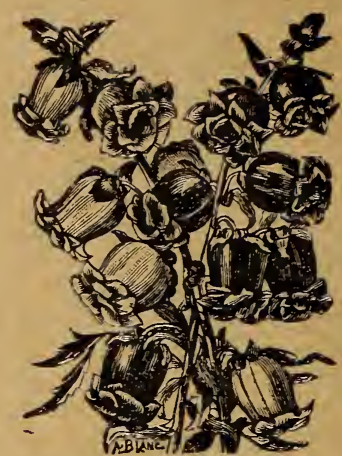

Canterbury Bells.

\section{CANTERBURY BELLS.}

A well-known biennial, growing about one foot growing about one foot
high, producing beautiful high, producing beaut
bell-shaped flowers.

Double Blue.......... 10

Double White ........... 10

Double MiXed $\ldots \ldots \ldots \ldots .10$

\section{CATCHFLY.}

A hardy annual, about one foot high; produces brilliant flowers in great mer. profusion in early sum-

RED .............................................

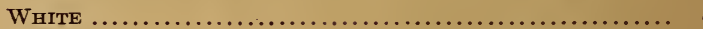

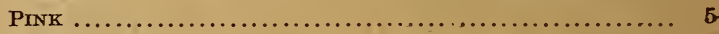

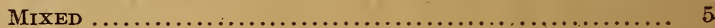

\section{CENTAUREA.}

Silver-leaved plants, fine for ribbon borders, baskets, etc. Half-hardy perennial.

Candidissima. Thick foliage; $3 / 4 \mathrm{ft} . \ldots \ldots \ldots \ldots \ldots \ldots \ldots . \ldots$

GYMnocarPa. Graceful white foliage $; 3 / 4 \mathrm{ft} \ldots \ldots \ldots \ldots \ldots . .10$

\section{CINERARIA.}

Well-known favorite, free-flowering plants for the greenhouse, which may be had in splendid bloom through the greater portion of the year, and from the richness and diversity of the colors are among the most valuable of our early spring flowers; succeed best in light, rich, free and open soil. Greenhouse perennial.

Carter's Brilliant Prize. Choicest varieties ........... 25

Fine Mixed Varieties .............................. 25

\section{CHRYSANTHEMUM.}

Handsome, hardy annual, about two feet high, blooming from July to October.

Double White $\ldots \ldots \ldots \ldots \ldots \ldots \ldots \ldots \ldots \ldots \ldots \ldots \ldots \ldots \ldots, 5$

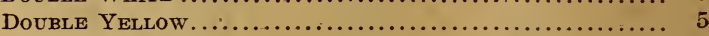

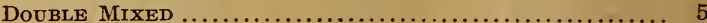

\section{CLARKIA.}

A very beautiful hardy annual, about eighteen -inches high, blooming from June to September. Set six inches apart.

Fine Mixed. Ounce $30 \mathrm{c} . . . .$.

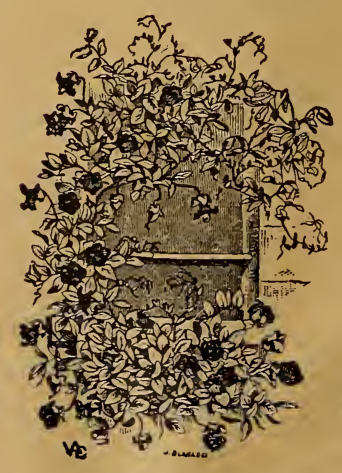

5

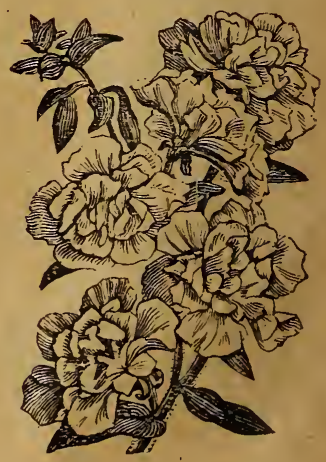

Crarkia.

COBAEA SCANDENS.

The most useful of climbers, on account of its rapid growth, fine foliage, and large, bellshaped flowers, purple in color. In sowing place the seeds or. In sowing place the seeds Half-hardy perennial ......... 10 


\section{COCKSCOMB.}

Very singular and attractive, half-hardy annuals, about two feet high. To perfect the flowers they should be sown in the hot-beds and transplanted into rich soil one foot apart. Mixed. Double...

\section{COLEUS.}

One of the most popular foliage plants. Is very decoraOne of the most popt and easily grown from seed, which trequently produces new and distinct varieties. Half-hardy perennial.

New Hybrids. Mixed.

\section{COLUMBINE.}

A well-known, showy, hardy perennial, about two feet high, blooming in May and June.

Mixed .............

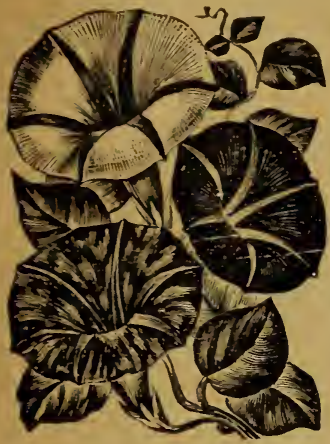

CONVOLVULUS MAJOR. (Morning Glory•)

A well-known beautiful, climbing annual, suitable for covering arbors, trel$l i$ s es, etc. Blooms from July until autumn.

Fine Mixed. Ounce 10c. 5 JAPANESE. Gigantic flowers, exquisite new colors, magnificent foliage. Finest mixed.............

Morning GLORY.

\section{CONVOLVULUS MINOR.}

Beautiful and showy, half-hardy annuals, producing an abundance of rich colored flowers. Set plants one foot a part. Blooms from July until autumn.

Fine Mixed................ 5

MaURitanicus. Beautiful for

hanging baskets and vases.

Flowers blue...... 5

\section{COREOPSIS.}

Showy, hardy annuals about two feet high, succeeding well in any soil. Produces a fine effect when grown in a mass. Blooms from June until September.

Fine Mixed

Drummond's. Large yellow.

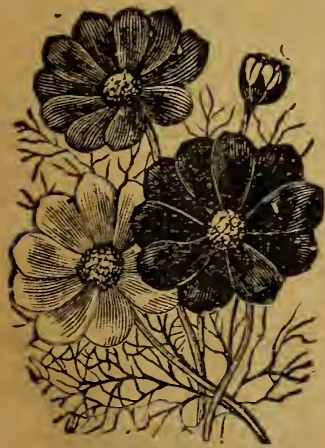

Cosmos.

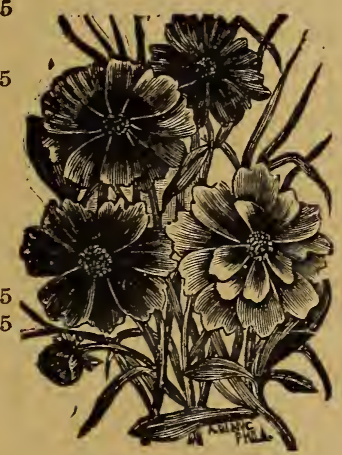

COREOPSIS.

\section{cosmos.}

Splendid flower for cut ting purposes, plants growing five to seven feet high, which are beautifu masses of the most elegant foliage, with hundreds of large, showy blossoms. Both foliage and flowers are excellent for cutting. are excellent for cutting. and transplant to the garden in June.

Early Flowering. Mixed colors.................... 10 LADY LENNox. Tall growing, late variety, with gigantic shell-pink flowers, borne on long stems... With gigantic 10

CYPRUS VINE.

One of the most popular of all summer climbers; flowers small, thickly set in a most beautiful dark-green foliage, forming a striking contrast. Tender annuals.

SCARLET.

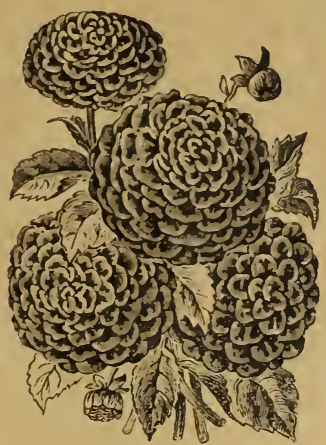

DAHLIA. pril trany in March or April, transplant carefully $t$ el y me soil moderately moist. When all danger from frost is over set out in the bed or borin the garden.

Finest Mixed. Single... 10

Finest Mixed. Double.. 10

\section{DATURA.}

White bordered with lilac. Continues in bloom from July until September. A beautiful, half-hardy annual, growing from two to three feet in height and producing very large flowers.

WRIGHTII

\section{DELPHINIUM FORMOSUM.}

A hardy perennial, about two feet high, producing an abundance of exquisite blue and white flowers. Blooms the first season...........................................

\section{DRACOENA.}

Beautiful, ornamental-leaved plant, extensively used in vases and for house decoration. Tender perennial.

INDIVISA. Narrow, dark green foliage.

\section{ESCHSCHOLTZIA. (California Poppy.)}

A very showy, hardy annual, about one foot high, blooming from June until September. Produces a brilliant effect; admirable for borders when grown in a mass.

ALBA. White........... 5

CALIFOR NICA. Yellow; orange center ...........

MANDARIN. Orange and scarlet..................

Finest Single Mixed.... 5 Carter's Carmine King. A splendid new variety, of a beautiful carminerose color............... 10

M A N D A R I N . Double; orange and scarlet...... 10

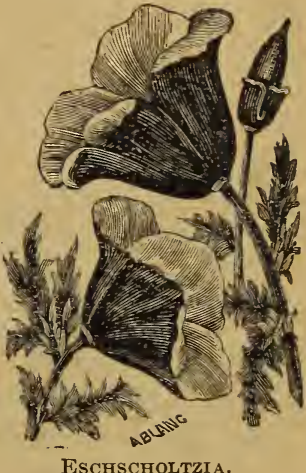

EschSCHOLTZIA.

\section{FEVERFEW. (Pyrethrum.)}

Handsome, free-flowering, highly ornamental plants, producing a fine effect in the mixed flower and shrubbery borders. Succeeds in any rich soil.

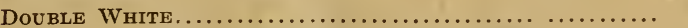

GOLDEN FEATHER. Prized fốr its yellow foliage ...........

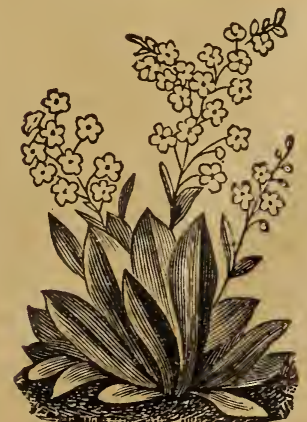

FORGET-ME-NOT.

\section{FORGET-ME-NOT.}

A very pretty little halfa rdy perennial, about ten inches high. Will thrive best in a cool, moist situation, and is well adapted for bedding, blooming the first year from seed.

Victoria. Dwarf, sky blue, of bushy habit. Fine for bordering ................ 5 MIXED................... 5 


\section{FOXGLOVE.}

A hardy bieunial, growing three to four feet high, and very ornamental in a garden or amongst shrubbery, as it produces tall spikes of bell-shaped flowers.

Fine Mixed

\section{FRENCH HONEYSUCKLE.}

A fine border plant. Hardy perennial.

WHITE

RED

MIXED

\section{GAILLARDIA.}

Showy and universally-admired annual. Very beautiful; fine for bedding and bouquets.

Fine MrXed

\section{GOURDS.}

A valuable and highly interesting class of climbing plants. Tender annuals.

AfRICAN PIPE. The stem end used in making pipes......... BоттLE. Well known and very useful ...................... Hercules Club. Club shaped

New Miniature. Orange and green striped; one of the best .................................................. ORANGE. Very ornamental, fruit resembling an orange.... POWDER HORN Fine Mrxed.

\section{GLOBE AMARANTH.}

A tender annual, about two feet high, very ornamental in the garden. The flowers will retain their beauty for a long time if gathered and dried as soon as they are open. Start early in hot-beds, and transplant one foot apart in the borearly in hot-beds, and transplant one

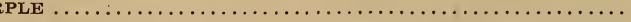

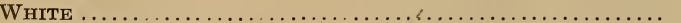

CRIMSON .

VARIEGATED

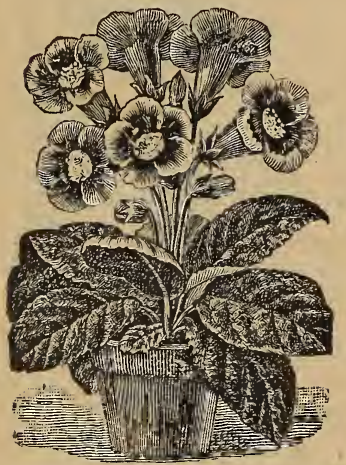

\section{GLOXINIA.}

Greenhouse plants, producing richly colored and brilliant flowers. Perennial.

CA R T E R' S INVINCIBLE PRIze. Contains all the best self-colors, crimson, sapphire, purple, ruby, rose, blush violet and white, together with the most beautiful spotted or marbled kinds.......... 25

GLoxinia.

\section{GRASSES. (ơnamental.)}

The ornamental grasses produce a beautiful and pleasing contrast when interspersed with flowering plants. Most of the varieties may be dried for winter bouquets, or used for the varieties may be dried for winter bouquets,
filling vases, either in a dried or a green state.

Agrostis Nebulosa.

One of the most graceful grasses in cultivation. Hardy

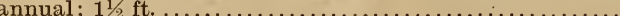

Avena Sterilis. (Animated Oats.)

Very graceful, with large, drooping spikes on slender stems. Hardy annual; 2 ft................................ Briza Maxima. (Quaking Grass.)

A most beautiful variety; one of the best. Hardy annual;

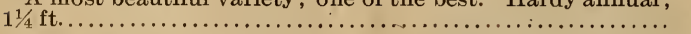
Briza Gracilis. (Qaking Grass.)

Very delicate and graceful. Hardy annual; $1 \mathrm{ft} . . . \ldots \ldots .5$

Coix Lachrymae. (Job's Tear's.)

A well-known variety. Half-hardy annual; $2 \mathrm{ft} . . . . . . .$.

\section{GRASSES-Continued.}

Per Pkt.

Eragrostis Elegans. (Love Grass.)

A favorite variety, graceful habit and very much admired.

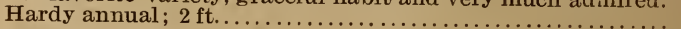

Gynerium Argentium. (Pampas Grass.)

The finest ornamental grass in cultivation. Half-hardy perennial; $10 \mathrm{ft}$. .............................

Hordeum Jubatum. (Squiriel Tail Girass.)

Very handsome light purple plumes. Hardy annual; $3 \mathrm{ft} . \overline{-}$ Lagurus Ovatus. (Hrire's Tail Grass.)

Small white plumes. Hardy annual; $2 \mathrm{ft}$..

Sectaria Microcheta.

Large, drooping plumes of the most graceful description.

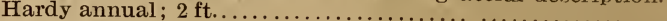
Stipa Pennata. (Feather Grass.)

One of the finest of the ornamental grasses. Hardy peren-

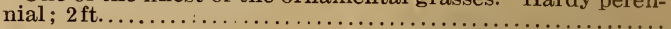

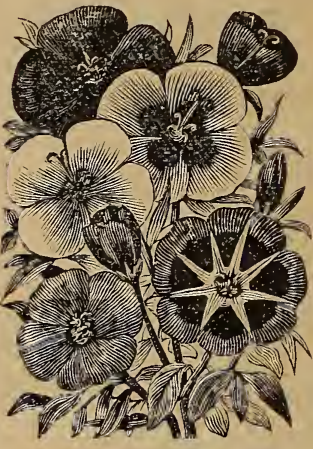

Godetia.

\section{GREVILLEA ROBUSTA.}

A very graceful decorative plant, with evergreen, fernlike foliage. Tender perennial.........

\section{GYPSOPHILIA.}

A free-flowering annual that should be in every garden for it thrives abundantly, furnishing the loveliest material for bouquets.

Paniculata. (Baby's Breath.) White flowers, fine for bou-

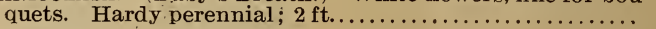
Elegans. Hardy annual; pure white.................

\section{HELICHRYSUM. (Eternal Flower.)}

A hardy annual, very ornamental in the garden, and very desirable for winter bouquets, as they will retain their form and color for years if gathered and dried when first open. Double YeLLOW..................................... 5 Dou $B L E$ White $\ldots \ldots \ldots \ldots \ldots \ldots \ldots \ldots \ldots \ldots \ldots \ldots \ldots \ldots, 5$ Double Scarlet $\ldots \ldots \ldots \ldots \ldots \ldots \ldots \ldots \ldots \ldots \ldots \ldots \ldots \ldots \ldots, \mathbf{5}$

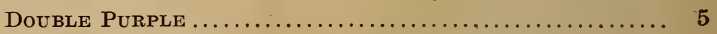
Double Fine MrXed $\ldots \ldots \ldots \ldots \ldots \ldots \ldots \ldots \ldots \ldots \ldots, 5$

\section{HELIOTROPE.}

A well-known, halfhardy perennial, particularly prized on account of its delightful fragrance. It is well adapted for bedding or pot culture. Sow the seeds early in spring, in pots or in the hothouse, in pots or in the hothouse, garden when the weather garden when the

Lou is e Deluax. Rosetinted flowers ........... 10

Mad. DE Blonay. White; for bouquets .......... 10

Finest Mrxed. Dark varieties ................. 10 HeLIOTROPE.

5 5

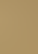




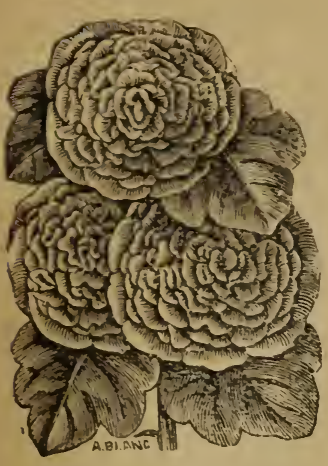

\section{HOLLYHOCK.}

Per Pkt.

Showy perennials, four to six feet high ; very effective amongst slurubbery.

Double White. Flower's pure white, perfectly double................. 10

E X T R A Chotce Double HINEST MIXED .......... 10 Frse Mixed. Double .... 5 SINGLE. Finest mixed.... 5

\section{HONESTY.}

A hardy biennial, two feet high, flowering the second year in May and June. The flowers are succeeded by singular semi-transparent seed vessels that are quite ornamental and

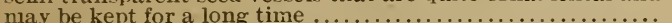

HUMULUS JAPONICUS. (Hop.)

An extremely rapid-growing cliniber, with handsome, variegated foliage. Hardy anuual; $20 \mathrm{ft} . . . . . . . . . . . . . . \ldots . .$.

\section{HYACINTH BEAN.}

Tender, climbing annual, producing clusters of blue and white flowers: $10 \mathrm{ft}$.

\section{ICE PLANT.}

A singular-looking, tender annual, with thick, fleshy leaves that have the appearance of being covered with crystals of ice. Start early in pots and transplant into light, sandy soil, in a warm situation .......................

\section{JACOBEA.}

A very gay-colored, showy class of hardy annuals, very effective for bedding. Grows about one foot high.

Dovble Finest Mixed

KOCHIA TRICHOPHYLLA. (GIOwing BaII.)

This ornamental annual plant grows quickly from seed sown in the open ground, when the trees are coming out in leaf, and the plants are always of a rounded or globe-like form. The stems are clotlied with slender, light green leaves . Early in the fall the ends of the shoots are set thickly with small, bright scarlet flowers, the bushy plants resembling balls of fire. The plants are equally showy resembling balls of fire. The plants are equally showy
planted singly to show the round ball-like form on all sides or grown in continuous rows .............................

\section{LANTANA.}

Highly valnable plants of vigorous growth and branching habit, producing brilliantly-colored flowers constantly changing in hue. Very effective, either for pot culture or for bedding.

Fine Mixed

\section{LARKSPUR.}

Very beautiful, showy annuals, producing dense spikes of flowers, which are very decorative, either in the garden or when cut for vases. Set ten inches apart.

Dwarf Double Rocket. Finest mixed................ 5

Double Branching. Fine mixed.

\section{LA VENDER.}

A shrubby plant, half-hardy. Delightful fragrance.

\section{LINUM. (Flowering Flax.)}

Per Pkt.

Grandiflorum Rubrum. Brilliant, dark scarlet. Hardy aninual

\section{LOBELIA.}

Most excellent and useful plants, free-flowering and of easy culture. Fine for borders, baskets, vases and window boxes.

Gracilis. Fine for hanging baskets, vases, etc.; light blue; trailing.................................. ('Rystal Palace. Compact; dark blue; excellent for edging

White GEM. The best white variety for edging........... 5 CArDinalis. Long spikes, bright scarlet flowers. Hardy perennial.

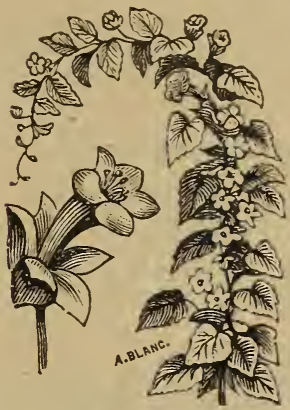

\section{LOPHOSPERMUM.}

One of the most beautiful climbing annuals. Graceful flowers of large size, resembling foxgloves in shape, and of a rich rose color. The foliage is of velvety texture. Scandens. Rose

LOPHOSPERMUM.

\section{LOVE-LIES-BLEEDING.}

A hardy annual, three to four feet high, with pendant spikes of blood-red flowers............................

\section{LOVE-IN-A-MIST.}

A curious, hardy annual about one foot high, witl finely cut leaves and singular flowers.

Mixed.

\section{LUPINS.}

Showy plants, two to three feet high, producing tall spikes of attractive flowers.

Fine Mixed. Annual.

\section{MALOPE.}

Handsome, half-hardy annual, about two feet high. Set eighteen inches apart. Well adapted to mixed borders.

Fine Mixed

\section{MARVEL OF PERU. (FOUT O'clock.)}

The old and well-known four o'clock. A beautiful plant, with flowers of various colors, making a fine summer hedge when set one foot apart. Grows two feet high.

Fine Mixed ......................................

\section{MARIGOLD.}

Extremely showy, halfhardy annual, one to two feet high, well adapted to garden culture, blooming profusely through the season. Set one foot apart.

African. Double mixed..... 5

French. Double mixed; all colors ..................... Nana PULChra.
double, striped
................ Orange. Double......

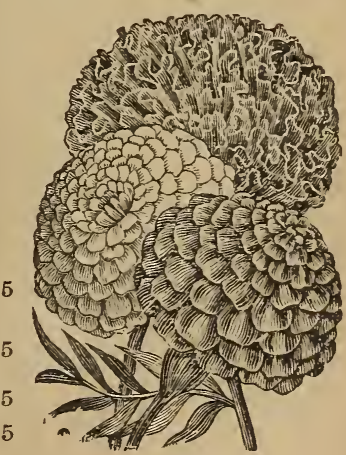

MIARIGOLD. 


\section{MAURANDIA.}

An elegant, half-hardy, climbing perennial, blooming the first season if sown early, and is well adapted to the conservatory or trellis work in the garden. Start early in pots, transplant when the weather becomes warm. Continues in bloom through the season.

BARCLAYANA. Rich violet flowers ................... 10

ROSEA ......................................... 10

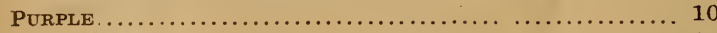

Fine Mitred $\ldots \ldots \ldots \ldots \ldots \ldots \ldots \ldots \ldots \ldots \ldots \ldots \ldots \ldots \ldots \ldots, 10$

MORNING GLORY. (See Convolvulus.)

MOURNING BRIDE.

A class of very pretty, hardy annuals, from one to two feet high, suitable for bedding or bouquets.

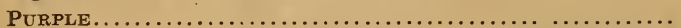

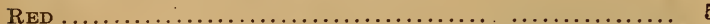

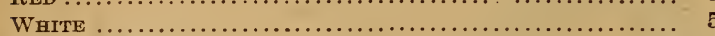

FINEST MIXED

\section{MIGNONETTE.}

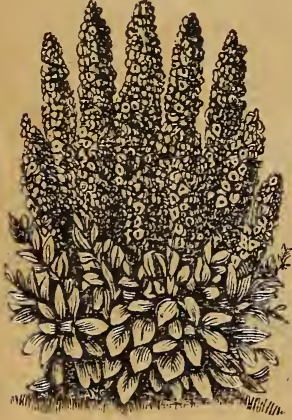

MignONETTE.

A well-known, $\mathrm{h}$ ardy a $\mathrm{n}$ nual, universally grown and esteemed for its delicious fra estence. If well thinned frathe plants will grow stronger and produce larger spikes of bloom.

Mignonette, Sweet.

Large-flowered variety, very fragrant. Per ounce, 15c..... Dwarf, compact.

A very desirable variety, distinct in character, forming a tinct in character, forming a

Large Flowered, Pyramidal.

Greatly superior to the old variety of pyramidal growth and much larger flowers......

Machet.

The finest variety for pot culture; sweet-scented, red flow-

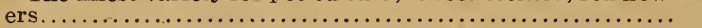

White Pearl.

Flowers nearly white; a desirable variety ............ 5 Gabriele.

A variety of dwarf pyramidal growth with large spikes of reddish flowers; fine for pots, or in the open ground ........ Allen's Defiance.

Spikes of immense size; deliciously fragrant...........

\section{MIMULUS.}

Handsome, profuse-blooming plants, with flowers of singular form and brilliant colors, fine for greenhouse or shady situations. Half-hardy perennials, blooming from seed the first year.

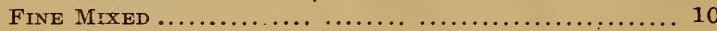

\section{MUSK PLANT.}

Much esteemed for the strong musk odor of its leaves. It has a yellow bloom

\section{NEMOPHILA.}

Charming hardy, low annual, producing an abundance of extremely delicate and beautiful flowers. Very useful for bediding or for pot culture. Sow early in pots and transplant into a cool, rather moist, location.

InsIGNIs. Clear, bright blue, white center............... Finest Mixed ..............

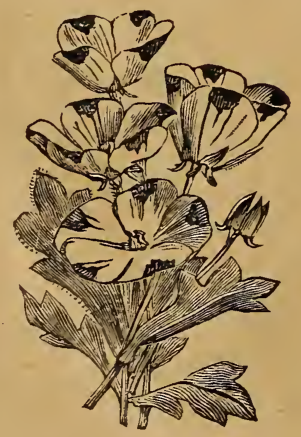

NEMOPHILA.

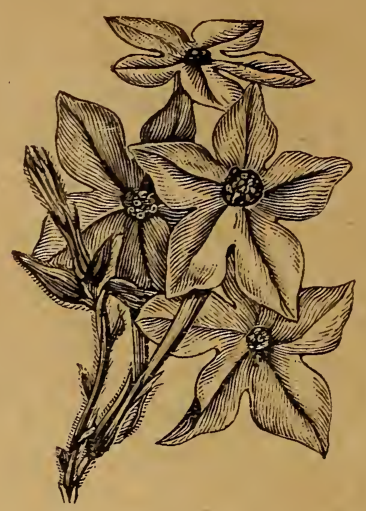

Nicotiana.
NICOTIANA.

Per Pkt.

Deliciously fragrant flowers, very ornamental, of easy cultivation, excellent for cutting. Halfhardy annuals.

AfFinis. White, very fragrant................

SYLVESTRIS. Plants of pyramidal growth, about four feet high. Flowers pure white and very fra-
grant $\ldots \ldots \ldots \ldots \ldots \ldots \ldots . . .10$

SANDERAE. Branching habit; two feet. Strikingly beautiful plants. B 10 os 5 m s brilliant carminered; delicious fragrance.............. 10

\section{NIEREMBERGIA GRACILIS.}

Profuse-blooming little plants, with white, lilac-shaped flowers; exceedingly valuable for small beds, edging and

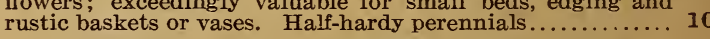

\section{NOLANA.}

Very pretty trailing, hardy annuals; fine for rockwork, hanging baskets or for bedding. Select light, rich soil.

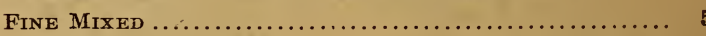

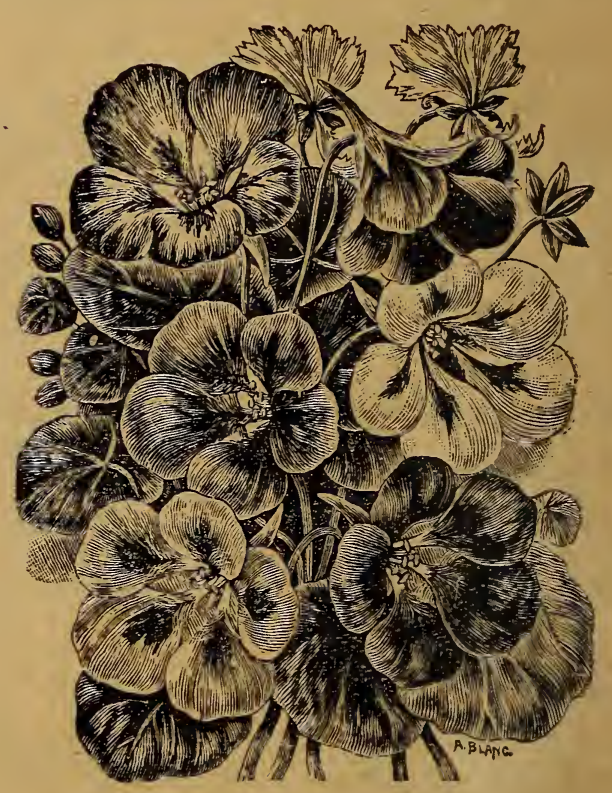

NASTURTIUM.

One of the most popular flowers of the present time, and constantly growing in favor. Is a rapid climber, of easiest culture, bearing beatifully colored flowers in profusion until killed by frost. Hardy annual.

The "K. \& W." Mixed Varieties, both Tall and Dwarf, cannot be surpassed for brilliancy and variety of color. The plants, for about three months in the year, producea lavish profusion of bloom, even through the hottest weather, and a trial of them is sure to give great satisfaction. 


\section{NASTURTIUM-Continued.}

NASTURTIUM.（Tall.）

Per Pkt.

Coccineum. Scarlet............................... 5

Duniett's Orange. Pure orange.................. 5

Eduard OtTo. Brownish lilac ..................... 5

Heinemanni. ('hocolate color ...................... 5

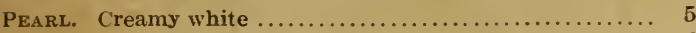

Prince Henry. Cream, spotted and tipped scarlet........ 5

Regelianum. Purplish violet $\ldots \ldots \ldots \ldots \ldots \ldots \ldots \ldots \ldots . \ldots \ldots$

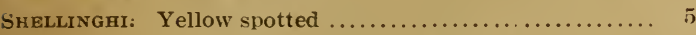

SCHEUCRIANUM. Straw colored, spotted brown........... 5

Vesuvius. Salmon-rose; an exquisite shade............ 5

Von Moltke. Dark rose $\ldots \ldots \ldots \ldots \ldots \ldots \ldots \ldots \ldots \ldots \ldots$

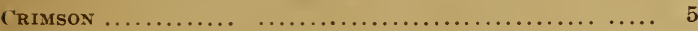

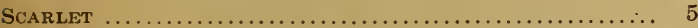

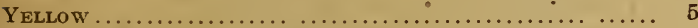

Variegated Foliage. Mixed colors .................. 5

Ivy-Leaved Foliage. Leaves are an English ivy-leaved type, while the flowers are of a most delicate fringed formation. Mixed colors...................................
NASTURTIUM.-Continued.

Per Pkt.

Ivy-LEAved Foliage. Identical in style with the tall variety. Mixed colors................................

LILLIPUT. The most dwarf of all nasturtiums. Of compact growth with the bloom in a beautiful mass above the foliage; fine for potting and bedding ........................

“K. \& W." Mixed Varieties.

\begin{tabular}{rrrrrrr}
11 b. & $1 / 21$ b. & $1 / 41$ lb. & 2 oz. & 1 oz. \\
$\$ 1.00$ & .60 & .35 & .20 & .10 & 5 \\
& & & \multicolumn{20}{c}{ COLLECTION OF 6} & PKTS., & 25
\end{tabular}

\section{OXALIS.}

Elegant flowering plants, particularly adapted for the greenhouse or parlor, where they bloom in mid-winter.

Fine Mixed Varietiss.

\section{OENOTHERA. (Evening Primrose.)}

A half-hardy annual and perennial, about six inches high, bearing bright, showy flowers in white, pale yellow, rose, etc. Of the easiest culture.

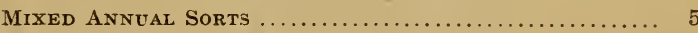

Mixed Perennial Sorts . . . . . . . . . . . . . . . . . . . .

\section{"K. \& W." Mixed Varieties}

$\begin{array}{cccccc}11 \mathrm{~b} . & 1 / 21 \mathrm{~b} . & 1 / 41 \mathrm{~b} . & \mathbf{2} \mathrm{oz} . & 1 \mathrm{oz} . \\ \$ 1.00 & .60 & .35 & .20 & .10 & 5 \\ & & \text { Collection of } 6 & \text { PKTS., } & 25\end{array}$

\section{NASTURTIUM LOBBIANUM.}

This class is remarkable for the intensely brilliant colors of its flowers, blooming most profusely, and is very useful for covering verandas, or for trellis and rustic work. Half-hardy annual.

Madame Gunter Hybrids. A French strain, noted for its fine colors..........

MARGUERITE. Pale yellow, flushed blood

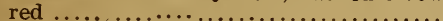

Fine Mixed ... . . . . . . . . . . . . . . .

NASTURTIUM. (Dwarf.)

The dwarf improved varieties of nasturtium are among the most useful and beautiful of garden favorites for bedding, massing or ribboning. Hardy annuals.

Bronze. Bronze-orange.

CLOTH OF Gold. Scarlet flowers and yellow foliage ..............................

Crystal Palace Gem. Sulphur, maroon blotches.................................

EMPRESS oF INDIA. Fiery crimson, dark foliage........................ dark

GoLDEN KIng. Rich, golden yellow......

KING THEODoRE. Deep crimson maroon, dark foliage. ...........................

K ING of ToM Thumbs. Dark scarlet, dark leaves...........................

LADY BIRD. Orange-yellow; suffused with red and a bright red blotch at the base of the petals ..................

Ruby KIng. Rich crimson rose......... 5

SpotTed. Golden yellơw, spotted garnet. 5

Crimson ............................ 5

SCARLET

YELLOW

Variegated Foliage. Mixed colors.....

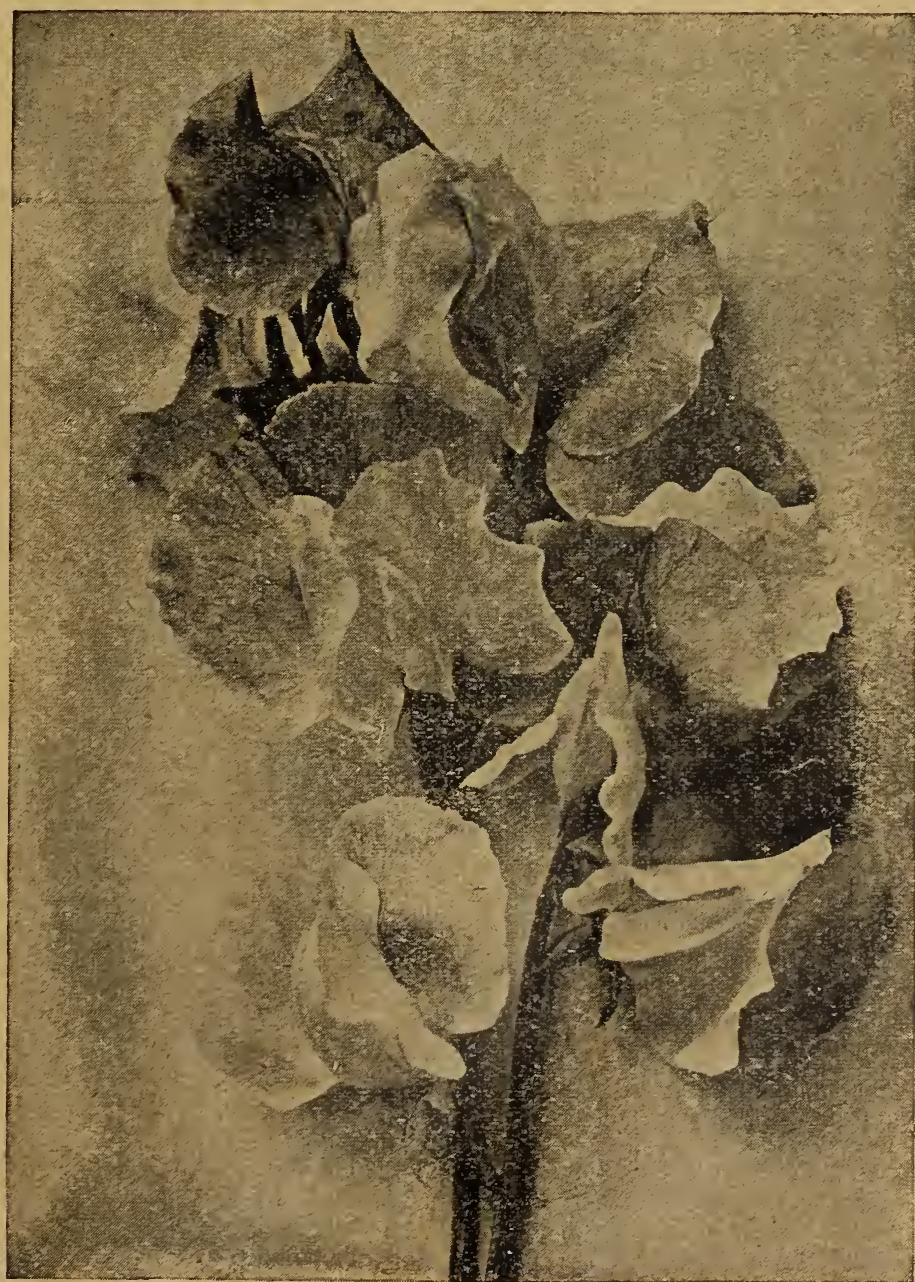

SWEET PEAS. 


\section{SWEET PEAS.}

Sweet peas are among the most desirable hardy annuals srown, being exceedingly beautiful and highly ornamental, and will grow and blossom well in any good garden soil. Select an open, sunny location, and sow as early as the ground can be worked in the spring, to enable the vines to geta good strong growth before to enable the vines to get
the warm weather comes.

\section{SPENCER VARIETIES.}

The Waved or Spencer class represents a type of sweet pea the original of which, the Countess Spencer, is still the best and most popular pink. The advent of this variety and the development from it of numerous new varieties only covers a short period, and the chief interest of sweet pea experts is centered on this class. They are strong growers, bear long stems and very large blossoms, with usually four blossoms to a stem. The standard is large, round, and fluted or wavy on the edges. The wings, too, are large and more or less wavy, but not so much so as the standard.

AMERICA. Bright red, striped and flaked on white; Pkt. Oz. ApPle Blossom. Crimson, buff and light pink..... $10 \quad 25$ Asta OнN. Pinkish lavender................. $10 \quad 25$ AUrora. White, striped with orange-pink ....... $10 \quad 25$ Beatrice. Rose, pink and buff............... $10 \quad 25$ Blanche Ferry. Crimson pink and light pink.... $10 \quad 25$ Clara Curtiss. Large, wavy, light primrose ...... $10 \quad 25$ Countess Spencer. Pure, soft rosy pink ......... $10 \quad 25$ DAInty. White, with pink edge .............. $10 \quad 25$

Evelyn Hemus. Buff and primrose, with clear rose

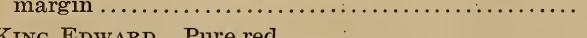

LOVELY. Deep pink, shading to blush............ Maud Holmes. Rich crimson .

Mrs. C. W. Breadmone. Primrose, with rose edge. Othello. Deep maroon.$\ldots \ldots \ldots \ldots \ldots \ldots \ldots \ldots$ Paradise Ivory. Ivory white.......

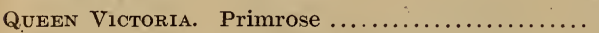
SEnator. Chocolate, purple and white striped ..... ST. George. Brilliant orange pink, or, more correctly, flame color........................... Tennant. Beautiful purple mauve ..............

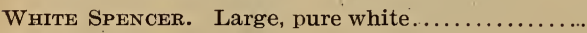
FINEST MIXED

LARGE FLO IVERED-GRANDIFLORA TYPE Admiration. Brilliant red and white striped ...... AMERICA. Crimson scarlet, irregularly striped...... Apple Blossom. Rosy pink, blending with white... AUrora. Orange, rose and white striped..........

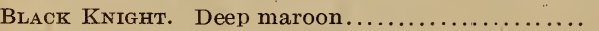
Blushing Beauty. Very beautiful flesh pink...... Blanche Burpee. Pure white.

BlaNCHE FERRY. Extra early; standards carmine pink, wings almost pure white

BURPEe's EARLIEST White. Extremely early; clear white:

Captain of the Blues. Blue and purple.........

Captivation. A beautiful light claret

Coccinea. Cherry red.

Coquette. Primrose and very light purple.

Countess of CADogan. Lilac and green .

Countess of LAthom. Delicate cream pink

Countess of RAdnor. Pale lavender, lovely flower.

DAlnty. Crystal white, with pink edge...........

DOROTHY ECKFoRd. - Large white.

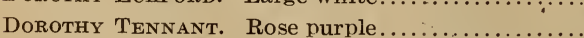

DUKE OF Clarence. A brilliant, dark claret .......

DukE of SUTHERLAND. Dark purple and violet....

Duke of Westminster. Deep purple.

EARLIEST OF ALL. Rose and white; fine for forcing EMILy Eckford. Rose-lilac and blue............

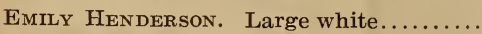

Fascination. Tints of blue and lilac ...........

Firefuy. Bright red.
SWEET PEAS-Continued.

GEORGE Gordon. Reddish maroon.

GLADYS Unwin. Large light pink.....

GOLDEN Rose. Light primrose and rosy pink ............ GoRGEOUs. Scarlet, orange and rose $\ldots \ldots \ldots \ldots \ldots . . . .$.

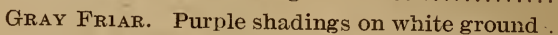
Helen Pierce. Blue mottled on white. . . . HENRY ECKFORD. Large flowering; orange scarlet. Hon. F. Bouverie. Deep pink, shading to light

pink..................................... shading to light Hon. Mrs. E. Kenyon. Large primrose yellow..... JANET SCOTT. Soft rosy pink and buff.

Katherine Tracy. Brilliant pink; large flowering

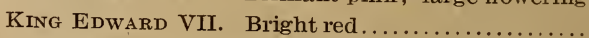
Lady Grisel HamцLton. Pale lavender $\ldots \ldots \ldots \ldots$. LAdy MARY CURRIE. Salmon-pink and carmine.... LAdY Nina Balfour. Mauve and lavender......... Lady Penzance. Delicate rose.

LORD ROSEBERRY. Magenta rose $\ldots \ldots \ldots \ldots \ldots \ldots$ Lоттіе EcKford. White, blended with blue lilac... Lоттіе Hutchins. Light pink and primrose, striped Lovely. Deep pink, shading to light pink......... Majestic. Deep rose crimson

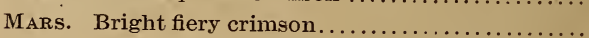
MidnIGHT. Indigo blue and violet; very dark...... Miss WiLlмотт. Large orange pink .............. Modesty. White with pink edge ....

Monarch. Bronze crimson and blue ................. MoNT. BLanc. Early white; fine for forcing......... Mrs. Dugdale. Crimson rose $\ldots \ldots \ldots \ldots \ldots \ldots \ldots$. Mrs. EckFord. White, shaded with primrose ..... Navy Blue. Indigo blue and violet............... Oriental. Cream, heavily veined with salmon ...... OTHello. Dark, glossy maroon.................. Painted Lady. Rosy crimśon and blush white..... Phyllis Unwin. Bright pink .................... Prima Donna. Lovely shade of soft pink ........... PRINCE EdWARD of York. Scarlet and crimson.... Prince of Wales. Bright rose and crimson........ QueEn Alexandra. Scarlet..................... QUEEN Victoria. Soft primrose yellow............ RAMONA. Cream white, splashed with pale pink .... ROYAL Rose. Crimson pink, shaded light pink..... Sadie Burpee. Pure pearly white................ Salopian. Deep crimson and orange scarlet.......... Sensation. Rosy cream, with white wings........... SHAZADA. Dark maroon and violet.

STella Morse. Deep cream, with blush-pink edge. StANLEY. Deep maroon........................ SybIL ECKFord. Buff and pink......

Venus. Salmon-buff and rosy pink.................

"K. \& W." CHOICE MIXED. This magnificent assortment is a mixture of the finest varieties produced, the flowers being of the largest sorts, and so combined as to give the most delightful harmony of colors.
$1 \mathrm{lb}$.
$1 / 2 \mathbf{I b}$.
$1 / 41 b$.
.90
.50
.30

PRICES FOR ANY OF THE ABOVE FIVECENT PACKAGES: 6 pkts. for $25 \mathrm{c}$; 12
pkts. for 40 .; collection of 75 pkts., $\$ 2.25$. NEWV BUSH SWEET PEAS.

Grow in perfect bush form, sixteen to eighteen inches high, producing flowers of large size.........

\section{EVERLASTING SIVEET PEAS.}

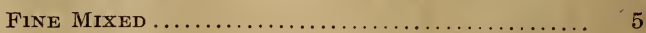

Full flowering season is greatly extended by inoculating sweet peas with Farmogerm. See page 42.

$\begin{array}{ll} & \\ \mathbf{5} & \mathrm{Oz} . \\ 5 & 10 \\ 5 & 10 \\ 5 & 10 \\ 5 & 10 \\ 5 & 10 \\ 5 & 10 \\ 5 & 10 \\ 5 & 10 \\ 5 & 10 \\ 5 & 10 \\ 5 & 10 \\ 5 & 10 \\ 5 & 10 \\ 5 & 10 \\ 5 & 10 \\ 5 & 10 \\ 5 & 10 \\ 5 & 10 \\ 5 & 10 \\ 5 & 10 \\ 5 & 10 \\ 5 & 10 \\ 5 & 10 \\ 5 & 10 \\ 5 & 10 \\ 5 & 10 \\ 5 & 10 \\ 5 & 10 \\ 5 & 10 \\ 5 & 10 \\ 5 & 10 \\ 5 & 10 \\ 5 & 10 \\ 5 & 10 \\ 5 & 10 \\ 5 & 10 \\ 5 & 10 \\ 5 & 10 \\ 5 & 10 \\ 5 & 10 \\ 5 & 10 \\ 5 & 10 \\ 5 & 10 \\ 5 & 10 \\ 5 & 10 \\ 5 & 10 \\ 5 & 10 \\ 5 & 10 \\ & \end{array}$




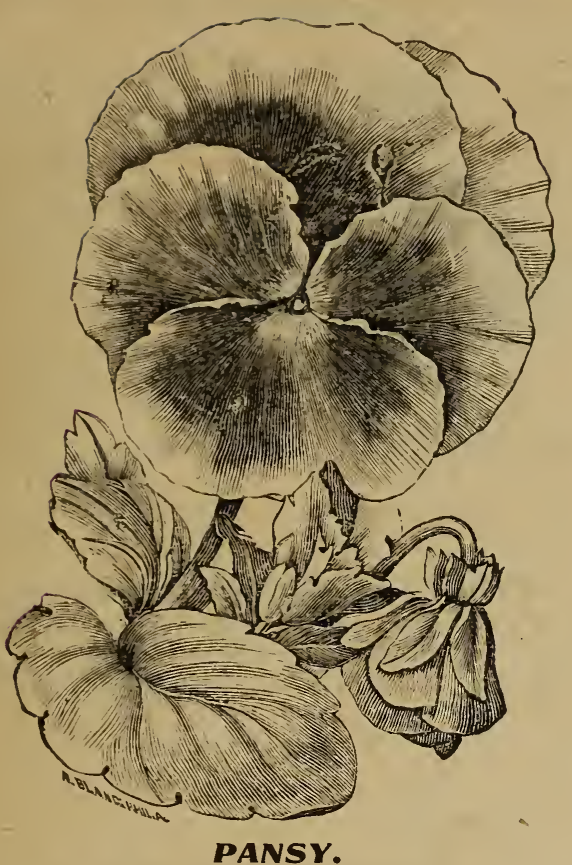

Per Pkt.

A well-known and universal favorite. Prefers a moist, shady situation; cover during the winter months. Seeds sown in August or September, kept in a cold frame through the winter and planted out in the sprin $₫$, will blossom the whole season. Hardy perennial.

CARTER's Prize. Extra choice strain; very large flowers and choice colors ................................... 15

Giant Five-Spotred. Enormous flowers of perfect symmetry; beautifully blotched with the richest deep velvety plum-crimson, bordered with white and various colors.... 15

CARTER's Peacock. Unique flowers of marvelous beauty, the upper petals being of a beautiful ultra-marine blue, resembling in shade the peacock feather................ 10

Giant Striped. The perfection of all the striped varieties. 15

BUGNoT. A French variety, of large size, beautiful colors, handsome broad blotches, finely penciled with stripes of delicate hue.

KING of THE BLACKs. Velvety jet black.............. 10

ODIER. Finest blotched ............................ 10

Buve. Beautiful light blue...................... 10

YeLLow. Pure golden yellow $\ldots \ldots \ldots \ldots \ldots \ldots \ldots \ldots \ldots, 10$

PUrple. Dark, rich purple ...................... 10

Whiтe. Pure white; dark eye....................... 10

"K. \& W." Extra Cholce Mixed. Superb mixture of finest large flowered varieties.............................. 10

Fine Mixed

5

PASSION FLOWER.

A splendid class of climbers, with curious flowers produced in great profusion; fine for conservatory or will answer for the garden, flowering freely during the autumn.

Fine Mixed

\section{PERILLA NANKINENSIS.}

An annual, growing from two to two and one-half feet; stems branching, well covered with an ample foliage of a dark purple, almost black

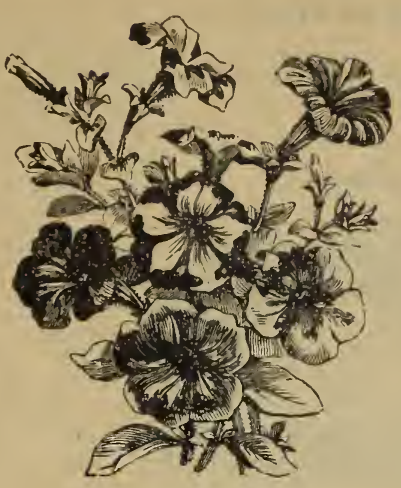

PETUNIA.

Per Pkt

Favorite, hardy annuals, succeeding well in any rich soil. For the brilliancy and variety of their colors. their abundance of flowers and the long duration of their blooming period, they a re indispensable in any garden.

Double Fringed. Extremely double, edge finely fringed, petals fluted and crinkled, unmatched by crumpled velvet, which the flowers resemble. 25

Petunia.

SI NGLE FRINGED. ('hoicest firinged sorts

California Giants. A strain of incomparable beauty, size and luxuriance. The flowers are exquisitely ruftled or fringed on the edges, and are enormous...

CARTER's EMPress. ('rimson shaded, with lovely penciled throat. Blossoms of grand size and form.

Clematis Flowered: Resembling in form the well-known Clematis Jackmanni; dark and light blue ............... 15 Whire. Single, large, pure white.

Fine Mixed. Single varieties.

PHLOX DRUMMONDI.

The flowers are of extreme beauty and are greatly admired by all. Their long duration in bloom, combined with their almost , combined wichness of color, make thenl invaluable in the general flower garden. Hardy annuals.

Pure White...

Pure Deep Scarlet

Rose

YeLLOW

CRIMSON.

Finest Mixed. Ounce $\$ 1.00$.

H R Y PERENYIAI. Fine mixed varietie

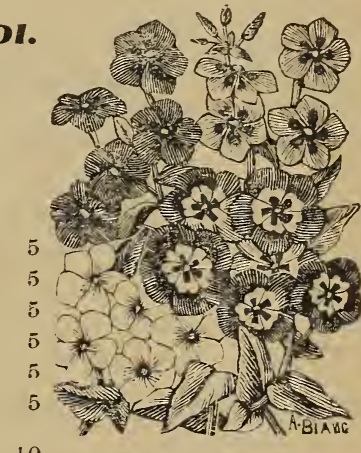

PhLox.

PINK. (Dianthus.)

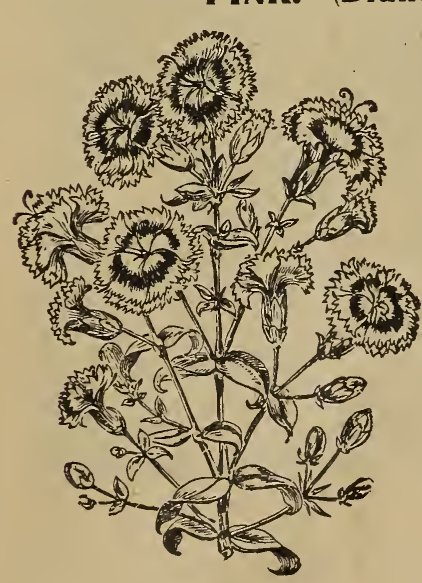

Heddewigi Ping.
One of the most popular flowers in cultivation, $\mathrm{p} \mathrm{r}$ oducing a great vaducing a great variety of brillian nd profusion of bloom.

CARNATION. A magnificent class of popular flowers, ver y fragrant, and of rich and bea utifu colors. Hordy perennial.......

HeDdewigi. Flowers very large and of rich and brilliant c ol or Hardy annual... 10

Chinese. Splendid double mixed 5

CARNATION - M A R G U E R I T E." V e r y early, and when sown in the spring will bloom in July or A ugret and continue until frost, or may be potted to bloom durins the winter in the house. Many of the flowers are double, and are finely fringed and fragrant.

Whiтe. Large, perfect flowers

YeLlow Clear, soft yellow.

GIANT MIXED. Extra large, flowering profusely, in brightest colors.... 


\section{POLYANTHUS.}

Per Pkt.

Showy and profuse-flowering, hardy perennial, about one foot high, blooming in June and July.

Finest Mixed

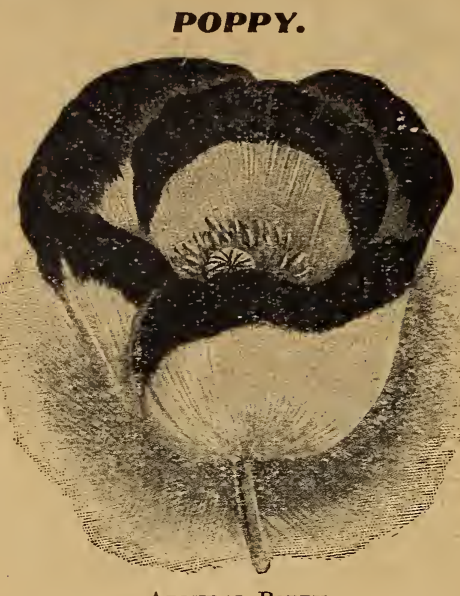

Admiral Poppy.

Brilliant and showy, hardy annual, growing freely in any garden soil. Sow as early in spring as the weather will permit at intervals for a succession. Barely cover seed: PRESS DOWN FIRMLY, and when up thin to six inches apart. $2 \mathrm{ft}$.

ADMIRAL. Single, peony-flowered variety. Glistening pure white, with scarlet band around the top; very handsome. 10

CARDINAL. Dark foliage, deeply cut; very double flowers. Color vivid scarlet on white ground ....................

ICELAND. The colors range from pure white and yellow to the deepest orange-scarlet. Hardy perennial, blooming

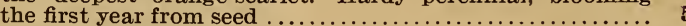

MIKado. Double white, fringed flowers, purple margins.... 5 Orientale. Deep crimson flowers with black blotch; $3 \mathrm{ft}$. 10 PEAcock. Cup-shaped, crimson blossoms, with ring of black at the base of the petals; equally good for pots or borders. 10

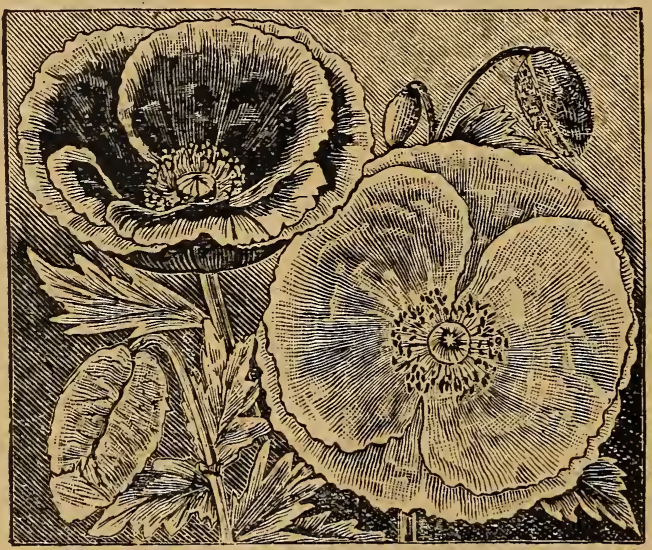

SHiRley POPPY.

TULIP. Grows twelve to fourteen inches high, and produces well above the foliage fifty to sixty large flowers of the most briiliant scarlet

WHITE SWAN. The acme of perfection in double poppies. The profusely produced blossoms are perfectly formed, and the purity of their color is beyond reproach $\ldots \ldots \ldots \ldots \ldots \ldots$

Double SCARLET.

Fine Double Mixed

SHIRLEY. Beautiful strain of single mixed poppies; bright, delicate colors; fine for cutting...

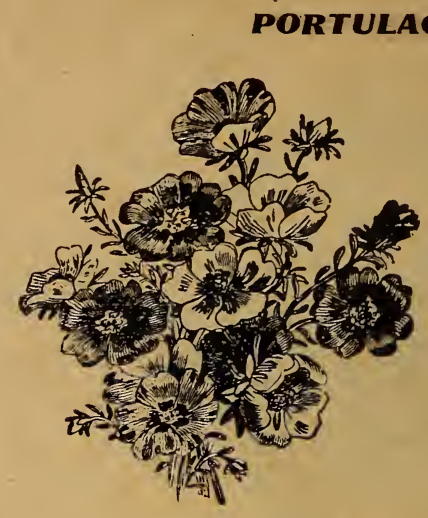

Per Pkt.

Very popular, low-growing, hardy annuals, making a most brilliant display in the garden, and very suitable for borders or edgings. Sow early in warm, light, rich soil and thin plants to four inches.

Single Crimson .. 5 Single Scarlet... 5 Single White .... 5 Single Yellow... 5 SINGLE, ALL COLORS MIXED .......

Portulaca.

MIXED

\section{PRIMUla. (Chinese Primrose.)}

These are beautiful and desirable plants for the parlor and greenhouse, and produce a constant succession of their charming flowers all through the winter and spring. The seeds may be sown at any time from January to July, in pots, using a light soil.

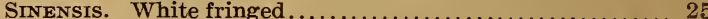

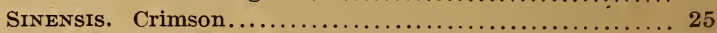

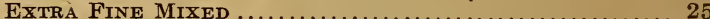

Double Extra Mixed $\ldots \ldots \ldots \ldots \ldots \ldots \ldots \ldots \ldots \ldots \ldots, 50$

\section{PRINCE'S FEATHER.}

Ornamental plants, with elegant plumes of rich colored flowers.

LARge Flowered. Crimson; $2 \mathrm{ft} . \ldots \ldots \ldots \ldots \ldots \ldots \ldots \ldots$

\section{RHODANTHE.}

A well-known everlasting ; valuable for the decoration of the conservatory and flower garden: fine for be d d ing or ribboning. b e d ding or ribboning. athered when young, mat ble winte ceed best in a light, rich soil and a warm, sheltered situation. Half-hardy annual; $1 \frac{1}{2} \mathrm{ft}$.

Fine Mixed ............. 5

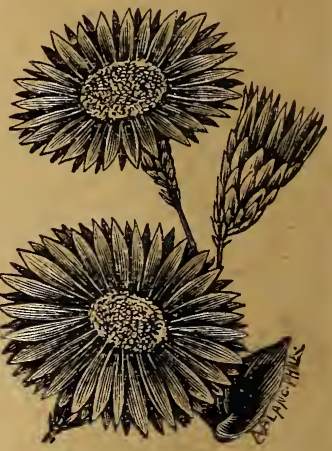

RHODANTHE.

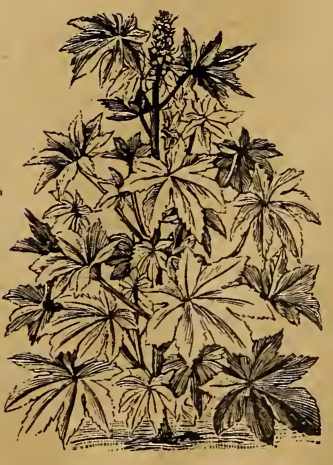

RICINUS.

(Castor Bean.)

Plants with very ornamental foliage and showy fruit and quite a tropical appearance. With other arnamental-leaved plants, ornamental-leaved plants, ive bed on the lawn, and ive bed on the lawn, and are also desirable when grown as single specin
Half-hardy annuals.

Barbonensis ARboreus. Beautiful, large green foliage; $15 \mathrm{ft} . . . . . . . . . .$. .

CAMBodgensis. Dark foli-. age; black stem; 9 feet. . SANGUINEUS. Scarlet fruited; $10 \mathrm{ft} . . . \ldots \ldots \ldots \ldots . . . .$.

ZANZIBARIENSIS. Immense, dark green foliage; $12 \mathrm{ft} . . . . .$. Mixed Varieties .................................... 


\section{ROSE CAMPION.}

Per Pkt.

The rose campion is perfectly hardy and very easily raised from seed. The flowers are produced on long stems, blooming freely throughout the season. Hardy perennials.

Fine Mixed

\section{RUDBECKIA. (Cone Flower.)}

Showy, hardy perennial, suitable for borders or clumps among shrubs.

Amplexicaulis. Golden yellow; $3 \mathrm{ft}$. ..................

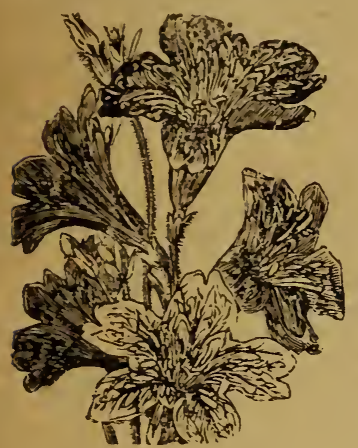

SALPIGLOSSIS.

Very beautiful,rich, halfhardy annuals, one and one-half feet high. Start early in the hot-bed and transplant to light, warm, $\mathrm{rich}$ soil. Blooms from July to September.

Fine Mixed ............ 10

SALPIGLossis.

\section{SALVIA.}

Very ornamental, producing tall spikes of brilliant flowers. Start early in $\mathrm{h}$ ot-beds and transplant two feet apart. Half-hardy annual.

SPLendens. Early brilliant scarlet Howers.... 10

GLORY OF STUTTGART.

Brilliant scarlet, large

bouquet ................. 10

Bonfire. Dwarf scarlet. 10

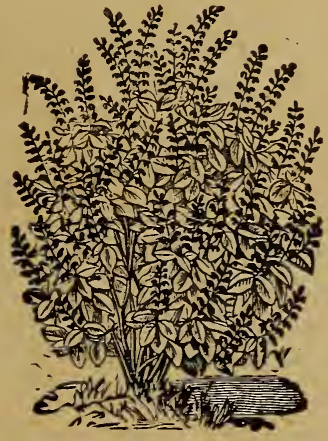

SALVIA.

\section{SCHIZANTHUS.}

Tender annual, one to one and one-half feet high, blooming from August to October. Fine for pot culture.

FINE MIXed

\section{SENSITIVE PLANT.}

A pretty, curious annual, being so sensitive that the leaves close together at the slightest touch .......................

\section{SMILAX.}

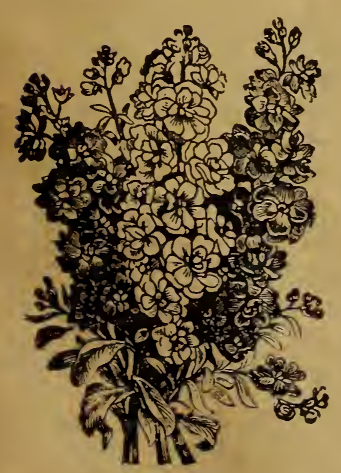

STOcks.

A beautiful winter climbing plant, adapted to the conservatory. Nothing can excel this plant in beauty of foliage and orange fragrance of the orange fragrance of the flow or bouquets and flora decorations of every de-
scription $\ldots \ldots \ldots \ldots \ldots \ldots$

\section{STOCKS.}

$\mathrm{H}$ a lf $-\mathrm{h}$ a rd $\mathrm{y}$ annual, producing splendid spikes of very rich and beautiful flowers of delightful frafrance. For early flowering sow early in the spring. ing sow early in the spring, in pots or in the hot-bed, and transplant one foot until October.

\section{STOCKS-Continued.}

PRINCESS ALICE (White Perpetual). "Cut and Come Again." Of fine branching habit, growing to the height of eighteen inches. Large, double flowers, of roset te-like form. Fine for forcing

"Cut and Come Agarn." Finest mixed

BEAUTY OF NICE. Handsome winter flowering stock of quick growth, with flowers of large size and very double. Color, daybreak pink. Flowers in from twelve to fifteen weeks from seed-sowing

QUEEN ALEXANDRA. Same type as Beauty of Nice. flowers delicate rosy lilac, of great beauty, and of exceptionally high value for cut bloom, market and bouquet work. The percentage of double flowering plants is very large ............. 10

SNOW ELAKE. A dwarf variety, with large, double, snow-white flowers; fine for pot culture; very early.

WHIтE. Ten weeks, double ......................, 10

Purple. Ten weeks, double ....................... 10

Scarlet. Ten weeks, double ....................... 10

MIXED. Ten weeks, double....................... 10

\section{SUNFLOWER.}

Well-known, showy plants; remarkable for their rapid and stately growth and the large size and brilliancy of their flowers.

CALIFornia. Double, bright yellow flowers ........... 5

MAMmoth RUSSIAN. Very large flowers $\ldots \ldots \ldots \ldots \ldots \ldots \ldots$ b

Miniature. Covered with hundreds of brightest orange, small, single flowers; of pyramidal growth, with bright, neat foliage

\section{SPHENOGYNE.}

A very showy, free-blooming plant, with yellow flowers. Very effective for beds or mixed borders. Hardy annual...

\section{SWEET ROCKET.}

Fine early spring flowering plant, very fragrant, growing in any soil. About eighteen inches in height.

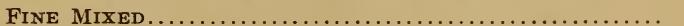

\section{SWEET SULTAN.}

Showy, hardy annual, one or two feet high, succeeding well in any soil.

Fine Mixed

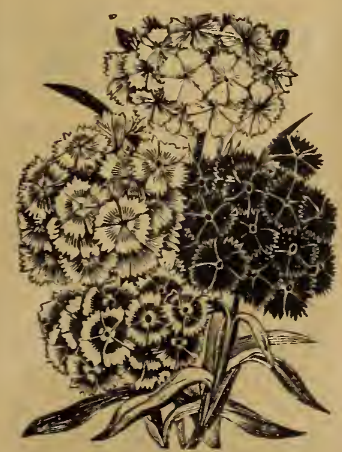

Sweet William.

\section{SWEET WILLIAM.}

A well-known, show and beautiful hardy per. ennial, about one foot high, making a most splendid appearance in May and June.

HUNT'S PERFECTION. $\mathrm{Mixed}$ variety, large, bright-colored flowers..

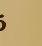

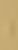

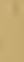

5

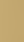




\title{
SWEET CLOVER.
}

A half-hardy perennial, much resembling the common red

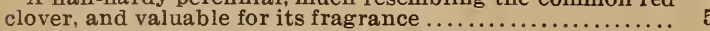

\section{TASSEL FLOWER.}

A beautiful, half-hardy annual, with small, tassel-like flowers, blooming profusely from July to October.

SCARLET

\section{THUNBERGIA.}

Very ornamental, trailing, half-hardy annual, admirably adapted for trellis or rustic work, or for the conservatory.

FINE MIXED.

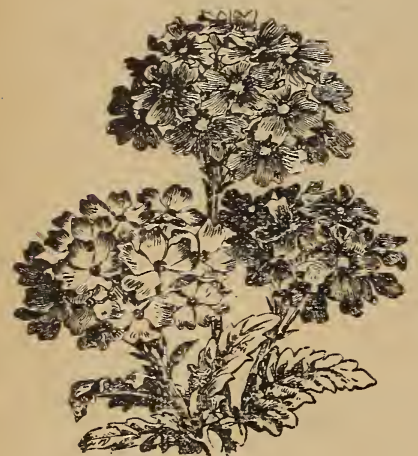

VERBENA.

\section{VERBENA.}

Well-k nown and universally popular bedding plant. loring mer. Plants grown from seed are more healthy and $\mathrm{make}$ larger and hardier plants than those from cuttings. If sown in spring will flower quite early. Half-hardy perennial.

Candidissima. Pure white........... 10

Scarlet Defiance. Brightest scarlet.. 10

MAMмотH FINEST MixED .......... 10

Fine Mixed $\ldots \ldots \ldots \ldots \ldots \ldots \ldots \ldots \ldots \ldots \ldots \ldots \ldots \ldots \ldots \ldots \ldots$

LEMON VERBENA. Lemon-scented foliage ............ 10

\section{VIOLA ODORATA. (Sweet Violet.)}

A charming little perennial, highly prized on account of its delicious fragrance. Succeeds best in a sheltered loca-

\section{VISCARIA.}

Very pretty, profuse-flowering, half-hardy annual, producing a fine effect in beds or mixed borders, and growing readily in any soil.

Fine Mixed

\section{WALLFLOWER.}

Very fragrant and ornamental, half-hardy perennial, suitable for background and amongst shrubbery.

Fine Mixed

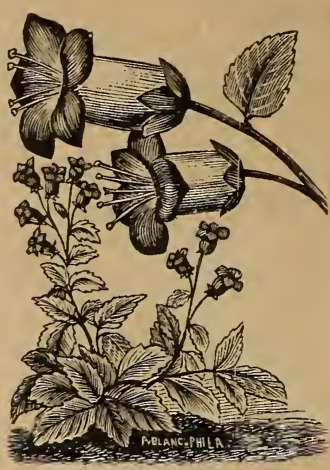

Charming, hardy annual with delicate foliage and clusters of beautiful, bellshaped flowers; fine for ribboning or mixed borders; $1 \mathrm{ft}$.

Fine Mixed

\section{WILD CUCUMBER -VINE.}

A very rapid-growing climber which reaches a height of twenty feet in one season. It is covered with clusters of white, sweet-scented flowers, followed by an abundance of ornamental prickly seed pods. It will quickly cover a trellis, pillar or an unsightly building, and will reproduce itself from self-sown seed every year. Soak seed over night in warm water. Hardy annual.

\section{ZEA. (Japanese Maize.)}

An ornamental foliage plant. Grows to the height of four or five feet, furnished from the bottom with long, wavy leaves, broadly ribboned with alternate stripes of white and green.

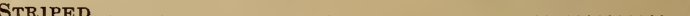

\section{ZINNIA.}

A most splendid class of hardy annuals, and one of the finest summer flowering the finest summer fowering plants. The flowers a re large, handsome and in a very great variety of colors, blooming throughout the whole season. Start early in pots or under glass and transplant one foot apart.

HaAGEANA. Double, orange;

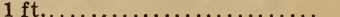

New Zebra. Double, dwarf; finest mixed.............. 10

Double Giant Mixed ......

\section{WILD GARDEN SEED.}

A mixture of over one hundred varieties of flow-

\section{SPECIAL

..CONSISTING OF..

\author{
35-5c. Pkts., or 18-10c. Pkts.
}




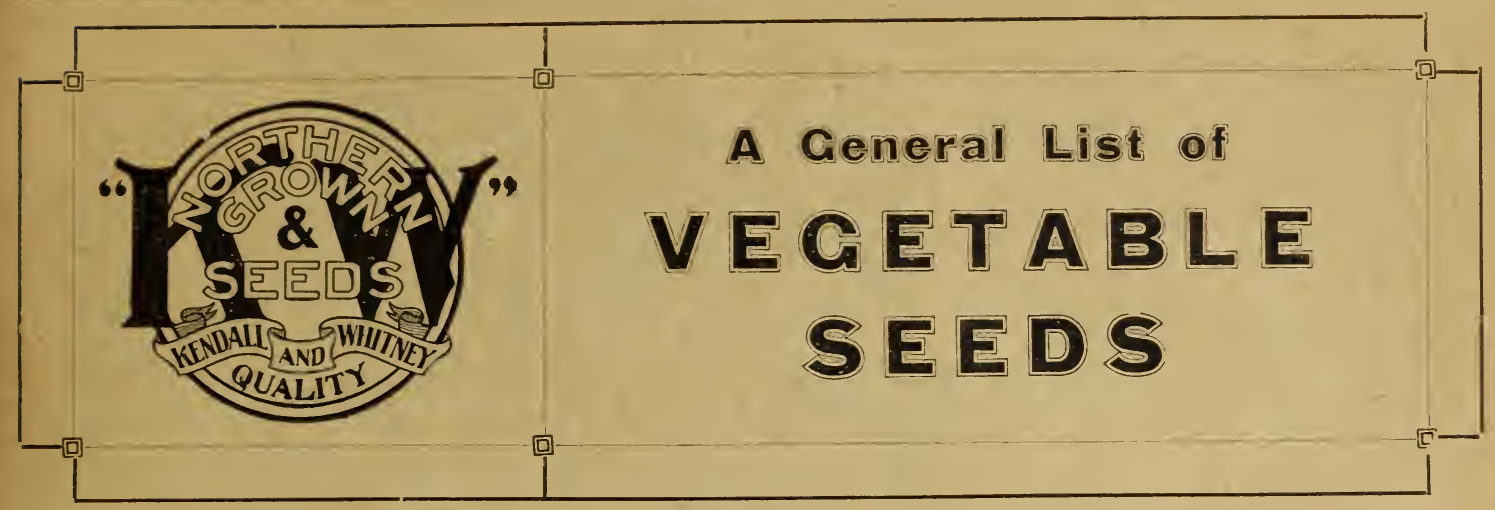

We forward seeds by Mail, Express or Freight as the purchaser may wish. When ordered by mail, add postage for corn, beans and peas at the rate of fifteen cents per quart to Catalogue prices, and for larger shipments by mail, see Parcel Post rates on page 3 of this Catalogue. (Eight cents per pound.)

\section{ASPARAGUS.}

Sow early in May, thinly, in rows one inch deep and two feet apart. The next season plant in drills two inches deep and two feet apart, spreading the roots well out in ground thoroughly manured and trenched, at least two feet deep.

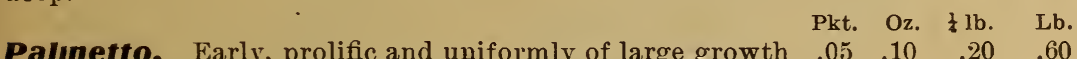

$\begin{array}{llllll}\text { Conover's Colossal. A well-known standard variety. } & .05 & .10 & .15 & .40\end{array}$

Conover's Colossal Roots. Two years old, per $100, \$ 1.50$.

\section{BEANS-Dwarf or Bush.}

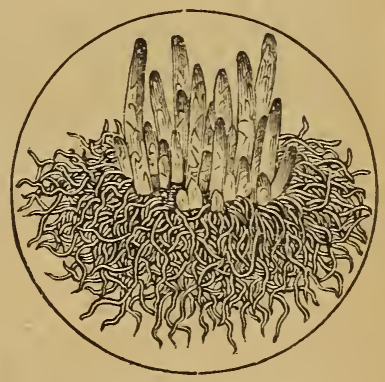

ASPARAGUS ROOTS.

A succession of sowings can be made from the first week in May until August. Plant in drills about two inches deep, and from eighteen inches to two feet apart, according to the richness of the soil; the poorer the soil the closer they can be planted; the plants should be about three inches apart.

One quart is sufficient for one hundred feet of drill; one and one-half bushels for one acre in drills.

Beans ordered by mail are subject to an extra charge of fifteen cents per quart for postage. Pints furnished at quart rates. For larger shipments by mail, see rates on page 3 of this Catalogue. (Eight cents per pound.)

Broad Windsor. (English beans.) Plant as early in the spring as the ground can be worked, from two to four inches apart, in drills from twenty-four to thirty inches apart. As soon as the plants are in full blossom, and the lower pods begin to set, pinch off the tops; this will insure the filling of the pods and hasten the maturity of the seed.......

Burpee's Bush Lima. The only bush form of the true large Lima bean. The bushes Pkt. Qt. Pk. grow eighteen to twenty inches high. Is an immense yielder of handsome, large pods, well filled with very large beans, which are identical in size and luscious flavor to the

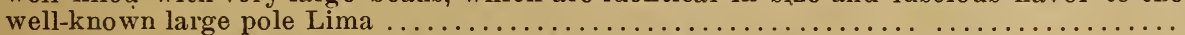

Burpee's Stringless Green Pod. Very early. Pods four and a half to five and a half inches long; nearly round, slightly curved, light green in color, flesh tender and of

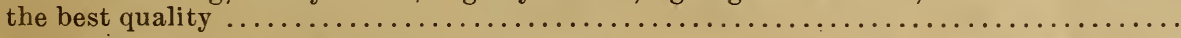

Low's Champion. Early, hardy, thrifty and enormously productive; combines extreme tenderness and delicious flavor, being absolutely without strings to the pods, and excels many other varieties as a snap or string bean. As a shell bean it has but few equals, and

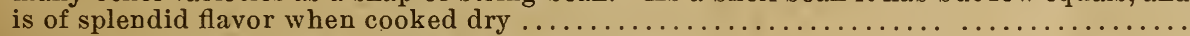

Early Long Yellow Six Weeks. Hardy and prolific . . . . . . . . . . . . . . . .

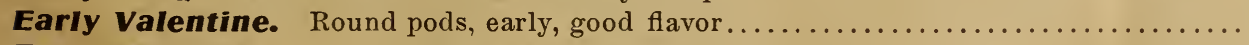

Early Mohawk. Very productive and of good quality $\ldots \ldots \ldots \ldots \ldots \ldots \ldots \ldots \ldots \ldots$

Dwarf Horticultural. A fine early shell bean . . . . . . . . . . . . . . . . . . . .

Goddard, or Boston Favorite. A larger, later Dwarf Horticultural type..........

Garland (New). Superior early shell bean, very productive, identical in color with Low's

Champion, the seed being much larger and longer $\ldots \ldots \ldots \ldots \ldots \ldots \ldots \ldots \ldots \ldots \ldots \ldots \ldots \ldots \ldots \ldots \ldots$. $\ldots \ldots \ldots$. $\ldots \ldots$.
Milliken's Wax. An extra early variety. The bushes grow from twelve to sixteen inches high, producing golden yellow pods that are entirely stringless and very prolific.

Wardwell's Kidney Wax. Hardy and vigorous vine, producing a heavy crop of hand-

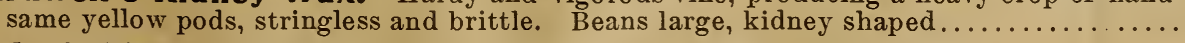

Early Golden-Eyed Wax. Hardy and prolific, with flat, yellow pods .............

.10

Qt.

$.30 \$ 1.75$

Pk. Bu.

$.30 \quad \$ 1.85 \quad \$ 6.75$

$.25 \quad 1.50 \quad 5.50$

$\begin{array}{lll}.20 & 1.35 & 4.75\end{array}$

$\begin{array}{lll}.20 & 1.35 & 4.75\end{array}$

$\begin{array}{lll}.25 & 1.50 & 5.00\end{array}$

$\begin{array}{lll}.25 & 1.50 & 5.00\end{array}$

$\begin{array}{lll}.25 & 1.60 & 5.75\end{array}$

$\begin{array}{lll}.25 & 1.50 & 5.25\end{array}$

$.25 \quad 1.50 \quad 5.00$

$\begin{array}{lll}.30 & 1.75 & 6.50\end{array}$

$\begin{array}{lll}.30 & 1.75 & 6.50\end{array}$

$\begin{array}{lll}.25 & 1.50 & 5.00\end{array}$ 


\section{BEANS-Continued.}

Brittle Wax. One of the earliest wax beans. Pods fleshy, entirely stringless, and of fine quality. Very hardy and prolific.........

Michigan White wax. Pods and seeds white and of rich flavor...

Golde $\boldsymbol{n}$. W a $x$. Very e arly; r o u nd, golden pods ...........

Black Wax. Pods yellow; a superior snap bean. .

Currie's RustProof Wax. Pods long, flat, tee $n$ de $r$ and of fine quality.....

\section{Snowflake Pea.}

A decided improvement on the common pea bean. Productive and very early.........

$.20 \quad 1.10 \quad 4.00$

$\begin{array}{lll}.25 & 1.60 & 6.00\end{array}$

$.25 \quad 1.75 \quad 6.50$

$.25 \quad 1.50 \quad 5.00$

$\begin{array}{lll}.25 & 1.50 & 5.00\end{array}$
Qt. Pk. Bu.

$.25 \$ 1.50 \$ 5.50$

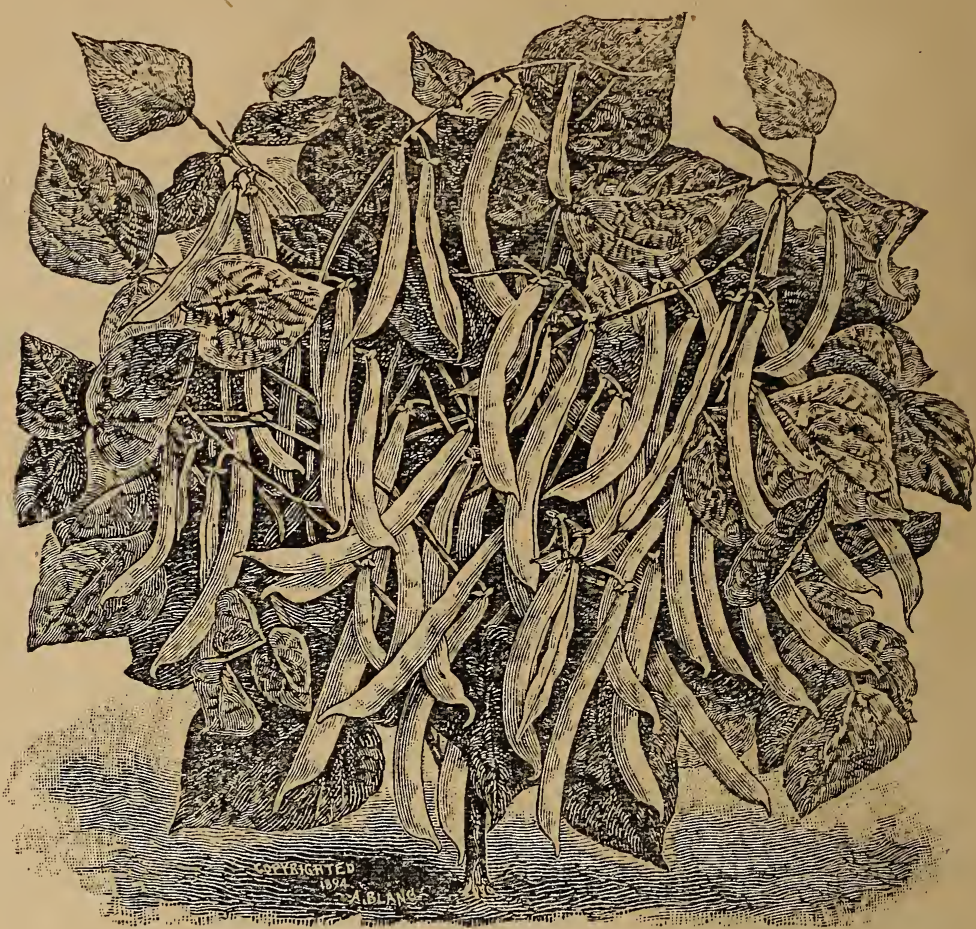

DWARF OR BUSH BEAN.

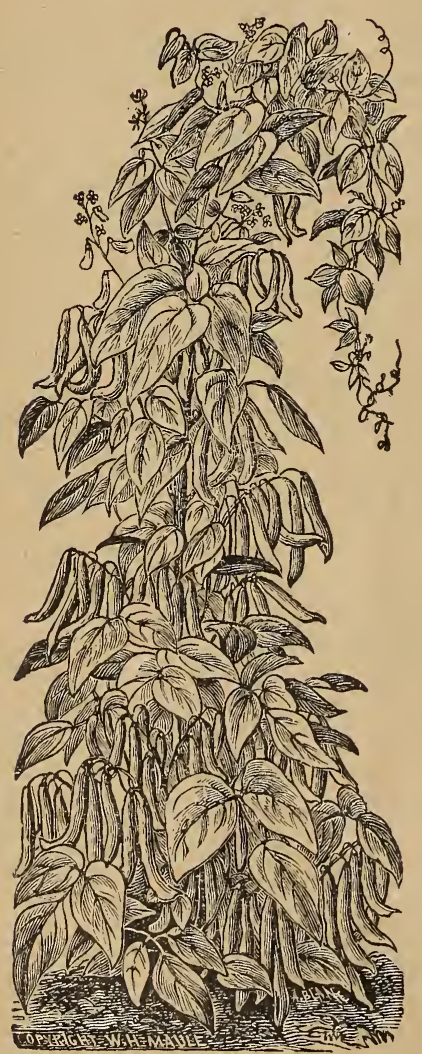

KENTUCKY WONDER BEAN.
Sulphur Pea. Larger than the white pea bean; golden

yellow color; early and of fine quality..............20 $\quad 1.25 \quad 4.50$

Yellow Eye. Very prolific; fine for baking .......... .20 $\quad 1.10 \quad 4.00$

Red Kidney. Excellent as a shell bean and for baking . . $\quad .20 \quad 1.10 \quad 4.00$

\section{BEANS-Pole or Running.}

The planting of the various sorts of pole beans should be delayed a week or more after tle first planting of the early dwarf sorts. They succeed best in sandy loam, which should be liberally enriched with short manure in the hills, which are formed, according to the variety, from three to four feet apart; from five to six seeds are planted in each hill, about two inches deep.

One quart will plant one hundred and fifty hills; ten to twelve quarts to the acre.

\section{KING HORTICULTURAL.}

An early, robust grower, the pods being large, stringless, and bright carmine. Tender and of delicious flavor.

Qt., 30c.; PK., \$1.85; Bu., \$6.75

London Horticultural. An old favorite. Very produc-

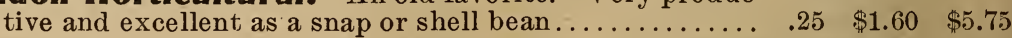

Red Cramberry. Almost stringless; one of the very best of string beans.................................. $1.65 \quad 6.00$

Lazy Wife's. Abundantly productive, and of excellent flavor, with long, green, fleshy and stringless pods..... .25 $\quad 1.75 \quad 6.50$

Kentucky Wonder. Very productive, and of fine quality. Entirely stringless pods, of a silvery green color... $.25 \quad 1.7$ ว $\quad 6.50$

Indian Chief, or Black Wax. A very tender snap bean; yellow pods.............................. $25 \quad 1.75 \quad 6.50$

White Case Knife. Good green-podded variety ...... .25 $\quad 1.75 \quad 6.50$

Large Lima. A large, late variety of excellent flavor. . . $\quad .25 \quad 1.75 \quad 6.50$

Small Lima. Earlier and hardier than the preceding .... .25 $\quad \begin{array}{llll}1.75 & 6.50\end{array}$ 
BEANS-Continued.

\section{FLOWERING BEANS.}

Valuable for use on trellises and arbors, being highly ornamental and free climbers; plants are of strong, quick growth, bearing large sprays of handsome flowers.

B U T T E R F Y. Beautiful, large, snowwhite wings, with salmon-rose standard

Scarlet Runner. Very ornamental, bright scarlet flowers ........................... 05

White Runner. Similar to above, flowers being white $\ldots \ldots \ldots \ldots \ldots \ldots \ldots \ldots \ldots \ldots \ldots . .05$

Pkt. Qt.

Inoculate beans with Farmogerm, to secure full pods and rich flavor. See page 42.

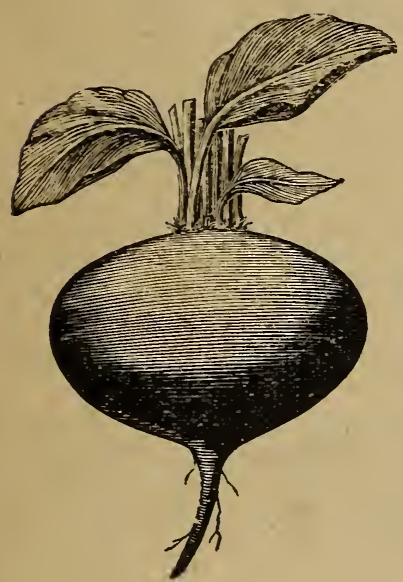

DIRIGO EXTRA EARLY BEET.

\section{BEET.}

The best results are obtained on a deep, rich, sandy loam. For early use sow as soon as the ground will admit, in drills fourteen inches apart, and thin to four inches; for the main crop, sow the first week in May, and for winter use as late as June. The soil should be deeply manured and well

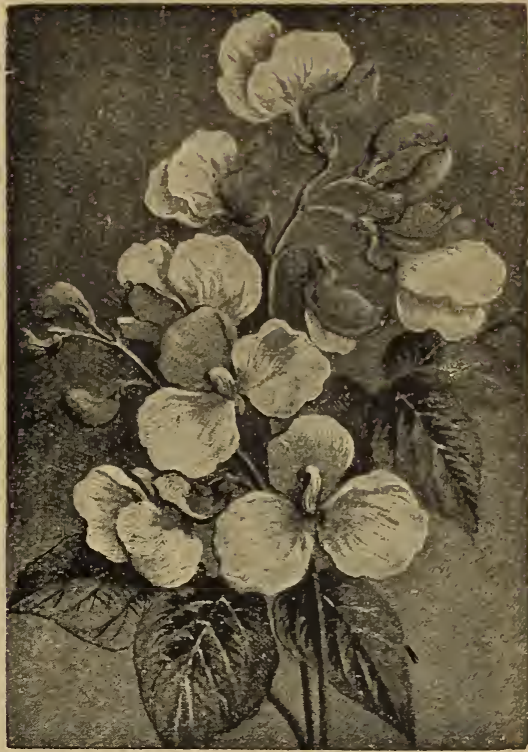

BUTTERFLY BEAN. cultivated. In lifting and storing the roots, care must be taken that they are not bruised.

One ounce to fifty feet of drill; six pounds to the acre.

Dirigo Extra Early. A rich, blood-red beet of fine grain and flavor, earlier than the Egyptian or the Eclipse...

Egyptian Blood Turnip. Very early and of rapid growth; color, deep crimson; of excellent quality..

Crosby's Egyptian. An improved strain of the

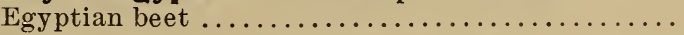

Eclipse. This variety is about as early as the Egyptian but larger and of finer quality;

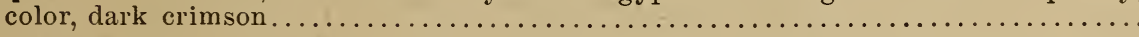

Edmand's Early Turnip. A variety of handsome round shape.. The skin is deep blood red in color, the flesh very dark and exceedingly sweet and tender in quality...

CRIMSON GLOBE. Remarkable for its smooth skin and fine shape. Is a second early variety, does not qrow large and coarse, the matured beets being medium in size. The flesh and skin are both very dark and of fine quality, being sweet and tender. The tops

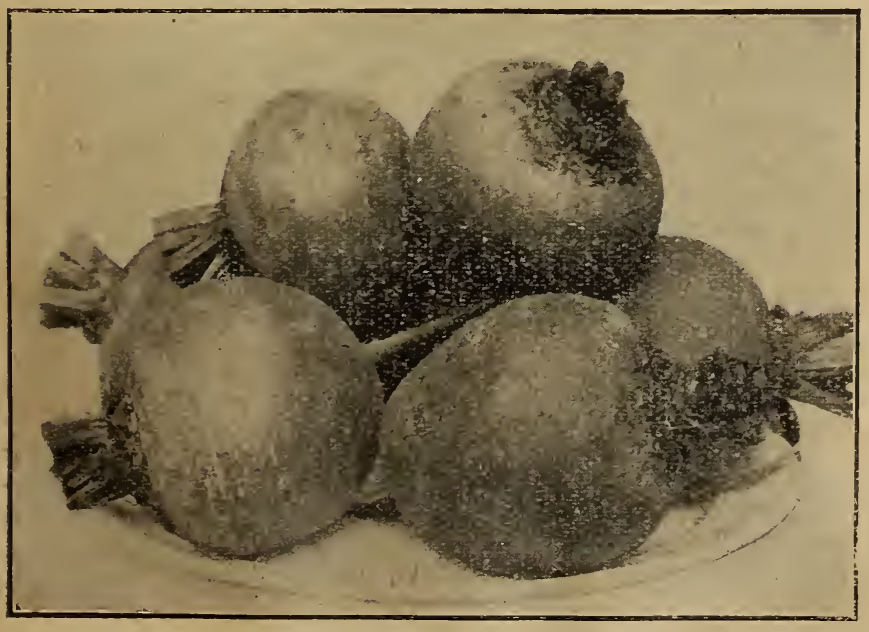

CRIMSON GLOBE BEET. are sinall and dark in color

Pkt. Oz. $\frac{1}{1 b}$. Lb.

$\begin{array}{llll}.05 & .10 \quad .20 \quad .60\end{array}$

$\begin{array}{llll}.05 & .10 & .15 & .50\end{array}$

$\begin{array}{llll}.05 & .10 \quad .20 \quad .60\end{array}$

$\begin{array}{llll}.05 & .10 & .15 & .50\end{array}$

$\begin{array}{llll}.05 & .10 & .15 & .50\end{array}$

$\begin{array}{llll}.05 & .10 & .25 & .75\end{array}$

Dewing's B IOOd Turnip. Of fine form and flavor blood red; a desirable variety...

Detroit Dark Red. Similar in shape to the Dewing's, of dark red color, with small tops.

Long Smooth BIOOd Red. This is a long, smooth beet, g row ing to a good size; color, dark blood red..

Swiss chard. Leaves used as greens; mid rib cooked and served as asparagus ... 


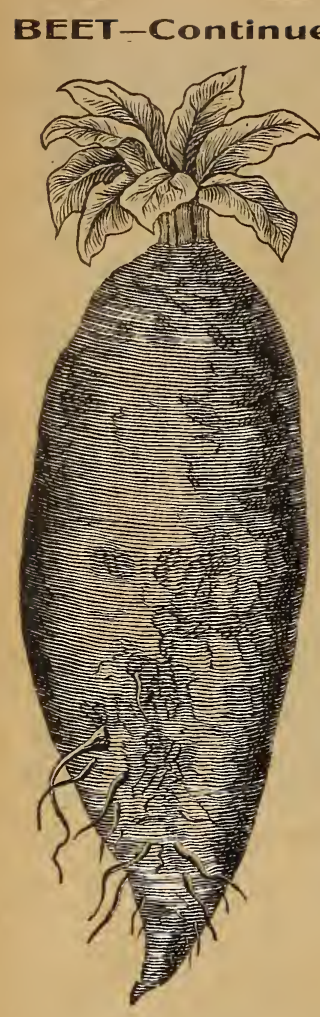

ALLEN'S MAMMOTH LONG RED MANGEL WURZEL.

Varieties grown for feeding stock. Sow in May or Junesix pounds per acre.

White French Sugar Beet. Largely cultivated for feeding...............

Lane's Imperial Sugar Beet. A greatly improved variety of the White

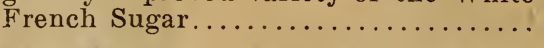

Alien's Mammoth Long Red Mangel Wurzel. A variety producing roots of mammoth size .................

Norbiton Giant Mangel Wurzel. Extra fine long red; very large..........

Yellow Globe Mangel Wurzel. Roots of large size and globular form; very

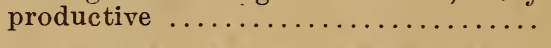
Carter's Warden Orange Globe
Mangel Wurzel. The very best globe-shaped variety in cultivation....

Golden Tankard Mangel Wurzel. Bright yellow; very productive.......

Pkt.

$.05 \quad .10 \quad .35$

.05

$.05 \quad .15$

$\begin{array}{lll}.05 & .15 & .40\end{array}$

$\begin{array}{lll}.05 & .15 \quad .40\end{array}$

$.05 \quad .15 \quad .40$

$\begin{array}{lll}.05 & .15 \quad .40\end{array}$

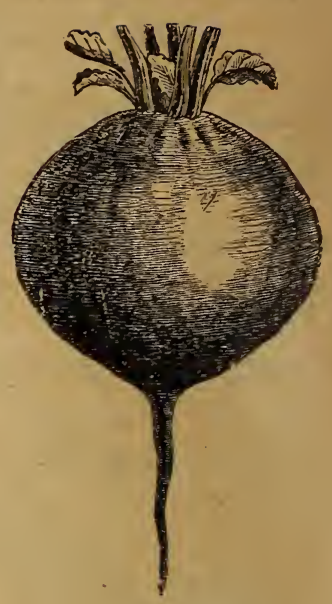

DEWING'S TURNIP BLOOD BEET.

Kelway's Best of All. An improvement on existing stocks of Yellow Mangels, being one of the heaviest croppers and easiest pulled, and is of very fine quality. Shape between Mammoth and Tankard; beautiful pale yellow skin with fine top.........

.05 $.20 \quad .60$

\section{BROCCOLI.}

Broccoli is nearly allied to the cauliflower, and may be regarded as a variety of that delicious vegetable. It is hardy and sure to head, but inferior in flavor.

Purple Cape. Heads greenish purple; a good variety $\ldots \ldots \ldots \ldots \ldots \ldots . .05 \quad \begin{array}{lll}\text { Pkt. } & \text { Oz. } \\ .25\end{array}$

White Cape. Very white; sure to head; standard sort. $\ldots \ldots \ldots \ldots . .05 \quad .25$

\section{BRUSSELS SPROUTS.}

Produces from the stem small heads resembling cabbage in miniature. The sprouts are used as greens, and become very tender when touched by the frost. Sow in May and manage as winter cabbage.

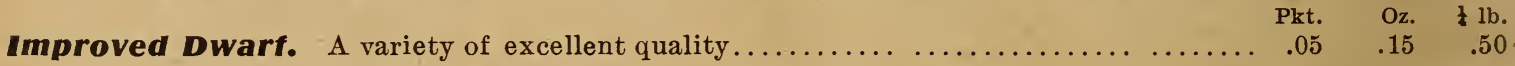

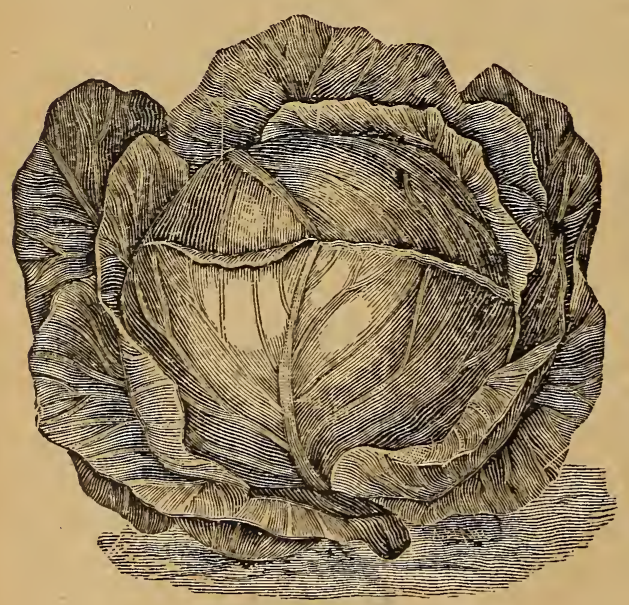

COLUMBIA CABBAGE.

\section{CABBAGE.}

The cabbage is one of the most important vegetables, and some of its varieties are universally cultivated. The ground must be highly manured, deeply dug or ploughed, and thoroughly worked, to insure good, full-sized heads. A heavy, moist and fresh loam is the most suitable. The early sorts should be sown very early in the spring, in hot-beds, or later in the open ground. Eighteen inches by three feet apart is the common distance.

One ounce will produce about 3,000 plants.

COPENHAGAN MARKET. O ne Pkt. Oz. Ib. Lb. of the best large, round head, early cabbages in cultivation, the type being thoroughly fixed and nearly all the heads maturing at the same time. The plant is short stemmed; heads set near the ground, are very solid, with a small core, and of fine quality. One of the best early cabbages for market gardeners . ............ .10 .40 $\$ 1.25 \$ 4.00$

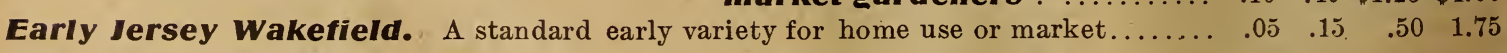
Charleston Wakefield. Resembles the Jersey Wakefield, heads larger and more

uniform $\ldots \ldots \ldots \ldots \ldots \ldots \ldots \ldots \ldots \ldots \ldots \ldots \ldots \ldots \ldots \ldots \ldots \ldots \ldots \ldots \ldots$
Henderson's Eariy Summer. $.05 \quad .20 \quad .65 \quad 2.25$ $.05 \quad .15 \quad .50 \quad 1.75$ 


\section{CABBAGE-Continued.}

Columbia. Very early and com- Pkt. Oz. $\quad$ lb. Lb. pact. Is hardy and vigorous ; produces splendid solid heads, of marketable size, and is recommended as one of the most desirable summer varieties...

Early Spring. Short-stemmed, round, flat-headed, early variety. Solid and uniform in growth

$.10 \quad .30 \$ 1.00 \$ 3.50$

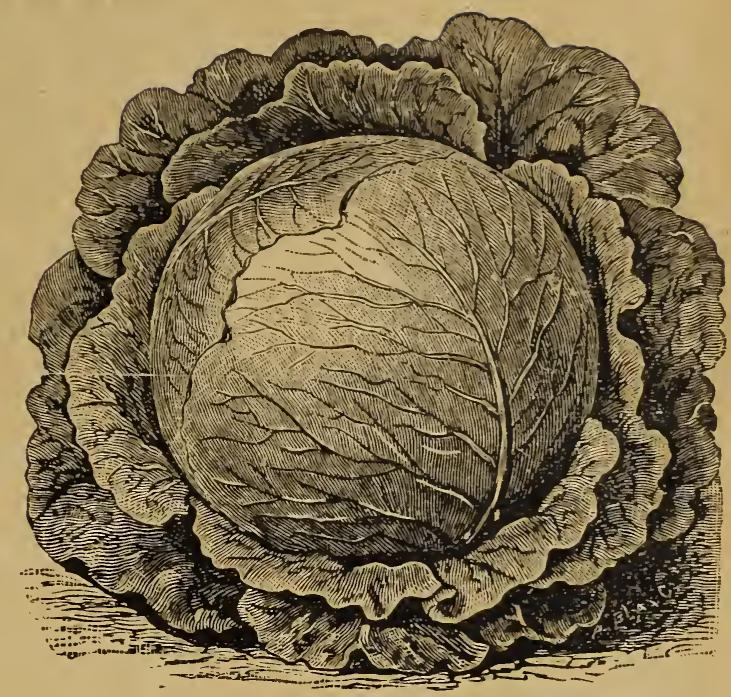

arly Winningstadt. An excellent sort; heads of large size.

AII Seasons. Larger than Hendersoul's Early Summer, nearly as early; very solid and sure heading.................

Fottler's Improved Brunswick. An excellent early Drumhead variety; produces a firm and solid head.........

Premium Flat Dutch. A standard late variety.........

Stone-Mason Drumhead. $\begin{array}{lllll}\text { One of the best for a main crop } & .05 & .15 & .50 & 1.75\end{array}$

DANISH BALL HEAD CABBAGE.

STONE-MASON DRUMHEAD. Cape Elizabeth grown. A great improvement on the above; medium-sized, round, hard head. An excellent

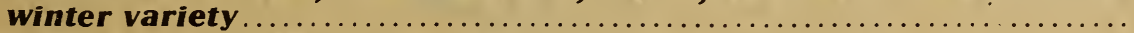

Henderson's Succession. An excellent second-early or late sort...............

Marblehead Mammoth Drumhead. The largest variety of Drumheads..........

Danish Ball Head (Imported). Heads round and solid. A good winter variety...

DANISH BALL HEAD OR HOLLANDER. Cape Elizabeth grown. A valu-
able, round, solid winter variety. Is a long keeper, and profitable for shipping, keeping long after other sorts have gone.

Danish Round Head (Imported). Similar in style and habit to the Ball Head, but shorter stemmed and about two weeks earlier. Perfectly round, solid head..........

Improved American Savoy. Very sweet and tender; good-sized, firm heads; very

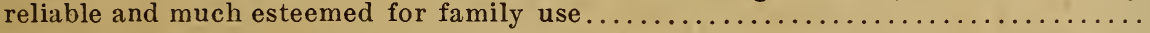

Mammoth Red Rock. Used almost exclusively for pickling

$\begin{array}{rrrr}.10 & .30 & \$ 1.00 & \$ 3.50 \\ .05 & .15 & .50 & 1.75 \\ .05 & .15 & .50 & 1.75 \\ .05 & .20 & .60 & 2.00\end{array}$

$\begin{array}{llll}.10 & .40 & 1.25 \quad 4.00\end{array}$

$\begin{array}{llll}.05 & .15 & .50 & 1.75\end{array}$

$.05 \quad: 20 \quad .60 \quad 2.00$

$\begin{array}{llll}.05 & .15 & .50 & 1.75\end{array}$

\section{CARROT.}

Carrots require a very finely pulverized soil to grow them to perfection. A good, light and well-enriched sandy loam is the best for this crop. For field culture, sow in drills, three to three and one-half feet apart, and for table use sow the smaller varieties in rows sixteen to eighteen inches apart. For early crops, cover one-half an inch deep, and thin to three inches a part in the rows; for late, cover three-fourths of an inch deep, and thin to four inches.

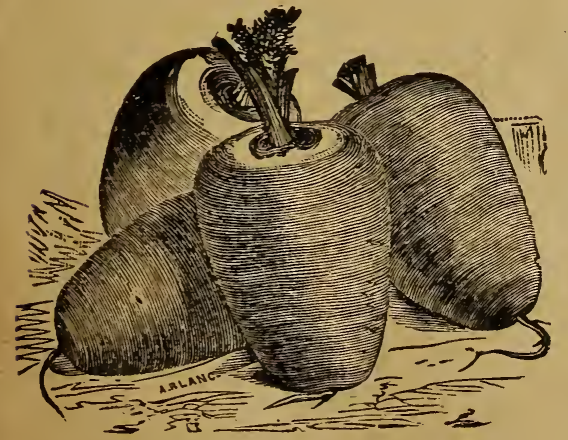

OXHEART CARROT.
One ounce to one hundred feet of drill; the acre.

Early French Forcing. The earliest variety; valuable for forcing....

Early Horn. Early, fine grain, medium size; an excellent table sort.

EA RLY MAR KET. A thick stumprooted early variety of brilliant color, broad at the top, gradually getting smaller towards the root, which is blunt. An excellent market sort.

oxheart. Very thick and short, fine grained and sweet...

Chantenay. A choice variety; longer than the Scarlet Horn, and a little broader at

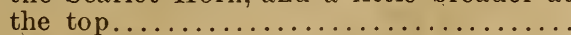

Danver's Half Long. In form it is midway between the Long Orange and Short Horn. The root is of a rich, dark orange color and grows very smooth. Very pro-

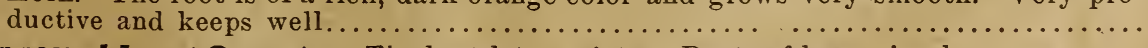

Improved Long Orange. The best late variety. Roots of large size, heavy cropper;

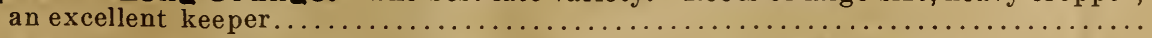

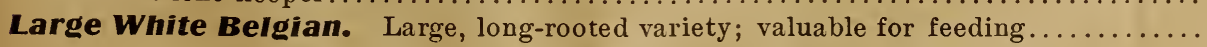
ee to four pounds to kt. Oz. \& lb. L L $\begin{array}{llll}.05 & .10 & .30 & \$ 1.00\end{array}$ $\begin{array}{llll}.05 & .10 & .30 & 1.00\end{array}$ $\begin{array}{llll}.05 & .10 & .30 & 1.00\end{array}$ $\begin{array}{llll}.05 & .10 & .25 & .75\end{array}$ $.05 \quad .10 \quad .30 \quad \$ 1.00$ $\begin{array}{llll}.05 & .10 & .25 & .75\end{array}$ $\begin{array}{llll}.05 & .10 & .25 & .75\end{array}$ $\begin{array}{llll}.05 & .10 & .15 & .50\end{array}$ 


\section{CAULIFLOWER.}

Any soil that will grow early cabbages will grow cauliflower, as their requirements are almost similar, but as the product is more valuable, extra manuring and preparation of the soil will be well repaid.

The seeds may be sown in the hot-bed in March or April, and transplanted to open ground about the first of May.

One ounce will produce about 3,000 plants.

Extra Early Dwarf Erfurt. The earliest variety; large, compact heads, of fine quality.

Henderson's Early Snowball. One of the early sorts. Very reliable and grown largely for the market.........

THORBURN'S GILT EDGE. Large, heavy sort; one of the best and surest of all the sorts now in cultivation.................... 15

Carter's Dwarf Mammoth. A hardy variety, of dwarf and compact habit, with a firm, white head; stands dry

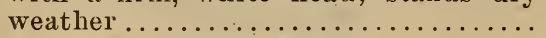

Carter's Autumn Giant. A large late variety.

$\begin{array}{ll}.15 & \mathrm{Oz} \\ .15 & 2.00 \\ .15 & 2.25 \\ .15 & 2.00 \\ .10 & .50\end{array}$

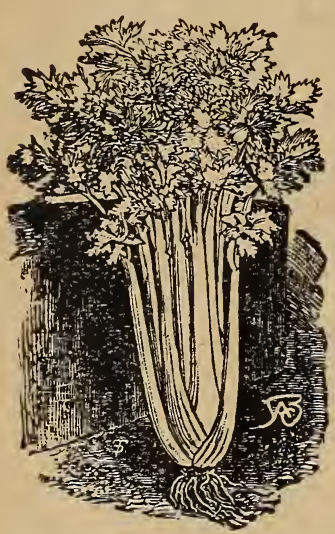
GOLDEN SELF=BLANCHING
CELERY.

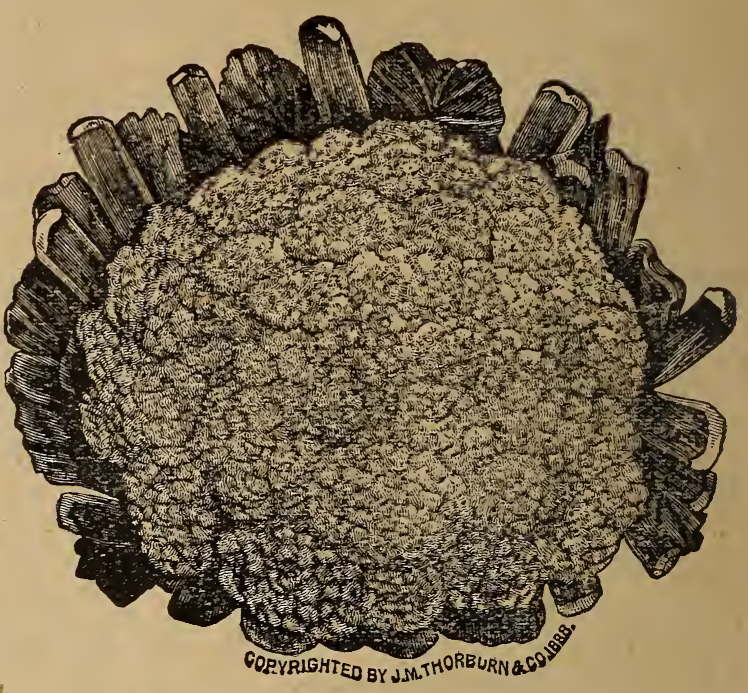

THORBURN'S GILT=EDGE CAULIFLOWER.

\section{CELERY.}

To have celery early it should be sown in a hot-bed, quite early in the spring, and when three inches high plant out in a well-prepared bed, which must be covered in frosty weather. For the principal crop sow early in the spring, very shallow in the seed-bed, and when the plants are about six inches high transplant them six inches apart into trenches for blanching. Dig the trenches four feet apart, a foot wide and ten inches deep. Fill in five or six inches of well-rotted manure, and mix thoroughly half a spade deep with the earth at the bottom. The tops of the plants should be shortened before they are set. Earth up to blanch three or four times during their growth, taking care that no earth falls in the center of the plant.

One ounce of seed produces about 4,000 plants.

Boston Market. A favorite variety, remarkable for its tender, crisp and succulent stems, and its peculiarly mild

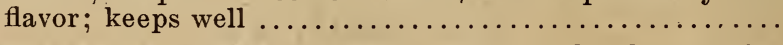

Henderson's White PIume. Crisp, solid and possessing a sweet, nutty flavor; requires very little labor in blanch-

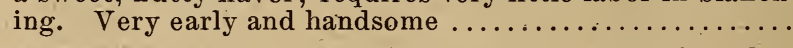

Pink PIume. Similar to White Plume, except in color;

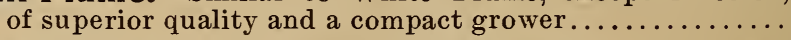

Golden Self-Blanching. A fine, solid variety, of a beautiful waxy, golden color; very thick stalks of excellent flavor; growth close, compact and of medium height...

Giant Pascal. An easily blanched variety, superior for late use $\ldots \ldots \ldots \ldots \ldots \ldots \ldots$ Pkt. Oz. 1 lb. Lb. $.05 \quad .20 \quad .60$ $.05 \quad .20 \quad .60$

$.05 \quad .30 \quad 1.00$

$\begin{array}{rrr}-.05 & .20 \quad .60\end{array}$

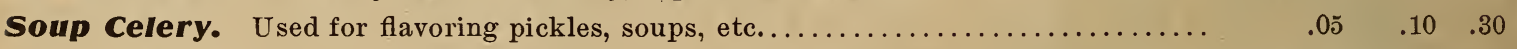

\section{CHARD-Swiss.}

Swiss Chard. (Sometimes called Sea Kale Beet.) After once having used Swiss Chard for greens we believe your garden will always have at least a row of it, for it is delicious. The leaves are used as greens, and served like spinach. The mid-ribs may be cooked like asparagus. Cuttings may be made all summer, as it can be cut down

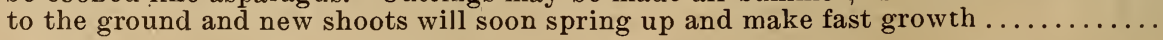

$\begin{array}{llll}.05 & .10 & .15 & .50\end{array}$

\section{CHERVIL.}

Curled Chervil. An aromatic sweet herb. The young leaves are used in soups and salads. Pkt.

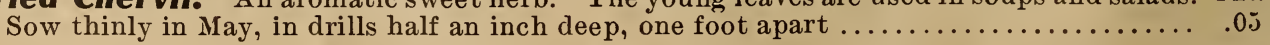

Oz. $\frac{1}{4} \mathrm{lb}$.

$.10 \quad .25$

\section{CHICORY.}

Large Rooted. Used to mix with, or as a substitute for coffee. Cultivation same as the

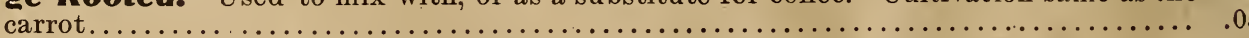




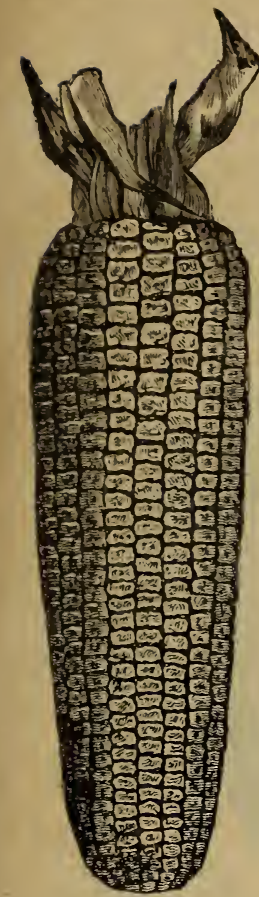

CROSBY EXTRA EARLY SWEET CORN.

\section{CORN-Sweet.}

The sweet or sugar varieties being liable to rot in cold, wet ground, should not bc planted before the middle of May, and for a succession continue planting evcry two weeks until July, in rich, well-manured ground, in hills three feet apart each way, covering about an inch, and thin out to three plants to a hill, or plant in rows four feet apart, and to stand eight inches apart in the rows. The field varieties should be planted four feet apart each way, leaving three plants to a hill.

One quart to two hundred hills; ten quarts to an acre.

Corn ordered by mail is subject to (in extra charge of fifteen cents per quart for postage. Pints furnished at quart rates. For larger shipments by mail, see rates on page 3 of this Catalogue. (Eight cents per pound.)

EARLY MAYFLOWER. The earliest va- Pkt. Qt. Pk. Bu. riety yet produced, being from seven to ten days earlier than the cory. Is a perfectly white corn, eight, ten and twelve rowed, very productive, and for so early a variety, is of excellent quality.

$.10 \quad .25 \$ 1.75 \$ 6.00$

Peep O'Day. One of the first to mature. Stalks from three and one-half to four and onehalf feet in height, with from two to three ears each. Small, white cob, with tender kernel.

Cory. Very early, dwarf variety, desirable for

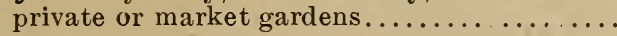

White Cory. Similar to the above, with white cob Burbank's Early. As early as the Cory. Has a pure white cob, with a rich, cream-white

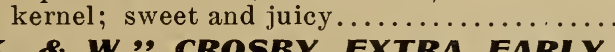

"K. \& W." CROSBY EXTRA EARLY.
The best early sort, sweet and of fine flavor. Dwarf, with ears set low, averaging from sixteen to eighteen rows. An excellent market variety, and largely grown for canning. The seed offered is from selected stock of our own growing

$\begin{array}{llll}.05 & .20 & 1.15 & 4.00\end{array}$

$\begin{array}{llll}.05 & .20 & 1.15 & 4.00\end{array}$

$.05 \quad .20 \quad 1.15 \quad 4.00$

$\begin{array}{llll}.05 & .20 & 1.15 \quad 4.00\end{array}$

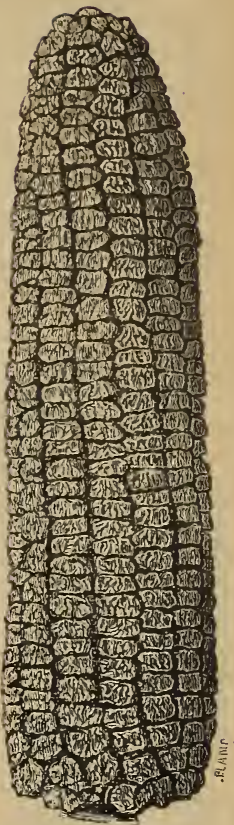

GOLDEN BANTAM SWEET CORN.

$\begin{array}{llll}.10 & .25 & 1.75 & 6.00\end{array}$

$\begin{array}{llll}.05 & .20 & 1.15 & 4.00\end{array}$ . Similar to the above, the stalks being taller and heavier; nearly ten

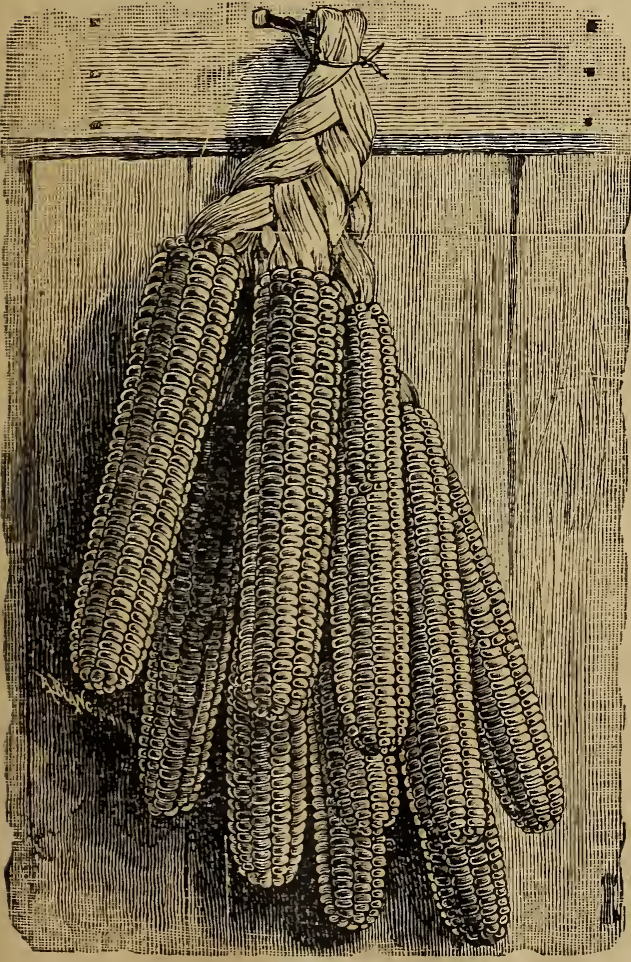

EARLY YELLOW FIELD CORN.
GOLDEN BANTAM. A superior variety of a bright golden color; is very hardy and productive and is of a rich sugary flavor ..........................

Stowell's Evergreen. A late variety of excellent quality, remaining longer in the green state than any other kind

Potter's Excelsior. Twelve-rowed, very sweet and tender.............

Country Gentleman. Medium early

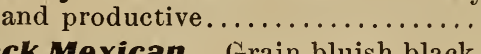

Black Mexican. Grain bluish-black
especially rich in sugar qualities...

FIELD AND ENSILAGE CORN.

Winn's Hybrid. A very fine field variety; safe to plant in this state; yields large crops.

Qt. Pk. Bu.

$.15 \quad .75 \quad \$ 2.50$

Longfellow. A fine field variety, having very long ears, small cob, and large kernel

Early Yellow Canada. Well known, early eight-rowed variety ............

Evergreen Fodder. Sweet corn for ensilage .

Red Cob Ensilage. A pure white corn. Is tender and juicy, has short joints, and grows to a great height, with an abundance of leaves.

Leaming. An early, very productive variety. One of the best for ensilage; profitable as a green fodder ...........

Early Sanford. Very early; ears white; excellent for fodder and ensilage ......

$.15 \quad .75 \quad 2.50$

$.15 \quad .65 \quad 2.25$

$.60 \quad 2.00$

Price quoted on application.

$.75 \quad 2.50$ 


\section{CRESS OR PEPPERGRASS.}

A well-known salad. Requires to be sown thickly and covered very slightly. Sow at frequent intervals to keep up a succession, as it soon runs to seed.

Extra Curled. Very fine; may be cut two or three times......................... Pkt. Oz. $\quad \begin{aligned} & \mathbf{1} \text { lb. } \\ & \text {. }\end{aligned}$

Water Cress. A hardy perennial aquatic plant, growing in water along the margins of streams $\quad .10 \quad .30 \quad \begin{aligned} & \$ 1.00 \\ & n_{1}\end{aligned}$

\section{CUCUMBER.}

The cucumber is a tender annual, and therefore should not be planted or set out in the open air until there is a prospect of continued warm and pleasant weather. Cucumbers succeed best in warm, moist, rich, loamy ground. The hills should be four or five feet apart in each direction. When all danger from insects is passed, leave but three or four of the strongest plants in the hill. One ounce to fifty hills.

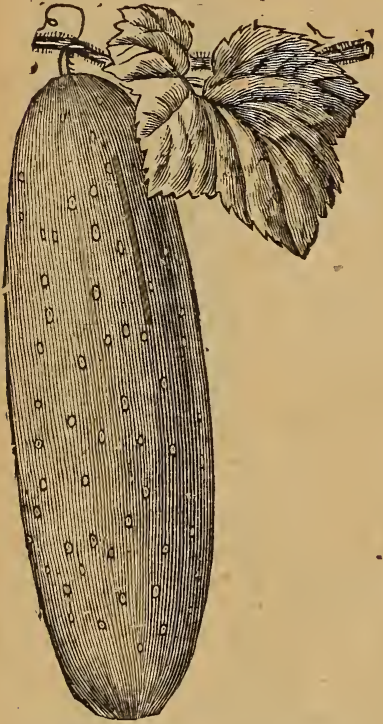

IMPROVED WHITE SPINE CUCUMBER.

Cumberland. A variety of the Pkt. Oz. $\frac{1}{\mathrm{l}}$ b. Lb. Improved White Spine type. Is a splendid table sort, and excellent for pickling. Color, deep green, with white tip; flesh firm; very crisp and ten-

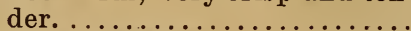

Early Russian. The earliest variety $\ldots \ldots \ldots \ldots \ldots \ldots$

Early Frame. An early standard variety, about five inches

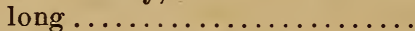

Improved White Spine. Superior for table use; very productive; medium size, straight and well formed; a favorite market variety..............

Early Green CIuster. Grows in clusters; early and produc-

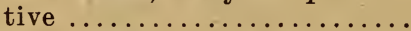

Short Green. Similar to Early

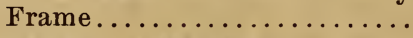

Japanese Climbing. Quick, strong growing vines, which may be trained upon a trellis or poles. Fruit from twelve to sixteen inches in length, skin dark green, flesh pure white, crisp and of fine flavor. $\quad .05 \quad .10 \quad .35 \quad \$ 1.00$

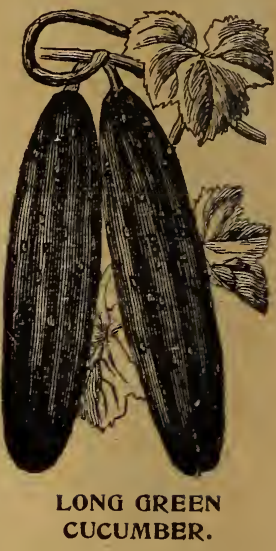

$\begin{array}{llll}.05 & .10 & .20 & .65\end{array}$

$.05 \quad .10 \quad .20 \quad .65$

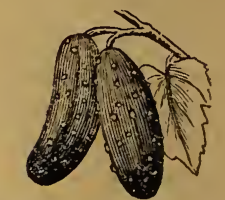

BOSTON PICKLING CUCUMBER.

Lemon. A distinct type; nearly round, with the yellow and green markings and smooth

skin of the lemon, while the flesh is exceedingly tender, crisp and sweet ...........

Long Green. Long and crisp; a popular and reliable variety for pickling...........

Boston Pickling. The finest variety to grow for pickles; yields large crops; short,

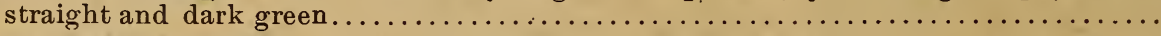

West India Gherkin. Small prickly variety; grown exclusively for pickling.......

$\begin{array}{rrrr}.10 & .15 & .50 & 1.50 \\ .05 & .10 & .20 & .65 \\ .05 & .10 & .20 & .65 \\ .05 & .10 & .35 & 1.00\end{array}$

\section{DANDELION.}

A hardy perennial plant, with broad, thick leaves, affording one of the earliest as well as one of the most healthful of spring greens. Sow as early as the weather will permit, in good, wellenriched soil, in rows twelve inches apart, covering seed onefourth of an inch deep, the earth firmly pressed over the seed. One ounce to one hundred feet of drill.

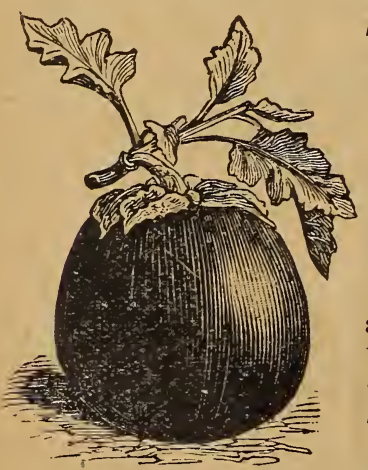

EGG PLANT.

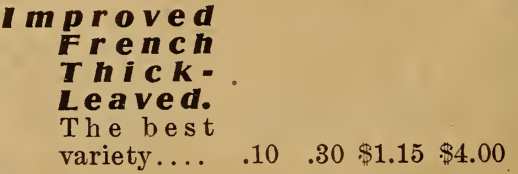

EGG PLANT.

The egg plant will thrive well in any good garden soil. Sow in the hot-bed, and when two or three inches high prick out into pots, or rows two and one-half to three inches apart. When the weather will permit, transplant into good, rich soil, thirty inches apart each way.

New York Improved Purple. The leading market variety; very

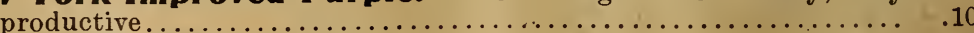

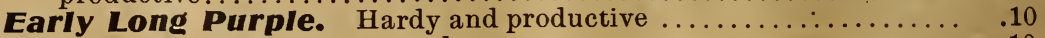

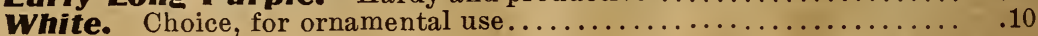

.25

.25 .25 


\section{ENDIVE.}

For early use, sow in May, scattering the seed thinly in drills ten inches apart, covering it lightly, and for a succession, every two or three weeks until mid-summer. The plants must be blanched before using, which is accomplished by gathering the large outer leaves to a point at the top, and tying them together.

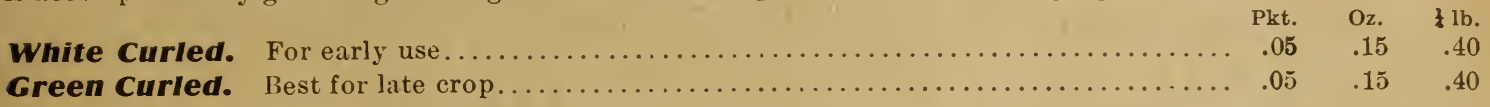

\section{KALE.}

Sow early in May in a prepared bed, covering the seed lightly. Transplant in June, and treat in the same manner as for cabbage.

Green Curled Scotch. A round dwarf variety, rarely exceeding eighteen inches in

height, but spreading out under good cultivation to three feet in diameter............ $\quad .05 \quad .10 \quad .30$

\section{KOHLRABI.}

A vegetable intermediate between the cabbage and turnip. It is best cultivated by sowing the seeds in rows, in May, June and July, according to latitude.

Early White. Flesh white and tender; the best market sort................... $05 \quad .15 \quad .40$

Early Purple. Differing from the above in color, being of a bluish purple $\ldots \ldots \ldots \ldots . .05 \quad .15 \quad .40$

\section{LEEK.}

The leek is very hardy and easily cultivated. It succeeds best in a light, well-enriched soil. Sow as early in the spring as practicable, in drills one inch deep, and one foot apart. When six or eight inches high, they may be transplanted in rows ten inches apart each way, as deep as possible, that the neck, being covered, may be blanched.

London Broad Flag. A large variety with broad leaves $\ldots \ldots \ldots \ldots \ldots \ldots \ldots \ldots \ldots \ldots$

\section{LETTUCE.}

Lettuce thrives best in rich, moist ground. Sow the seeds in hot-beds in February or March, and transplant into a sheltered border with a southern exposure. For successive crops, sowing may be made in the open ground as early as spring opens, and continuing until July.

One ounce to one hundred and twenty feet of drill.

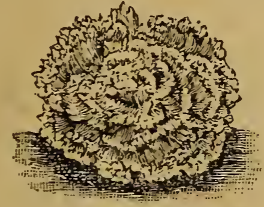

BOSTON CURLED LETTUCE.

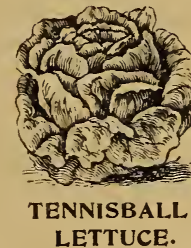

LETTUCE.

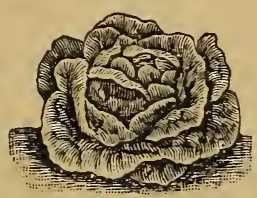

VICTORIA CABBAGE LETTUCE.

Big Boston. Fine for forcing in cold frames, and for planting in the open ground......

Boston Curled. A variety of great beauty and of very superior quality. Leaves beauti-

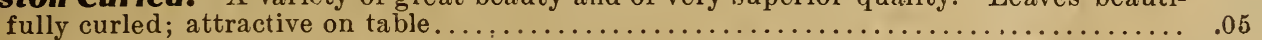

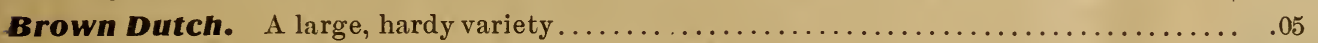

Deacon. Large and very solid heads, crisp and tender $\ldots \ldots \ldots \ldots \ldots \ldots \ldots \ldots \ldots \ldots \ldots \ldots$

Defiance. Large, solid and crisp; stands the summer heat ...................

Early Curled Silesia. Fine for summer use $\ldots \ldots \ldots \ldots \ldots \ldots \ldots \ldots \ldots \ldots \ldots \ldots \ldots \ldots$

Giant Crystal Head. Outside leaves curled, with red edges. Heads large and solid.... .05

Golden Queen. Medium sized; golden-yellow heads, tender and crisp; a fine early head

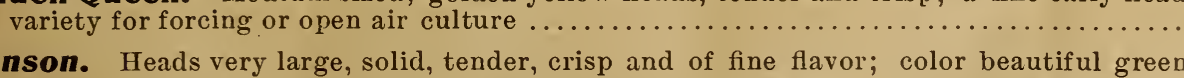

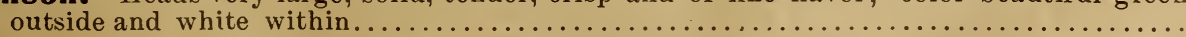

Hittinger's BeImont Forcing. Larger than the White-Seeded Tennisball, nearly as early and of excellent quality; a choice strain for forcing $\ldots \ldots \ldots \ldots \ldots \ldots \ldots \ldots \ldots$.

Iceberg. A large-heading variety; crisp and brittle, and color bright green, lightly tinged with brown on top of the head; leaves curled on the edges . . . . . . . . . . . . . . . . . .

Mignonette. Small, compact, creamy-yellow heads tinged outside with russet; of superior quality, sweet, crisp and tender, very early and hardy; excellent "all seasons" variety. . 


\section{LETTUCE-Continued.}

Salamander. A fine summer lettuce. Is slow to run to seed, and will stand the drought Pkt. Oz. $\quad$ lbs.

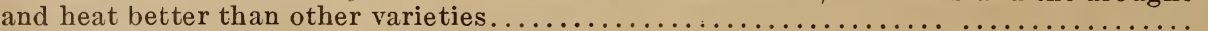

Tennisball, Black-Seeded. Popular for open-air culture; heads compact, crisp and

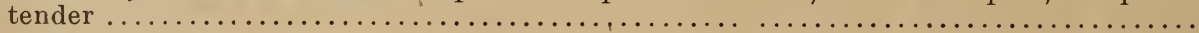

Tennisball, White-Seeded. A good early sort, used largely for forcing.............

Victoria Cabbage. Hardy and fine for early sowing $\ldots \ldots \ldots \ldots \ldots \ldots \ldots \ldots \ldots \ldots \ldots$

Victoria Pick-Edged. Outer leaves edged with pink, hearts of a pale golden tinge.

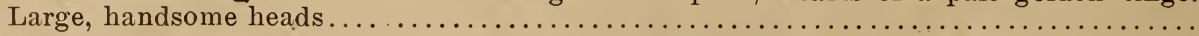

White Paris Cos. A sort with long, narrow, upright leaves; does not head, but when tied up blanches very easily

$\begin{array}{lll}.05 & .10 & .30 \\ .05 & .10 & .30 \\ .05 & .10 & .30 \\ .05 & .10 & .30 \\ & & \\ .05 & .15 & .40\end{array}$

\section{MARTYNIA.}

A strong-growing, hardy annual, with curious-shaped seed-pods, which, when young and tender, are highly prized for pickling. The pods are produced in great abundance, and should be gathered when about half grown. Plant in May or June, in rows two feet apart, making hills about a foot apart. Pkt. Oz. Martynia Probosidea. Best for pickling $\ldots \ldots \ldots \ldots \ldots \ldots \ldots \ldots \ldots \ldots \ldots \ldots \ldots \ldots \ldots \ldots . . \ldots 5.25 \quad .75$

\section{MELON-Musk.}

Melons thrive best in moderately enriched, light soil. The hills should be six feet apart each way. After all danger of frost is passed, plant twelve or fifteen seeds in each hill, and when well up, thin out to three or four plants.

One ounce to sixty hills; two to three pounds for an acre.

Emerald Gem. Medium size; flesh rich salmon, of delicious

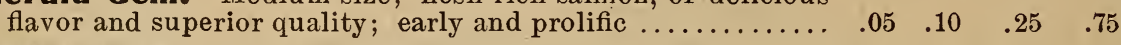

Green Citron. Fruit medium size, deeply netted, shape nearly round, flesh green, and of rich, delicious flavor............ $.05 \quad .10 \quad .25 \quad .75$

$\begin{array}{lllllll}\text { Montreal. Large, round netted; flesh thick and light green. } & .05 & .10 & .25 & .75\end{array}$

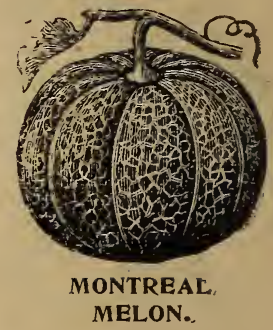

Large Round Yellow Cantaloupe. Flesh reddish orange, sweet and of good flavor;

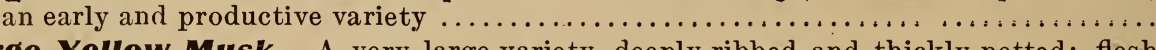

Large Yellow Musk. A very large variety, deeply ribbed and thickly netted; flesh

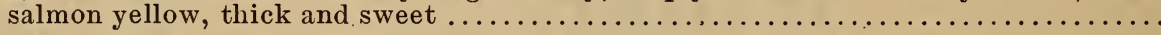

Surprise. Very early; medium size; salmon colored; flesh of superior flavor........

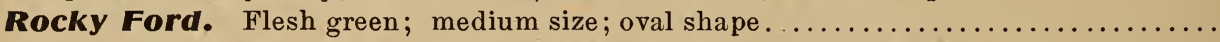

Banana. So called on account of its shape. The color is a delicate straw; flesh (the melon being nearly solid) a rich salmon. The flavor is delicious when the melons are thoroughly ripe. A fine early variety

$\begin{array}{llll}.05 & .10 & .25 & .75 \\ .05 & .10 & .25 & .75 \\ .05 & .10 & .25 & .75 \\ .05 & .10 & .25 & .75\end{array}$

\section{MELON-Water.}

Plant in hills eight feet apart and cultivate same as musk melon. One ounce for thirty hills; four to five pounds to the acre.

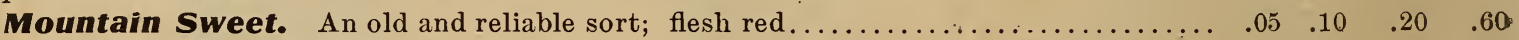

$\begin{array}{llllllllll}\text { Black Spanish. Fruit of large size, almost round; skin dark green, flesh red . . . . . } & .05 & .10 & .20 & .60\end{array}$

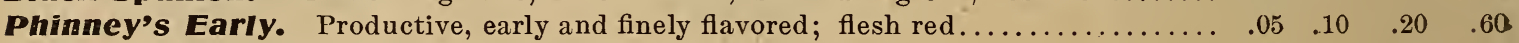

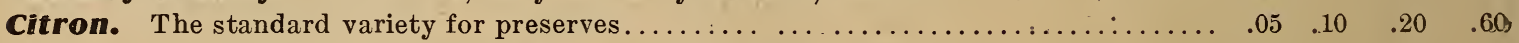

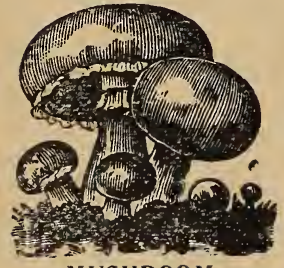

MUSHROOM.

\section{MUSHROOM SPAWN.}

Mushrooms may be grown in a warm cellar or shed in winter, or in the open air ir summer. Take partially dry, fresh horse manure and lay it in a heap to ferment; turn. and mix it well every few days, and when well fermented, it may be made into a bed, mixing it well together and beating or treading it firmly. Use a thernometer to thrust into the bed, and note the temperature. When the heat has partially subsided; leaving a temperature of $70^{\circ}$ to $80^{\circ}$, put in the spawn, which may be inserted in pieces the size of a walnut, about two inches deep and six inches apart. After about two weeks, cover with fresh soil about two inches deep and beat it down evenly and firmly. Finish off with a covering of clean straw or hay about a foot thick. If the temperature is right, mushrooms will begin to come up in about six to eight weeks, and the bed will continue bearing for about a month. One pound of spawn is sufticient for a bed $2 \times 6$ feet.

\section{English Spawn} In bricks, per lb., 12 cts.; 10 lbs., $\$ 1.00$

By mail, add eight cents per pound for postage, and for larger shipments by mail, see rates.on page 3 of this Catalogue.

\section{MUSTARD.}

A pungent salad used with cress. The seed is used for flavoring pickles, etc. Sow in May thickly in rows and cut when two or three inches high.

One ounce to forty feet of drill.

White London. Best for salads. 


\section{OKRA.}

Sow late in the spring, after the ground has become warm, in drills three feet apart, where the plants are to remain. Thin out from nine to twelve inches. They should be well manured. They may also be raised in pots, or in a hot-bed, and transplanted.

Improved Dwarf Green. Small, green, round, smooth pods.

Pkt. Oz. $\quad$ l lb.

\section{ONION.}

No vegetable is more extensively known and cultivated than the onion. A good crop is impossible unless the soil is very rich and kept clean. Use well-rotted manure freely, and get the crop in as soon as possible in the spring, no matter if the weather is cold and unpleasant. Sow in drills one foot apart and cover about one-tliird of an inch, treading or rolling after sowing, so that the hot, dry atmosphere may not dry up and destroy the sprouting seed.

One ounce to one hundied feet of drill; five pounds to the acre.

Early Yellow Cracker. Flat, early onion, of mild Pkt. Oz. \&lb. Lb. and delicate flavor, and a good keeper......... .05 $\quad .15 \quad .50 \quad \$ 1.75$

"K. \& W." YELLOW GLOBE DANVERS. EXtra choice Maine grown seed, the most popular of all the yellow onions for market and home use. Uniform in shape, heavy cropper, good keeper, and of fine, mild flavor. A profitable variety for market gardeners ......................... .05 $\quad .25 \$ 1.00 \quad 3.25$

Yellow Globe Danvers. Grown from selected stock; a standard variety .................... $05 \quad .15 \quad .35 \quad 1.25$

Large Red Wethersfield. Large size, productive and a good keeper........................ 05 .15 $\quad .35 \quad 1.25$

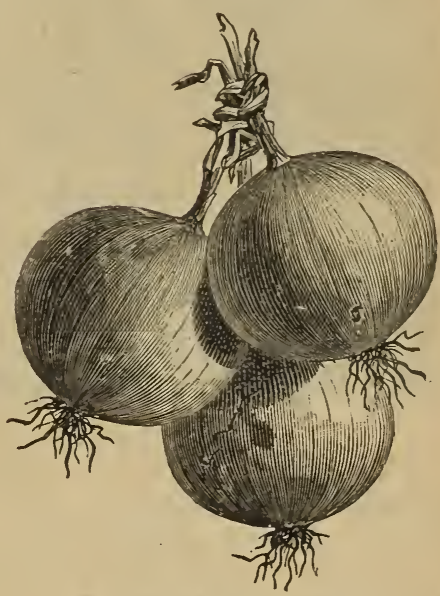

YELLOW GLOBE DANVERS ONION.

Extra Early Red Globe. Ten days earlier than the Wethersfield, of medium size and deep, rich color; an abundant producer, and of good form and flavor, keeping well. .

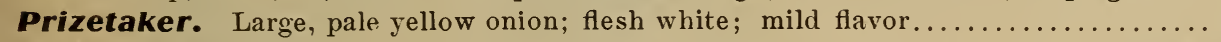

White Portugal. A mild and desirable summer variety; extensively grown for pickling. New Queen. A silver-skinned variety, of quick growth and remarkable keeping qualities . Red Globe, Southport. Flesh fine grain,mild and tender; matures quite early; good size White Globe, Southport. Clear white skin, large, globe-shaped; heavy yielder and

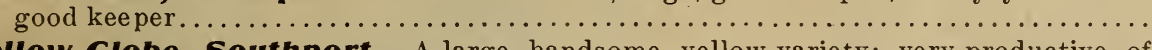

Yellow Globe, Southport. A large, handsome, yellow variety; very productive, of

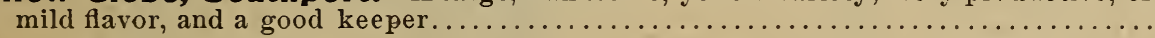

$\begin{array}{llll}.05 & .15 & .35 & 1.25 \\ .05 & .15 & .50 & 1.75 \\ .05 & .20 & .60 & 2.00 \\ .05 & .20 & .60 & 2.00 \\ .05 & .15 & .50 & 1.50 \\ .05 & .20 & .60 & 1.75 \\ .05 & .15 & .50 & 1.50\end{array}$

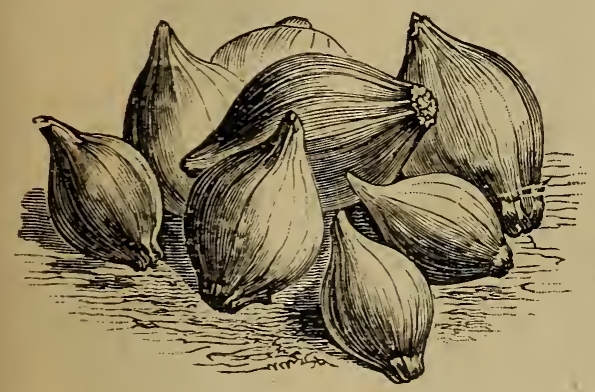

ONION SETS.

\section{ONION SETS.}

Onion sets should be planted near the surface as early in the spring as the ground will permit, in drills about twelve inches. apart and four inches in the rows. They produce a very early and profitable crop, and grow in any good soil.

Add ten cents per quart if sent by mail, and for larger shipments by mail, see rates on page 3 of this Catalogue. (Eight cents per pound.)

White Onion Sets . . . . . . . . . . . . . . .15 $\$ 1.00$

Yellow Onion Sets .................... .15 .90

For larger quantities, prices will be given on application.

\section{PARSLEY.}

Parsley requires rich, mellow soil; sow thickly in drills, one foot apart and half an inch deep. As tlie seed germinates slowly, it is best to soak it for a few hours in tepid water before sowing. For winter use protect in a glass frame or light cellar.

One ounce to one hundred and fifty feet of drill.

Extra Double Curled

Pkt. Oz. \$lb.

Fern Leaved

$.05 \quad .10 \quad .20$

$.05 \quad .10 \quad .20$

\section{PARSNIP.}

Sow as early in the spring as the weather will admit, in drills fifteen inches apart, covering half an inch deep. When well up thin out to five or six inches apart in rows. Unlike carrots, they are improved by frosts, and it is usual to take up in the fall a certain quantity for winter use, leaving the rest in the ground until spring, to be dug as required.

One ounce to two hundred feet of drill; five pounds to the acre. 


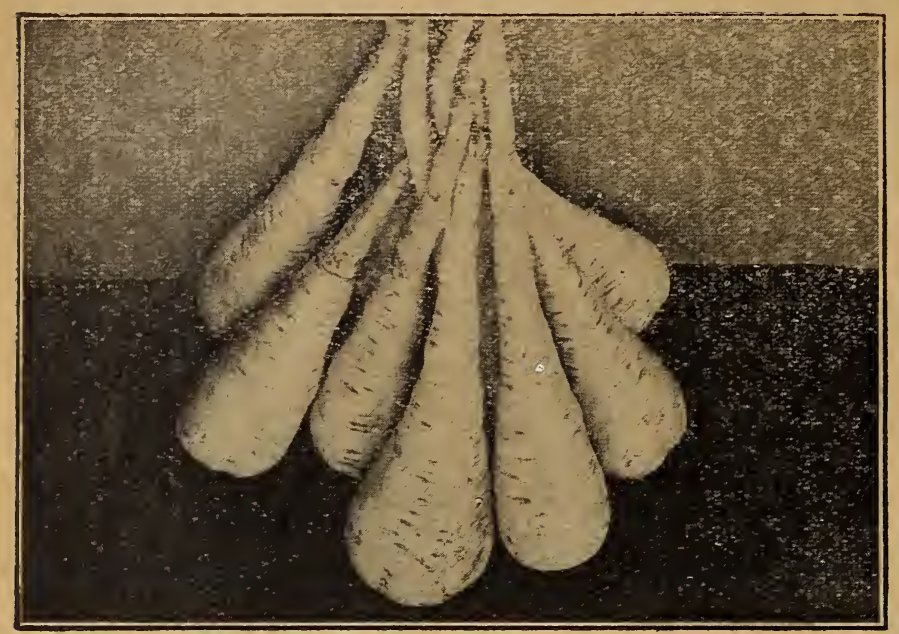

PARSNIP-Continued.

DON PARSNIP.

Abbott's Improved.

Smooth and quite

large; one of the best

$.05 \quad .10 \quad .20$

.50

Hollow $\boldsymbol{C}$ ro w $\boldsymbol{w}$.
Roots very long, growing mostly below the surface of the ground ..........

.05

.50

\section{PEAS.}

Peas, for an early crop, should be sown as soon as the ground is in working condition. The soil for their reception should be light, dry and well sheltered. Mild manure, such as leaf mold, has a beneficial effect; but for many of the varieties the soil cannot be too rich. For general crops, the ground should be well manured the previous year, which causes them to yield more abundantly. When grown as a market crop, peas are never staked, and are sown in single rows, two or three inches deep, and from two to three feet apart, according to the variety or strength of the soil. When grown in small quantities for private use, they are generally sown in double rows, six or eight inches apart, and the tall varieties staked up by brush.

One quart to seventy-five feet of drill; from one to two bushels to the acre.

Peas ordered by mail are subject to an extra charge of fifteen cents per quart for postage. Pints furnished at quart rates. For larger quantities by mail. see rates on page 3 of this Catalogue. (Eight cents per pound.)

D O N. A variety Pkt. $\mathrm{Oz}$ lb. Lb. selected for h a $n$ d $s$ om e form, size, whiteness of skin and flesh, and solidity of texture. Specially recomme nd ed for market trade.

Arlington Long White. Roots very. long and smooth; on ef the best for market gardeners....
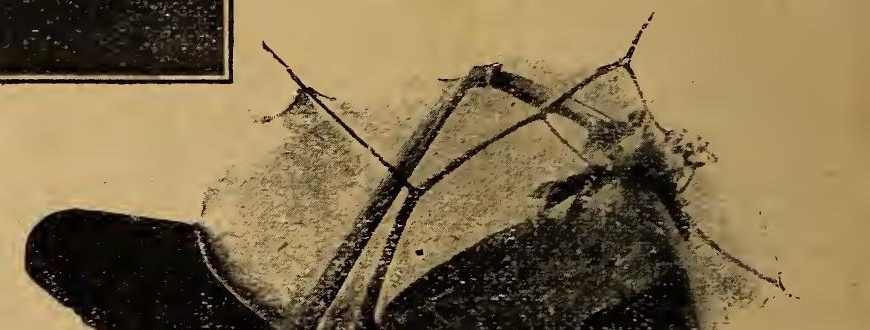
GRADUS. One of the earliest large-podded peas grown, being extra early. combining quality, size and productiveness. Produces healthy, vigorous vines two and one-half feet high, bearing well-developed pods, containing peas of fine flavor.

Early Morn. Of Gradus type. Early, with large pods, and peas of good flavor; 3 feet .

THOMAS LAXTON. One of the best early wrinkled varieties, closely resembling the Gradus in size; pods large and well filled with peas of finest flavor. Hardy and extremely productive

NOTT'S EXCELSIOR. Robust and vigorous in growth, producing handsome pods, closely packed with large peas of fine flavor. An improvement on American Wonder, being more vigorous and prolific; height, 12 inches

SUTTON'S EXCELSIOR. Same habit of growth as Nott's Excelsior, bearing larger pods, filled with large peas, tender and of most delicious flavor, and produced in greater abundance.

LAXTONIAN. One of the earliest large, wrinkled peas. Vines are vigorous, growing about eighteen inches high; large, even-sized, deep green pods, long and curved; peas of fine quality. inches high; dark green pods, often growing in pairs; very prolific

Carter's Daffodil. A dwarf pea of the rich color of the later types. Vine of bushy habit, and about eighteen inches high. Peas of fine quality.

Cleveland's Alaska. A fine blue-seeded, extra early pea, with dark green colored pods; uniform in growth and almost entirely free from sports or runners; height, $2 \frac{1}{2}$ feet...

"K. \& W." Extra Early. A variety similar to, but an improvement upon, the Alaska, being fully as early, but bearing larger pods; height, about 2 feet.

Cleveland's Eclipse. This pea is a very early variety, a vigorous grower and a large producer, with pods of good size and true American Wonder in shape. Seeds green and wrinkled and of sweet and delicious flavor; height, 2 feet. . .

Bliss' American Wonder. One of the earliest wrinkled sorts; grows about 9 inches

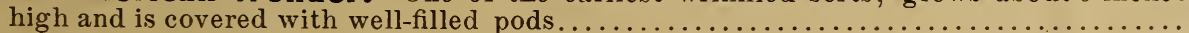

McLean's Little Gem. A dwarf green, wrinkled sort of superior flavor; 1 foot.......
Carter's Premium Gem. A very fine dwarf, wrinkled pea, an improvement on Little Gem; 1 foot.

Carter's First Crop. An extra early, smooth variety; $2 \frac{1}{2}$ feet..

Maud S. One of the earliest smooth peas; 21 feet.

\section{Second Early.}

Dwarf Telephone. A choice variety with dwarf vines, bearing large, handsome pods, with peas of fine quality. Vine eighteen inches high, stocky, healthy and vigorous, with almost no tendency to sport.

Heroine. A medium early, green, wrinkled variety; pods remarkably long and handsome, slightly curyed, well filled with large peas; 2 feet well fild Advancer. A second early, green, wrinkled, market variety; pods long and well filled with peas of fine flavor; 2 feet. . . . . . . . . . . . . . . . . . . . . . . . . . . . .

Horsford's Market Garden. An excellent wrinkled variety, productive and of good quality; 2 feet.

Carter's Quite Content. Pods longer and larger than any other second early variety. Vines and pods deep green, large peas of excellent flavor. Recommended for market gardeners. Height, 3 to 4 feet.

\section{For General and Late Crop.}

PRINCE EDWARD. A favorite of the extra large-podded varieties. Vines about four and one-half feet high. Pods are large, filled with enormous peas of tender, sweet and excellent flavor....

ADMIRAL DEWEY. A variety entirely distinct from any pea yet grown. Foliage, vine and pods rich, dark green. Healthy and vigorous, producing pods of large size, filled with peas of splendid flavor. One of the best of all long-vine, large-podded peas; height, 3 1-2 feet........

$.25 \quad 1.75 \quad 6.00$

CARTER'S IMPROVED TELEPHONE. An improvement on Carter's Telephone for PURITY and Uniformity of HABITS, being true to name, showing no tendency to small, late pods, but bearing in great abundance LARGE, HANDSOME, FINELY FORMED PODS, from five to six inches in length. A superior wrinkled variety; height, 3 feet.........

Duke of Albany. Resembling Telephone in appearance; vine more dwarf; height, $2 \frac{1}{2}$

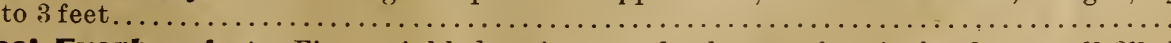

Bliss, Everbearing. Fine wrinkled variety; pods three to four inches long, well filled

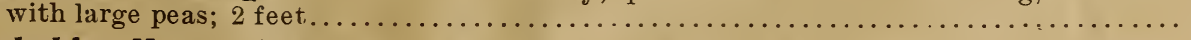

Yorkshire Hero. A green, wrinkled variety, of branching habit and fine flavor; $2 \frac{1}{2}$ feet. 


\section{PEAS-Continued.}

Sutton's Dwarf Defiance. Very productive. Pods handsome, long, straight, dark

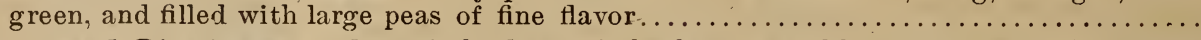

Improved Stratagem. One of the best of the large, wrinkled varieties, with pods of immense size, uniformly filled with very large, dark green peas of the finest quality; 2 feet

Champion of England. A well-known popular variety, unsurpassed in flavor, and very

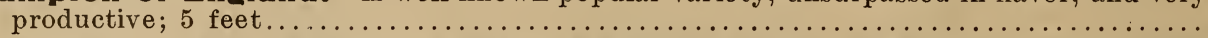

AUTOCRAT. Late variety. A very strong grower, quite free from mildew; very productive, with handsome, long dark green pods. Ex-

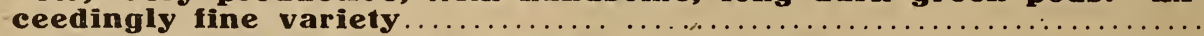

Mammoth Podded Sugar (Edible Pods). Broad pods; cooked as string beans they

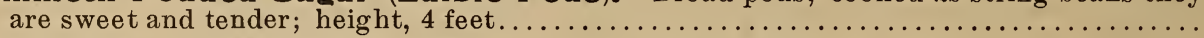

Royal Dwarf White Marrowfat. One of the best late sorts; white seeded; very pro-

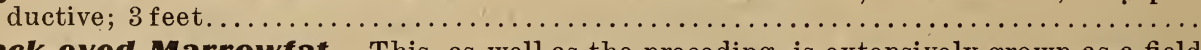

Black-eyed Marrowfat. This, as well as the preceding, is extensively grown as a field pea; hardy and productive; 4 feet. . . . . . . . . . . . . . . . . . . . . . . . . . . .

White Canada Field. Valuable for sowing with oats for green fodder; excellent for

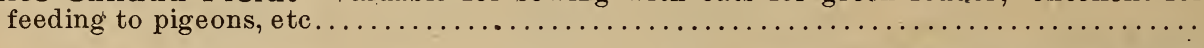

$\begin{array}{lll}\text { Qt. } & \text { Pk. } & \text { Bu. } \\ .25 & 1.8 .5 & 6.75 \\ .25 & 1.8 .5 & 6.75 \\ .25 & 1.6 .5 & 5.50 \\ & & \\ .25 & 1.75 & 6.25 \\ .35 & & \\ .15 & 1.15 & 4.00 \\ .15 & 1.15 & 3.75 \\ .10 & .70 & 2.50\end{array}$

For a larger and better yield inoculate peas with Farmogerm. See page 42. PEPPER.

Grown largely for pickles. Sow in hot-beds early in April and transplant to the open ground when the weather is warm and settled. The rows should be two feet apart and the plants fifteen inches apait in the rows. Rich, warm, mellow soil.

One ounce of seeds will produce about 2,000 plants.

Iarge Bell. Pkt.

Sweet Mountain or Mammoth. Similar to the Bell, but larger $\ldots \ldots \ldots \ldots \ldots \ldots \ldots \ldots \ldots \ldots$

Large Squash. Productive; much used for pickles . . . . . . . . . . . . . . . . . . . 05

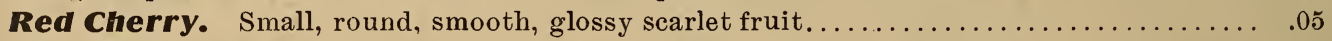

Long Red Cayenne. Bright red; very productive $\ldots \ldots \ldots \ldots \ldots \ldots \ldots \ldots \ldots \ldots \ldots \ldots \ldots$

Oz. $\frac{1}{2} \mathrm{lb}$. $.20 \quad .65$ $.20 \quad .65$ $.20 \quad .65$ $.20 \quad .65$ $.20 \quad .65$

\section{POTATOES.}

\section{"ALL OUR STOCK IS GROWN IN MAINE."}

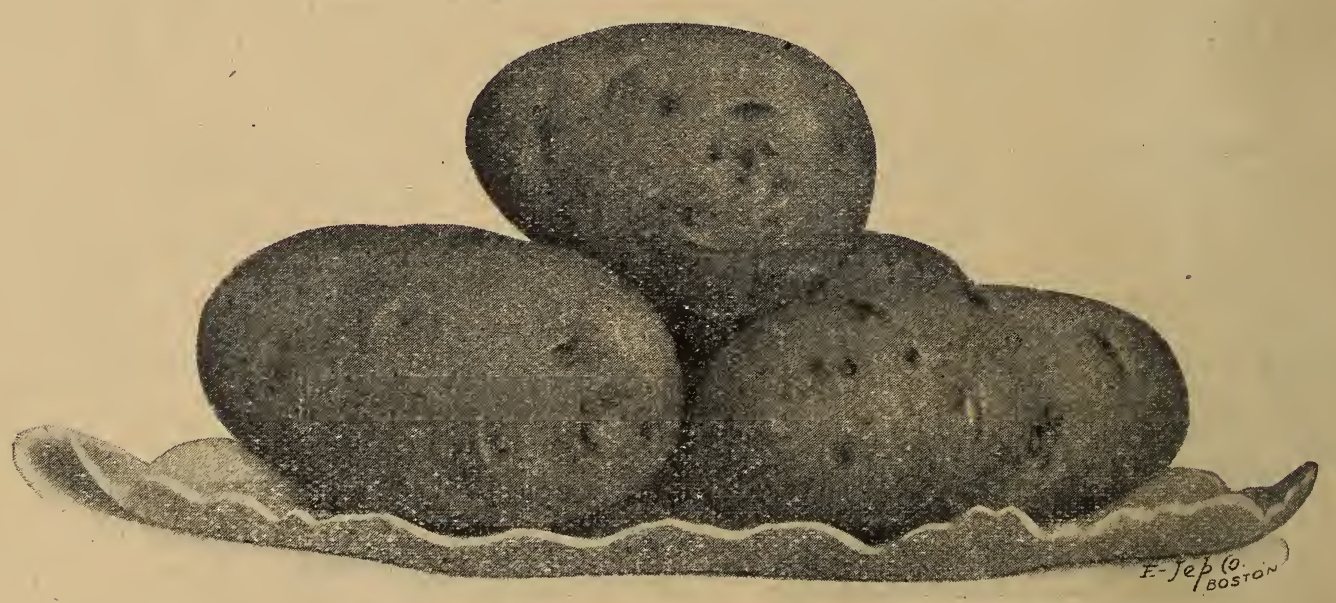

Prices quoted on application.

Sunlight. An extra early market variety, medium size, oval or oblong in shape, color very white; a handsome potato, of good quality.

Extra Early White Rose. As near perfection as any white potato grown, and one of the most reliable for earliness, quality, and productiveness. Is uniform in size and shape, being oblong, with roundish seed end, and smooth surface. A grand general crop variety.

Noroton Beauty or Quick Lumch. One of the earliest potatoes. Is white in color and uniform in size and shape. Its table quality is excellent.

Early White Ohio. Extra early white potato, with pinkish eyes, skin slightly streaked with pink, smooth and round, rather long in shape.' A good keeper and excellent cropper.

Irish Cobbler. One of the most reliable of the early varieties. Cream-white color, vigorous grower, ripens uniformly, and a good keeper.

Early Harvest. Extra early, large yielder; superb quality. The tubers average large size. A desirable early variety. 


\section{POTATOES-Continued.}

Early Rose. The pioneer of all the improved varieties, still very popular and highly esteemed.

Gold Coin. Tubers are of a desirable size, in form slightly oblong, rather broad and quite thick, skin smooth, and of a light golden tint, sufficient to inake them distinct from the white-skinned varieties; flesh pure white.

Improved Green Mountain. Improved by careful selection of seed. In season it is medium; one of the best yielders, and keeps well; color white, form round or oval, smooth skinned and a heavy yielder.

Norcross. Large white potato; flat, oval, and perfect in shape; very fine in quality, and a large yielder.

\section{PUMPKIN.}

Same cultivation as for cucumbers and melons.

Large Cheese. Medium size; best for cooking. .

Pkt. Oz. \&lb. Lb.

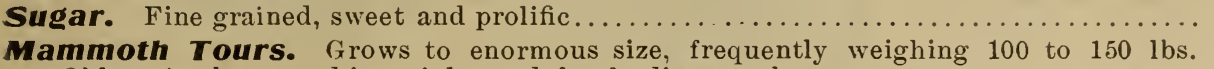

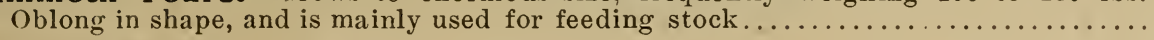

Connecticut Field. Large; used for stock.

$\begin{array}{llll}.05 & .10 & .20 & .60 \\ .05 & .10 & .20 & .60 \\ & & & \\ .05 & .10 & .30 & .90 \\ .05 & .10 & .15 & .35\end{array}$

\section{RADISH.}

Radishes thrive best in a light, rich, sandy loam; heavy or clayey soils not only delay their maturity, but produce crops much inferior, both in appearance and flavor. For a successive supply, sow from the middle of A pril until September, at intervals of two or three weeks. For an early supply they may be sown in a hot-bed in February.

One ounce for one hundred feet of drill.

Non PIus UItra. The earliest forcing radish; extra early, Pkt. Oz. llb. Lb. maturing in about twenty days; round, bright red, with

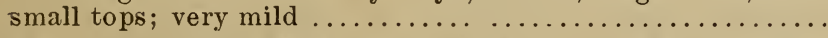

Crimson Giant Forcing. Rich crimson color; flesl white and solid, and of a mild delicious flavor. Grows to a large size $\begin{array}{lllllll}\text { without becoming pithy. Excellent for forcing } \ldots \ldots \ldots \ldots \ldots & .05 & .10 & .20 & .50\end{array}$

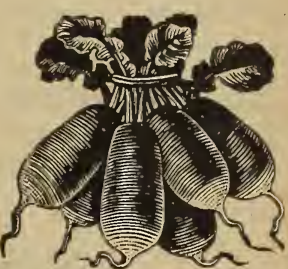

FRENCH BREAKFAST RADISH.

Early Scarlet Turnip (white tip). Handsome bright scarletcolor, with white tip. $\quad .50 \quad .10 \quad .20 \quad .50$

Long Scarlet Short Top. Very long and crisp; for frames or open ground ..... $\quad .05 \quad .10 \quad .20 \quad .50$

Early Scarlet Turnip. Round, scarlet, small, short top; mild and crisp........ $\quad .05 \quad .10 \quad .20 \quad .50$

French Breakfast. A variety of quick growth; very mild and tender. One of the

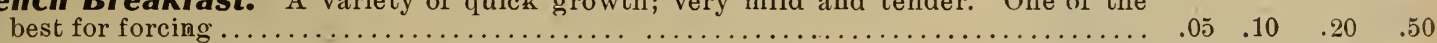

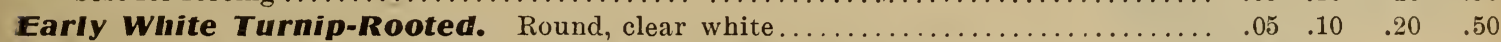

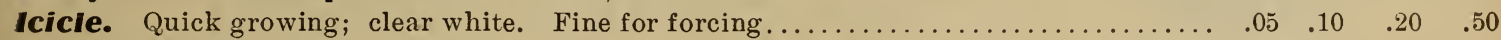

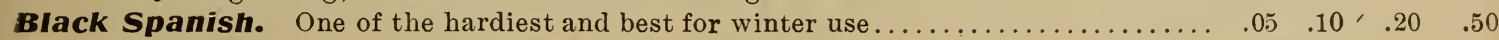

\section{SALSIFY.}

Commonly called vegetable oyster. Used stewed, boiled or fried. When cooked has an oyster flavor. Sow early in drills fifteen inches apart; cover the seeds with fine soil, an inch and a half deep.

One ounce to fifty feet of drill.

Pkt. Oz. $\frac{1}{6} \mathrm{lb}$ L Lb.

Long White French

$.05 \quad .10 \quad .35 \quad \$ 1.25$

\section{SPINACH.}

Sow early in the spring, in drills a foot apart, every two weeks for a succession, and as it grows, thin out for use. For fall use sow in August, and for winter crops in September. Cover that which is left out over winter with straw or leaves, after the weather becomes quite cold.

One ounce to one hundred feet of drill; ten to twelve pounds per acre.

Victoria. A variety producing large, thick leaves of fine color and quality. Especially recommended for market gardeners

Round Thick-Leaved. A valuable variety, with thick, dark green leaves; long stand-

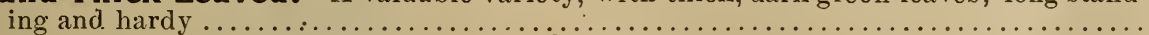

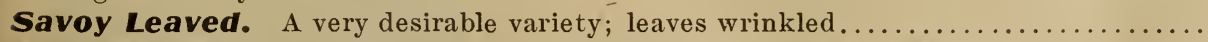

Long Standing. Dark green; the longest standing before going to seed

Fall or Winter. One of the hardiest for fall planting.

Pkt. Oz. \&lb. Lb.

New Zealand. Of branching habit, makes a very large plant, which stands drouth

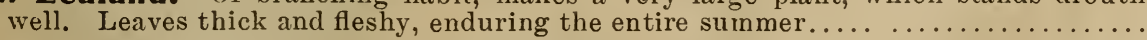

$.05 \quad .10 \quad .25$

.05

$.05 \quad .10 \quad .25$

$.05 \quad .10 \quad .25$

$.05 \quad .10 \quad .25$

$.05 \quad .10 \quad .25$

Market gardeners, and others using large quantities, are requested to write for special quotations.

\section{SQUASH.}

Any good, rich soil is adapted to the growth of the squash. They only thrive well in a warm temperature. as all the varieties are tender annuals, and the seed should not be sown in the spring until all danger from frost is past and the ground is warm and thoroughly settled. The hills for bush varieties should be about six feet apart; for running sorts, ten feet. Leave two plants to a hill.

Running varieties, one ounce to fifteen hills; four pounds per acre. Bush varieties, one ounce to fifty hills. 


\section{SQ UASH-Continued.}

DELICIOUS. In color it closely follows the Hubbard, and in thickness of flesh it surpasses nearly every variety. No squash compares with it in fineness and compactness of grain, dryness and sweetness and richness of flavor. It is a fall and winter squash, but does not acquire its best qualities until winter. Per Pkt., 5c.; Oz., 10c.; 1.4 1b., 30c.: Lb., \$1.00.

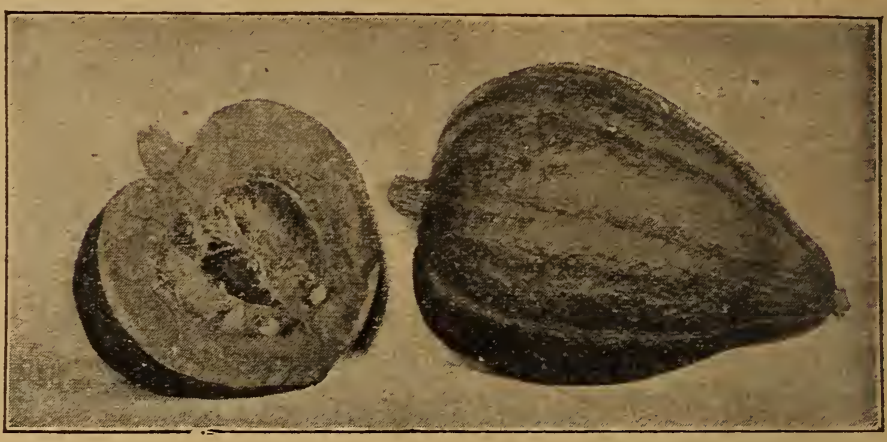

DELICIOUS SQUASH.

Hubbard. Standard winter squash, a general favorite and grown more extensively than any other late variety; color dark green, shell extremely hard; flesh dry, fine-grained

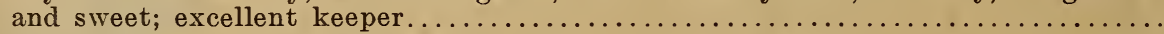

Golden Hubbard. Similar to Green Hubbard, of a rich orange-red color, and of fine flavor Warted Hubbard. Dark green color, shell hard and warted, good keeper........... Early Prolific Marrow. For fall and winter use this is a very desirable sort. Is of

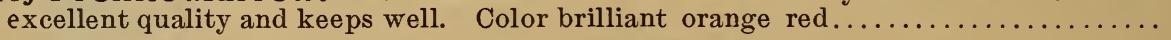

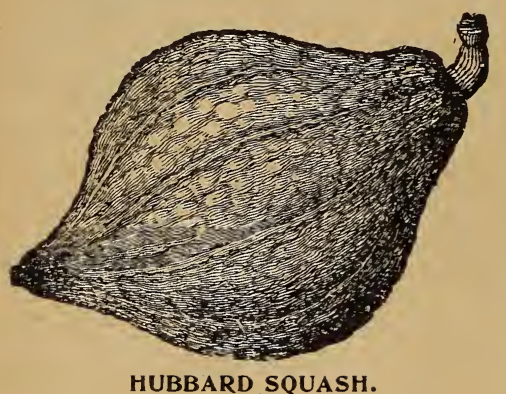

HUBBARD SQUASH.

Boston Marrow. A much esteemed variety; a good keeper and of excellent flavor........

Yellow Bush Scalloped.' An early market variety; excellent for shipping.............

Summer Crook-Neck. Early, productive, and of good quality; color orange yellow.........

Winter Crook-neck. A n o ld, well-known variety; hardy and a good keeper..........

Mammoth Chili. Grows to a large size, often weighing over two hundred pounds; excellent

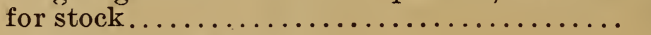

\section{TOMATO.}

This vegetable is one of the most important of all garden products. They thrive best in a warm, light, rich soil. For early plants, sow about the first week in March in a hot-bed, or in boxes or pots in a warm window. When the plants are about two inches high, set out in boxes, three inches deep and four inches apart, in the same temperature, or pot singly. If again transplanted before setting out, the plants will be still more stocky. Set out in the open ground about the first of June, four feet apart each way, using a shovelful of rotted manure in each hill.

One ounce for 1,500 plaints.

EARLIANA. The earliest large tomato. Its large size, handsome shape, beautiful red color and fine quality are unsurpassed by any of the best early and medium sorts.

$\begin{array}{lll}\text { Pkt. } & \text { Oz. } & \frac{1}{\mathrm{l} l \mathrm{~b}} \\ .05 & .20 & .65 \\ .05 & .30 & .90 \\ .05 & .30 & .90 \\ .05 & .20 & .65 \\ .05 & .20 & .65\end{array}$

$.05 \quad .20 \quad .60$

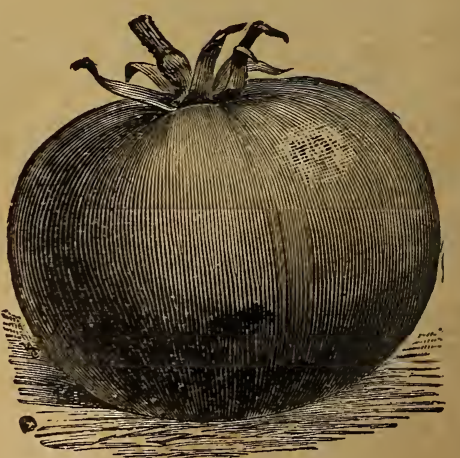

EARLIANA TOMATO.

Livingston's Beauty. Color very glossy crimson;
grows in clusters of four or five; fruit large and solid ish and slightly flattened at stem end Early, prolific, and uniform in shape and size........

Scarlet GIobe. Brilliant scarlet, ripens evenly, is smooth, round, a vigorous grower, and a most desirable table and canning variety............

Table Queen. Early, smooth, bright red color; flesh very solid; fine table variety.............

Fordhook. Extra early; perfectly smooth and

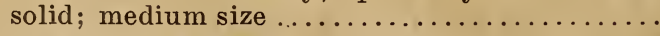
vingston's Favorite. Productive; good flavor; few seeds; flesh solid, smooth and

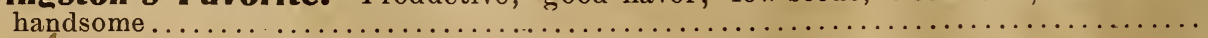

Livingston's Perfection. Early, large, smooth and solid; blood red color........... 05

Dwarf Champion. Dwarf variety; fruit medium size, resembling the Acme in color... .05 $.20 \quad .60$ $.20 \quad .60$ $.20-\quad .65$ 
TOMATO-Continued.

Dwarf Stone. The largest fruited of the dwarf varieties, the fruit being of a bright scar-

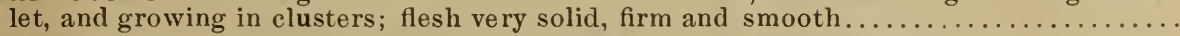

Red Cross. Early, very smooth and even in size throughout the season..............

Red Cherry. A small early variety; size and shape of a cherry; for pickling ..........

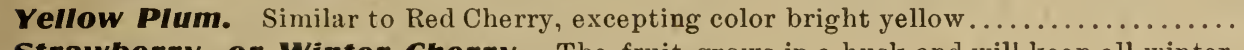

Strawberry, or Winter Cherry. The fruit grows in a husk and will keep all winter.

It has a pleasant strawberry-like flavor, and is much used for preserving, also for sauce.

Pkt. Oz. $\quad \frac{1}{\mathrm{llb}}$.

$.05 \quad .20 \quad .65$

$.05 \quad .20 \quad .65$

$.05 \quad .20 \quad .65$

$.05 \quad .20 \quad .65$

$.05 \quad .20 \quad .65$

The following varieties at a uniform price of 5c. per pkt.; 20c. per oz.:

Royal Red, Stone, Essex Hybrid, Acme, Trophy, Paragon, Early Ruby, Canada Victor, Dwarf Aristocrat, Lorillard, Ponderosa.

\section{TOBACCO SEED.}

Connecticut Seed Leaf

.05

.25

.85

\section{TURNIP.}

Turnips thrive best in rich, sandy, gravelly soil. The earliest varieties can be sown as soon as the ground can be worked, either in drills or broadcast. For a succession, sow at intervals of a fortnight until the last week in July for the fall and main crops.

One ounce for one hundred and fifty feet of drill; one to two pounds in drill to the acre.

To keep the roots fresh during the winter, they may be placed in a cool, dry cellar and buried with dry sand.

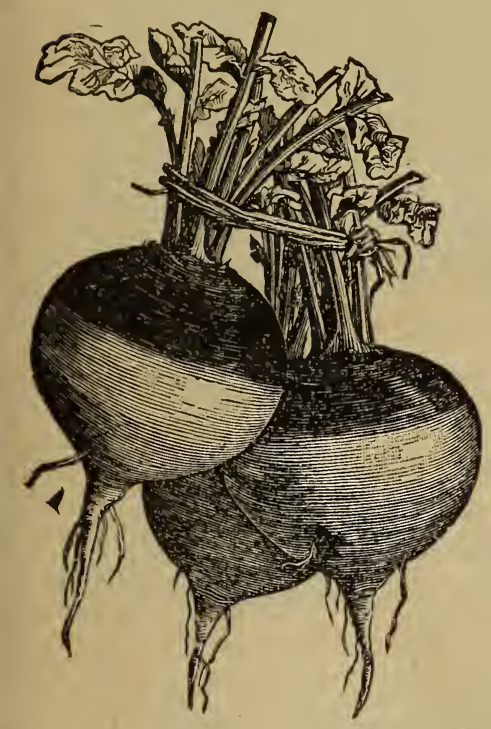

CARTER'S IMPERIAL HARDY SWEDE.

Purple-Top Milan. The earliest variety in cultivation. Flesh white, hard, and of excellent

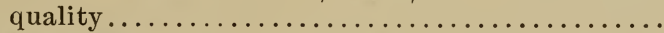

White Eg.. Oval; handsome and sweet..........
Purple-Top Strap Leaf. Best variety for main crop, equally good for spring or fall sowing;

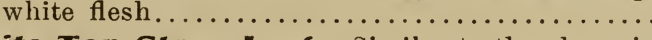

White-Top Strap Leaf. Similar to the above in

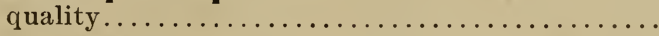

Yellow Stone. Fine, hard winter sort..........

Early White Six Weeks. Pure white; very early

Long White or Cow Horn. Flesh white, finegrained and sweet, and of excellent quality......

Golden Ball. A rapid grower of excellent flavor; bright yellow, good keeper, and a superior table

Yellow Aberdeen. An excellent hardy variety,

$\begin{array}{llllll}\text { keeping well through the winter............. } & .05 & .08 & .15 & .50 \\ \text { Sweet German. White, sweet and a good keeper } & .05 & .08 & .15 & .50\end{array}$

Pkt. Oz. $1 \mathrm{lb}$. Lb.

$\begin{array}{llll}.05 & .08 & .20 & .70\end{array}$

$\begin{array}{llll}.05 & .08 & .15 & .50\end{array}$

$\begin{array}{llll}.05 & .08 & .15 & .50\end{array}$

$\begin{array}{llll}.05 & .08 & .15 & .50\end{array}$

$\begin{array}{llll}.05 & .08 & .15 & .50\end{array}$

$\begin{array}{llll}.05 & .08 & .15 & .50\end{array}$

$\begin{array}{llll}.05 & .08 & .15 & .50\end{array}$

$.05, .08 \quad .15 \quad .50$

$\begin{array}{llll}.05 & .08 & .15 & .50\end{array}$

RUTA BAGA Or SWEDE TURNIP.

Carter's Imperial Hardy Swede. An improvement upon the other varieties, being larger, the flesh firmer, and an excellent keeper........

Skirving's Purple-Top. A standard variety; hardy and productive............................

\section{SWEET AND · MEDICINAL HERBS.}

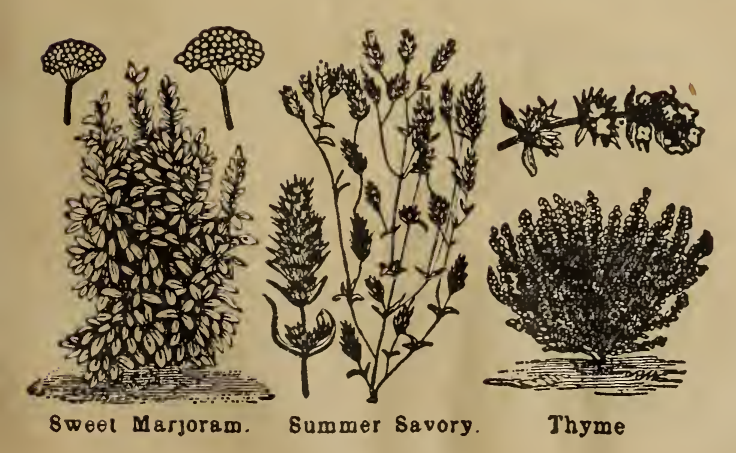

Sow in spring, in shallow drills, one foot apart and when well up thin out or transplant to a proper distance apart.

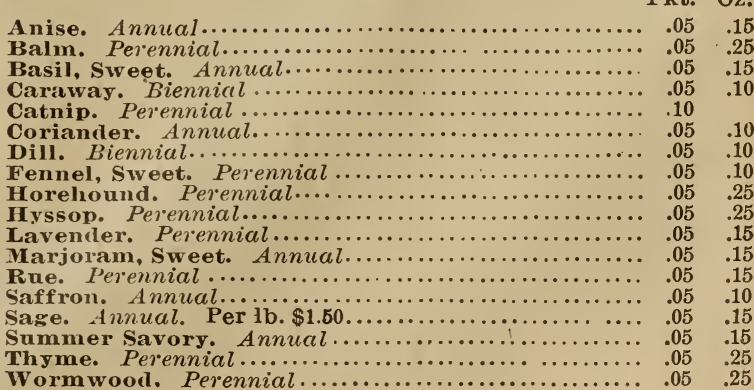




\section{FORAGE SEEDS, GRAINS, ETC.}

At the Lowest Market Rates and of the Best Quality.

WHEAT, RYE, BARLEY, OATS AND BUCKWHEAT. Early Green Soja Beans.

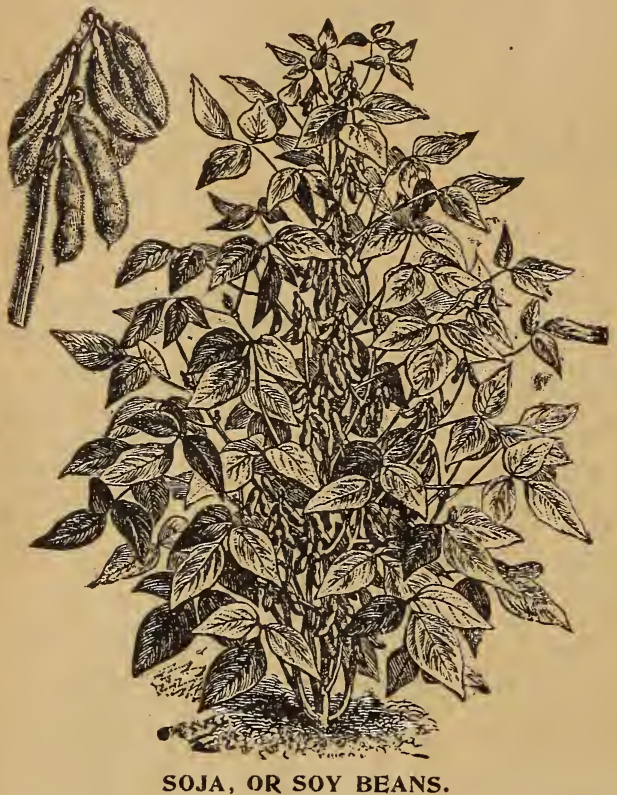

SOJA, OR SOY BEANS.

An excellent variety for planting in northern and eastern states. Ripens early and produces an enormous crop of both vines and pods. Valuable as a forage crop, and for fertilizing the soil, also for pasturing, feeding as green fodder, and for silo purposes. Sow one-half bushel to the acre.

Per qt., 20 cts. Per pk., \$1.15. Per bu., $\$ 4.00$.

\section{Vetches or Tares.}

Spring Vetches.-Highly valuable for soiling or for green manuring. Sometimes grown with oats, for mowing and feeding to stock. Use 120 to $180 \mathrm{lbs}$. to acre broadcast, or 60 to $120 \mathrm{lbs}$. in drills. Per lb., 8 cts. Per 100 lbs., $\$ 6.00$.

Winter Vetches.-Also called Sand Vetch, or Hairy Vetch. Recommended for fall sowing with rye, which serves as a support. It is perfectly hardy in all parts of the country, can be harvested or plowed under, and the ground used for the usual spring crop. Sow $60 \mathrm{lbs}$. of the seed per acre, together with one-half bushel of rye.

Per lb., 15 cts.

Per $\$ 1.00$ lbs., $\$ 12.00$.

\section{Early Dwarf Essex Rape.}

A forage plant of great merit, easily grown in any locality, and one of the most satisfactory quick-growing crops, especially for sheep.

As a fattening food for sheep, cattle, calves or pigs, it is without a rival in point of cheapness, is hardy, withstands drought, and will produce a crop in any soil. The seed may be sown from May to July, 10 to 12 pounds per acre.

Per lb., 10 cts. Per 100 lbs. $\$ 7.00$.

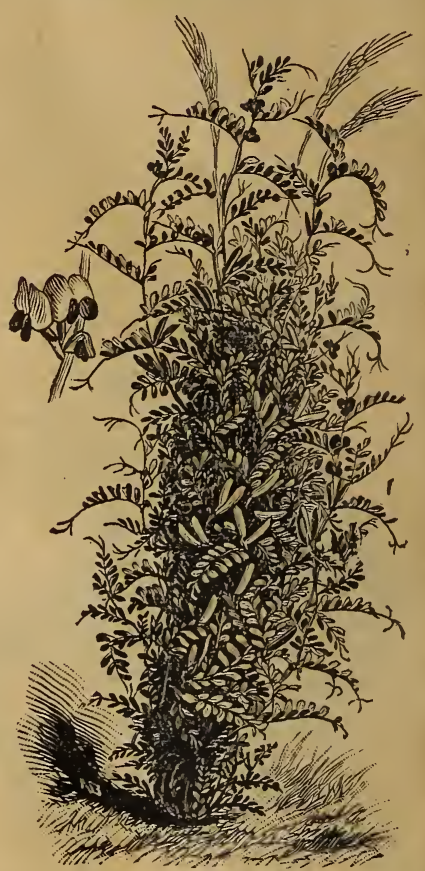

VETCHES.

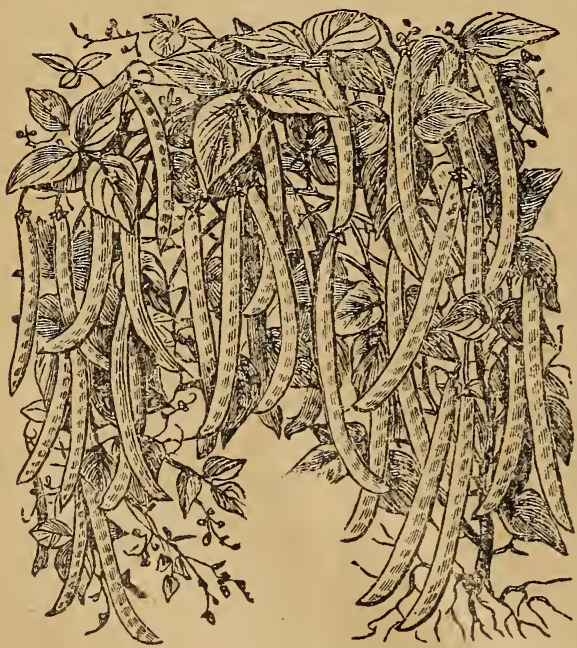

COW PEAS.

\section{Japanese Barnyard Millet.}

Exceedingly popular as a forage plant. Heavy cropper. Succeeds best in a moderately moist soil, and may be sown from the middle of May untilJuly, at the rate of 25 pounds per acre.

It is quite distinct from other varieties, being an enormous cropper and excellent, either green or cured, as hay.

Write for quotations.

\section{Velvet Beans.}

A rival of the cow pea. Both vines and pods are eaten by live stock, and the beans can be ground, either with or without the pods, and fed instead of corn or oats, or can be mixed with them.

Per qt., 20 cts. Per pk., $\$ 1.15$. Per bu., $\$ 4.00$.

\section{New Era Cow Peas.}

Smaller in size than the Whip-poor-will, and nearly two weeks earlier. One of the best varieties to sow, as it is extremely early, a good cropper, and produces more seed pods than most other kinds. A very valuable forage piant. Sow at the rate of $1 \frac{1 / 2}{\text { bushels per acre. }}$

Per qt., 15 cts. Per pk., $\$ 1.00$. Per bu., $\$ 3.25$.

Inoculation of all legumes with Farmogerm is absolutely necessary for the best results. See page 42. 


\section{"K. \& W." LAWN GRASS SEED.}

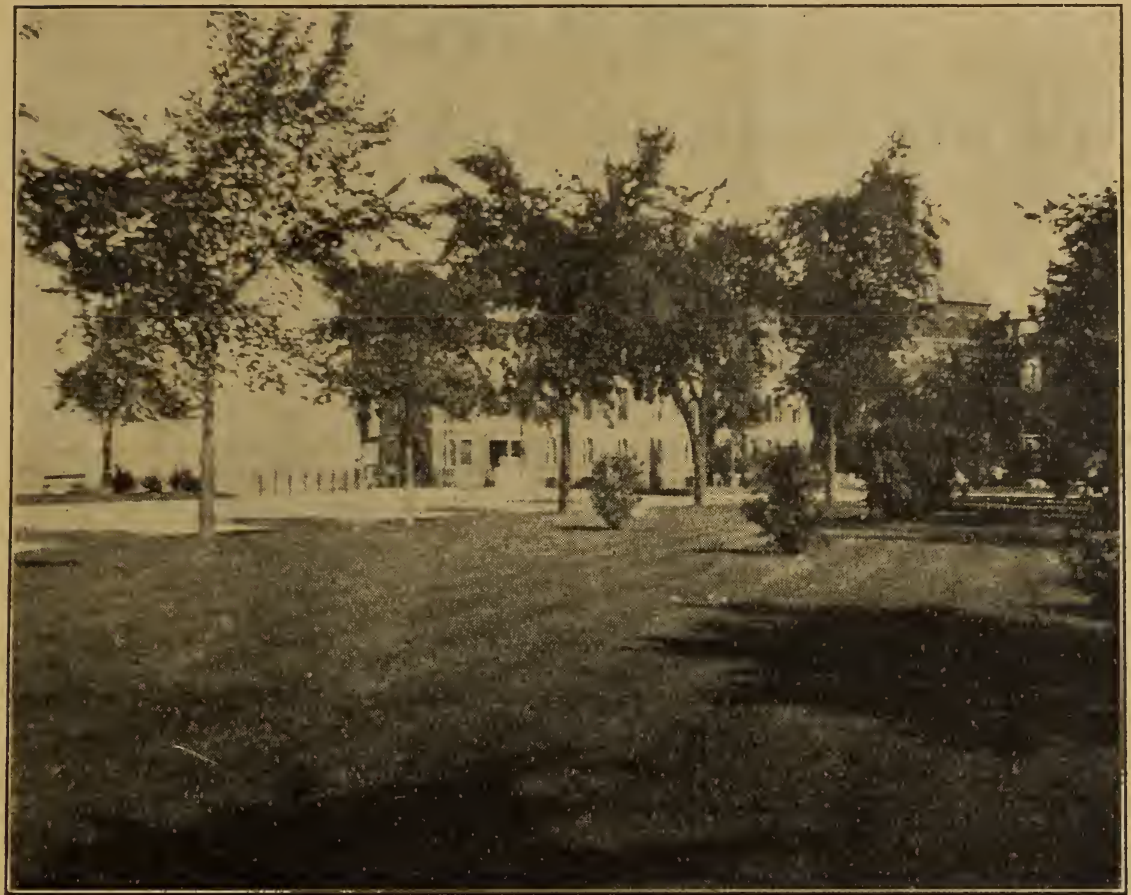

VIEW ON THE WESTERN PROMENADE, PORTLAND.

To secure a rich, firm, deep and enduring lawn of luxuriant richness, not only should it be thoroughly prepared, well drained and graded, and enriched with decayed manures and commercial fertilizers, but if carefully sown with a sufficient quantity of

"K. \& W." LAWN GRASS SEED,

it will result in a beautiful compact sward which will remain fresh and green throughout the season.

If sent by mail, add eight cents per pound for postage, and for 'larger shipments by mail, see Parcel Post rates on page 3 of this Catalogue.

Per pound, 20 cents.

Bag containing 5 pounds, 90c.; 10 pounds, $\$ 1.70 ; 25$ pounds, $\$ 4.00$

\section{PERMANENT MIXTURE.}

For Golf Links and Putting Greens.

Especially prepared for sowing to produce a short, dense sward.

If sent by mail, add eight cents per pound for postage, and for larger shipments by mail, see Parcel Post rates on page 3 of this Catalogue.

Per pound, 25 cents.

\section{THE "K. \& W." NORTHERN WHITE OATS.}

This unexcelled variety is free from rust, early and extremely hardy, yielding remarkably heavy crops, the grains being large, white, plump and first-class in every particular.

These oats have been carefully selected, thoroughly cleansed, and are free from foul seeds.

Write for Quotations.

\section{MARQUIS WHEAT.}

Similar to Red Fife, the heads being heavier and the straws shorter, making it less likely to lodge. The kernel is flinty, darker red and more plump than the Fife, and is beardless, having smooth, yellow chaff. A valuable feature is its extreme earliness and productiveness, ripening a week to ten days earlier than Red Fife and frequently yielding 40 to 50 bushels per acre. Weight, 64-66 lbs. per measured bushel. Marquis Wheat won the $\$ 1,000$ prize offered by Sir Thomas Shaughnessy for the "Best wheat in America", also the $\$ 3,000$ prize at Lethbridge, Canada, in a competition open to the world. 


\section{BOOKS}

\section{ON THE FARM, ORCHARD AND GARDEN.}

\section{All books sent postpaid on receipt of price.}

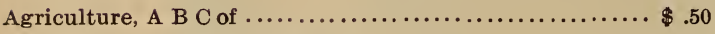

Amateur's Practical Garden Book.................. 1.00

American Apple Orchard........................ 1.00

American Farm Book ........................... $\quad 2.00$

Asparagus Culture $\ldots \ldots \ldots \ldots \ldots \ldots \ldots \ldots \ldots \ldots \ldots \ldots \ldots, \quad .50$

Beautiful Flower Garden .......................... $\quad .40$

Beekeeping Explained, Mysteries of $\ldots \ldots \ldots \ldots \ldots \ldots \ldots \ldots \ldots \ldots$

Bommer's Method of Making Manure $\ldots \ldots \ldots \ldots \ldots \ldots \ldots, \quad .25$

Bulbs and Tuberous-Rooted Plants ................ 1.50

Butter Making, A B C in .......................... $\quad .50$

Cabbage, Cauliflower and allied Vegetables ........... $\quad .50$

Canary Birds .......................................

Celery for Profit $\ldots \ldots \ldots \ldots \ldots \ldots \ldots \ldots \ldots \ldots \ldots \ldots \ldots \ldots, \quad .20$

Chemistry of the Farm $\ldots \ldots \ldots \ldots \ldots \ldots \ldots \ldots \ldots \ldots \ldots, \quad 1.25$

Clean Milk $. . \ldots \ldots \ldots \ldots \ldots \ldots \ldots \ldots \ldots \ldots \ldots \ldots \ldots, 1.00$

Crop Growing and Crop Feeding. $. \ldots \ldots \ldots \ldots \ldots \ldots \ldots \ldots, 1.00$

Crops, Spraying.................................... $\quad .25$

Dairy Farming. $\ldots \ldots \ldots \ldots \ldots \ldots \ldots \ldots \ldots \ldots \ldots \ldots \ldots \ldots, \quad 1.00$

Draining Land $\ldots \ldots \ldots \ldots \ldots \ldots \ldots \ldots \ldots \ldots \ldots \ldots \ldots \ldots \ldots \ldots \ldots, \quad 1.00$

Duck Culture $\ldots \ldots \ldots \ldots \ldots \ldots \ldots \ldots \ldots \ldots \ldots \ldots \ldots \ldots, \quad .50$

Economic Entomology $\ldots \ldots \ldots \ldots \ldots \ldots \ldots \ldots \ldots \ldots \ldots, \quad 2.50$

Egg Farm, New, Revised and Enlarged .............. 1.00

Farm Drainage .................................. 1.00

Farm Grasses of the U. S. ...................... 1.00

Farm of Four Acres, Our $\ldots \ldots \ldots \ldots \ldots \ldots \ldots \ldots \ldots \ldots \ldots \ldots \ldots \ldots, \quad .30$

Farming with Green Manures $\ldots \ldots \ldots \ldots \ldots \ldots \ldots \ldots \ldots \ldots \ldots \ldots$

Feeds and Feeding $\ldots \ldots \ldots \ldots \ldots \ldots \ldots \ldots \ldots \ldots \ldots \ldots \ldots, 2.00$

Ferns and How to Grow Them .................. 1.10

First Lessons in Dairying......................... $\quad .50$

Fruit Harvesting, Marketing, Storing............... 1.00

Gardening for Pleasure. New and Enlarged Edition..... 1.50
Gardening for Profit. New and Enlarged Ediiion ....... \$1.50

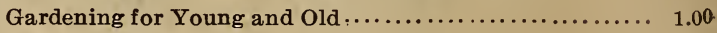

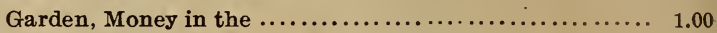

Greenhouse Construction ........................ 1.50

Greenhouse Management......................... 1.50

How to Make a Flower Garden $. . \ldots \ldots \ldots \ldots \ldots \ldots \ldots . . .61 .60$

How to Make the Garden Pay .................... 1.00

Injurious Insects and the Use of Insecticides .......... $\quad .40$

Insects and Insecticides $\ldots \ldots \ldots \ldots \ldots \ldots \ldots \ldots \ldots \ldots \ldots, \quad 1.50$

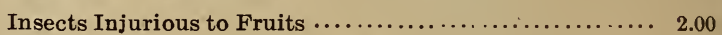

Key to Profitable Stock Raising $. . \ldots \ldots \ldots \ldots \ldots \ldots \ldots \ldots \ldots, \quad .25$

Making Poultry Pay............................ 1.00

Manures-How to Make and How to Use Them ......... $\quad .40$

Manures, Talks on. Revised Edition................. 1.50

Modern Methods of Testing Milk and Milk Products. ... $\quad .75$

Money in the Garden............................ 1.00

Mushrooms-How to Grow Them................. 1.00

Onions, How to Raise Them...................... $\quad .25$

Potato Culture, A B C of ......................... $\quad .60$

Poultry Craft .................................... 1.50

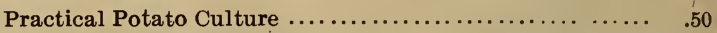

Profits in Poultry and Their Profitable Management..... 1.00

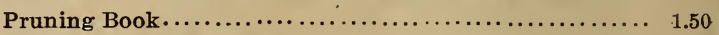

Silos, Ensilage and Silage......................... $\quad .50$

Small Eruit Culturist ............................ 1.00

Strawberry Culture, The A B C of ................... $\quad .45$

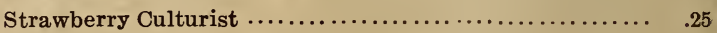

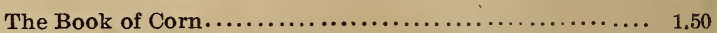

Turkeys, How to Raise Them $\ldots \ldots \ldots \ldots \ldots \ldots \ldots \ldots \ldots \ldots, 1.00$

Window Flower Garden $. . . \ldots \ldots \ldots \ldots \ldots \ldots \ldots \ldots \ldots \ldots, \quad .50$

\section{QUANTITY OF SEEDS REQUIRED FOR A GIVEN NUMBER OF HILLS OR LENGTH OF DRILLS.}

Asparagus $. \ldots \ldots \ldots \ldots \ldots \ldots \ldots, 1$ ounce....

Beet....................... 1 ounce...

Beans, Dwarf ................... 1 quart...

Beans, Pole ................. 1 quart....

Carrot.......................... 1 ounce...

Celery...................... 1 ounce....

Corn...$\ldots \ldots \ldots \ldots \ldots \ldots \ldots \ldots \ldots \ldots \ldots .1$ quart....

Cucumber.................. 1 ounce...

Dandelion .................. 1 ounce....

Lettuce ...

Melon, Water.

1 ounce...

Melon, Musk.

ounce....

1 ounce...
50 feet of drill

50 feet of drill

100 feet of drill

$150 \mathrm{hills}$

100 feet of drill

100 feet of drill

200 hills

50 hills

100 feet of drill

150 feet of drill

30 bills

60 hills
Onion $\ldots \ldots \ldots \ldots \ldots \ldots \ldots \ldots \ldots, 1$ ounce...

Onion sets $\ldots \ldots \ldots \ldots \ldots \ldots \ldots \ldots, 1$ quart....

Parsley..................... 1 ounce...

Parsnip ................... 1 ounce...

Peas ....................... 1 quart....

Pumpkin................... 1 ounce...

Radish $. . . \ldots \ldots \ldots \ldots \ldots \ldots \ldots, 1$ ounce....

Salsify $\ldots \ldots \ldots \ldots \ldots \ldots \ldots \ldots \ldots \ldots, 1$ ounce....

Spinach ................... 1 ounce...

Squash, Early.................. 1 ounce...

Squash, Late................ 1 ounce.... Turnip .................. 1 ounce... 150 feet of drill
100 feet of drill 60 feet of drill 150 feet of drill 100 feet of drill 75 feet of drill 40 hills 50 feet of drill 70 feet of drill 50 feet of drill 50 hills 15 hills 


\section{SUMMER-FLOWERING BULBS.}

\section{GLADIOLUS.}

Plant in good garden soil, after the ground becomes warm in the spring, in full exposure to the sun. Set bulbs from 4 to 6 inches deep.

America. Soft pink. Per doz., 75c.; per 100, $\$ 5.00$.

Augusta. White. Per doz., 65c.; per 100, $\$ 5.00$.

Baron Joseph Hulot. Deep blue. Per doz., \$1.35; per $100, \$ 10.00$. $\$ 5.00$.

Hollandia. Salmon shaded rose. Per doz., 75c.; per 100,

Pink Beauty. Bright rose. Per doz., 75c.; per 100, $\$ 5.00$.

Princeps. Scarlet. Per doz., $\$ 1.25$; per $100, \$ 9.00$.

Brenchleyensis. Scarlet. Per doz., 40c.; per 100, $\$ 3.00$.

Groff's Hybrid. Mixed. Per doz., 25c.; per 100, $\$ 1.50$.

Superfine Mixed. Per doz., 50c.; per 100, $\$ 2.00$.

\section{CALADIUM ESCULENTUM.} $\$ 1.00$.

Each, $5 \mathrm{c}$; ; per doz., 50c.

$$
\text { MADEIRA VINE. }
$$

GLOXINIAS.

Mixed Varieties. Each, 10c.; per doz., \$1.00.

\section{TUBEROUS BEGONIAS.}

The tuberous-rooted begonias are among the handsomest of summer-flowering bulbs, as they bloom continuously throughout the summer.

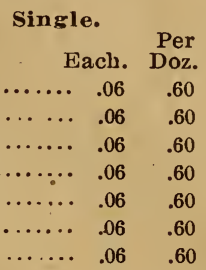

\section{Double.} $\begin{array}{ccc}\text { Each. } & \text { Doz. } \\ \text { Scarlet } \ldots \ldots \ldots \ldots & .10 & \$ 1.00\end{array}$ Orange.......... . .10 1.00 Crimson........ $10 \quad 1.00$ Pink $\ldots \ldots \ldots \ldots . \quad .10 \quad 1.00$ White .......... .10 1.00 Yellow .......... .10 1.00 Mixed.......... .10 $\quad 1.0$

\section{TUBEROSE.}

Large bulbs. Each, 5 c. ; per doz., 50 c. ; per 100, $\$ 3.00$.

DAHLIAS.

Double Named Varieties. Growing plants; ready about May 15th. Each, 15c.; per dozen, $\$ 1.25$.

Bulbs, except Caladium and Dahlias ordered by mail are subject to an extra charge of five cents per dozen for postage.

Caladium and Dahlias ordered by mail are subject to an extra charge of twenty cents per dozen for postage.

\section{SEEDLINGS AND VEGETABLE PLANTS. FLOWER SEEDLINGS.}

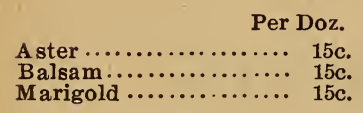

Per Doz.

Snapdragon $\cdots \cdots \cdots \cdots \cdots$ 15c.

Stocks $. \cdots \cdots \cdots \cdots \cdots \cdots, 15 \mathrm{c}$.
Per Doz.

Pansies (choice strain).. 30c Verbenas............... $30 \mathrm{c}$

\section{VEGETABLE PLANTS.}

CABBAGE PLANTS-Hot-bed plants.

Ready May 1st to 15th.

Henderson's Summer, Per doz. Per 100 Per 1,000 $.15 \$ \$ 1.00 \quad \$ 8.00$

For Winter Crop. Ready June 15th to 20th.

Stone Mason Drumhead,

$.35 \$ 3.00$

CAULIFLOWER PLANTS-Hot-bed plants.

Ready May 1st to 15th.

Henderson's Snowball,

Per doz. Per 100 $.20 \$ \$ 1.25$

CELERY PLANTS-Ready June 1st to 15th.

Golden Self-Blanching,

Per 100 Per 1,000

White Plume,

Boston Market,

TOMATO PLANTS-Ready May 15th to 20th.

Earliana,

Canada Victor,

Beauty,

Red Cross,

Scarlet Globe,

Table Queen,

One dozen in each box, 30 cents.

RHUBARB ROOTS.

15 cents each; $\$ 1.50$ per dozen. 


\section{The Man with the Hoe Wants a Good Fertilizer.}

\section{"For the land's sake" give him BOWKER'S.}

Don't do a good job with the hoe and a poor one with the fertilizer. As long as you must hoe, why not have the best possible crops to show for it? Thorough cultivation, coupled with the right fertilizer, and enough of it, will increase the production and profits of any farm.

\section{GOOD POTATOES WANTED.}

A prominent commission merchant writes "How many complaints I hear to the effect 'How poor the potatoes are this year'. The man who produces a good eating potato will be a winner just as sure as the man who produces a better quality of apples-(a thing which has already been done)-and consumers I think would willingly pay a higher price.'

The market wants good eating; medium size, potatoes.

\section{YOU CAN GROW THEM WITH STOCKBRIDGE POTATO MANURE.}

The best potato is a ripe potato. The Stockbridge produces not only a large yield, but it hastens maturity and ripens the crop. In our Potato Contests of 1912 and 1913, we had the following quality crops.

31 crops of over 300 bushels per acre.

17 of them over 400 bushels per acre;

4 of them over 500 bushels per acre.

The Census gives 148 bushels as the average yield for New England and 94 for the whole country. The average yield in our two contests $(53$ acres) is 329.98 bushels.

These results were not all due to the climate, for that varied; they were not due to the seed, for that varied; they were not due to the planting or cultivation, or the general care of the crop, for all these varied with the different growers.

The one thing that did not vary was the fertilizer, which was the STOCKBRIDGE POTATO MANURE and even if that varied in the amount applied, it did not vary in the plant food supplied.

Will it not pay you to consider using the Stockbridge on your farm the coming spring for all kinds of crops?

\section{CHEAP FERTILIZERS COST TOO MUCH.}

The U. S. Department of Agriculture says, in Bulletin 467 , "no one thing has been more clearly demonstrated by the work of the experiment stations than that it does not pay to buy low-priced, low-grade fertilizers."

D $\$ 20$ worth of our Stockbridge Manures will go further and supply better plant food than a ton of the usual fertilizer selling for $\$ 30$.

The Stockbridge, selling around $\$ 40$ a ton, contains twice as much nitrogen and often five times as much potash as the average $\$ 25$ to $\$ 30$ fertilizer.

SAVE a THIRD of YOUR FERTILIZER MONEY by USING the STOCKBRIDGE.

Write us about your fertilizer plans and ask for quotations.

\section{BOWKER FERTILIZER COMPANY, \\ 43 Chatham Street, - Boston} KENDALL \& WHITNEY, Agents, . - Portland 
"The World's Best by Every Test."

\section{BRADLEY'S}

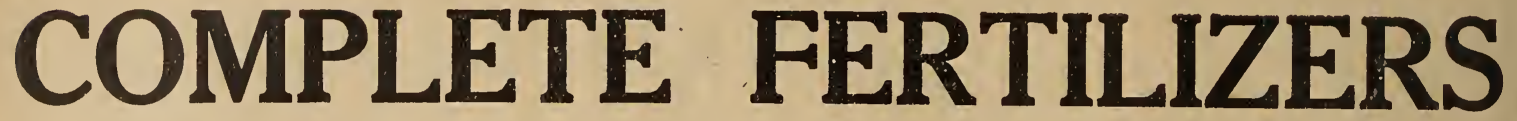

Supply the available plant food elements required, and they also help to overcome unfavorable conditions of weather and soil, maintaining an adjustment between the needs of the crop and the varying climatic conditions, which it is impossible for incomplete mixtures or single element materials to do.

Bradley's Complete Fertilizers promote early and continuous growth, bring maturity at proper time for harvesting, and they keep up the balance of soil fertility.

BRADLEY'S FERTILIZERS are compounded of the Highest GRAdE MATERIALs skillfully combined in proper proportions, carefully and thoroughly manufactured to a PERFECT MECHANICAL CoNDITION.

A full stock of the following standard fertilizers constantly on hand:

Bradley's XL Superphosphate,

Bradley's Potato Manure,

Bradley's Potato Fertilizer,

Bradley's Eureka Seeding-down Manure, Bradley's Corn Phosphate,

Bradley's Complete Manure for Top-dressing Grass and Grain, Bradley's Complete Manure with 10\% Potash,

Bradley's Complete Manure for Corn and Grain, Bradley's Complete Manure for Potatoes and Vegetables.

Send for Bradley's Descriptive Booklet for 1914, containing interesting information to all farmers.

\section{GRASS AND LAWN TOP DRESSING.}

The best time to apply this fertilizer to grass land is just after the frost is out. The spring rains quickly dissolve it and wash the plant food within reach of the grass roots. When grass becomes run out it is best to plow the land, cultivate one season and then reseed, but when there is a good sod the yield of hay can be kept up for a long period by using this fertilizer as a top dressing.

It makes a lawn more luxuriant and obviates the necessity of offending the senses by applying stable. manure to the home grounds.

It is sown broadcast like grass seed and at the rate of six hundred to eight hundred pounds per acre.

\section{A QUICK-ACTING FERTILIZER FOR TOP DRESSING GRASS.}

For top dressing mowing lands and lawns, for oats and general application where it is desired to supply an unusual quantity of nitrogen in a quickacting form, the one best fertilizer to use is three hundred to eight hundred pounds per acre of

\section{THE A. A. C. CO.'S SPECIAL}

GRASS AND GARDEN MIXTURE.

\section{The American Agricultural Chemical Company. BRADLEY FERTILIZER WORKS,}

92 State Street, Boston.

KENDALL \& WHITNEY, Agents, - - - - - - - - Portland 


\section{Chemicals and Fertilizers.}

PRICES QUOTED ON APPLICATION.

Sulphate of Ammonia. 20.16 per cent. nitrogen; 24.50 per cent. ammonia. In 200 pound bags.

Kainit. 22.19 per cent. sulphate of potash; 12 per cent. actual potash. In 200 pound bags.

Dried Blood. 9.87 per cent. nitrogen; 12 per cent. ammonia. In 200 pound bags.

Ground Tankage. 6 per cent. ammonia; 30 per cent. bone phosphate of lime. In 200 pound bags.

Slag. 17 to 19 per cent. total phosphoric acid. In 200 pound bags.
Dissolved Bone Black. 15 to 17 per cent. soluble and available phosphoric acid. In 200 pound bags.

Muriate of Potash. 77.53 per cent. muriate of potash; 49 per cent. actual potash. In 200 pound bags.

Nitrate of Soda. 15 per cent. nitrogen; 18.23 per cent. ammonia. In 200 pound bags.

Sulphate of Potash. 88.75 per cent. sulphate of potash, 48 per cent. actual potash. In 200 pound bags.

Plain Superphosphate or Acid Phosphate. 12 to 14 per cent. available phosphoric acid. In 200 pound bags.

PURE GROUND BONE.

A valuable fertilizer, especially for lawns, vines and fruit trees.

Per 100 lbs., $\$ 2.00$.

Per ton, $\$ 37.00$

LAND PLASTER.

Price-Bag of $200 \mathrm{lbs} ., \$ 1.00$; ton, $\$ 9.50$.

Bag of 100 lbs., .55; ton, 10.50 .

ASHES. Unbleached, hard wood ashes, put up in $100 \mathrm{lb}$. bags.

Especially valuable for lawns.

Per 100 lbs., $\$ 1.00$.

\section{SHEEP MANURE.}

A pure, natural manure, and the most nutritious food for plants. Its effect is immediate and lasting; it is clean to handle, and is the best of all manures for mixing with the soil for greenhouse plants. As a lawn top-dressing it is unequalled. For mixing with soil, take one part of manure to six parts soil. For making a liquid, take one pound manure to five gallons of water, which can be used with safety daily, if necessary.

Price-5 lb. pkg., 25 cents; 10 lb. pkg., 45 cents.

$251 \mathrm{~b}$. bag, 60 cents; $50 \mathrm{lb}$. bag, $\$ 1.00 ; 100 \mathrm{lb}$. bag, $\$ 2.00$.

\section{SHREDDED CATTLE MANURE.}

Packed. especially for florists and greenhouse vegetable growers. In $100 \mathrm{lb}$. bags only. Price, $\$ 1.50$ per bag.

\section{AGRICULTURAL LIME.}

Especially prepared for agricultural purposes, and, being finely ground, it can be used in any broadcaster. Many plants and all grains show a decided increase, and are greatly benefited by the use of lime, as it corrects all acidity of the soil, sweetening it, and freeing it from impurities.

HOW TO TEST THE SOIL FOR ACIDITY.-Take a little soil from the field and place it in a saucer, moisten it well with water and place in it a little piece of blue litmus paper. If within twenty-four hours the litmus paper changes to a red color, the soil is acid and an application of lime should be added at the rate of from 1,000 to 2,000 pounds per acre.

For the ordinary piece of land that requires lime it will be found that once in the rotation of crops, or, say once in four years, is as often as lime should be applied, as it will hold the land in its proper condition for that length of time. Price, $100 \mathrm{lb}$. bags, 60c.; ton, $\$ 10.00$.

\section{BORDEAUX LIME.}

Prepared expressly for use in making Bordeaux Mixture; is finely powdered, and ready for immediate use. Price, $100 \mathrm{lb}$. bags, 85c. 


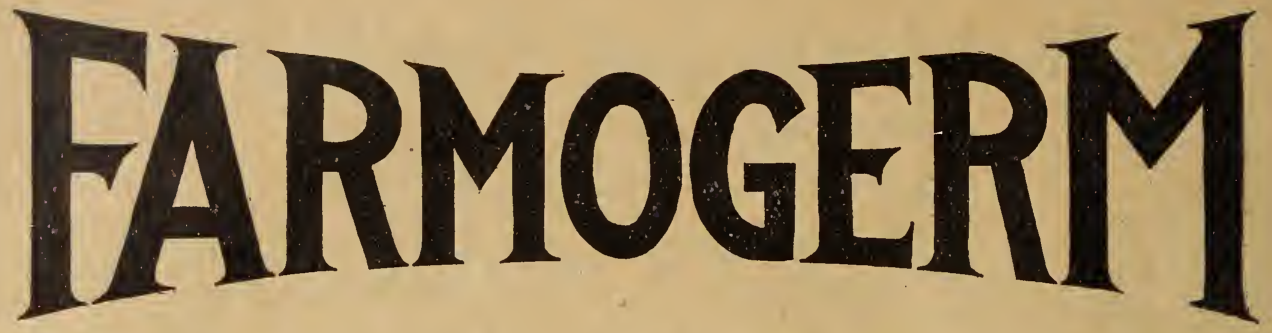

\section{ALFALFA-CLOVERS-SOJA BEANS-COW PEAS}

and all other pod growing plants called legumes, enrich the soil through the action of small bacteria growing upon their roots. These bacteria live only upon the roots of legumes and by an action of their bodies extract the free nitrogen of the air, and deposit around themselves as nitrates, thus forming little sacks or nodules on the roots of the growing plants. These sacks furnish the growing plant with all the nitrates it requires, and still leaves large amounts unused in the soil ready for future crops or other crops growing at the same time with the legumes.

The method of inoculation by transfer of soil for inoculation is both costly and dangerous-weed seed, soil and plant diseases are transferred in this way. All inoculations should be done by means of the pure cultures of nitrogen-gathering bacteria which are free from contamination and contain only active bacteria of the proper kind. These standard inoculations are known as "Farmogerm," and we strongly advise the use of the cultures whenever you plant legumes of any description.

\section{WHAT FARMOGERM IS-WHAT FARMOGERM WILL DO.}

Farmogerm is a pure culture, or growth of nitrogen-fixing bacteria that have been selected and bred up to transform large amounts of nitrogen from the air into soluble nitrates. These bacteria are grown in a jelly, in which they remain active for long periods of time, and sent out in a bottle which admits the necessary supply of pure air, yet keeps out destructive contaminations. If alfalfa can be grown on hot, sandy land of South New Jersey, why can't you grow it?
Unless the soil is very acid or wet (in which case it should be drained and limed), Farmogerm will:Increase the yield and quality of legume crops, giving quicker growth and earlier maturity.

Increase the food value of legumes.

Make legumes grow in new localities where they. cannot otherwise be grown successfully.

Supply nitrates to other crops growing with the inoculated legume crop.

Enrich the soil for future crops.

Price, Regular or Farm Size, 5 acres, $\$ 9.00$; Farm Size, 1 acre, $\$ 2.00$; Garden Size, $\frac{1}{4}$ acre, .50.

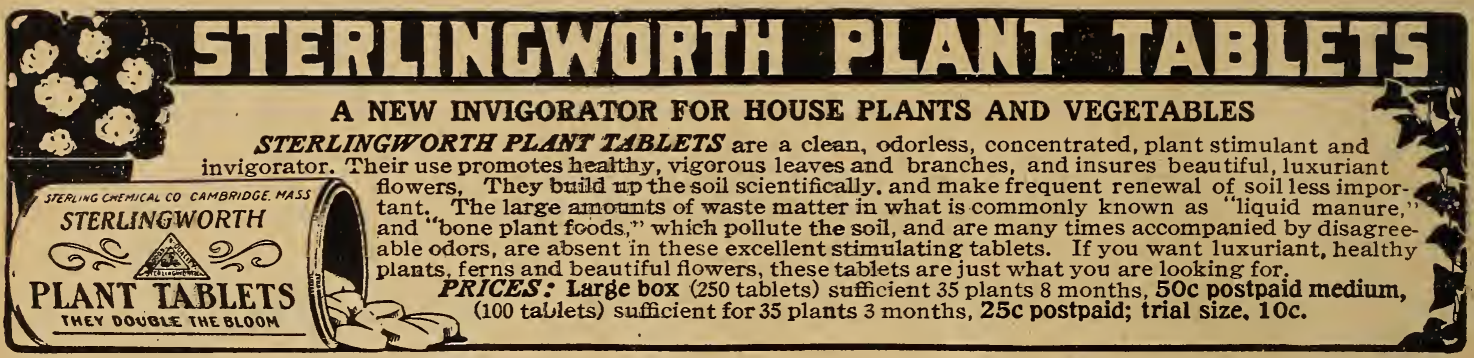

BOWKER'S PLANT FOOD.

For Stimulating Growth and Rapidly Developing the Plant Organism. 15c. and 25c. per package.

\section{STERLINGWORTH LAWN COMPOUND.}

This preparation, when applied to weedy lawns, will adhere to the rough, hairy leaves of dandelions. plaintains, etc., and, by absorbing all the sap, destroy them beyond recovery.

\section{DIRECTIONS FOR USE.}

Apply during bright, dry weather with a prospect of 24 to 48 hours settled weather. The grass should be cut previous to application. To dandelions and plaintains, apply a heaped teaspoonful or more to each of the crowns, according to the size of the weeds. For chickweeds and moss, apply with the hand, distributing evenly about five ounces for every square yard. Gauge the quantity according to the number of weeds. Repeat the application if any escape the first dressing. The weeds soon wither and disappear. Apply in dry weather; the hotter the weather the quicker the weeds are killed. Should the eveather continue dry beyond 48 hours after application, the grass should be well rotered.

Price-5 lb. package,

$50 \mathrm{lb}$. package,

$10 \mathrm{lb}$. package,

1.00

$100 \mathrm{lb}$. package,

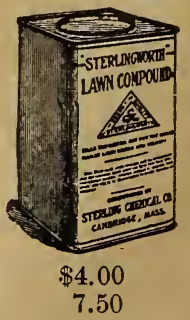




\section{STANDARD FLOWER POTS.}
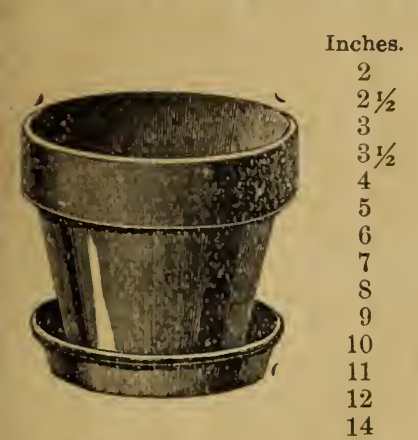

$\begin{array}{cr}\begin{array}{c}\text { Pots. } \\ \text { Per dozen. } \\ \$ .10\end{array} & \begin{array}{c}\text { Sancers. } \\ \text { Per dozen. }\end{array} \\ .12 & \\ .15 & \$ .12 \\ .20 & .15 \\ .25 & .18 \\ .40 & .24 \\ .60 & .32 \\ .90 & .45 \\ 1.25 & .60 \\ 1.75 & .75 \\ 3.00 & .95 \\ 3.50 & 1.10 \\ 5.00 & 1.35 \\ 9.00 & 2.25\end{array}$

\section{NEPONSET PAPER FLOWER POTS.}

Round Seed and Bulb Pans.

$\begin{array}{ccc}\text { Inches. } & \text { Each. } & \text { Per doz. } \\ 6 & \$ .07 & \$ .72 \\ 7 & .08 & .85 \\ 8 & .10 & .96\end{array}$

Special quotations to florists.

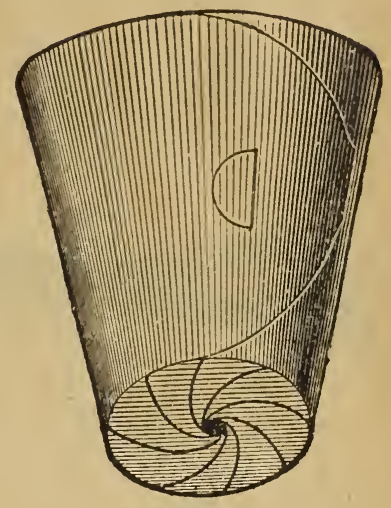
fabric which gives them all the necessary rigidity. $\mathrm{T}$ h e $\mathrm{y}$ are unbreakable and give ample drainage.

$\begin{array}{lrr}\text { Size. } & \text { Per } 100 . & \text { Per } 1,000 \\ 21 / 4 & \$ .30 & \$ 2.40 \\ 21 / 2 & .35 & 2.80 \\ 3 & .40 & 3.85 \\ 31 / 2 & .60 & 5.25 \\ 4 & .75 & 6.60 \\ 5 & 1.25 & 11.00 \\ 6 & 1.65 & 14.70\end{array}$

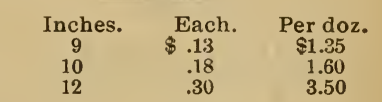

\section{FLORISTS' VASES.}

FOR DISPLAYING CUT FLOWERS.

\begin{tabular}{|c|c|c|c|c|c|c|c|c|c|c|}
\hline No. & 0 & 51 & es 1 & me & 13 & inch & dec & 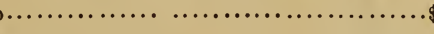 & .60 & each. \\
\hline t. & 1 & $5 \frac{1}{2}$ & “. & "“ & 10 & "״ & “ & 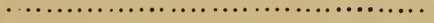 & .50 & $\bullet$ \\
\hline$\therefore$ & 2 & $4 \frac{1}{2}$ & “. & .. & 9 & .. & . & 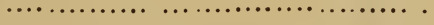 & .45 & $"$ \\
\hline “ & 3 & 4 & .. & “. & 6 & 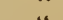 & 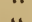 & 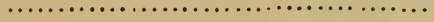 & 40 & "“ \\
\hline . & 4 & 3 & . & ." & 42 & . & 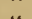 & 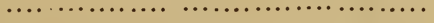 & .30 & $\cdots$ \\
\hline$\pi$ & 00 & 9 & ." & 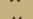 & 22 & 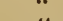 & $"$ & 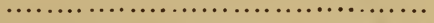 & 2.31) & “ \\
\hline & 01 & 7 & . & 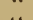 & 20 & 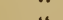 & 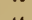 & 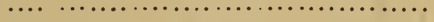 & 1.20 & 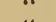 \\
\hline & 11 & 52 & . & . & 18 & 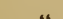 & 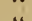 & $\cdots \cdots \cdots \cdots \cdots \cdots \cdots \cdots \cdots \cdots \cdots \cdots$ & .60 & ". \\
\hline & 22 & $4 \frac{1}{2}$ & $\ddot{0}$ & 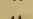 & 15 & 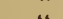 & . & 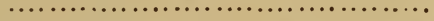 & .50 & \\
\hline . & 33 & 4 & ." & 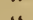 & 12 & “4 & 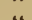 & 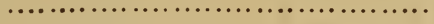 & .45 & 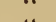 \\
\hline & 44 & 3 & . & & 9 & & & $\cdots \cdots \cdots \cdots \cdots \cdots \cdots \cdots \cdots \cdots \cdots \cdots \cdots \cdots$ & 40 & 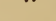 \\
\hline
\end{tabular}

\section{FIBRE FLOWER POT SAUCERS.}

$\mathrm{No}$ moisture passes through to injure table, floor or carpet.

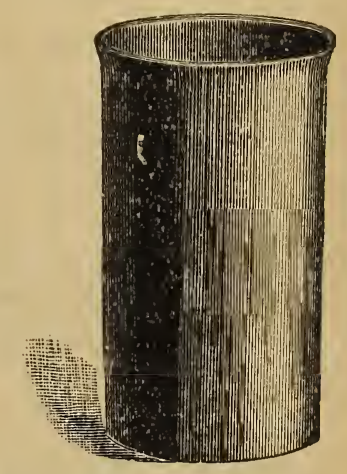

\section{TRELLISES.}

No. 00, 18-in. stick, $3 \frac{1}{2}$ in. wide....... $\$ 0.06 \$ 0.60$

" 00 wide, 20 -in. stick, 8 in, wide. 12

" 0,24 -in. stick, 5 in. wide........ $\quad .12 \quad 1.25$

" 0 wide, 24-in. stick, 8 in. wide... $\quad .15 \quad \cdot 1.50$

BOW TRELLIS.$$
\begin{aligned}
& 1 \\
& 2 \\
& 2 \\
& 3 \\
& 4 \\
& 5 \\
& 6
\end{aligned}
$$

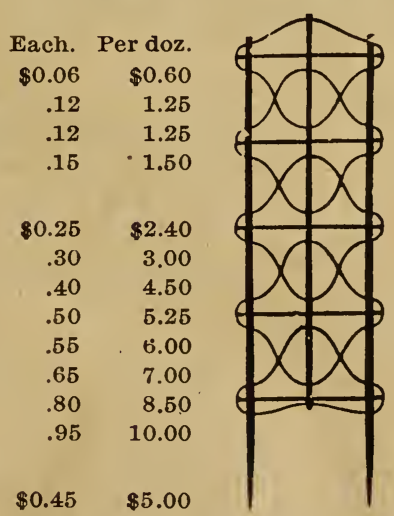

\section{PLANT STICKS.}

From one and one-half to six feet in length, used for supporting single stalks of roses, dahlias, etc.

Per doz. Per 100 $\$ .20 \quad \$ 1.12$ $.25 \quad 1.75$ $.35 \quad 2.50$

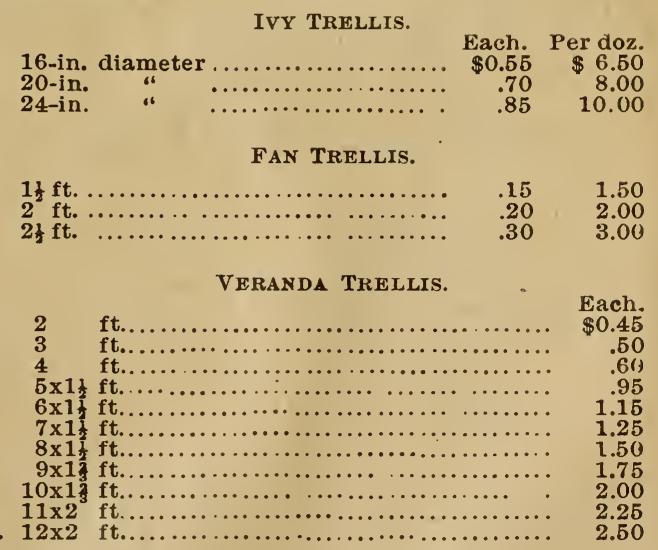

16-in. diameter 20-in.

er doz. $\begin{array}{rr}.70 & \$ 6.00 \\ 85 & 10.00\end{array}$
WOOD POT LABELS.

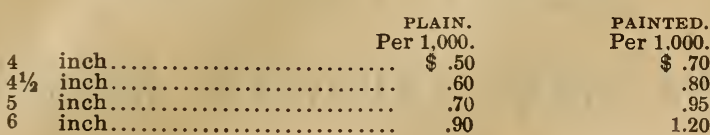

WOOD TREE LABELS. 


\section{BOUQUET HOLDERS.}

No. 1 , Small, iron.............. 20 cents No. 2, Medium, iron............... 25 cents No. 3, Large, iron ............... 30 cents Medium, stone ................. 20 cents
FOLDING LAWN SETTEE.

Made from hard wood and finished in varnish and vermilion.

Price, \$1.00.

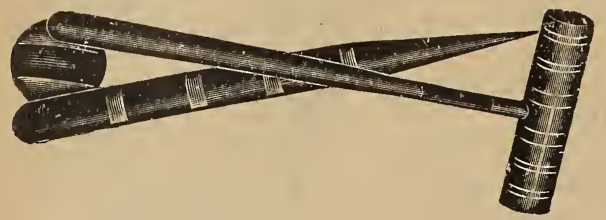

\section{CROQUET.}

We carry a complete assortment, manufactured from selected hard wood, handsomely painted and varnished.

90 cents to $\$ 4.00$ per set.

"IRON AGE"

HORTICULTURAL ROW INDEX.

Made of galvanized iron, the label protected by sheet of mica. Will be found indispensable for private gardens, trial grounds, greenhouses, parks, etc.

Price, 18 inch, 15 c. each.

66 per dozen, \$1.50.
WIRE

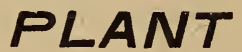
STANDS.

1 shelf, folding,

$266 \quad 6$

$\$ 1.75$

2.50

3 6 6

3.25

4.00

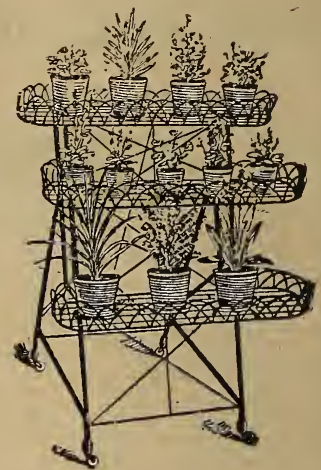

\section{TROWBRIDGE'S GRAFTING WAX.}

The finest quality made, put up in neat packages with directions for use. 25c. per 1b.; 1/2 lb. packages, 15c.; $1 / 4$ lb. packages, 10c. By mail, 5c. per lb. extra. Beeswax, 40c. per lb. By mail, 5c. per lb. extra.

\section{"Peerless Glazing Points.}

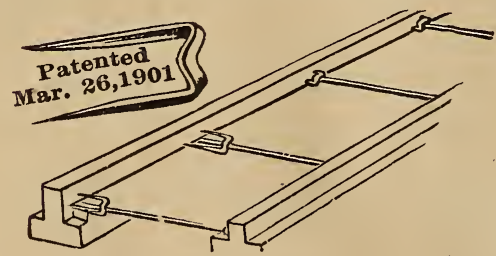

Made from galvanized steel wire; are cheap and indestructible. Easy to apply and perfectly satisfactory to use. Per 1,000, 60 cts.; by mail, 65 cts.
Self-Registering Thermometer. Registers accurately the coldest, also the warmest point of temperature. $\$ 3.25$ each.

Hot Bed Mats. Best rye straw, 6 x $6 \mathrm{ft}$, $\$ 1.50$ each.

Tinfoil. For bouquets. Lb., $12 \mathrm{cts}$.

Twine, Soft. For tying vines, etc. Large balls, 15 cts.

Tarred Yarn. Low priced material for raspberries, shrubs, etc. Lb., 12 cts.

\section{NATURAL COLORED RAFFIA.}

The best material for tying plants; very soft,

Colored Raffia (all shades), 10 cents per package. strong and pliable. Fine, long, selected raffia for fancy work. 20 ets. per pound.

Reed, for fancy basketry (6 sizes), 20 cents per $\frac{1}{4}-1 b$. package. 


\section{TOMATO AND PLANT SUPPORT.}

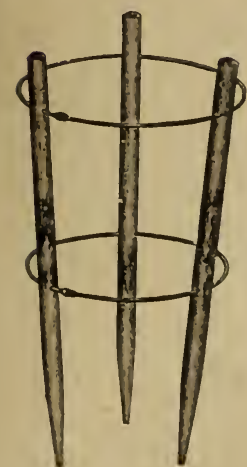

BARTLETT.

Designed especially to protect tomatoes, peonies, small shrubs, and tall growing plants.

\section{THE BARTLETT.}

MADE FROM HARD WOOD, WITH WIRE HOOPS.

Price, 20 cents each: $\$ 1.75$ per dozen.

THE BRYANT.

MADE OF HARD WOOD STANDARDS AND WOOD HOOPS.

Price, 15 cents each: $\$ 1.50$ per dozen.

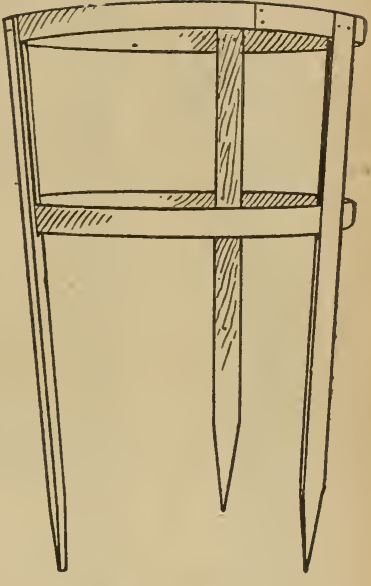

BRYANT.

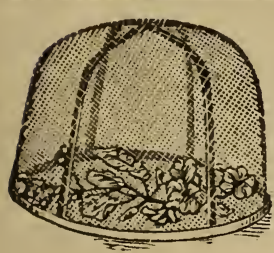

\section{ARLINGTON PLANT PROTECTOR.}

\section{Price, 15 cents each; $\$ 1.50$ per dozen.}

\section{HOT-BED SASH.}

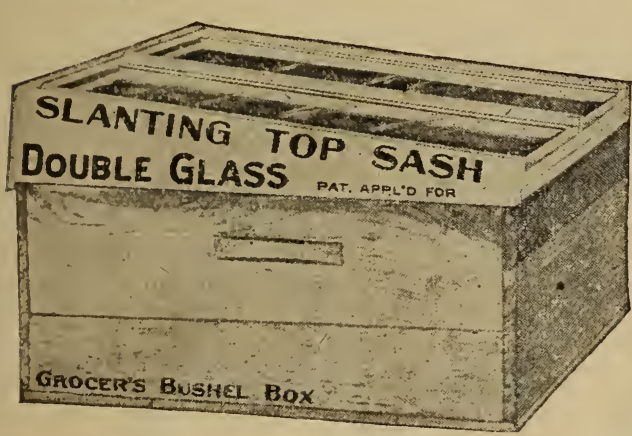

pane. The smallest size fits over an ordinary bushel box, size $18 \times 18$ inches.

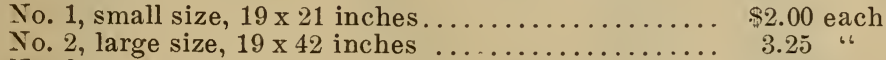

Yo. 3, extra large, $19 \times 63$ inches .............. 4.25
GRAFTING CHISEL.

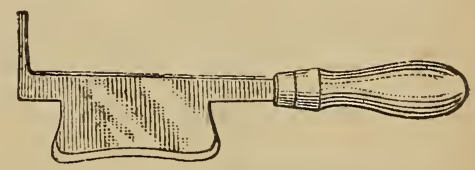

Price, 60c. each.

Hazeltine Weeder.

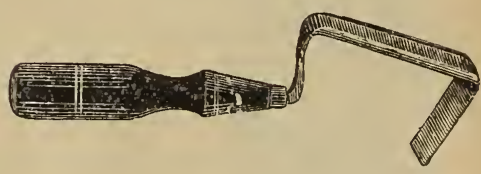

Price, 25 cents each.

\section{SHEEP SHEARS.}

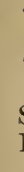

True Vermonter, $5 \frac{1}{2}$ inch, $\$ .85$

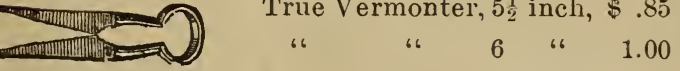

Sheep shears, for trimming grass, 25 to 50 cents. Lightning shears, for trimming grass, 40 cents.

\section{EXCELSIOR WEEDER.}

This instrument will work well among rows of seedlings and ornamental plants, or in any place where freedom from weeds is desired.

Price, 10c. each.

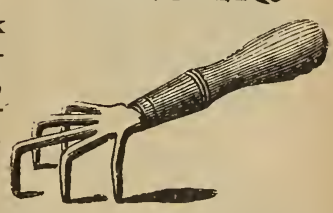

\section{DOUBLE=EDGED PRUNING SAWS.}

For use with or without pole. The lightning edge teeth are for cutting the limbs and the back teeth are for cutting off the twigs.

18 inch, 85 cents each; 20 inch, 95 cents each.

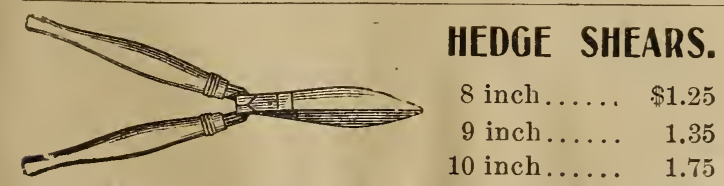

PRUNING AND BUDDING KNIVES. 50 cents to $\$ 1.00$ each.
BORDER SHEARS. With Long Mandle.

8 inch.......................... \$1.75

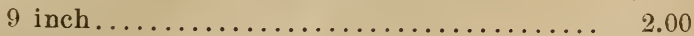

10 inch............................ 2.50

With wheel, 50 cents extra. 


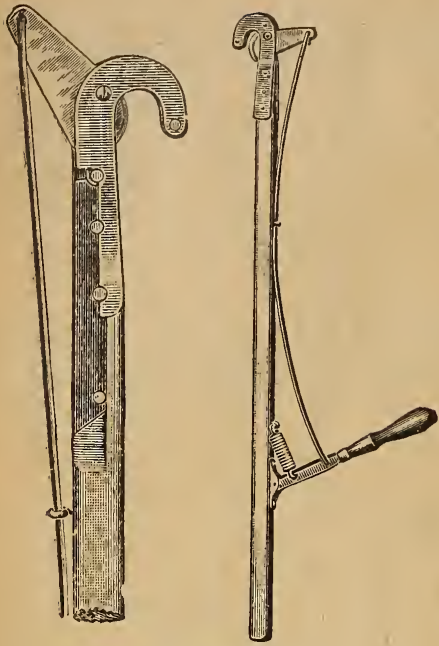

Standard.

Prices.

(Either style pruner.)

6 feet........... \$1.50 each

8 feet................ 1.75 each

10 feet............ 2.00 each

16 feet (Detroit only), 2.50 each

\section{STANDARD TREE PRUNER.}

Is the lightest device made for the purpose.

Will cut as large wood as any other device that is practical to handle. Will clip the slightest twig on the extreme end of the limb.

\section{Prices.}

8 feet.............. \$.85

10 feet............... $\quad .90$

14 feet.............. $\$ 1.10$

$.90 \quad 16$ feet................

12 feet...................... $\quad 1.00 \quad 15$

\section{HAPPY THOUGHT and DETROIT PRUNERS.}

The Happy Thought Knife will cut a limb three-quarters of an inch in diameter, the Detroit Knife, a limb one inch in diameter, doing the work easily because of the great leverage and the same drawing cut that is an important factor in all of our pruning knives.

These knives are made in three lengths, 6,8 and 10 feet, and of the best material that can be produced for the purpose. The blades are of high carbon crucible steel, tempered in lead and drawn in oil.

Detroit.
KING PRUNERS.

\section{WITH ROPE PULL.}

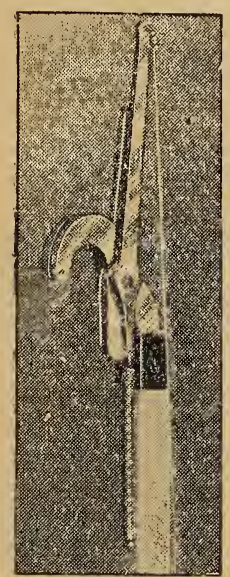

No danger of receiving shock by crossing electric wires, as they are operated by a cord running the entire length of pole. These pruners are made from a fine quality of steel and carefully tested, the cutters are concaved, making the easiest cut possible, and can readily be taken apart for grinding, etc.

Price.

$12=f t$. pole, $\$ 1.00$ each $14=f t$. pole, 1.10 “" $16=f t$. pole, 1.15 “ $18=$ ft. pole, 1.35 “

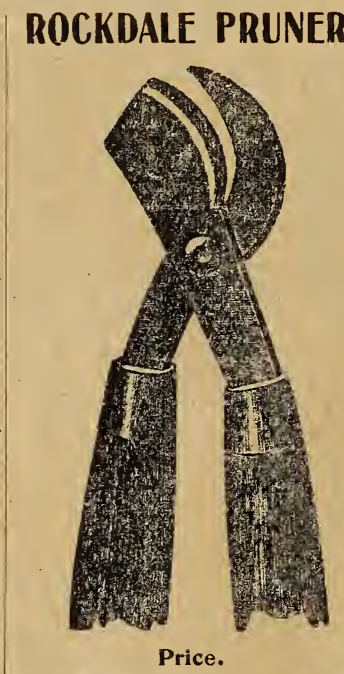

No. 35,26 in. long, No. 38,41 in. long,
$\$ .75$
PRUNING SHEARS.

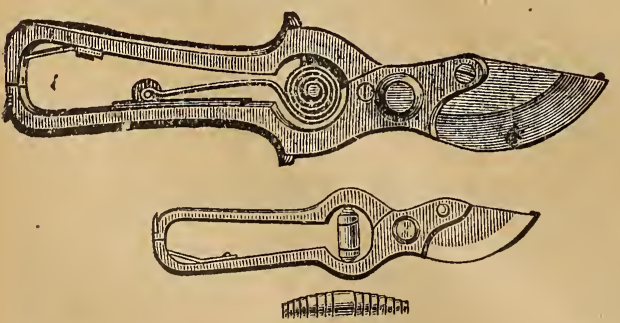

American $\ldots \ldots \ldots \ldots \ldots \ldots \ldots \ldots \ldots \ldots, 35 \mathrm{c}$. and $50 \mathrm{c}$

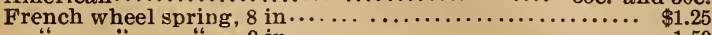

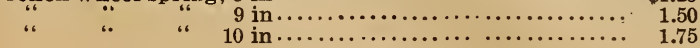

\section{Kansas Pruning Knife.}

Where the Kansas Pruning Knife has been introduced it has revolutionized tree pruning, on account of the speed and ease with which it can be done.

On heavy limbs or cutting any limb close to the body of the tree the knife works automatically-no levers to operate by hand-just put the hook over the limb and give a quick, straight pull on the handle. For cutting small outer swinging branches, attach a strong cord to the sliding sleeve, put the hook over the branch to be cut, and pull on the cord. It will cut any green limb, from the very smallest to one that is one and onequarter inches in diameter, and any length handle can be used, giving the great advantage of standing on the ground to do the work, and doing it properly.

Price, $\$ 3.00$ each. 


\section{Cyclone Sanitary Lawn and Yard Fence.}

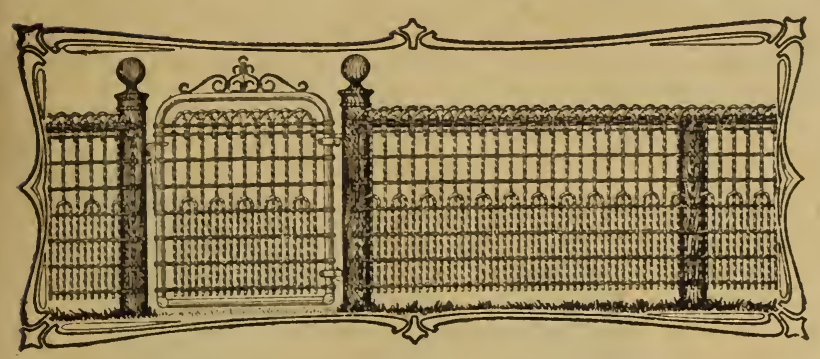

Lets in fresh air and sunshine-makes gardens, flower-beds, lawns, possible-a popular, attractive and inexpensive ornamental fence for residences, front lawns, division fences, back yards, as well as for schools, churches, parks and cemeteries.

Heavily galvanized No. 9 pickets are spaced $27 / 8$ inches a part at the top and $13 / 8$ inches apart at the bottom. This gives an extremely closemesh, chicken-tight fence for less than what ordinary boards would cost.

Best heights are 36 -inch, 42 -inch and 48-inch. Other heights made to order.

Price per lineal foot, "F", fabric only, 36 inches high,11c.; 42 inches high, $12 c . ; 48$ inches high, 14c. Gate, with scroll top, to match this fence, 3 -foot opening, $\$ 2.50$.

\section{Cyclone Universal Walk Gate.}

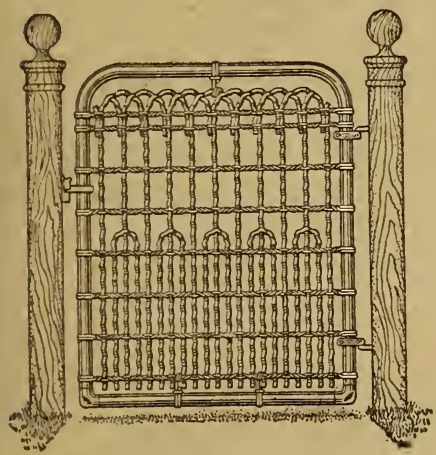

Suitable for the mos t particular home and at a price so low that no home can afford to be without one.

Frame is of highcarbon $\mathrm{tubular}$ steel $1 \frac{1}{8}$ inches in diameter.

Gate comes complete with all malleable fittings ready to hang to post. Either 36,42 or 48 inches high.

PRICE.

Either height, 3-foot opening, \$2.25 each.
Flower and Vine Trellis.

Just the thing for climbing plants and flowers.

Crimped wires are No. 10 and cable No. 13 , heavily galvanized.

A perfect vine climber that adds greatly to the appearance of the home.

PRICE.

Per foot, 16-in., 6c.
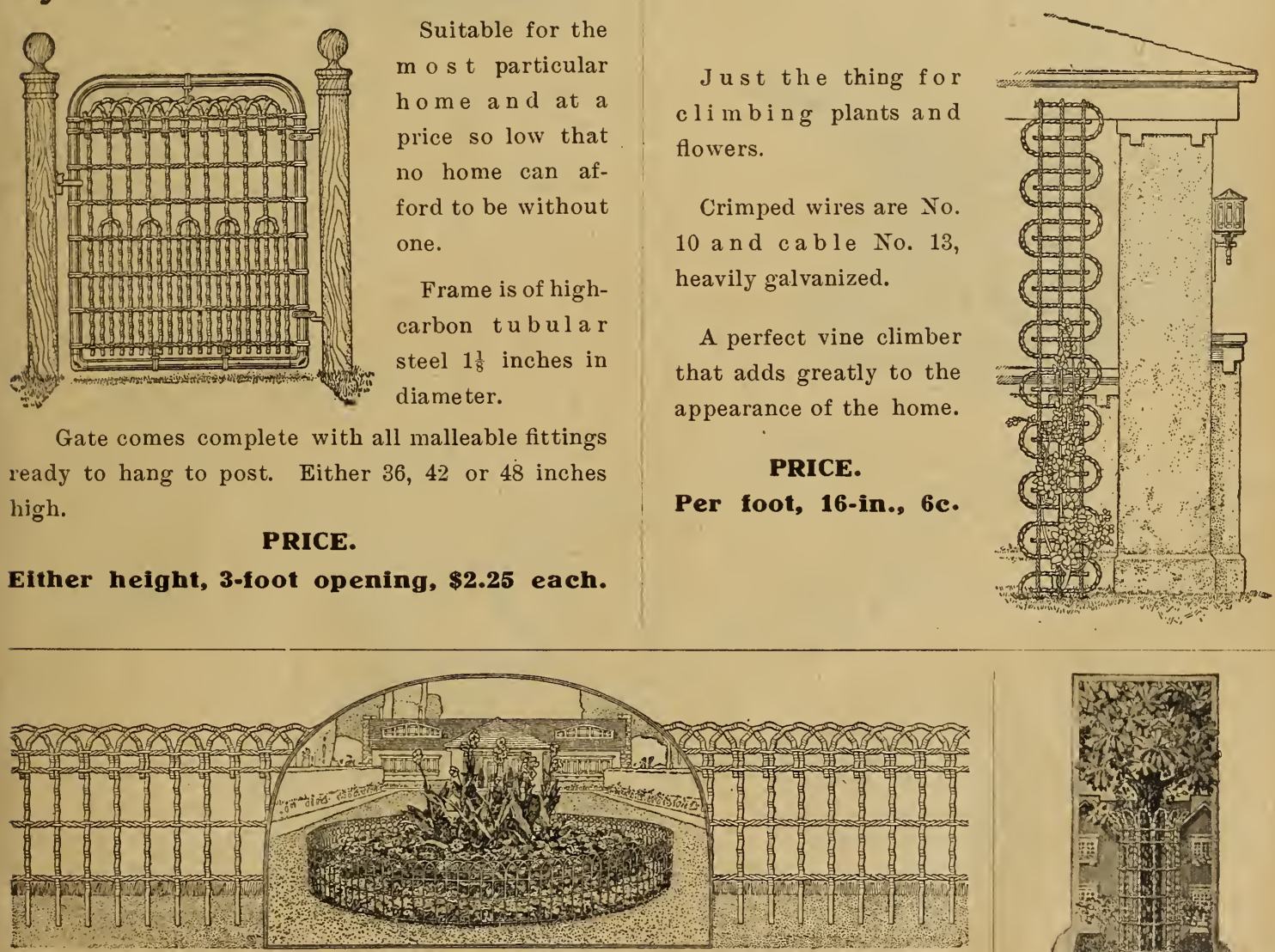

\section{Perfection Flower Border.}

Fits any form or shape of flower bed. No posts are required; the picket ends are left straight for inserting in the ground.

Pickets are of No. 9, cables of No. 13, heavily galvanized wire. Made in two heights, 16 and 22 inches.

PRICE.

Per lineal foot, 16-in., Per lineal foot, 22-in.,

\section{Cyclone Tree Guard.}

Six feet high, made of heavily galvanized wire.

Set up in a minute by clasping the hooked ends.

PRICE.

9 inches in diameter, 75c. each. 


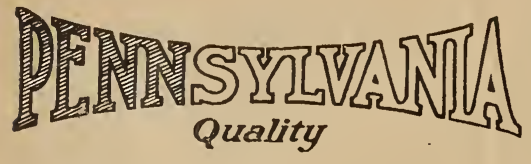

\section{LA WN MOWERS.}

By "Pennsylvania Quality" is meant absolutely the best that can be put into lawn mower construction. All blades are crucible tool steel, oil tempered and hardened, and all castings are reamed and machined to fit perfectly, insuring easy cutting and long life.

\section{Great American Ball Bearing.}

This machine is one of the most popular of the line, and consequently is more imitated than any other lawn mower manufactured. Raised edge, selfsharpening lower knife, highest grade ball bearings, smooth running, are special features.

10-inch driving wheels.

5 blades.

Sizes.

15 inch

17

19

21

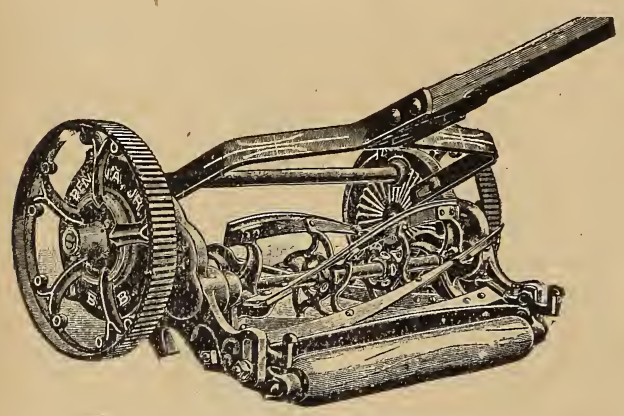

Prices. $\$ 9.50$

10.50

11.50

12.50

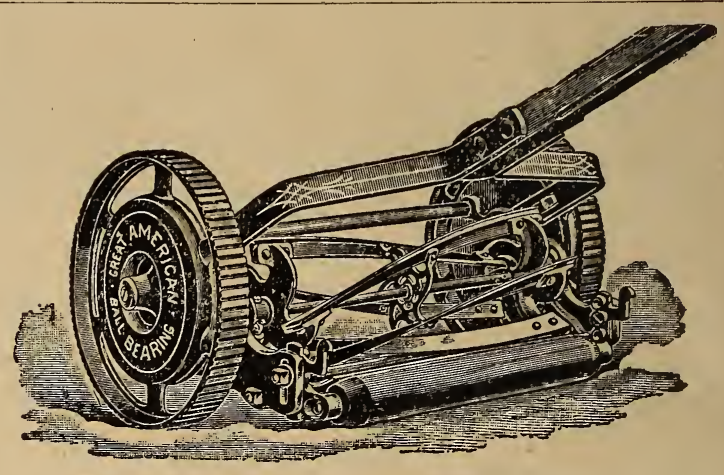

\section{Pennsylvania Junior Ball Bearing.}

The highest grade lawn mower made. A train of three gears on each side drive the 5-blade cylinder, insuring easy running. Raised edge, self-sharpening lower knife.

Made in both low and high wheel size.

8-inch wheels.

Sizes. Prices.

14 inch......... \$9.50

16 ، $\ldots \ldots \ldots \ldots, 10.50$

$19 \quad \ldots \ldots \ldots \ldots+11.50$
5 blades.

10-inch wheels.

\begin{tabular}{|c|c|}
\hline $\begin{array}{l}\text { Sizes. } \\
\text { inch }\end{array}$ & $\begin{array}{l}\text { Prices. } \\
\$ 13.00\end{array}$ \\
\hline ". & 14.50 \\
\hline 6. & 16.00 \\
\hline
\end{tabular}

\section{Pennsylvania Grand Horse Mower.}

Any product of the Pennsylvania factory insures it being of the highest quality, both in material and workmanship. Until a few made only one style of horse mower, that with the lower knife adjust. able to the revolving cylinder, similar to the majority of other horse and hand mowers, but recently they perfected and patented a new design, radically different from all others. The lower $\mathrm{knife}$ is rigidly bolted to the frame, and set to cut $3 / 8$ inches from the ground, while the cylinder is adjustable for taking up the wear. The height of the cut can be regulated from $3 / 8$ to $2 \% 8$ inches, by the wheel at the right of the machine. This new mower is called the Pennsylvania Grand.

Complete with seat, shafts, etc., as illustrated. Write for Price List.

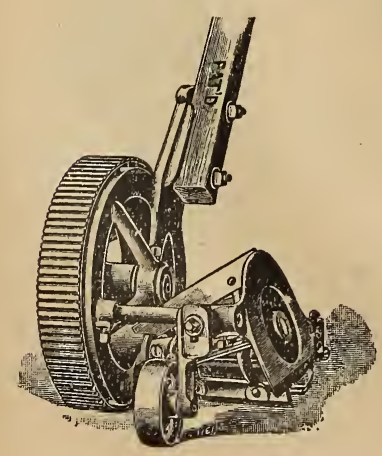

Pennsylvania B. B. Under Cut Trimmer.

This machine is the only one to successfully replace the use of hand shears. The slanting side plate and conical cylinder make it possible to cut all the grass left by the regular style of lawn mower. The unique construction of the Under Cut Trimmer permits cutting, not only close up to a wall, fence, trees, etc., but it will get the grass under a fence or rockcut base of tombstones, house foundations, and other places hitherto out of reach of anything but hand shears. For cemeteries it has the special advantages of not marking or smudging the stones, as the side plate does not come in contact with the stone above the grass line.

Price, \$7.50. 


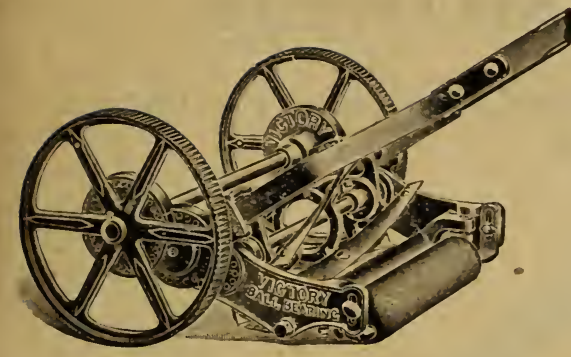
TOWNSEND'S "VICTORY" LAWN MOWER.

Constructed with ball bearings, of the very highest grade. Triple gear, entirely closed, and a removable cutter bar, which, by loosening four small screws, may be rolled out of the machine for sharpening without disturbing the frame.

$\begin{array}{lrrrrrr}\text { Width of cut: } & 14-\text {-in. } & 16 \text {-in. } & 18 \text {-in. } & 20 \text {-in. } & 22 \text {-in. } & 24 \text {-in. } \\ \text { Net price: } & \$ 8.00 & \$ 9.00 & \$ 9.50 & \$ 10.00 & \$ 11.00 & \$ 12.00\end{array}$

\section{TOWNSEND'S “SPIDER” LAWN MOWER.}

Like the Victory, the "Spider" runs and cuts with ease and rapidity.

It is light, strong, and finely made and adjusted, and is one of the best medium priced lawn mowers ever offered.

Is ball bearing, has nine-inch wheels, four-bladed open wiper, and a simple and easy adjustment.

width of cut:

Net price:

12-in. 14-in. 16-in. 18-in. $\$ 6.00 \quad \$ 7.00 \quad \$ 7.50 \quad \$ 8.00$

$\$ 8.50$
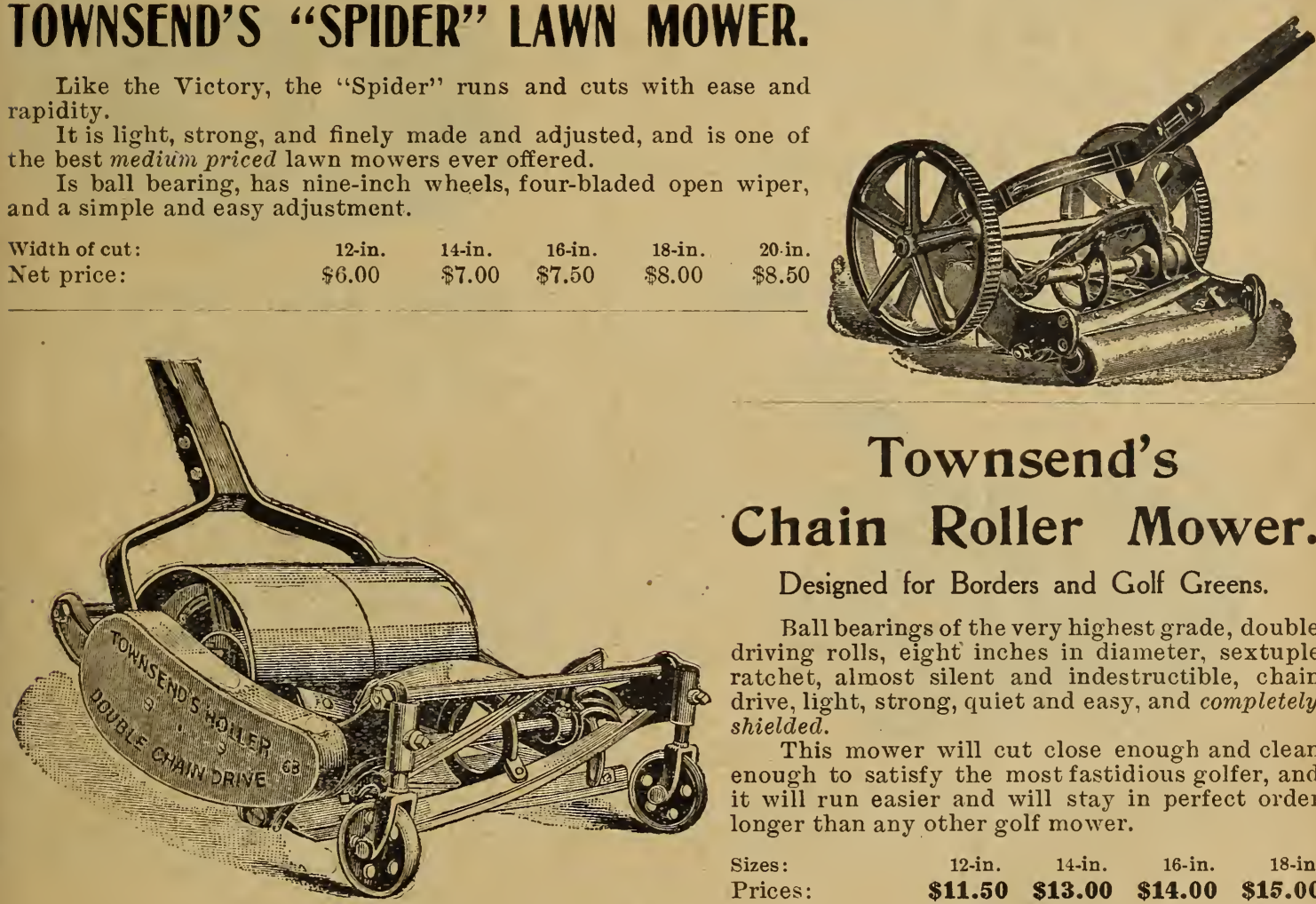
Chain Roller Mower.

Designed for Borders and Golf Greens.

Ball bearings of the very highest grade, double driving rolls, eight inches in diameter, sextuple ratchet, almost silent and indestructible, chain drive, light, strong, quiet and easy, and completely shielded.

This mower will cut close enough and clean enough to satisfy the most fastidious golfer, and it will run easier and will stay in perfect order longer than any other golf mower.

$\begin{array}{lrrrr}\text { Sizes }: & \text { 12-in. } & 14-\text { in. } & 16 \text {-in. } & \text { 18-in } \\ \text { Prices: } & \$ 11.50 & \mathbf{\$ 1 3 . 0 0} & \mathbf{\$ 1 4 . 0 0} & \mathbf{\$ 1 5 . 0 0}\end{array}$

THE TOWNSEND

\section{Horse Lawn Mower.}

The Townsend Mower has triple rolls, with triple pawls in each roll, making a most powerful and instantaneous driving mechanism. Unlike other mowers, the motion of the blades is maintained even when turning sharp corners. The self-aligning journal boxes will be found in this mower only, and prevent cramping, a very common fault in Horse Lawn Iowers.

All machines are fitted complete with tool-box, seat, handles, shafts, and slide-bar attachment, wh i ch keeps the horse on the cut grass.

Width of cut, 30 in., 35 in., 38 in.

Write for Pricel List.

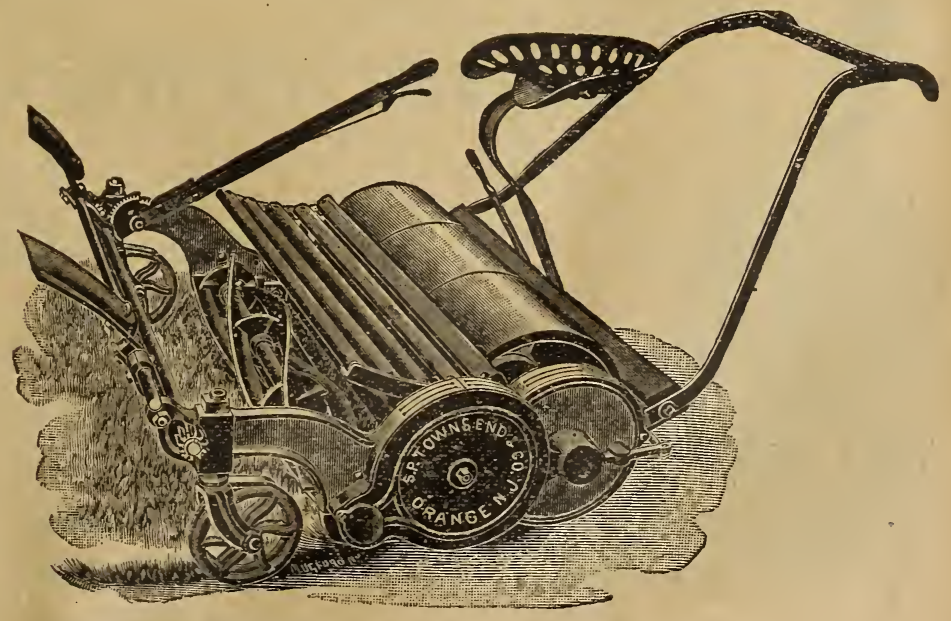




\section{FEDERAL LAWN MOWER.}

\section{8-INCH WHEELS.}

THE COMBINED POINTS ARE PRICE, SIMPLICITY, DURABILITY, UTILITY.

Width of Cut.

12 ihch.

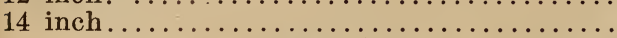

Net Price.

$\$ 3.00$

3.00
Width of Cut.

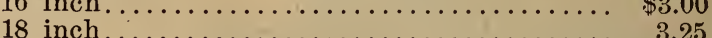

\section{PHILLADELPHIA LAWN MOWER.}

STYLE A.

Large, open wiper, 10-inch wheel, train of three gears, and many other special advantages.

STYLE C.

Has all the improvements, with four blades, open cylinder, and $8 \frac{1}{2}$-inch d riving wheel.

STYLE K.

Open wiper, 10-inch wheel; five knives, insuring a fine cut.

Write for quotations.

\section{TOWNSEND'S “GLEANER" LAWN TRIMMER.}

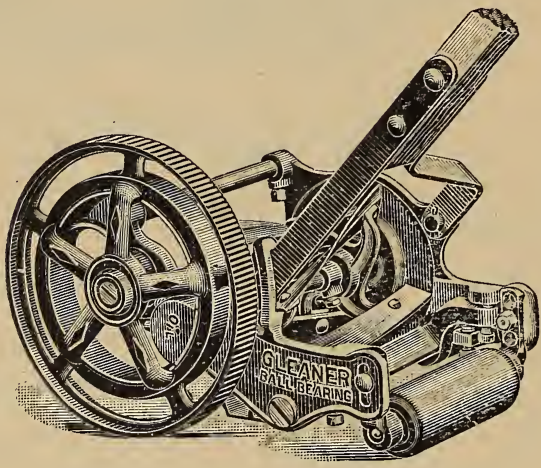

- Does what lawn mowers leave undone. Trims and edges the lawn with remarkable speed and perfection. 9-inch wheel, ball-bearing; 4 steel blades, 8-inch cut. Strictly high grade in every particular.

Price, \$5.00.

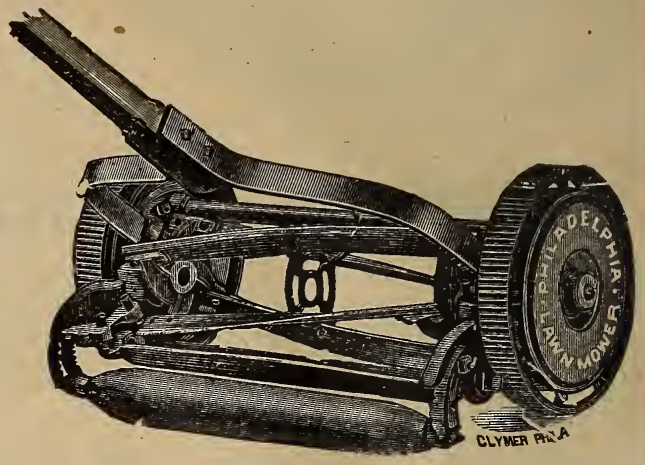

"Simplex" Grass Catchers.

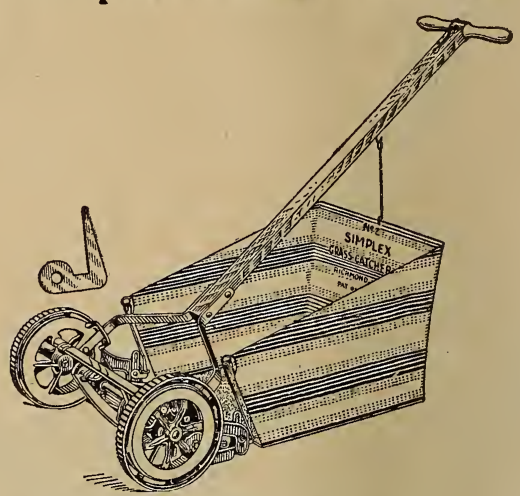

Will fit any mower made. Instantly attached and detached. Canvas body, galvanized iron bottom, combining strength with lightness.

No. 1 for 12,14 and 16 -inch mowers.

No. 2 for 16,18 and 20 -inch mowers.

Price, $\$ 1.25$ each.

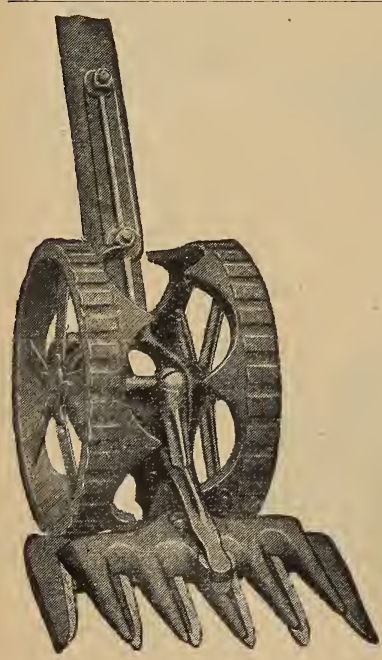

\section{THE VICTOR GRASS CLIPPER}

\section{AND \\ Handy Lawn Trimmer}

is intended to substitute the regular mower only where the mower is too large to takejcare of the work, as when clipping close to a fence or wall, clipping around trees, bushes or flower beds, and when the grass is too tall for the regular mower. The Victor will cut grass of any height. 


\section{TYRIAN PLANT SPRINKLERS.}

STRAIGHT NECK.

$1 / 2$ pint size.......\$\$ .65

$3 / 4$ " " 6 . $\ldots \ldots \ldots \ldots \quad .75$

1. " " $6 \ldots \ldots \ldots . .90$

\section{BENT NECK.}

$1 / 2$ pint size.......\$ $\$ .75$

$3 / 4$ " $6 \begin{array}{llll} & 6 \ldots \ldots\end{array}$

1 "6 " 1 . $\ldots \ldots \ldots 1.00$

If sent by mail, 5 cents each, extra.

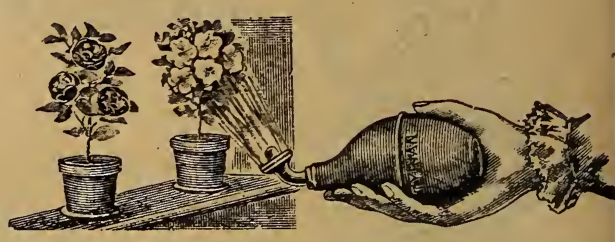

\section{THE GIBBS LAWN RAKE.}

A perfect implement for cleaning lawns from leaves, grass and all kinds of rubbish without injuring the grass and roots.

Price, each, 40 cents.

\section{GRASS HOOKS.}

All sizes. All kinds.

Prices, 25 cents to 50 cents each.

FLORAL TOOLS IN SETS.

From 10 cents to $\$ 1.00$ per set.

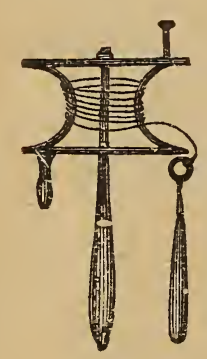

GARDEN REELS.

Each, \$1.00.

\section{GARDEN LINES.} 100 feet long. '50 cents each.
CAST STEEL GARDEN RAKES.

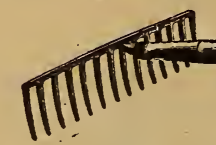

10 teet

Price, 45 cents

16 6

18

\section{Wire Fruit Picker.}

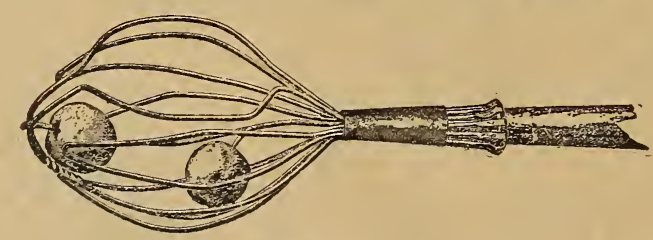

Price, 25 cents each.

\section{Cast Steel Garden Irowels.}

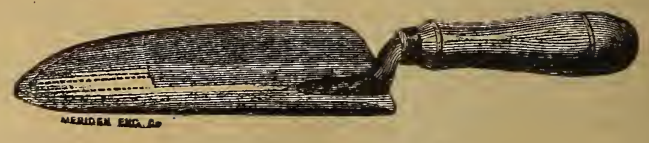

Price, 10 cents.

6 inch extra solid steel blade and shank,

7 inch extra solid steel blade and shank,

40 cents 45 cents
Border Knife.

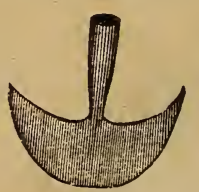

9 inches, 60 cents each.

\section{BOSTON}

HOSE

NOZZLE.

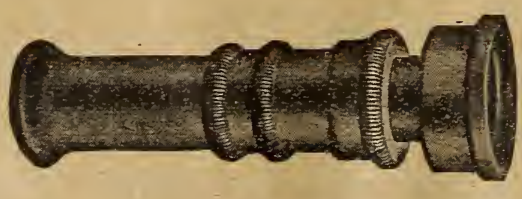

Price, 40 cents each.
Eureka Fumigators, FOR FUMIGATING WITH TOBACCO STEMS.

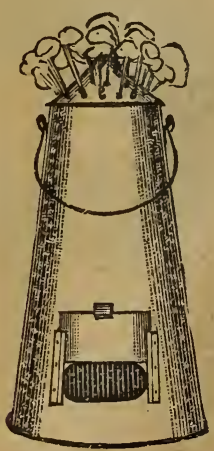

No. 1, 12 inches high, $\$ 1.5$ C

" 2,16 " " $2.0 C$ 


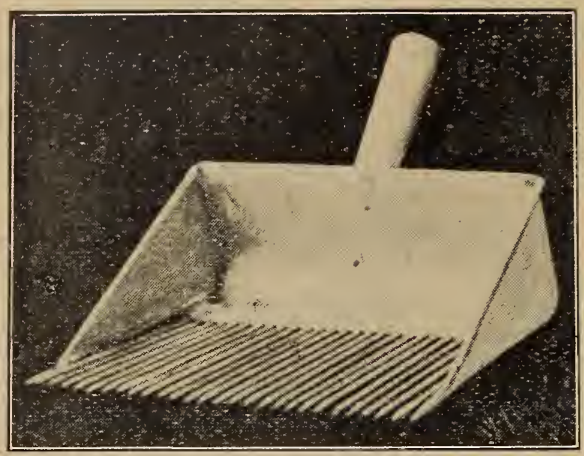

\section{BLUEBERRY PICKER.}

The picker is made from the best quality of heavy tin, and fitted with points made from highest tempered steel spring wire. These points are thoroughly soldered, making a very substantial and convenient picker.

Made in the following sizes:

\begin{tabular}{|c|c|c|c|c|c|c|c|c|}
\hline Price, & 18 & oint, & - & - & - & - & $\$ 1.25$ & each. \\
\hline c6 & 20 & 66 & - & - & - & - & 1.35 & 66 \\
\hline 66 & 24 & 6 & - & - & - & - & 1.65 & 66 \\
\hline 66 & 26 & 66 & - & - & - & - & 1.85 & 66 \\
\hline 66 & 28 & o6 & - & - & - & - & 2.00 & 66 \\
\hline 66 & 30 & 66 & - & - & - & - & 2.15 & 66 \\
\hline
\end{tabular}

Arlington Scuffle Hoes. 8-inch and 9-inch blade. Each \$1.75.

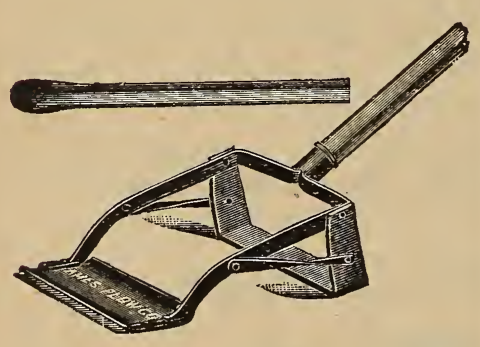

Arlington Scuffle Hoe.

\section{Dutch Hoe.}

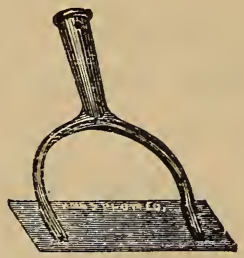

Price, 50 cents.

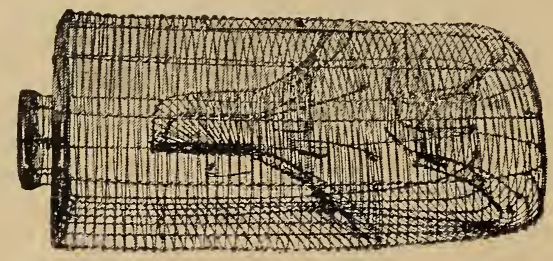

\section{WIRE RAT AND MOUSE TRAPS.}

The most effective wire trap ever produced.

Price-Giant, 75c.; Surprise, 40c.; Clipper, $25 \mathrm{c}$.

Tin Mouse Trap.

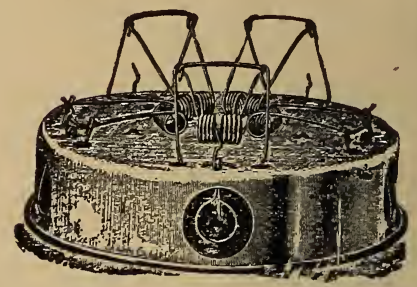

10c.

\section{Round Wood Mouse Trap.}

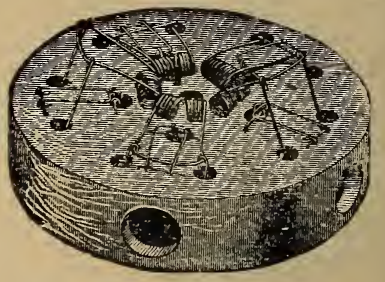

10c.

\section{BERRY BASKETS.}

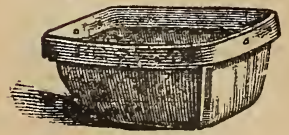

Oblong Pint.

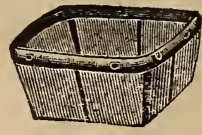

Quart.
Our berry baskets are made of best quality clear wood and put up in good strong crates. Packed 1,000 in a crate. Write for prices. 


\section{WHEELBARROWS.}

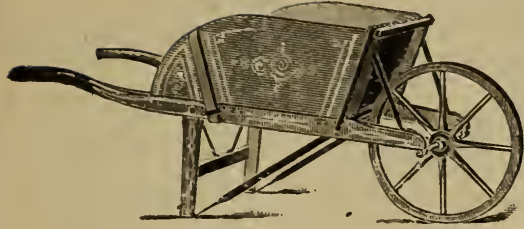

GARDEN BARROW.
No. 2. K. \& W. Garden Barrow.

$\$ 3.00$

No. 3

66

3.25

No. 4. "

No. 5. 66

No. 6. 66
3.50

3.75

4.25

3.75

4.25

4.75

9.00

Lawn or Stable Barrow. Extra size (box being 32 in. $x 25$ in. $x 18$ in.)...

\section{CANAL BARROWS.}

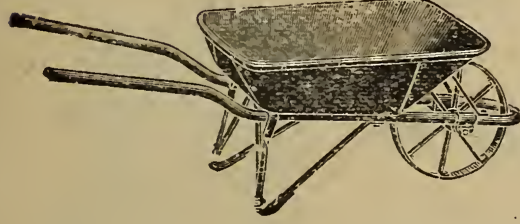

STEEL TUBULAR CANAL BARROW.

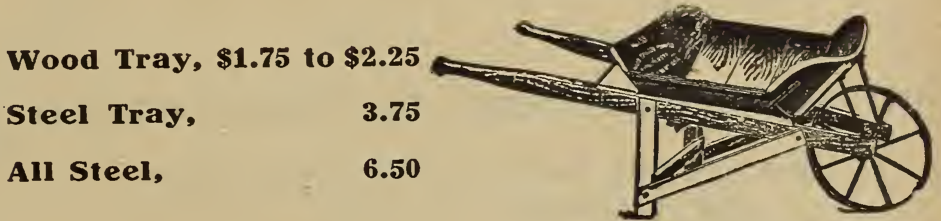

CANAL BARROW.

STEEL ROAD SCRAPERS.

No. 0. Price.............................. \$8.25

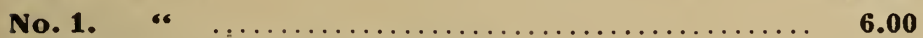

No. 2. 6 . $\ldots \ldots \ldots \ldots \ldots \ldots \ldots \ldots \ldots \ldots \ldots \ldots \ldots \ldots \ldots \ldots$

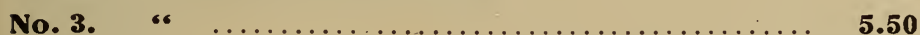

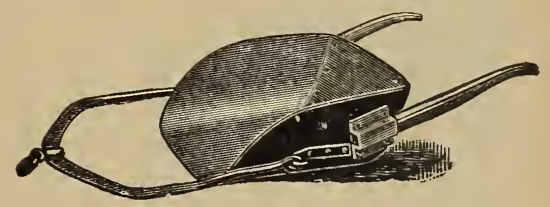

\section{CAST IRON HEAD FOR DRAG.}

This illustration shows a simple device whereby a drag can be readily made by using STRAIGHT plank.

Price, $\$ 3.00$

We also furnish the drag complete as shown below.

Price, $\$ 7.00$
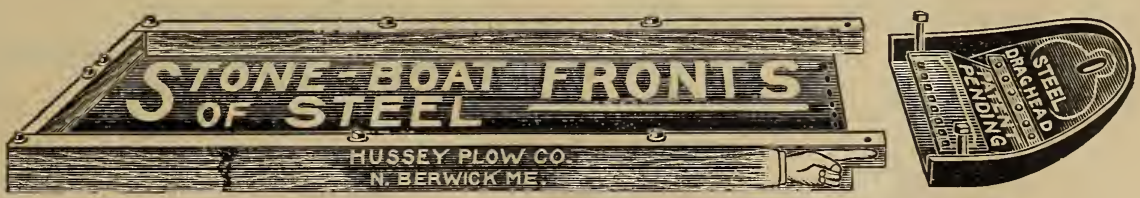

\section{CAST IRON HOG TROUGHS.}

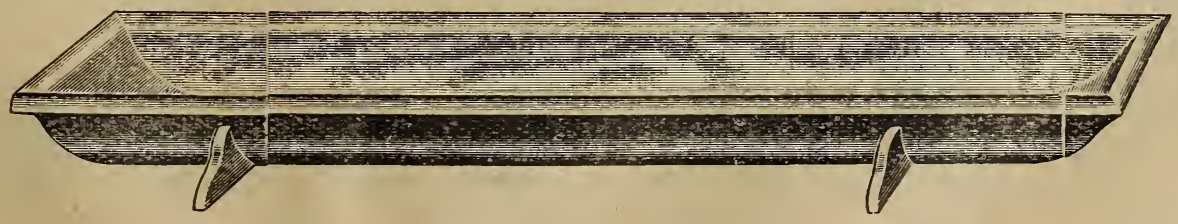

Prices from $\$ 1.25$ to $\$ 3.00$. 


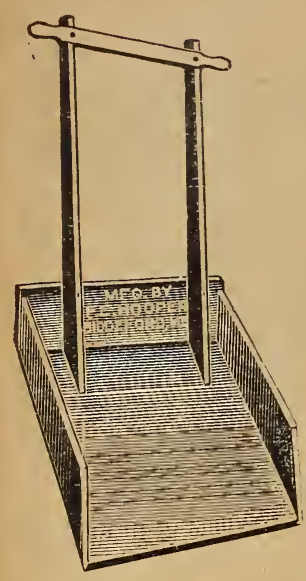

Price, 2 feet,

- $\quad-\quad+\quad \$ 2.50$

2 o 6 inches, $\quad . \quad . \quad .00$

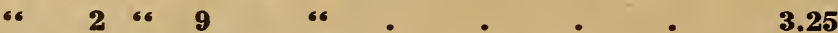

Steel Shovels, Spades, Scoops, Hoes, Forks and Rakes.

Complete Assortment of all Garden Tools constantly on hand.

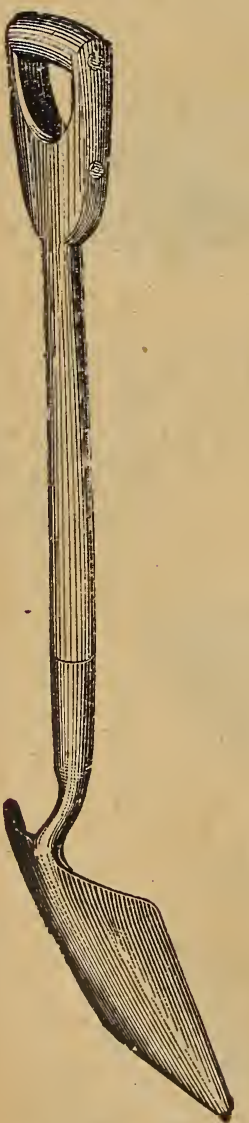

Maynard's Solid

Steel Socket Shovels and Spades.

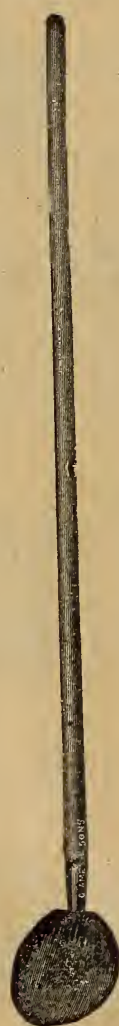

Post

Spoon.

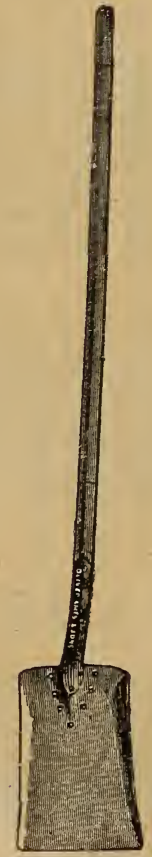

Long Handle Square Point Shovel.

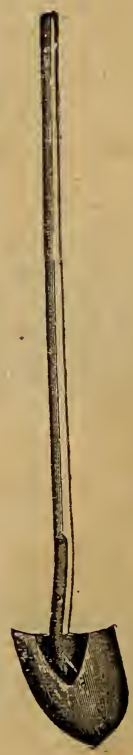

Long Handle Round Point Shovel.

\section{Wooden}

and

Steel

Snow

Shovels.
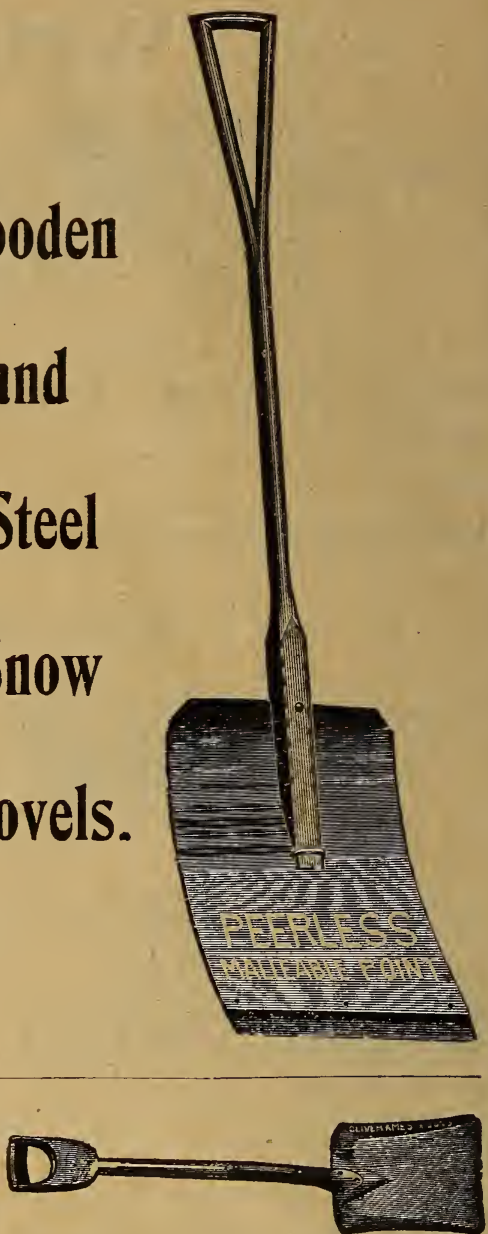

D Handle Square Point Shovel.

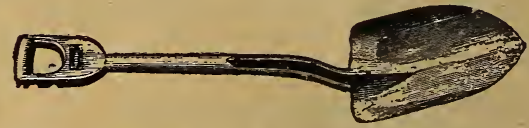

D Handle Round Point Shovel.

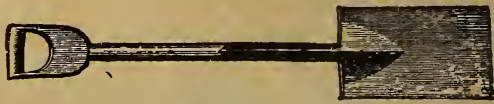

D Handle Spade.

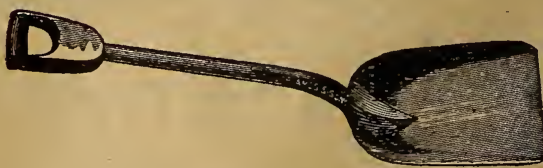

Solid Steel Scoop.

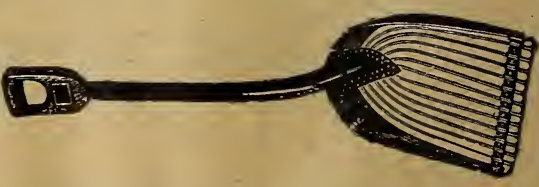

Wire Potato Scoop. 


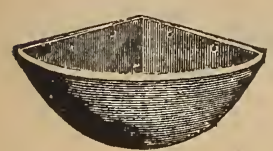

Corner Manger.

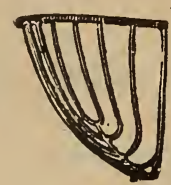

Feed Racks.

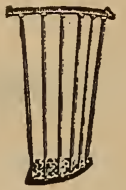

IRON CORNER FEED RACKS AND MANGERS.

WRITE FOR PRICES.
ANIMAL TETHER.

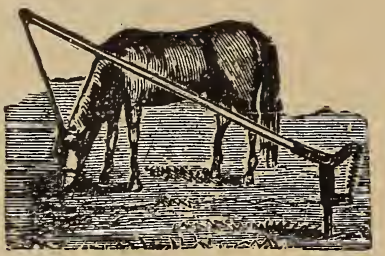

Price, \$3.00 each.

\section{CARRIAGE JACKS.}
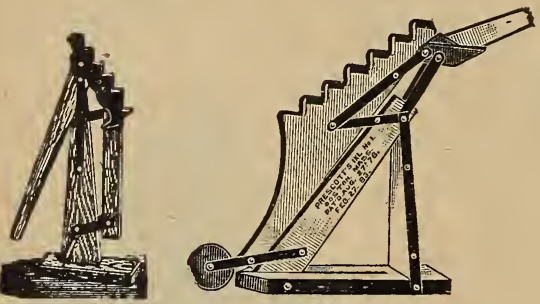

$\$ 1.00$ to $\$ 4.00$.
GALVANIZED IRON BUSHEL BASKEIS.

These baskets are made of galvanized iron, and are fur$n$ ished with malleable iron handles. Strong, durable and useful.

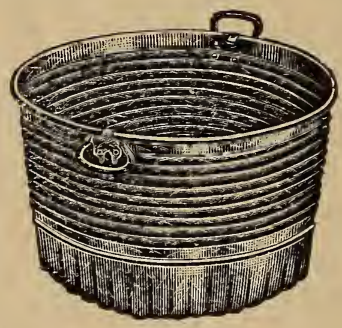

Price, 65c.

\section{FEED BAGS. MADE FROM} HEAVY CANVAS. PLAIN OR WITH BRIDLE.

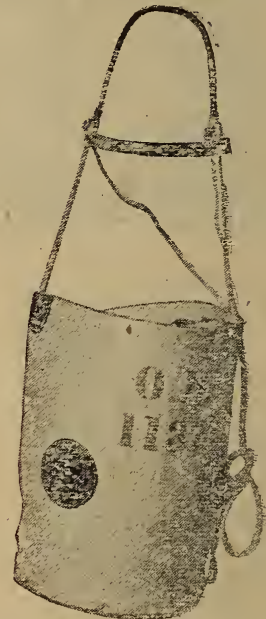

Price, 35c. to 75c. each.

\section{BARREL HEADER.}

This is the most simple labor-saving machine ever invented for heading up barrels and is used extensively for heading up apples, fish and other merchandise.

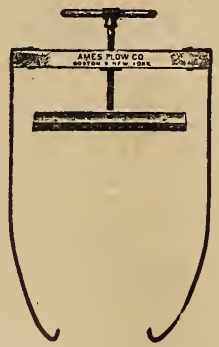

STORE AND BAG TRUCKS. MADE OF HARD WOOD AND WELL IRONED. RUBBER TIRED WHEELS, for hotel use.

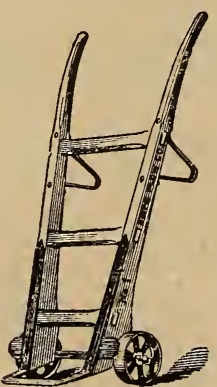

HAY KNIFE.

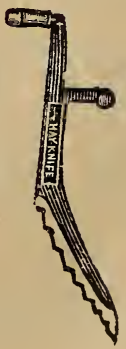

Price, 75c.
BULL RINGS.

Copper and steel.

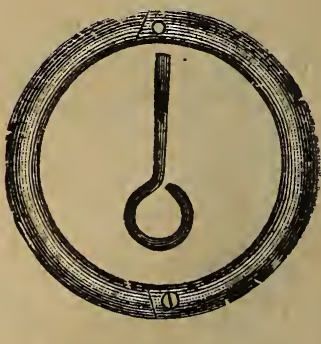

Price, 15c. to 30c. each.

Price(1-in. screw), \$1.25. Price, $\$ 2.25$ to $\$ 10.00$.

PICKS AND MATTOCKS.

Pick.

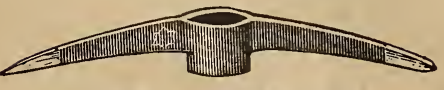

Price. $75 c$.
Axe Mattock.

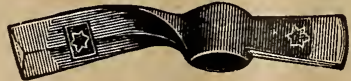

Price, $75 \mathrm{c}$.
Pick Mattock.

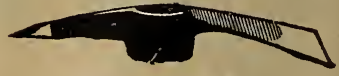

Price. $75 c$. 


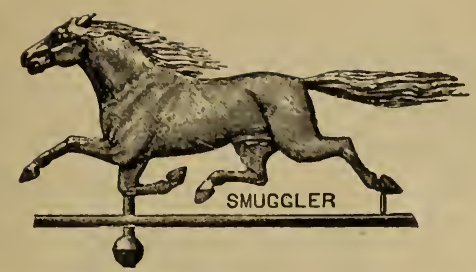

\section{WEATHER VANES.}

All our vanes are made of copper and gilded with 23-karat goldleaf that will remain bright for years. The vanes include iron spire with steel spindle point, points of the compass and gilded balls and letters.

Descriptive Circular and Price List on Application.

\section{BIRD CAGES, SEEDS AND SUPPLIES.}

\section{Brass and Japan Bird Cages,}

\section{Parrot and Squirrel Cages.}

CANARY SEED, RAPE, MILLET, HEMP, RICE, SUNFLOWER AND CUTTLE FISH

Prepared Mixed Canary Seed.

GRAVE, SONG RESTORER, PARROT FOOD AND MOCKINGBIRD FOOD.

Cage Springs, Cups, Hooks, Ladder Chains, and Wire Guard Cloth.
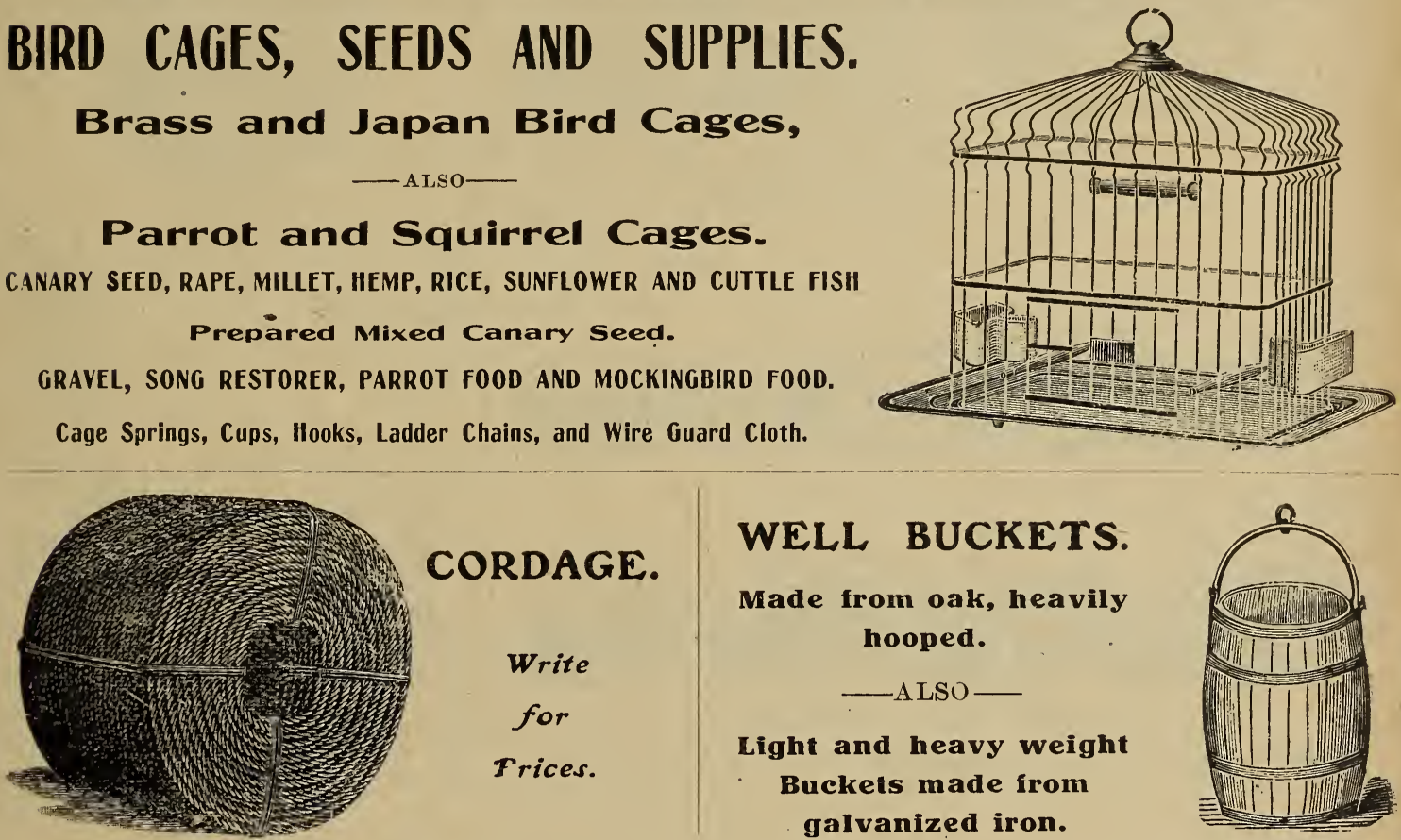

CORDAGE.

Write

for

rices.
WELL BUCKETS.

Made from oak, heavily hooped.

$-\mathrm{ALSO}$

Light and heavy weight

Buckets made from galvanized iron.

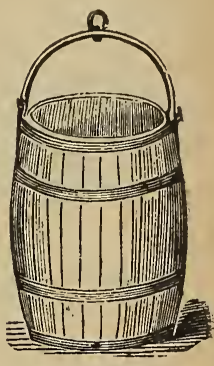

\section{THE FAIRFIELD LAWN SWING.}

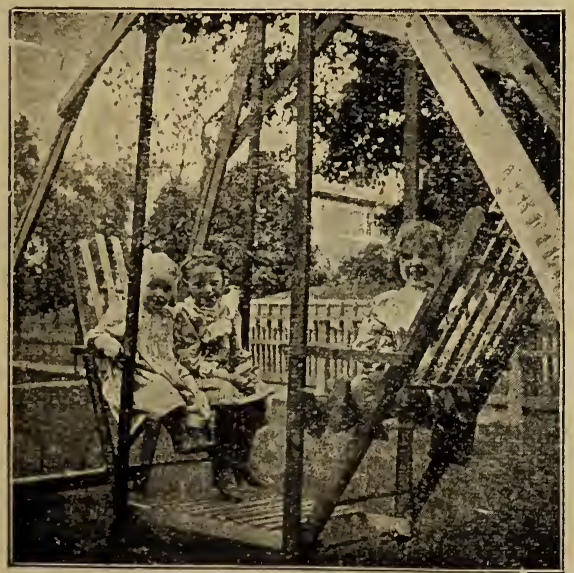

Wooden

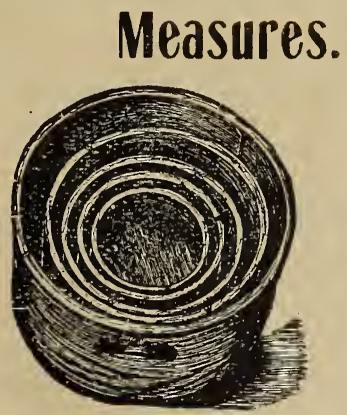

In sets of

$1,2,4,8$, and 16 qt. sizes.

Price per set, $\$ 1.65$

This swing easily takes precedence over all others in the market. Made of clear mountain spruce. Mechanical perfection, durability and ease of operation are combined in its construction.

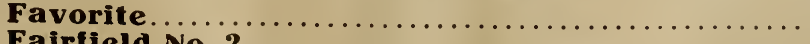

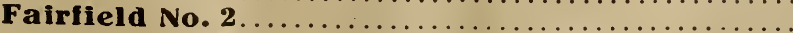

GARDEN VASES,

STONE DRAIN PIPE AND LAND TILE.

Send for llustrated Catalogue and Price List.

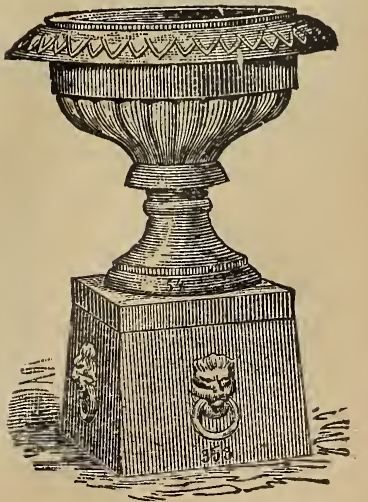




\section{BASKETS}

OF EVERY SIZE AND STYLE FOR

FACTORY, MILL, STORE, FARM AND OFFICE. Corn Packers' Baskets a Specialty. Write for Quotations.

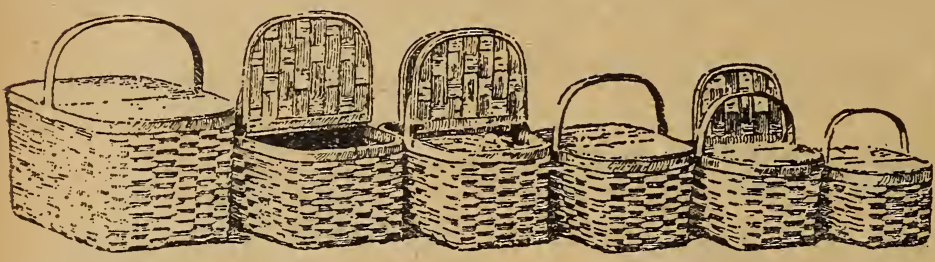

Ash $=$ Covered Lunch Baskets.

One or Two Bail, Ash-Covered Lunch Baskets.

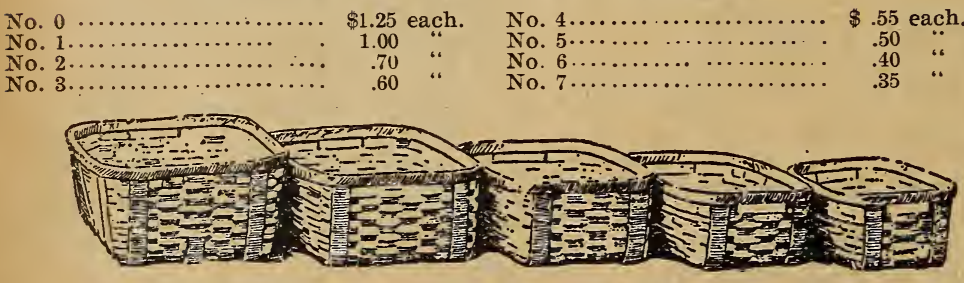

Hole=Handled Market Baskets.

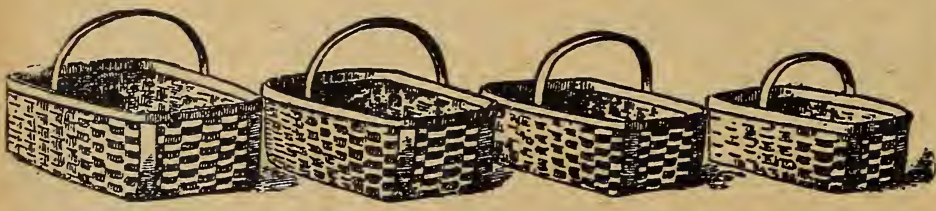

Bail=Handled Market Baskets.

Solid Oak Market Baskets, with Bail, Hole or Block Handle Strapped.

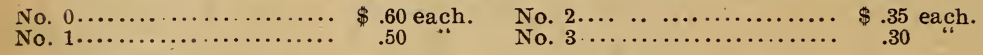

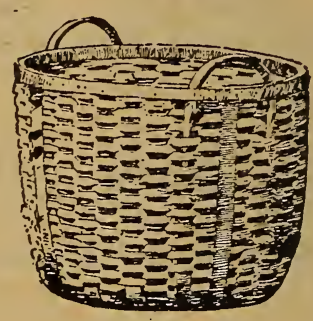

Oak Splint Basket.

Each.

No. 1. 5 bush., solid oak, nailed rim.. $\$ 3.25$ No. 1.4 " " " " 4 " .. 3.00

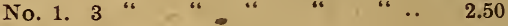

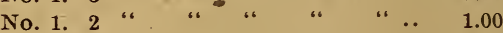

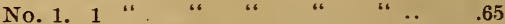

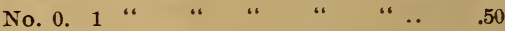

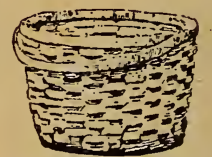

$1=2$ bush. Basket.

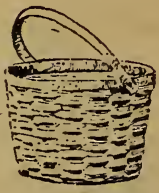

1=4 bush. Basket. Each. $\frac{1}{2}$ bush., solid oak, nailed rim, stiff bail. $\$ .35$

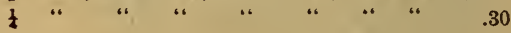

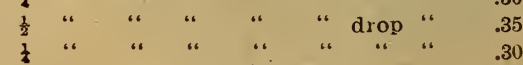

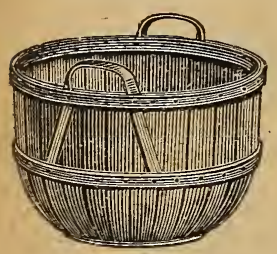

\section{IHE HOLDEN ASH SIAVE BASKEIS.}

One of the smoothest, strongest and best baskets for farmers and grocers. Made in every size from $1 / 4$ bushel to 4 bushels.

\section{OVAL WILLOW CLOTHES BASKETS.}

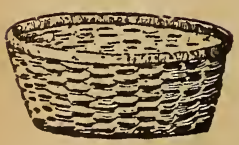
Small (n.

\section{OBLONG ASH CLOTHES BASKETS.}

Barrel Baskets. Small .................................. \$ .75 each. 35 cents.

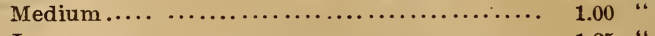

Large.................................... 1.25 "

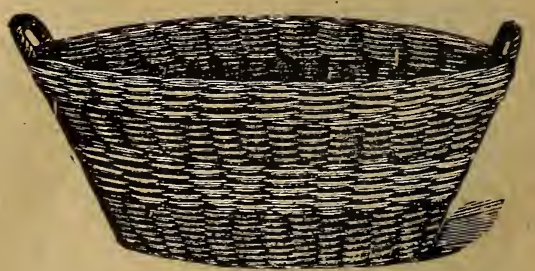

Oval Willow Clothes Baskets.

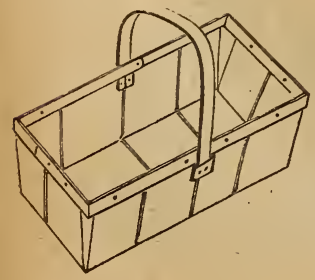

\section{VERBENA BASKETS.}

With wood or wire handle. 10 inches long; 5 inches wide; 3 inches deep. $\$ 2.00$ per hundred; $\$ 18.00$ per thousand.

Wood handle. 12 inches long; 7 inches wide; 4 inches deep. $\$ 2.50$ per hundred; $\$ 23.00$ per thousand. 


\title{
"K. \& W." SANITARY SWEEPING POWDER.
}

Can be used on carpets, rugs, linoleums, mattings, tile and wood floors; is economical, non-inflamnable, and absorbs the dust, thereby preventing the scattering of disease germs.

This powder is mixed by machinery only, and is composed of a special wood pulp combined with absorber and silica, which gives it its cleansing property. There is no sand used, the grit which is noticeable being silica. The oil of cedar, which is used as a disinfectant, is one of the best known to medical science. This powder always runs uniform, will cover a large area, and its use is recommended in every home, public building, store and factory.

\author{
Price-1-4 bbl., \$1.00; $1-2 \mathrm{bbl.0} \$ \$ 1.75 ; b b l . . \$ 3.00$. \\ Special quotations on large quantities.
}

\section{O-CEDAR POLISH}

\section{AND DUSTLESS MOP.}

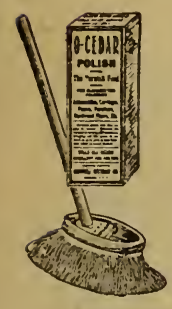

The one Perfect Polish for pianos, automobiles, furniture, hardwood floors, and all waxed, varnished and polished surfaces, as it will not gum, and aside from its high lustre, it is a dust allayer, a labor saver, and clean and sanitary in every particular.

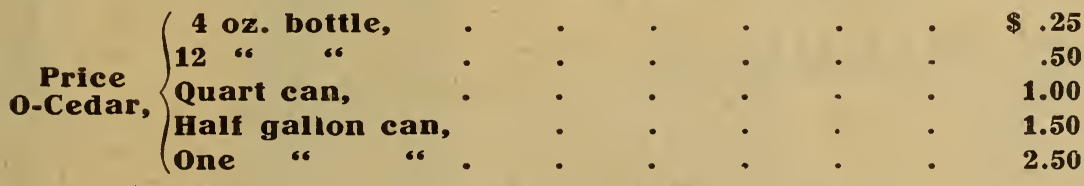

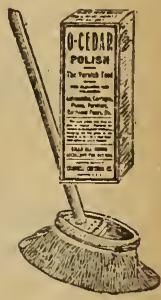

Price 0-Cedar Mops, No. $1, \$ 1.50 ;$ No. $2, \$ 1.00$.

\section{THE REGINA PNEUMATIC CLEANER.}

Weighs but 25 pounds and is easily carried in one hand. Occupies small space when not in use and does the same work as other vacuum cleaners costing several times as much. The hose is of a superior grade of rubber and is nine feet long. It has a large duplex pump, and is so constructed that a strong suction is created by both the forward and backward stroke of the lever.

\section{Price, \$18.00.}

\section{TH CENTURY \\ BARREL PUMP}

FOR VINEGAR.

Nade fro'm chemicalized wood and is strictly non-corrodible; does away with the slow, leaky faucet; will pump the liquid at the slightest stroke of the piston.

Price, $\$ 1.00$.

\section{STONE WARE.}

ALC SIZES OF

Stone Pork Barrels, Butter Pots, Bean Pots, Preserve Jars, Jugs and Churns.

Write for Price List.
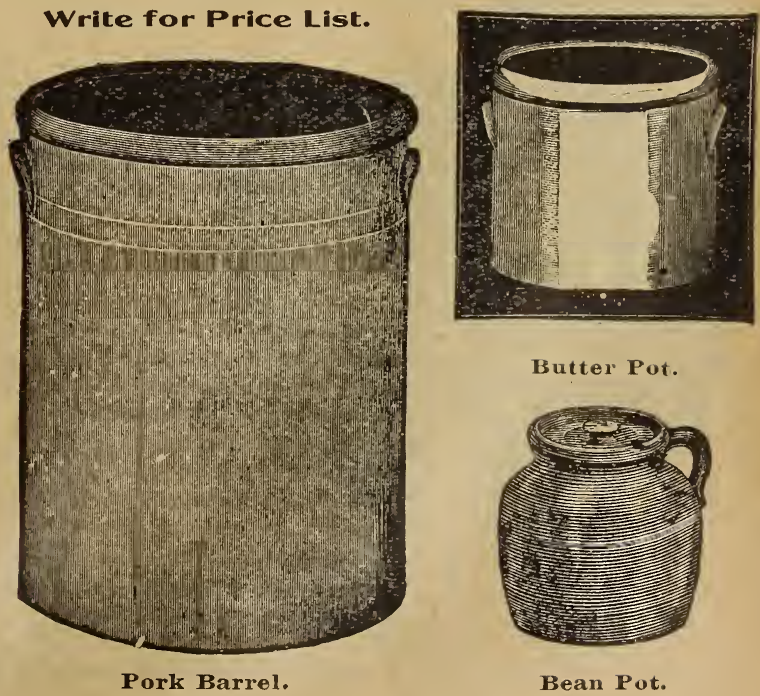

Butter Pot.

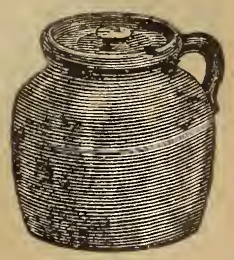

Bean Pot. 


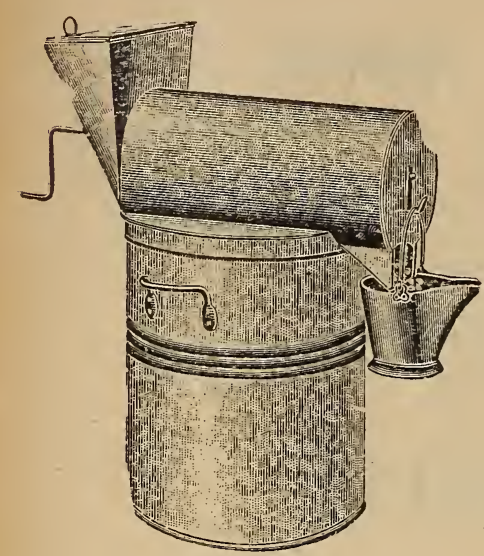

"THE HUSTLER."
"THE HUSTLER"

ROTARY ASH SIFTER.

In galvanized iron case. No dust. Works easily, quickly and well.

Price-No. 1, fits 18-in. iron can, or flour barrel, $\$ 4.50$ No. 2, fits 20 -in. iron can, or sugar barrel, $\quad 6.50$

\section{THE "LOWELL" COAL SIFTER.}

This is an all wire sifter, sifting the ashes through the sides as well as the bottom.

Price, complete, with cover, 75 c.

\section{THE FAVORITE COAL SIFTER.}

Price, complete, with cover, 50c.

\section{GALVANIZED IRON ASH BARRELS.}

Solid heavy barrels. No danger from hot ashes.

Price, No. 41,

، “5, 5 ,

a c6 190,

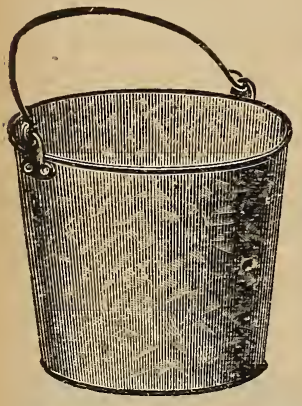

\section{GALVANIZED IRON} PAILS.

10 quart, 12 ."

14 "

16 "6

10 66

12 "

14 "6

16 66

$\begin{array}{cc} & 25 \mathrm{c} . \\ & 30 \mathrm{c} . \\ & 35 \mathrm{c} . \\ & 40 \mathrm{c} . \\ \text { extra heavy, } & 40 \mathrm{c} . \\ 6 & 45 \mathrm{c} . \\ 6 & 50 \mathrm{c} . \\ 6 & 55 \mathrm{c} .\end{array}$

$\$ 1.85$

2.10

2.60

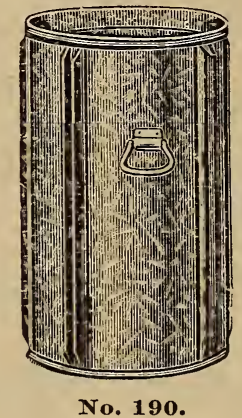

No. 190.

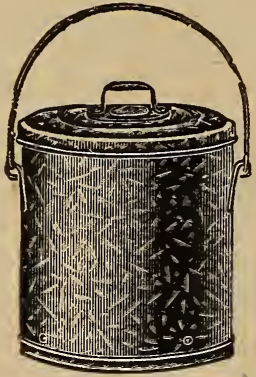

GARBAGE PAILS.

Made from

Galvanized Iron.

No. 02,

$\$ .75$

" 03,

.85

"6 04,

1.00

“ 40,

1.25

" 50 ,

1.65

"310,

2.00

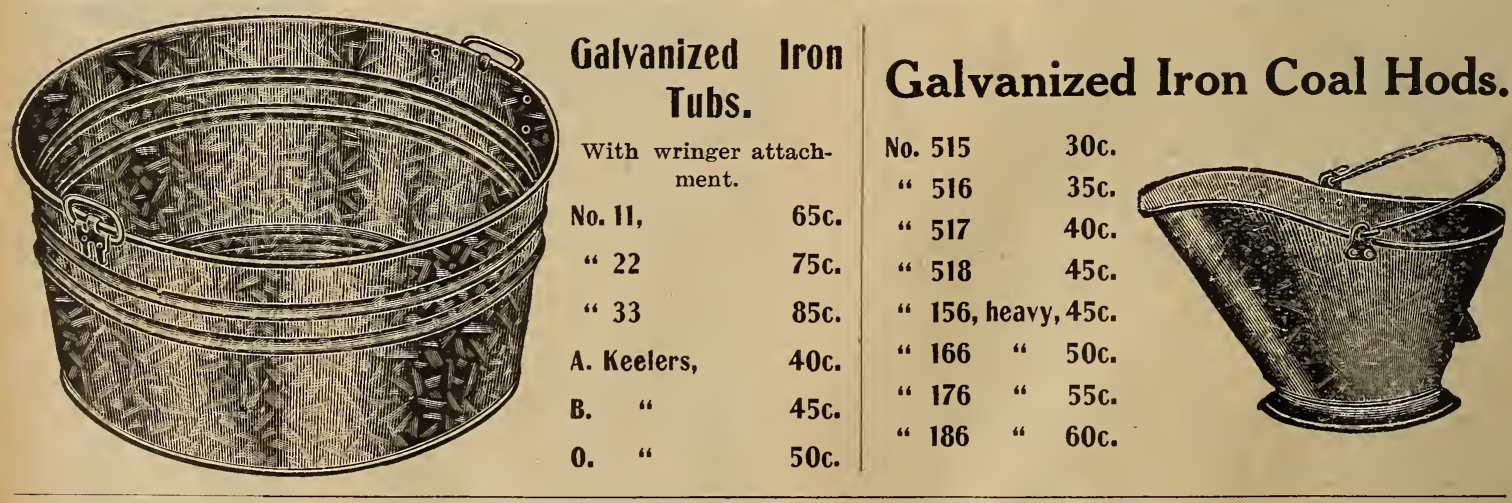

\section{BROOMS AND BRUSHES,}

AND A LARGE VARIETY OF WOODEN WARE OF ALL KINDS. ALL ORDERS PROMPTLY EXECUTED. 


\section{MAJESIIC ROTARY WASHER.}

The Rotary is simple, strong, easy running and noiseless, the rotary motion being continuous, and the fly wheel heavy. Very little power is required to operate the machine. It is constructed of the Best White Cedar, and is strong and finely made.

Price, \$7.00.

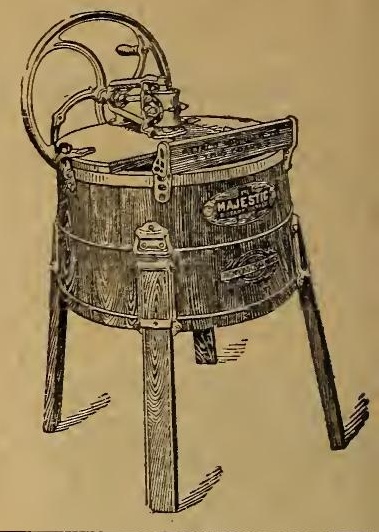

\section{CLOTHES WRINGERS.}

\section{TUB WRINGERS.}

Universal,

Household,

Eureka,

Daisy.

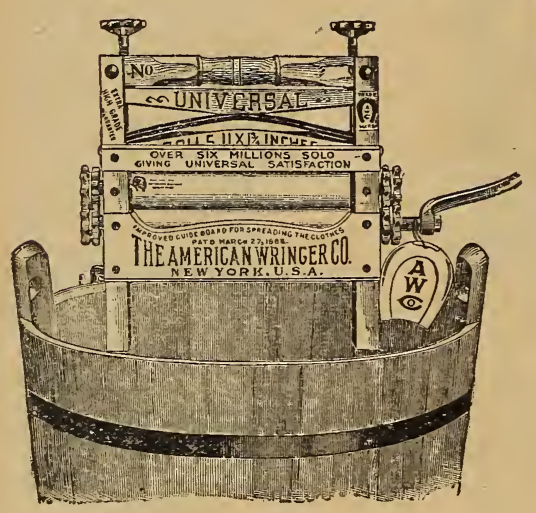

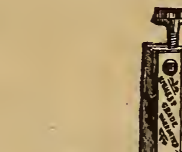

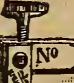

UNII

ENCLOSEDCOG TIS

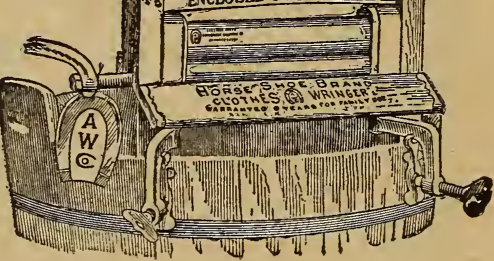

UNIVERSAL.

BEST KNOWN AND LARGEST SELLER.

$\mathrm{Mad}$ e either with regular bearings, ball bearings, or with enclosed gears.

Write for Prices.

\section{BENCH WRINGERS.}

Universal,

Household.

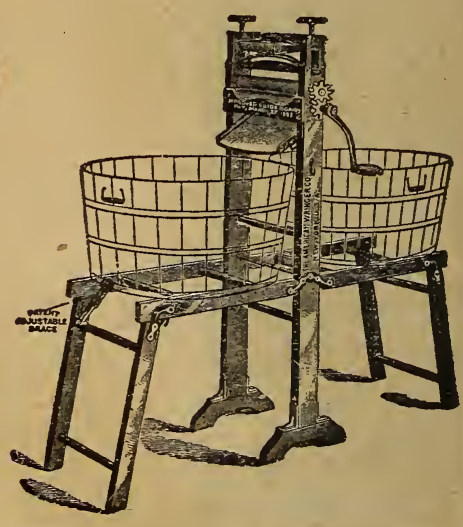

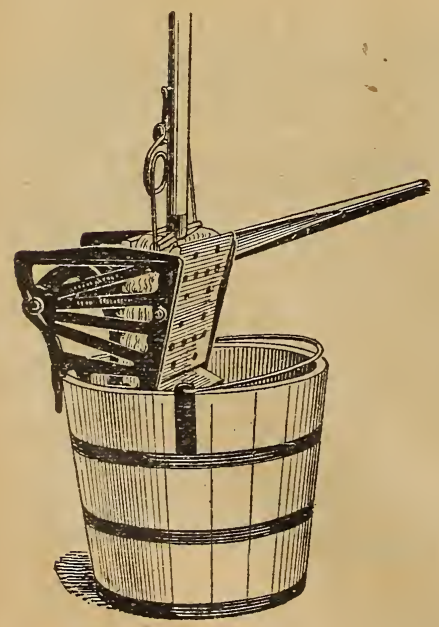

Hotel Size.

\section{WHITE'S \\ Patent Mop Wringers.}

Will quickly wring a mop perfectly dry,

without touching mop with hands.

The wringer may be instantly attached to the pail and quickly removed.

Always place the wringer on the opposite side of pail from the bail.

Use mop made of any material desired. A short, thick mop is generally best liked, and is the best wrung by the wringer.

$\begin{array}{ccc}\text { Price, Family Size, } & \$ 1.50 \\ \text {.. Hotel } & \text {.. } & 2.00\end{array}$

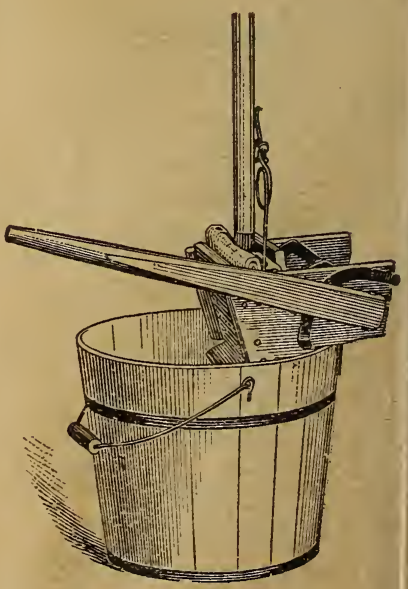

Family Size. 

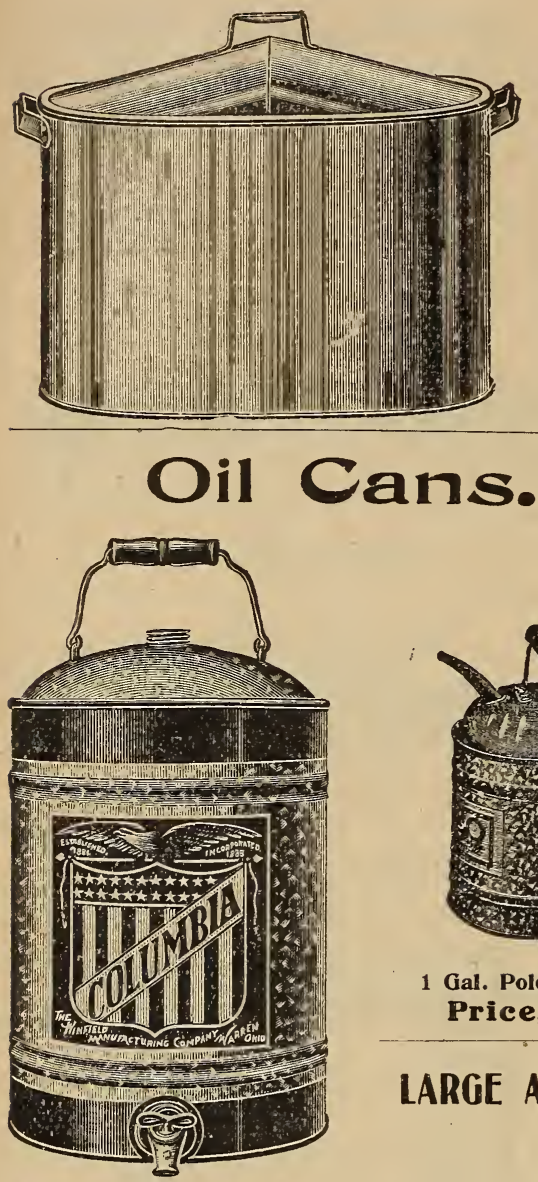

5 Gal. Columbia Oil Can. Price, 75c.

\section{WASH BOILERS.}

8 in. $\mathrm{X}$ tin bottom,

9 in. $X$ “ “

8 in. $X$ copper bottom,

9 in. $X$ "

\begin{tabular}{r|rlr}
$\$ .90$ & 8 in. XX copper bottom, & $\$ 1.35$ \\
1.00 & 9 in. XX “ & " & 1.60 \\
1.25 & 8 in. all copper, “ & 2.75 \\
1.40 & 9 in. " “ “ & " & 3.00
\end{tabular}

\section{TEA KETTLES.}

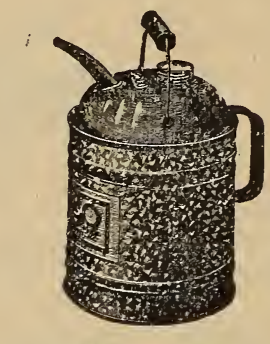

NICKLE

COPPER.

PRICE,

$\$ 1.10$.

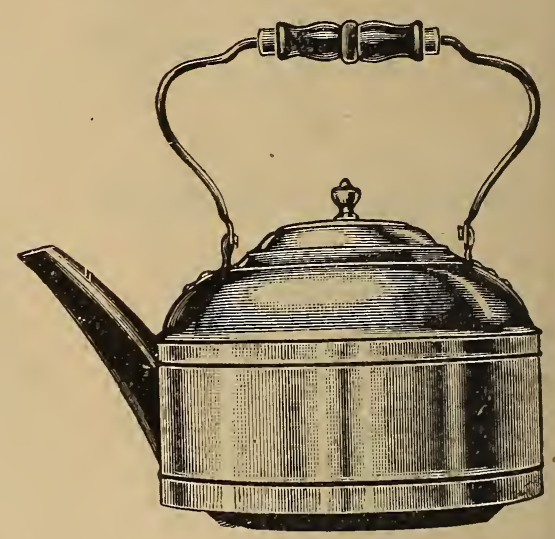

Gal. Polo Oil Can. Price, 25c.

\section{LARGE ASSORIMENI OF METAL AND GLASS OIL CANS,}

holding from one to ten gallons each.

\section{“K. \& W." Oil Tanks.}

For use where a considerable quantity of oil is kept. These tanks are fitted with a pump, and are safe, convenient and durable.

Price, 60-gallon tank,
66 110-gallon tank,
$\$ 5.00$ each.

9.00 “6

\section{CORN POPPERS.}

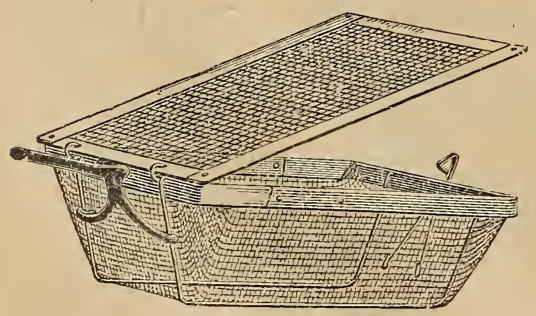

Firm and well braced popper with detachable handle, and with wire guards to protect bottom of popper from wear.

1 quart,

1 1-2 quart,

\section{Price.}

12c. 2 quart,

15c. 4 quart,

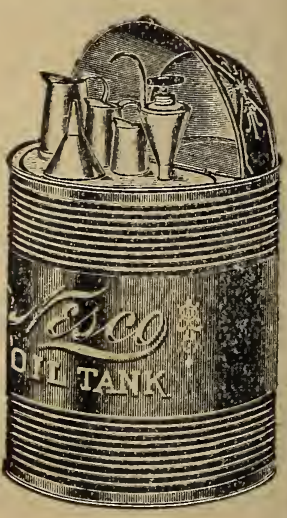

SHERWOOD POPPER (2 quart size). Made with sliding cover. One of the heaviest and best poppers made.

Price, 50c. 


\section{-ICE CREAM FREEZERS.- "WHITE MOUNTAIN."9}

Perfected by the introduction of an important feature of a double self-adjusting wood scraping bar attached to the duplex dasher. By means of this device the actual time of freezing cream has been very materially reduced.

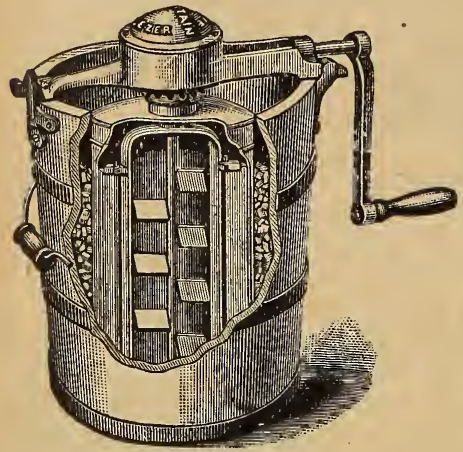

The cut shows the construction and position of the mechanism of the White Mountain Freezer. The can moves from right to left, the outside beater moves from left to right, scrapes with its wooden bars the frozen cream from the can and throws it toward the center, where it is met by the floats of the inside beater moving in an opposite direction and returned to the inside surface of the can to be re-frozen. The triple motion thus induced keeps the cream constantly moving and ensures every lparticle being smoothly and evenly frozen.

PRICES.

\begin{tabular}{|c|c|c|c|c|c|c|c|}
\hline Junior, & $\$ 1.00$ & & 1art, & $\$ 2.75$ & 12 & 1art, & $\$ 7.00$ \\
\hline 1 quart, & 1.50 & 6 & 66 & 3.50 & 15 & 66 & 8.50 \\
\hline 66 & 2.00 & 8 & 66 & 4.50 & 20 & “ & 11.00 \\
\hline c6 & 2.25 & 10 & 66 & 5.50 & 25 & 6 & 14.00 \\
\hline
\end{tabular}

\section{"LIGHTNING.",}

\section{EASY RUNNING. QUICK FREEZING. CONVENIENT AND PRACTICAL.}

Drawn Steel-Bottom Cans, which will not leak or break. The body of can is made of heavy tin plate of finest quality. Tubs with electric welded wire hoops, which are guaranteed not to fall off or break.

\begin{tabular}{|c|c|c|c|c|c|c|c|}
\hline \multirow[b]{2}{*}{1 quart, } & \multicolumn{4}{|c|}{ PRICES. } & \multirow{2}{*}{\multicolumn{2}{|c|}{10 quart, }} & \multirow{3}{*}{$\begin{array}{r}\$ 5.50 \\
6.50\end{array}$} \\
\hline & $\$ 1.35$ & 4 & quart, & $\$ 2.50$ & & & \\
\hline “ & 1.75 & 6 & “6 & 3.25 & 12 & 66 & \\
\hline c6 & 2.00 & 8 & c6 & 4.00 & 14 & 66 & 7.50 \\
\hline
\end{tabular}
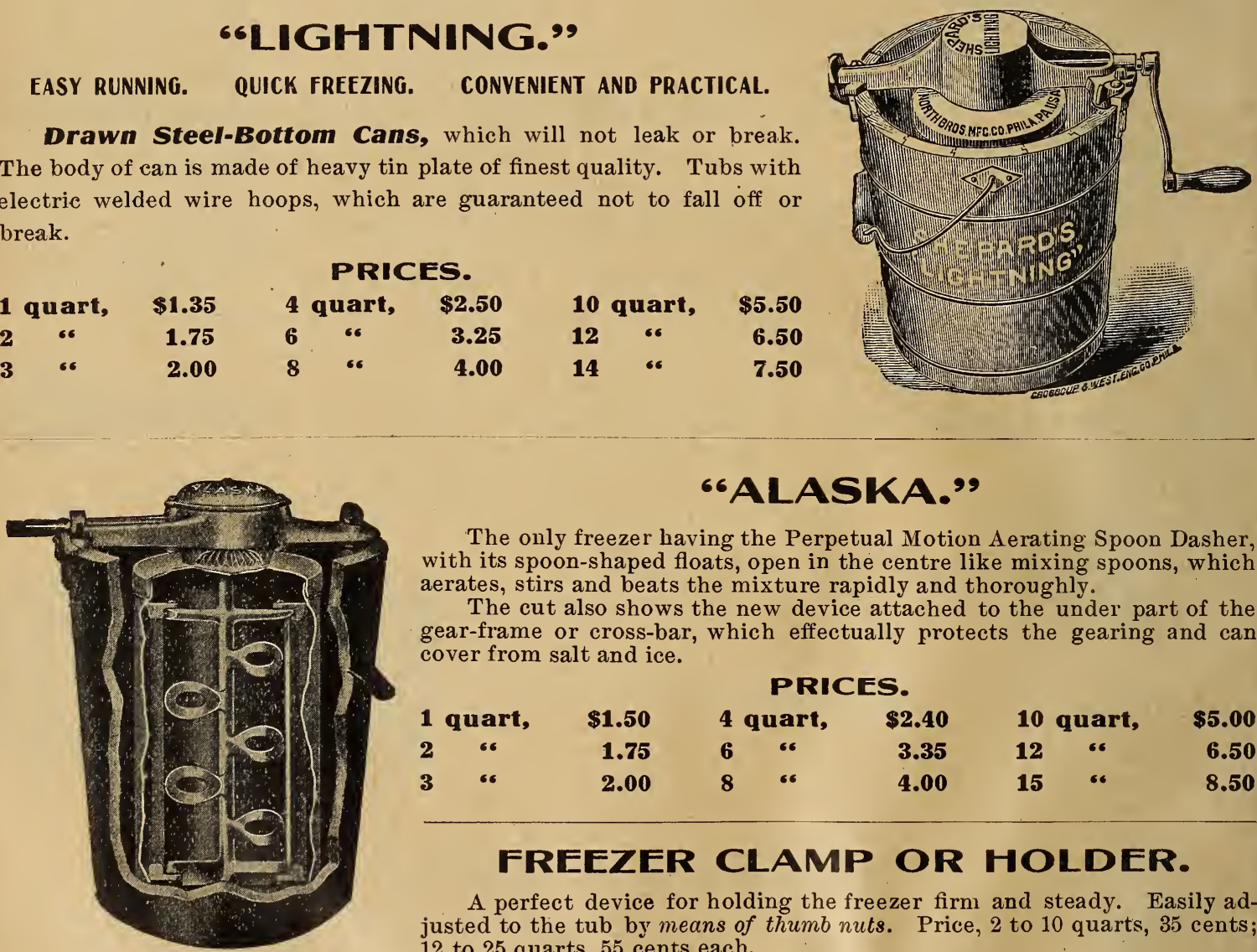

\section{ALASKA."9}

The only freezer having the Perpetual Motion Aerating Spoon Dasher, with its spoon-shaped floats, open in the centre like mixing spoons, which aerates, stirs and beats the mixture rapidly and thoroughly.

The cut also shows the new device attached to the under part of the gear-frame or cross-bar, which effectually protects the gearing and can cover from salt and ice.

\begin{tabular}{|c|c|c|c|c|c|c|c|}
\hline \multirow[b]{2}{*}{1 quart, } & \multirow[b]{2}{*}{$\$ 1.50$} & & \multirow{2}{*}{\multicolumn{2}{|c|}{10 quart, }} & \multirow{2}{*}{$\$ 5.00$} \\
\hline & & 4 & uart, & $\$ 2.40$ & & & \\
\hline 66 & 1.75 & 6 & 66 & $\mathbf{3 . 3 5}$ & 12 & 66 & 6.50 \\
\hline 66 & 2.00 & 8 & c6 & 4.00 & 15 & so & 8.50 \\
\hline
\end{tabular}

\section{FREEZER CLAMP OR HOLDER.}

A perfect device for holding the freezer firm and steady. Easily adjusted to the tub by means of thumb nuts. Price, 2 to 10 quarts, 35 cents; 12 to 25 quarts, 55 cents each.

An Illustrated Catalogue of Power and Fly Wheel Freezers. Repairs. and Tubs and Cans for Packing Purposes furnished on Application. 


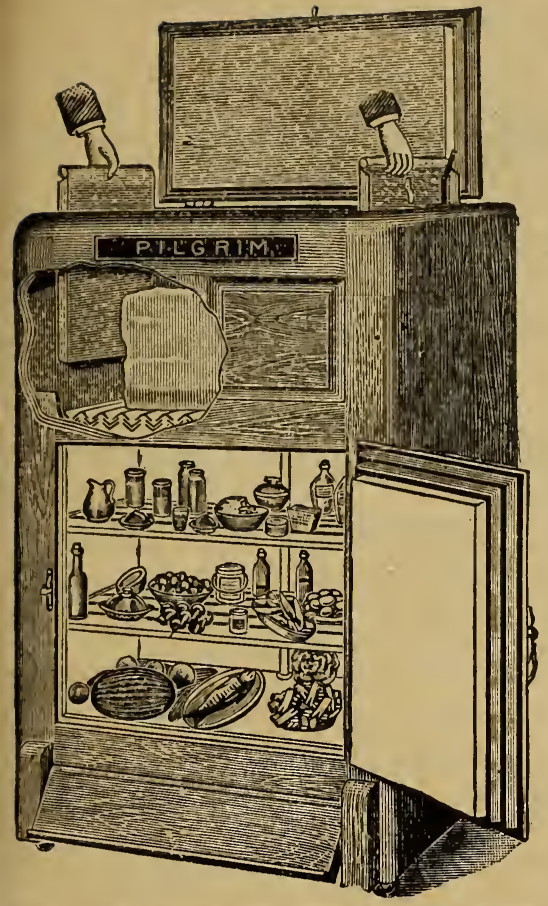

\section{"K. \& W." \\ Lightning and Mason FRUIT JAR RINGS.}

1 dozen in each package. 12 packages in a carton.

\section{THE "PILGRIM" Refrigerators and Ice Chests.}

Thoroughly constructed from hard wood, and beautifully finished. Cleanable and perfectly sanitary. The economy of ice is a very important consideration, and the consumption of ice will be much smaller in our refrigerators than in many others, and at the same time insure a low and even temperature, and perfect circulation of cold, dry air.

GROCERS' REFRIGERATORS A SPECIALTY.

Send for Illustrated Catalogue and Price List.

FRUIT

JARS.

"GENUINE" LIGHTNING.

$1=2$ pint, 1 pint, 1 quart and 2 quart sizes.

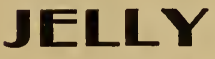

\section{TUMBLERS.}

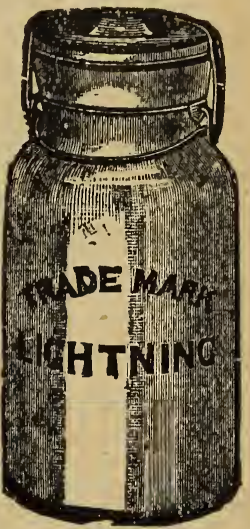

1-3 pint and 1-2 pint sizes.

\section{THE “H. \& D.” FIRELESS BROODER.}

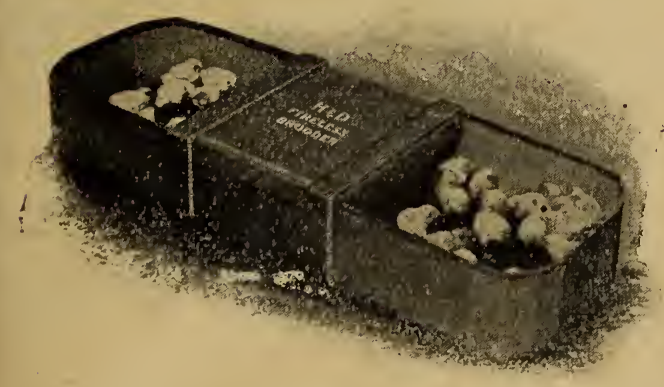

A practical, common sense, heavy paper brooder, complete with cloth hover, or blanket. Made in one size only, of fifty chick capacity.

The "H. \& D." Fireless Brooder is ideal in all respects, providing the necessary protection, and even temperature in the hover chamber, perfect ventilation, free circulation of air without draught, making sweating impossible. All openings are set on an angle, and as there are no corners in the yard or hover, chamber, crowding is prevented.

Will care for chicks until they are six weeks old, when they may be transferred to the colony house.

Price, \$2.00.

Write for Descriptive Circular.

\section{ECONOMY OATS SPROUTER.}

\section{THE NATURAL PROCESS FOR SPROUTING.}

Contains five sprouting pans and one drip pan $16 \times 17$ inches. Iron rack is 35 inches high.

By feeding sprouted oats through the winter, egg production can be kept up to a much larger degree than otherwise.

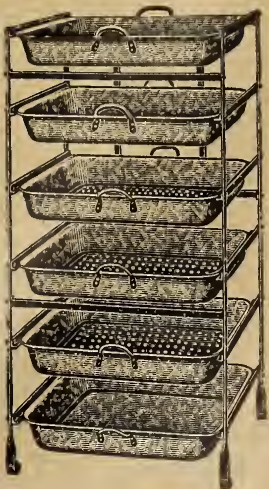


WE ARE AUTHORIZED AGENTS FOR
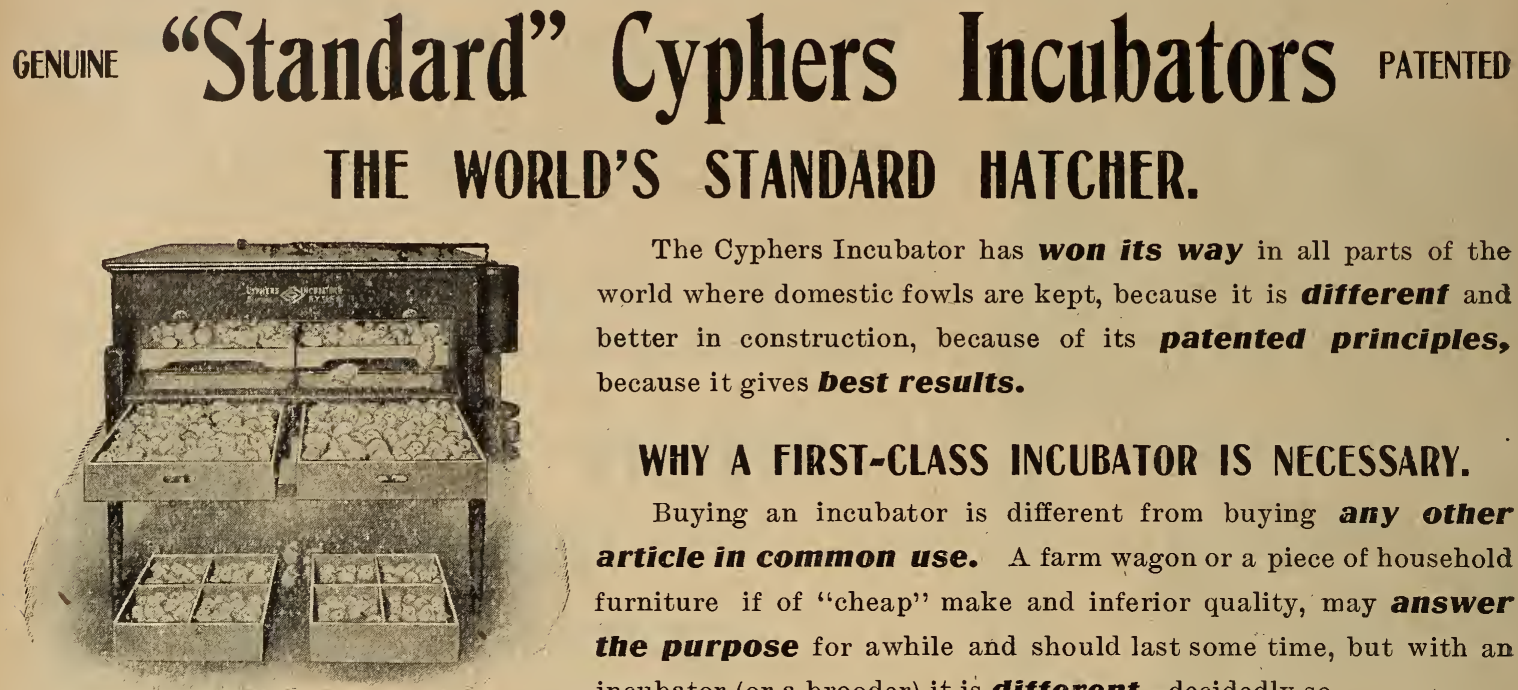

The Cyphers Incubator has won its way in all parts of the world where domestic fowls are kept, because it is differenf and better in construction, because of its patented principles, because it gives best results.

\section{WHY A FIRST-CLASS INCUBATOR IS NECESSARY.}

Buying an incubator is different from buying any other article in common use. A farm wagon or a piece of household furniture if of "cheap" make and inferior quality, may answer the purpose for awhile and should last some time, but with an incubator (or a brooder) it is different-decidedly so.

And the reasons are plain. An incubator deals with the life principle! It must be relied on to do the delicate work of producing a living organism-a complete chick in perfect health, with all the vitality Nature requïres.

This matter of "vitality" in chicks is of the very highest importance.

It is not alone the question of "how many" chicks, but also of HOW GOOD -of how strong, vigorous and healthy they are, how well hatched.

\section{FIRST-INSTEAD OF LAST.}

If you are going to use an incubator at all, buy a good one-the best to be had. If you decide that you would like to own a Cyphers, we urge you to buy it first-not after you have "tried" some cheap machine and met with discouraging losses.

The Cyphers is the logical incubator for the poultryman who has reached success. It also is the logical incubator for the man or woman or boy or girl who is beginning in the work, and who plans to get out of poultry the most there is in it.

EVERY STANDARD CYPHERS INCUBATOR IS GUARANTEED by the manufacturers to do first-class work in the hands of every purchaser who will give it a fair trial, and we hereby place our guarantee back of theirs. In buying a Cyphers you take no chances. Persons who earnestly desire to succeed in the poultry business should have the right tools with which to work. Write us to-day for free illustrated catalogue telling all about these superior hatching machines.

DEMAND THIS LABEL

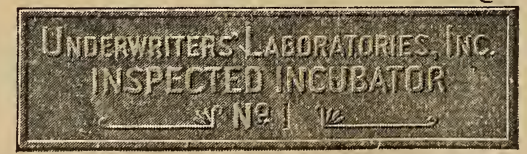

\section{YOUR SAFETY}

Form of Brass Label to be found (in serial numbers) on every Standard Cyphers Incubator.

\section{SIZES AND PRICES OF CYPHERS FIRE-PROOF INCUBATORS.}

\begin{abstract}
No. 0. Holds 70 Hen's Eggs,
\end{abstract}
No. 1

\section{No. 2. Holds 244 Hen's Eggs,}

No. 3. " 390 " "
$\$ 15.00$

$\$ 32.00$

38.00

NOTICE: The above prices are factory prices. In buying of us you save on freight and also save valuable time. Incubators, brooders and supplies carried in stock the year round. 


\section{Cyphers Improved Insulated Brooder Stove.}

This stove combines a heater proper, a burner equipped with new-style metallic chimney, which protects the flame at all heights from drafts and prevents smoking, an insulating plate that serves also as a stove slide, and an upright plate of galvanized iron that forms the door to the brooder through which the stove is operated.

Price, \$1.75.

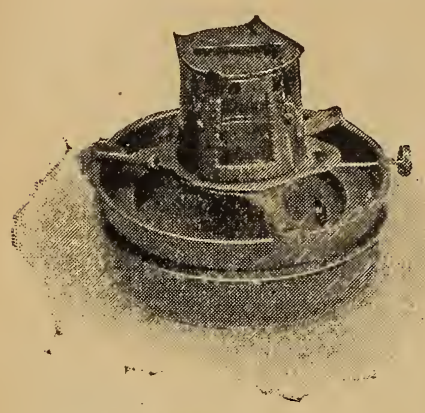

Cyphers Safety Brooder Stove.

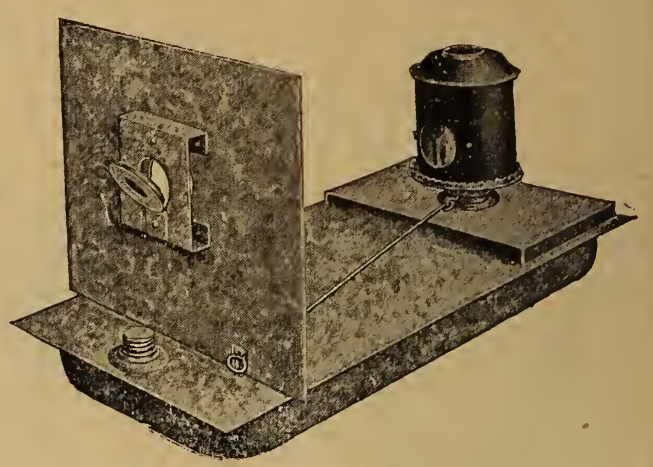

Cyphers Improved Insulated Brooder Stove.

\section{Cyphers Safety Brooder Stove.}

The safety water pan on the Cyphers Safety Brooder Stove holds nearly a quart of water, and extends out over the entire surface of the oil bowl, thus placing a sheet of cold water one inch to one and onehalf inches in thickness between the oil bowl and the flame jets.

Price, \$1.25.

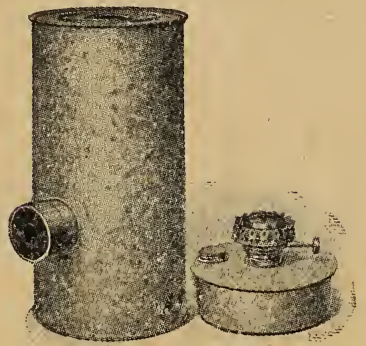

Cyphers Practical Egg Tester.

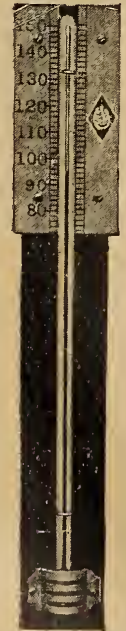

Cyphers

Brooder Thermometer. Price, 50 cents.

\section{Cyphers Practical Egg Tester.}

Is 15 inches high, $7 \frac{1}{2}$ inches in diameter. Is made of galvanized iron, and is equipped with an extra strong reflector. The lamp is made of the best block tin, the seams being machine turned, and soldered and tested for leaks. The burner is of the latest pattern and construction. No chimney is furnished, because of the liability of breakage in shipping. An ordinary glass chimney will fit the burner and is exactly adapted to the purpose.

\section{Price, complete (including box, lamp and reflector), $\$ 1.50$.}

\section{Cyphers X-Ray Egg Tester.}

Is made of block tin and consists of a central cylinder or lamp flue $51 / 4$ inches high, with an outside diameter of $25 / 8$ inches at the base, and $23 / 8$ inches at the top. It is designed for use on an ordinary hand lamp, and fits over any style of burner with a diameter approximating that of the tester.

Price, 25 cents.

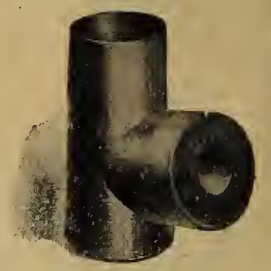

Cyphers X=Ray Egg Tester.

\section{HIGH-GRADE TESTED THERMOMETERS.}

The price of incubator thermometers does not include the wire hanger. Wire hangers will be supplied at ten cents extra for each thermometer. In ordering wire hangers, be sure to state size of your incubator and year manufactured. your incubator and year manufactured. date of manufacture, send description of machine. This is important.

When ordering brooder thermometers name the style of brooder in which it is intended to be used.

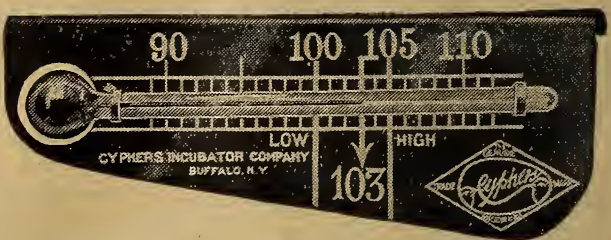

Cyphers Incubator Thermometer. Price, 60 cents.

\section{Incubator Hygrometer.}

The cut shows the correct position of the instrument in use, taking the place of one egg in the egg tray, thus showing the condiegg in the egg tray, thus showing the condiglass bottle should be filled with clean water and the wick inserted and wet thoroughly, from end to end, before placing in the egg tray. The wick must be kept clean, otherwise the water will not draw up to the thermometer bulb. Should the wick become clogged, it must be replaced.

Price, $\$ 1.50$.

Extra wicks, each, 10 cents.

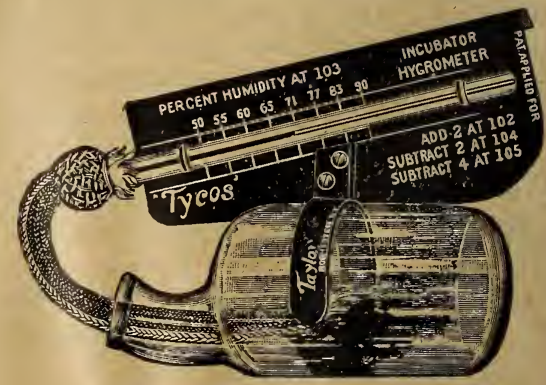




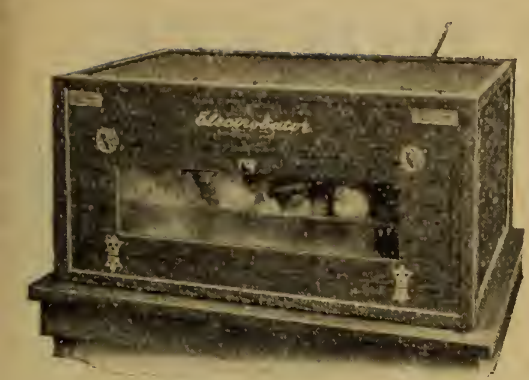

CYPHERS “ELECTROBATOR.'

An electrically heated and regulated incubator designed expressly for fanciers and poultry keepers who require small hatching capacity " Fire-proof and bears Fire Underwriters' "Inspected Incubator" label. Made in two sizes: No. 1, 60-egg capacity; No. 2, 120-egg capacity.

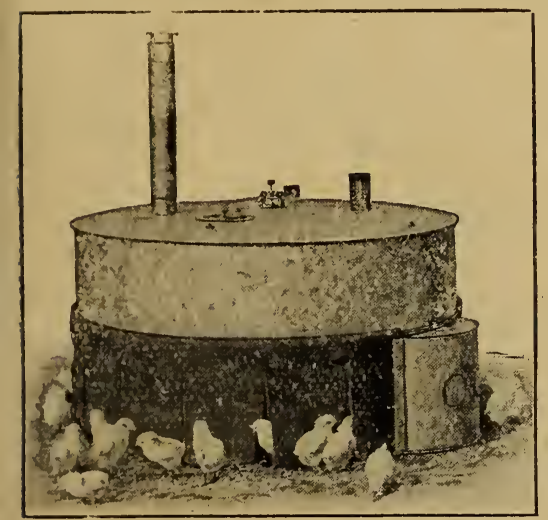

CYPHERS PORTABLE HOVER

In Use on Floor of Poultry House.

\section{Hatching and Brooding by Electricity.}

The use of electricity in hatching and brooding has several advantages over the usual methods-convenience in operation and saving in labor, while absence of fumes and gases allows of locating apparatus whenever most convenient. Regulation is simple and accurate. Heat distribution by this method is very uniform.

Cyphers Electrobator. Made in two sizes, finely finished, quarter sawed oak cases. Price, No. 1, capacity 60 hell eggs, $\$ 17.50$; No. 2, capacity 120 hen eggs, $\$ 22.00$.

cyphers Electrohover. Used in either indoor or outdoor brooders. Easily moved about. Capacity, seventy-five newly hatched chicks. Price, $\$ 10.00$.

Electric Brooder, complete. With electrobator and wooden case $\$ 15.00$.

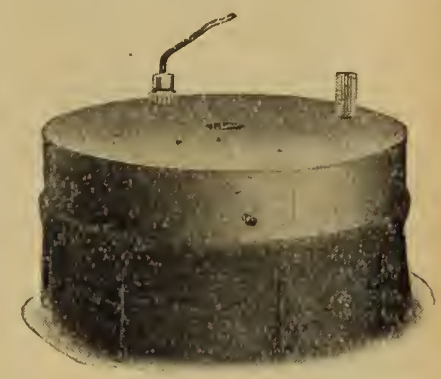

CYPHERS "ELECTROHOVER."

\section{Cyphers Portable Hover.}

The Cyphers Portable Hover is the only self-regulating and selfventilating brooder hover thus far invented, and we guarantee it to be the best device of the kind on the market. Equipped with the same high grade thermostat as the Cyphers Adaptable Hover, it maintains a steady, uniform heat. It is positively and infallibly automatic in ventilation, preventing the trapping of "dead" air or poisonous gases underneath the curtain. A continuous supply of fresh air is automatically forced beneath the hover. This portable hover, as its name indicates, can be picked up at any time, all complete, and moved about without hindering its operation. Very convenient for cleaning and moving. Rated capacity of seventy-five newly hatched chicks, or fifty chicks that are ten days to six weeks old.

Price, \$8.50.

\section{Boston Dry-Food Hopper. MADE OF HEAVY, GALVANIZED IRON.} Large, for dry feed, holds 1-2 bushel, each, Small, for meat scraps, grit, etc., holds 1 peck, each, Short, chicken size, holds 1-2 peck, each, Long, chicken size, holds 1 peck, each,

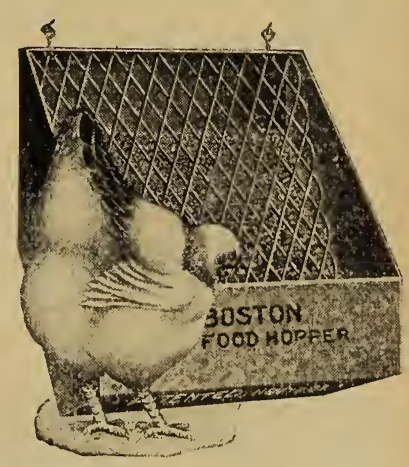

BOSTON DRY FOOD HOPPER Ready for Use.

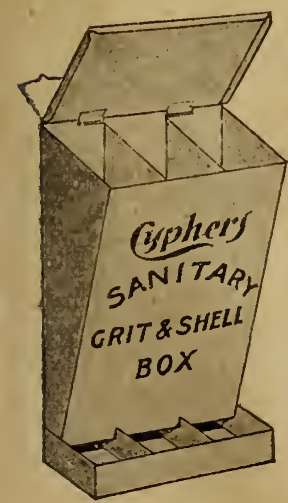

\section{Cyphers \\ Grit and Shell Box.}

Made of best grade galvanized iron, in one size only. Has three compartments, for grit, oyster shell and charcoal. Cover lid on a slant prevents fowls roosting on the box and keeps contents clean.

Price, 50 cents.

\section{Cyphers Dry-Food Hopper.}

Is similar to the grit and shell box, but is larger and has two compartments, holding 3 quarts in one and 6 quarts in the other.

Price, 75 cents.

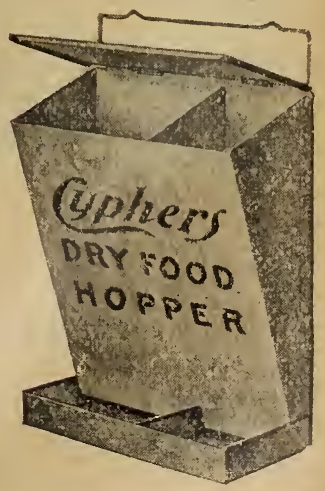




\section{SEXTON DRY FEED HOPPER.}

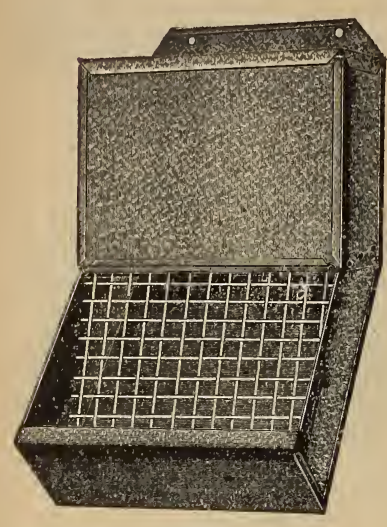

OPEN.

This Hopper is arranged to hang on the wall the desired distance from floor and never need be removed from the wall to be refilled. It is impossible to waste any feed, as the pan at the bottom takes any feed that may be picked out, and the last crumb can be used, therefore saving any waste. The body being covered keeps feed dust proof and clean, and is always dry.

Body made of galvanized iron and the grating is of round galvanized wire, preventing the poultry from cutting their bills.

The lower cover is so arranged that it is held up by locking the top cover of Hopper over same, and by raising the top cover the lower cover will fall in place. Simple in construction, easily operated and absolutely "rat" and "mouse proof."

Price, poultry size, $\$ 1.00$.

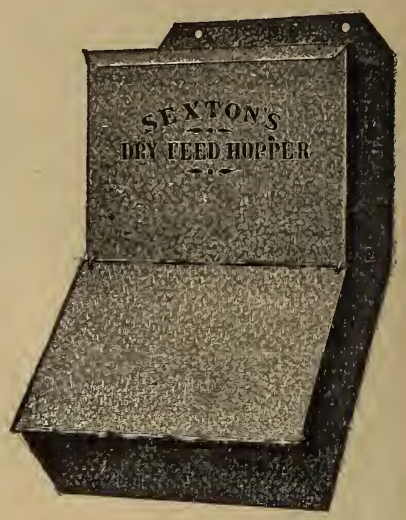

CLOSED.

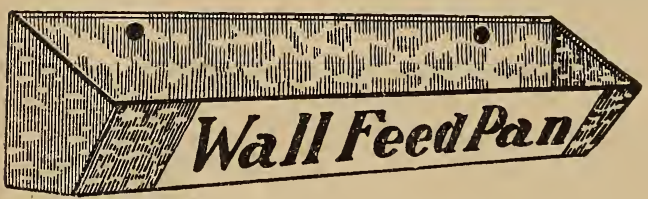

Hangs on two nails. Easy to clean. Saves waste. Always out of the way. Holds three quạrts.

Price, 35 cents.

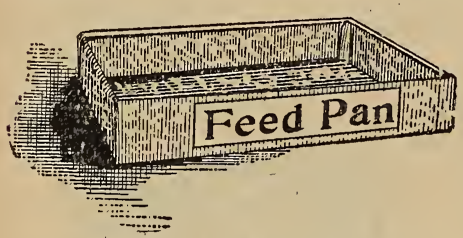

No. $3,18 \times 6 \times 2 \frac{3}{4}$ inches deep; capacity, 5 quarts.
No. $1,6 \times 7 \times 1 \frac{1}{4}$ inches deep; capacity, 1 quart.

Price, 15 cents.

No. $2,7 \frac{1}{4} \times 8 \frac{1}{2} \times 1 \frac{1}{2}$ inches deep; capacity, $1 \frac{1}{2}$ quarts.

Price, 20 cents.

Price, 35 cents.

\section{Atsatt Chick Feeder.}

\begin{abstract}
A neat device for feeding young chicks; they cannot get into it or stand on it. The top removes easily for cleaning or filling. $10 \mathrm{in.} \mathrm{long,} 4 \mathrm{in}$. wide.
\end{abstract}

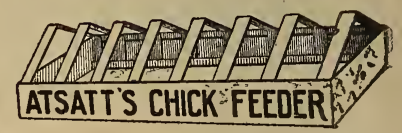

Price, 25 cents.

\section{NORWICH AUTOMATIC FEEDER.}

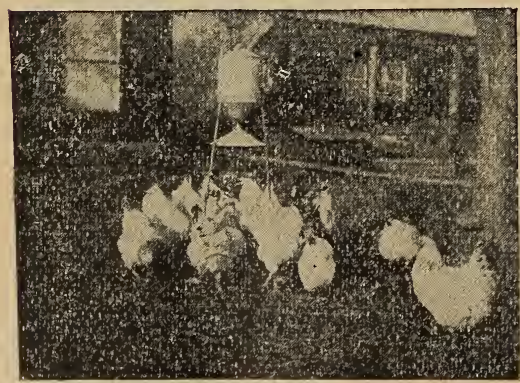

"FILL THE hOPPER AND THE BIRDS DO THE REST."

Fill the hopper with any dry grain feed, or any mixture of dry grain feed, and the revolving bait bar with cracked corn. Stand the Norwich Automatic Feeder anywhere in the yard, pen or house, and put any kind of litter under machine. Adjust valve to feed desired quantity. Adjust legs for required height. Every kernel of grain put in the hopper will go to your flock. Nothing will be lost from any cause. The exercise given by the action of the machine is just sufficient to keep the flock in perfect condition; a few days' trial will show the breeder that the flock will be bright and alert, and with a total absence of dull, stupid, or drooping appearance.

$$
\begin{array}{rrrrr}
\text { Price-No. 1, } & \text {. } & . & \text {. } & \$ 2.50 \\
\text { No. 2, } & \text {. } & . & \text {. } & 3.25 \\
\text { No. } 3, & \text {. } & \text {. } & \text {. } & 4.10
\end{array}
$$

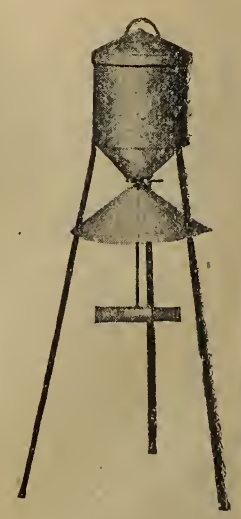

\section{WIRE HEN'S NEST.}

Strongly made of heavy japanned wire, and are very durable. Fasten to the wall with two heavy screws. Easily kept clean. No harbor for vermin.

Price, 20c. each; $\$ 1.50$ per dozen.

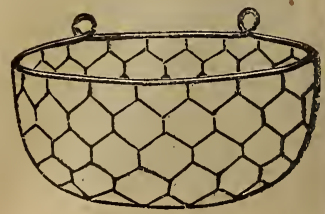




\section{"K. \& W." EGG CASES.}

The most popular Egg Cases in the market and used largely by shippers of egis.

PRICES COMPLETE.

\begin{tabular}{|c|c|c|}
\hline 8 & lozen & $\cdots \ldots$ \\
\hline 15 & 66 & $\ldots \ldots \ldots \ldots$ \\
\hline & 66 & $\ldots \ldots \ldots$ \\
\hline & 66 & \\
\hline & 66 & 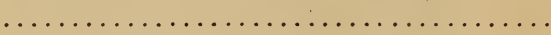 \\
\hline
\end{tabular}

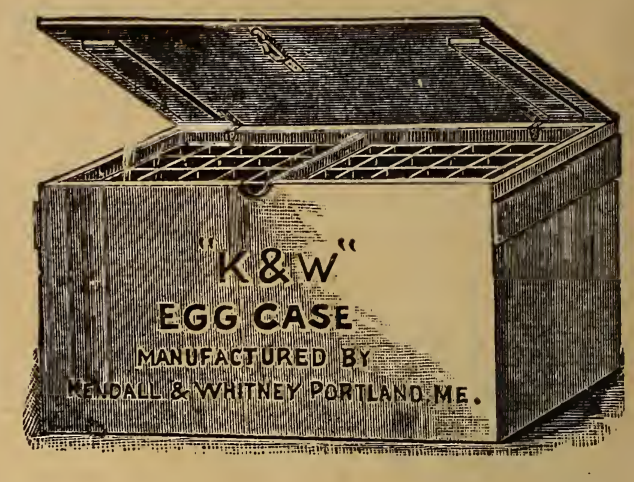

RELIABIE EGG CARRIER.

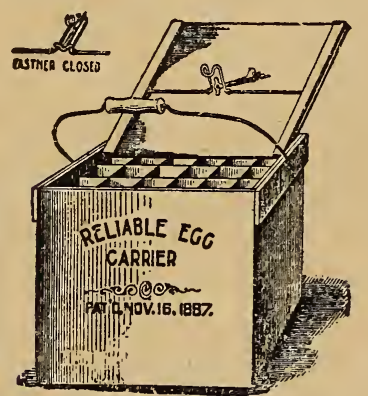

Has a patent fastening on the cover. Each carrier, with a capacity of 12 dozen, complete with fillers. Price, 65 cents.

\section{EYRIE SHIPPING EGG BOX.}
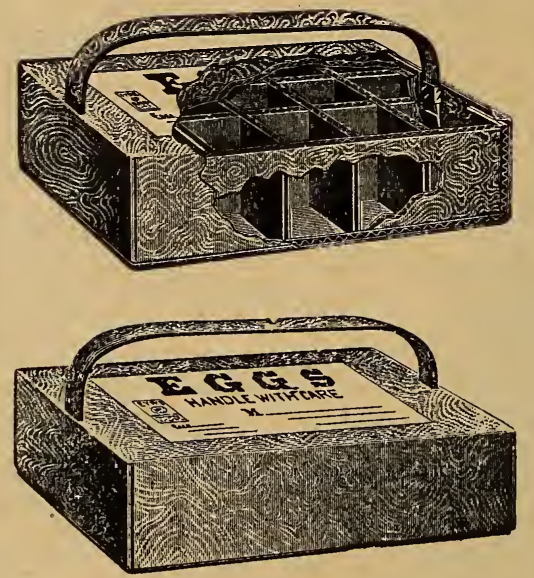

Eyrie Shipping Egg Box.
Unquestionably the best box on the market for shipping safely fancy eggs by express. Made of heavy corrugated cardboard. They are very strong, compact, light and convenient. The handle, when put in place, locks the box and it cannot be tampered with in transit. The handle prevents the putting of anything on top of the box and thus prevents rough usage. 1 setting, 15 cts. each, $\$ 1.50$ per doz.; 2 settings, 20 cts. each, $\$ 2.00$ per doz.

\section{LEO BANDS FOR POULIRY AND PIGEONS.}

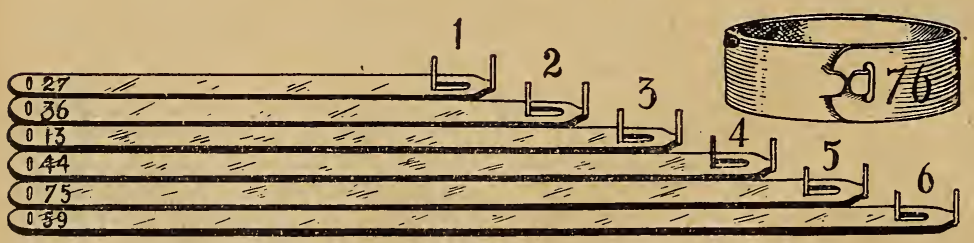

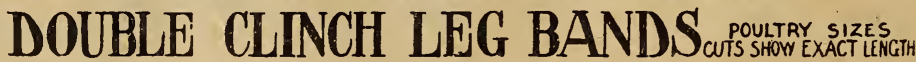

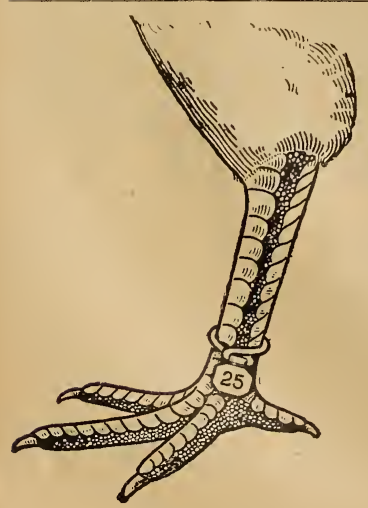

\section{CLIMAX LEG BANDS.}

\section{Easily Applied and}

Easily Removed.

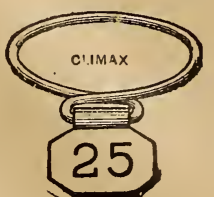

PRICE.

75 cents per hundred.

\section{DOUBLE CLINCH}

\section{LEG BANDS.}

\section{(Aluminum)}

These bands are neat, easily applied, and cannot come off by accident.

In ordering state what breed they are for, and what letters or numbers you wish put on them.

\section{Price.}

75 cents per hundred. 


\section{AMERICAN FIELD AND HOG FENCE.}

\section{Headquarters for Farm Fences.}

\section{AMERICAN FENCE}

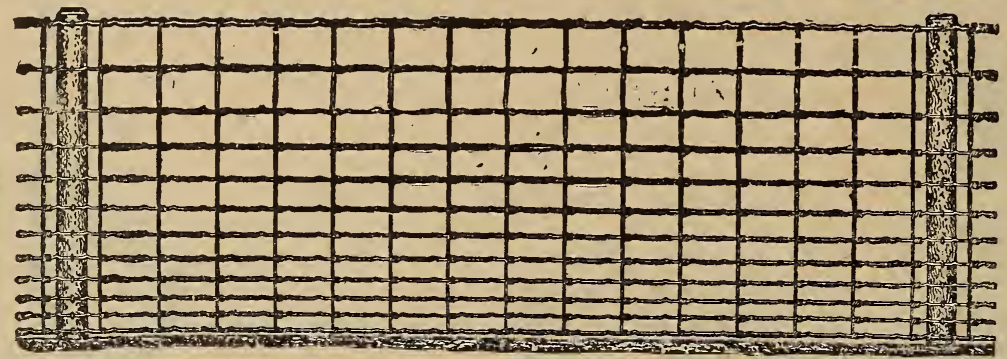

MADE IN ALL HEICHTS

Made of large, strong, high-grade steel wires, heavily galvanized. Amply provides for expansion and contraction. Is practically everlasting. Never goes wrong, no matter how great a strain is put on it. Does not mutilate nor injure stock.

\section{Turns Cattle, Horses, Hogs and Pigs}

EVERY ROD GUARANTEED by us and guaranteed by the manufacturers. Call and see it. We can show you how it will save you money and fence your fields so they will stay fenced.

\section{NEW AMERICAN POULTRY FENCE.}

The American Poultry Fence, as now made, is without doubt the best on the market, adequate for all requirements in fencing against poultry, large and small. Hence, for poultry yards, gardens, orchards and yards, it is a great favorite. It is made with stays six inches apart. Spacing from one and one-half inches at the bottom to five inches at the top.
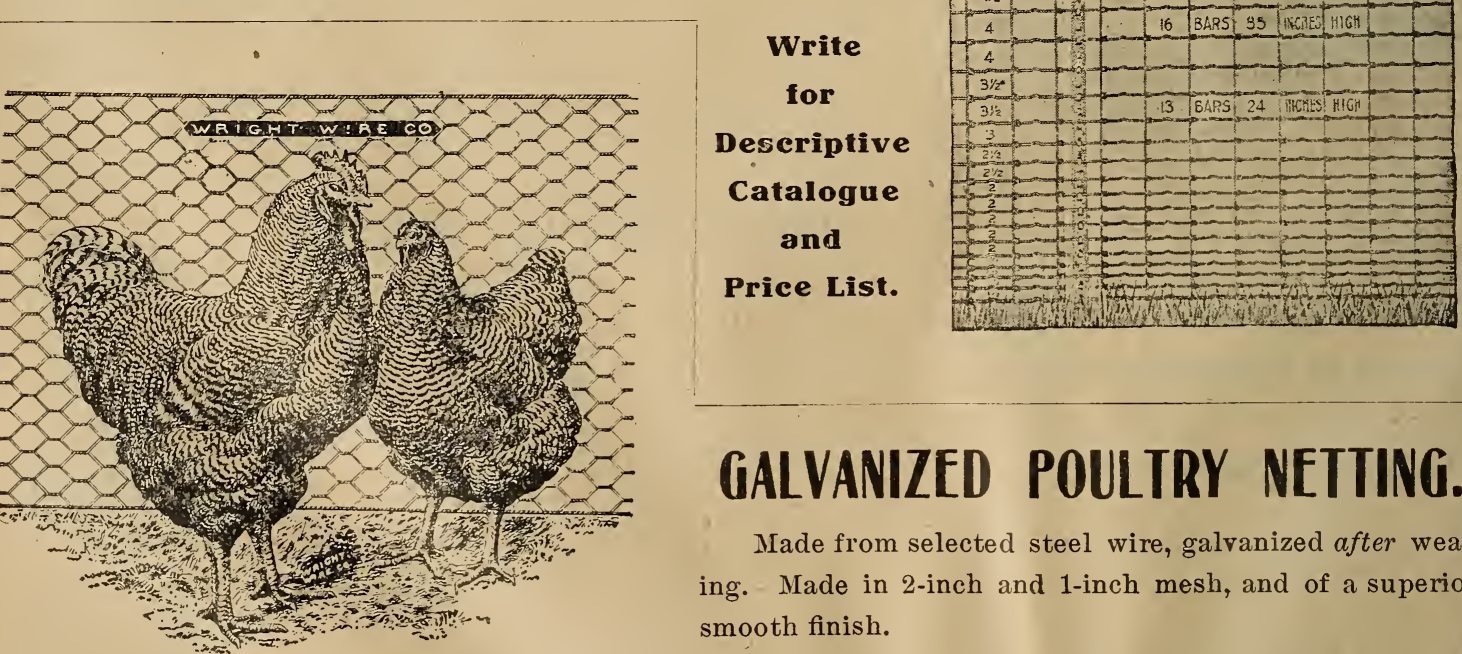

WRITE FOR PRICES. 


\section{Poultry Foods and Specialties.}

“K. \& W." Superior Oyster Shells.

Chicken Grit (fine).

Pigeon Grit (medium).

Poultry Grit (coarse).

Bone Meal.

Poultry Bone.

Superior Beef Scraps.

Bowker's Animal Meal.
Bradley's Meat Meal.

Alfalfa Meal.

Sunflower, Millet and Hemp Seed.

Linseed Meal.

Buckwheat.

Barley.

Wheat.
White Canada Peas.

Kafir Corn.

Tobacco Dust (in bulk).

Powdered Tobacco (in packages).

Charcoal.

Lice Killers.

Nest Eggs.

Write for Quotations.

\section{STERLINGWORTH POULTRY CHARCOAL.}

Prepared expressly for feeding chicks and fowls.

$X$ (fine powdered), for mash foods for poultry and stock.

XX (fine granulated), especiaily for chicks.

$X X X$ (medium granulated), for half-grown fowls and pigeons.

XXXX (coarse granulated), for fowls, geese and turkeys.

Price, $50 \mathrm{lb}$. paper lined burlap bags, $\$ 1.00$ each.

"6 2 lb. pkg.,

.1066

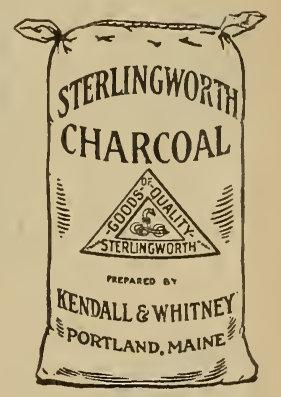

\section{“K. \& W." Poultry Remedies.}

Remedy No. 1. For all forms of indigestion, liver disease, sour crop, crop-bound.

Remedy No. 2. For rheumatism and cramps.

Remedy No. 3. For all sudden colds, with sneezing, watery discharge from eyes and nose. Prevents roup.

Remedy No. 4. For catarrhal colds, with rattling in throat.

Remedy No. 5. For all diarrhœas of poultry, and particularly in cholera.

Remedy No. 6. For diphtheritic roup and canker.

Remedy No. 7. For chicken-pox, bumble-foot, to promote healing of sores. Cures chronic catarrh.

Remedy No. 8. For soft-shelled eggs, all diseases of egg organs and to correct sterility.

Remedy No. 9. For egg-bound. Also for the diseases where there is swelling of the eye with an accumulation of yellow matter under the lids.

Remedy No. 10. For worms.

These remedies are put up in tablet form, 100 tablets to a vial. Each label contains full directions for use and the diseases which the remedy will prevent or cure. Price, postpaid, 40c. per vial. Please order by number.

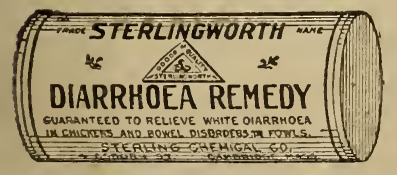

\section{STERLINGWORTH DIARRHOEA REMEDY.}

A reliable remedy for diarrhœa, dysentery and other kindred bowel troubles in young chickens, full-grown fowls and pigeons. Keep it on hand and use it as a preventive. It is a powder for use in the drinking water. The chickens and fowls take their own medicine.

Price, per box, sufficient for several floçks, 50 cents, postpaid.

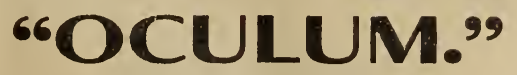

Scientific Remedy and Preventive for Cholera, Roup, White Diarrhoea and Sore Head; also Cure for Gapes.

Price, small bottle, 50 cents; large bottle, $\$ 1.00$ (postpaid).

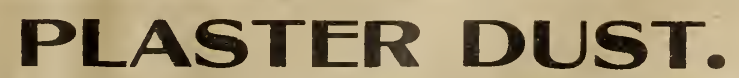

Ground and bolted fine as flour. Valuable to use about the henhouse and to dust into nests.

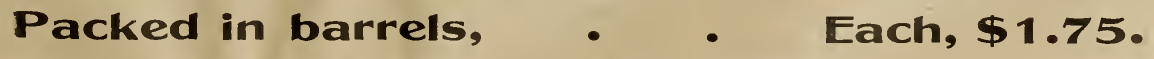




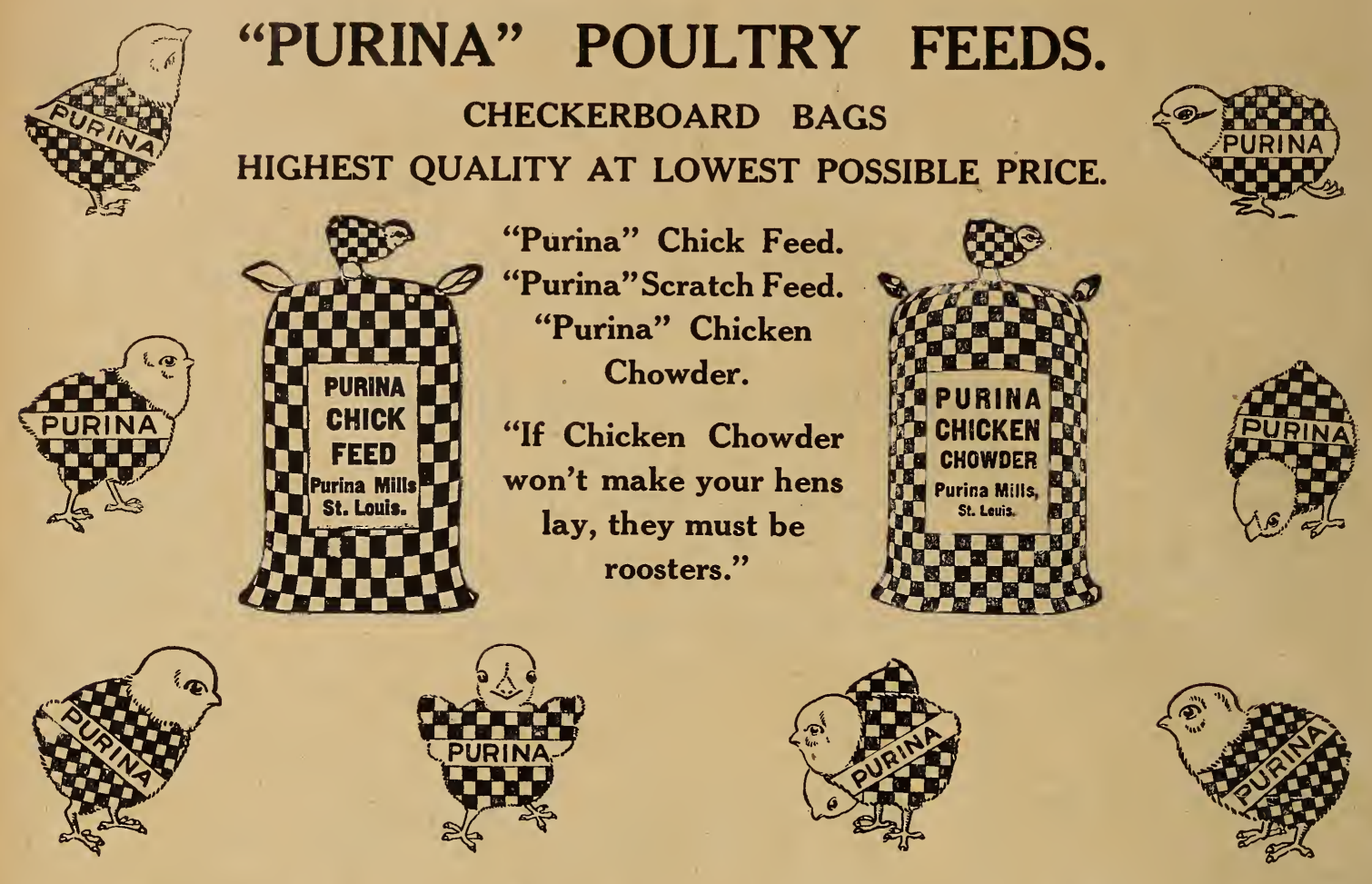

\section{"Purina" Chick Feed.}

Special care has been taken in balancing this feed. Nothing but sound, sweetingredients are used. The finest mixture of grain possible for developing growing chicks and poultry.

\section{"Purina" Scratch Feed.}

This feed has been used for years by the foremost poultry fanciers. Will keep fowls healthy; affording thein plenty of exercise, an ideal "scratch feed".

\begin{abstract}
"Purina" Chicken Chowder.
A complete mash, which can be fed either wet or dry, at any time during the day. Is a highly nutritious balanced ration for laying hens, as it is high in eggmaking qualities, and feeding this mash once a day will keep the flock in a healthy condition.
\end{abstract}

\section{INTERMEDIATE CHICK FEED.}

This is designed to follow the fine Chick Feed. It contains practically the same properties as Fine Chick Feed, only larger.

\section{ALfalfa MEAL.}

This makes a green food the year round. It is very high in protein and furnishes to chicks a growing food, which at the same time has a medicinal value.

\section{FIRST FEED.}

A scientific food ration to be fed chicks from the time they are hatched, till they are two weeks old. It will save the baby chicks.

WRITE FOR QUOTATIONS ON ALL POULTRY FEEDS.

\section{CARBONOL.}

CARBONOL IN THE HEN HOUSE.

Carbonol should be used as a general disinfectant in hen houses to keep them clean and healthful, kill lice and destroy any disease germs before they have a chance to infect the flock.

\section{LICE AND ALL KINDS OF VERMIN.}

May be destroyed on poultry, pigeons, etc., by painting roofs and spraying floors and walls of their coops and houses with a 1-65 solution of Carbonol (about one tablespoonful to a quart of water).

\section{PRICE.}

4 ounce bottle, 25c.; pint bottle, 50c.; quart bottle, $75 c$.; 1 gallon can, \$1.75. 


\section{BLATCHFORD'S CALF MEAL.}

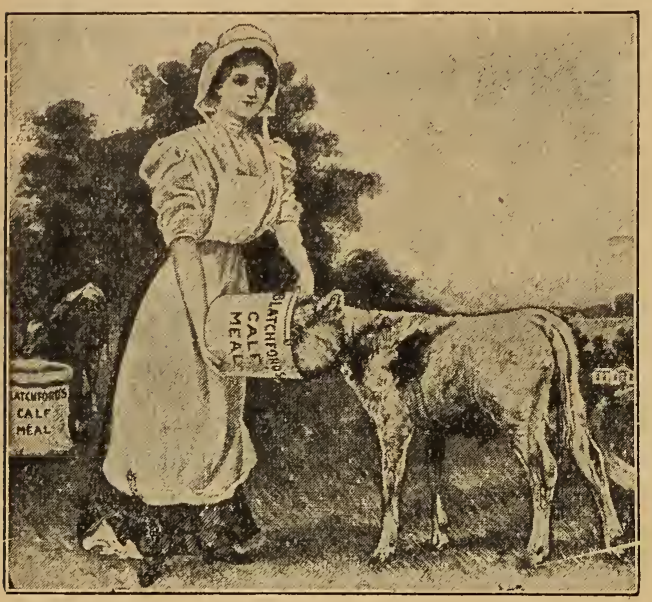

The Perfect Milk Substitute for Raising Calves.

100 Pounds of It Makes 100 Gallons of Rich, Nutritious Gruel.

Thousands of farmers are raising their calves on Blatchford's Calf Meal at about half what it costs to raise them on milk.

It is absolutely the only milk substitute that contains all the elements necessary for bodily growth in approximately the proper proportion, and it is the only calf meal that is thoroughly cooked and prepared for digestion.

It pushes calves, pigs, colts, etc., forward better and quicker than any other food.

\section{Price, \$3.50 per 100 pounds.}

\section{KENDALL \& WHITNEY, State Agents.}

\section{INIERNATIONAL POULTRY AND STQCK TONIC.}

The farmer and poultrymen will find in the International everything necessary to keep all stock and poultry in the best of condition.

INTERNATIONAL POULTRY TONIC,

INTERNATIONAL STOCK TONIC.

25c. and $50 \mathrm{c}$, packages.

25c., 50c. and $\$ 1.00$ packages, and $\$ 3.50$ pails.

\section{CLOVER BRAND POULTRY TONIC.}

Will keep poultry in a healthy condition, and at the same time furnishing a tonic for the entire system, regulating their digestion, and furnishing bone-making and egg-producing materials.

Price, small package, 25 cents; medium package, 50 cents; 25 Ib. pail, \$3.00.

\section{LAMBERT'S DEATH TO LICE POWDER.}

15 oz. pkg., 25c.; 3 lb. pkg., 50c.; 6 1-4 Ib. pkg., \$1.00.

\section{LEE'S LICE KILLER.}

A liquid preparation having all the killing properties of any powder or dip; besides, the vapor that it gives off is.destructive to insect life, though harmless to fowl. It permeates every crack and crevice of the poultry house, and all hiding places of vermin and destroys them.

PRICE.

1 qt., 35c.; 1-2 gal., 60c.; 1 gal., $\$ 1.00$.

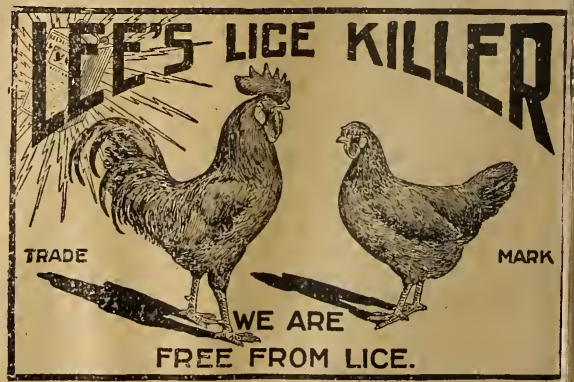




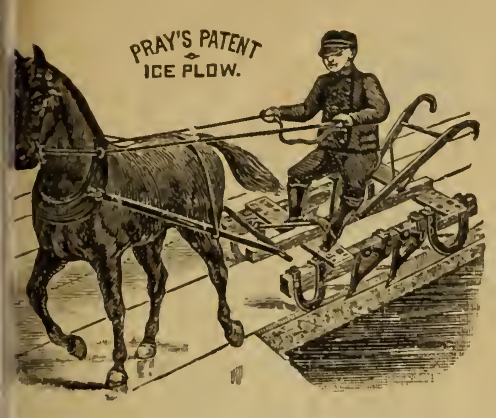

\section{PRAY'S PATENT ICE PLOW.}

This plow is especially designed to meet the demand for a cheap and efficient ice cutter for farmers and dairymen. It will cut from 20 to 40 tons an hour, cutting the ice blocks of uniform size, which saves much labor when packing.

The extra weight of the rider holds the plow to its work and allows the horse to be hitched much closer to the plow-an advantage where the pond is small and all the ice needed from the edge of the pond.

It is the only plow that can be successfully used by one person. The draft back of runners omits the necessity of leader or rider.

It is the only plow that has an adjustable tooth.

It is the only plow that works with runners.

It turns easier at the end of the row than any other plow.

It cuts ice with more economy on a small pond than any other plow.

Upon a shallow pond where a saw cannot be used this plow is indispensable. A horse ind one man can cut as much ice as ten men with saws.

WARRANTED TO WORK AS REPRESENTED.

Price, Four-Tooth Plow, \$12.00; Six-Tooth Plow, \$16.00; Eight-Tooth Plow, \$12.00; Ten-Tooth Plow, \$18.00.

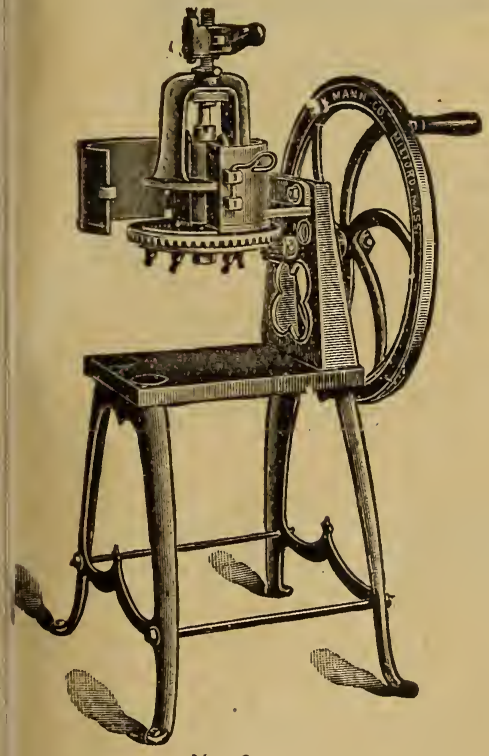

No. 9.

\section{Mann's Bone Cutters.}

THE STANDARD OF EXCELLENCE.

A Standard which has only been Obtained by Years of Experience.

PRICE LIST.

NO DISCOUNT FROM THESE PRICES.

No. 5C (with Crank Handle), $\$ \mathbf{6 . 0 0}$

No. 5B (with Balance Wheel), $\mathbf{8 . 0 0}$

No. 5BM (with Bal. Wheel \& Iron Stand),

No. 7 (witb Balance Wheel), 12.00

No. 7 1-2 (Semi-power Machine), $\quad 16.00$

No. 9 (Standard Bone Cutter), 18.40

No. 11 (Comb'n Power Cutter), 26.00

No. 12 (Small Power Cutter), $\quad \mathbf{3 0 . 0 0}$

No. 15 (Large Power Cutter), $\quad \mathbf{6 0 . 0 0}$

No. 14 (Large Power Cutter), $\mathbf{7 6 . 0 0}$

Send for Illustrated Catalogue.

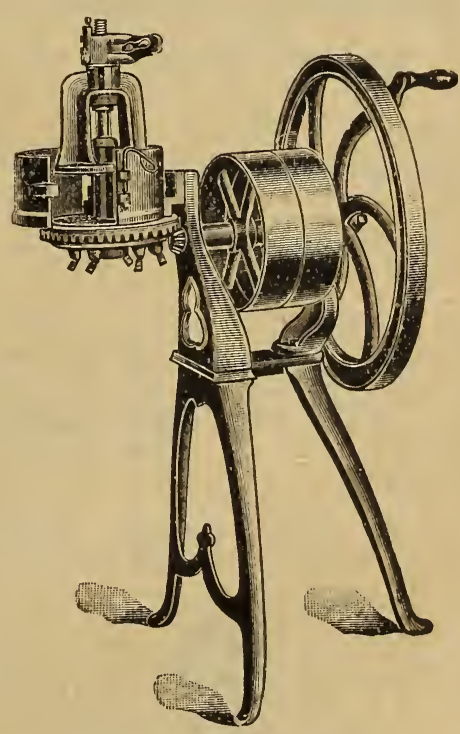

No. $71=2$.

\section{STOVER HAND MILL.}

In this mill are embodied all the good features of other hand grinding mills to which have been added universal burrs or grinding plates that are adjustable for grinding coarse or fine. This machine grinds oats, barley, rye, corn, peas, dry bone, shells, etc., for feeding to poultry. It is a well designed machine, is strong and well made throughout and of excellent finish; has a sixteen-inch fly wheel and is light running.

Capacity, 1 or 2 bushels per hour.

Price, \$5.00. 
Bar Chisel. Price, \$3.50.

Breaking Bar. Price, \$3.50.
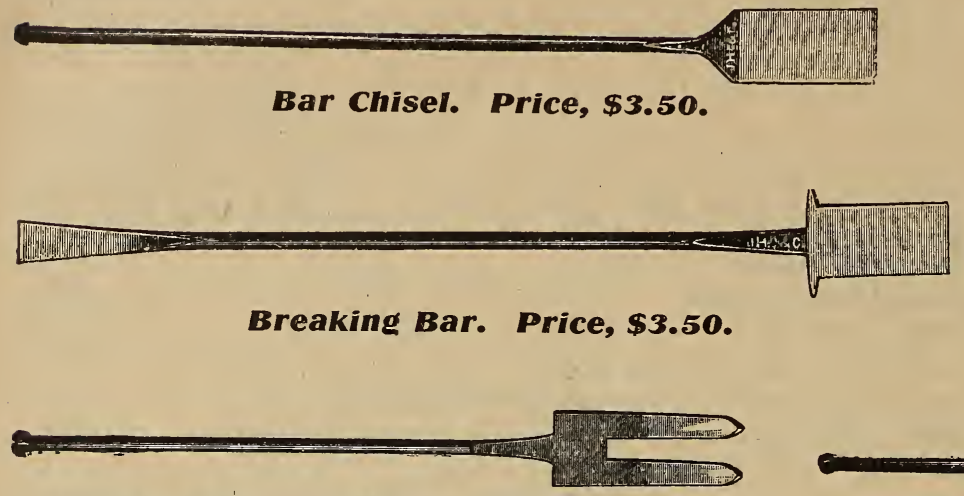

Splitting Fork. Price, $\$ 4.00$ and $\$ \mathbf{\$ 4 . 5 0}$.

Splitting Chisel. Price, $\mathbf{\$ 2 . 2 5}$ and $\mathbf{\$ 2 . 5 0}$.
Everything in ice harvesting tools and supplies for ice men, dairymer and farmers. Complete illustrated catalogue sent upon request.' Write us for pamphlet "How to Har. vest Ice."
Ice Shaver. $\$ 2.00$ to $\mathbf{\$ 2 . 2 5}$.

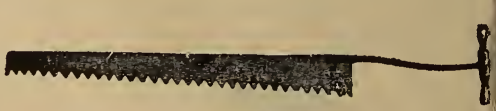

Ice Saws.

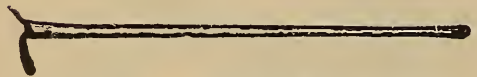

Ice Hooks.

$\bigcirc$ Price, $\mathbf{\$ 2 . 5 0}$ and $\mathbf{\$ 2 . 2 5}$.

Line Markers.

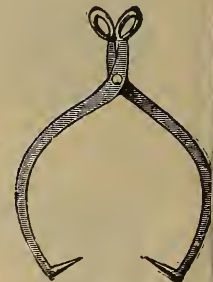

Tongs.

\section{UNITED STATES CREAM SEPARATORS.}

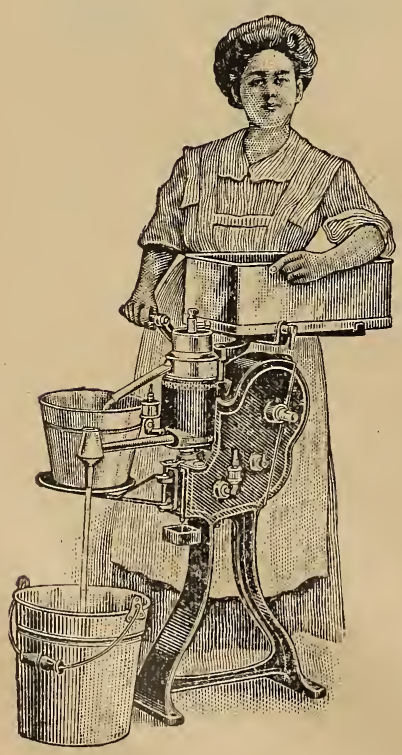

The cream separator has two uses:

To extract all the cream possible from the milk.

To lessen the labor of caring for the milk and cream.

The United States Cream Separator gives every pur chaser the positive assurance of great efficiency. It was on of the first cream separators put on the market, and in th twenty years of its manufacture many thousands have bee sold.

It is easily handled, and is a close skimming, light run ning separator.

Write for Catalogue and Price List 


\section{DE LAVAL CREAM SEPARATORS}

\section{Skim Cleanest, Have Largest Capacity, Turn Easiest, Are Easiest to Wash, Last the Longest.}

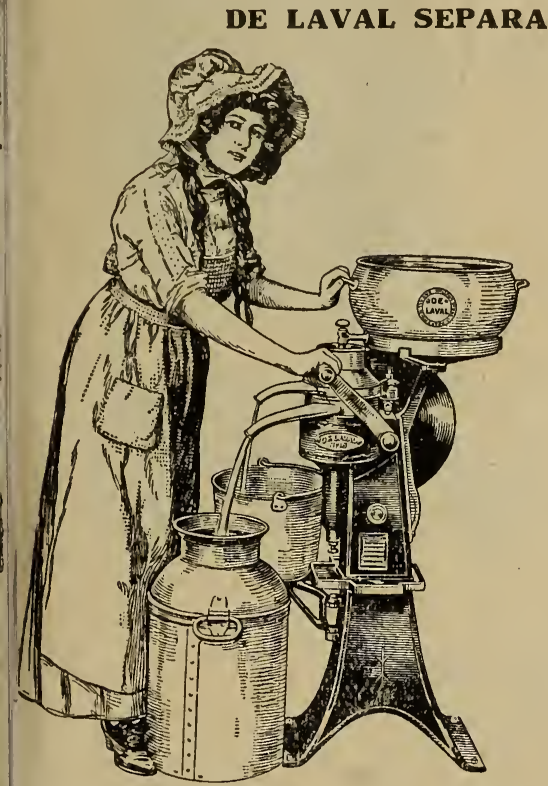

If you are a cow owner you ought to have copy of the De Laval Dairy Hand=Book. ree upon request.

If you are milking even as few as two or three cows and are not using a De Laval Cream Separator you are wasting both quantity and quality of cream every day you go without one.

The De Laval saves enough over any gravity setting system in butter fat, quality of cream, sweet skim milk, labor, time and trouble, to pay for itself every six months.

The De Laval saves enough over other separators in closer skimming, in running heavier and smoother cream, skimming cool milk, greater capacity, easier cleaning, easier running and fewer repairs, to pay for itself every year.

The 1914 Improved De Laval saves enough over De Laval machines of five, ten, fifteen or twenty years ago, in closer separation under all conditions, greater capacity, easier running and greater mechanical perfection, to pay for itself every two years.

We will be glad to give you a free trial, and we have an arrangement whereby the purchaser, if he desires, may make a partial payment at time of purchase and pay the balance on such easy terms that it will pay for itself out of its own savings.

\section{EXCHANGE ALLOWED ON ALL OLD MACHINES.}

We will be glad to mail you a catalogue.

\section{THE RANDOLPH GOVERNOR PULLEY FOR SEPARATORS.}

Absolutely governs the speed of he separator, releasing automatically hen the proper speed is attained nd absorbing all shocks from the asoline engine. It runs in either irection without any change or adistment. The pulley standard can e placed on the floor, side wall, $r$ overhead, to suit conditions. mbodied in the construction of is pulley is the loose pulley feaire, whereby the separator may be opped without stopping the engine. ttention is called to the fact that ter the proper speed has been atined by setting the jamb nuts on le hand wheel thread, the correct seed will be maintained without irther attention.

Price, \$10.00.
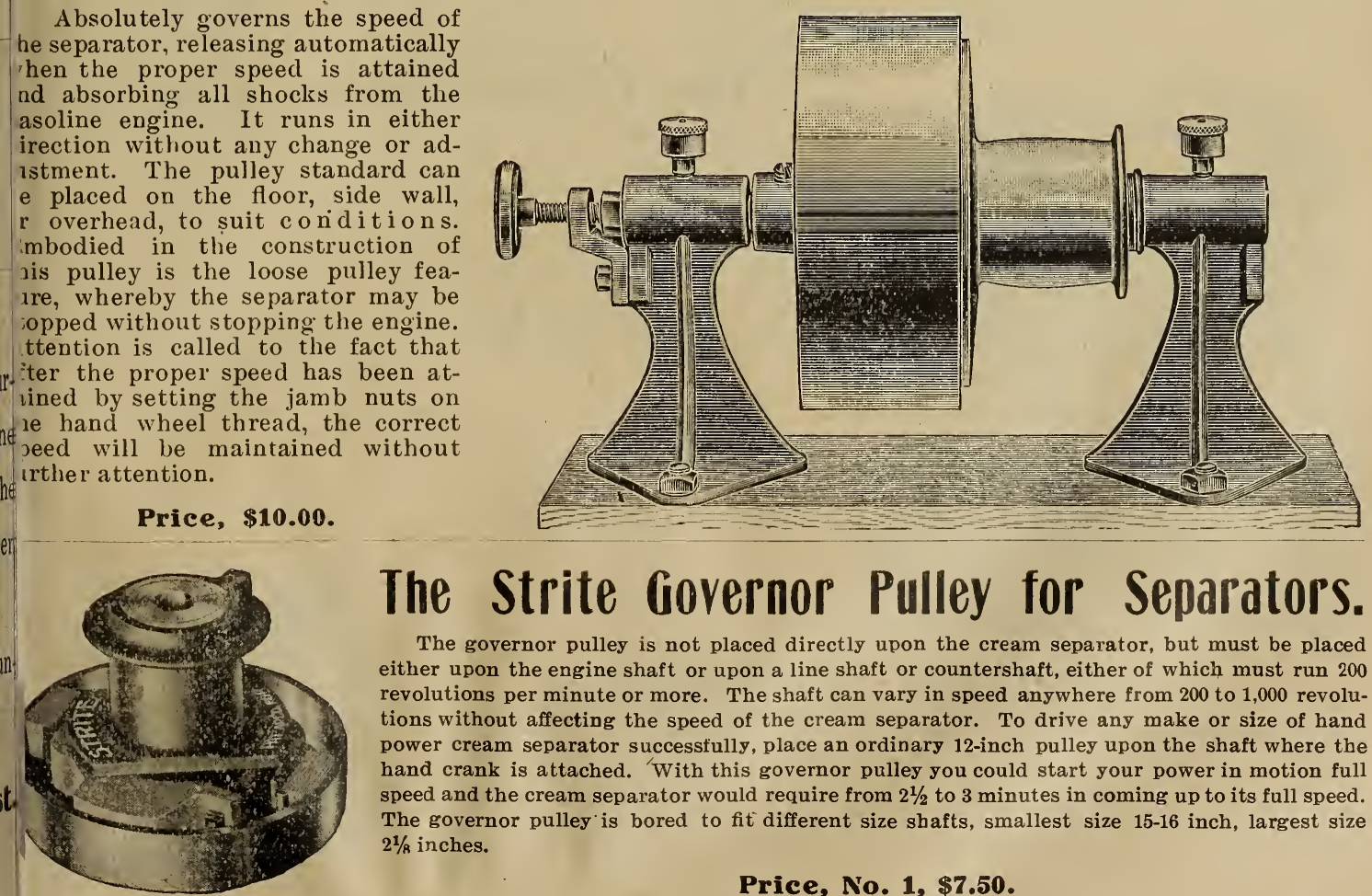

The Strite Governor Pulley for Separators.

The governor pulley is not placed directly upon the cream separator, but must be placed either upon the engine shaft or upon a line shaft or countershaft, either of which must run 200 revolutions per minute or more. The shaft can vary in speed anywhere from 200 to 1,000 revolutions without affecting the speed of the cream separator. To drive any make or size of hand power cream separator successfully, place an ordinary 12-inch pulley upon the shaft where the hand crank is attached. 'With this governor pulley you could start your power in motion full speed and the cream separator would require from $2 \frac{1}{2}$ to 3 minutes in coming up to its full speed. The governor pulley is bored to fit different size shafts, smallest size 15-16 inch, largest size $2 \frac{1}{8}$ inches. 


\section{The Stoddard Churn.}

\section{ONE OF tHE MOSt PERFECT CHURNS MADE.}

The Stoddard Churn is made by hand in the most thorough manner and of kiln-dried white oak. It will last for years. The principle is concussion and not friction-has no floats or paddles inside. It is easily operated and easily cleaned. Perfect in construction, and having no parts liable to break or get out of order, it fully meets the requirements of large or small dairies.

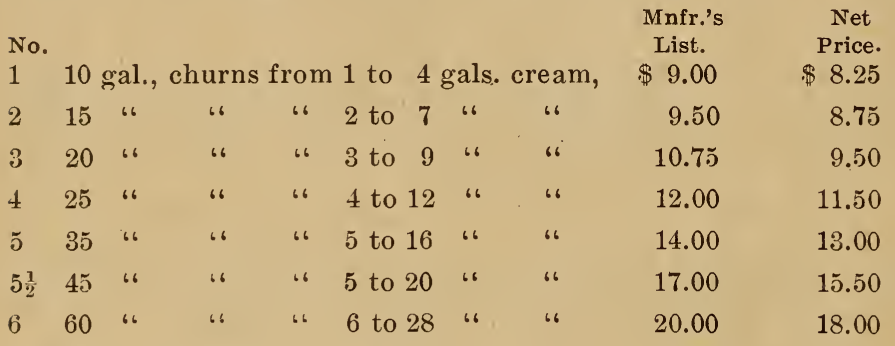

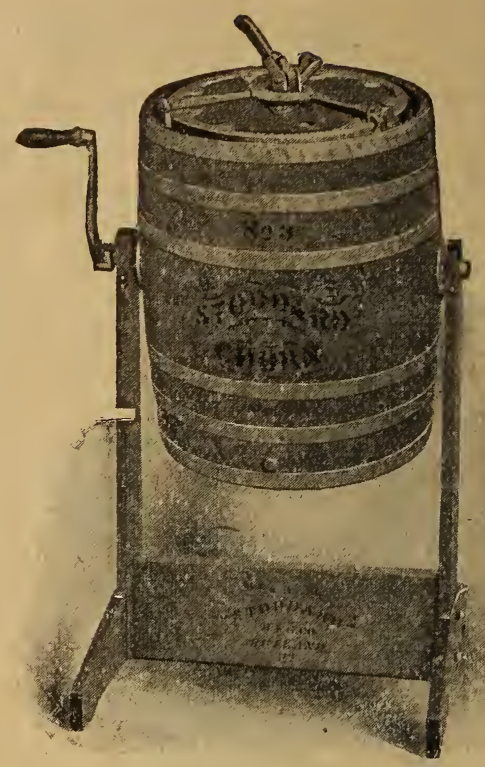

\section{THE MAGIC CHURN.}

The Magic Churn we offer to those desiring a low-priced barrel churn.

The churns are made of white oak, thoroughly seasoned and kiln dried. The cover fastening is simple an efficient.

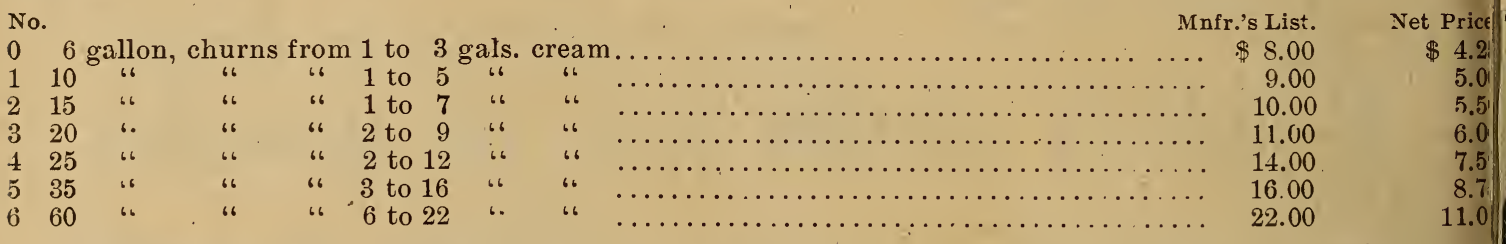

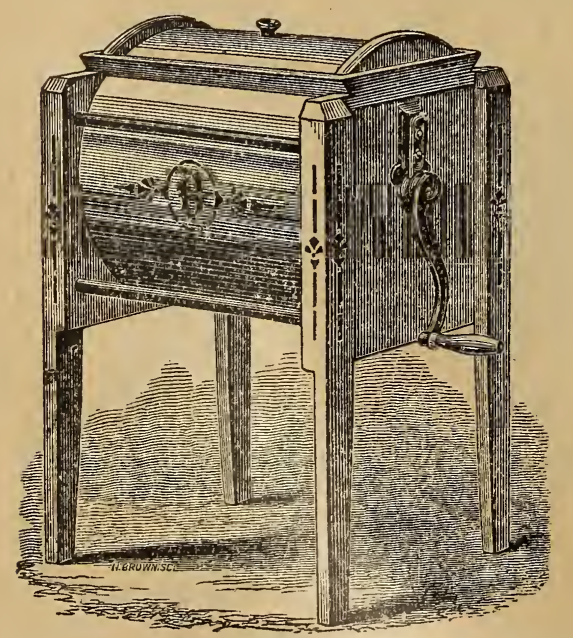

THE BLANCHARD CHURN.

The following are the leading merits of the BLANCHARD CHURI

Perfect quality of all materials used. Excellency of manufar ture. Simplicity of construction, having no cog wheels or gearin Durability. Ease of operation. The action of the dasher is such a to cause agitation of the cream by creating currents, and not b beating or by friction of the cream, which may injure the grain c the butter. Facility in removing the dasher and getting at th butter. Ease of cleaning, the form of construction making the in side without any inaccessible or invisible angles or corners.

No. 3, for up to about 2 gallons of cream,

Mnfr.'s List.

Net Pric

No. 4

No. 5,

No. 6 ,

No. 7 ,

66

"6 46

4 ' 6

66 66

"6

$\$ 6.00$

7.00

8.00

10.00

12.00

\section{CYLINDER CHURNS.}

A favorite style of Churn which has been in use for many years.

Mnfr.'s List. Net Price.

No. 1 , capacity $2 \frac{1}{4}$ gallons ................. $\$ 2.50$

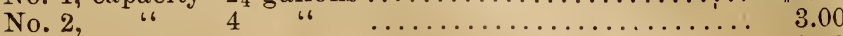

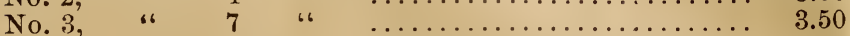

No. $4, \quad$ " $10 \frac{1}{2} \quad$ " $\quad \ldots \ldots \ldots \ldots \ldots \ldots \ldots \ldots \ldots, 4.00$

$\$ 2.25$

2.50

2.75

3.00

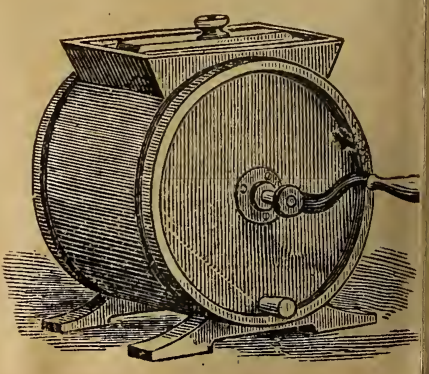




\section{COMBINATION BUTTER MOULDS.}

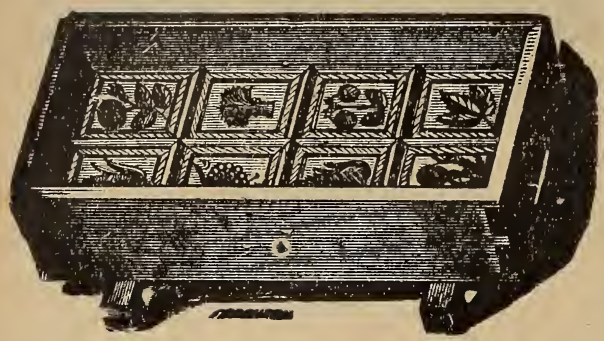

These moulds are expressly designed to meet the demand for strictly first-class, hand-carved designs.

The cut here shown represents No. 6, which holds two pounds, and is divided into eight $1 / 4$-pound cakes.

Prints engraved to order, with ordinary designs, initials, or monogram, without extra charge, excepting that, should more than six letters be wanted on each cake, a charge of five cents per letter will be made for each letter in excess. Prices quoted on application for special or complicated designs or lettering.

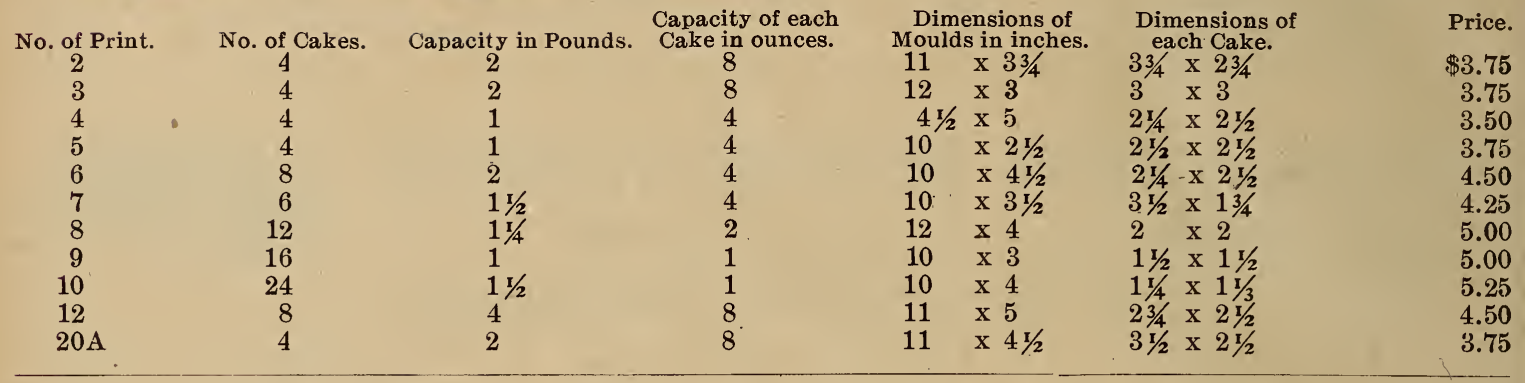

\section{BLANCHARD BUTTER MOULDS.}

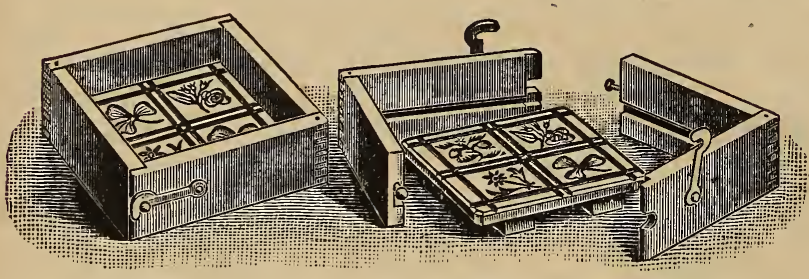

1-2lb., two 1-4 Ib. prints, 40c.; I Ib., four 1-4 Ib. prints, 50c.; 2 Ibs., eight 1-4 Ib. prints, $75 c$.

If engraved with initials, or any hand carving, add to the REGULAR PRICE, 25 cents for each cake so engraved.

\section{TUB COVER FASTENERS.}

Made from tin; easily applied, easily withdrawn. Tin is turned back over head of nails; impossible for nails to drop out.

1,000 in a package. Price, 85c. per thousand.

\section{BRUSHES.}

We are in a position to furnish the best kind of brushes for dairy use, and recommend especially our line of can, separator and bottle brushes.

Bottle Brushes, each ........... 25̌c. and $40 \mathrm{c}$.

Test Bottle, each............. $5 \mathrm{c}$

Milk Can, each.................... $50 \mathrm{c}$

Separator, each ................
Separator Bowl, each........... 35c. and $50 \mathrm{c}$ Separator Tube, each............. $8 \mathrm{c}$

Separator Cover Spouts, each........ 1 .

\section{SPECIAL PRICES FOR LARGE QUANTITIES.}

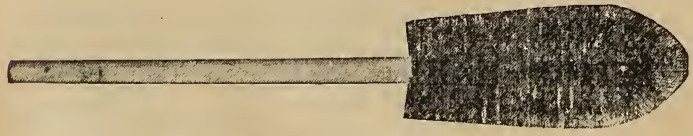

No. 86. Black Bottle Brush, 40 c.

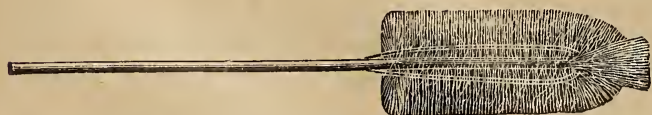

No. 63. White Bottle Brush, 25e.

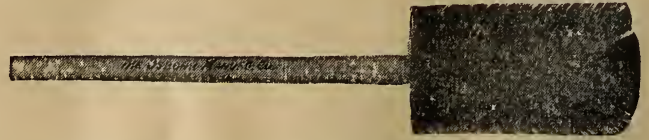

No. 70. Black Bottle Brush, 40c.

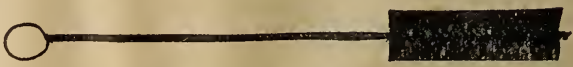

Cover Spout Brush, 15e. 


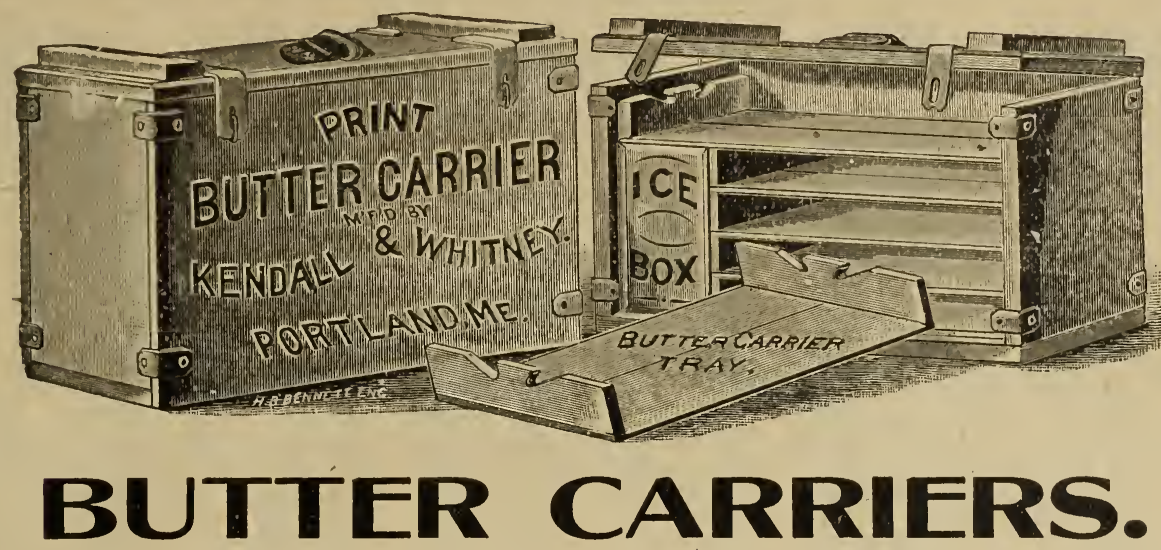

These carriers are made of spruce and white wood and are very strong and durable, with trays so arranged that the butter is not marred in the least in handling. The ice box is made of zinc, and has two compartments, the top for ice and the bottom for the water as the ice melts, so that the ice is melted by air alone, thereby lasting much longer than if the ice rested in the water.

Each carrier is filled with long trays, and the capacity given is for prints of the standard creamery size.

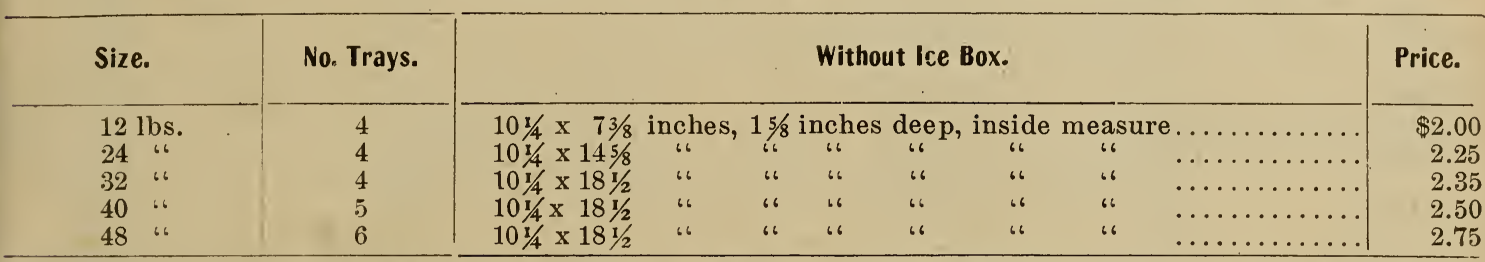

Price, complete with both long trays, and ice box and short trays, for summer use.

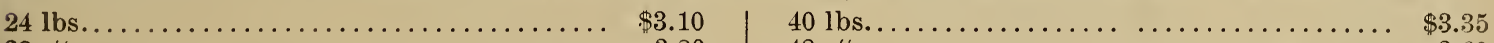

The 12 lb. carrier, being very small, cannot be fitted with ice box.

\section{Non=Returnable Butter Shipping Boxes.}

These boxes are furnished in shook, and are made in the following standard sizes. 25 boxes in a package. $10 \mathrm{lbs}$. per one hundred, with printed ends, $\$ 8.00 \mid 40 \mathrm{lbs}$. per one hundred, with printed ends, $\$ 14.00$

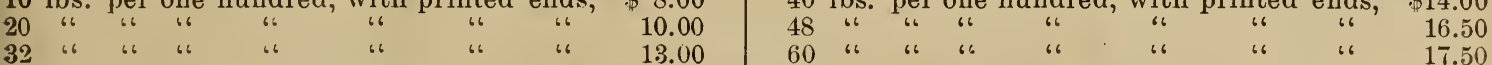

Price, not printed, 50 cents per hundred less.

\section{MORE'S Pyramidal Milk Strainer.}

Most perfect milk strainer ever offered to dairymen. Can be used on creamery cans, milk cans, small pans, etc. Cleans milk rapidly, will not clog, has large straining surface.

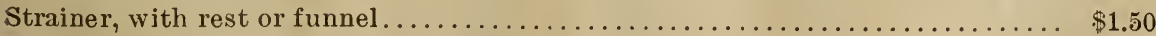

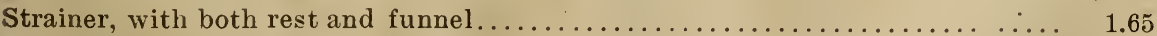

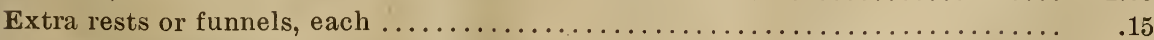

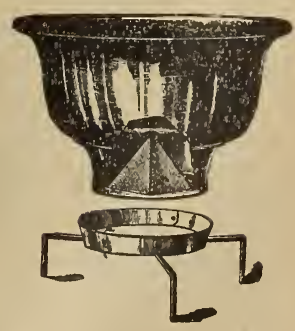

\section{PARCHMENT BUTTER PAPER.}

FOR WRAPPING AND COVERING BUTTER.

Better, cheaper and more convenient to use than ordinary muslin. Price, 15c. per pound. Write for quotations for large quantities and for printing special designs. 


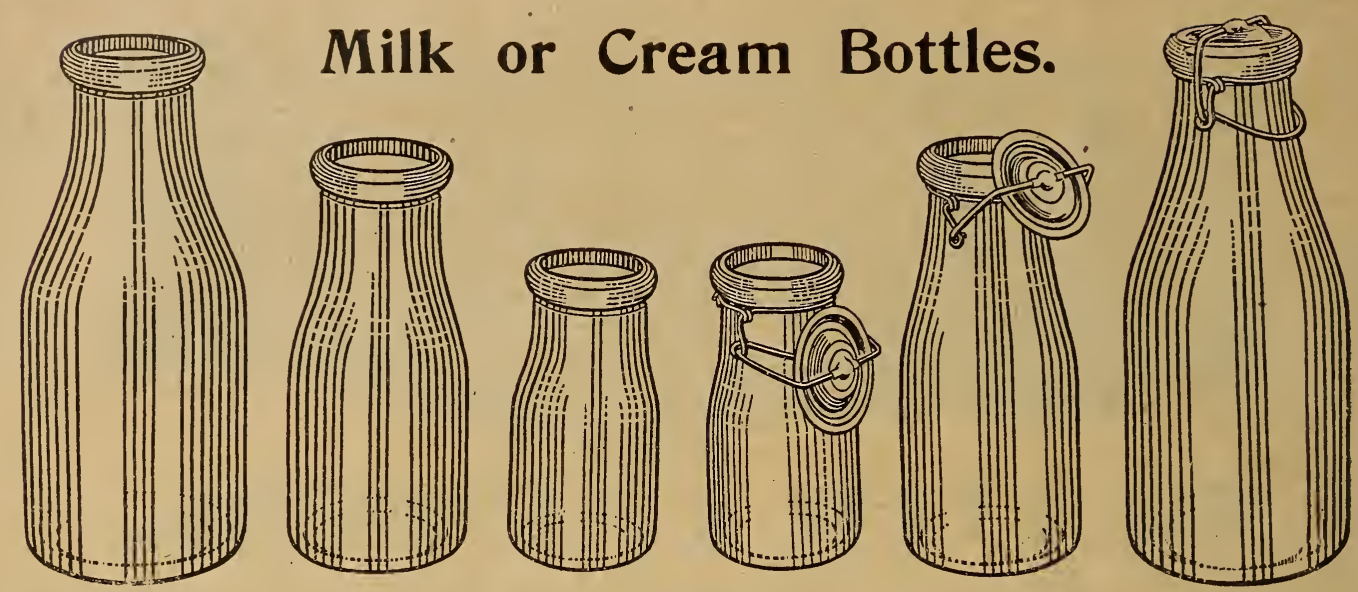

Did it ever occur to you that you should investigate the source of your milk supply and the process by which it is handled and delivered?

If you will do so, you will refuse to receive milk in any other vessel than glass bottles, as it is the only way by which you can get milk that has not come in contact with the numberless street odors, flies, and many other undesirable influences.

The "COMMON SENSE" Bottle, capped by a strong, clean paper cap, is the best, and no taint is possible in milk put up in these bottles.

1-2 Pint, Common Sense,
1 Pint, Common Sense,

1 Quart, Common Sense, Per Dozen.

\begin{tabular}{l|cc}
$\$ .45$ & $1-2$ Pint, Lightning (tin top), \\
.50 & 1 Pint, Ligtning \\
.65 & 1 Quart, Lightning, 6 \\
or more quoted on application.
\end{tabular}

Price for gross or more quoted on application.

\section{"TESTED" GLASS WARE FOR BABCOCK TEST. \\ Lactometer (Fig.91), for testing quality of milk, $\underset{\$}{\text { Each. }} .50$ Floating Dairy Thermometer (Fig. 93), . .25 Standard Floating Dairy Thermometer(Fig.94), .50 Flange Dairy Thermometer (Fig. 92), . . . $\quad .20$ Cream Test Tubes, . . $\quad .25$ Babcock Test Bottles (for milk), 10 to 2. \% , .30 \\ Pipettes, \\ Acid Measures, 2-oz. Graduates, 4-oz. Graduates, 6-oz. Graduates, 8.oz. Graduates, \\ Each. \\ .30 \\ .30 \\ .40 \\ .50 .60} Babcock Test Bottles (for cream), 25 to $50 \%$, .35
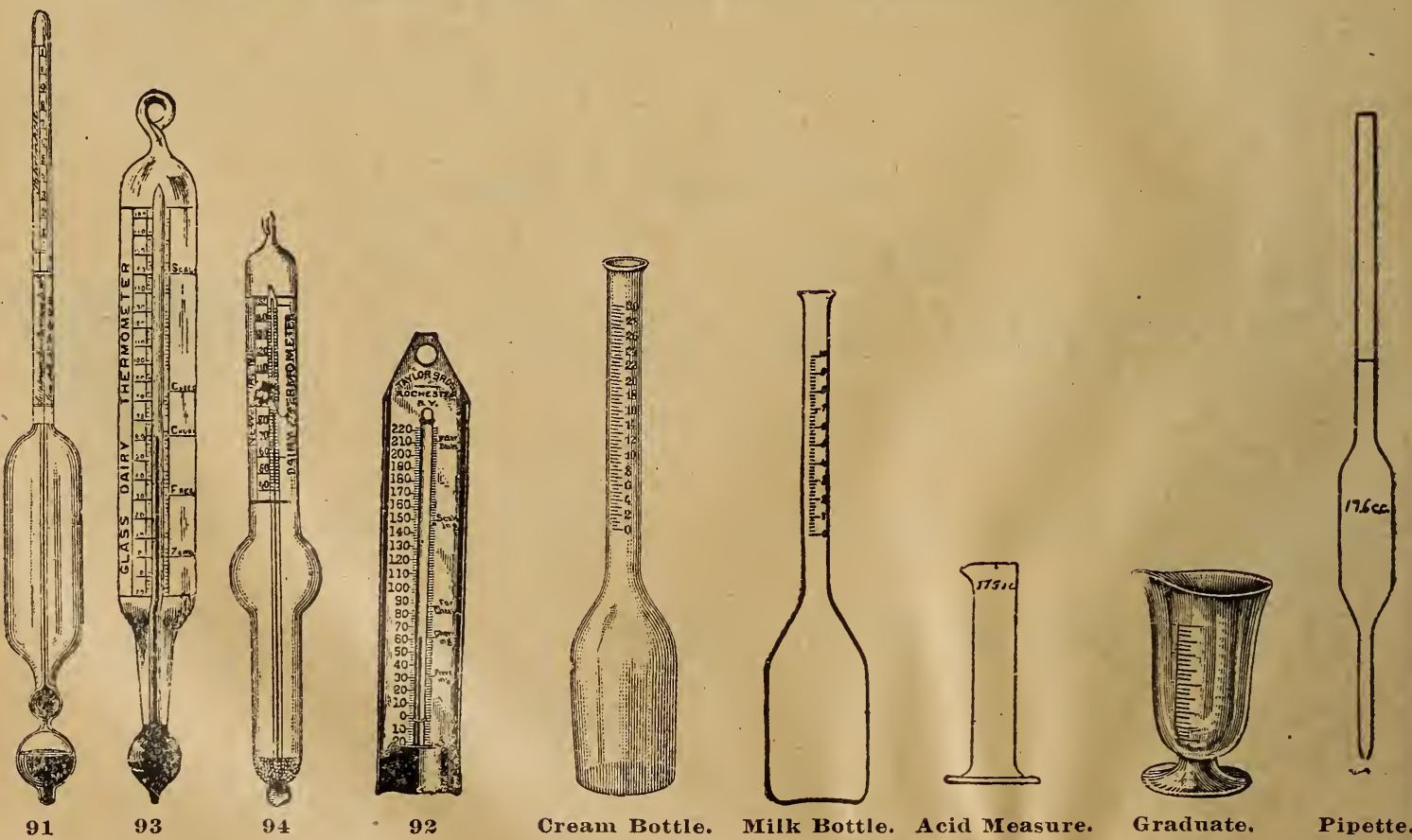

92

Cream Bottle.

Gradnate.

Pipette. 


\section{MIL CANS. We can furnish rin, Wood Stopper Milik Cans in any style, size or quantity.}

\section{Quart and 40 Quart Shipping Cans.}

The parts of all our shipping cans are made of steel and heavily tinned by the hand dipping process, after they are formed.

Prices furnished on application.

\section{CREAMERY CANS.}

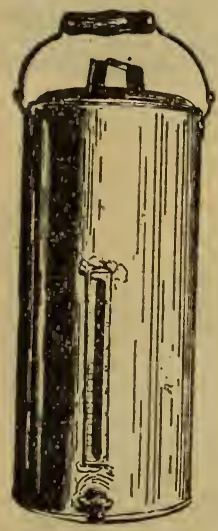

“K. \& W." Can.

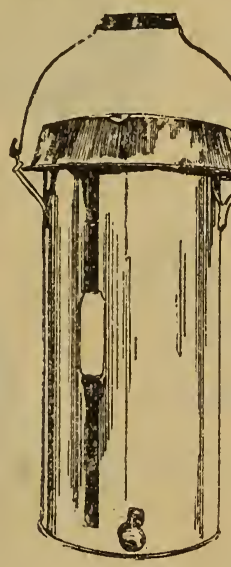

Cooley Can.

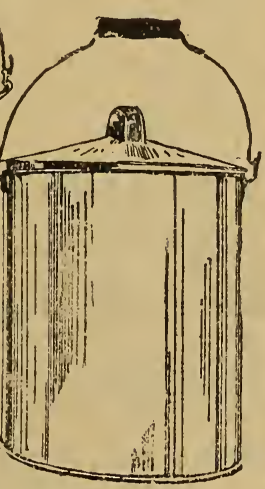

Cream Pail.

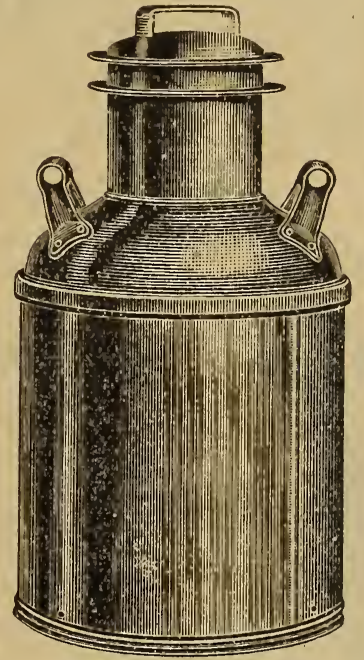

40 Qt. Shipping Can.

"K. \& W.",

Cooley,

Gross,

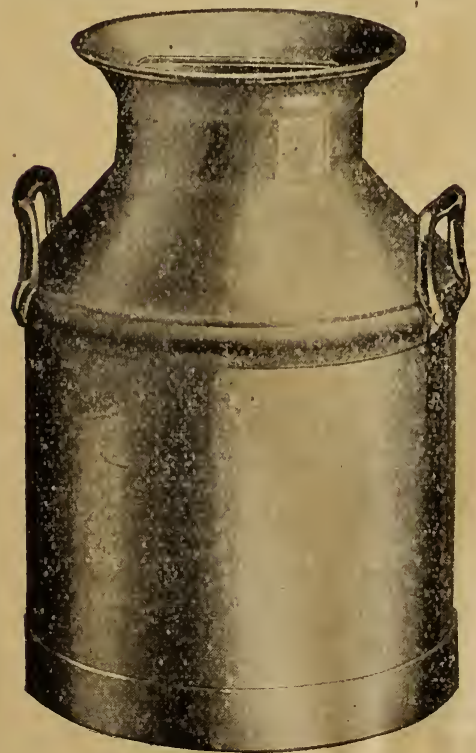

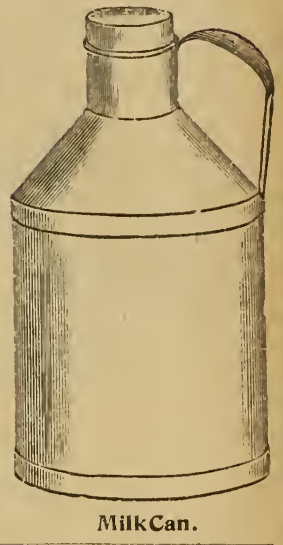

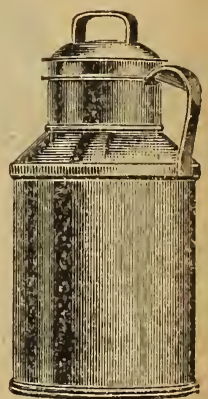

20 Qt. Shipping Can. 


\section{CHAMPION MILK COOLER AND AERATOR.}

A perfect aerator, removing all flavors arising from excessive cabbage, turnip or silo rations.

A complete deodorizer, removing the animal heat or cowy taste and all odors arising from the absorption by the milk of stable or other unpleasant gases,

$A$ thorough cooler, reducing the temperature of the milk in one minute nearly to the temperature of the cooling medium.

It is equally well adapted to the use of any cooling medium, either running water, ice water, or, if a very low temperature is not required, ordinary well or spring water.

Is automatic, requiring no attention while in operation.

Is low down, combining greatest cooling surface with least height.

It is as simple in construction and easily cleaned as a pail-no joints or seams for the harboring of impurities and no crooked pipes to rust.

No.
3
4.

$\begin{array}{ll}\text { No. } & \begin{array}{c}\text { Capacity of } \\ \text { Milk Receiver. }\end{array} \\ 2 . & 18 \text { quarts } \\ 3 . & 3 \pm \text { 66 } \\ 4 . & 52 \quad 6\end{array}$

\begin{tabular}{llc}
$\begin{array}{c}\text { Size of } \\
\text { Dairy. }\end{array}$ & \multicolumn{1}{c}{$\begin{array}{c}\text { Takes } \\
\text { Care of }\end{array}$} \\
10 to 25 cows & 3 milkers \\
25 to 50 66 & 5 & 6 \\
50 to 100 66 & 8 & "6
\end{tabular}

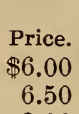

$\$ 6.00$

8.00
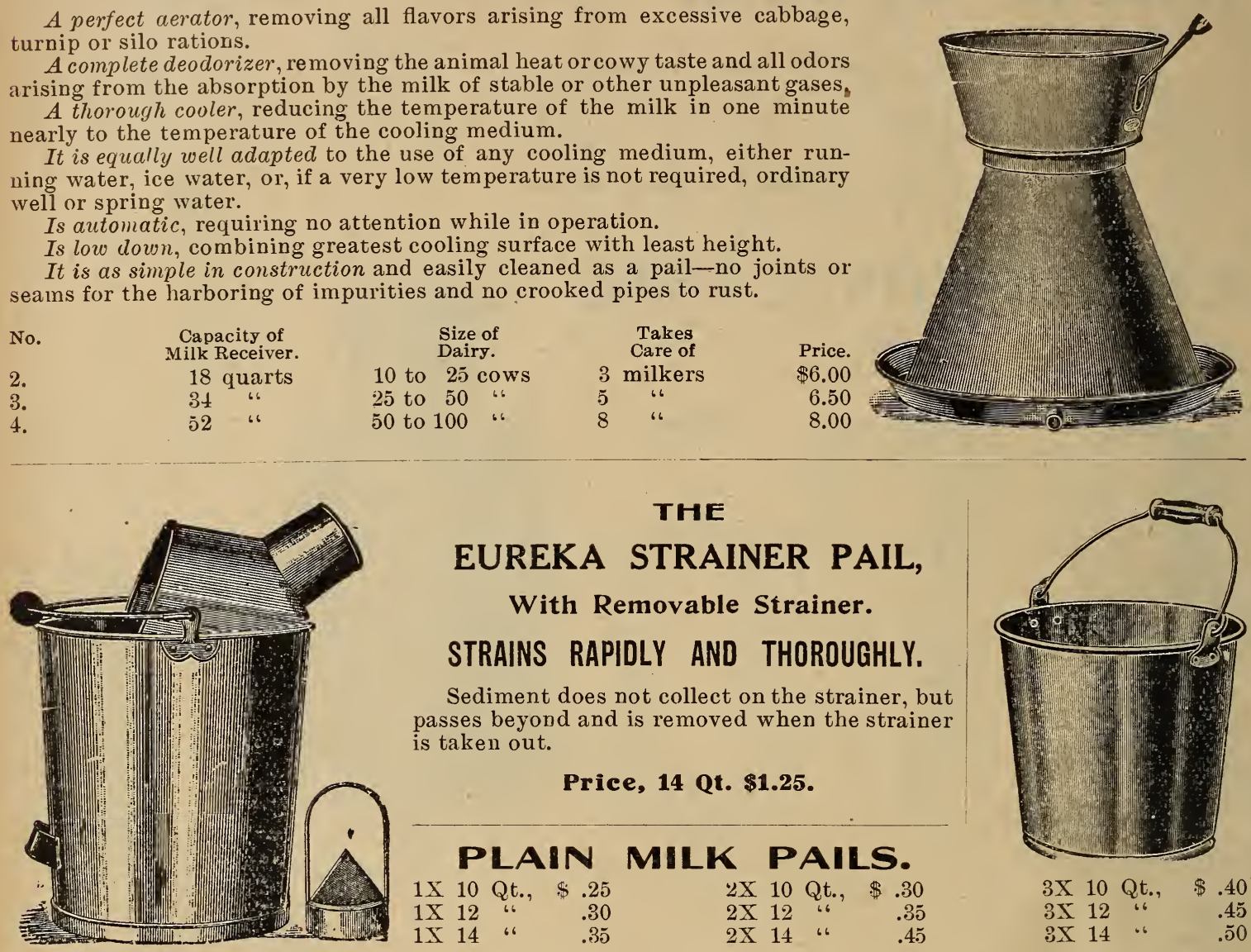

\section{EUREKA STRAINER PAIL, With Removable Strainer. STRAINS RAPIDLY AND THOROUGHLY.}

Sediment does not collect on the strainer, but passes beyond and is removed when the strainer is taken out.

Price, 14 Qt. \$1.25.

\section{PLAIN MILK PAILS.}

$1 \mathrm{X} 10$ Qt., \$.25

1X 12 "6 $\quad .30$

$1 \times 14$ " 135

$\begin{array}{lllll}2 \mathrm{X} & 10 & \mathrm{Qt} ., & \$ .30 \\ 2 \mathrm{X} & 12 & \text { "6 } & .35 \\ 2 \mathrm{X} & 14 & \text { 66 } & .45\end{array}$

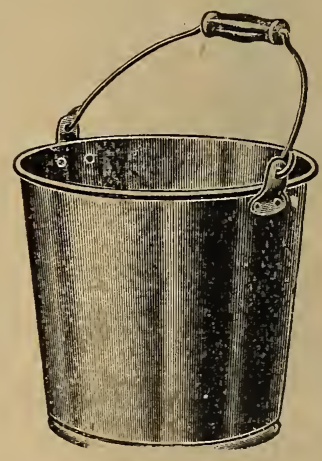

$3 \mathrm{X} 10$ Qt., $\$ .40$

$3 \mathrm{X} 12$ "6 $\quad .45$

3X $14 \quad \cdots \quad .50$

\section{THE ROCHESTER “ADJUSTO” DAIRY PAIL.}

With Shield and

Leg Rest.

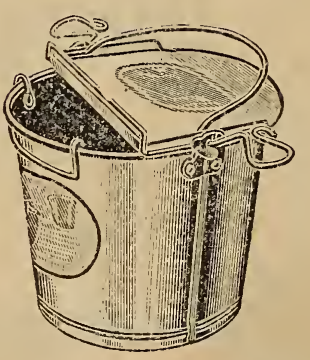

Keeps

Dirt Out.

\section{AMONG ITS MANY FEATURES ARE}

Adjustable opening-Can be made any size desired.

Sliding Shield-Allows milk to be poured from clean side of pail.

Patent Hinge-Releases shield, making it easy to wash.

Patent Leg Rest-Holds pail on milker's knees and causes no cramped position. Leg rest holds pail from ground and assures a clean bottom, thus preventing any impurities from getting into the milk.

Reduces bacteria, and produces higher milk test.

$\begin{array}{rlll}\text { Price-12 Quart, } & \bullet & \cdot & \$ 1.00 \\ 14 & \text { *. } & \text { - } & \$ 1.25 .\end{array}$




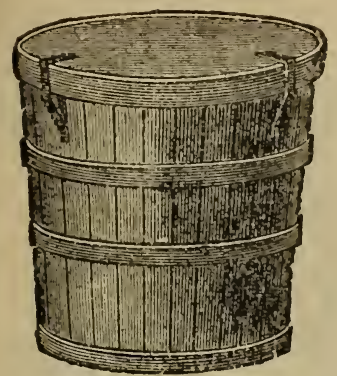

\section{Improved Oblong Butter Box,}

\section{With Parchment Lining.}

The box holds five pounds of packed butter, is nearly brick shaped, flaring so the butter will turn out, and is in the best possible shape to cut up for the table in square-like prints, and free from waste.

Write for prices.

\section{Butter Tubs.}

We are in a position to furnish superior spruce butter tubs, in any quantity desired. Tubs are kept in stock in 10,20, 30 and 50 pound sizes, and shipments can be promptly made. Special prices for large quantities.

\section{Write for quotations.}

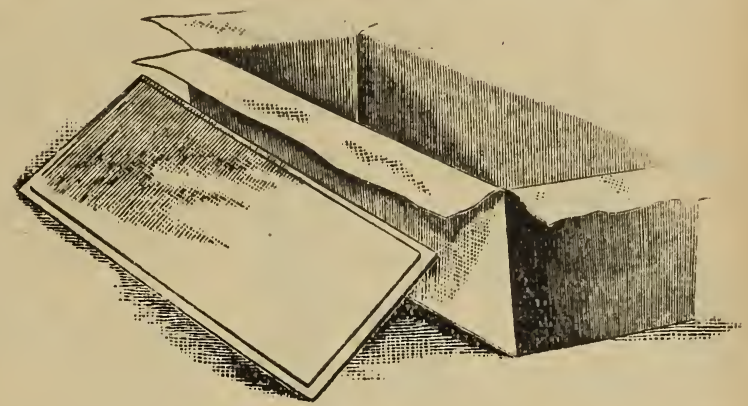

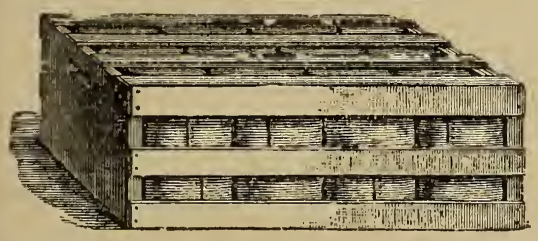

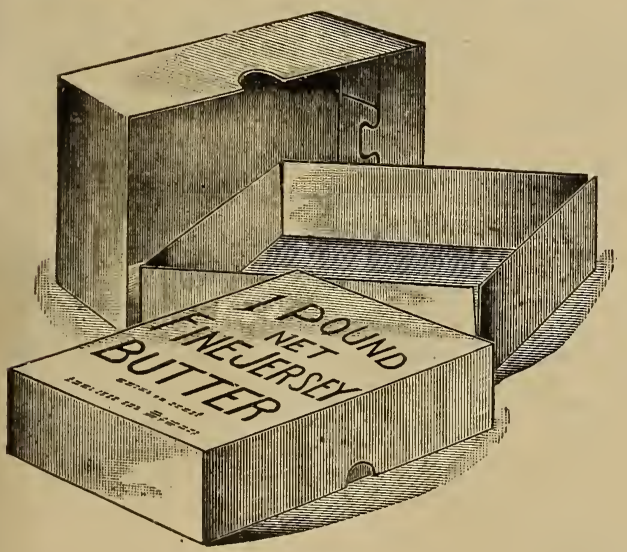

\section{ROUND BUTTER BOX.}

This is a round, firm, clean and cheap package in which to send butter to market. The wood from which it is made is thoroughly steamed before working, which makes it as nearly odorless and tasteless as possible.

Write for prices.

\section{ONE POUND \\ Folding Parraffined Paper Butter Boxes. ODORLESS AND TASTELESS. Write for quotations.}

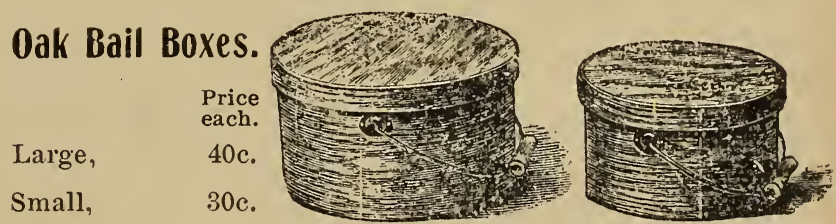

Butter Ladles,

Plain Butter Spades,

Creased Butter Spades,
$15 c$.

10c.

10c.
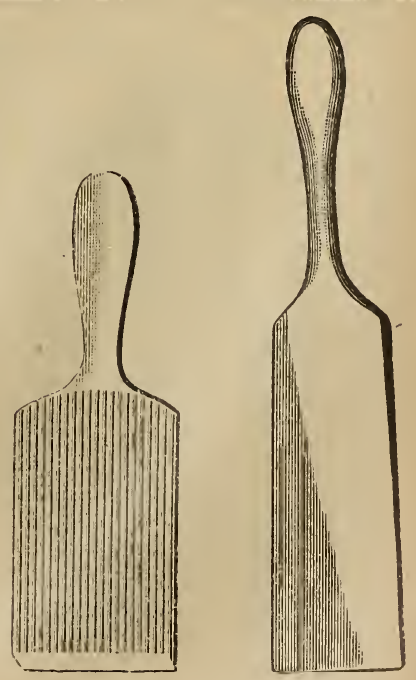


\section{Small's Calf Feeder.}

This is a device by which the calf may be fed away from its dam, and with any mixture of milk (or whatever else is healthful and desirable), with convenience and in the natural way with that admixture of saliva which does not occur when calves drink from a pail.

Price, \$2.50. Extra Nipples, 25c. each.

\section{COMMON SENSE CALF FEEDER.}

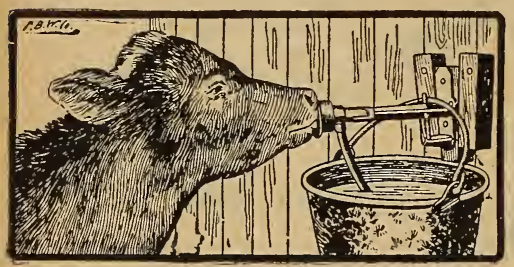

One of the best made, most durable and convenient feeders on the market. Has the endorsement of many of the leading dairymen and stock raisers.

\section{PRICE.}

Single Calf and Colt Feeder, $\$ \mathbf{\$ 5 . 0 0}$

$\begin{array}{lll}\text { Double " " " } " ~ & 6.00 \\ \text { Extra Nipples, } & .25\end{array}$

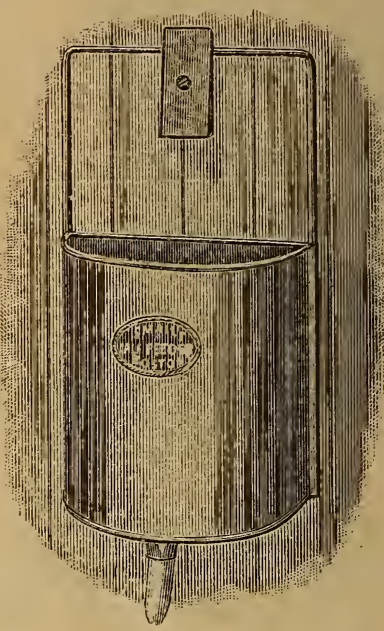

\section{RICE'S WEANER.}

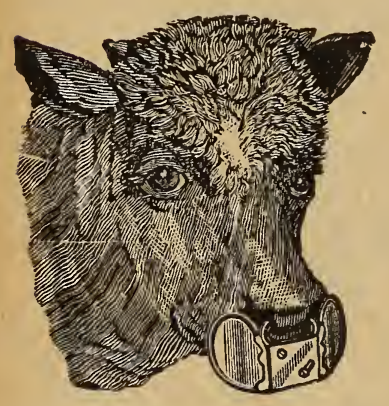

For preventing calves and cows sucking themselves or each other.

$$
\text { Price, }\left\{\begin{array}{c}
\text { No. } 1, \text { for calves, 30c., } \\
\text { No. } 2, \text { for heifers, 50c., } \\
\text { No. } 3, \text { for cows, 75c., }
\end{array}\right\} \text { postpaid. }
$$

\section{WIRE MILK BOTTLE CARRIERS.}

2 quarts, round wire, each, $\$ .50$

4 " 6 " 6 655

$\begin{array}{lllll}6 & 6 & 6 & 6 & 6\end{array}$

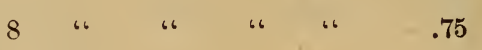
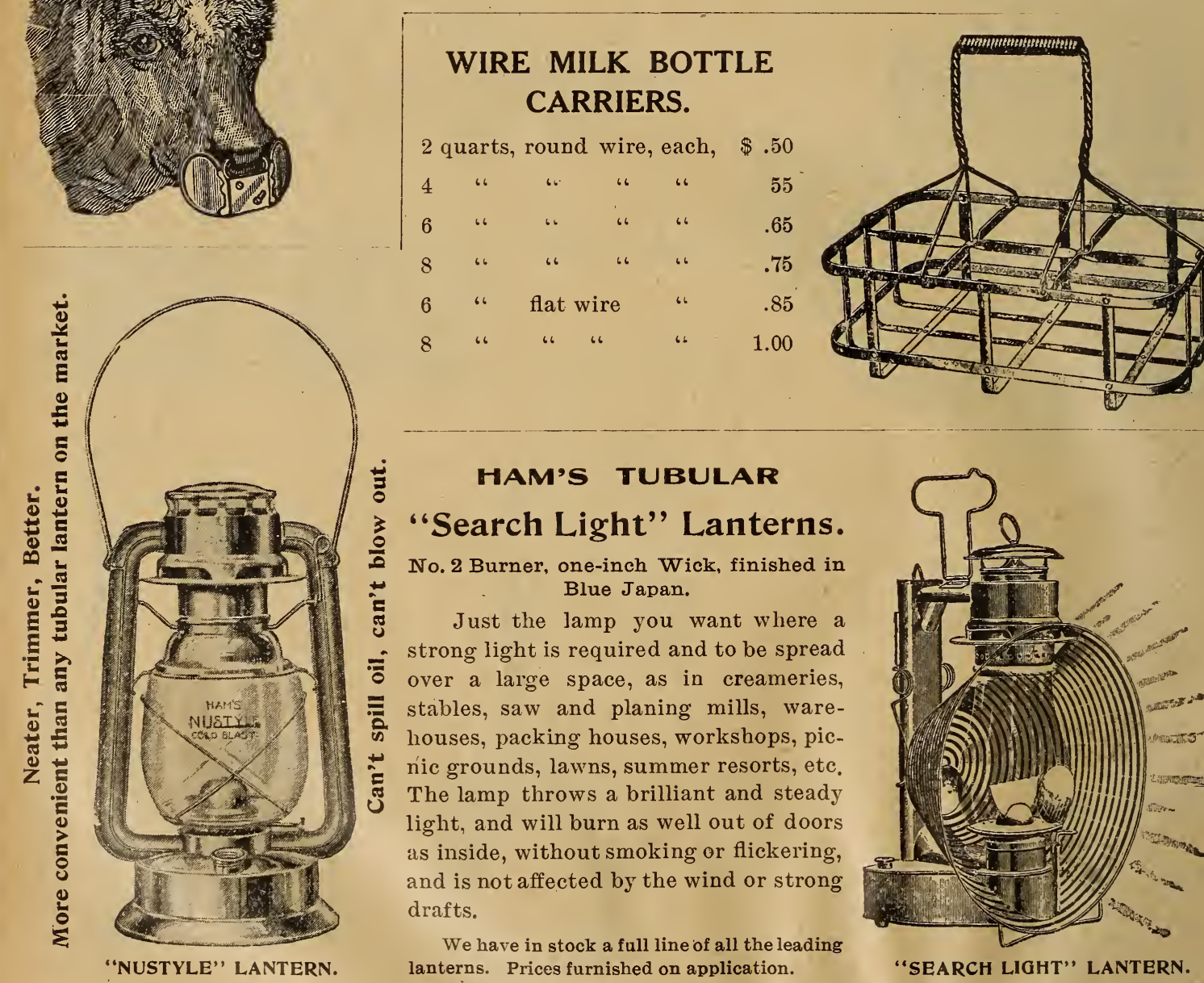

\section{HAM'S TUBULAR "Search Light"' Lanterns. No. 2 Burner, one-inch Wick, finished in Blue Japan. \\ Just the lamp you want where a strong light is required and to be spread over a large space, as in creameries, stables, saw and planing mills, ware- houses, packing houses, workshops, pic- nic grounds, lawns, summer resorts, etc. The lamp throws a brilliant and steady light, and will burn as well out of doors as inside, without smoking or flickering, and is not affected by the wind or strong drafts.}

We have in stock a full line of all the leading lanterns. Prices furnished on application.

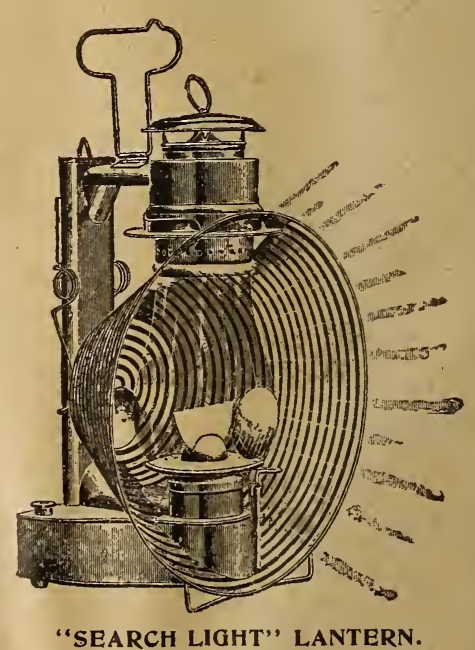




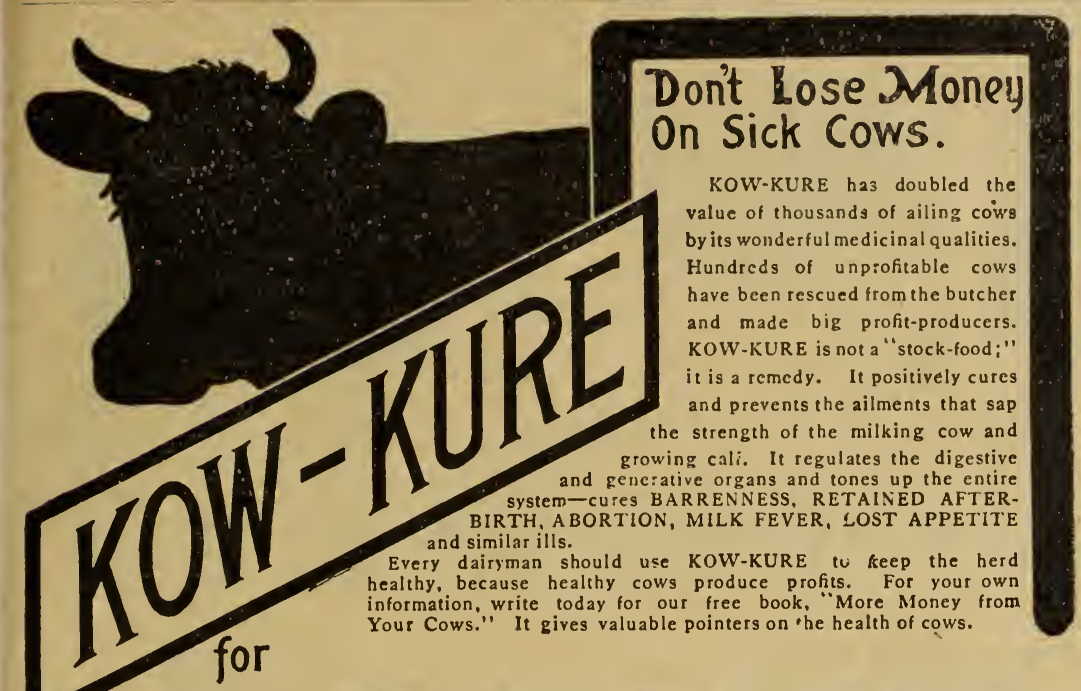

Cows only Price, Kow Kure, 50c. and $\$ 1.00$ per can.
GRANGE

GARGET

REMEDY.

Positively cures garget without in any way injuring the cow.

Price, 50c.iper can.

BAG BALM.

For sore teats, caked udder and inflammation.

Price, 50c. per can.

\title{
COW'S RELIEF.
}

A standard remedy among dairymen. A sure relief for caked udder, and will keep bag and teats free from soreness. Price, 50c. and $\$ 1.00$ per can.

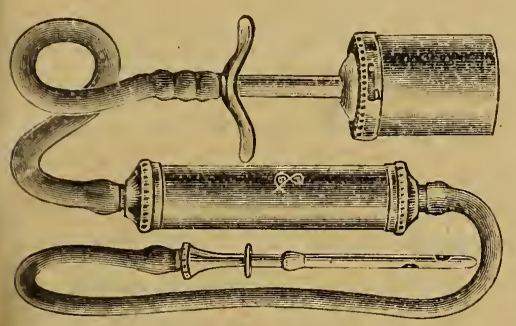

\section{THE PILLING MILK FEVER OUTFIT FOR STERILIZED AIR TREATMENT.}

This Treatment has cured 97 per cent. of all Cases Treated.

Recommended by the Bureau of Animal Industry of the United States Government Department of Agriculture.

'The outfit consists of the instrument, a roll of tape, a package of carbolized cotton, and full directions.

Price, postpaid, $\$ 3.00$.

\section{PILLING LEAD 'PROBE, \\ WITH FULL DIRECTIONS.}

For the treatment of obstructed teats, also for enlarging the opening.

Price, postpaid, 25 cents each.
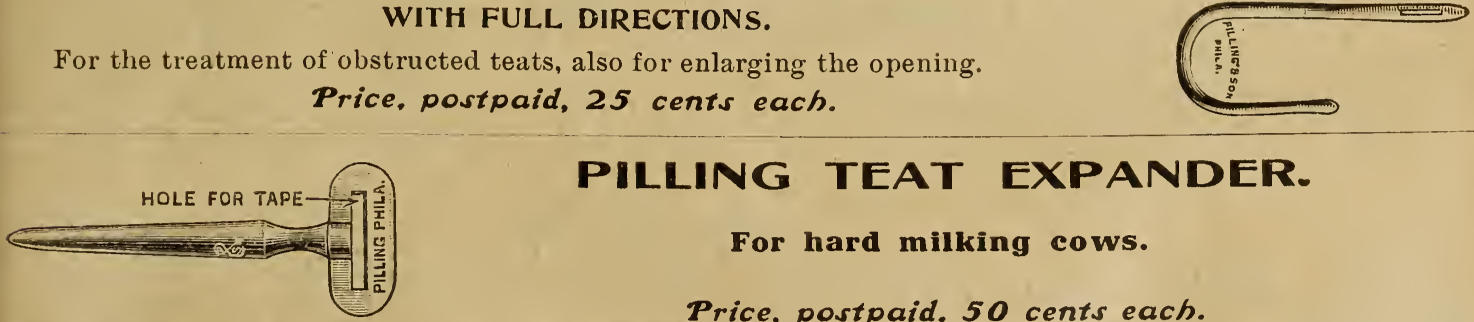

\section{PILLING TEAT EXPANDER.}

\author{
For hard milking cows.
}

Price, postpaid, 50 cents each.

\section{PILLING HARD RUBBER TEAT PLUG.}

Especially designed for two purposes ; first, to prevent dropping of milk in cows where there is relaxation of the little muscle at the end of the teat and consequent leakage of milk; and secondly, to dilate the canal of the teat above the muscle in cases where hard milking is due to contraction of this part of the canal.

Price, postpaid, 50 cents each.

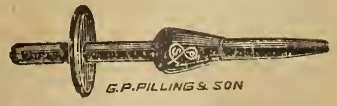

\section{THE "BOSTON" ASEPTIC MILKING TUBE.}

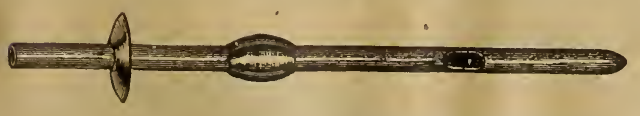

For drawing milk from cows with sore or obstructed teats. Made from white metal, in $2 \frac{1}{2}, 3,3 \frac{1}{2}$, and 4 inch lengths, heavily plated with pure silver, and warranted equal to solid silver ones in every respect, at about one-fourth the cost.

Sent by mail to any address on receipt of price.

Price, each, 25 cents. 


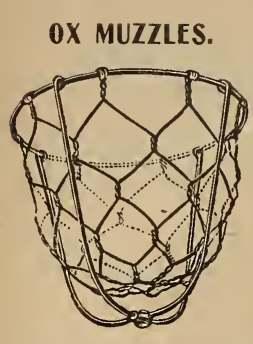

Small, per pair, 30c. Large, " " $40 \mathrm{c}$.
COW BELLS.

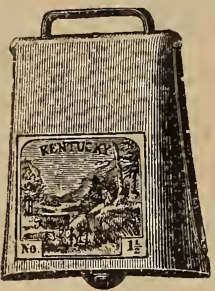

No. 1 ,

No. 2 ,

No. 3 ,

No. 4 ,

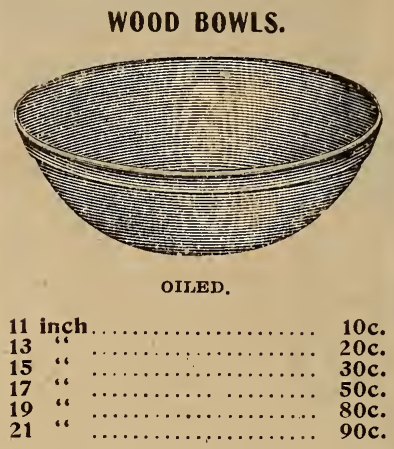

SIEVES.

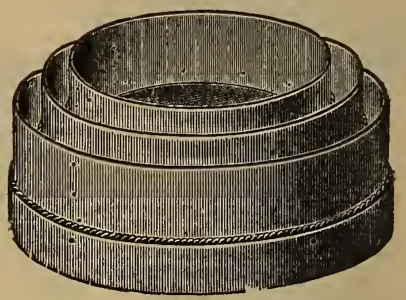

Wirre Sieyes, 12 inçhes, Prịce, eaçh, 20c.

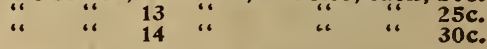

WOOD, MILK OR CREAM BOTTLE CASES.

The case is designed to put the bottle in when filled with milk for delivery. The rack inside is removable for the purpose of cleaning.

Quart case, holding 12 quart bottles,

Pint $66 \quad 66$ pint 12 6

SCOTT'S (with heavy wire bottom and partitions).

Quart case, holding 12 quart bottles,

Pin

620 pint

MILK BOTTLE CAPS.

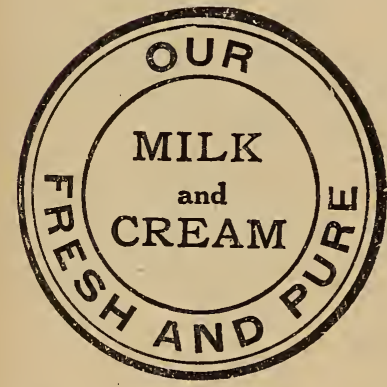

No. 1 and No. 2 size, plain or printed caps, 25 c. per $1,000$.
In cases of $5,000, \$ 1.10$ per case. No. 1 and No. 2 size, plain or printed "lip" caps, 25c. per 1,000.

Special price on barrels containing 50,000 caps.

\section{ACID-For Babcock Test. Pure, Clear, Free from Specks.}

We guarantee this acid to be of proper strength for making tests. By the pound or in carboys. Price on application.

\section{WYANDOTTE DAIRYMEN'S CLEANSER AND CLEANER.}

A powder especially compounded for use in the dairy and creamery for washing all dairy utensils, glass and tin ware, in a most satisfactory and sanitary manner. The use of this powder means absolute cleanliness.

Price, 5 lb. bags, 25c. each; 80 lb. kegs, $\$ 3.20$ each; 280 lb. barrels, $\$ 8.40$ each.

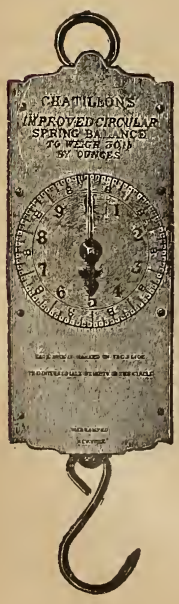

\section{IMPROVED USED BY MOST DAIRYMEN.$$
\text { DAIRY SCALES. }
$$ \\ FULL LINE-ALL SIZES. \\ PLATFORM SCALES FOR FARMERS AND DAIRYMEN. Circular Spring Balance Milk Scales. Weighing up to 60 pounds. Price, $\mathbf{\$ 3 . 5 0}$.$$
66 \quad 66,1366 \quad 30 \quad 66 \quad 66 \quad 3.00 \text {. }
$$

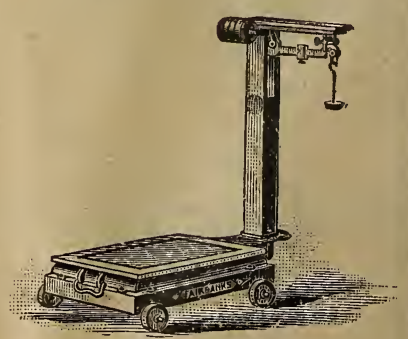




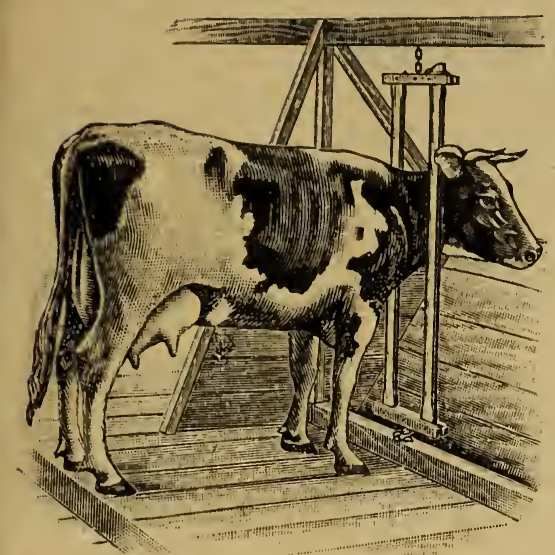

\section{Robertson's Patent Chain Hanging Stanchions.}

Practical, Safe and Durable, and Afford Comfort to the Animal.

Made with either rigid or adjustable neck space.

A pleased customer is the best possible endorsement that an article can have. These stanchions are in use by thousands of the most successful dairymen and farmers all over the country, who have had practical experience and know that these stanchions are not experiments, but are "best by test".

WRITE FOR PRICE LIST.

\section{HANSEN'S DANISH BUTTER COLOR.}

The Most Uniform, the Purest and the Most Natural Shade.

Made with the finest in ported vegetable oil.

To butter makers desiring a pure, vegetable butter color, we do not hesitate to recommend Hansen's Danish as unquestionably the best in every respect.

Its high quality has never been approached by any competing preparation, and many shippers of the finest butter demand the exclusive use by their butter makers.

\section{Price List.}

Small size, to color about 500 pounds...................... \$.25

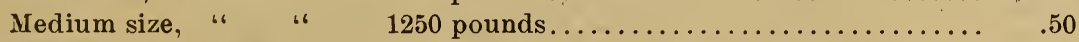

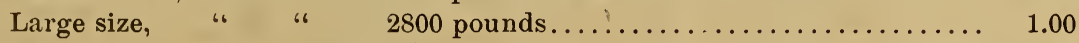

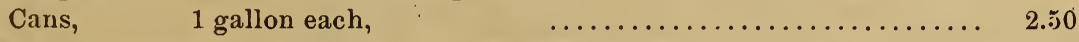
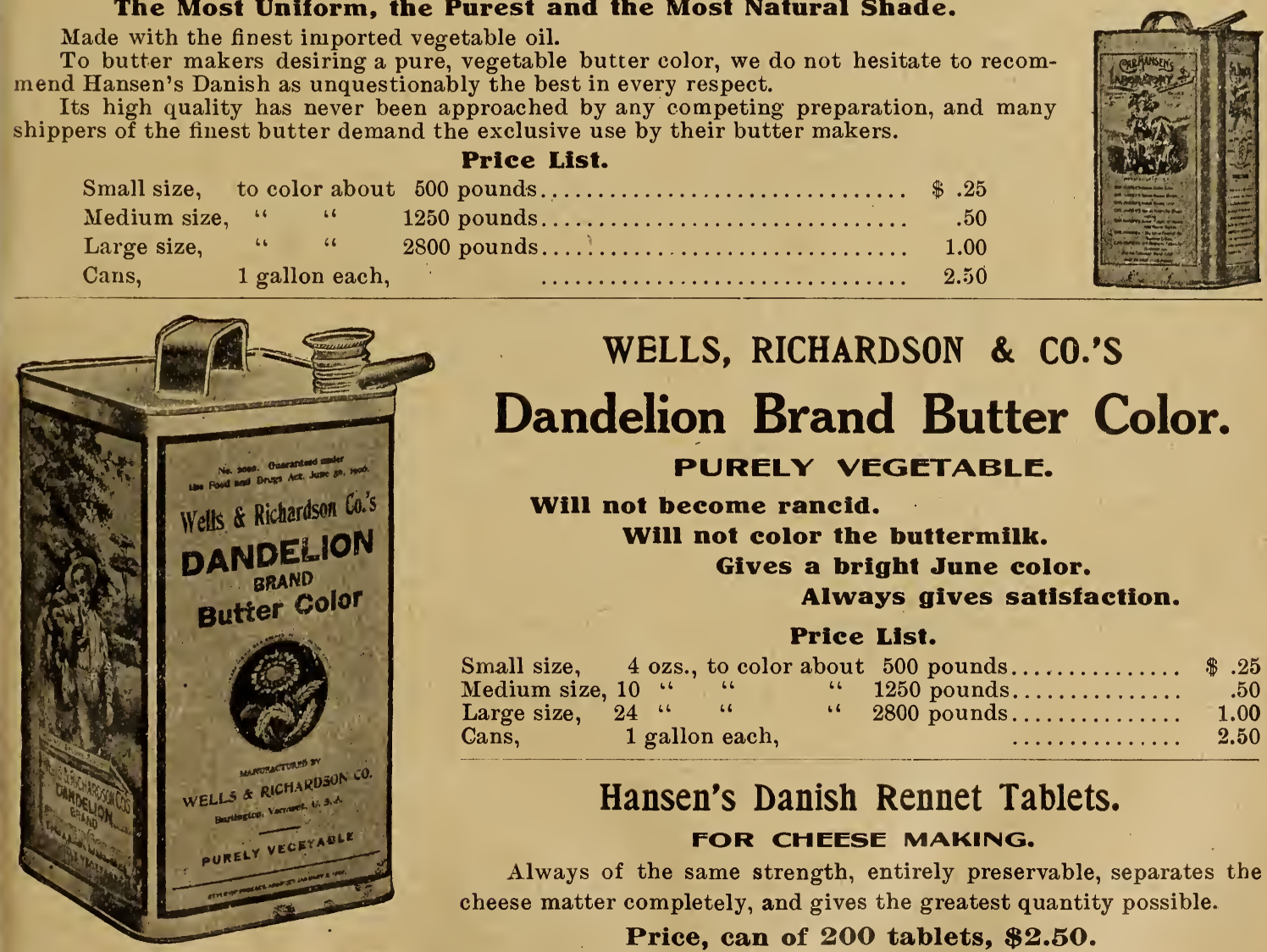

\section{WELLS, RICHARDSON \& CO.'S Dandelion Brand Butter Color.} PURELY VEGETABLE.

Will not become rancid.

Will not color the buttermilk. Gives a bright June color. Always gives satisfaction.

Price List.

Small size, 4 ozs., to color about 500 pounds........... \$ .25 Medium size, 10 " " 6 " 1250 pounds..............

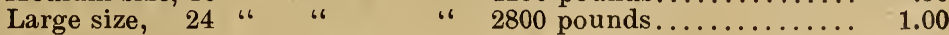
Cans, $\quad 1$ gallon each, $\quad \ldots \ldots \ldots \ldots \ldots .2 .50$

\section{Hansen's Danish Rennet Tablets.} FOR CHEESE MAKING.

Always of the same strength, entirely preservable, separates the cheese matter completely, and gives the greatest quantity possible.

Price, can of 200 tablets, $\$ 2.50$.

\section{Hansen's Danish Dry Lactic Ferment.}

FOR RIPENING CREAM AND MILK.

PRICE LIST.

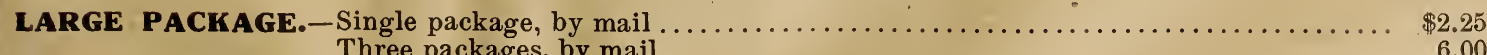

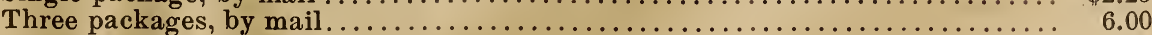

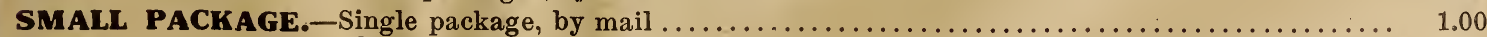

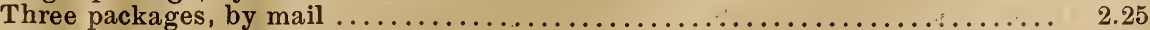




\section{SPRAYING CALENDAR.}

Spraying should be practiced regularly, and trees, plants or vines should never be neglected because they do not show prospects for fruit. By keeping a healthy, vigorous foliage, better fruit bud development will be secured for the crop of the succeeding year. Spray every year and spray thoroughly.

In preparation for spraying fruit trees, they should first be properly pruned. Trees which have grown too tall should be reduced in height. by cutting back topmost branches to lateral ones. Lateral limbs which extend out too far should also be shortened. All old bark should be scraped from the trunk and main limbs, as it offers a favorable hiding-place for certain insects.

\begin{tabular}{|c|c|c|c|c|c|c|}
\hline Fruit. & Pest. & What to Use. & Dilution. & First Spraying. & SECOND SPRAYING. & THIRD SPRAYING. \\
\hline Apple & $\begin{array}{l}\text { Codling } \\
\text { Moth }\end{array}$ & $\begin{array}{l}\text { Arsenate of Lead-dry } \\
\text { Arsenate of Lead-paste }\end{array}$ & $\begin{array}{l}\text { *3 to } 5 \mathrm{lbs} \text {. } \\
\text { *6 to } 10 \mathrm{lbs} \text {. }\end{array}$ & $\begin{array}{l}\text { Immediately af ter } \\
\text { blossoms fall }\end{array}$ & Ten days later & $\begin{array}{l}\text { For second brood up- } \\
\text { on their appearance }\end{array}$ \\
\hline Apple & Curculio & $\begin{array}{l}\text { Arsenate of Lead-dry } \\
\text { Arsenate of Lead-paste }\end{array}$ & $\begin{array}{l}* 3 \text { to } 5 \mathrm{lbs} . \\
{ }^{*} 6 \text { to } 10 \mathrm{lbs} .\end{array}$ & $\begin{array}{l}\text { As soon as blossoms } \\
\text { fall }\end{array}$ & Ten days later & Two weeks later \\
\hline Apple & $\begin{array}{l}\text { San Jose } \\
\text { Scale }\end{array}$ & Lime-Sulfur & $\begin{array}{l}1 \text { to } 11-1 \text { to } 8 \\
\text { in bad cases } \\
\text { of infection }\end{array}$ & $\begin{array}{l}\text { Ten days after leaves } \\
\text { have dropped in fall }\end{array}$ & $\begin{array}{l}\text { Early in spring be- } \\
\text { fore leaves appear }\end{array}$ & \\
\hline Apple & $\begin{array}{l}\text { Leaf Skele- } \\
\text { tonizer }\end{array}$ & $\begin{array}{l}\text { Arsenate of Lead-dry } \\
\text { Arsenate of Lead-paste }\end{array}$ & $\begin{array}{l}* 3 \text { to } 5 \mathrm{lbs} . \\
* 6 \text { to } 10 \mathrm{lbs} .\end{array}$ & $\begin{array}{l}\text { When young leaves } \\
\text { first appear }\end{array}$ & As may be necessary & \\
\hline Apple & $\begin{array}{l}\text { Canker } \\
\text { Worm }\end{array}$ & $\begin{array}{l}\text { Arsenate of Lead-dry } \\
\text { Arsenate of Lead-paste }\end{array}$ & $\begin{array}{l}{ }^{*} 3 \text { to } 5 \mathrm{lbs} . \\
{ }^{*} 6 \text { to } 10 \mathrm{lbs} .\end{array}$ & $\begin{array}{l}\text { When young first ap- } \\
\text { pear }\end{array}$ & Four to six days later & $\begin{array}{l}\text { Same as second if } \\
\text { worms are still there }\end{array}$ \\
\hline Apple & $\begin{array}{l}\text { Tent } \\
\text { Caterpillar }\end{array}$ & $\begin{array}{l}\text { Arsenate of Lead-dry } \\
\text { Arsenate of Lead-paste }\end{array}$ & $\begin{array}{l}* 3 \text { to } 5 \mathrm{lbs} . \\
{ }^{*} 6 \text { to } 10 \mathrm{lbs} .\end{array}$ & As insects appear & As needed & \\
\hline Apple & $\begin{array}{l}\text { Leaf } \\
\text { Crumpler }\end{array}$ & $\begin{array}{l}\text { Arsenate of Lead-dry } \\
\text { Arsenate of Lead-paste }\end{array}$ & $\begin{array}{l}* 3 \text { to } 5 \mathrm{lbs} . \\
{ }^{*} 6 \text { to } 10 \mathrm{lbs} .\end{array}$ & About middle of May & As needed & \\
\hline Apple & $\begin{array}{l}\text { Oyster } \\
\text { Shell Bark } \\
\text { Louse }\end{array}$ & Lime-Sulfur & $\begin{array}{l}1 \text { to } 11-1 \text { to } 8 \\
\text { in bad cases } \\
\text { of infection }\end{array}$ & $\begin{array}{l}\text { When trees are dor- } \\
\text { mant in early spring }\end{array}$ & $\begin{array}{l}\text { Spraying at same } \\
\text { strength in fall after } \\
\text { leaves have fallen, is } \\
\text { advisable }\end{array}$ & - \\
\hline Apple & $\begin{array}{l}\text { Lesser Leaf } \\
\text { Worm }\end{array}$ & $\begin{array}{l}\text { Arsenate of Lead-dry } \\
\text { Arsenate of Lead-paste }\end{array}$ & $\begin{array}{l}* 3 \text { to } 5 \text { lbs. } \\
{ }^{*} 6 \text { to } 10 \mathrm{lbs} .\end{array}$ & $\begin{array}{l}\text { Ten days after blos- } \\
\text { soms have fallen }\end{array}$ & Ten days later & \\
\hline Apple & Bark Louse & Lime-Sulfur & 1 to 8 & $\begin{array}{l}\text { When trees are dor- } \\
\text { mant in early spring }\end{array}$ & & . \\
\hline Apple & Scab & Lime-Sulfur & 1 to 8 & Just before budsopen & $\begin{array}{l}\text { When blossoms have } \\
\text { dropped ( } 1 \text { to } 35)\end{array}$ & Ten days later \\
\hline Pear & $\begin{array}{l}\text { Leaf Blis- } \\
\text { ter Mite }\end{array}$ & Lime-Sulfur & 1 to 8 & $\begin{array}{l}\text { While trees are dor- } \\
\text { mant }\end{array}$ & $\begin{array}{l}\text { After foliage is out } \\
(1 \text { to } 40)\end{array}$ & \\
\hline Pear & Slug & $\begin{array}{l}\text { Arsenate of Lead-dry } \\
\text { Arsenate of Lead-paste }\end{array}$ & $\begin{array}{l}* 3 \text { to } 5 \mathrm{lbs} . \\
{ }^{*} 6 \text { to } 10 \mathrm{lbs} .\end{array}$ & When insects appear & $\begin{array}{l}\text { Repeat after ten days } \\
\text { or two weeks if nec- } \\
\text { essary }\end{array}$ & : \\
\hline Plum & Curculio & $\begin{array}{l}\text { Arsenate of Lead-dry } \\
\text { Arsenate of Lead-paste }\end{array}$ & $\begin{array}{l}{ }^{*} 3 \text { to } 5 \mathrm{lbs} . \\
{ }^{*} 6 \text { to } 10 \mathrm{lbs} .\end{array}$ & $\begin{array}{l}\text { With starting of } \\
\text { buds }\end{array}$ & $\begin{array}{l}\text { Just after bloom falls } \\
\text { from calyx }\end{array}$ & $\begin{array}{l}\text { At intervals of ten } \\
\text { days to two weeks }\end{array}$ \\
\hline Plum & Gouger & $\begin{array}{l}\text { Arsenate of Lead-dry } \\
\text { Arsenate of Lead-paste }\end{array}$ & $\begin{array}{l}{ }^{*} 3 \text { to } 5 \mathrm{lbs} . \\
{ }^{*} 6 \text { to } 10 \mathrm{lbs} .\end{array}$ & $\begin{array}{l}\text { Before leaves and } \\
\text { buds are completely } \\
\text { out }\end{array}$ & & \\
\hline $\begin{array}{l}\text { Straw- } \\
\text { berry }\end{array}$ & $\begin{array}{l}\text { Crown } \\
\text { Borer }\end{array}$ & $\begin{array}{l}\text { Arsenate of Lead-dry } \\
\text { Arsenate of Lead-paste }\end{array}$ & $\begin{array}{l}* 3 \text { to } 5 \mathrm{lbs} . \\
{ }^{*} 6 \text { to } 10 \mathrm{lbs} \text {. }\end{array}$ & $\begin{array}{l}\text { Late in summer to } \\
\text { catch the beetles }\end{array}$ & $\begin{array}{l}\text { After fruit has been } \\
\text { gathered burn fields } \\
\text { over }\end{array}$ & \\
\hline $\begin{array}{l}\text { Straw- } \\
\text { berry }\end{array}$ & Leaf Roller & $\begin{array}{l}\text { Arsenate of Lead-dry } \\
\text { Arsenate of Lead-paste }\end{array}$ & $\begin{array}{l}\text { *3 to } 5 \text { lbs. } \\
\text { *6 to } 10 \mathrm{lbs} \text {. }\end{array}$ & In August & $\begin{array}{l}\text { After fruit has been } \\
\text { gathered burn fields } \\
\text { over }\end{array}$ & : \\
\hline $\begin{array}{l}\text { Straw- } \\
\text { berry }\end{array}$ & Slug & Paris Green & $\begin{array}{l}4 \text { to } 6 \text { oz. to } \\
50 \text { gallons }\end{array}$ & In May & & \\
\hline $\begin{array}{l}\text { Straw- } \\
\text { berry }\end{array}$ & Root Worm & $\begin{array}{l}\text { Arsenate of Lead-dry } \\
\text { Arsenate of Lead-paste }\end{array}$ & $\begin{array}{l}* 3 \text { to } 5 \mathrm{lbs} . \\
{ }^{*} 6 \text { to } 10 \mathrm{lbs} \text {. }\end{array}$ & $\begin{array}{l}\text { After fruit has been } \\
\text { harvested burn fields }\end{array}$ & & \\
\hline $\begin{array}{l}\text { Cur- } \\
\text { rant }\end{array}$ & Aphis & $\begin{array}{l}\text { Arsenate of Lead-dry } \\
\text { Arsenate of Lead-paste }\end{array}$ & $\begin{array}{l}\text { *3 to } 5 \mathrm{lbs} . \\
\text { *6 to } 10 \mathrm{lbs} .\end{array}$ & $\begin{array}{l}\text { Early in spring be- } \\
\text { fore buds are exposed }\end{array}$ & & \\
\hline $\begin{array}{l}\text { Cur- } \\
\text { rant }\end{array}$ & $\begin{array}{l}\text { Currant } \\
\text { Worm }\end{array}$ & $\begin{array}{l}\text { Arsenate of Lead-dry } \\
\text { Arsenate of Lead-paste }\end{array}$ & $\begin{array}{l}* 3 \text { to } 5 \mathrm{lbs} . \\
\text { *6 to } 10 \mathrm{lbs} \text {, }\end{array}$ & $\begin{array}{l}\text { As soon as insects } \\
\text { appear }\end{array}$ & & Later as needed \\
\hline $\begin{array}{l}\text { Goose- } \\
\text { berry }\end{array}$ & $\begin{array}{l}\text { Fruit } \\
\text { Worm }\end{array}$ & $\begin{array}{l}\text { Arsenate of Lead-dry } \\
\text { Arsenate of Lead-paste }\end{array}$ & $\begin{array}{l}* 3 \text { to } 5 \mathrm{lbs} . \\
{ }^{*} 6 \text { to } 10 \mathrm{lbs} \text {. }\end{array}$ & $\begin{array}{l}\text { As soon as insects } \\
\text { appear }\end{array}$ & & Later as needed \\
\hline $\begin{array}{l}\text { Rasp- } \\
\text { berry }\end{array}$ & Slug & Paris Green & $\begin{array}{l}4 \text { to } 6 \text { oz. to } \\
50 \text { gallons: }\end{array}$ & Early in spring & & \\
\hline $\begin{array}{l}\text { Black- } \\
\text { berry }\end{array}$ & Fungus & Lime-Sulfur & 1 to 11 & $\begin{array}{l}\text { When bushes are } \\
\text { dormant }\end{array}$ & & $\begin{array}{l}\text { When leaves are out } \\
\text { (1 to 50) }\end{array}$ \\
\hline
\end{tabular}

- To one hundred gallons of water. 


\section{SPECIAL ATTENTION IS CALLED TO OUR STOCK OF}

\section{Insecticides}

\section{Atomizers, Sprayers and Spray Pumps}

INCLUDING

Bug Death, Arsenate of Lead, Paris Green, Lime-Sulphur, Tuber-Tonic, Pyrox, Aphine, Bordeaux Mixture, Tree Tanglefoot, Kerosene Emulsion, Cut Worm Killer, Sheep Dip, and Cattle Oil.

New Misty, Midget, Rapid, Easy and Acme Atomizers.

Champion and Acme Powder Guns, "Auto Spray", "Kant Klog" and Perfection Sprayers, Myers, King, Ideal, Eureka, "Pomona", "Fruitall", New Monarch, "Will Spray", Little Giant No. 28, Simplex, Deyo and "Ironage" Hand and Power Spray Pumps.

$$
\text { A L S O }
$$

Spray Pump Fittings, including Jasmin Controller, Nozzles, Steel and Bamboo Extensions, Hose, Couplings, Agitators, Valves, Rods, Bushings, Packings, etc.

$$
\text { I- SEe other side eil }
$$




\section{We Ask Your Careful Examination}

\section{of the Following Complete and Up-}

to-Date Stock of

Walking Plows, Sulky Plows, Disc Harrows, Spring Tooth Harrows, Spike Tooth Harrows, Hand Cultivators, Riding Cultivators, Wheel Hoes, Seed Drills, Seed Sowers, Fertilizer Drills, Fertilizer Sowers, Grain Drills, Weeders, Potato Hoes, Hand Garden Cultivators, Manure Spreaders, Land Rollers, Corn Planters, Potato Planters, Mowers, Rakes, Tedders, Corn Binders, Grain Binders, Potato Diggers, Grain and Bean Threshers, Hay Presses, Gasoline Engines, Saw Machines, Feed Mills, Corn Shellers, Ensilage Cutters, Feed Cutters, Root Cutters, Fan Mills, Cider Mills, etc., also

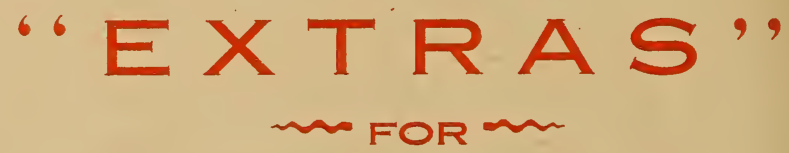

Cultivators, Seeders, Harrows, Plows, Grain and Fertilizer Drills, Spreaders, Planters, Rollers, Mowers, Rakes, Tedders, Diggers, Binders, Hay Presses, Ensilage Cutters, Feed Mills, Threshers, Gasoline Engines, etc.

\section{CAREFUL ATtENTION GIVEN ALL ORDERS} FOR MACHINE "EXTRAS"

IN ORDERING "EXTRAS", PLEASE CAREFULLY SPECIFY MAKE OF MACHINE, AND NUMBER OR LETTER OF PART WANTED.

THIS LINE WE INTEND TO HAVE IN STOCK AT ALL TIMES, AND WE SOLICIT YOUR VALUED ORDERS WHICH WE WILL ENDEAVOR TO SHIP PROMPTLY. 


\section{6 \\ BUG

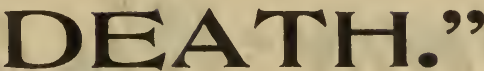

The multiplication of insect pests and increase of fungous diseases place the question of spraying outside the line of debate. It mustberesoited to. It is the only salvation of the fruit, vegetable or crop producer. Spraying is a recessity for successful cropping. There is one insecticide on the market, abso'utely harmless to animal life, which will kill the bugs and insects, protect the life if the leaves and plants, increase the yield, insure highest quality and promote :he vigor of the plant or tree.

Bug Death will do all this, for it is the only insecticide on the mariet which feeds and strengthens the leaves while destroying the pests which therwise would destroy the crop, killing the potato, squash and cucumber oug, currant and tomato worm, and all other plant and vine-eating pests.

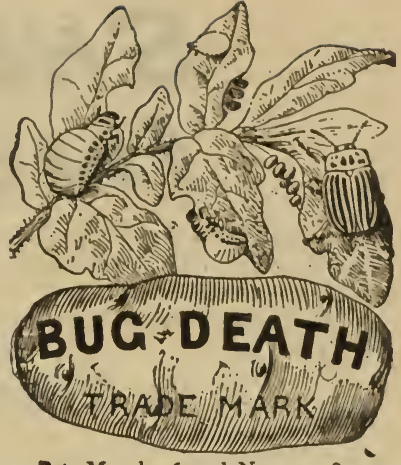

Pat. March 16 and Nov. 9, 1897.

\section{DIRECTIONS FOR SPRAYING ONE ACRE OF POTATOES.}

Fill a pail holding about 12 quarts, half full of water. Stir 15 to 25 pounds of Bug Death into this water. Fill sprayer tank nearly full with clear water, then pour Bug Death from bucket into tank and start niachine it once, being sure that the agitator is working properly.

\section{DIRECTIONS FOR SPRAYING ONE ACRE OF POTATOES WITH BUG DEATH AND BORDEAUX MIXTURE.}

Dissolve 6 pounds copper sulphate (blue vitriol) in 6 gallons of water. Slack 6 pounds lump lime, slowly adding water as it slacks, being careful not to burn the lime. When thoroughly slacked strain it to remove any lumps before it goes into sprayer. When ready to spray, fill tank two-thirds full of clear water and add the 6 gallons blue vitriol water. Next put in 15 to 25 pounds Bug Death (first mix Bug Death in pail of water, same as under directions for using Bug Death alone). Fill tank almost full of clear water; lastly put in the lime water. Stir well and start machine at once, being sure that agitator is working properly.

The above solution, if properly applied, reill prevent blight on potatoes, tomatoes. etc.

\section{IF USED DRY}

apply with Dickey Bug Death Duster or Acre-an-Hour Sifter at the rate of 15 to 25 pounds per acre, per application. Dust plant evenly and thoroughly. The more freely used the better the plant will thrive, as the increased yield and improved quality more than pays the expense. A perfectly sure, safe, effective insecticide.

1 pound package (is provided with a sifter top, making it easy to distribute contents on to plants or vines) ............... .15

3 pound package.
5 pound package. ................. \$.50

12 1-2 pound package ............. 1.00

100 pound $\mathrm{keg} . \ldots \ldots \ldots \ldots \ldots \ldots \ldots .6 .6 .6$

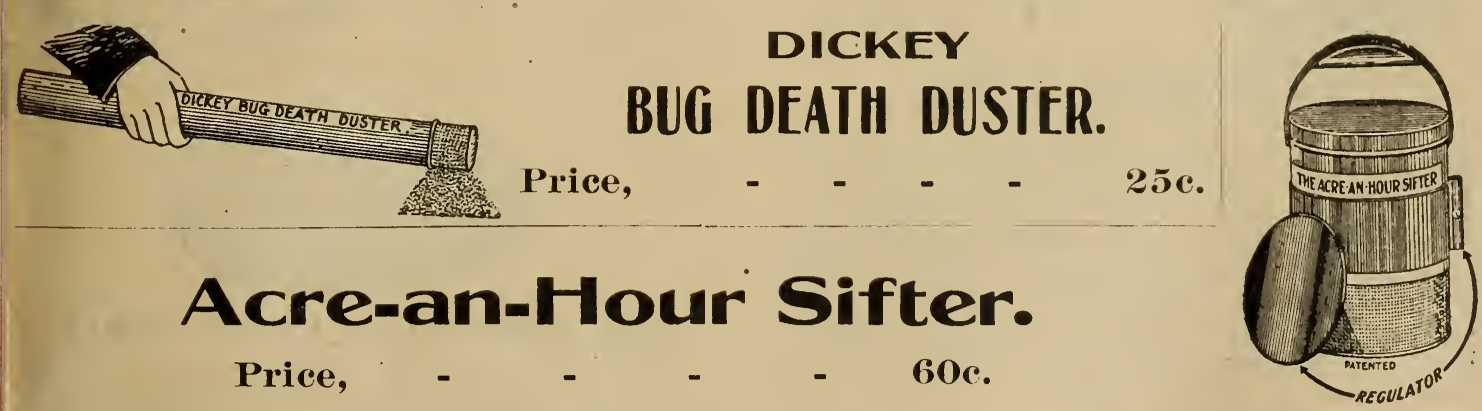

\section{SWIFT'S ARSENATE OF LEAD.}

The latest and one of the best known insecticides for leaf-eating insects, such as elm leaf beetle, gypsy and brown-tail moths, canker worm, coddling moth, tent caterpillar and potato bug, as it adheres to the foliage for a long time.

On large trees, the best results are obtained by a nozzle giving a fine, mist-like spray. Spray until the leaves commence to drip, and then stop. Select a warm, dry day; so that the insecticide will have a chance to dry on the foliage.

1 pound package,

2 pound package,

5 pound package,

\section{PRICES.}

\$. 20

.38

.90
10 pound keg,

25 pound keg,
$\$ 1.60$

3.75
50 pound $\mathrm{keg}$,

100 pound keg,
$\$ 6.50$

12.00
Price for larger quantities upon application. 


\section{SHERWIN-WILLIAMS INSECTICIDES}

After giving the spraying question due consideration, we have stocked a complete line of Sherwin-Williar Insecticides and Fungicides believing that they represent the highest development in spray materi manufactured.

They are guaranteed under the Insecticide Act of 1910, Serial No. 57. To this we add our own person warranty.

\section{S-W DRY ARSENATE OF LEAD.}

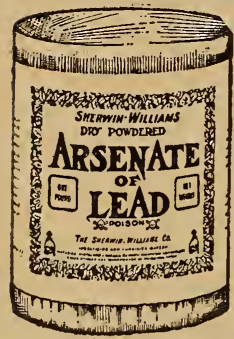

Because of its dry form, it is more convenient than the paste, as it is easier convenient than the paste, as it is easier water. Its suspension qualities are unsurpassed, due to its fine, fluffy condition. Its effectiveness and safety is evidenced by its 31 to $33 \%$ arsenic oxide contents thoroughly combined with lead. One pouind of this material will accomplish the same results as 2 to 3 pounds of the paste. For leaf-eating insects on fruits and vegetables, use from 1 to $1 \frac{1 / 2}{2}$ pounds to 50 gallons water.

Put up in 1, 5, 10, 25, 50 and 100 pound packages.

\section{S-W NEW PROCESS ARSENATE OF LEAD.}

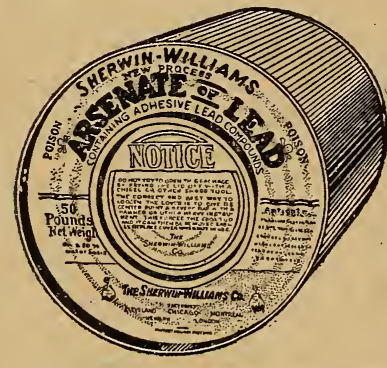

For those who desire a paste material, we will continue the sale of S-W New Process Arsenate of Lead (containing adhesive lead compounds), which is among the most effective and convenient materials of this character. Use 2 to 3 pounds to 50 gallons of water.

Put up in one pound glass jars, $5,12 \frac{1}{2}, 25,50$ and 100 pound steel packages.

\section{S-W LIME-SULFUR SOLUTION.}

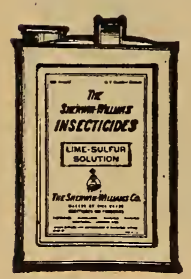

Contains the greatest amount of sulphur which can be brought into solution in sulphide form, and therefore it is as strong a solution as can be made. It registers $33^{\circ}$ Baume. S-W Lime-Sulfur is thoroughly filtered, and will not clog the spray nozzle when spraying. Reduced with water, one to eight, it is effective against San Jose scale, and other insects of like character. Used at a weaker insects of like character. Used at a weaker
dilution or when combined with arsenate of lead as a summer spray, it controls such fungous diseases as bitter rot, apple scab, etc.

Put up in quarts, half gallons, gallons 5 gablons and barrels.

\section{S-W BORDEAUX MIXTURE.}

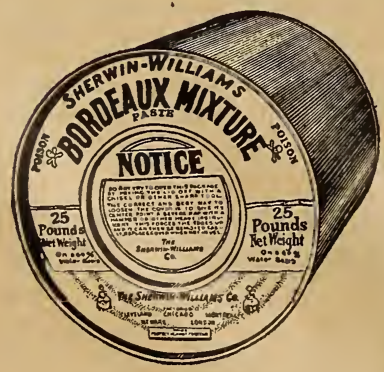

This material is a combination of blue vitriol and lime combined in semi-paste form. Guaranteed of absolutely pure materials, hence the results from its use are sure to be more satisfactory than when home-made Bordeaux made of inferior raw materialsis used. Bordeaux Mixture is used principally for vegetablespraying at the rate of 6 to 8 pounds to 50 rate of 6 to 8 po

g-W Bordeaux Mixture is put up in 1 pound glass jars, $5,12 \frac{1}{2}, 25$ and 100 pound steel packages.

\section{S-W PARIS GREEN.}

For years this green has been the standard for effectiveness, safety and enconomy. It contains the maximum amount of arsenic in combination with copper, and the minimum of uncombined arsenic, therefore, it kills the insects quickly, butdoes not blight the foliage. Usually 4 to 6 ounces to 50 gallons of water will be satisfactory.

Put up in $1 / 2$ and 1 pound cartons.

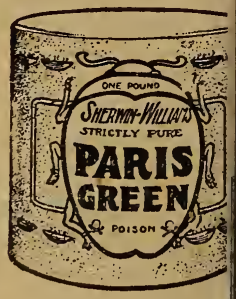

\section{S-W PRUNING COMPOUND.}

This is an oil paint having a heavy body, which dries on the cut with a rubbery, elastic film. Its covering capacity and special preservative qualities make it more adaptable than tar or white lead. Apply with a flat instrument or stiff brush.

$P u t u p$ in quarts and gallons.

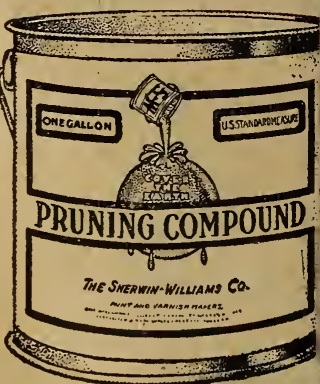

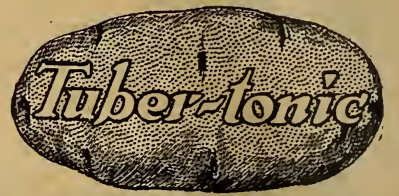

THE COMBINATION POTATO SPRAY.

This material is a three-in-one spray for potatoes, desigr to kill leaf-eating insects, prevent and eradicate blight and : as an indirect tonic to the plant. It has the quick killing tion of Paris Green, the adhesiveness of arsenate of lead a the fungous preventive qualities of Bordeaux Mixture. H ing desirable adhesive qualities, it will remain on the folis indefinitely, making future sprayings necessary only to prot the new foliage as it develops.

"Tuber-tonic" prolongs the growing season of the potatoat a timewhen every day means bigger crops.

"Tuber-tonic". will prove most economical to the farmer who has in the past sprayed with Bordeaux Mixture to which has been added either arsenate of lead or Paris arsenate of lead or Paris ureen. For from 4 to 6 pounds to 50 gallons of water.

50 "gallons of water. in one pound glass jars, 5 10,25 and 100 pound stee drums.

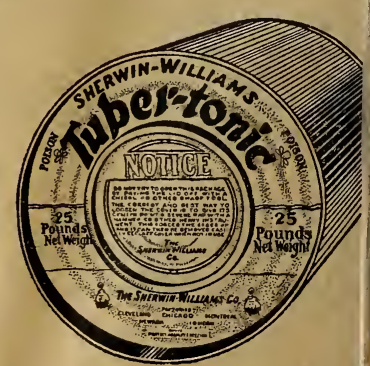




\section{Sterlingworth Whale 0il Soap and Tobacco}

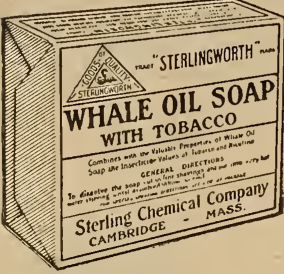

Is a compound of fish oils, $t$ he efficiency of which is greatly increased by the addit i o $n$ of tobacco extractive matter. Is a most effective, reliable and cheap remedy for destroying San Jose scale, oyster shell scale, plant lice, and all sucking insects on trees, shrubs, plants, vines, rose bushes, etc. It is put up in tightly sealed boxes, which conserves the strength of the soap almost indefinitely. Directions for use on every package. Price, 1 lb. box, 20 cts.

\section{STERLINGWORTH WEFD KILLER.}

Sterlingworth Wood Killer is a most satisfactory and powerful weed killer compounded especially for use on walks, drives, tennis courts, golf links, etc. It is a dry powder to be dissolved in water. When applied to vegetation it completely destroys all kinds of weeds, grass and other objectionable vegetable growths. It may be applied with an ordinary watering can. One gallon covers three to four square yards.

Price, 1 lb. package (makes 15 gals.), 50 cts

\section{TO DESTROY APHIS, THRIPS, ETC.} WITHOUT INJURY TO FOLIAGE, SPRAY WITH

"BLACK LEAF 40," SULPHATE OF NICOTINE.

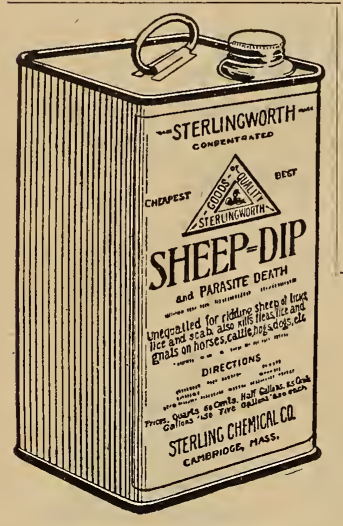

"Black Leaf 40" is highly recommended by experiment stations and sprayin experts throughout the entire United States. Owing to the large dilution, neithe foliage nor fruit is stained. Also "Black Leaf 40 " is perfectly soluble in water-nc clogging of nozzles.

Price: 10 Ib. ean, $\$ 12.50$ (makes 1,600 to 2,000 gallons for spraying pea) thrips and hop louse, with addition of 2 per cent. distillate oil emulsion; or 1,00( gallons for spraying green and wooly aphis, with addition of three or four pound: of any good laundry soap to each 100 gallons of water); 2 1b. can, \$3.00; 1-s 1b. ean, 85 ets.

\section{"STERLINGWORTH” SHEEP DIP.}

A highly-concentrated, non-poisonous liquid for sheep-washing pur. poses-killing ticks and lice, curing scab and promoting the growth of wool anc flesh. Used also for cattle, horses, pigs, fowls, dogs, etc. A protector of sows seed from birds, slugs and "smut." Does not require heating nor any preparationsimply add cold water and it is ready for use. Easily applied and always effective Price: 1Iqt. can, 50 cents; 2 qt. can, 75 cents; per gal., $\$ 1.40$.

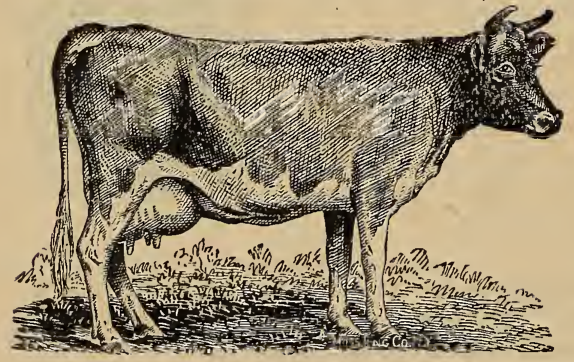

By spraying your cows with Lewis' Lice and Fly Destroyer. Allows cows to feed in peace, making more milk and consequent]y more money. Keeps cows in good condition and saves many times its cost in extra milk.

\section{INCREASE THE EGG PRODUCTION}

By using Lewis' Lice and Fly Destroyer. It is the best thing on the market, and will actually kill body lice on fowls and animals. Keeps your poultry houses and barns free from all lice, mites, flies; and insects.

Price: 1 qt., 35 cents; 2 qt., 60 cents; 1 gal., $\$ 1.00$.
Price, per gallon, 75 cents.

\section{INCREASE THE FLOW OF MILK}




\section{SPRAYERS AND POWDER GUNS.}

For Spraying all Insecticides on Potato Vines. Shrubs. Small Trees. House Plants. Live Stock and Poultry.

A Great Labor Saver on the Farm and in every Garden, Barn, Greenhouse, Orchard and Hennery.

Will apply the finest possible spray on any object desired, and exterminate any kind of insect life.

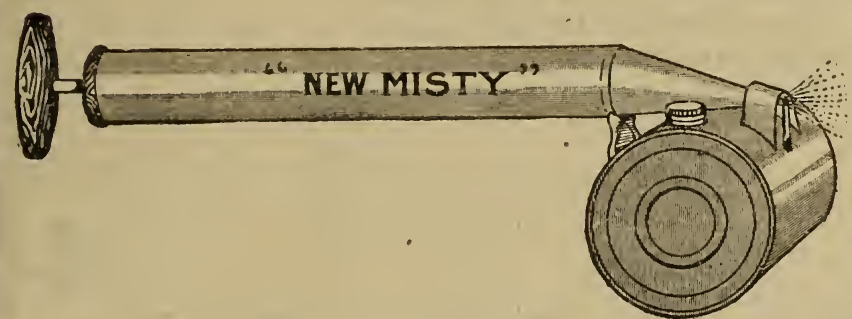

"New Misty", Tin, 40c.

"Rapid", Double Tube,

Galvanized Iron, 50c.

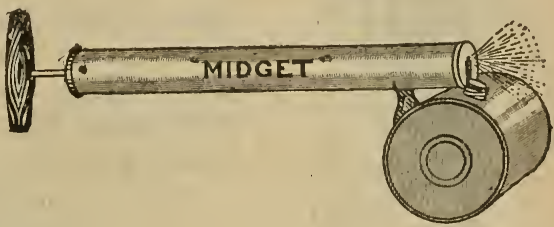

A size made to fill the need for small sprayer for household requirements.

"Midget", Tin, 25c.

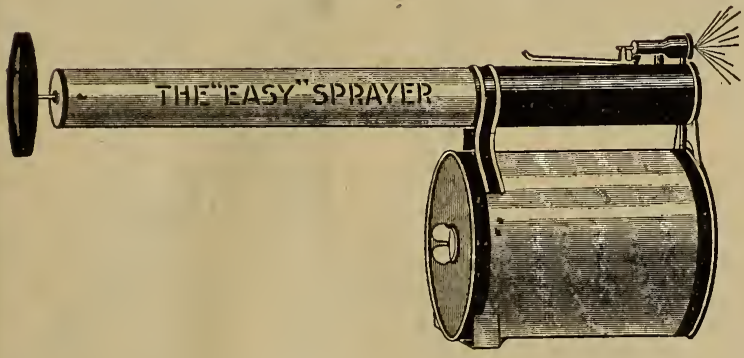

\section{THE "EASY" COMPRESSED AIR SPRAYER.}

Made of heavy galvanized steel throughout, with sufficient capacity for one gallon of liquid. Has a powerful pump with which pressure can be maintained by an occasional stroke as the liquid is being discharged.

Price, $\$ 2.00$.

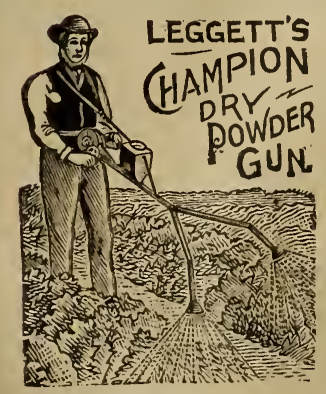

LEGGETT'S CHAMPION DRY POWDER GUN.

Will cover two rows of potatoes at once, as fast as a man walks. Adjustable to any width of row. Distributes Paris green, hellebore, sulphur, lime, "f u ng i r o i d", tobacco dust, etc.

Price, \$8.00.

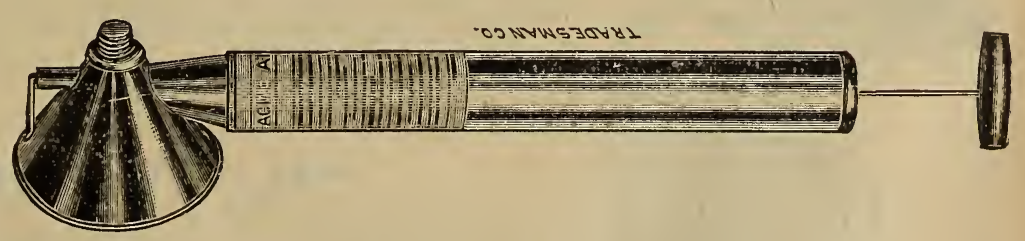

Acme, Tin, 40c.

Canteen, Brass, $75 \mathrm{c}$.

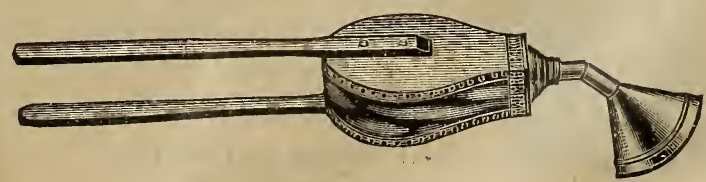

Acme Powder Gun, 75c. 


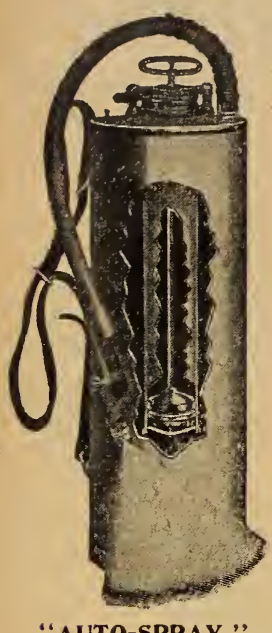

\section{“AUTO-SPRAY."}

A practical compressed air sprayer, indispensable in the fullest variety for spraying shrubs, growing crops, greenhouses, etc. The pump is of large capacity, and the pumpings of eight or twelve strokes of the plunger will charge the tank and deliver the solution under high pressure. Capacity of tank, three gallons of solution. Furnished in" brass or galvanized steel. Style with auto-pop recommended.

\section{PRICES.}

Auto-Spray No. 1A. Brass tank (with stop-cock), . . - • \$6.75 Auto-Spray No. 1B. Brass tank (with auto-pop), • • . 7.25 Auto-Spray No. 1C. Galvanized tank (with stop-cock), • $\quad$ - 4.50 Auto-Spray No. 1D. Galvanized tank (with auto-pop), • $\quad$ - 5.00 2-ft. Brass Extension, Brass Elbow,

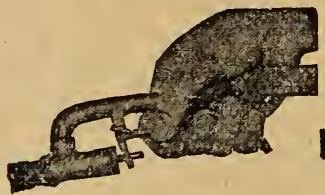

AUTO=POP.

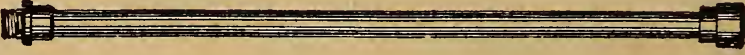

AUTO EXTENSION.

\section{“PERFECTION" SPRAYER.}

Built on the best lines, of high grade material and with the idea of turning out a spray which has none of the faults and defects so common in many Knapsack sprayers heretofore on the market.

The tanks are made of heavier metal than has ever been used in sprayers of this kind, are lock seamed at the corners to convex heads of metal two guages heavier than the sides, a single seam runs lengthwise of the tank. This seam is reinforced by rivets, making the tank practically unbreakable. The pump is $13 / 4$ inch seamless brass tubing with a brass valve, and is sealed into the top of the tank with heavy threads, following the construction used in the best makes of fire extinguishers. The pump rod is $5-16$ inch and is fitted with leather and special metal expanders.

The hose is attached to the sprayer at an angle, so that it will not kink and become cracked and broken. The shoulder strap is attached with snaps and can be quickly and easily removed. The hose is $3 / 8$-inch 5-ply cloth inserted and is equipped with automatic shut-off nozzle.

This sprayer will handle whitewash, water paints, Bordeaux mixtures, etc., perfectly.

For whitewash and all heavy mixtures it is necessary to use a " $\mathrm{W}$.

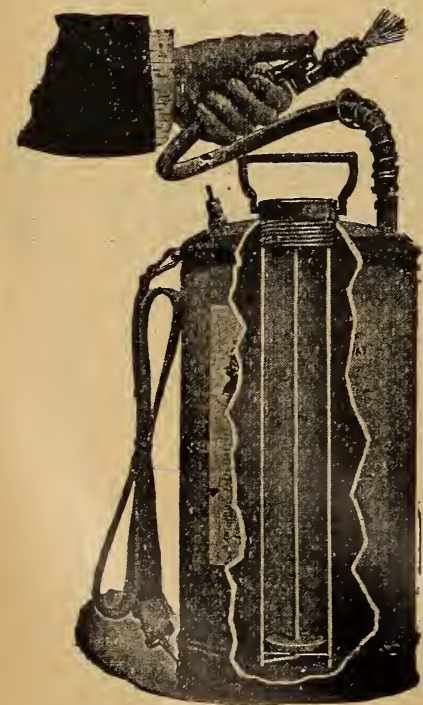

"KANT=KLOG." Style G. W." cap in nozzle, which is furnished with sprayers.

These sprayers are made in galvanized steel or brass as ordered. Weight, 9 pounds empty. All sprayers tested to 60 pounds before leaving factory.

Price, galvanized steel, $\$ 5.00$; all brass, \$7.50.

\section{“KANT-KLOG."}

Sprayer body is made of heavy polished brass or galvanized steel, as desired. Top and bottom are dome shaped, joined to body under heavy pressure, making a complete double seam. The body is supported and further strengthened by a heavy steel band around the bottom.

Price of Style G, with galvanized steel body, brass air pump,

hose, escape valve, "Kant-Klog" nozzle, spring shut-off and car-

rier strap,

Pollshed Brass Body, with same attachments, . . . .

$\$ 4.00$

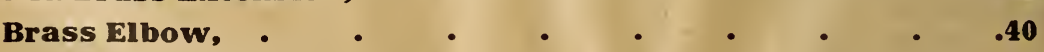




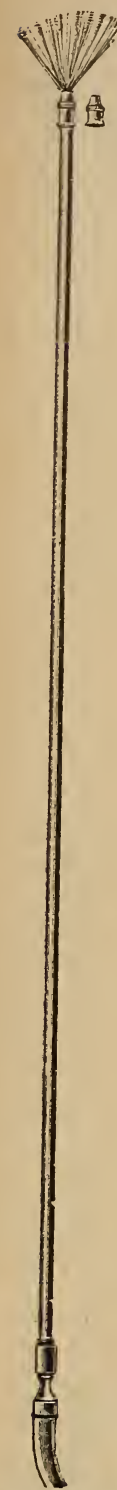

$8=$ ft. Pipe Extension 40c.

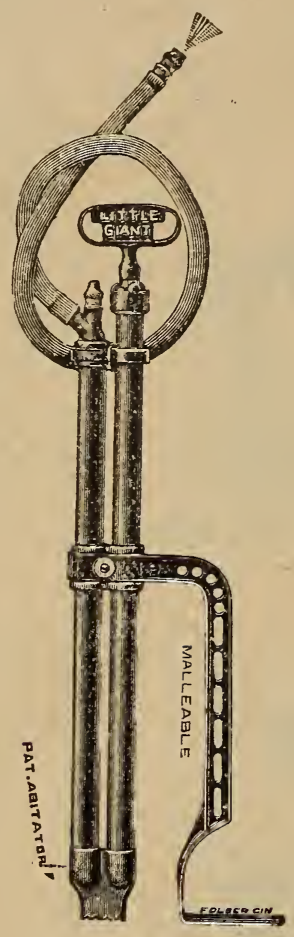

No. 327 1-2.

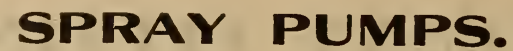

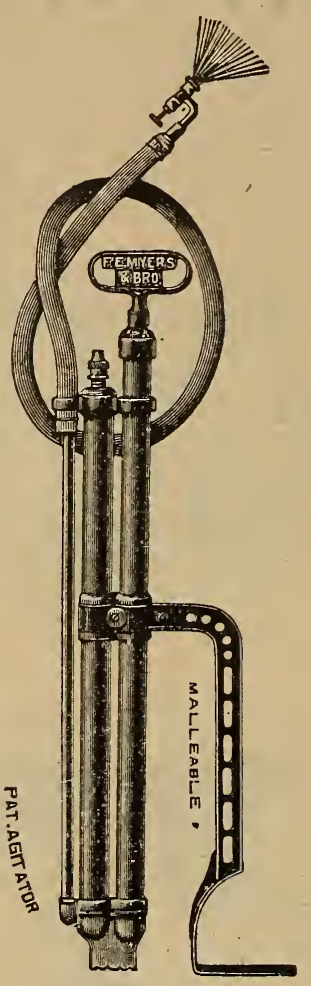

No. 325.

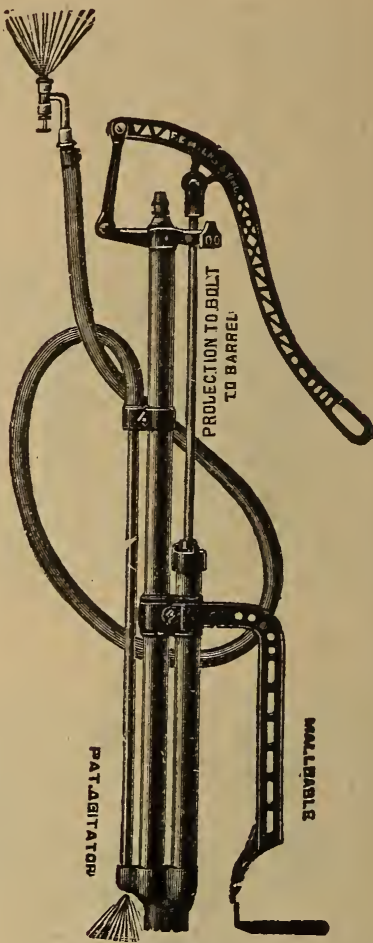

No. 324.

No. 327 1-2. Myers Little Giant Brass Spray Pump, with agitator, complete with hose and Imperial combination fine and coarse spray and solid stream nozzle. Price, \$2.75.

No. 325. Myers Imperial Brass Spray Pump with agitator, complete with hose and graduating Vermorel fine and coarse spray and solid stream nozzle and malleable foot rest. Price, \$3.25.

No. 324. Myers Lever Brass Spra yPump, with agitator, complete with and bose graduating Vermorel fine and coarse spray and solid stream nozzle. Price, \$4.00.

Price, fitted with Bordeaux nozzle for spraying whitewash, 65c. additional.

\section{"MODOC" BUCKET PUMP.}

All brass except the foot piece and handle. The cylinder, or barrel, is very large and is made of heavy seamless brass tubing. The plunger is hol-

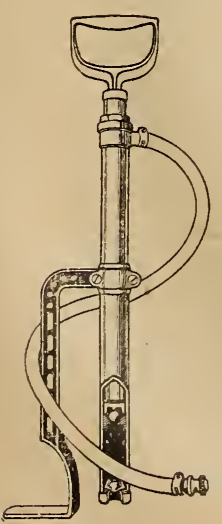
low, thus forming an air chamber which insures a steady flow of liquid. The valves are bronze balls. The foot piece holds the pump firmly in the bucket or pail in just the proper position for work. The pump is equipped with 3 feet $\frac{1}{2}$-inch spray hose attached with clamps.

Price, each, \$3.50.

\section{THE STANDARD SPRAY PUMP. "THE BEST AND MOST POWERFUL LOW. PRICED SPRAYING APPARATUS ON THE MARKET TO-DAY:"}

For Spraying Orchards, Gardens, Vineyards. Whitereashing. Disinfecting Chicken Houses, etc.

MADE ENTIRELY OF BRASS.

With two solid brass ball valves.

No leather suckers or washers.

No castings to rust.

No leaking joints.

Nothing to get out of order.

PRICE, \$4.OO. 


\section{SPRAY PUMPS.}

No. R318B. A spray pump of a construction that is the very best in all its parts, being self-contained and ready for operation, when bolted to the barrel, and is so made that it may be attached to the end or the side of the barrel, working equally well in either position.

Has bronze ball valves and brass seats; the plunger, cylinder, and discharge pipe are all brass. The air chamber is 30 inches, in length, enabling the pump to throw a powerful, uniform, constant and elastic spray. Equipped with 15 feet of best quality rubber hose.

Price (without barrel),

$\$ 9.00$

Myers O. K. The handle is wrought steel, with adjustable stroke, so as to enable the operator to get up a pressure of $200 \mathrm{lbs}$, or more if necessary. It is fitted for two leads of discharge hose.

Price (without hose or barrel), but with graduat-

ing spray nozzles, and couplings, $\$ 13.50$ Superior lose, per foot,

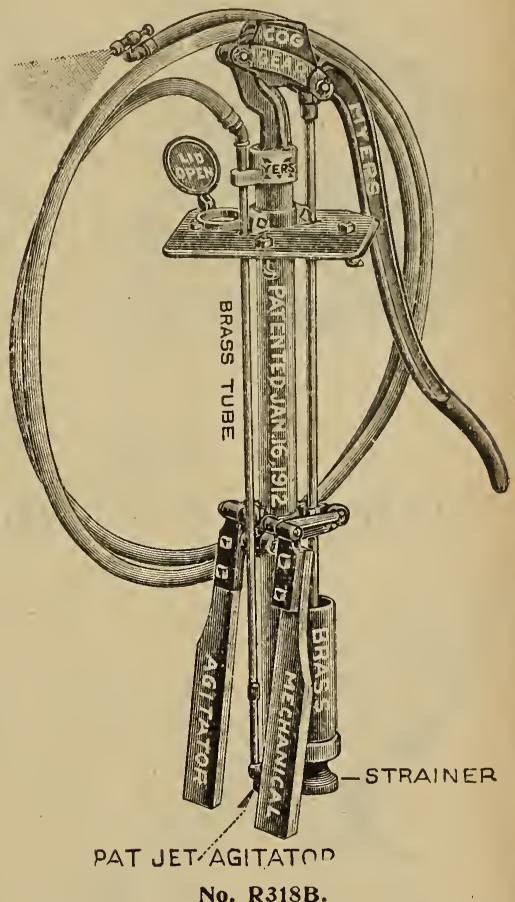

No. 329. Whitewash, Cold Water Painting Machine and General Purpose Sprayer, with patent double agitator, a most complete and serviceable outfit. The tank is made of heavy galvanized iron with a wide bottom, so as to set steady in operation. The cover is removable, is held securely in

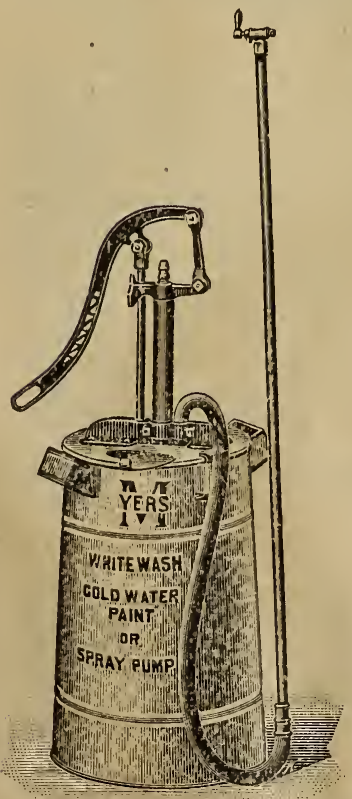

No. 329. place by two spring wire catches, one on each side, which holds the cover tight and prevents any spilling or splashing of the liquid. Holds 7 gallons and is fitted with Bordeaux nozzle, brass ball valves, and has both jet and dasher agitator.

\section{Price, \$7.50.}

No. 330. Myers Knapsack Spray Pump, fitted with 5 feet of $\frac{1}{2}$-inch lose, pipe extension and Bordeaux or graduating Vermorel spray nozzle, which can be graduated from a fine mist spray to a solid stream, or shut off entirely.

\section{Price, \$5. 75 .}

No. 331. Myers Perfect Knapsack Spray Pump, made with Copper Tank. Complete with hose, stop-cock, pipe extension and Bordeaux or graduating Vermorel nozzle.

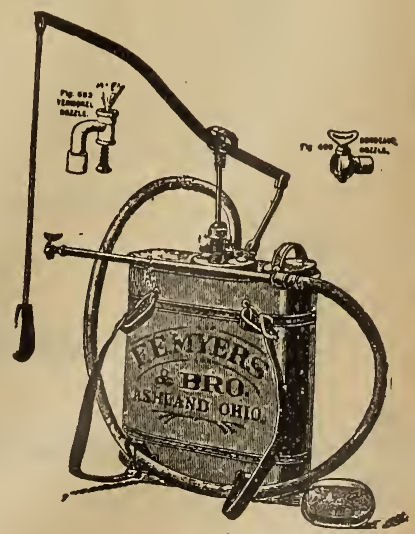

Myers Knapsack Spray Pump. 


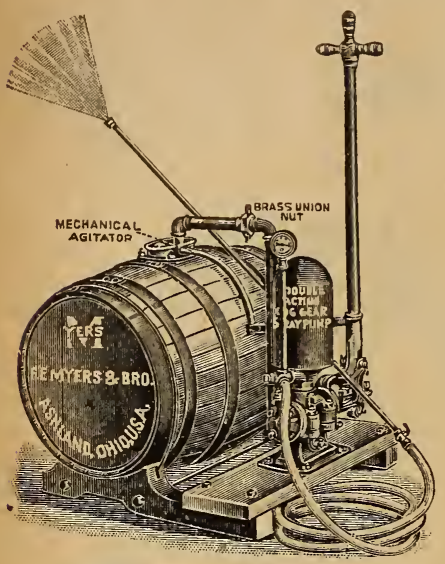

No. $\mathbf{R 3 1 6 B}$

\section{The Myers, Double Acting Cog Gear, Complete Spray Pump Outfit.}

Mounted on Skids with 50 Gallon Barrel and Mechanical Agitator.

With brass valves and ground bevel brass seats, 2-inch seamless brass removable cylinder, hemp packed plunger.

SPECIAL FEA TURES: Cog gear movement, increased leverage adapted for spraying under heavy pressure, mounted complete, occupying smallest possible space. Capacity sufficient for eight nozzles; well adapted for spraying potatoes.

Pump complete, 50 gallon barrel mounted on skids, with pressure gauge; one 15 foot lead, $\frac{1}{2}$-inch, 7-ply discharge bose, one Fembro nozzle, one 8-foot pipe extension with lever shut-off and mechanical agitator.

Price, complete, $\$ 25.00$.

MYERS 0. K. COG GEAR SPRAY PUMP.

\section{THE}

"JASIMIN" CONTROLLER.

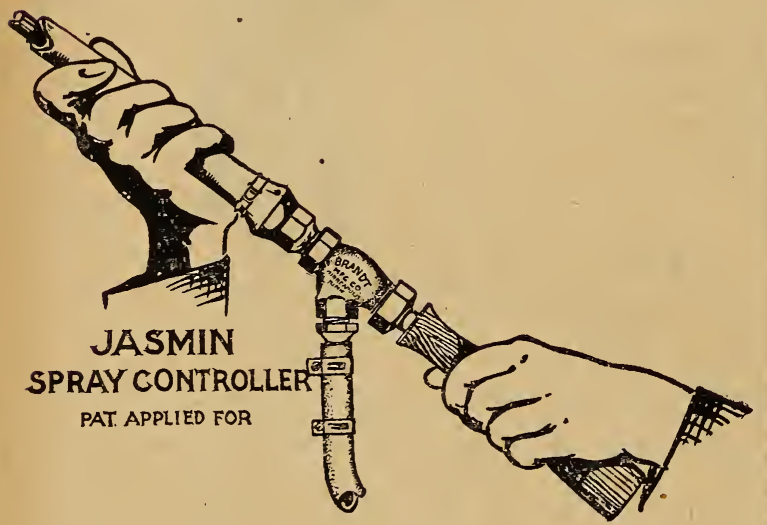

A new way of controlling the flow of the liquid through bamboo poles, iron pipes and extensions of every sort used with spraying pumps and outfits. It attaches to end of pole in place of the old stop-cock. The hose attaches at an angle of 45 degrees and is not liable to bend and break as with the old forms of connection. The flow of liquid is controlled by a onequarter turn of the wood handle. When using it, the. operator does not have to take his eyes off of his work, but shuts off the flow of liquid instantly when spraying is finished, thus saving the cost of the controller inany times over. Made of brass, fits $\frac{1}{4}$-inch pipe.

Price, \$1.25.

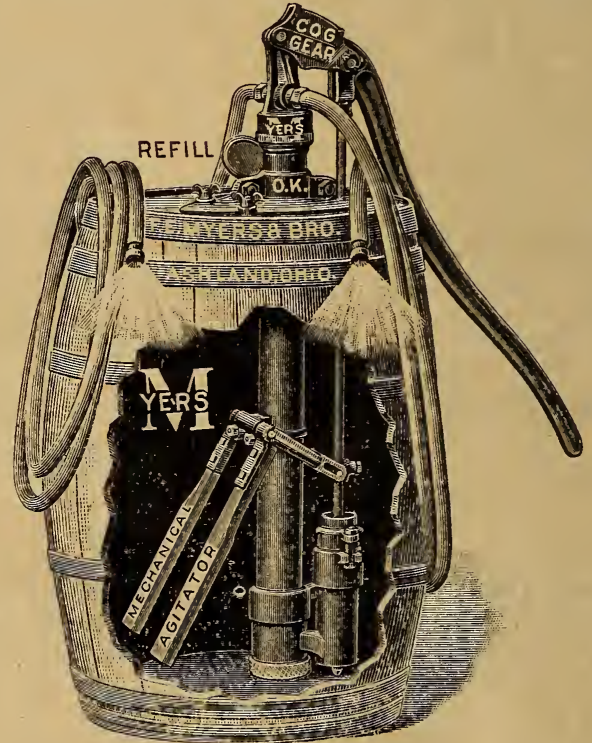

No. R308B

The cog gear increases the leverage $25 \%$ over the ordinary plain handle. The special features are the cog gear, the malleable iron base, which is adjustable and is made for end or side of barrel; base for end of barrel is furnished regularly. If pump is wanted for side of barrel it must be so stated on order. The plunger is a solid brass tube with closed end, is outside packed, with hemp packing. The packing gland is adjusted by two bolts. The valve and seat are hard brass. The air chamber is $2 \frac{1}{2}$-inch. This in connection with the $\operatorname{cog}$ gear enables the operator to carry a pressure of 200 or more pounds, if necessary. Has one lead of 15 feet $\frac{1}{2}$-inch hose and one Fembro nozzle.

Price, complete, $\$ \mathbf{1 6 . 0 0}$.

\section{BAMBOO EXTENSION.}
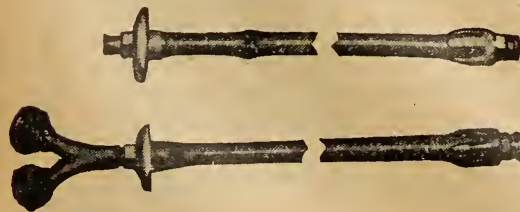

Consists of a non-corrosive tube mounted inside a bamboo rod. It is strongly reinforced where the shut-off is attached to the tube to prevent breakage when dragging the hose. The tube is ${ }_{4}^{1}$-inch inside diameter, and is fitted with a brass stop-cock with 1 -inch female pipe thread. The other end of extension is fitted for brass coupling, $\frac{1}{4}$-inch male pipe thread to fit the nozzle.

Price, 8 ft., $\$ 2.25\}$ complete with shut-off and drip shield. 


\section{“KING” PUMPS AND OUTFITS.}

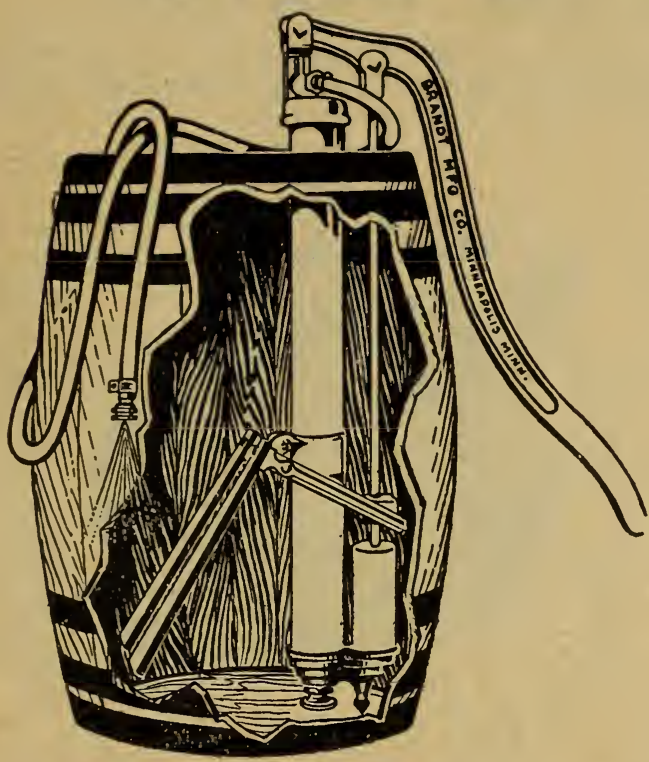

These pumps are built in two sizes, and are so arranged that they may be mounted in any barrel and can be adjusted to varying hejghts. They have extremely large air chambers, which insure a uniform pressure at the nozzle, large cylinders which give great capacity, and removable ball valves which enable the user to keep pump in good working condition without taking it a part. These pumps have self-oiling plungers and are constructed so that the packing may be tightened without taking the plunger out of the cylinder. The packing is specially prepared and will withstand the action of spraying chemicals longer than any other material and can be replaced in a few minutes at a nominal cost. No. 5 has 2 -in. cylinder, $2 \frac{1}{2}$-in. air chamber and fastens to end of barrel. No. 6 has $2-1 / 2$ in. cylinder and 3 -in. air chamber and fastens to end of barrel. Nos. 5 and 6 have door castings to cover filling hole, which make it unnecessary to cut more than one hole in the barrel head. The head castings carry a pattern for cutting the opening in barrel. These pumps have the twin type mechanical agitator, made of hard wood, extra long with adjustable stroke, so that it can be used in any form of tank or barrel.

No. 5̆"King" Pump, with 1 o feet pressure hose, 8 feet pipe, brass shut-off cock, nozzle, hose clamps, etc.

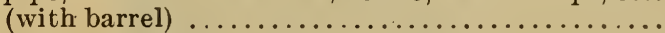

No, 6 "King" Pump, with one lead of 15 feet pressure hose, 8 feet pipe, brass shut-off cock, nozzle, hose, clamps, etc. (with barrel) ..................

\section{GOULDS HAND FORCE PUMPS.}

When large quantities of water must be pumped, as for watering cattle, etc., a pump such as the Goulds "Stock" Pump, is used This pump is made to deliver large quantities of water and is built extra strong.

When it is necessary to force the water to a higher level than the spout or to have it delivered with considerable force for washing wagons, sprinkling the garden, etc., it is necessary to use a force pump such as Goulds "Star" Force Pump.

When a constant even stream is desired, one of Goulds double-acting "Empire" Pumps is used. This pump has two cylinders and delivers water on both the up and down strokes, giving a steady flow at the spout.

For deep well service the pumps are similar to those shown except that the cylinder is lowered within 15 feet or less of the water and preferably below the water level. Heavier construction is also used when the pumps operate over very deep wells.

Goulds "New Alert" Double-Acting Force Pump, for forcing water into a tank. This pump will lift and force the water 100 to 150 feet above the level of the supply. The lever is long and in a vertical position, making it easy to operate the pump.

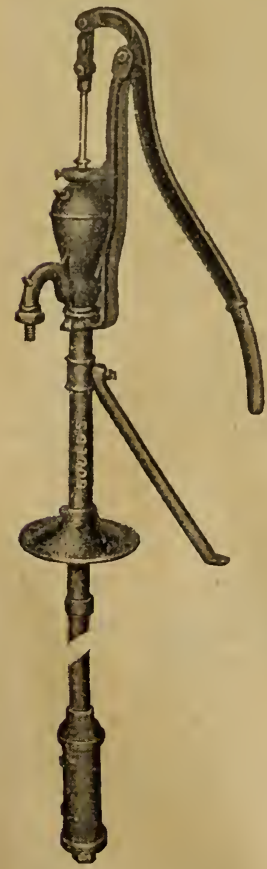

"Star" Force Pump.

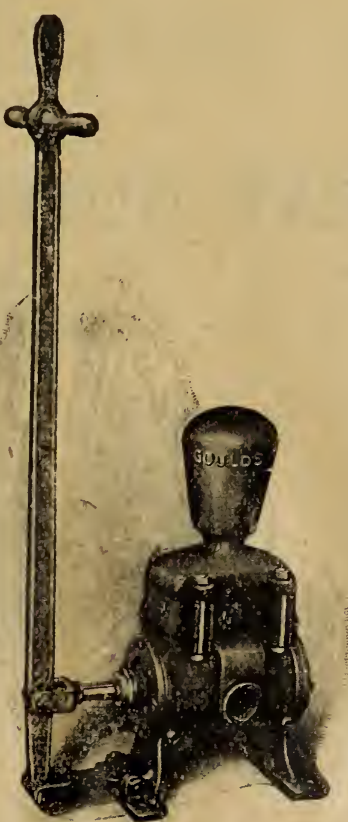

"New Alert" Double Acting Air and Water Force Pump.

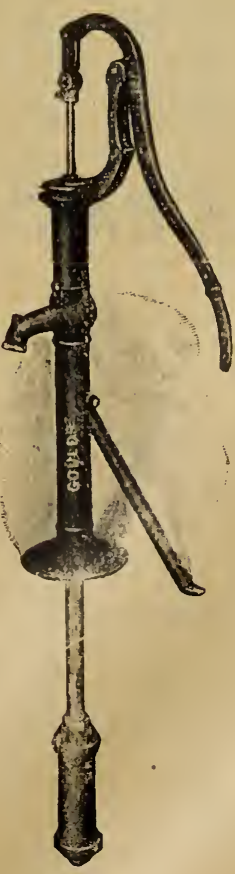

"Stock" Pump.

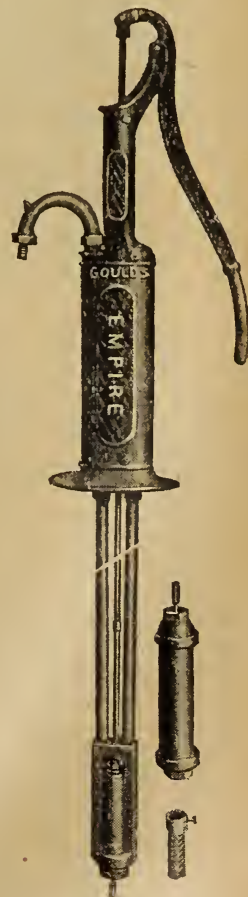

"Empire" Double= Acting Force Pump. 


\section{EUREKA COMPRESSED AIR SPRAYERS.}

We wish to call attention to the advantages found in an outfit with a large air chamber and pressure guage, as it permits the user to spray for ten or twelve minutes without pumping, thus enabling one man to spray without a helper, while the pressure guage indicates to the user the power behind the spray.

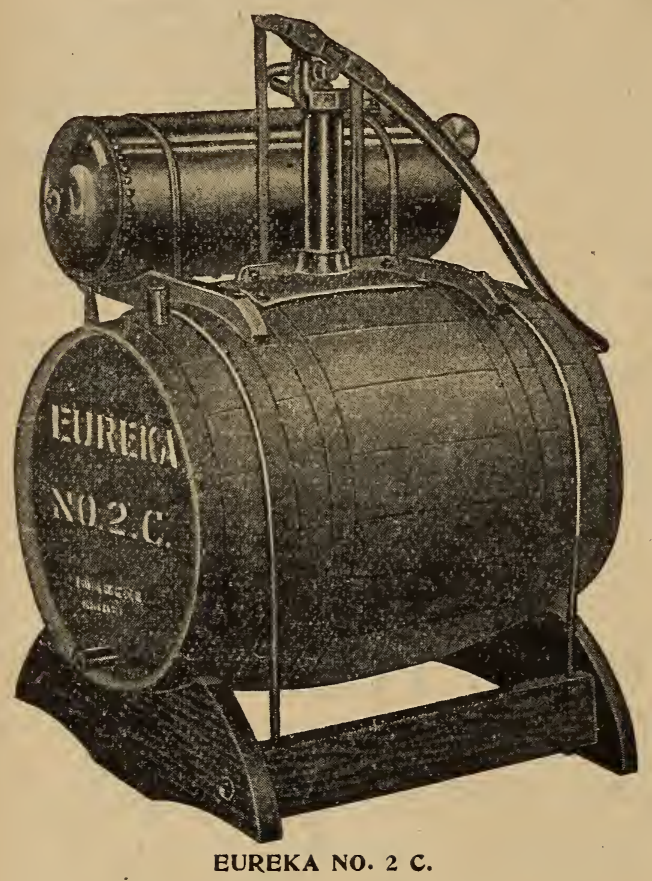

No. $2 \mathrm{C}$ consists of the No. 5 pump and 50 gallon barrel placed on cradles so as to ride easily on a wagón. Is complete with 15 feet hose, one 8-ft. iron extension, nozzle and pressure guage.

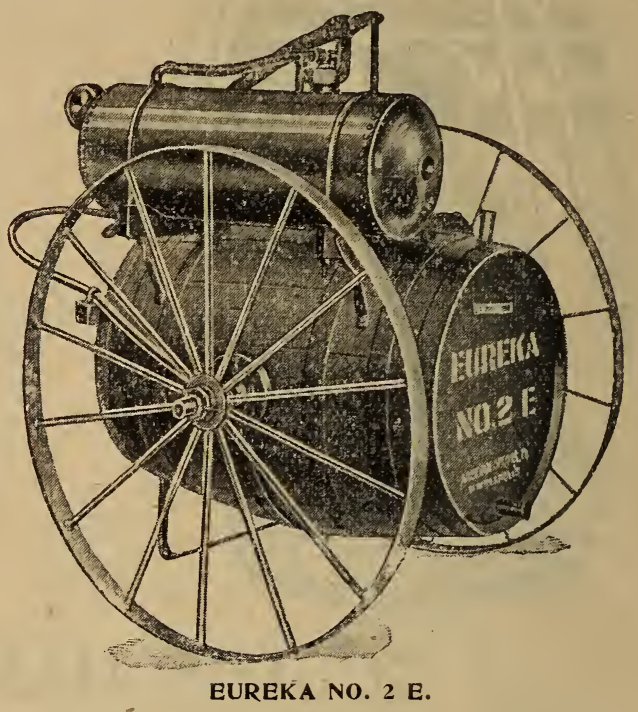

No. 2 E consists of the No. 4 pump and 50 gallon barrel mounted on wheels. Complete with 15 feet hose, one s-ft. iron extension, nozzle and pressure gauge.

Price, \$27.00.

Similar in construction to No. 2 E, excepting that it is equipped with thills for horse.

Price, \$25.00.

Price, \$30.00.

\section{"IDEAL" SPRAY OUTFIT.}

This outfit is light, compact and easy to operate. The tank holds fifteen gallons, is mounted so that the liquid will not slop or spill, and in a way that makes it easy to handle. The pump spreads across the top of the tank and is held firmly in place by a thumb nut. It has the largest air chamber of any spray pump of corresponding size. This enables the operator to keep a uniform pressure at the nozzle.

The pump barrel is $13 / 4$ inches in diameter, 7 inches in length. The plunger is made of brass and is selfoiling. The packing is cotton wick, which will resist the action of the chemicals used for spraying and can be tightened without removing from the pump. The valves are bronze balls $5 / 8$ of an inch in diameter, which allows free passage of the liquids and prevents clogging. Both valves are removable. The pump handle is of

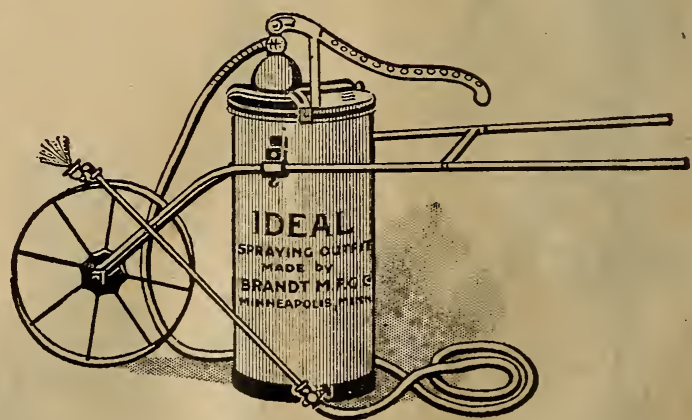
iron. It is extra lorig and a pressure of one hundred and fifty pounds can be easily maintained.

A mechanical agitator keeps the liquids well stirred. A fine strainer at the opening in the suction pipe prevents anything getting into the working parts of the pump. The pump has the following equipment: 10 feet $3 / 8$-inch pressure hose. 8 feet pipe extension, in 2 pieces.

1 "Ideal" nozzle.

1 brass shut-off cock.

Shipping weight, crated, 60 pounds. 


\section{GOULDS}

\section{"POMONA" BARREL PUMP, NO. 1100.}

\section{Outside Packed Plungers}

No Leather Packings.

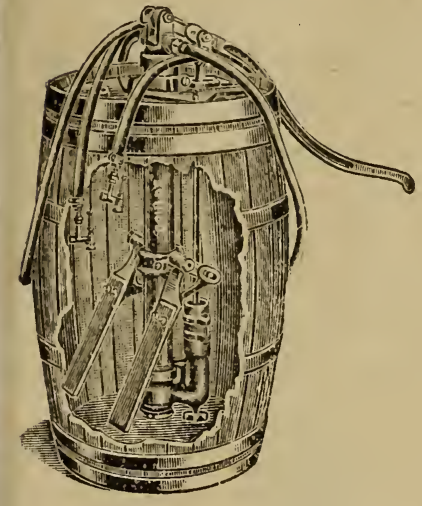

For small orchards of a few trees a good barrel pump will meet every requirement, and the "Pomona" is offered as one of the most satisfactory pumps of this kind.

It is usually powerful, fully capable of supplying one lead of hose, 15 feet, and one angle nozzle. The working parts, including the plunger, plunger connection, gland, valve, valve seats and strainer, are of solid bronze. They are simple, accessible and easily removed. The pump has a steel air chamber, extending from the top of the sprayer to the valve chamber, making it easy to produce sufficient pressure to continue spraying for some time after the pumping has stopped. It is equipped with a long adjustable lever, producing three, four or five inch strokes by simply removing and replacing a single bolt, thus varying the pump's capacity. The pump may be placed in any length barrel, as the barrel plate is adjustable. It is held firmly in place by this plate and a small anchor at the bottom of the barrel. The agitator is simple, but very effective, operated by the same lever that works the sprayer.

Price, complete, \$12.00.

“POMONA" PUMP PARTS.

PRICES.

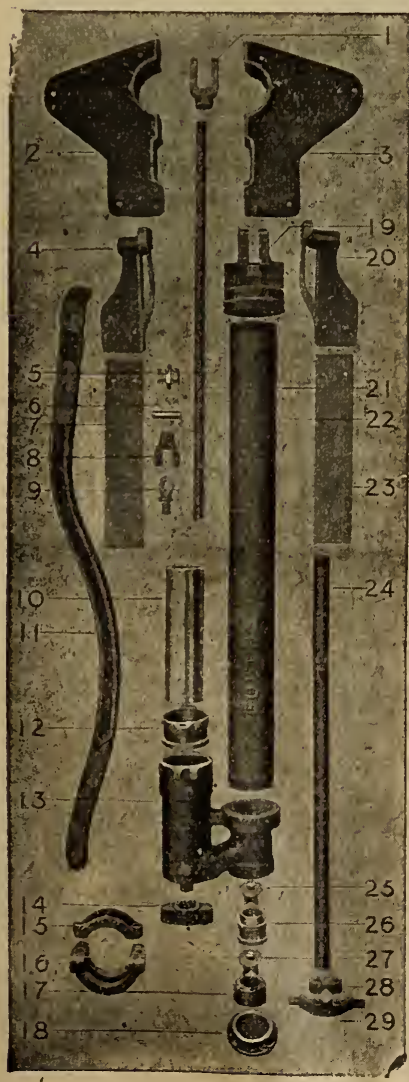

" 9 ,

" 10 ,

"، 11 ,

"6 12

"6 13 ,

"، 14 ,

"6, 15 ,

"6 16 ,

" 17,

"6 18 ,

"6 19 ,

" 20 ,

" 21 ,

" 22 ,

" 23 ,

"6 24 ,

" 25 ,

"6 26 ,

: 27 ,

، 28 ,

6 29 ,

\section{FIELD CROP ATTACHMENT.} Spraying Potatoes with a Goulds "Pomona" Sprayer and Field Crop Attachment.

Fig. 1, $\$ 1.25$

" $2, \quad .75$

"6 $3, \quad .75$

"6 $4, \quad .75$

$\because \quad 5, \quad .35$

"6 $6, \quad .15$

“. $7, \quad .15$

" $8, \quad .75$
.50

5.50

1.25

1.75

2.25

.25

.20

.40

1.25

1.00

.75

.75

.30

2.25

.15

.40

.35

.75

.35

.30

.20
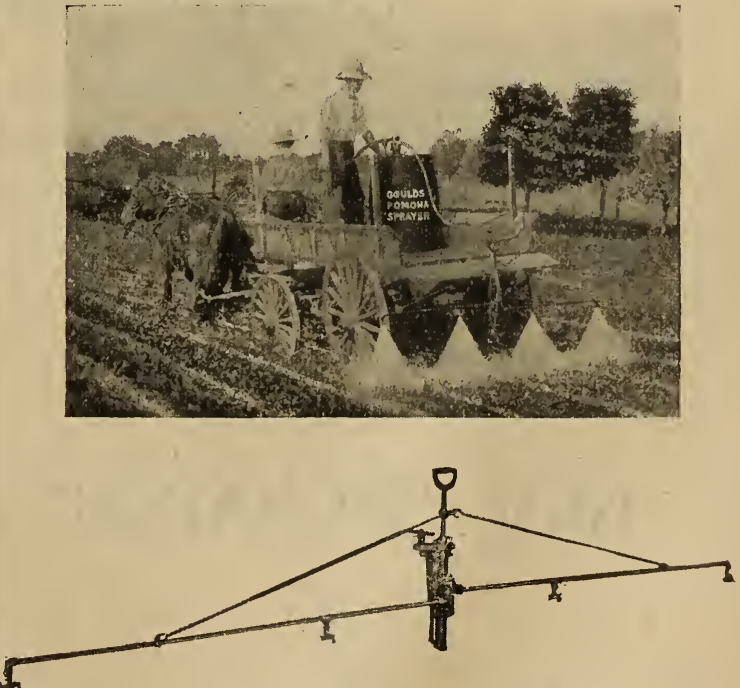

For field crop spraying we offer an attachment which will meet every need. These outfits are arranged for attachment to the rear end of a wagon, as shown in the illustration. One through bolt and two strong iron clamps secure the outfit to the wagon.

The discharge hose from the sprayer, located in the wagon, is connected to a threaded opening of the fixture. For distributing the spray, two iron pipes are connected to the attachment by a folding joint. These pipes contain two, three or more nozzles each. The pipes are beld in a horizontal position by iron rods which are attached to the handle of the fixture. By means of this handle the entire outfit is raised or lowered as desired. 


\section{GOULDS “FRUITALL” BARREL PUMP,NO. 1188.}

\section{A GOOD LOW-PRICED SPRAYER.}

There is a large demand for a high-grade barrel sprayer, somewhat

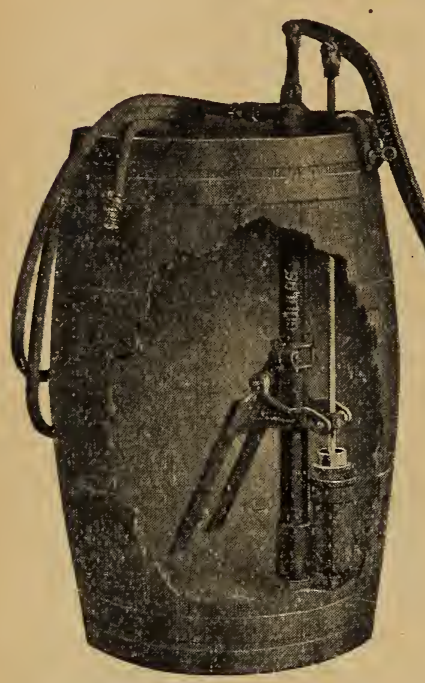
lower in price than the "Pomona". To meet this demand the "Fruital" sprayer was developed.

The "Fruitall" is extremely sinple in design, of smaller capacity and lighter in weight than the "Pomona". However, in every respect it is a thoroughly serviceable and reliable sprayer. It has one lead of hose, 15 feet, and one nozzle. All working parts, including plunger, gland, valves, valve seats and strainer, are of bronze. The air chamber is large. The lever is long, making it easy to operate the pump and produce high pressure. The plunger is packed from the outside; so it is not necessary to take the entire pump apart to repack it. . A wing agitator is used similar to that used with the "Pomona".

The pump is fitted for mounting on the end of the barrel only, where it is held in place by an adjustable clamp which fits over the end of a stave. It is also anchored to the bottom of the barrel.

Price, complete, $\$ 13.50$.

\section{GOULDS BARREL CART.}

BARREL CART. - This cart is so constructed that any barrel can be picked up and held in place by a hoop which encircles the barrel. It is designed for mounting our barrel sprayers and will also be found useful for handling extra barrels of spray mixture, etc. The wheels are strong and have wide tires.

Price, \$9.50.

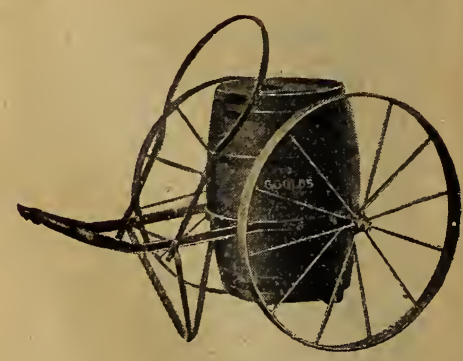

\section{NEW “MONARCH” SPRAYER, NO. 1610.}

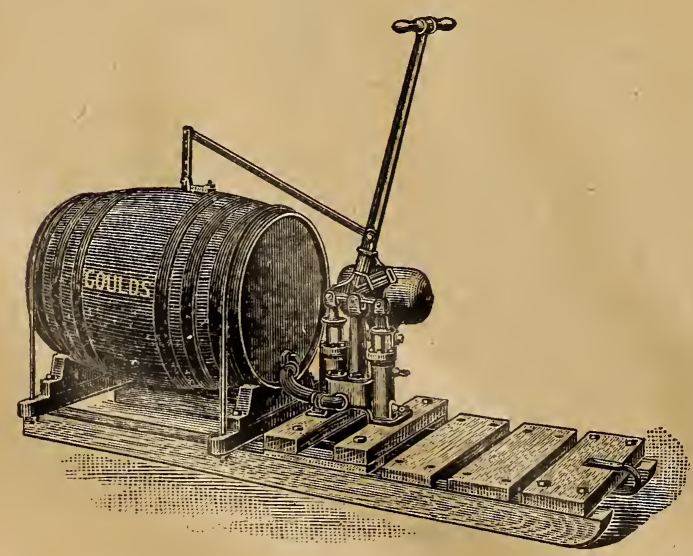

The new "Monarch" outfit is a barrel sprayer for service where the fruit grower needs a hand sprayer of larger capacity than the ordinary barrel sprayer. It consists of the "Monarch" two cylinder pump, mounted on skids with the barrel.

The barrel is provided with an agitator, which is operated by a lever connected to the pump lever. In addition to the barrel and pump, the skids carry a platform upon which the operator stands. A ring is also attached at the front for connection to the whiffletree.

The outfit is furnished complete with pump, barrel, agitator, connection between pump and barrel, and skids

Price, \$36.50. 


\section{DIRECT CONNECTED PUMPING OUTFIT.}

\section{SELF CONTAINED GASOLINE ENGINE AND GOULDS PYRAMID DOUBLE ACTING PUMP.}

No vibration and perfect alignment at all times.

\section{TABLE OF VARIOUS COMBINATIONS.}

$\begin{array}{lccrcc}\begin{array}{c}\text { Engine } \\ \text { Horse-power. }\end{array} & \begin{array}{c}\text { Pump } \\ \text { Diameter. }\end{array} & \begin{array}{c}\text { Pump } \\ \text { Stroke. }\end{array} & \begin{array}{c}\text { Gallons } \\ \text { per minute. }\end{array} & \begin{array}{c}\text { Suction } \\ \text { Inches. }\end{array} & \begin{array}{c}\text { Discharge } \\ \text { Inches. }\end{array} \\ \begin{array}{l}11 / 2 \text { to } 31 / 2 \\ 2 \text { to } 31 / 2\end{array} & 3 & 5 & 8 \text { to } 15 & 11 / 2 & 11 / 2 \\ 21 / 2 \text { to } 31 / 2 & 5 & 5 & 15 \text { to } 30 & 2 & 2 \\ 31 / 2 \text { to } 61 / 2 & 6 & 5 & 20 \text { to } 30 & 21 / 2 & 21 / 2 \\ 61 / 2 \text { to } 9 & 6 & 12 & 50 \text { to } 70 & 3 & 3 \\ \end{array}$

The power required for these outfits depends upon the capacity and pressure desired.
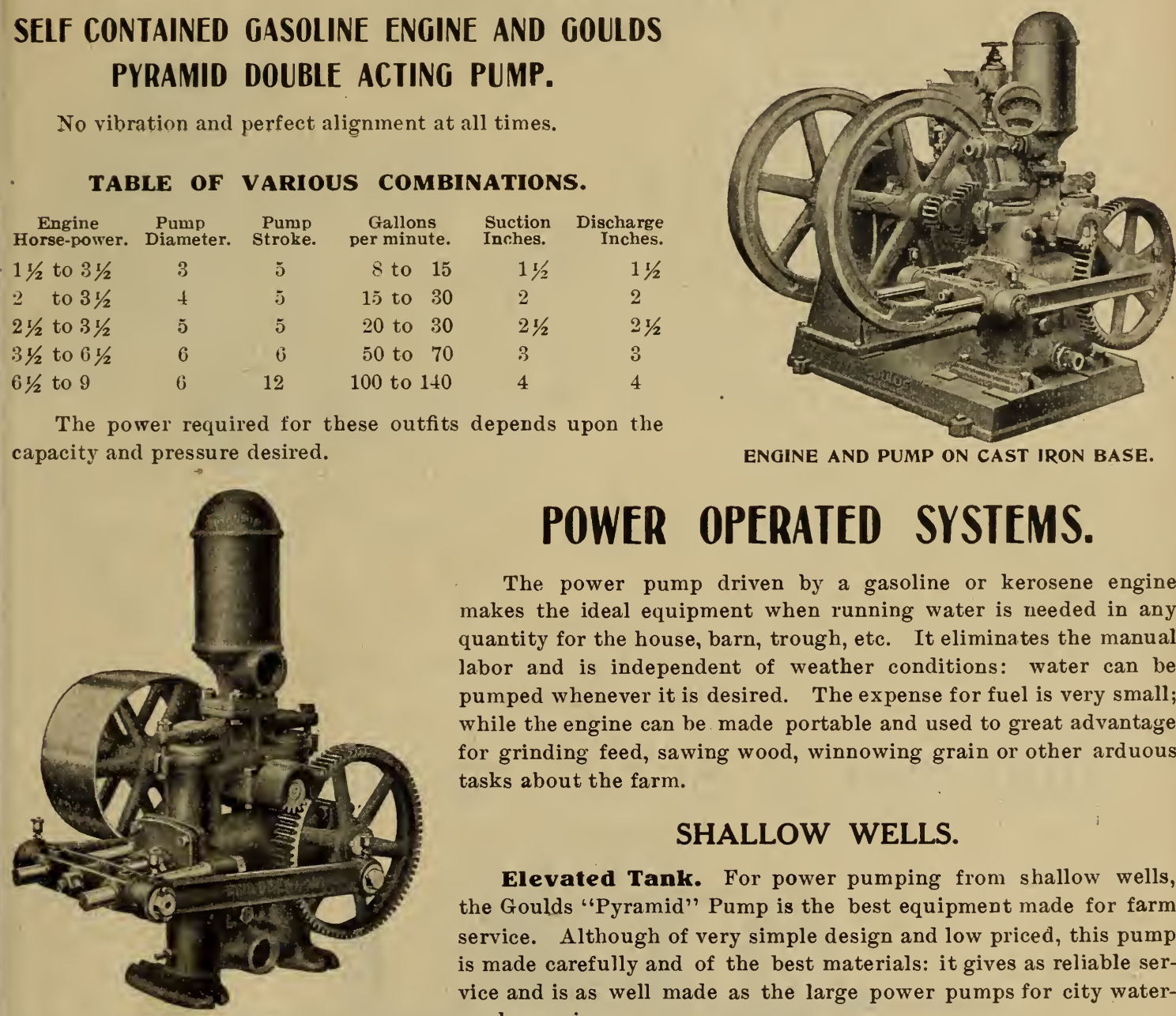

\section{POWER OPERAIED SYSTEMS.}

The power pump driven by a gasoline or kerosene engine makes the ideal equipment when running water is needed in any quantity for the house, barn, trough, etc. It eliminates the manual labor and is independent of weather conditions: water can be pumped whenever it is desired. The expense for fuel is very small; while the engine can be made portable and used to great advantage for grinding feed, sawing wood, winnowing grain or other arduous tasks about the farm.

\section{SHALLOW WELLS.}

Elevated Tank. For power pumping from shallow wells, the Goulds "Pyramid" Pump is the best equipment made for farm service. Although of very simple design and low priced, this pump is made carefully and of the best materials: it gives as reliable service and is as well made as the large power pumps for city waterworks service.

\begin{tabular}{|c|c|c|c|c|c|c|c|c|c|}
\hline \multicolumn{2}{|c|}{ Pistons. } & \multirow{2}{*}{$\begin{array}{c}\text { Capacity. } \\
\text { One Rev. } \\
\text { of Crank } \\
\text { Shaft. }\end{array}$} & \multirow{2}{*}{\multicolumn{2}{|c|}{$\begin{array}{l}\text { Usual Speed and } \\
\text { Capacity per Minute. }\end{array}$}} & \multirow{2}{*}{$\begin{array}{c}\text { For } \\
\text { Elevation } \\
\text { to }\end{array}$} & \multicolumn{2}{|c|}{ Size of Pipe. } & \multirow{2}{*}{$\begin{array}{l}\text { Approximate } \\
\text { Weight, Lbs. } \\
\end{array}$} & \multirow{2}{*}{$\begin{array}{c}\text { Tight and } \\
\text { Loose } \\
\text { Pulleys. }\end{array}$} \\
\hline Diameter. & Stroke. & & & & & Suction. & Discharge. & & \\
\hline $\begin{array}{l}3 \text { inch. } \\
4 \\
5 \\
6 \\
6\end{array}$ & $\begin{array}{r}5 \text { inch. } \\
5 \\
5 \\
6 \\
6 \\
12\end{array}$ & $\begin{array}{c}.31 \text { gals. } \\
.54 \\
.85 \\
1.47 \\
2.94\end{array}$ & $\begin{array}{l}40 \text { revs., } \\
40 \text { “. } \\
40 \\
40 \\
40\end{array}$ & $\begin{array}{r}12.4 \text { gals. } \\
21.6 \\
34.0 \\
58.0 \\
116.0\end{array}$ & $\begin{array}{l}175 \text { ft. } \\
175 \\
175 \\
175 \\
175\end{array}$ & $\begin{array}{ll}1 \frac{1}{1} / 2 & \text { inch. } \\
2 & . \\
21 / 2 & . \\
3 & . \\
4 & \end{array}$ & $\begin{array}{ll}11 / 2 & \text { inch. } \\
2 & \ldots \\
21 / 2 & 0 \\
3 & . \\
4 & \end{array}$ & $\begin{array}{l}280 \\
325 \\
500 \\
645 \\
875\end{array}$ & $\begin{array}{ll}15 \times 21 / 2 & \text { inch. } \\
15 \times 3 & \because . \\
16 \times 4 & \because \\
20 \times 4 & . \\
26 \times 4\end{array}$ \\
\hline
\end{tabular}

Price on application.

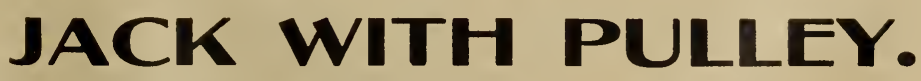

Jack, equipped with pulley for belt connection to the engine. The illustration shows it connected by gear. The rocker arm of the pump acts as a connecting rod between the pump and jack.

The jack consists of a strong box frame, carrrying two shafts, one with gear and the other with a pinion. The gear is provided with bolt holes for the connecting rod. The pinion shaft is extended for the pulley, sprocket or gear connecting to the engine.

Grease cups are provided for lubrication. The bearings are babbitted.

The gear ratio is 5 to 1 and the base dimensions are $7 \frac{1}{8} \times 10_{4}^{1}$ inches.

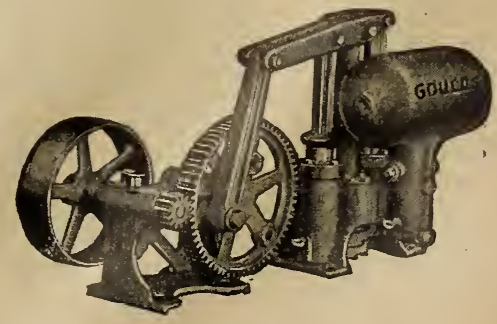




\section{"WILL-SPRAY."}

No. 20.

The solution tank is made of clear cypress, holding 100 gallons. It is provided with a brass strainer, and a plug is placed under the tank for cleaning or emptying same. The entire piping is of brass and the machine is equipped with a 200-pound pressure gauge and safety valve. The pump being double acting, the stroke is constant and there is no pounding or uneven use of power. The potato attachment is made of brass.

This machine is designed for handling Bordeaux, Paris green, lime-sulphur, sulphate of iron and copper, or any other solution, and the mechanical agitator is driven by an eccentric always in operation when the machine is moving, which keeps the solution thoroughly mixed.

"Will-Spray," No. 16. Similar in construction to No. 20, except that it has two double action pumps, one on each side of the machine. All its parts are made to correspond with its pumping capacity, making it the strongest, the most powerful two-wheel traction sprayer ever brought out. The machine is piped throughout with brass pipe, and is fitted with pressure gauge and relief valve, and has a 150 gallon solution tank.

Price on application.

\section{LIITLE GIANT NO. 28 FIELD AND POTATO SPRAYER.}

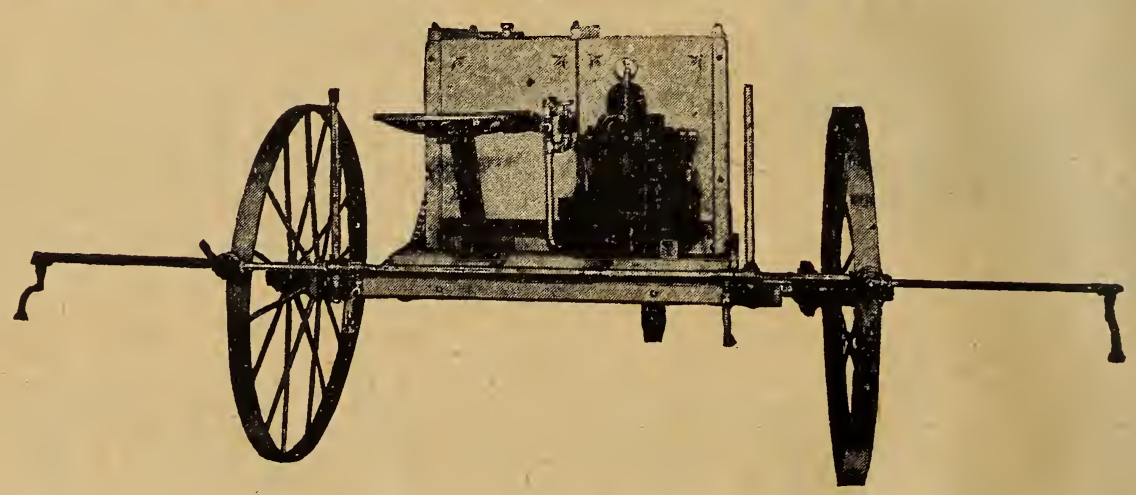

This 75 gallon Tank Sprayer can be equipped with either four or six row attachment for spraying.

Its width permits it to pass between two rows, leaving proper space between row and nozzles for the spray to become most effective. Equipped with vertical spraying attachment, every part of the vine from ground to a height of seven feet or more may be drenched with spray. For spraying potatoes, a five-row spraying attachment is provided, spraying a large acreage in the shortest possible time.

The pump is so situated in the machine that dirt will not fall into the working parts and cause trouble.

Has 44-inch steel wheels, 21/2-inch tire. Axle 15/8-inch cold rolled steel.

The wheels are of wrought steel and are so arranged that they will fit either side, and the machine can be made to track any width from three to six feet as ordered. The mechanical agitator is driven by a little sprocket always in operation when the machine is moving and keeps the solution thoroughly mixed. The solution tank is made of clear heart cypress, and will outlast the barrel or steel tank commonly used. It is provided with a galvanized strainer in the filler opening, and a plug is placed under the tank for cleaning or emptying same. The entire piping is brass and the machine is equipped with a 200-pound pressure gauge and safety valve. The pump being double acting, the stroke is constant and there is no pounding or uneven use of power. This machine is tested at 200 pounds pressure before it leaves the factory. The usual potato attachment is made of brass. We can furnish extra long neck yoke and double tree and extra long axle, which can be arranged for different width rows. Pole is convertible, viz., can be spread and used for shafts when it is desired to use one horse. 


\section{DEYO POWER SPRAYERS.}

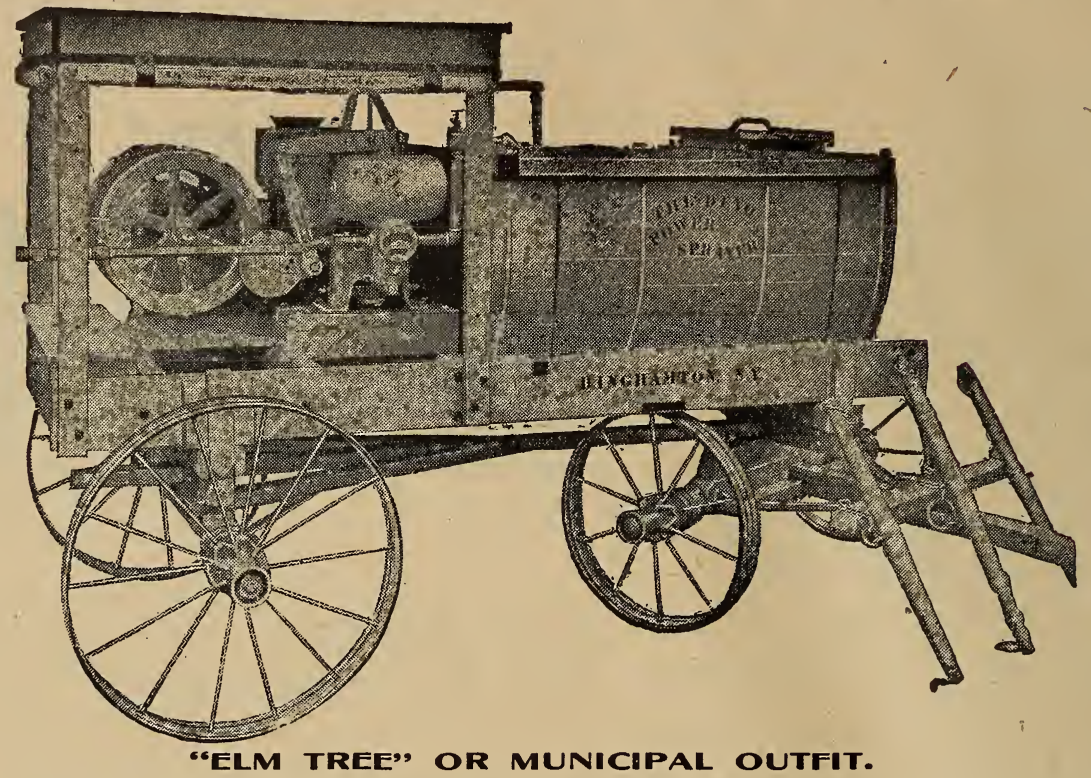

The Goulds "Invincible" Duplex Spray pump, a large capacity, high pressure power pump for service in covering large territory. It will give pressures of 200 to 400 pounds, and, at a speed of 50 revolutions per minute, has a capacity of 9 gallons per minute. At a speed of 65 revolutions per minute, it has a capacity of 12 gallons per minute.

Regular equipment includes the following : DEYO $3 \frac{1}{2}$ horse-power hopper cooled, gasoline engine, completely equipped with pulley, battery box, tool box, and full set of tools, lubricating oil and cup grease; Goulds two-cylinder spray pump connected to engine and mechanical agitator; ten foot lead of 1-inch suction hose, fitted with strainer ; two 25 -foot leads of special $\frac{3}{8}$-inch discharge hose fitted with connections for attaching to pump and extensions; two shut-offs for discharge ; one pressure guage ; one water relief valve ; two 8-foot -inch back extension rods, fitted with stopcocks, Y's and four nozzles; 200-gallon cypress tank with mechanical agitator.

All of the above equipment is connected complete and mounted on platform with cab over engine, and curtains to protect the engine and pump. Price on application.

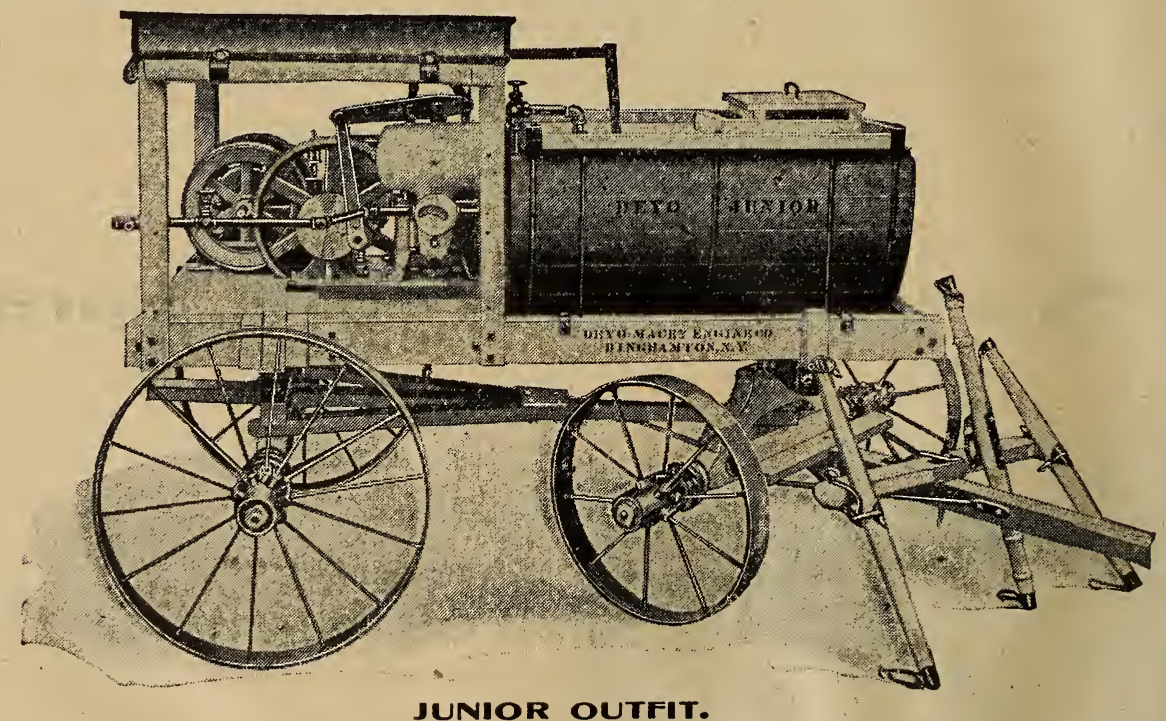

This cut shows the latest DEYO SPRAYER, which has been designed especially to meet the demand for a small, light power sprayer at a reasonable figure. The engine used is the Deyo $1_{2}^{\frac{1}{2}}$ horse-power hopper jacket horizontal engine, gear connected to Goulds two-cylinder pump. While the outfit is smaller and lighter in every way the same grade of material and workmanship is used as on the "Elm Tree" outfit. We especially recommend this outfit for use in very sandy soil and in small orchards which do not warrant the purchase of the "Elm Tree.

Price on application. 


\section{DEYO POWER SPRAYERS_continued.}

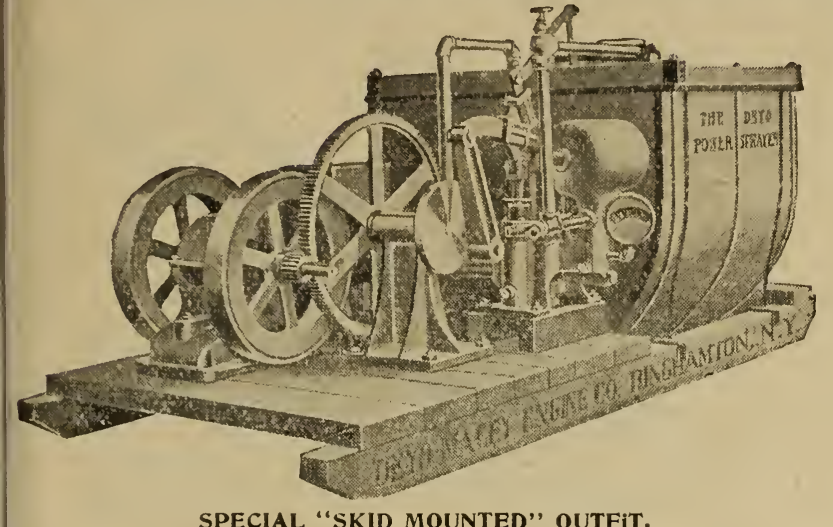

Constructed in every way as is

the "Junior", excepting that it is "skid mounted". An outfit quite popular, as it combines working qualities with the lowest price possible.

\section{Price on application.}

SPECIAL "SKID MOUNTED" OUTFiT.

\section{THE MYERS POWER SPRAY OUTFIT.}

\section{CAN BE FITTED WITH EITHER DUPLEX OR HORIZONTAL PUMPS. GEAR, BELT OR PITMAN DRIVEN.}

Is furnished complete, with the exception of the engine. The entire framework is made of chanuel and angle iron, making a very stiff frame with the least possible weight. It is fitted with a wrought steel bed plate on which the engine and pump are mounted, thus making a solid foundation which will not vibrate when under the most extrem e pressure. The tank is made of selected cypress, holds 200 gallons, has four hoops. is fitted with a rotary agitator with wooden blades. The agitator is driven by a link chain, which makes a flexible joint and relieves the tank from all strain. There are no pipe connections between the pump and the tank. The pipes extend upward from the pump and enter the tank from the top, thus preventing all twisting strains which cause leaks. The two cross channel bars underneath the frame fit the

bolsters of wagon, preventing forward or backward movement. The inside measurements of the cab afford coom for any size engine up to $2 \frac{1}{2}$ horse power. The cab lias sliding doors for protection of the engine and pump. The sills are placed 26 inches apart, which permits a short turn of the wagon. The guard rails on the top are to protect the operator from falling off. The rig can be furnished without these guard rails if required.

\section{Be Sure to State on Order the R. P. M. of Engine, Diameter of Crank Shait and Size of Key.} All of Above Equipped as Follows.

One 50-foot lead of $\frac{1}{2}$-inch 7 -ply hose.

One 10 -foot lead of $\frac{1}{2}$-inch 7 -ply hose.

Ten feet wire bound suction hose.

Two 10 -foot bamboo pipe extensions complete with lever shut-off.

Four Fembro nozzles, two 45 degrees, two straightaway.
Three Fig. $1560 \mathrm{Y}$ 's.

Rotary agitator.

Cut-offs for discharge lines.

Relief valve.

Pressure gauge and strainer. 


\section{"IRON AGE" GARDEN IMPLEMENTS.}

No. 4. "Iron Age" Combined Double and Single Wheel Hoe and Drill Seeder.

Remarkable for the variety of work it will accomplish, as it is very similar to the No. 6, excepting the opening plow and hill-dropping device. It does not place the seed in hills, but in continuous rows, and this feature makes it more desirable to some, as they do not wish to place the seed in hills, but prefer the saving in price. It can be used as a double or single wheel hoe, cultivator, rake or plow. Price (complete), \$11.00.

No. 5. "aron Age." As a drill seeder only. Price, $\$ \mathbf{\$ 8 0}$.

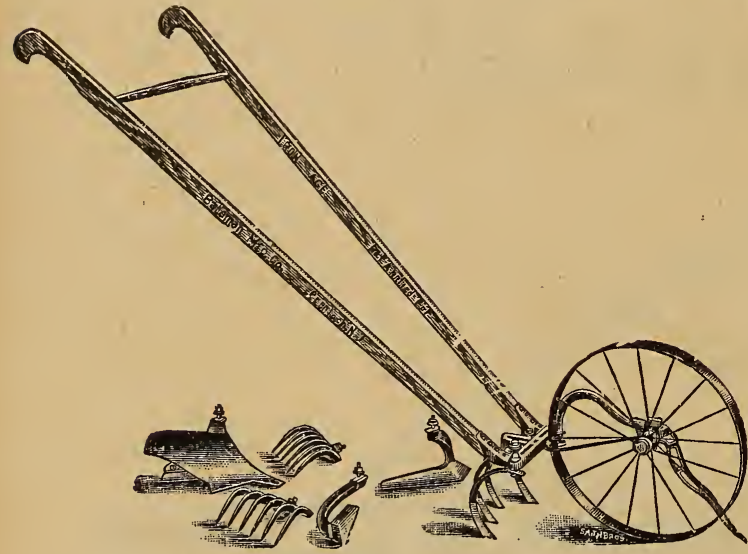

No. 9.

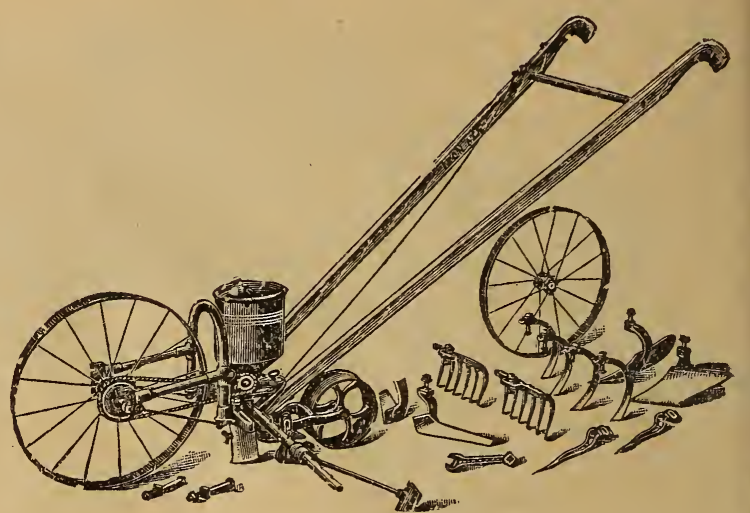

No. 4 .

\section{No. 9. "Iron Age" Single Wheel Hoe.}

Is especially suitable for narrow rows, is light, strong, and for work done is very similar to No. 20. A weeder attachment for killing small weeds and pulverizing the soil may also be added. Price, $\$ 5.25$.

\section{No. 10. "Iron Age."}

Same as No. 9, with hoes only. Price, \$3.25.

\section{No. 8. "Iron Age" Hill and Drill Seeder.}

This tool is very desirable for the market gardener who prefers an implement for a seeder only. It is simple, light, strong and capacious. The hopper holds four quarts. All small seeds are accurately placed in hills, $4,6,8,12$ or 24 inches apart, or in continuous rows. Price, \$11.00.

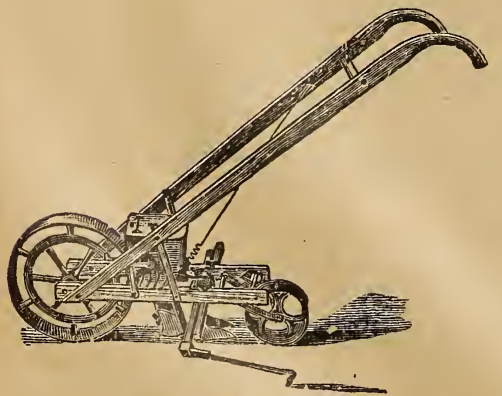

\section{New Model Seed Drill.}

This drill has been in use many years, and is well known to give perfect satisfaction. It has a large, broad-tired wheel, perfect and reliable index, a cut-off to stop the flow of seed when desired, and is very valuable and complete. Price, $\$ \mathbf{8 . 0 0}$. 


\section{“IRON AGE" GARDEN IMPLEMENTS_-Continued.}

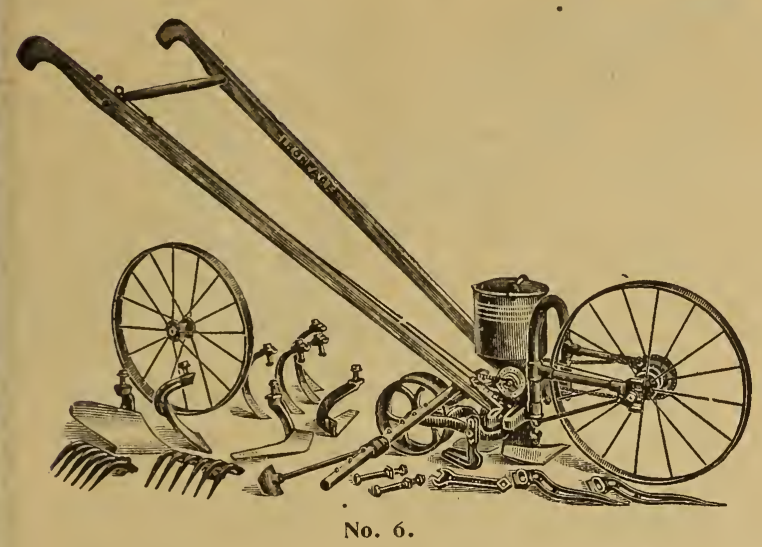

No. 6. "Iron Age" Combined Double and Single Wheel Hoe, Hill and Drill Seeder.

Ten tools in one, and each as satisfactory as a tool made for the special purpose. Places the seed in continuous rows or in hills, $4,6,8,12$ or 24 inches apart. Can be quickly changed to a double or single wheel hoe, cultivator, rake or plow. Price (complete), $\$ 12.00$.

\section{No. 15. "Gron Age" Combined Single} Wheel Hoe, Hill and Drill Seeder.

Very similar to the No. 6 above excepting it has only the single wheel. Price (complete), \$11.00.

No. 12. "Iron Age."

Complete, excepting the hill-dropping, device. Price, $\$ 10.00$.

No. 16. "Iron Age."

As a hill and drill seeder only. Price, \$\$8.50.

\section{No. 18. "Iron"Age.""}

As a drill seeder for continuous rows only. Price, \$Z.50.
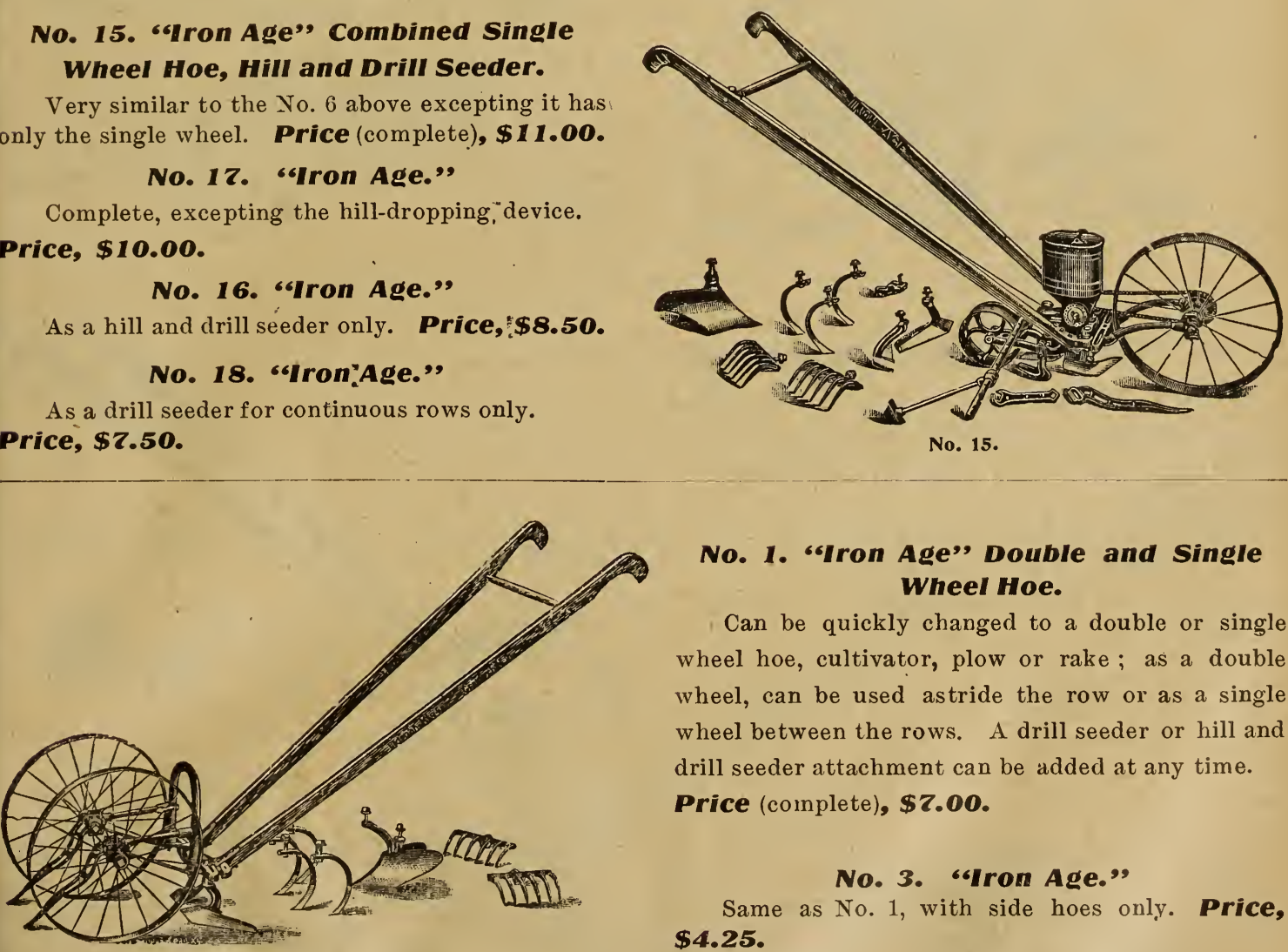

\section{No. 1. "Iron Age" Double and Single Wheel Hoe.}

Can be quickly changed to a double or single wheel hoe, cultivator, plow or rake; as a double wheel, can be used astride the row or as a single wheel between the rows. A drill seeder or hill and drill seeder attachment can be added at any time.

Price (coinplete), \$Z.00.

No. 3. "Iron Age."

Same as No. 1, with side hoes only. Price, $\$ 4.25$.

No. 22. "Iron Age" Combined Fertilizer Distributer, Hill and Drill Seeder.

Applies the fertilizer in connection with the seed, just where it will do its most efficient work. It is perfectly simple, light of draft, strong, and perfection in the quality of work done. The method of sowing fertilizer and seed, or of sowing the fertilizer alone, is ideal. Price, \$18.00. 


\section{"IRON AGE" GARDEN IMPLEMENTS-Continued.}

\section{No. 12. "Iron Age" Wheel Plow and Cultivator.}

Remarkable for its exceeding lightness, combined with great strength, the low price and variety of work it will accomplish. Will do all the work of a kitchen garden, as plowing, hoeing, raking and cultivating, and is especially suitable for those desiring such a variety of tools for a small amount. Price (complete), \$3.50.

No. 11. "aron Age."

As a wheel plow only. Price, \$2.50.

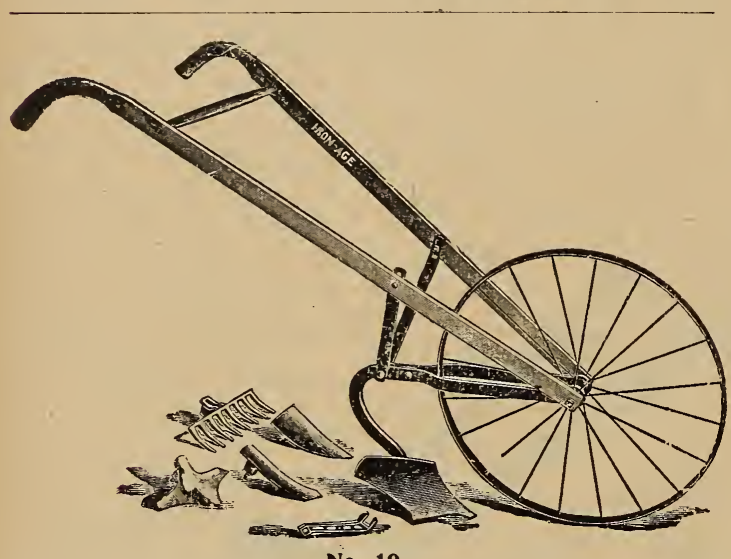

No. 19.

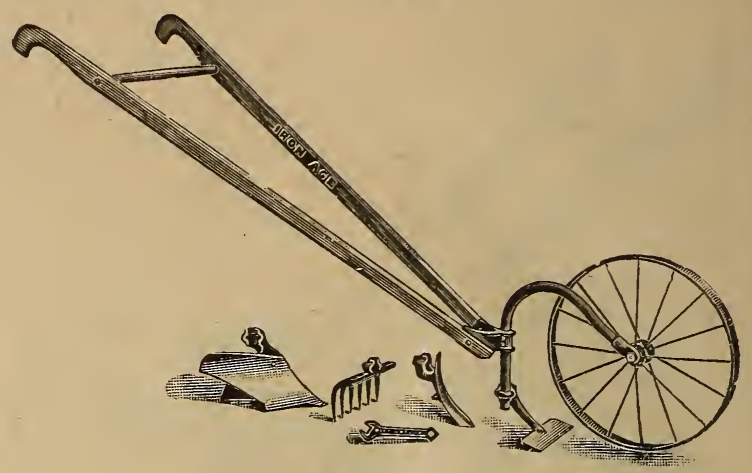

No. 12.

\section{No. 19. "Iron Age" Wheel Plow and Cultivator.}

Has a higher wheel than any previously offered, it being 24 inches high, with 1 -inch tire, and very strongly made. The frame is steel throughout, which insures durability and lightness. Price, $\$ 3.25$.

\section{No. 20. "Iron Age" Single Wheel Hoe.}

A most complete single wheel tool. One pair of side hoes, three cultivator teeth, one pair rakes, and a landside plow are furnished. Price (complete), \$6.00.

\section{No. 21. "Iron Age."}

Same as No. 20, with plain hoes only. Price, $\$ 4.00$.

Can be used as a seeder at any time by adding the drill, or hill and drill seeder attachment.

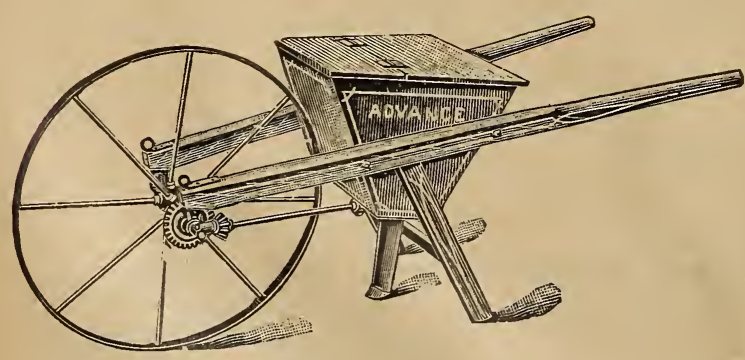

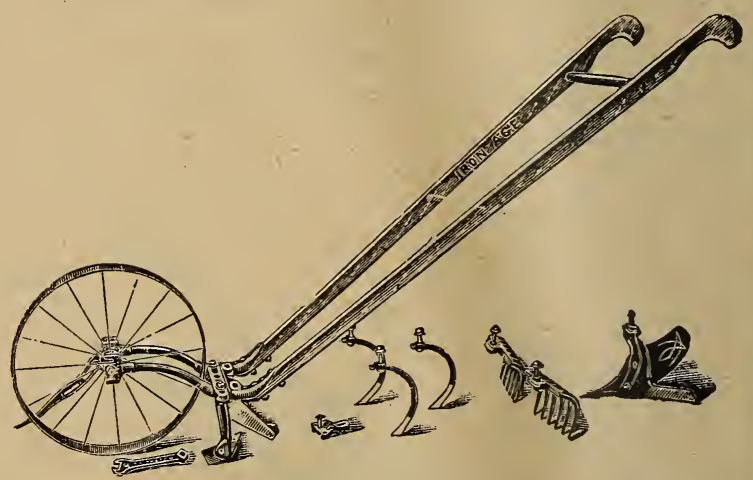

No. 20 .

\section{ADVANCE (“IRON AGE") FERTILIZER DRILL.}

One of the best low-priced fertilizer distributors made. Has galvanized iron disc, which will not rust or break; a light and strong wrought-iron wheel, and a shut-off to prevent escape of fertilizer at end of rows. A first-class tool for drilling peas and corn. Price, \$6.25.

As it is possible to shore only a fere of these implements, a complete descriptive "Iron Age" Catalogue ruill be sent free on request. 


\section{Foster (Racine) Broadcast Seeder.}

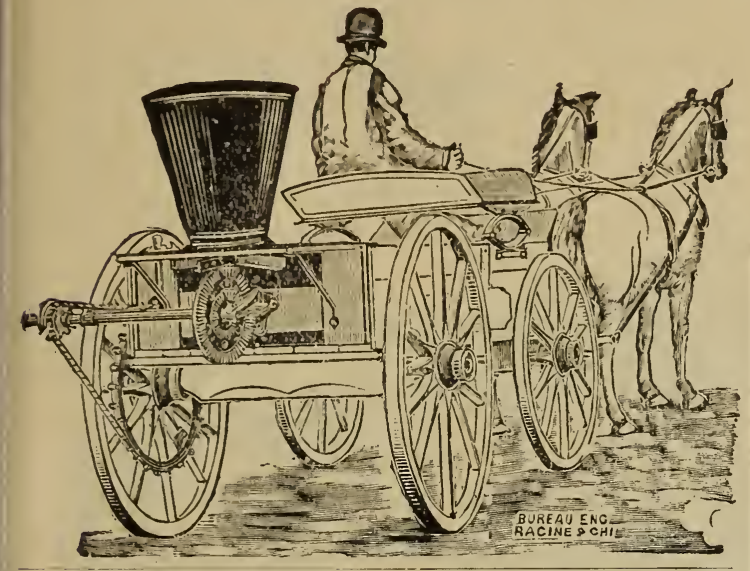

COLUMBIA BROADCAST SEED SOWER.

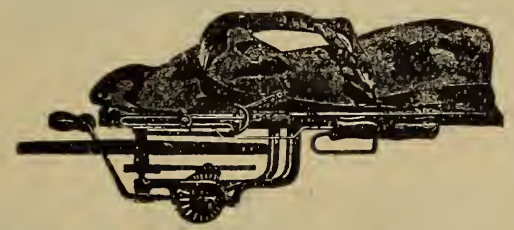

This seeder is practical, neat and mechanically correct in construction. It distributes seeds evenly, has an automatic cut-off, and the iron distributing wheel gives great momentum. No machine does better work, it being a strictly high grade seeder.

Price, $\$ 1.50$.
(DOUBLE GEAR.)

Will sow perfectly any quantity to the acre of oats, barley, rye, buckwheat, clover, millet, timothy, Hungarian, etc. Will also sow peas, corn and fertilizers, in a most satisfactory manner.

Price, \$8.50.

\section{THE CAHOON}

BROADCAST SEED SOWER.

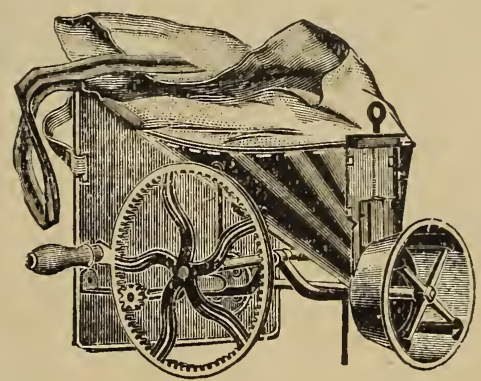

For Sowing Wheat, Oats, Barley, Rye, Buck= wheat, Grass Seeds, etc.

This hand machine sows from four to eight acres per hour, at a common walking gait.

Price, \$3.00.

\section{The New Columbia Garden Seeder.}

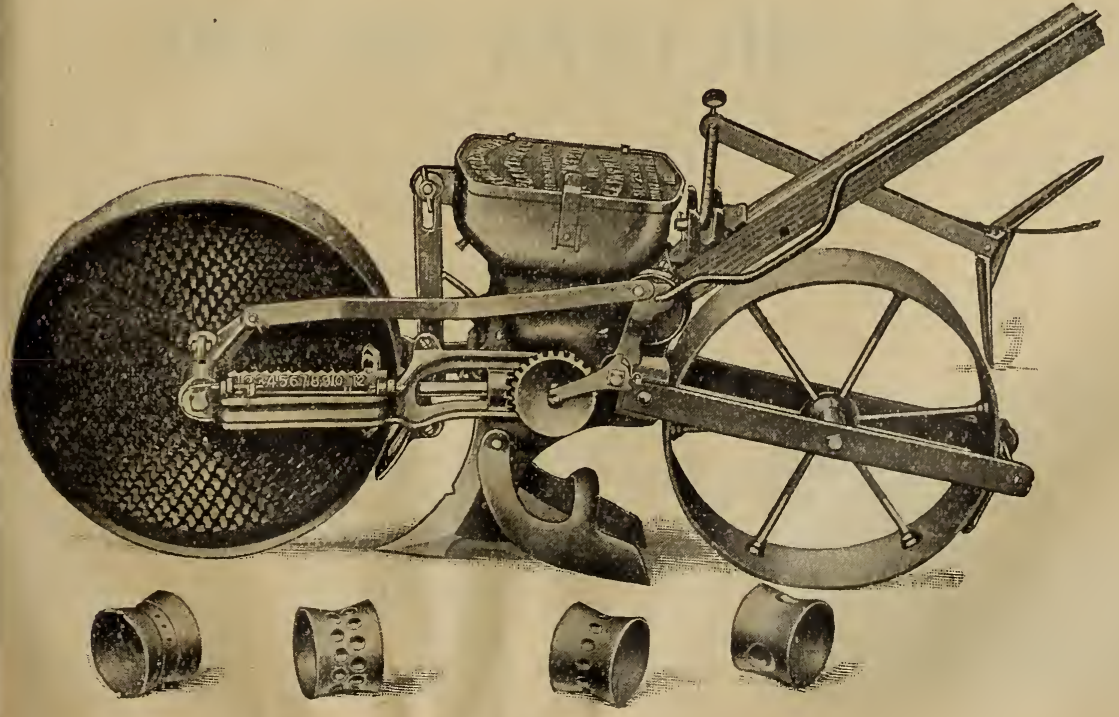

This new seeder has proved to be one of the most successful and accurate planters on the market. With the Columbia you can plant a greater variety of seed and more accurately than any other machine manufactured, and also bear in mind that it has positively a force feed. Seed can be drilled or planted in hills at various distances. Comes equipped with seven seed cylinders, and can furnish extra ones for any special seed you might have. Regul a r equipment will plant all common vegetable seeds, from the smallest up to beans and peas.

Price, \$11.00. 


\section{STEEL LAND ROLLERS.}

Heavy steel heads are used, making fully closed ends. The rims or drums of these rollers are of the best material of heavy gauge and are firmly riveted to the heads.

The hangers are of forged steel and cannot be broken. The middle hanger and draft bar prevents the frame from sagging and the a $x$ le from bending, and brings the draft in line with the axle. The bearings in the hangers when worn can be replaced at $s_{\mathrm{m}} \mathrm{m} 11 \mathrm{ex}$ pense.

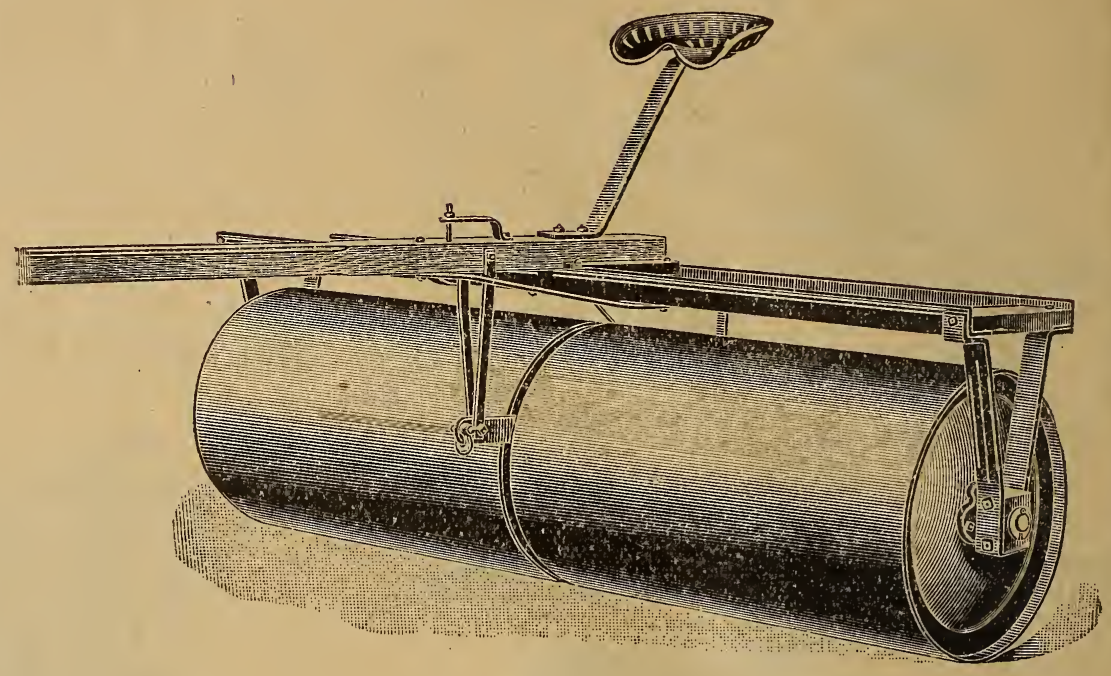

Price on application.

\section{ONE-HORSE STEEL LAND ROLLER.}

Similar in construction to two-horse roller, but made with smaller and shorter sections.

Price on application.

\section{IRON GARDEN AND LAWN ROLLERS.}

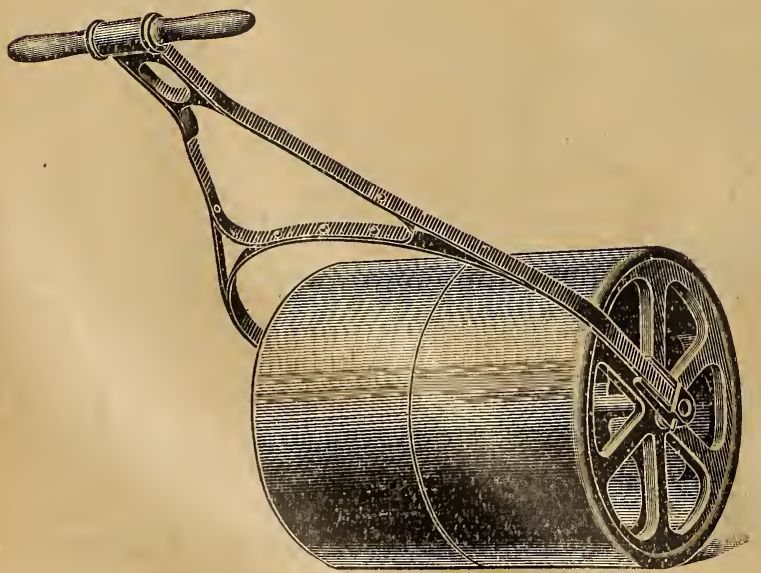

Outer edges beveled. Steel axles perfectly fitted in machined bearings, assure perfect alignment and ease in using.

Iron Handle with Counterweight. The only lawn roller made with a handle that is absolutely rigid and that will remain so.

No. 1 and No. 2 do not have handle counterweight.

Sections Inches Inches Weight. Price.
Each. long. diam:

$\begin{array}{llllllr}1 & 2 & 16 & 20 & 150 & \text { lbs. } & \$ 7.00 \\ 2 & 2 & 16 & 20 & 200 & 66 & 9.00 \\ 4 & 2 & 20 & 20 & 250 & \text { 66 } & 10.50 \\ 6 & 3 & 24 & 20 & 300 & \text { 66 } & 13.00 \\ 7 & 2 & 24 & 20 & 300 & \text { 66 } & 13.00 \\ 8 & 3 & 30 & 20 & 350 & \text { "6 } & 15.50 \\ 9 & 2 & 20 & 24 & 400 & \text { "6 } & 16.50\end{array}$




\section{HUSSEY PLOWS.}

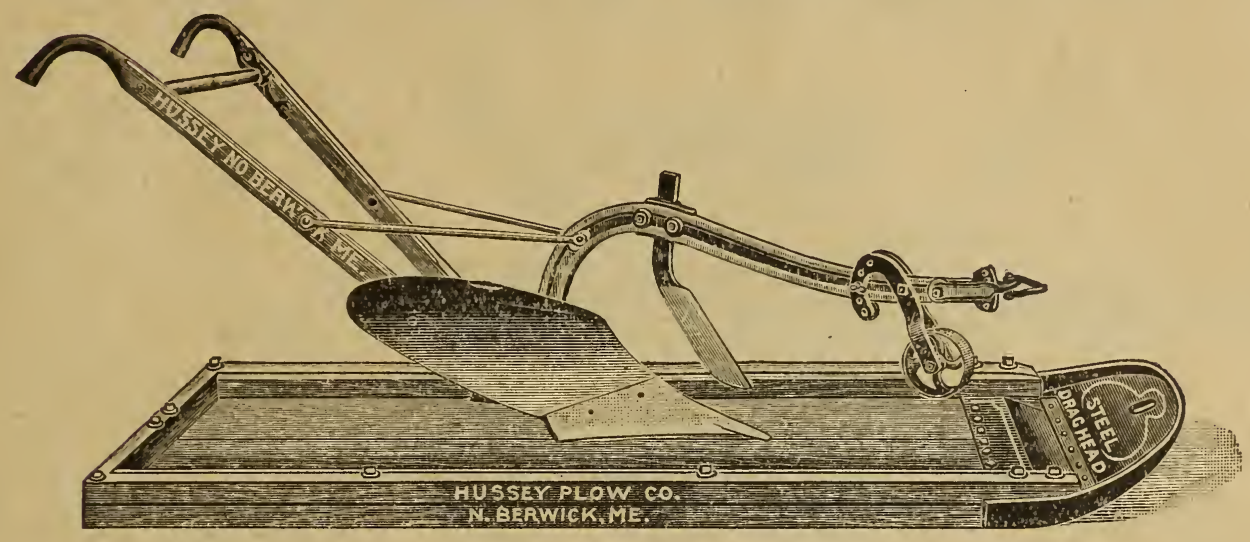

These plows are very strongly built, have the regular "Hussey" shaped mouldboard, which is so much liked by New England farmers, are made of the best materials throughout, are easily held, and are as nearly complete and satisfactory in every respect as the most critical farmer can.ask.

No. 23. MEDIUM OR LIGHT TWO-HORSE PLOW. Steel Mouldboard, "Hard Metal" Point.

Cuts from 4 inches to 7 inches deep, 11 inches to 13 inches wide.

Weighs, complete, $120 \mathrm{lbs}$.

No. 25. LARGE TWO-HORSE Plow. Steel Mouldboard, “hard Metal" Point.

Cuts from 5 inches to 7 inches deep, 13 inches to 16 inches wide.

Weighs, complete, $128 \mathrm{lbs}$.

No. 26. SAME PLOW as No. 25, with a Little Higher Mouldboard and Heavier Beam. No. 28. LARGE THREE-HORSE PLOW. Steel Mouldboard, “Hard Metal" Point.

Cuts 7 inches to 9 inches deep, 14 inches to 18 inches wide.

Especially adapted for breaking up new land.

Weighs, complete, $162 \mathrm{lbs}$.

No. 100. (Wood Beam.) ONE-HORSE PLOW.

Cuts from 5 inches to 6 inches deep, 10 inches wide.

Weighs, complete, $66 \mathrm{lbs}$.

No. 102. (Wood Beam.) LGHT TWO-HORSE PLOW.

Cuts from 5 inches to 7 inches deep, 12 inches wide.

Weighs, complete, $82 \mathrm{lbs}$.

No. 108. (Wood Beam.) HEAVY ROAD OR BUSH GROUND PLOW.

Cuts from 8 inches to 10 inches deep, 18 inches to 20 inches wide.

Weighs, complete, 190 lbs.

This size is made with heavy brace-cutter, and beam laid with wrought iron and braced with iron, for road work or bush ground.

Plows are always sent "complete" with wheel and common sword cutter, unless specially ordered otherwise.

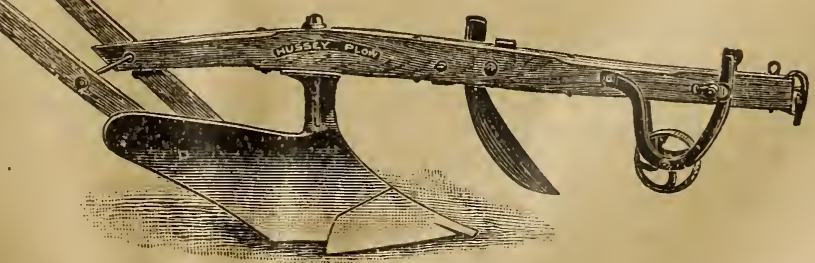

Descriptive Catalogue, showing

Complete Line,

WOOD BEAM HARD METAL PLOW.

Mailed on Applicatior. 


\section{OLIVER PLOWS.}

\section{REVERSIBLE SULKY PLOW.}

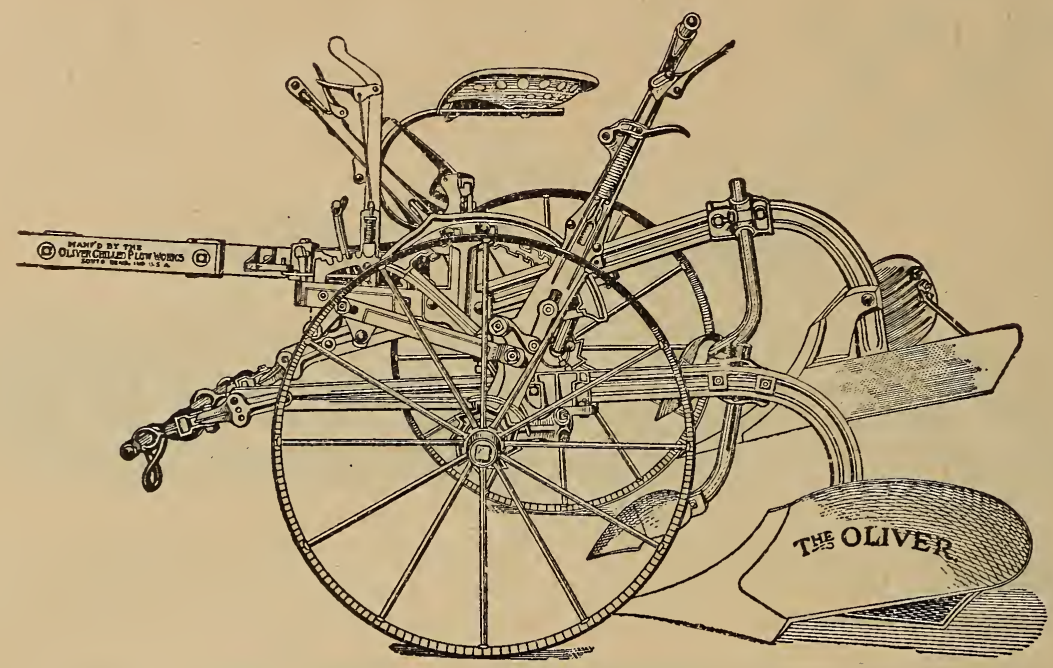

The No. 23 Oliver Sulky. Plow is not only one of the best in theory and practice, but the most expert and careful workmanship guarantees every plow as near perfect as human effort can make it. By means of a "horse lift", which is brought into play by simply pressing forward slightly on the foot trip, the operator's work is diminished by fully one-half and it is not necessary to use the hand lever. With this plow the operator can keep his eyes on his team and his hands on the reins-the feet only are needed in order to raise the plow. The wheels have staggered spokes and wide tires and are set so as to insure strength, easy running and long life. Made with either chilled or steel mouldboard as purchaser may wish.

NOS. 82, 83 AND 84.

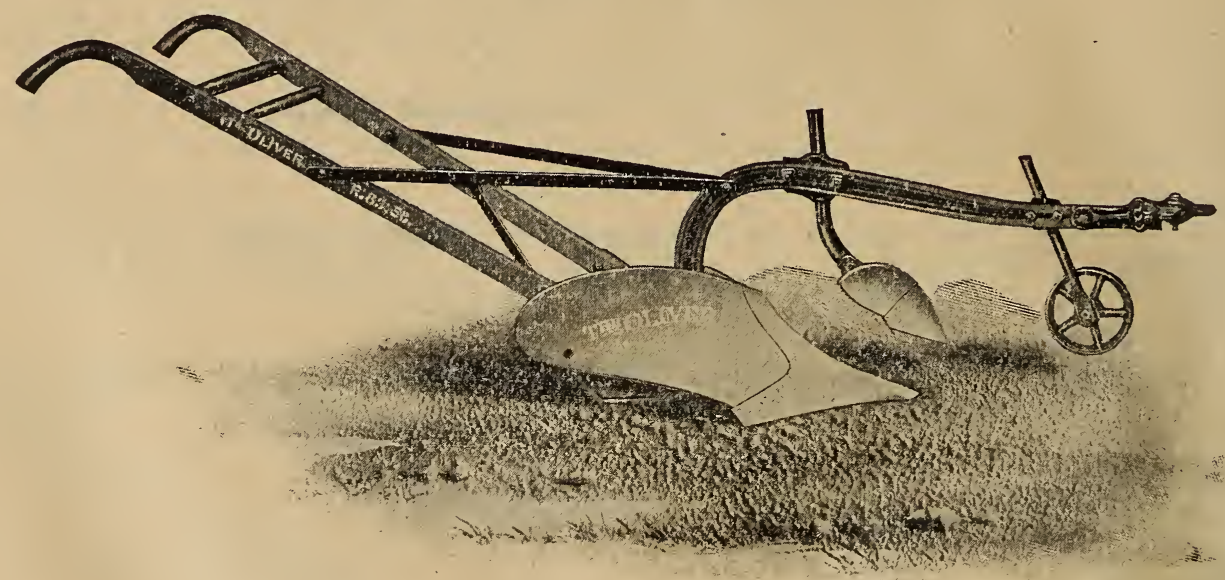

Nos. 82,83 and 84 plows are especially designed for general purpose work, and having superior turning qualities are well adapted to sandy, gravelly and stony soils. The long, graceful turn to the mouldboards also fits them for work in sod, in the turning and laying of which they give particular satisfaction. The plows are steady running, light in draft, easily handled and strongly braced.

No. 82. A light two-horse plow. Capacity, $6 \times 12$ inches.

No. 83. A medium two-horse plow. Capacity, $7 \times 13$ inches.

No. 84. A large two-horse or medium three-horse plow. Capacity, $8 \times 15$ inches. 


\section{SYRACUSE SULKY PLOW.}

THE FIRST PRACTICAL SULKY PLOW MANUFACTURED, AND IS STILL ONE OF THE BEST ON THE MARKET.

Hardened st e el mouldboards and steel strips. Chilled or steel shares. For two or three horses, as ordered. Does perfect work on hillside or level l a nd. No ridges or de ad furrows. Steel wheels with removable chilled boxes and dustproof caps. The beams, jointer standards, and bails are of steel.

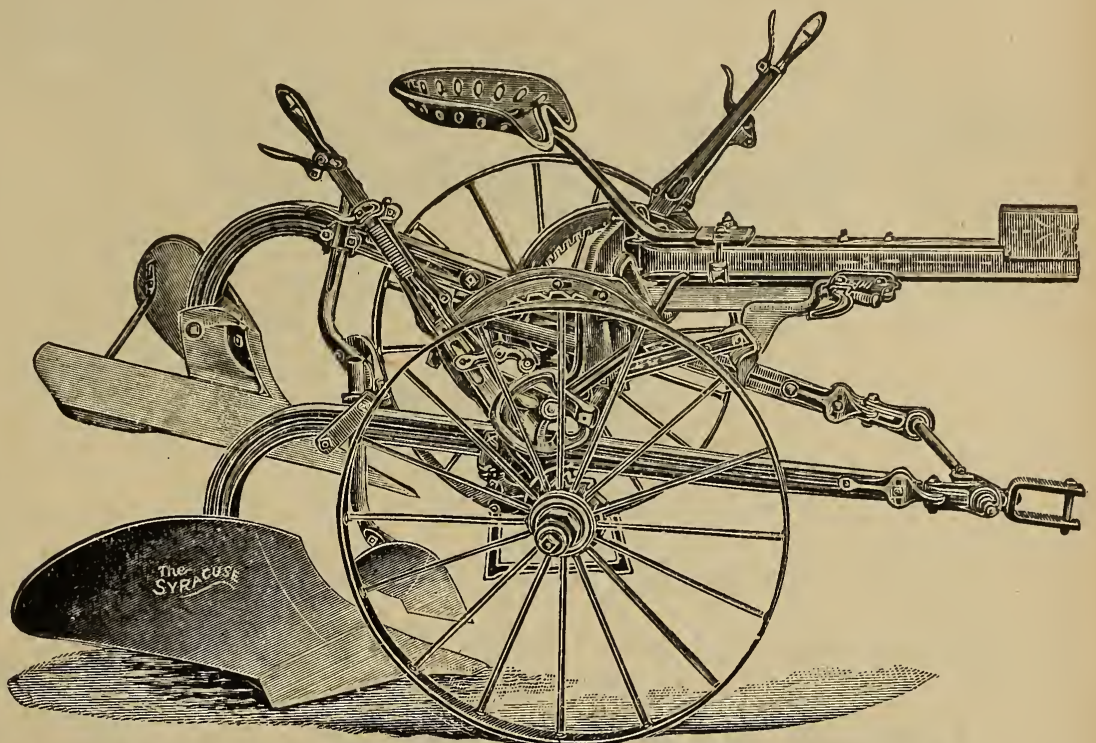

The demand for this kind of riding plow has increased rapidly of late years, as the feature of having level fields without dead furrows or ridges has commended it to numbers of our most successful farmers.

As appears in the cut, two flat land plows are mounted on separate steel beams and the movements of each controlled by a separate lever. In use one plow is raised, while the other turns the furrow. At the end of the furrow this plow is raised by pressing down on the foot trip, which transfers the labor to the team and automatically unlocks the plow when clear from the ground, leaving the driver both hands with which to manage his horses in turning. After the turn is made and the other plow lowered, the whiffletrees slide automatically to place at the end of the long clevis in front of the working plow, so that the plow draws in line of draft.

(All castings are malleable.)
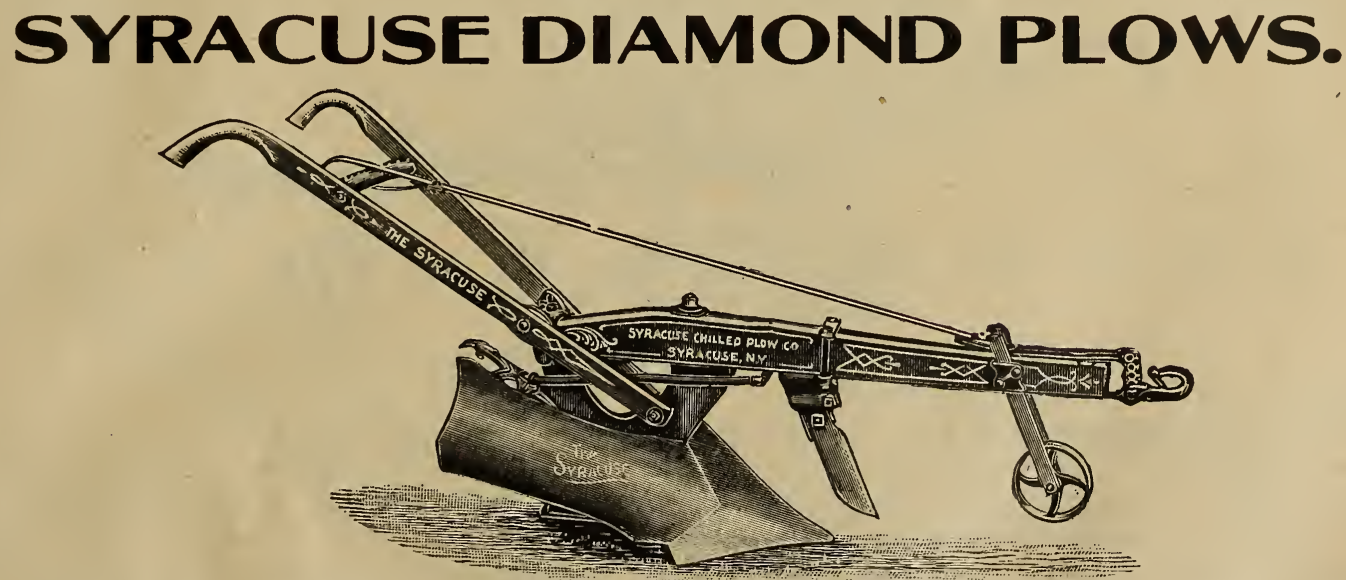

This series has proved very popular in New England. They are light reight. of good capacity and handle easily.

These plows are made with both steel and cast mouldboard ; steel, however, is preferable, as it is equally strong and much lighter.

$\checkmark$ MEDIUM TWO-HORSE, CAST SHARE, CAST OR STEEL BOARD.

$\triangle B$ LIGHT TWO-HORSE, CAST SHARE, CAST OR STEEL BOARD.

$\triangle C$ ONE-HORSE. CAST SHARE AND CAST BOARD ONLY.

Price mailed on application.

A complete descriptive Syracuse Catalogue will be sent free on request. 


\title{
SYRACUSE DOUBLE MOULDBOARD PLOW.
}

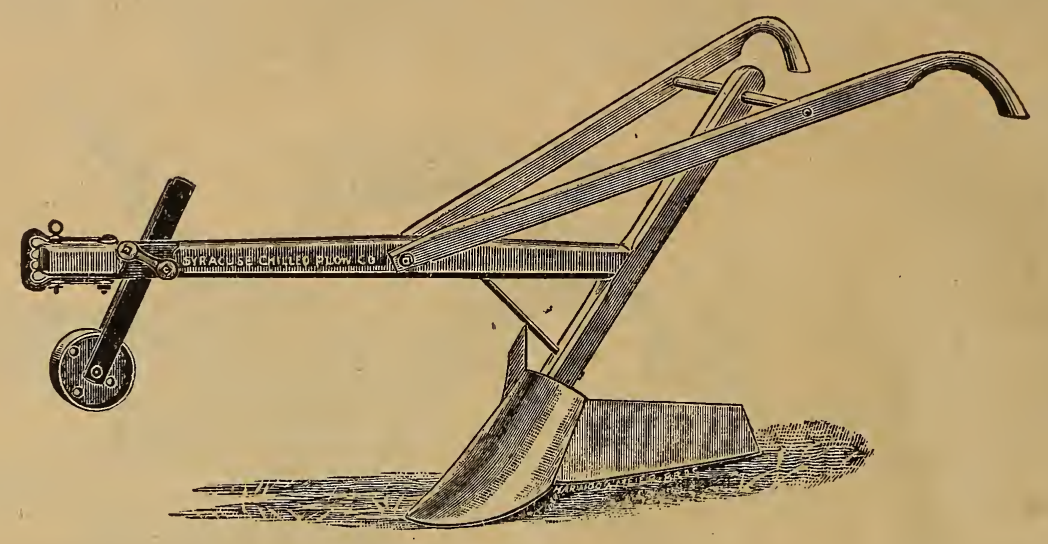

For cultivating all kinds of crops that are planted in rows this plow has no equal. It is powerfully built, perfectly balanced, runs easily, and in operation turns the loose mellow soil toward the plants, and gagainst them, as desired. Especially useful in cultivating and hilling potatoes.

Price on application.

\section{THE YANKEE SWIVEL PLOW,}

\author{
With Patent Steel Shifting Lever and Clevis. \\ IN SIZES FOR ONE, TWO, OR THREE HORSES.
}

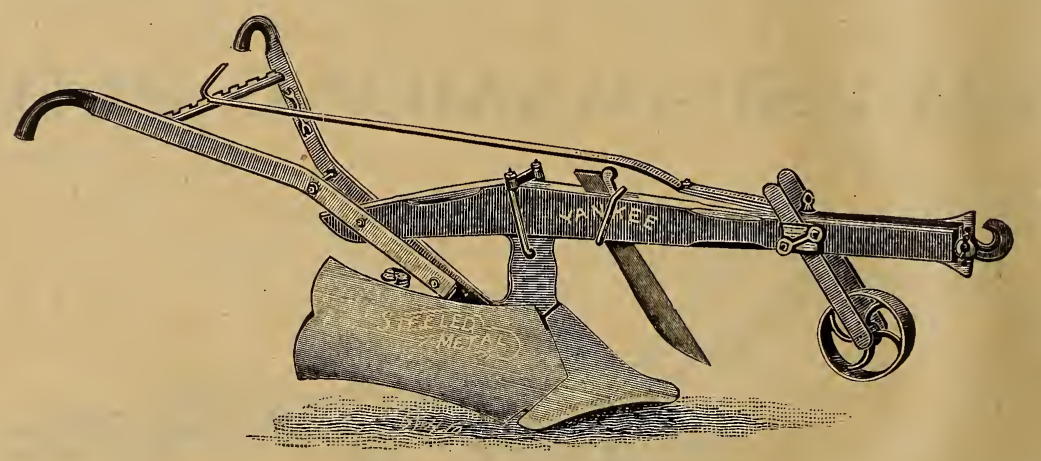

The special distinctive feature in the Yankee is the patented steel shifting lever and clevis, which, as shown in the above cut, consists of a steel lever attached to the clevis, held stationary and firmly in position by iron notches between the handles. When this lever is moved by the plowman, either to the right or left, which can be done instantly without stopping the team, the width of the furrow is changed. The excellence of such an arrangement will be seen by all, especially in view of the fact that heretofore reversible plows, as usually made, have no means of adjustment of any kind, and have frequently been condemned in consequence. Not only is this attachment so easy of operation that a child can manage it, but being of simple construction it will never get out of order. These plows are made from the patent steeled metal, with beams and handles of best Eastern white oak.

The $H$ series of Yankee Plows shown on this page, with patent spring foot latch, have to a large extent superseded the hand latch. This latch is an invaluable improvement, as, being operated entirely by the foot, the plow is ready for work as soon as reversed, which is done without taking the hands from the handles, or stopping the team. It is simple, strong and durable, and does not get out of order. 


\section{THE "LOVEJOY" REVERSIBLE SULKY PLOW.}

\section{WITH SINGLE LEVER FOOT LIFT FOR HILLSIDE OR LEVEL LAND.}

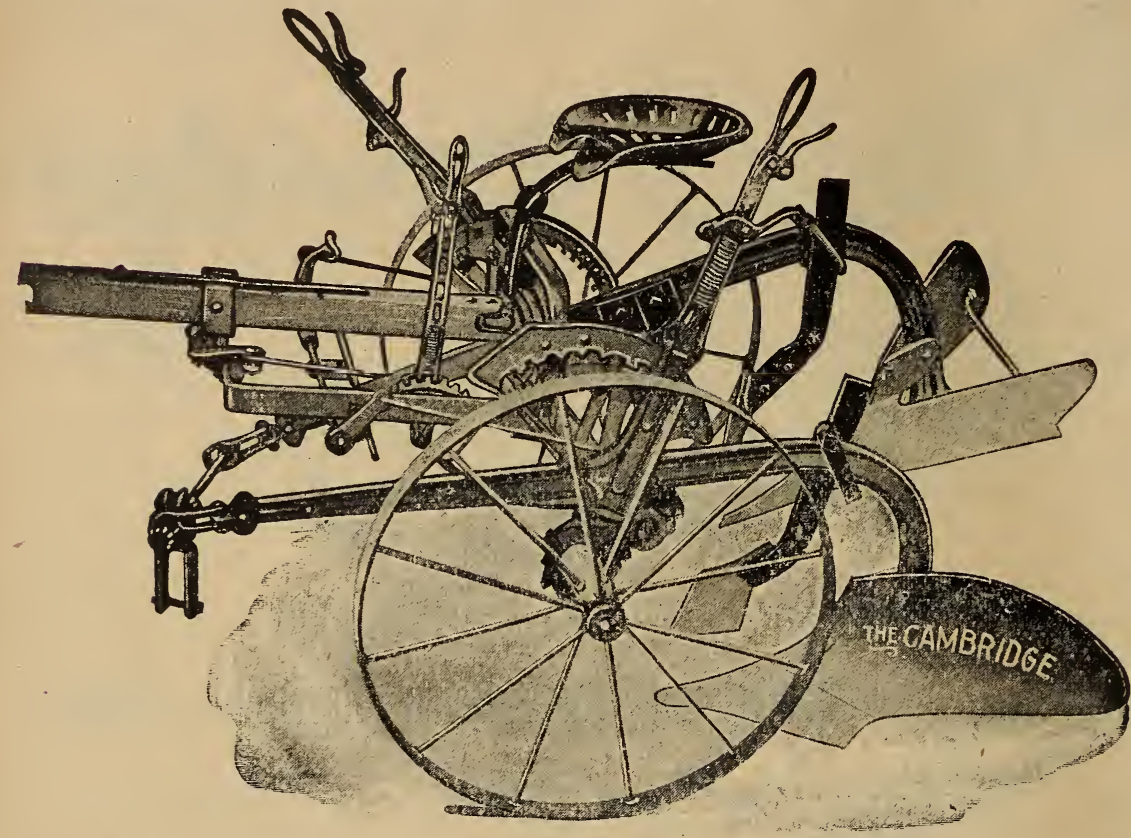

The "Lovejoy" Sulky is made from the best malleable iron and highest grade steel obtainable, materials that will stand the strain in the hardest kind of plowing. Is made in two sizes to suit the land to be plowed. Guaranteed to do equally good work on level or equally good work on level or hillside plowing, is lighter in draft than a walking plow doing the same amount of work and does better work. Adjustable pole does away with all side strain, and regulates the width of the furrow. Improved and extra heavy steel wheels with dust cap and removable chilled boxes.

In use one plow is raised while the other turns the furrow. At the end of the furrow this plow is raised by pressing down the lever with the right foot, which transfers the labor to the team and automatically unlocks the plow when clear from the ground. This leaves the driver with both hands free to manage $h$ is team in turning about. After the turn is made and the other plow is is mad and trees roll automatically to place at the end of the long clevis in at the end of the long clevis in
front of the working plow so that the draft is always in line with the plow turning the furrow.

Pricelonlapplication

\section{CHICOPEE REVERSIBLE SULKY PLOW.}

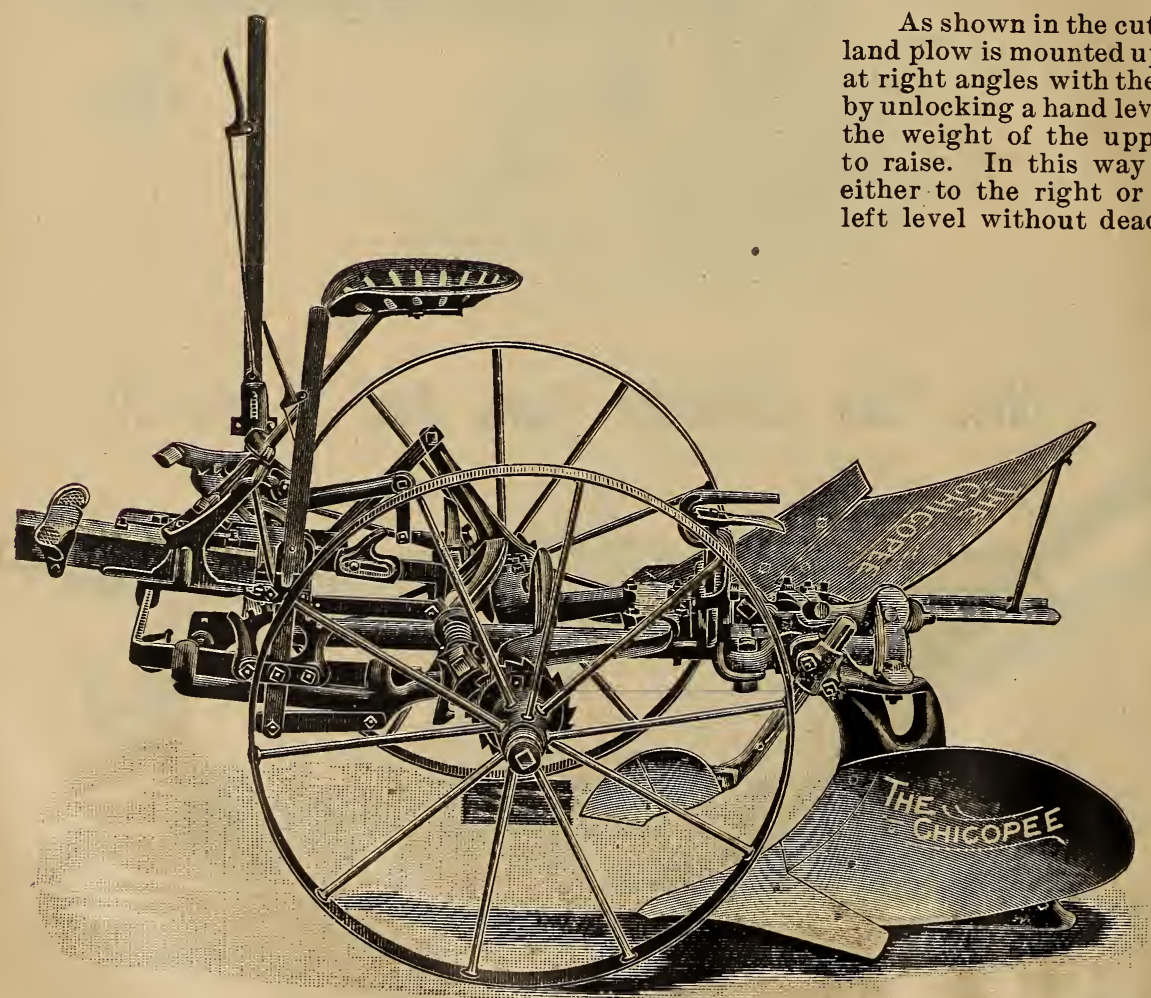

a right and left steel flatat right a is one being by unlocking a hand lever at the rear of the driver, weight of the upper plow causing the lower o raise. In this way a furrow may be turned either to the right or left, so that the lands are furrows. Each plow has an easy adjustment to make it cut a wide or narrow furrow, and is raised out of the ground by a perfect working power lift, and set in again by a foot lever, so that the operator has both hands with which to manage his team. With the adjustable seat the operator always sits in a level position, and on the uppermost side in plowing steep side hill land, preventing the plow from tipping.

With the hand lever that is turned backward (not shown in cut), the power lift can be operated by the driver when walking.

Neck yoke, evener, whiffletrees, which answer for two or three horses abreast, are sent with each plow.

Either jointers, or straight or rolling coulters are furnished, but, if not otherwise ordered, jointers will be sent with each plow.

Price on application. 


\section{THE SPAULDING DEEP TILLING MACHINE.}

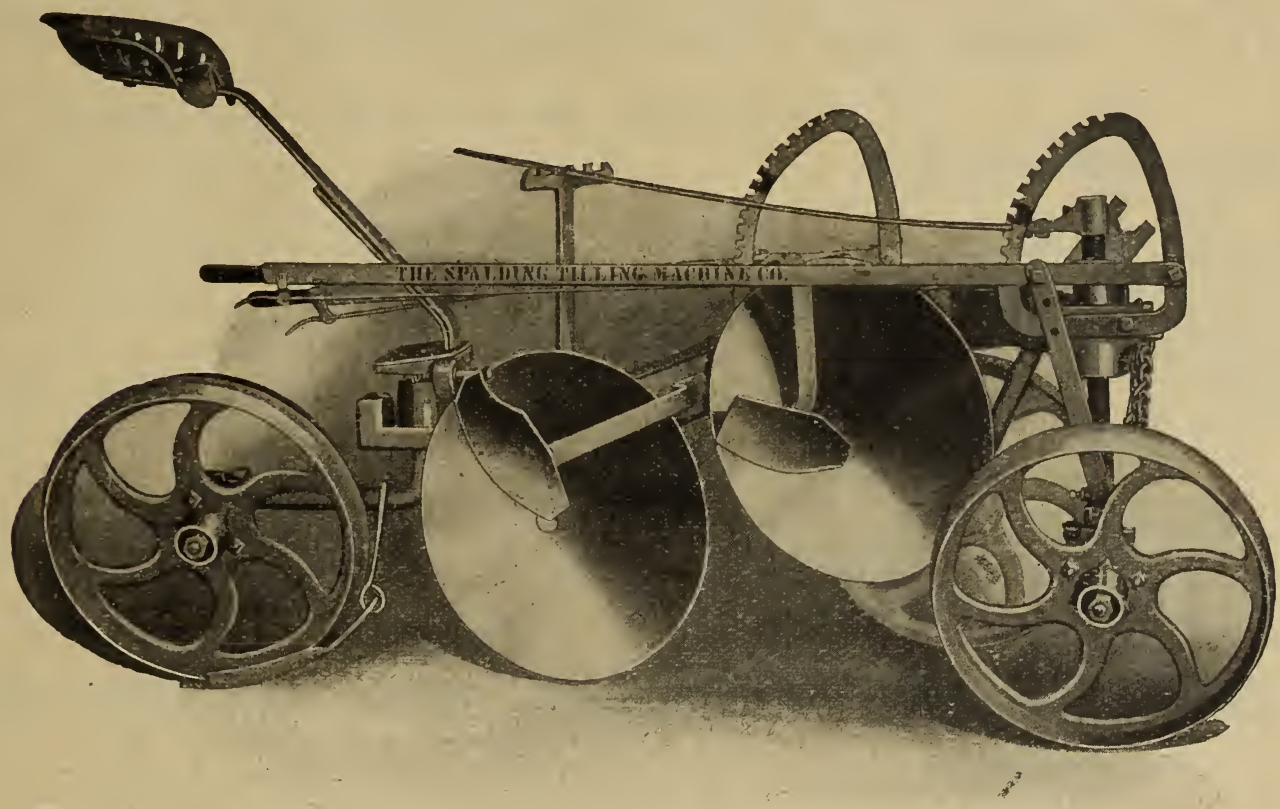

Especially designed and adapted for plowing, pulverizing and mixing the top and bottom soils together, to a greater depth than heretofore accomplished by any mechanical means, or by any implement (besides the spade), and to prepare a perfect seed-bed which will conserve the moisture, improve the physical condition of the soil, increase the crops and enhance the value of the farm at a single operation.

\section{How the Spaulding Deep Tilling Machine Operates.}

The front disc cuts from four to ten inches and turns the top trash over into the bottom of the furrow. The rear disc follows in the furrow of the front disc and cuts from six to ten inches deeper. The greater portion of the earth turned by the front disc comes within the path of the movement of the earth cut and lifted by the rear disc, and as the earth passes across the face of this revolving rear disc, it is disintegrated, pulled apart and thoroughly mixed with the earth plowed by the front disc, leaving the top trash turned under by the front disc completely covered in the bottom of the furrow.

In ordinary soils, and under average conditions, the machine will plow and thoroughly pulverize the earth to a depth of from eight to sixteen inches, and make an excellent seed-bed.

Under favorable conditions, the machine can be adjusted to plow and pulverize to the depth of twenty inches.

Often a long and continued drought makes the land so hard that it is impossible to plow it with the implements in general use. In such cases the Spaulding Deep Tilling Machine, when used, has never failed to plow from ten to fourteen inches deep, and will plow a furrow from eight to sixteen inches in width.

The machine does good work in muck land and in swamp land, even when filled with roots, stumps, etc., and does splendid work in turning under weeds, cornstalks, manure, etc.

It cuts off roots as thick as one's arm, and throws out stones and rocks, and turns them on top. If they are too large and heavy, it dodges around, or rolls over them, and quickly readjusts itself in the proper working position.

The capacity of the machine in acres per day depends on the character and condition of the soil, the power used, the judgment of the operator, and the length of the day. Generally, the machine may be relied upon to plow from one and one-half to two and one-half acres per day. When the object is to make a thoroughly pulverized seed-bed, in a single operation, and the quality of the work done is regarded as more important than the quantity, the operator must be depended upon to adjust the machine with respect to the character of the soil and the work to be done. 


\section{CLARK'S “CUTAWAY” TOOLS.}

\section{Clark's "Cutaway" Reversible Sulky Disc Plow.}

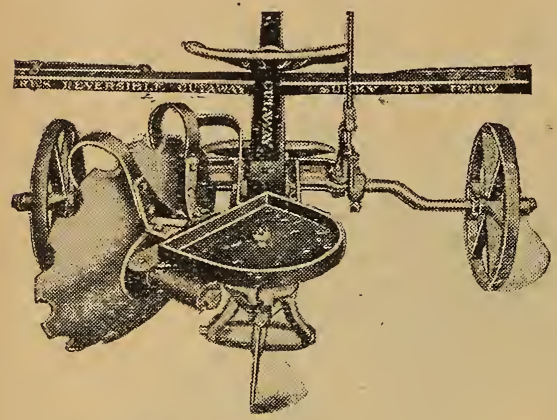

Economical, Easily Handled, Most Effective Made.

The wonderful achievements of this disc plow have attracted country-wide attention. It will make a 14 -inch furrow nine inches deep with less draft than a drag plow. For plowing under stubble and weeds that do not form sod, there is nothing more economical, more easily handled and more quickly hitched to. It is reversible, doing away with dead and back furrows. It will turn under weeds that average three feet in height, as well as any drag plow, but much faster and more easily, without clogging.

This is a light-draft machine, designed especially for trade, where they need a plow that two horses can handle and turn soil four to six inches deep. Has weight box to accommodate sand bag in hardest work.

Discs are 26 inches in diameter; two-horse hitch. Shipping weight, 370 pounds.

\section{CLARK'S "CUTAWAY" REVERSIBLE BUSH AND BOG PLOW}

\section{For Subduing Bogs or Newly Cleared Forest or Stump Land.}

Every Clark Bush and Bog Plow, and every Clark "Cutaway" Harrow, has the famous Clark oiled maple box bearing, the best bearing made.

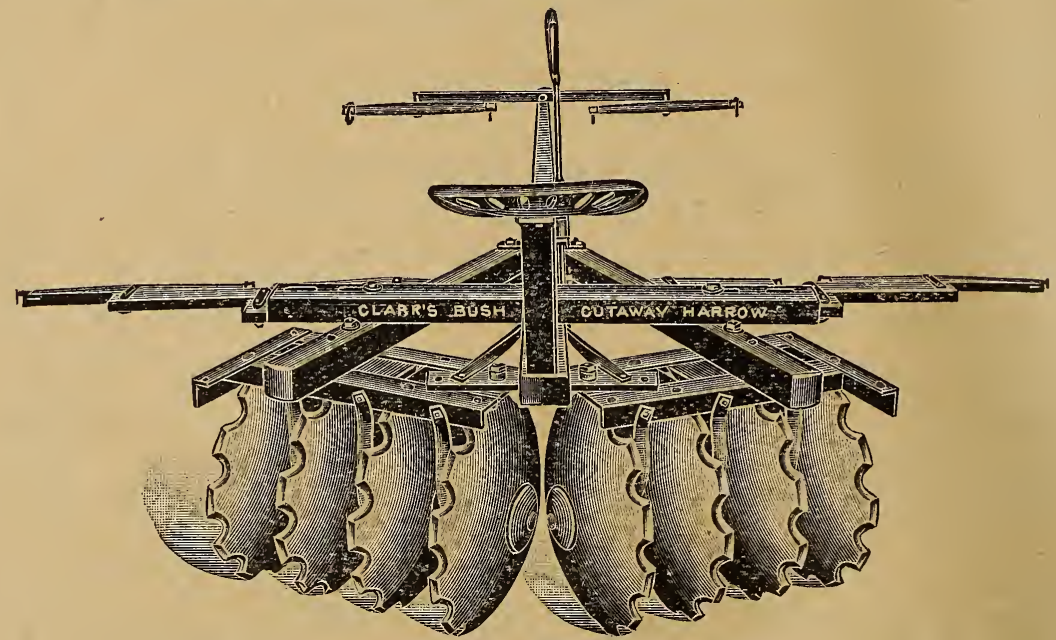

One of the best machines made for the purpose of cultivating timber lands just cleared of timber and burned over, or to plow and cultivate stump, bog or bush lands cheaply. Its strength and durability are guaranteed.

This machine has been in use over fifteen years, and in that time has been the means of turning many acres of newly cleared timber land into profitable grain land. It will reduce an ordinary bush pasture to a fine grass field.

Clark's Bush and Bog Killing Plow and Harrow is made reversible so that it will move the earth to or from the center, thus keeping the land true. In seeding to grass or grain it levels the land and connects the sub-soil water.

Cuts a track 5 feet wide, 9 inches deep; has eight 24 -inch steel discs. Shipping weight, 623 pounds. 


\section{CLARK'S CUTAWAY TOOLS-Continued.}

\section{Clark's Double Action "Cutaway" Harrow.}

These machines have four gangs of discs, two in front and two in the rear. The front gangs loosen and break up the dirt and throw the dirt out; the rear gangs throw the dirt in. All four gangs are carried by a main frame that gives a very strong unyielding connection between them. The rear discs are placed so as to track between the front discs, and the main frame holds the rear discs to their work, keeping them from dodging to either side and holding them in the ground, no matter how hard the land is. Any trash passing between the front discs is cut up and turned under by the rear discs, where it will turn into plant food. Having a fourpoint bearing on the ground these machines run steady and

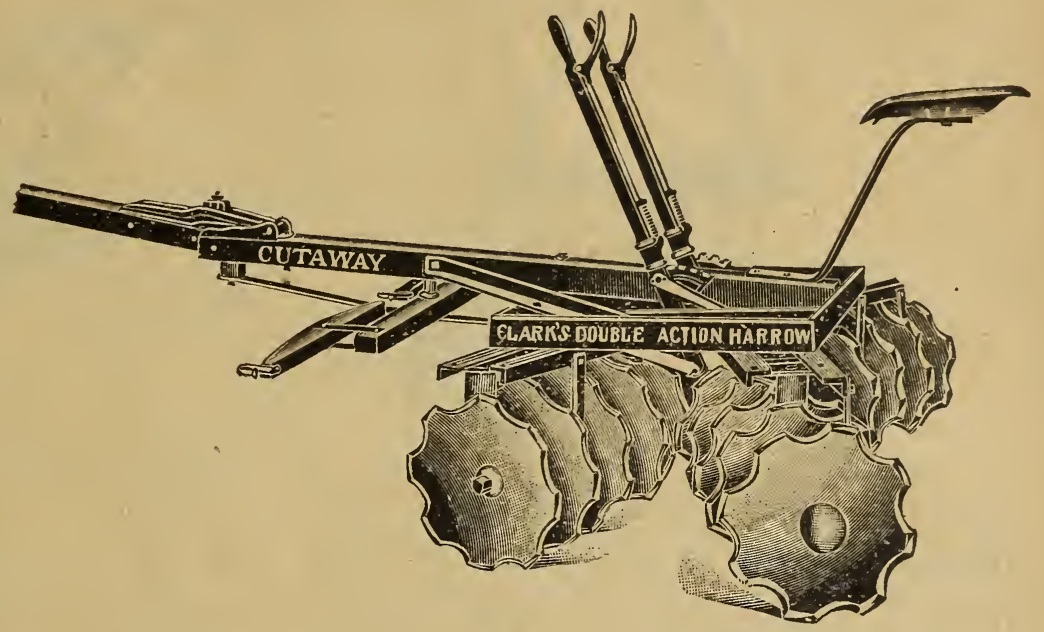
true in the line of draft. The draft of these machines is very light, as the rear discs work in loose soil and consequently are drawn easily.

The whole machine, with the exception of the pole, is made of either iron or steel. The main frame and the gang frame side pieces are made of heavy angle iron. The strain of the gangs is taken up by angle iron bars, one above and one below the inner end of the gang frame. Both side pieces on each gang extend out between these bars. Heavy pipe standards are used, with the oil hole for the bearing at the top of the standard.

\section{Clark's Reversible Double Lever “Cutaway" Harrow.}

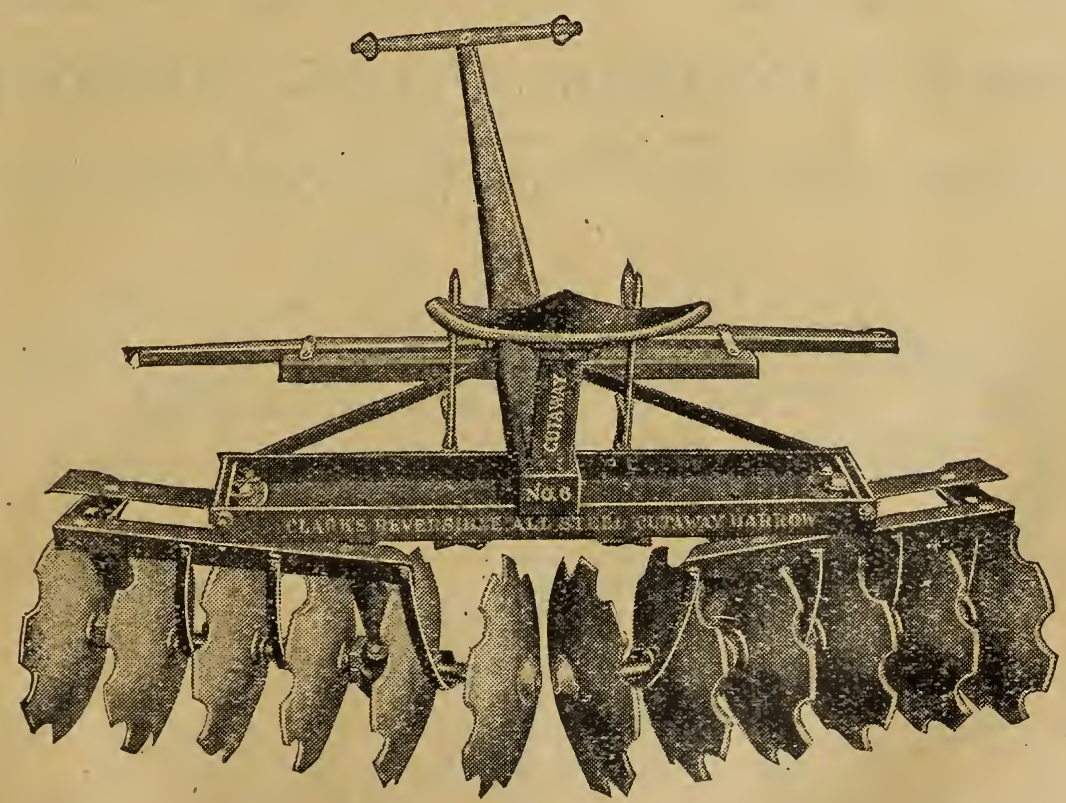

Clark's "Cutaway" Harrows have been in many competitive tests and have invariably.come off victorious. No other harrow will stand up and work the wool grass or salt grass sod, or other hard sods that are often found, like Clark's Disc Harrows. In fact, we have never found any hard lands that the "Cutaway" will not work.

Clark's "Cutaways" are light in weight, yet heavy enough to properly enter the ground; light on horses; strong and durably built to withstand the severest strains without breaking.

On all of Clark's "Cutaway" implements, the edges of the dises are hand forged and tempered, making them much stronger, and causing them to hold a sharp cutting edge longer than ordinary discs. 


\section{CLARK'S \\ Cutaway Ever-Handy Harrow.}

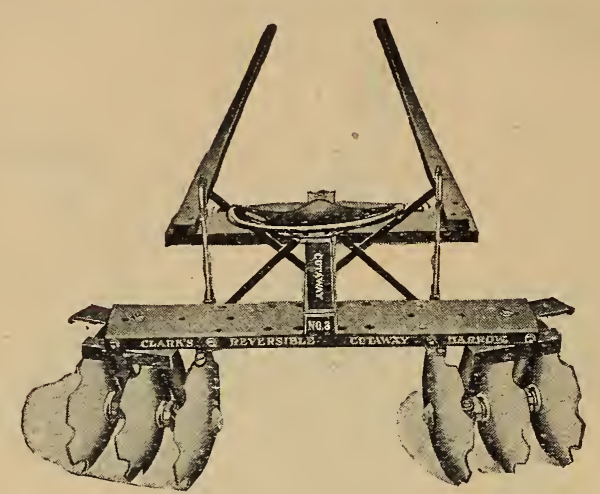

This harrow is made for the express purpose of meeting the needs of the man who has only one horse. By means of the Cutaway Ever-Handy Harrow intensive tillage is made as economical and as practical for the man with a small outfit as for the man with large equipment. When the gangs are closed the harrow cuts 3 feet wide, each cutting $1 \frac{1}{2}$ feet. When they are fully extended the machine cuts 4 feet 8 inches wide. The Ever-Handy is reversible; that is, the gangs may be set so the discs throw the soil either out or in. To reverse it you simply disconnect the lever links from the gang frames and swing the gangs "end for end", and reconnect links. This machine is equipped with 16 -inch Clark forged edge discs. The journals are hard wood.

Price on application.

\section{CLARK'S \\ Cutaway Smoothing Harrow.}

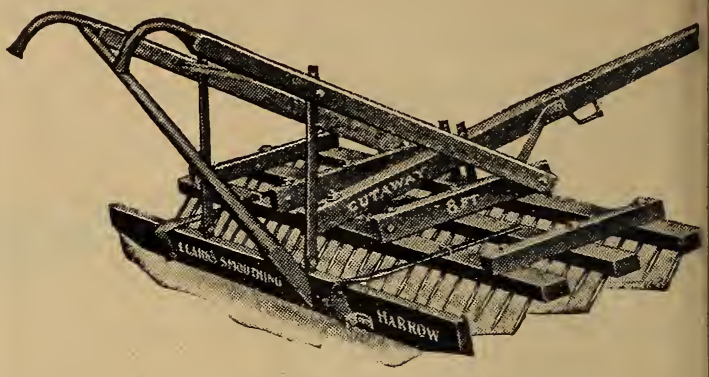

While a large per cent. of the users of cutawa harrows find their machines leave such a smooth finely pulverized seed-bed that a smoothing harror is not exactly necessary, we recommend this smooth er to follow the cutaway harrows. We know tha the last degree of perfection in a seed-bed pays and that the Cutaway Smoothing Harrow wil secure for you that perfection. It combines th. merits of the spike-tooth harrow and the plank drag The teeth dig, tear and pulverize, and the planiter levels, smooths and packs. Observe the handle which gives the driver perfect control over the planl and makes it easy for him to carry large or smal quantities of soil into the hollows. Also note thila steel spring by which the plank is attached. Thi fir Cutaway Smoothing Harrow is made in two sizes 6-foot, for one horse; 8-foot, for two horses.

\section{EUREKA COMBINATION HARROW. 16 OR 18 TEETH. CHANNEL STEEL TOOTH BARS AND WOOD CROSS BARS.}

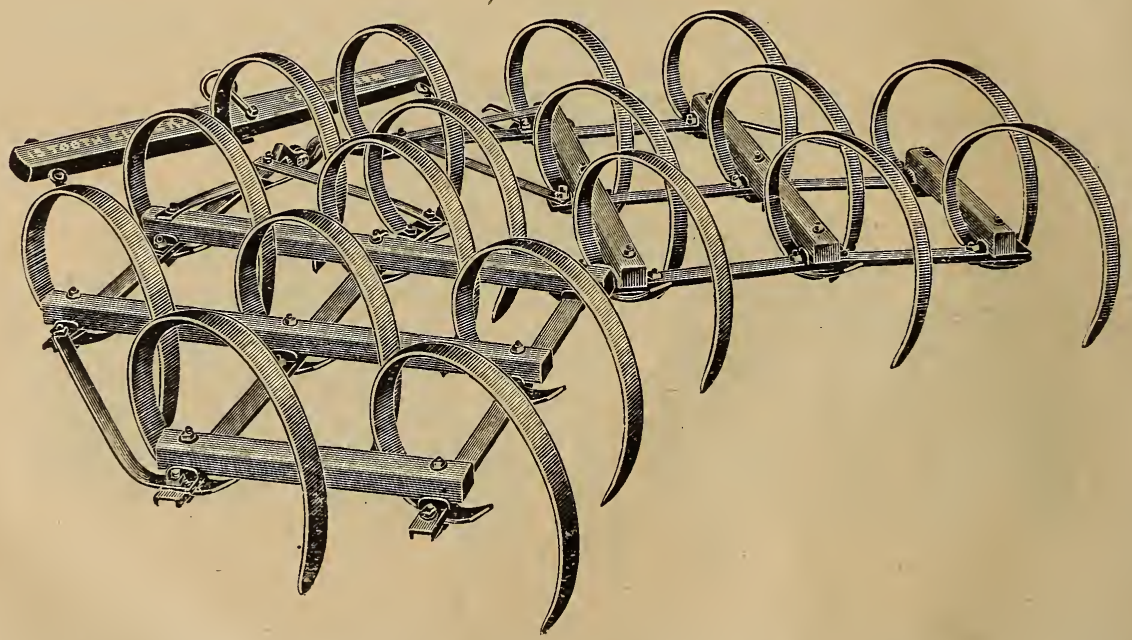

This harrow is far superior to the usual wood frame harrow, having the long life of the all-steel frame, bu much lower in price. All parts that are subject to wear are steel or malleable iron. Teeth are attached $t_{1}$ the under side of frame. The tooth clips are malleable. Neither the clips nor teeth come in contact with th. wood cross bars. 'The "Eureka" is a perfect smoothing harrow, has the butterfly or A shaped frame tha overcomes the objectionable features of other styles that leave the field in ridges, and will fold for storing o transportation without uncoupling. Price on application. 


\section{THE BADGER LEVER HARROW.}

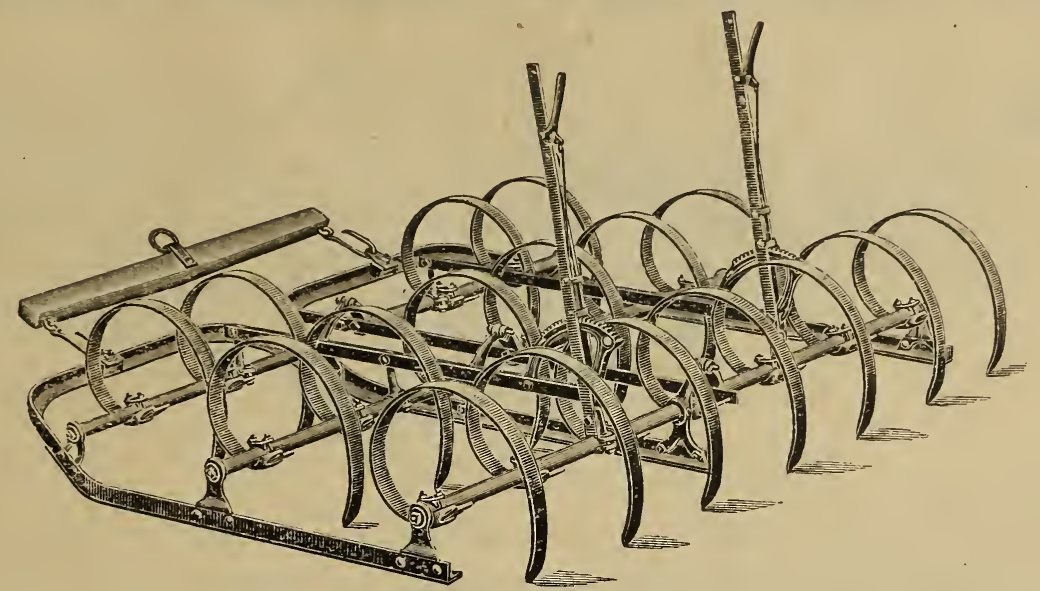

\section{Made with 15 or 17 Teeth, in Two Sections; 23 or 25 Teeth, in Three Sections.}

The frame is made of best quality angle steel. Only one runner is used in centre of harrow, thereby doing Nay with the clogging so often encountered in harrows of two or more sections. The frame hinges are of ecial design, and are unusually successful, allowing the harrow to conform naturally to all conditions. enewable steel shoes are bolted to under side of frame bars, which absolutely prevent any wear upon the ame and can be replaced at small expense. The tooth or cross bars are of high carbon steel pipe, 11/4-inch ameter. They are attached to the malleable frame brackets by steel rods running the whole length of the ipe on the inside-an extremely strong construction, as compared with harrows that have tooth bar connecons only at the extreme ends. The tooth clips are malleable and patented, and are the most successful ones use. The bottom clip is so formed that it protects the tooth and tooth bolts from wear. When the bolts e drawn up, the tooth is gripped by the bottom clip and forced against so much surface of the tooth pipe lat it is absolutely impossible for the tooth to slip or become loose. The clip is so designed that it will not ip on the tooth pipe. This clip gives any amount of adjustment desired, and allows a large part of the tooth , be used. No holes in teeth to weaken them. It is of the greatest importance that every tooth lould adjust individually. When teeth are strained, the depth of cut is changed. When new teeth are used nong those partially worn, the points must be adjusted evenly. Sometimes the lever alone will not give as cact adjustment of teeth as desired for fine work. These adjustments are impossible with teeth which are old by bolts passing through them.

\section{Badger One-Horse Lever Harrow.}

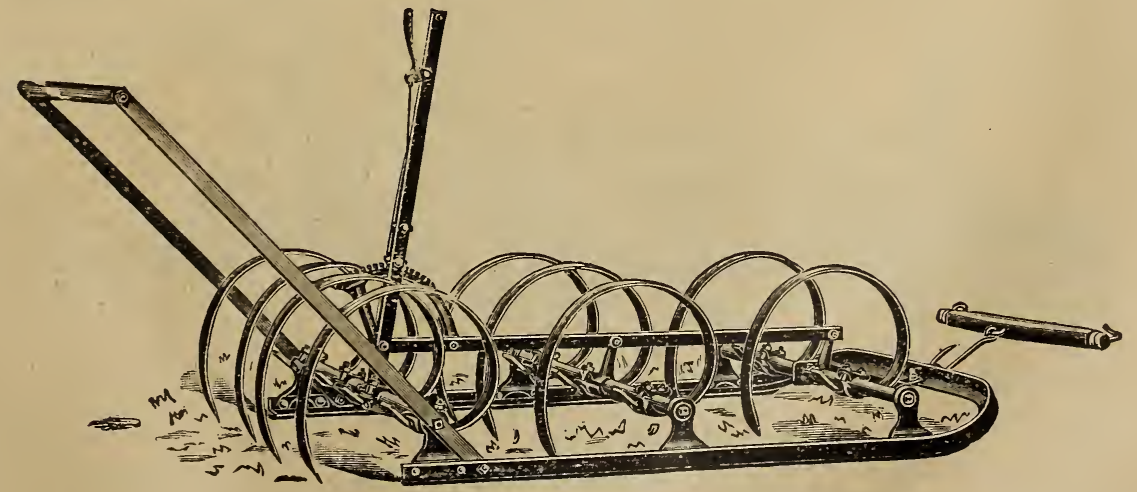

A very popular harrow, used extensively for orchards, gardens and small farms. Made entirely of stecl ad malleable iron. Is controlled by the handles, as easily as a cultivator. Frame is made of angle steel, and ; sloped at the front to avoid obstructions. Has renewable steel shoes. 


\section{SATTLEY CLOSED-END SMOOTHING HARROW.}

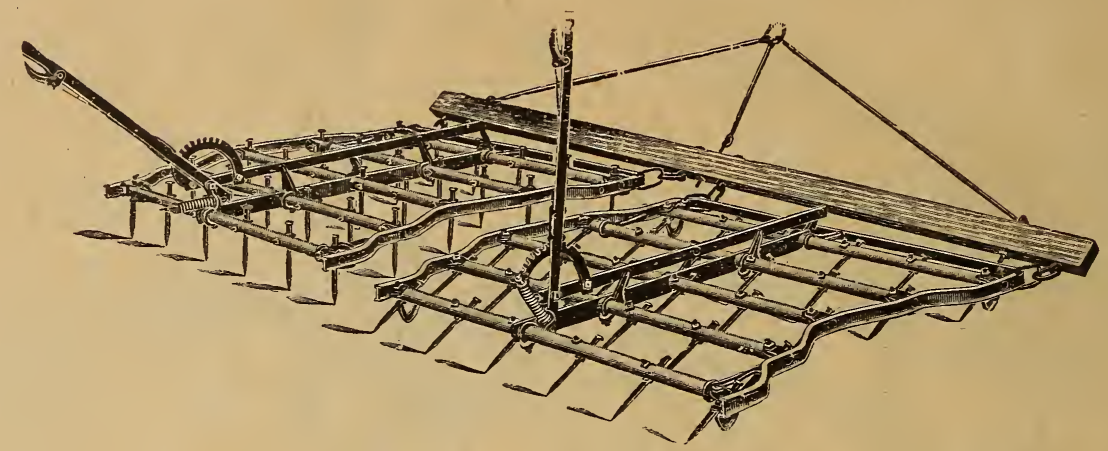

This style of harrow is especially adapted for use in orchards, as the closed end of the frame allows the ground to be worked very close to the trees, without danger of damage from catching the tooth bars.

Only the best steel pipe is used in the construction of these harrows, which also adds to their strength and durability.

The teeth are made of tempered steel. They have a wide curved flange shoulder, which fits snugly against the under side of the pipe bar, while a threaded head passes through the pipe and is held securely by a nut on top.

The levers are conveniently placed and easily operated while the harrow is in motion. They provide for giving the teeth any desired slant.

The harrow is built in thirty and thirty-five tooth sections, each section, independent in itself. We can furnish draw bars for working two, three or four sections together, as may be desired.

\section{SATILEY OPEN-END SMOOTHING HARROW.}

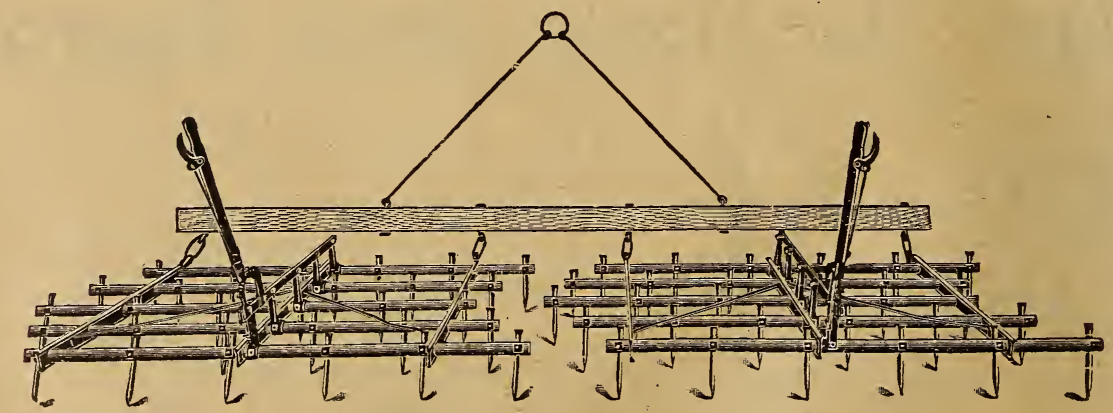

The general type of these harrows is very similar to the pipe bar harrows as described above, except that heavy "I" beams take the place of angle iron beams, and "U" bars are substituted for the pipe bars. The strong, heavy construction, and the very high grade of material used, make these harrows one of the mostdurable on the market. 


\section{SYRACUSE SPRING-TOOTH HARROW.}

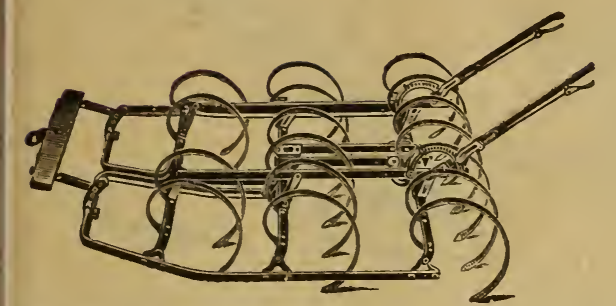

Frame bars of angle steel thoroughly protected by steel shoes, doubling the life of the harrow. Frame bars raised at the rear inner ends, as shown in cut, giving free outlet to trash. Tooth bars of channel steel journaled in malleable brackets above the frame, which give the teeth high support and great range of adjustment for depth of cultivation and clearance. Teeth instantly adjusted by levers to meet requirements of different soils, and may be raised so that the harrowrests upon the frame or runners, making it convenient for transportation. Central and direct draft without side motion, on account of the large bearing surface of the runners, causing the ground to be thorougly cut up and pulverized. Adjustable hitch, so that the teeth at front and rear can be regulated to work at the same depth.

\section{SYRACUSE SPRING-TOOTH CULTIVATORS.}

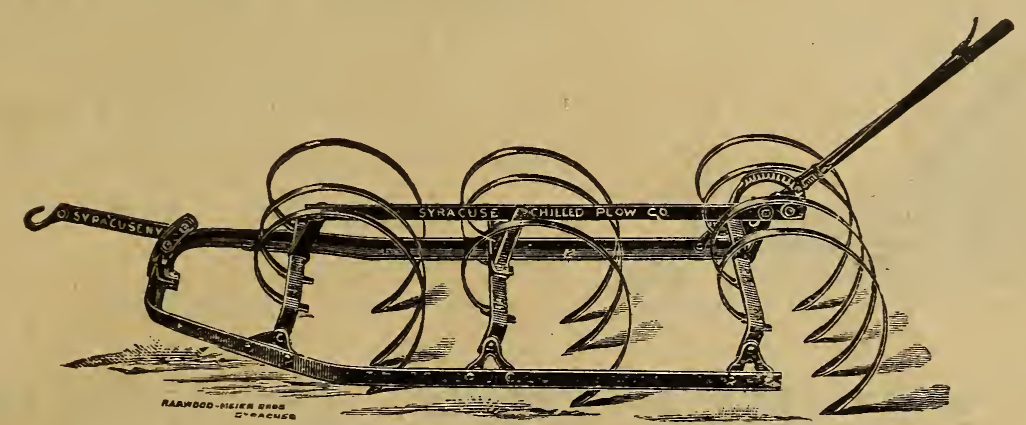

No. 145. Ten Tooth, One Horse, plain teeth, with lever.

This style is especially adapted for use in stony ground. The frames are steel, strong and well put together throughout. The teeth are fine oil-tempered springs, are alike and interchangeable, and are also adjustable for angle and depth.

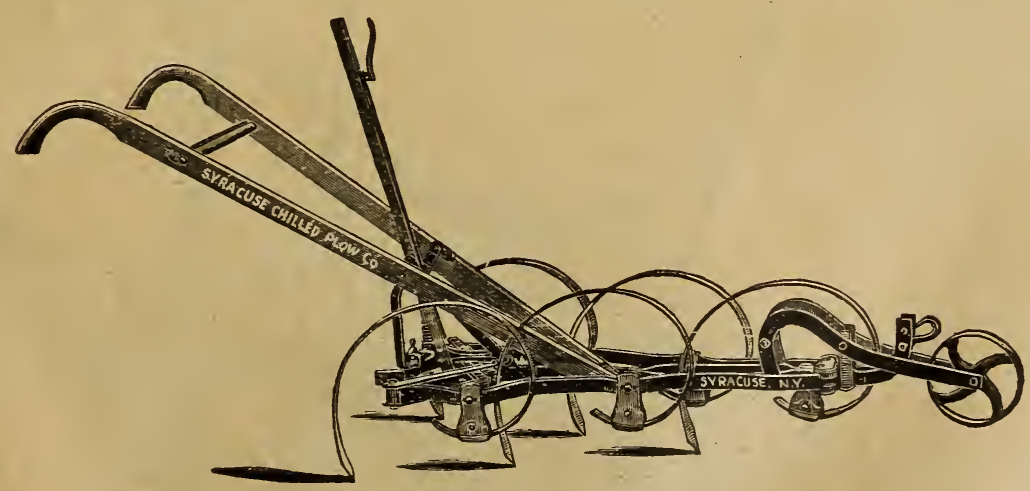

No. 64.

The No. 64 Cultivator, with expanding lever, is excellent for use in rough and stony, or smooth land, and for the cultivation of orchards, or for field work. The frame is of steel, strongly put together, and adjustable to wide or narrow rows. The teeth are interchangeable and adjustable both for angle and depth. 
"DIXIE" Horse Hoe and Cultivator.

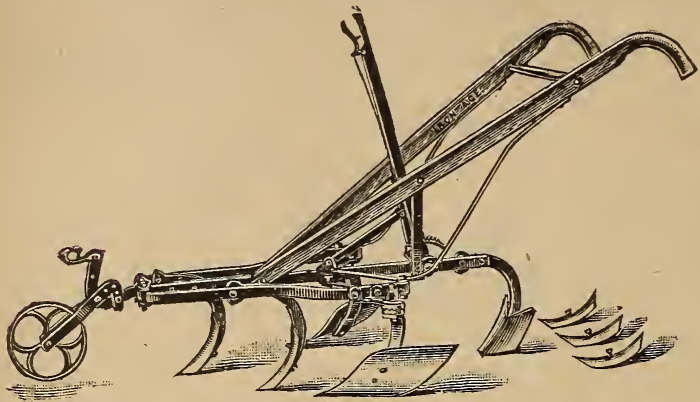

Frame high and long, runs steadily, and clears easily.

All attachments of solid steel, perfectly constructed, and will stand severe strain without injury. Expansion lever, quick adjustment.

Price, \$5.75.
"DIXIE", with Hilling Attachment.

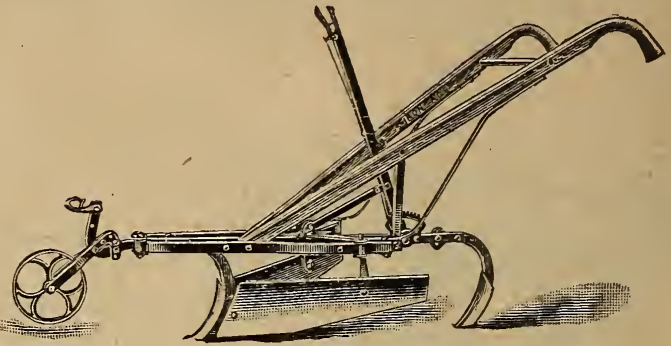

The hilling attachment is applied by simply removing four standards and placing the standard of the hiller on the middle bar and attaching the short standards of the blades to the side bars. This attachment is used in cases where higher ridging is desired than what can be accomplished with the regular horse hoe blades.

Price, \$6.50.

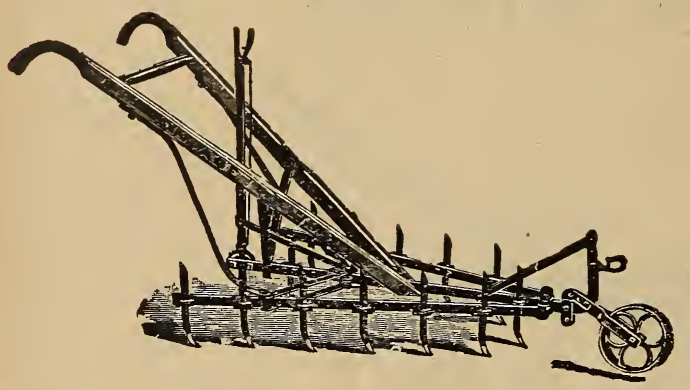

\section{DIAMOND TOOTH CULTIVATOR.}

As plainly shown in cut, the teeth are diamond shaped, with a small cultivator tooth forged on one end-steel, of course. For very close work, every other tooth can be quickly removed. Cultivating width, when equipped with lever expander, 34 inches.

Price, \$5.25.

\section{THE YANKEE DISC HARROWS.}

By using buffers on the inside ends of the gangs of these harrows, the friction caused by the side thrust is largely overcome, reducing the wear and draft to the smallest possible amount. The draft is directly from the axle and so arranged that the harrow is perfectly balanced, all the disks cutting uniform depth with heavy or light driver and always flexible. It is the only harrow that tills the entire width of the cut leaving no ridge in the center or between the gangs not cultivated. The gangs not being connected by a bar or otherwise, act entirely independent. The angle of the gangs can be changed quickly by the hand lever whether the team is at rest or in motion.

No. 1 , for one horse, 8 steel discs, 16 inches diameter, cuts 4 feet wide, plain.

No. 4, for two horses, 12 steel discs, 16 inches diameter, cuts $6 \frac{1}{2}$ feet wide, plain.

No. 5 , for two horses, 12 steel discs, 18 inches diameter, cuts $6 \frac{1}{2}$ feet wide, plain.

No. 6, for two horses, 12 steel discs, 20 inches diameter, cuts $6 \frac{1}{2}$ feet wide, plain.

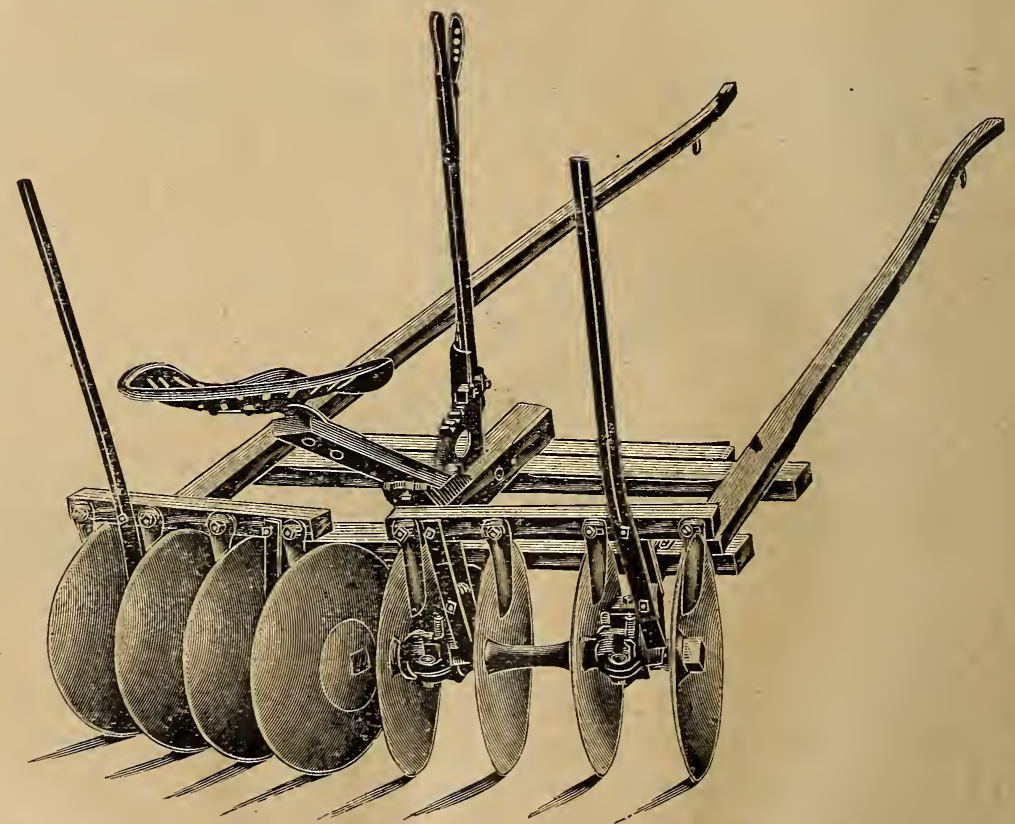

ONE HORSE HARROW.

PRICE ON APPLICATION. 


\section{SATTLEY DISC HARROWS.}

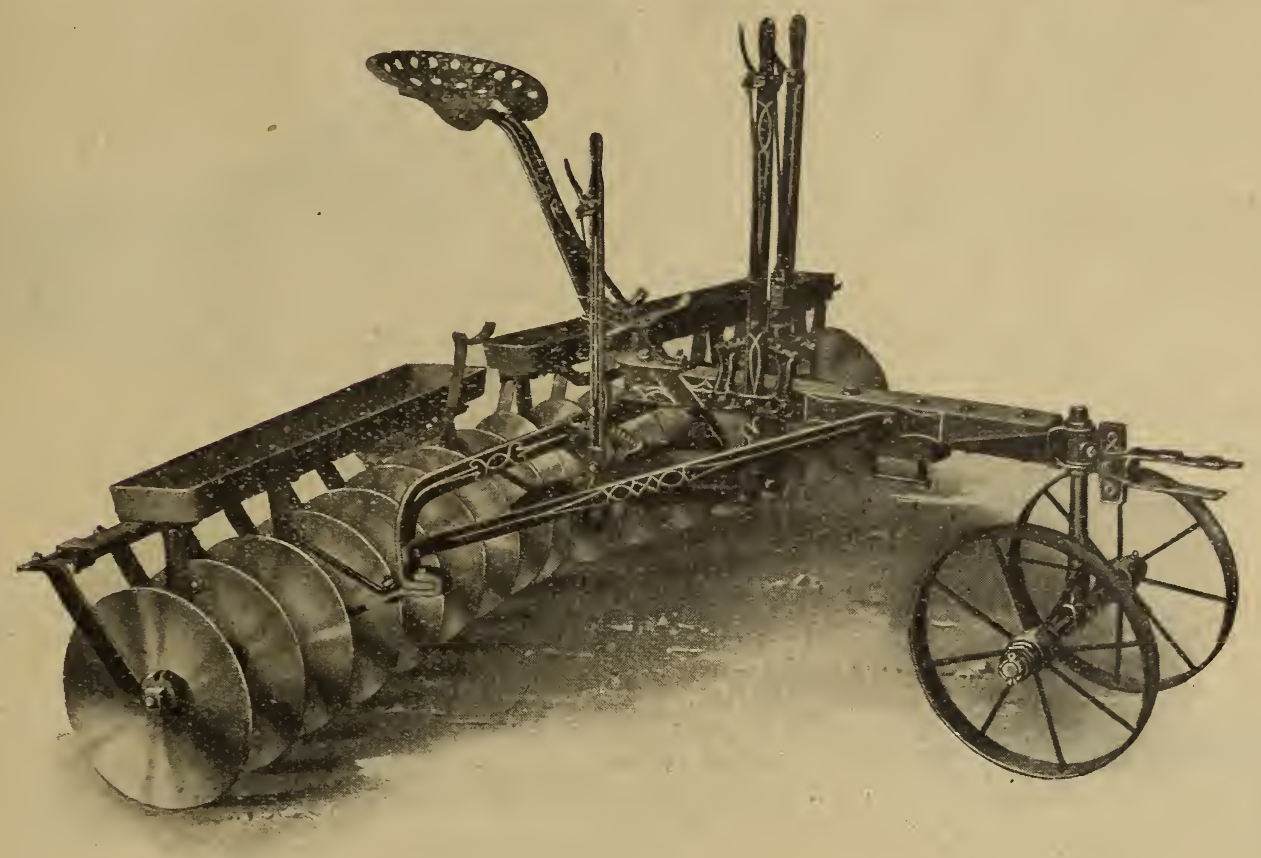

PLAIN DISC (showing pole truck attachment).

This attachment may be applied to any disc harrow made at an added cost of \$5.00.

The frame is of heavy forged steel throughout, not a single casting being embodied in its entire construction. It is simpler, stronger and much more capable of withstanding the severe racking and jarring than are those with numerous cast joints and connections to jar loose. The necessary flexibility to permit the gangs to rock and conform to the unevenness of the ground is secured in the strongest and simplest manner possible. As may be seen in the cut, the ends of the crossbar of the frame are bent forward at right angles and fit into the looped end of the standard braces, the two being bolted together by heavy bolts. There is sufficient play

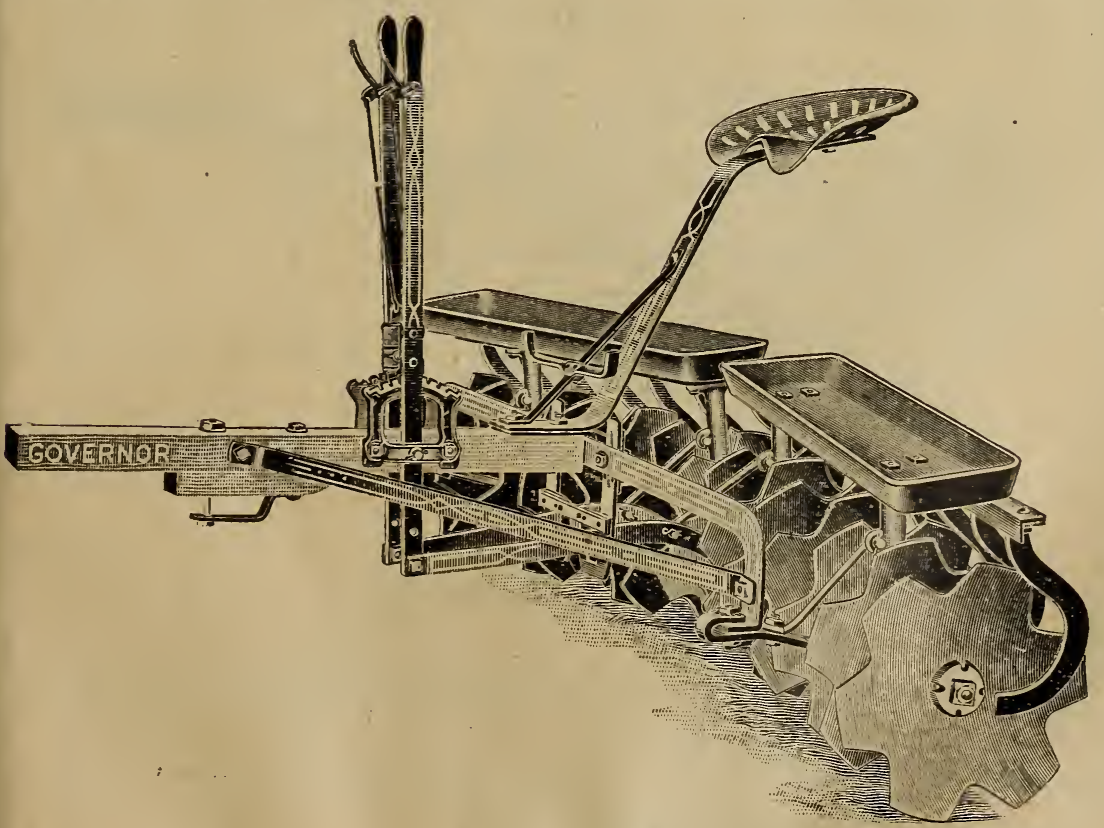
left in these joints to permit the gangs all the freedom of $\mathrm{m}$ ove ment demanded without resorting to clumsy and ill-fitting castings. The scraper bars are the wellknown "oscillating" type, which hold the scraper blades in constant contact with the dises by spring tension. By pressure upon the foot lever the scrapers can be held to their work at any point upon the dises, or made to sweep across the entire face from center to rim. The bearings are kept lubricated from large oil chambers, which ex tend from top to bottom within the standards. Having the lubricating device protected in this manner does away with the breakage or injury which is always possible with the exposed oilers used on some harrows.

A 11 Sattley Harrows have oiled maple bearings. 


\section{THE “KEYSTONE” ADJUSTABLE WEEDER.}

The "Keystone" is the only weeder that is adjustable to depth and width. It can be used as a shallow cultivator, working close to the plants, between the rows, until the crops mature.

Will not clog. The long, curved, spring teeth are so placed and shaped that clogging is impossible.

Can be weighted down and teeth will stand 150 pounds pressure.

Can be expanded to $7 \frac{1}{2}$ feet and narrowed to 30 inches.

Price ori application.
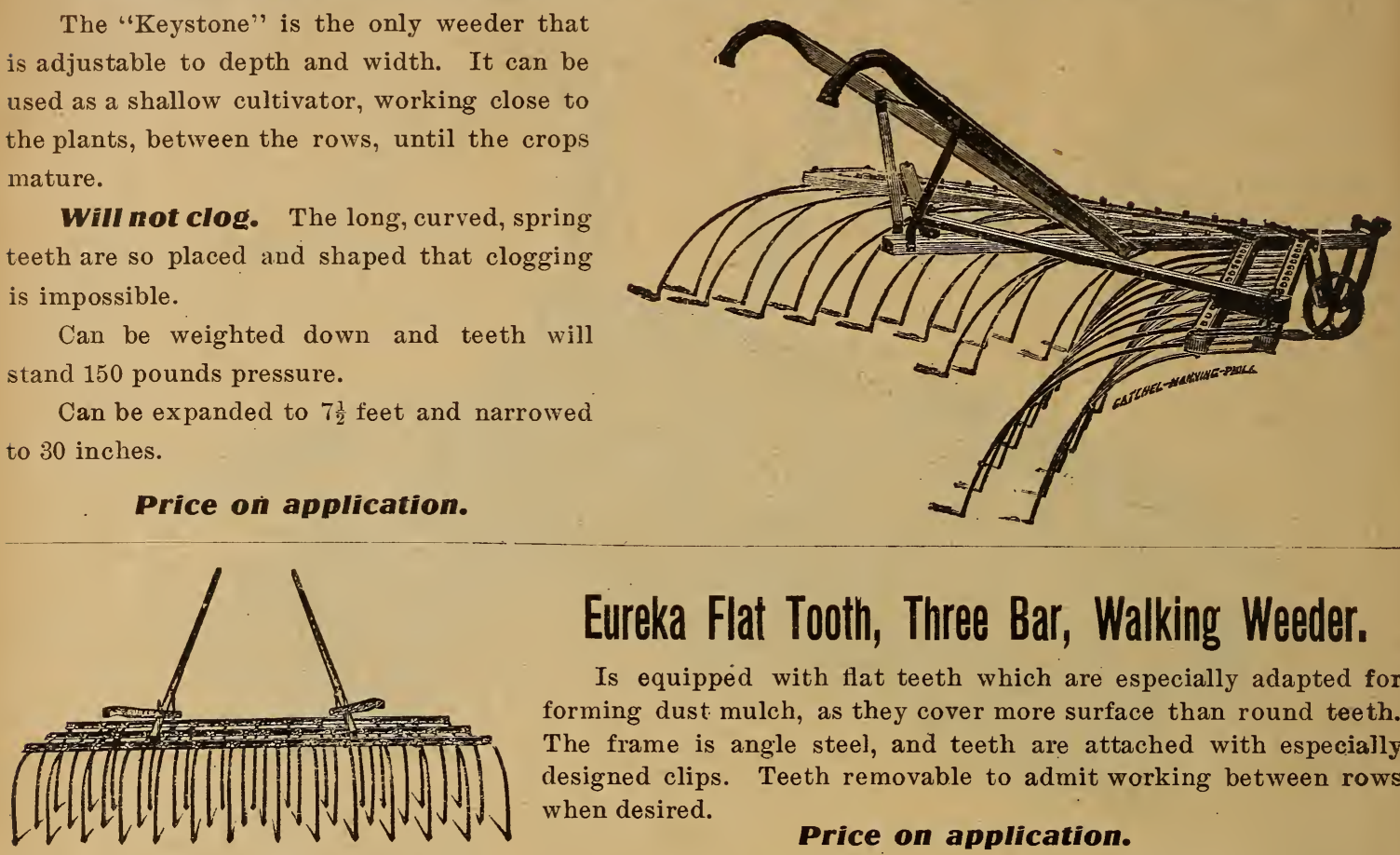

\section{Eureka Flat Tooth, Three Bar, Walking Weeder.}

Is equipped with flat teeth which are especially adapted for forming dust mulch, as they cover more surface than round teeth. The frame is angle steel, and teeth are attached with especially designed clips. Teeth removable to admit working between rows when desired.

Price on application.

\section{EUREKA \\ FLAT · TOOTH \\ MULCHER \\ AND SURfaCe CULtivator.}

The idea of dust mulch is not new, but has been used with great success for a number of years.

During the growing season, and especially in dry periods, a crust forms on the top soil, hardens and cracks and allows the moisture around the roots of the plants to escape, causing a failure or decreased yield of the crop. It is therefore important to prevent this crust forming. It is accomplished to the best advantage by the use of the Eureka Mulcher, which forms a blanket of loose soil, prevents baking and hardening, and conserves the moisture.

The Eureka flat teeth are especially adapted for forming dust mulch as they cover more of the surface of the soil than teeth with round points.

If desired to work only between rows, any number of the teeth can be quickly removed.

The teeth are controlled by the lever so as to merely scratch the surface or can be

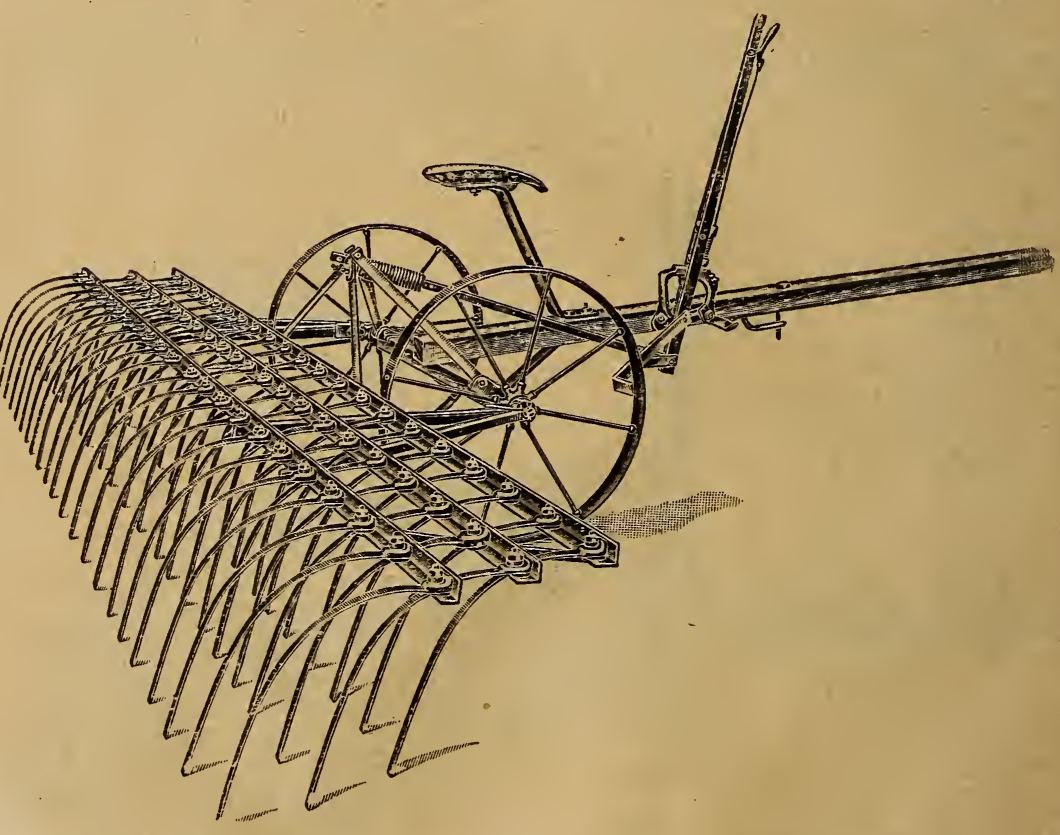
forced into the ground any reasonable depth, where they are assisted in accomplishing proper results by the use of a successful pressure spring. A foot lift attachment is used in conjunction with the hand lever, by which the teeth and head are very easily raised at any time desired.

A grass and grain seeder attachment can be furnished, which attachment may be regulated to sow any amount per acre desired.

Price on application. 


\section{THE HALLOCK WEEDER.}

The attention of farmers is called to the great saving effected in time and labor by using the Hallock Weeder. As many as eight rows can be worked at one time.

One of the best machines for level cultivation, will not injure the roots of growing crops, but kills out the weeds, and leaves a fine mulch on the surface of the ground.

\section{Price on application.}

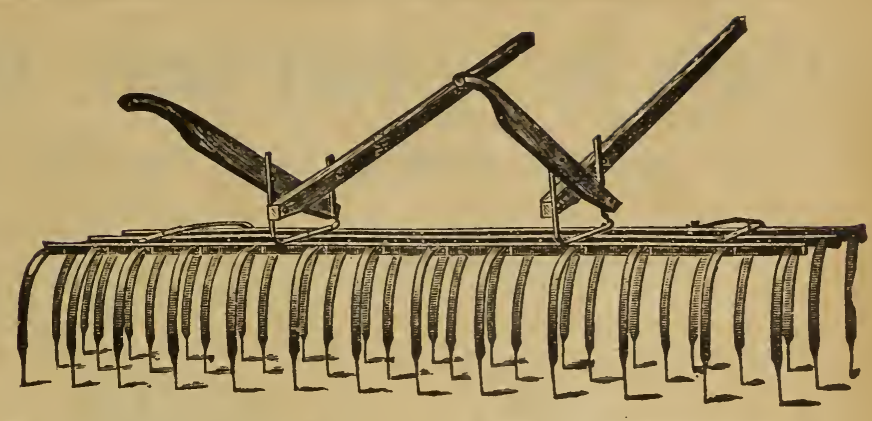

\section{"NEW MODEL CENTENNIAL."?}

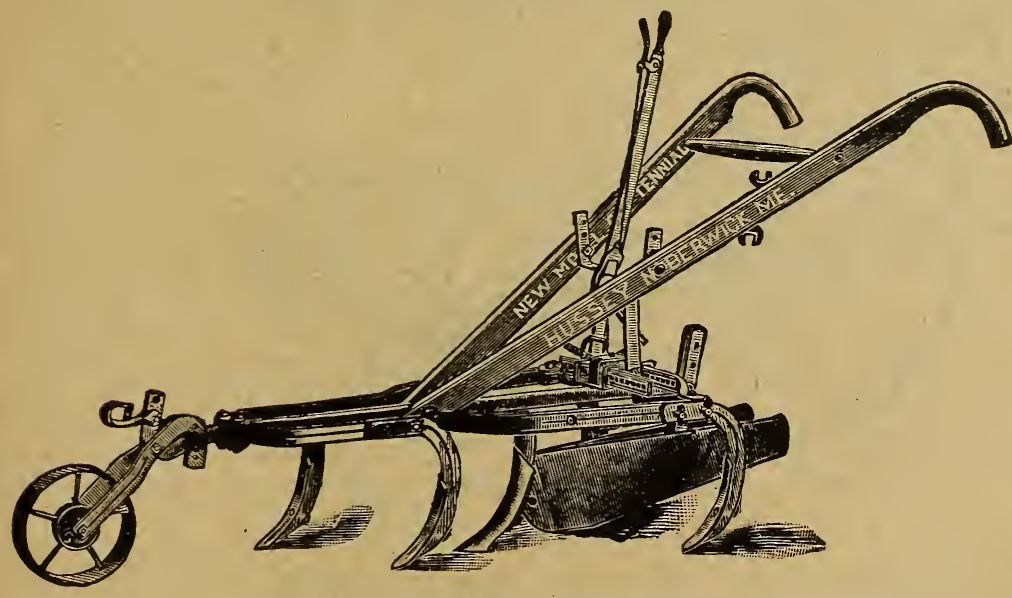

No. 1 NEW MODEL CULTIVATOR.

No. 8. An extra implement at small additional expense.

The regular 5-tooth Horse Hoe, Cultivator and Coverer combined (No. 1), or an 8-tooth Pulverizer, on same frame.

The long frame of the "New Model Centennial" allows us to add the extra teeth without danger of clogging.

No. 8.

has 8 l-inch points, long wings and lever.

No. 1.

has 5 3-inch points, longwingsand lever.

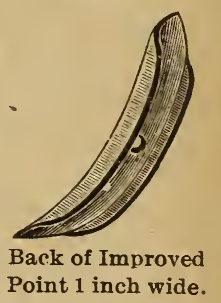

The "New Model Centennial" Horse Hoe, Cultivator and Coverer combined, has long been recognized as an implement of unusual merit. The simplicity and fewness of parts required for changing it over to suit the various kinds of work to which it is adapted, and its unique and very efficient expansion lever are among the reasons for its popularity.

An important improvement has recently been made in the one-inch reversible points for this cultivator. The illustration at the right shows the improved point with the strengthening flanges. It will be readily seen that the flanged point is not only much stronger than the old style, but the flanges prevent the point from swinging around on the standard in rough and rocky land.

Equipped with eight of these narrow flanged points, the No. 8 is one of the very best pulverizing cultivators on the market.

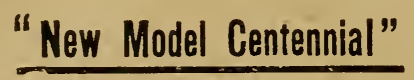

No. 8

As a PULVERIZING CULTIVATOR

with very FINE TEETH.

HAS 8 I-INCH REVERSIBLE FLANGED POINTS

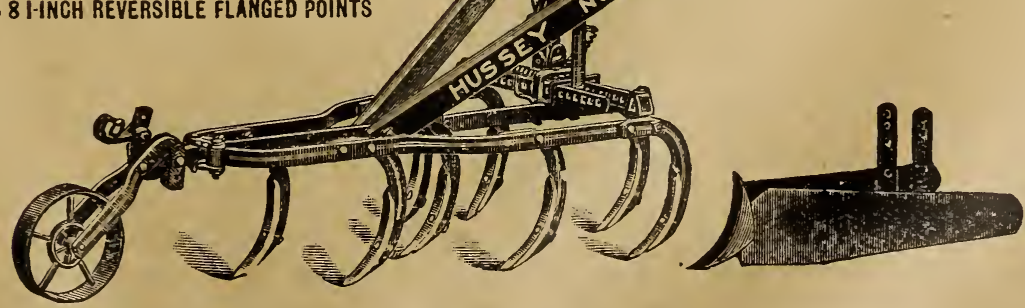

No. 8 as a PULVERIZING CULTIVATOR with FURROWING WINGS DETACHEO.

$$
\text { PRICE-NO. 1, \$7.00; No. 8, \$8.00. }
$$




\section{SATTLEY'S NO. 40 PIVOT WHEEL, SPRING TRIP CULIIVATOR.}

\section{Strong-Simple-Easily Operated-Readily Adjusted.}

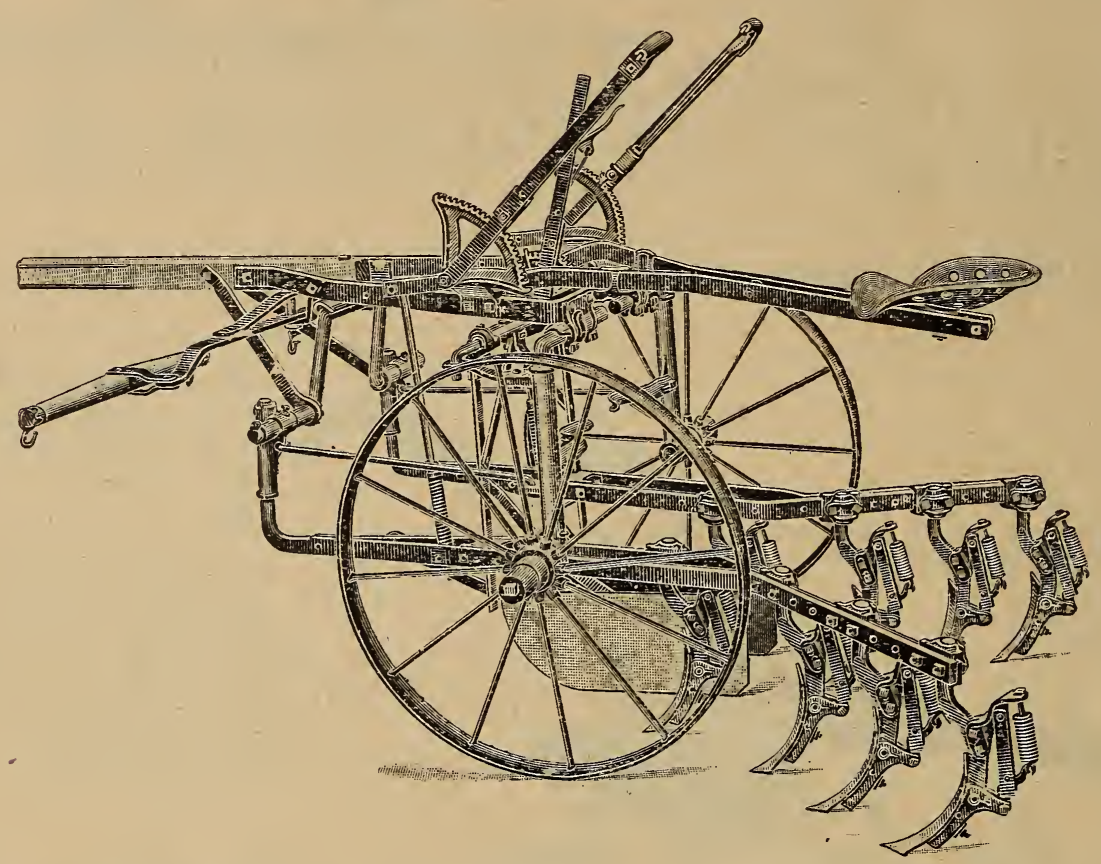

REASONS FOR BUYING THE SATTLEY CULTIVATOR.

Very low and strong wheels.

Heavy concave tires.

Long wheel boxes.

Dust proof and self oiling boxes.

Wheels easily pivoted.

Frame solid bar steel.
Cultivator made entirely from steel and malleable iron. Gangs adapted to stand heavy strain.

Gangs adjusted from seat.

Cultivator turns in small space.

Width of rows quickly changed.

Abundant clearance.

The Sattley is particularly adapted to the requirements of truck gardeners, potato farmers or general farmers, and is an especial advantage in cultivating hilly ground or very crooked rows. It is constructed entirely of steel and malleable iron. This naturally gives it extreme strength. The construction throughout is so designed that each piece and part assists in bracing and strengthening the general make-up of the implement. The frame is of one solid piece of heavy bar steel. There are no bolted corners or connections to work loose or to spring under excessive strain. The wheels being very low (32 inches), naturally compel the cultivator to respond very quickly to the guiding of the foot stirrups, and the wheels are very easily guided because the pivoting points of the axles are practically opposite the center of the wheels and operate upon hard steel bearings. The width can be quickly changed as required for cultivating rows of any distance from 28 to 48 inches apart.

\section{EQUIPMENT.}

The No. 40 is equipped regularly with eight spring hoe standards, with $2 \frac{1}{2}$-inch double edge points, which are exceptionally well designed and operate perfectly.

Disc Attachment. This attachment is used for ridging, and also for turning the soil from growing plants, or for covering. The discs are attached to the inside of each gang and work up close to the plants. The discs may also be reversed and used for hilling, in which case a tie rod is used, which is furnished with the cultivator, and which will keep the cultivator gangs from spreading. They are a great advantage for the purposes for which they are intended. 


\section{OLIVER RIDING CULTIVATOR, NO. 1.}

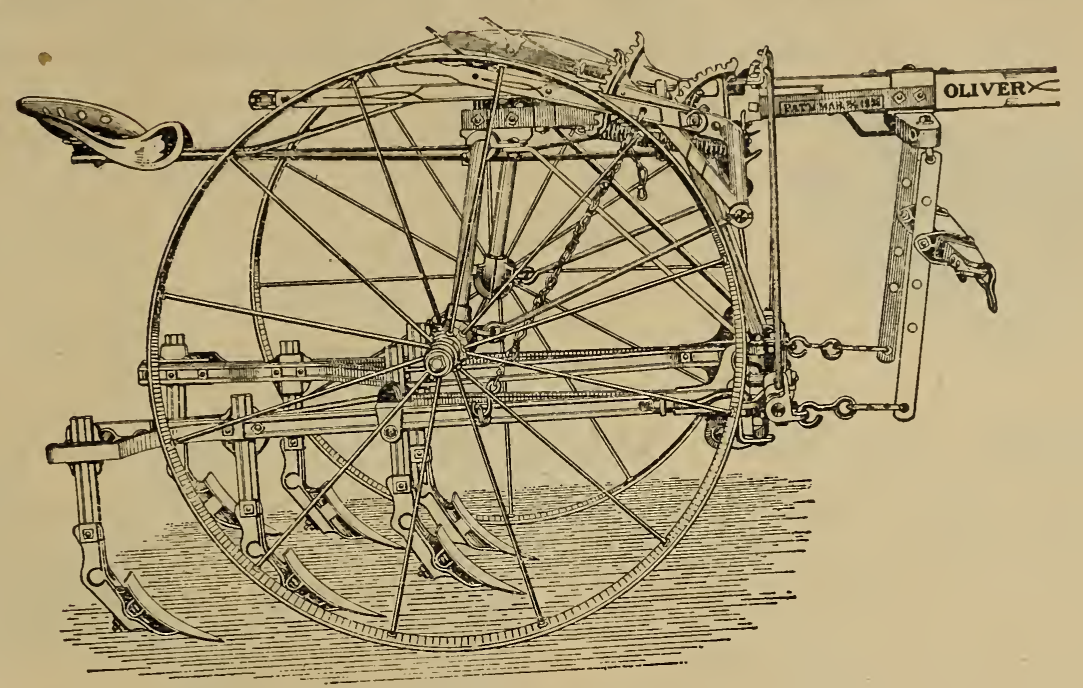

This cultivator has not only satisfactorily met factory tests, but it has gone out in the field and shown what it could do, and how well it could do it, and having been on the market and in actual service during four entire seasons, the field tests have been most extensively made.

The pivotal seat bar guides the frame and gangs, making unnecessary the use of hand lever, or complicated pivotal foot levers. The guiding of the cultivator, independent of the horses, is completely under the operator's control and the seat bar guide also automatically keeps the cultivator from drifting on hillsides, making it one of the easiest guiding cultivators made.

Price on application.

\section{"IRON AGE" RIDING CULTIVATOR.}

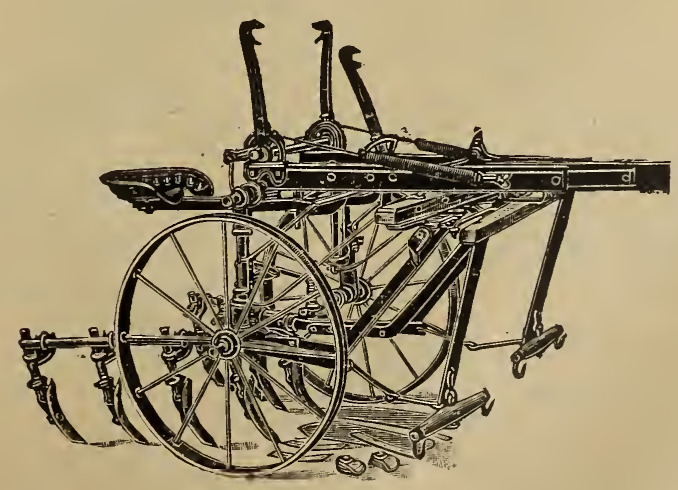

Pivot wheels-ball-bearing-gang-adjusting lever, strong steel wheels, and, although it is light and simple in construction, it is very strong, and possesses advantages not contained in far more complicated tools.

\section{Price on application.}


THE KING OF THE CORN FIELD

\section{Corn Planter and Fertilizer Distributor.}

\section{PLANTS CORN, BEANS, PEAS, BEETS AND OTHER SEEdS OF LIKE SIZE.}

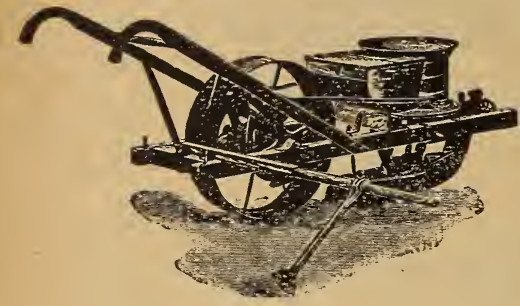

This planter is perfectly adapted to every requirement; durable and simple in construetion, not liable to get out of order, and is arranged to drop any desired quantity of seed or fertilizer at a time, at equal and various distances apart, in hills or drills of uniform depth. The seed-dropping device is positive, never misses or skips a hill.

Price, $\$ 20.00$.

Descriptive Catalogue mailed on application.

\section{ECLIPSE CORN PLANTER}

\section{And Fertilizer Distributor.}

For Planting Field or Ensilage Corn, Beans, Peas or Beet Seeds in Hills or Drills.

Price, \$20.00.
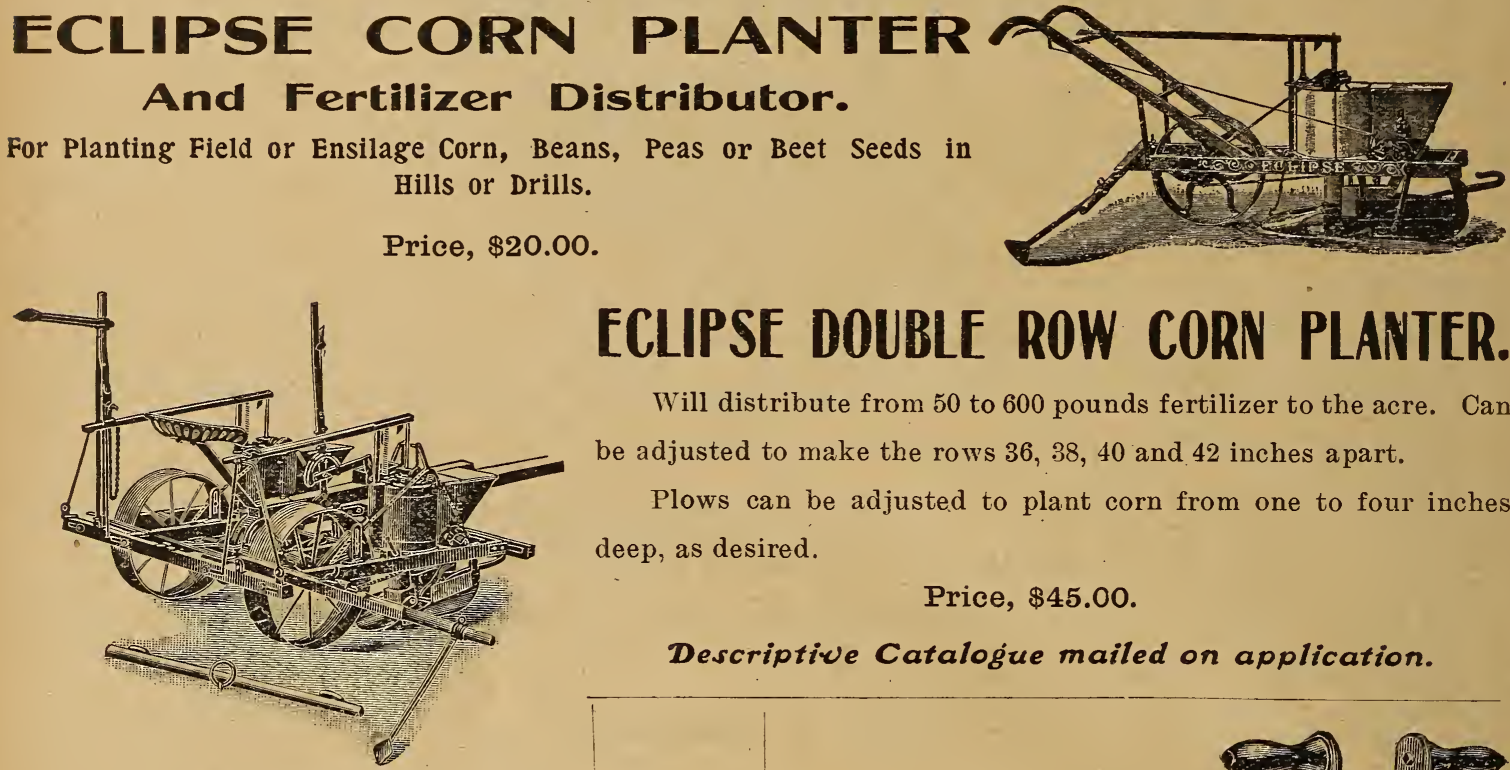

ECLIPSE DOUBLE ROW CORN PLANTER.

Will distribute from 50 to 600 pounds fertilizer to the acre. Can be adjusted to make the rows $36,38,40$ and 42 inches apart.

Plows can be adjusted to plant corn from one to four inches deep, as desired.

Price, \$45.00.

Descriptive Catalogue mailed on application.

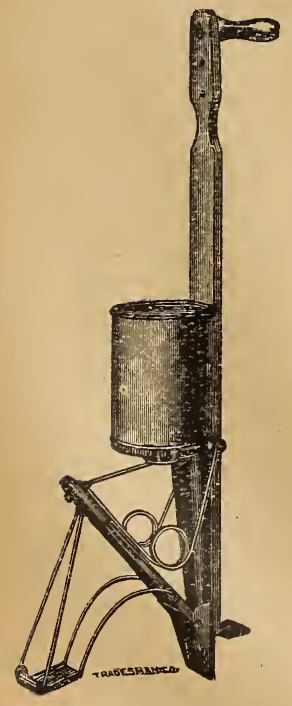

\section{Acme Rotary}

\section{ACME}

Rotary Automatic Hand

Corn Planter.

For planting corn, beans, peas and similar seed.

Capacity of hopper, two quarts.

Price, $\$ 1.75$.

\section{Two-Hand}

\section{Corn Planter,}

(Shown with Fertilizer Attachment.)

Similar in construction and use as the Acme Automatic Planter, but with fertilizer attachment.

Price, \$2.50.

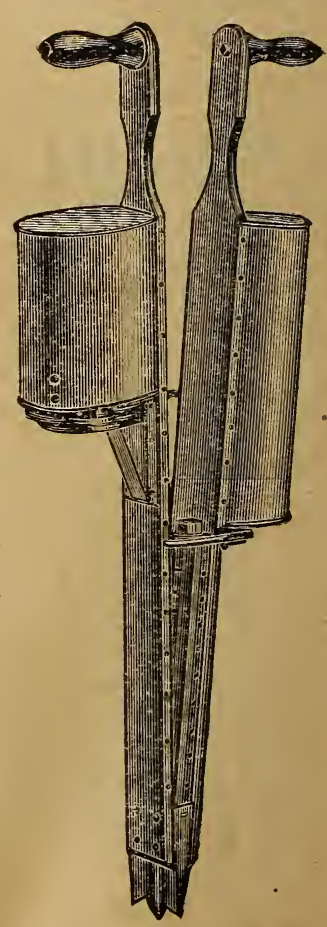




\section{SATTLEY SINGLE-ROW CORN PLANTER (Hill Drop or Drill),} WITH FERTILIZER ATTACHMENT.

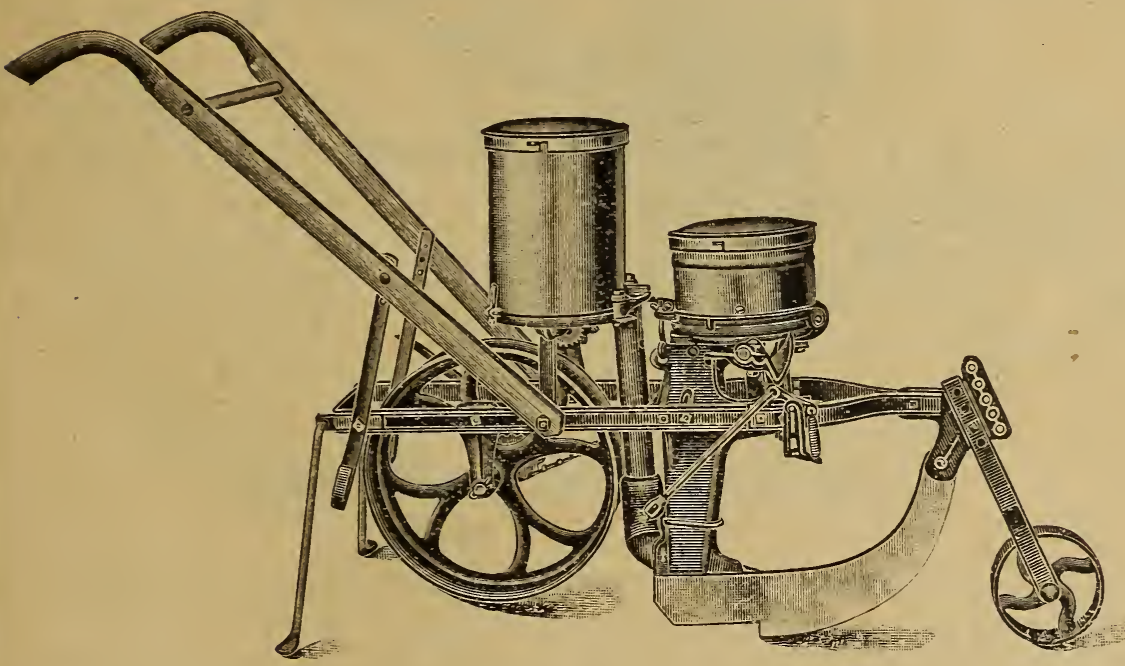

This Corn Planter embodies a number of advantageous features never before attempted in a one-row planter. The method of providing for both hill and drill drop is the simplest and most convenient to be found on any planter. It is built for strength, combined with comparative lightness. It has a rigid one-piece frame to which all parts are securely bolted and braced. The heavy steel runner is extra long, with an easy curve that prevents its becoming clog ge d with trash. The gauge wheel is adjustable for depth as desired. The large press wheel acts also as a drive wheel, and its very broad face provides abundant traction for operating the fertilizer and dropping mechanism. Both flat and edge drop plates in large, medium and small sizes are furnished regularly with each planter. Special plates can be furnished at small extra cost for planting peas, beans and similar seeds.

Price, \$20.00.

\section{SATTLEY TWO-ROW CORN PLANTER,}

\section{WITH FERTILIZER ATTACHMENT.}

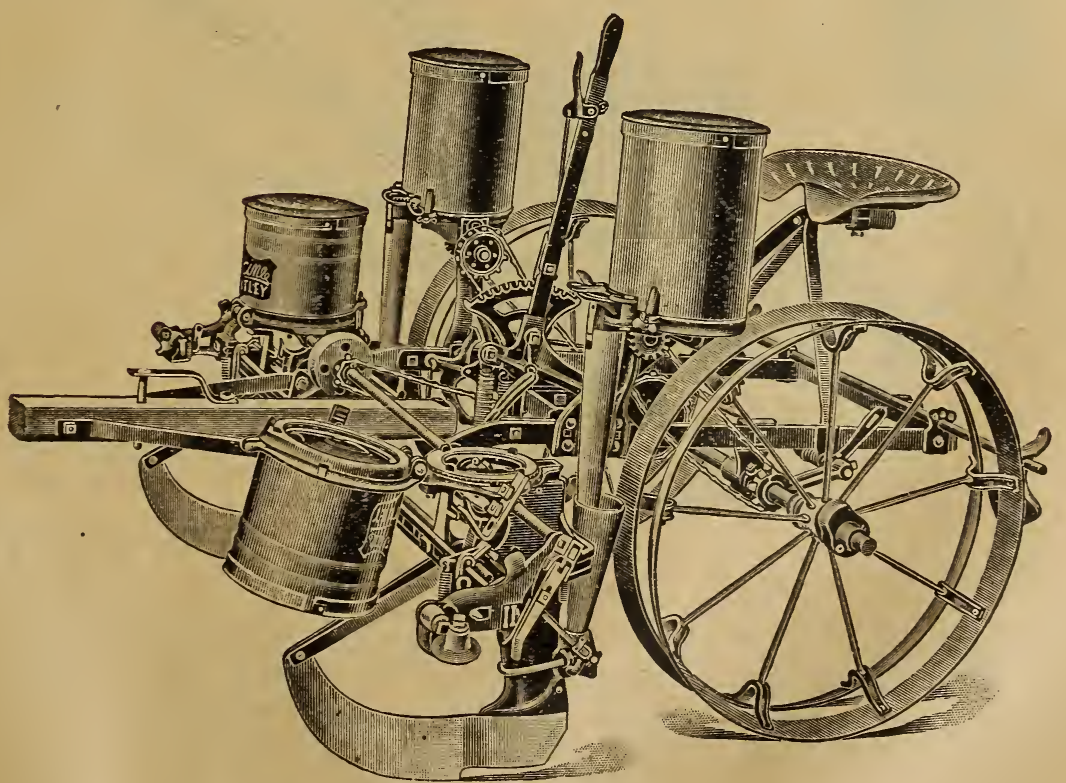

Similar in construction to the single row planter, but having twice the capacity. Especially recommended where a large acreage is to be planted. 


\section{EUREKA CORN PLANTERS.}

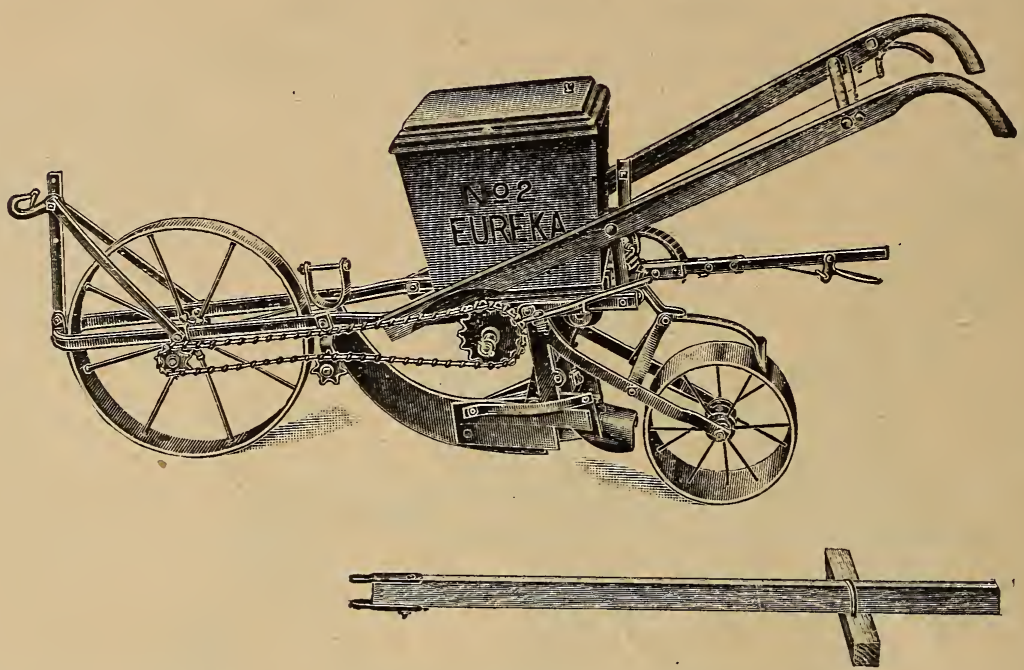

The material used in constructing these planters is almost entirely steel and malleable iron, making:a long lived planter with small cost for maintenance. Lock steel chain is used.

Nos. 2, 3 and 4 planters have interchangeable parts, and the general description applies to them alI.

Eureka No. 2, Price, \$20.00.

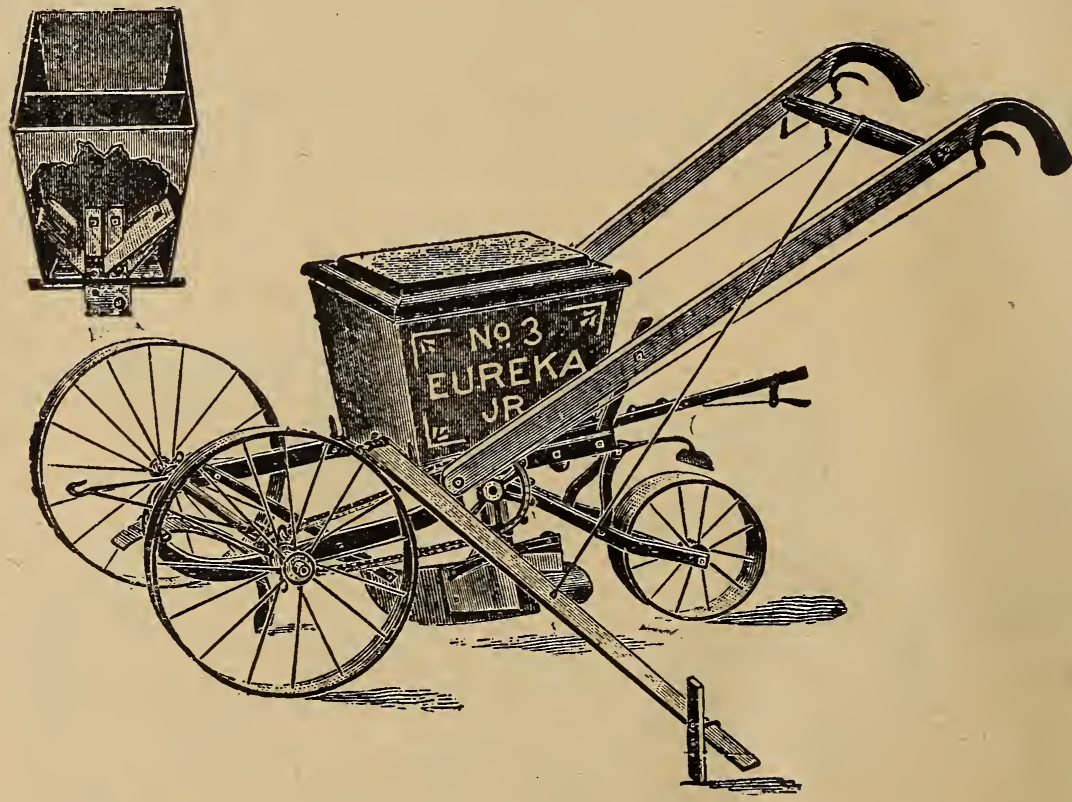

The seed droppers have holes of various sizes with which to deposit seed in the furrows. Brushes remove all surplus seed from the dropper, and prevents any skipping. These planters will drill in continuous rows or drop automatically in hills. Nos. 2 and 3 only are equipped with row checking device.

Will plant any ordinary sizes corn or beans, and will plant them alternately (first a hill of corn and then a hill of beans), if desired.

Special attachment may be had to sow small seeds, such as turnip, onion, etc. 


\section{EUREKA CORN PLANTERS-Continued.}

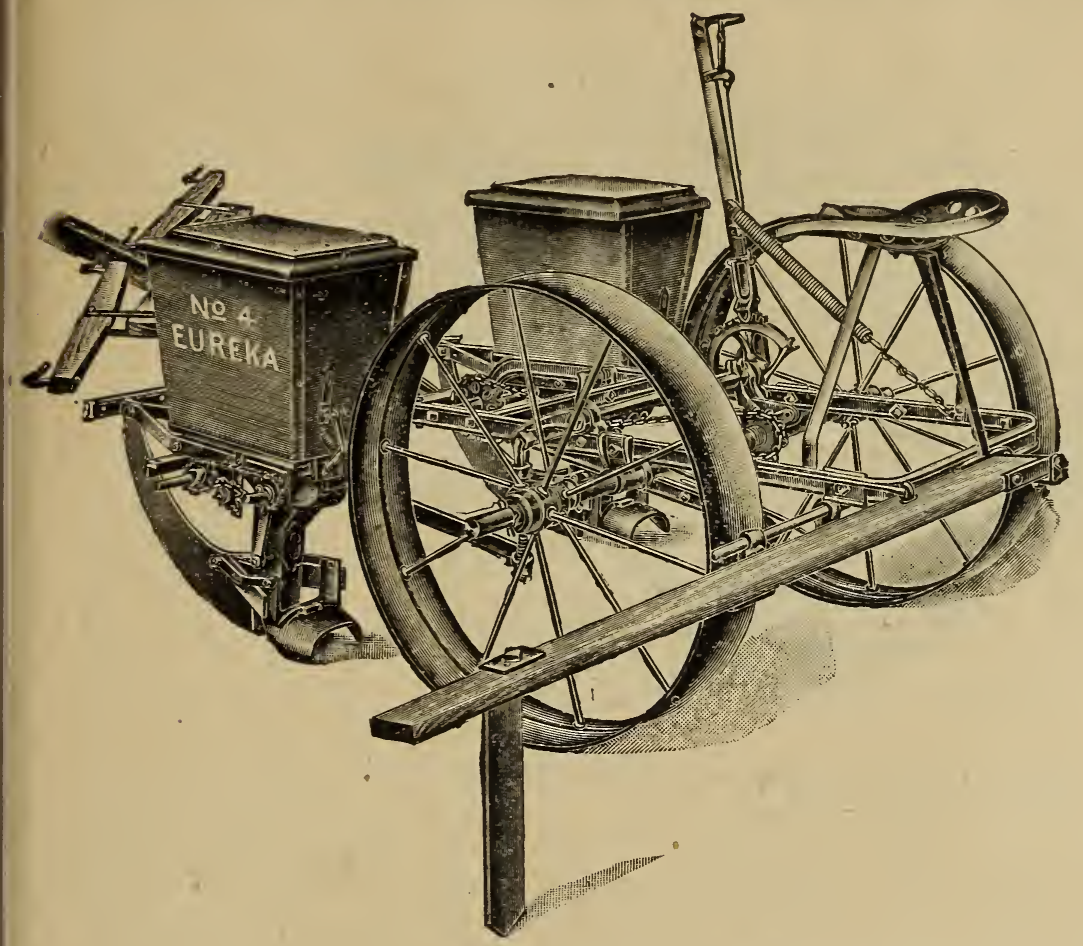

(See previous page.)

When desired, two kinds of seed may be carried separately in the Eureka hopper at the same time, and can be dropped alternately. Fertilizer does not come in contact with, but is deposited on each side of, the seed.

The Wizard Force Feed is positive and adjustable from 115 to 800 pounds per acre, and is unquestionably the best fertilizer feed manufactured, as it will handle ashes and plaster as well as fertilizer.

Eureka No. 4, Price, $\$ 40.00$.

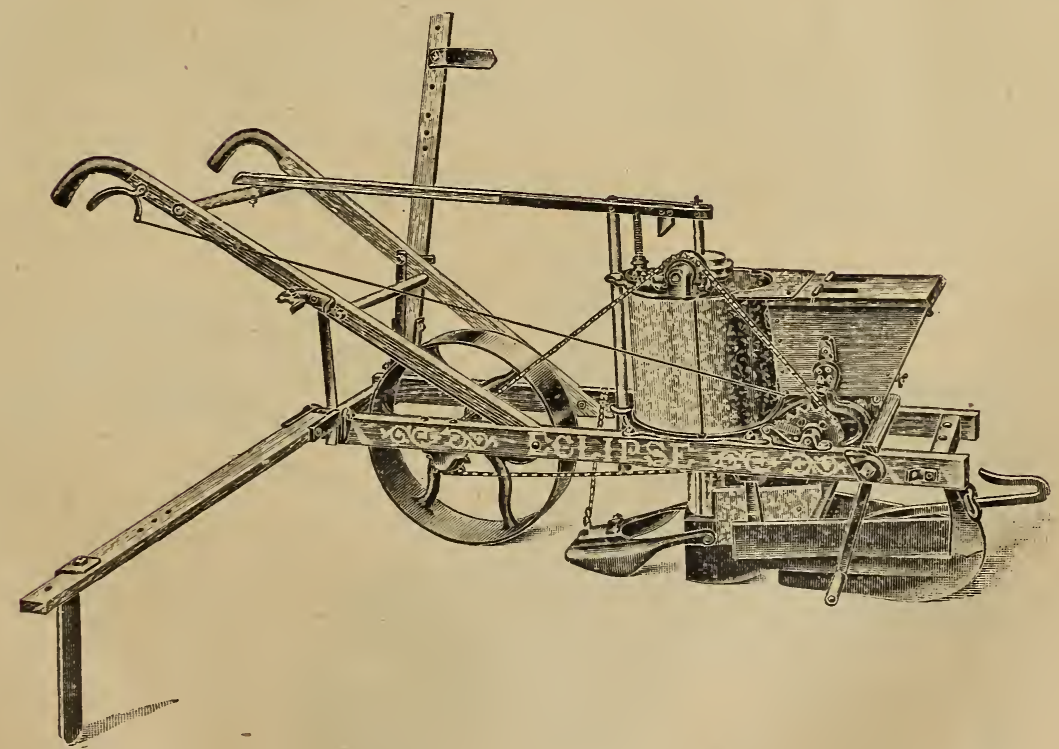

The Eureka Eclipse has been on the market for the past twenty-five years, and during that time has established an enviable reputation. Its working qualities are accurately described in the Nos. 2, 3 and 4 Eureka planters. 


\section{EUREKA POTATO PLANTERS.}

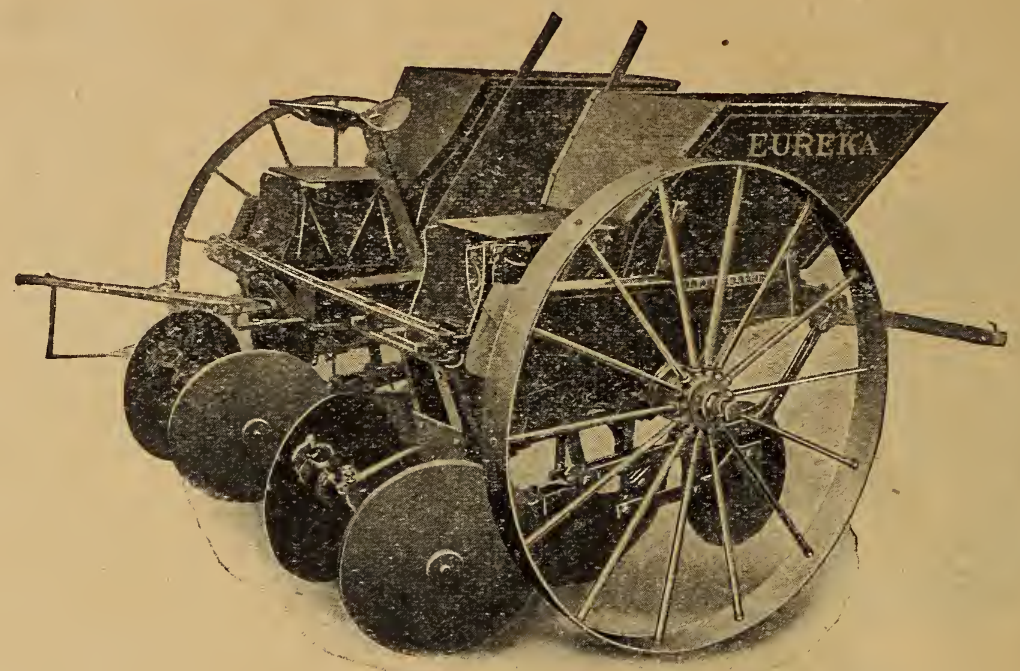

Disc openers supplied when ordered.

All Eureka planters are light weight. Main frame is made entirely of steel. Lightest draft. Wheels are higher and have wider tire than other makes. Under perfect control of driver. Does not require two men. Seed pickers in plain view. No guessing about accuracy. Plow placed directly under axle, and always runs at uniform depth. Covering discs close to plow. One lever puts machine in and out of gear, and raises and lowers plow and discs. Planter is perfectly balanced. No neck weight. Seed hopper feeds automatically to picker box. Pickers are special construction and perform more accurate planting and uniform spacing than other styles. Pickers do not squeeze, crush or bruise the seed. Sprockets are easily attached to change the distance of dropping seed. All working parts of planters are in plain view of driver. Eureka planters are sold with and without fertilizer attachment.

\section{No. 14, two row, two horse, Price, \$100.00.}

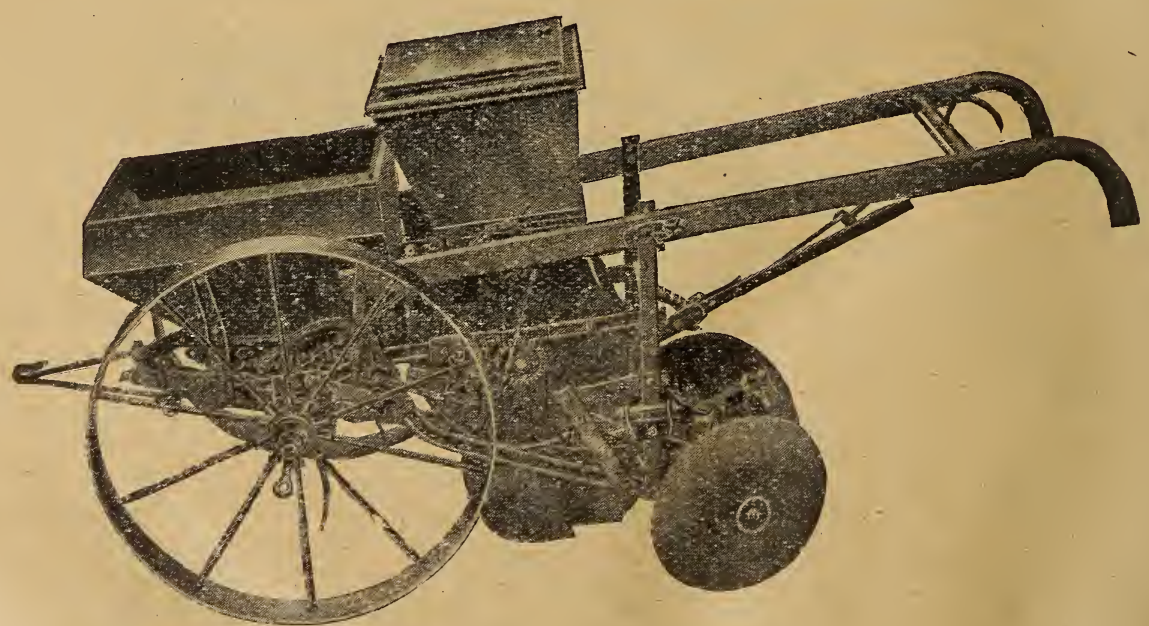

Identical in construction to the two horse, but is especially designed for use with one horse.

No. 9, one horse, Price, $\$ \mathbf{4 5 . 0 0 .}$ 


\section{Eureka Potato Planters-Continued.}

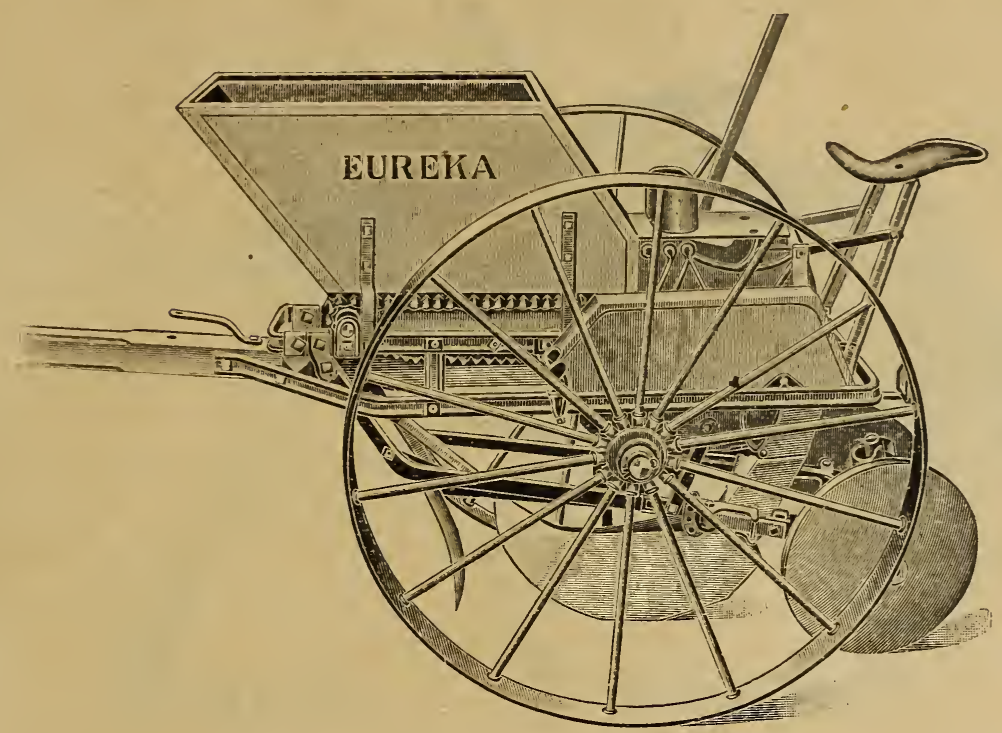

No fertilizer comes in contact with the potato seed. The Eureka discs are so arranged that they allow the seed to be placed, and carefully covered with soil, where it is impossible for the fertilizer to come in contact with seed, consequently there is never any loss from being burned with fertilizer. A valuable feature peculiar to this line of planters.

\section{No. 11, one row, two horse, Price, \$67.00.}

Read what delighted and satisfied customers, who used this planter last year, say about the No. 11.

FUREKA MOWER Co.,

Foxcrofre, ME., Dec. 2, 1913.

Utica, N.' Y.

Gentlemen:- Iy Eureka Potato Planter has planted 220 acres with a cost of only 37 cents for repairs. The potatoes have always come well when the seed and season were good and the yield averaged well.

I think I never saw a tool so well made. I like the Eureka Planter because I am in touch with the high cost of repairs of three other makes of planters.

Yours truly,

E. D. Coluins.

UNITY, ME., Dec. 5, 1913.

EUREKA MoWER Co.,

Utica, N.'Y.

Gentlemen:-I planted 24 acres of potatoes this year with your No. 11 Eureka Potato Planter, and will say it is the best planter I ever used. It mixes the fertilizer with the soil in a way that it never burns the seed. It is a perfect working planter in every respect.

Yours truly,

D. T. WALton.

Eureka Mower Co..

A UGusta, ME., Dec. $8,1913$.

Utica, N. Y.

Gentlemen :-I have sold several of your No. 11 Eureka Potato Planters the past season with satisfactory results. I am looking forward to a good trade on them the coming season.

Yours truly,

J. E. MCCORMICK \& SON.

EUREKA MOWER Co..

SAxgeryille, Me., Dec. 3, 1913.

Utica, N. Y.

Gentlemen:-The No. 11 Eureka Potato Planter, which I purchased last spring, gave splendid satisfaction. Iy potatoes never come better and its simplicity and accuracy is a strong point in favor of your planter.

I recommend it to all potato growers.

Yours truly,

E. J. PRINCE. 


\section{THE "IRON AGE" (Improved Robbins) POTATO PLANTER.}

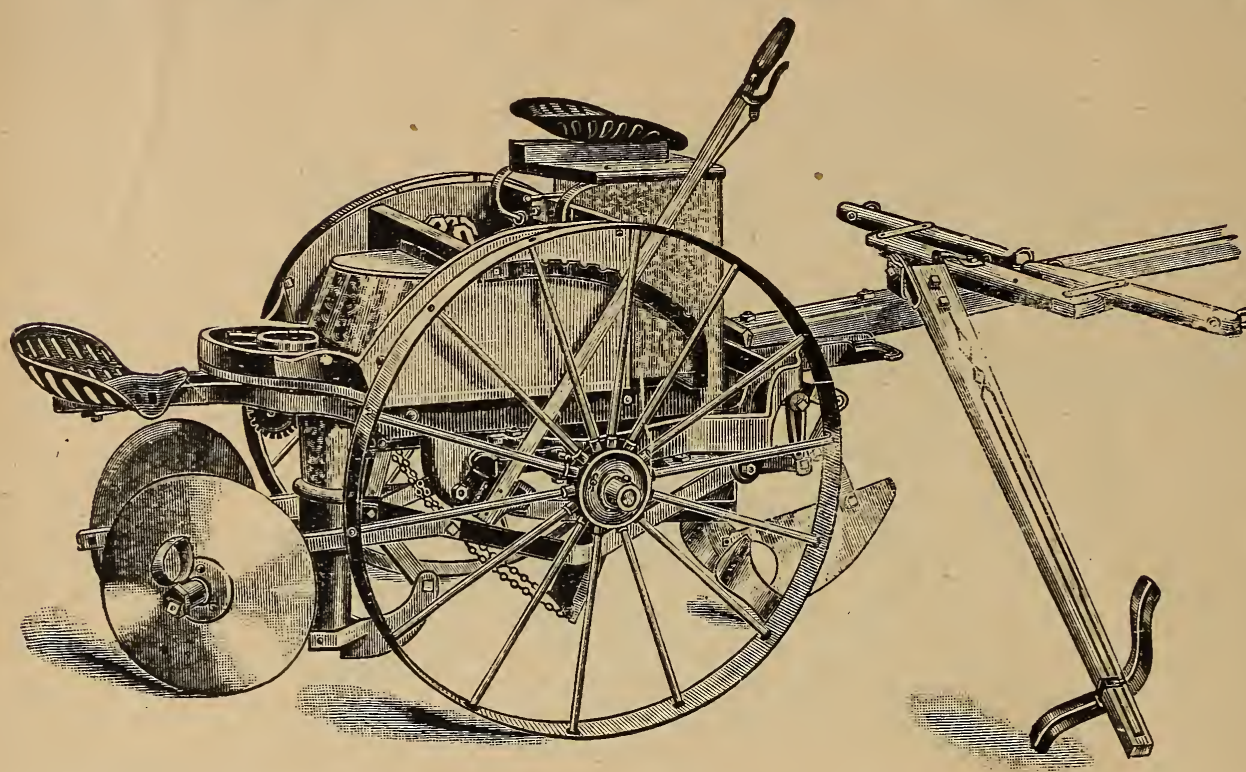

This planter is one of the most thoroughly constructed machines offered to the farming public. It is carefully made of the very best materials and consequently is strong, durable and thoroughly practical. It does not injur e the seed, although it is all $\mathrm{h}$ and led automatically. It places every seed piece exactly as you want it. It sows fertilizer at the same time, but none of it where it touches the seed. It is lig h weight, lig h t - d raft, strong, compact and is easy on the horses. With the boy on the rear seat you can be absolutely sure that a seed piece is in every place and one only.

Plain or with Fertilizer Attachment.

Price, No. 1.-Potato planter with fertilizer distributor (plow with shield), \$70.00.

\section{IMPROVED POTATO HOE,} Furrower, Marker and Coverer.

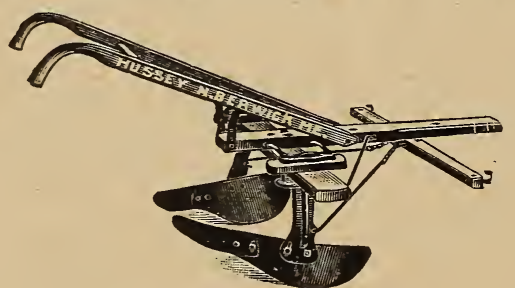

The Improved Potato Hoe is, as its name indicates, especially adapted for hilling potatoes, banking celery, and also as a coverer. It is much used as a "marker" for different crops, making the rows parallel and equally distant.

Price, \$7.00.

$$
\text { 6\%. \& W."9 }
$$

\section{IMPROVED 20-INCH DISC POTATO HOE.}

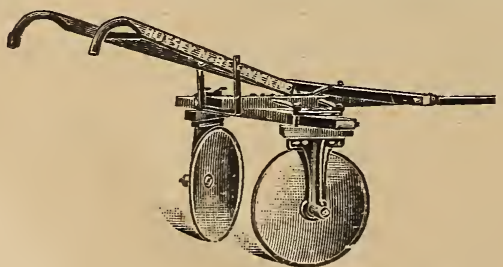

Considered by many farmers the best hoe made for hilling and covering. A distinct departure from the styles commonly in use, the large discs doing smooth and perfect work.

Price, $\$ 9.50$.

\section{EUREKA POTATO CUTTER.}

\section{Cuts Uniform Size. Prevents Waste of Seed. Reduces Labor.}

The Eureka Potato Cutter is the only machine made that will save the potato grower so large an amount of the labor and eliminate so much of the unpleasantness and drudgery of cutting seed. It meets the requirements of the most exacting by cutting the seed uniformly in size and shape, producing a $\mathrm{size}$ that is approved by the most successful growers and saving the

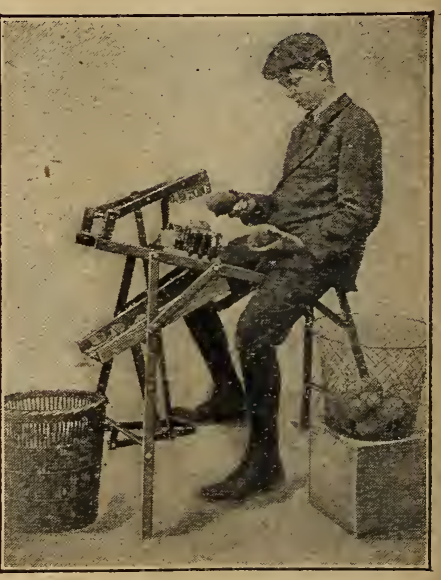
w a ste occasioned

by the irregularity of hand cutting. By operating with the foot, both hands are free for feeding. Three knives are placed crosswise and one lengthwise, with spring pressure guides on both sides, making a pocket into which the potato is easily placed in the position desired, and which centers the potato on the knives when the pressure block is forced down.

The Eureka will cut a bushel of clean and uniform seed in five minutes.

Price, \$8.75. 


\section{THE WORCESTER-KEMP MANURE SPREADER.}

\section{Suits All Classes of Farmers and Every Variety of Farming.}

There are no rakes, combboards or other obstructions to pitch over in loading, from the rear end. It is built low to the ground, but has high wheels, roller bearings, and is guaranteed to draw easier than any other machine, the weight of load and thickness of spread considered.

The Worcester-Kemp is one of the best designed, strongest, simplest and most perfect working spreaders in the world. Very little machinery and easy draft assured. Patented jointed end gate makes a tight box and acts as a pulverizer when the load is being spread. Direct draft through draft rods to rear axle. Operated by a single lever at the driver's right hand.

Special gears furnished for spreading ashes or line and for spreading thicker than twenty loads to the acre. A drill attachment is furnished for market gardeners for drilling the manure into rows after it is pulverized, and a wind break is furnished, if necessary, for windy weather.

The inspection that every Worcester-Kemp receives before leaving the factory is critical. Every spreader is put together and run until it is in perfect condition.

Write for quotations.

\section{"THE "CURTIS EASY PULL" MANURE SPREADER. MADE IN THREE SIZES.}

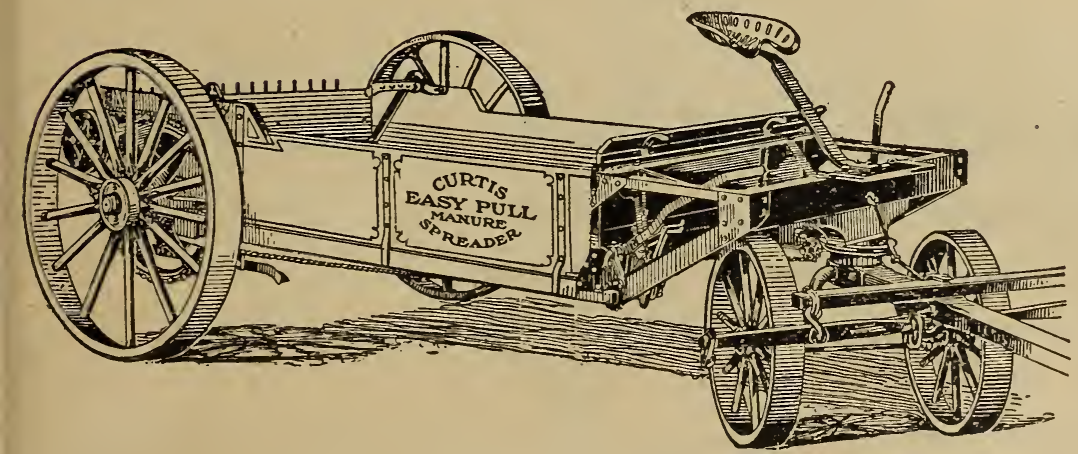

This new spreader, the "Curtis Easy Pull," has many of the same parts as the latest model "Worcester-Kemp", and all of the fine qualities. It is not a departure from the "WorcesterKemp" but a logical development of it, with a new feature of breaking the load in front of the beater and consequently a saving of the pull on the horses and the strain and wear on the machine.

Every effort thus far to reduce draft of a manure spreader has been directed toward $t h e$ reducing of mechanical friction only; but now another step has been taken, the first in the real reduction of draft.

A spreader is here that performs part of the work formerly done by the horses, without the expending of any power.

The load splits directly over the "hump in the floor" (a new feature).

The beater catches it, already partly broken up.

The beater does not have to tear the manure out of the load.

The hump in the floor prevents the load from packing on its under side in front of the beater.

The beater teeth raise the manure out and do not pack it back into the load.

The load does not come up under, but comes down on to the beater.

No pulverizer to prevent loading over the rear end.

When loading, end gate is down; when spreading, end gate is raised and acts as a pulverizer.

With the spreader is supplied whiffletree, neck yoke, and complete set of tools, and when wood wheels are shipped, mud lugs for icy or muddy soil are supplied. 


\section{JOHN DEERE SPREADER.}

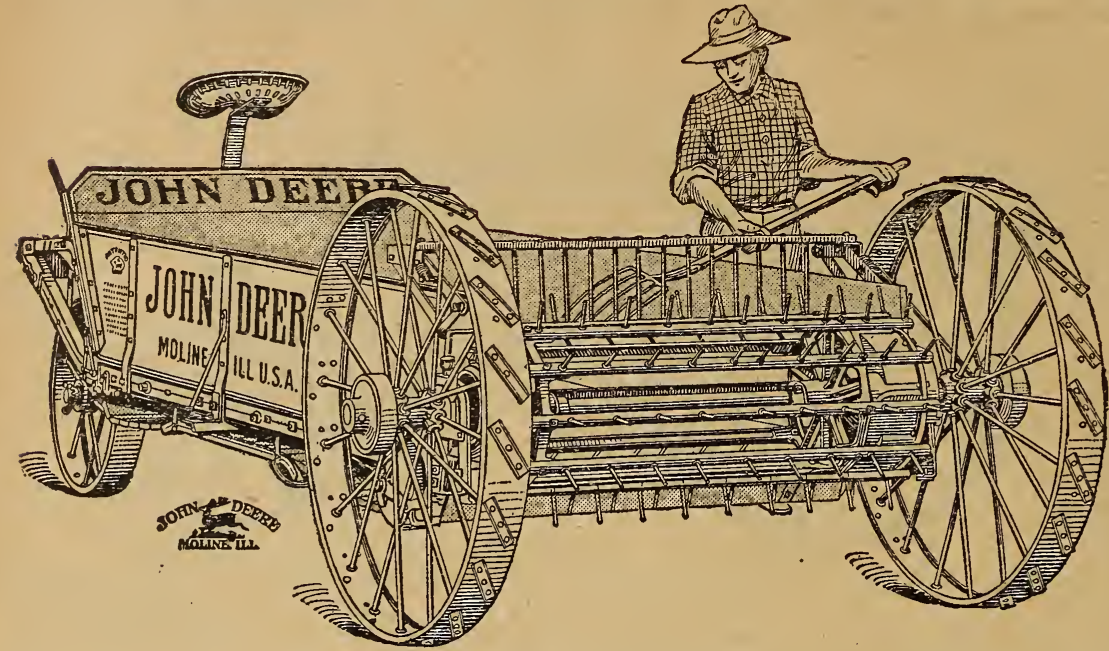

The John Deere Spreader-th e spreader with the beater on the axle-has only one-half as many parts as the simplest spreader heretofore manufactured. All its working parts are mounted on the rear axle. It has no chains, no clutches and no adjustments. B e in g low down, it is easy to load. The manure is taken from in front of the main axle and delivered at the rear of it. $\mathrm{There}$ are no clutches to give trouble, no chains to get out of

line, and no adjustments to be made. All the strain and stress of spreading is borne by the axle, and none of it is transmitted to the frame or the body of the machine itself. It is simply a wagon when out of gear.

Wheels at the rear of the machine do not interfere with loading. The entire side of the spreader is accessible for that purpose.

This spreader has from one hundred to one hundred fifty types of castings less than the simplest spreader heretofore made. As the machine is low down, it is only necessary to lift the manure thirty-eight inches in loading, as high as your hips. Each forkful of manure can be placed where it is wanted, because it is possible to see into the bed at all times. Loading the spreader evenly assists greatly in insuring uniform spreading.

The John Deere Spreader is very simple-it does not get out of order, and is always ready for business. Anyone can operate it.

Write for quotations.

\section{The Worcester Fertilizer Distributor. Simple, Strong, Durable.}

SOWS IN ROWS OR BROADCASTS.

This machine is built with a rotary agitator, combining the good features of all distributors and using a number of new devices not found on any other. It is a very simple, strong machine.

Shaker-board broadcasts evenly and supports a windbreak that saves the fertilizer. A hand shaker allows the driver to shake the load into the bottom of the box and so keep the machine spreading evenly. The usual steel feed plate is replaced by

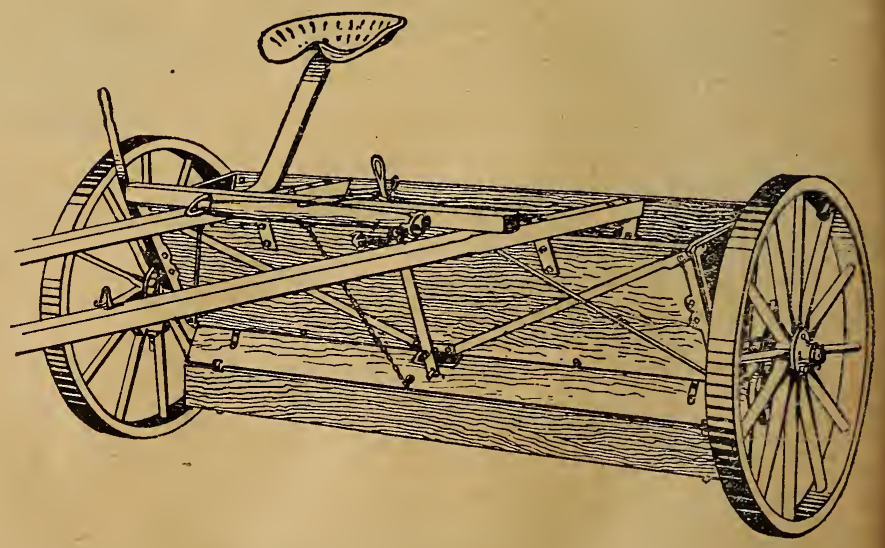
short sections of cast iron plate that are separated from the lower steel feed plate by liners. Iron and steel do not rust together and the liners still further help. Sows any quantity. 


\section{Ontario Fertilizer Broadcaster and Rower.}

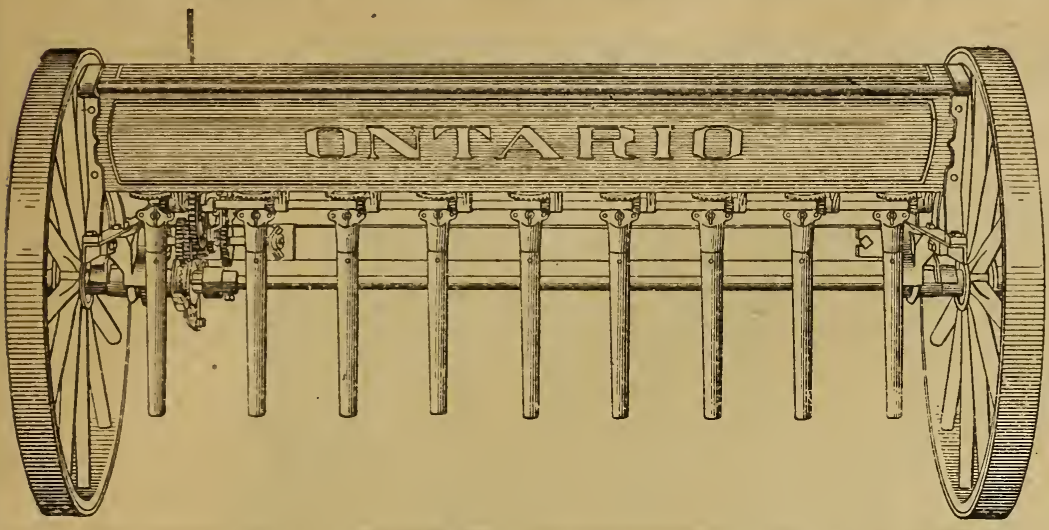

Is the only positive force-feed machine of its kind made in which the conductors have a lateral adjustment.

Its use is not confined to plaster, bone dust and other mealy fertilizers, for it handles lime and all commercial fertilizers, and is the best device known for handling those of home manufacture.

Sows broadcast or in any width of rows from eight irches up to five feet, in quantities ranging from two hundred to two thousand pounds per acre. Is equipped with a land measure that does not get out of order. It accurately measures the acres and fractions of acres sown, and is easily set at the nothing mark.

Price, \$45.00.

\section{Never Mind the Wind-Sow Any Time. THOMPSON'S " "THE ORLGGAa" GRASS SEEDER.}

This is really the greatest grass seeder made to-day. Not a toy, but a strong and durable implement specially designed and adapted to its use, 14 feet long. It's easy-it only weighs 45 pounds. Does not throw the seed into the wind. Puts it on the ground lightly and evenly where it bouns, insuring the operatore th blongs, intors a good even catch. Strong and durable. We know of Thompson seeder which have been in use 30 years which are thoroughly good and effective today.

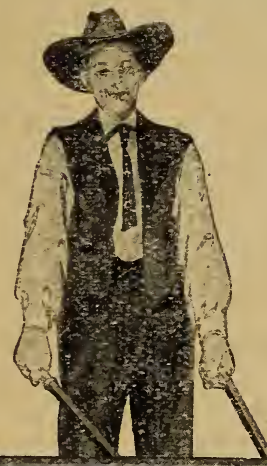

\section{WHEELBARROW SEEDERS.}

are a most valuable implement for sowing all grass seeds broadcast. The quantity of seeds sown per acre is accurately coverned by the wheel, which is run over the winds prevail, there is no machine made that will equal this implement for an even, accurate job of seeding. The quantity required per acre can be instantiy another. These seeders run light and are not complicated. Seeds can be sown mixed or separate and in any quantity desired.

Price, 14 feet, $\$ 8.50$.

\section{STEVENS, \\ FERTILIZER SOWER. \\ COMBINING}

SIMPLICITY, STRENGTH AND DURABILITY. EXCELLENT

FOR SOWING ALL KINDS OF FERTILIZERS,

BROADCAST OR IN DRILLS.

Price, \$42.00.

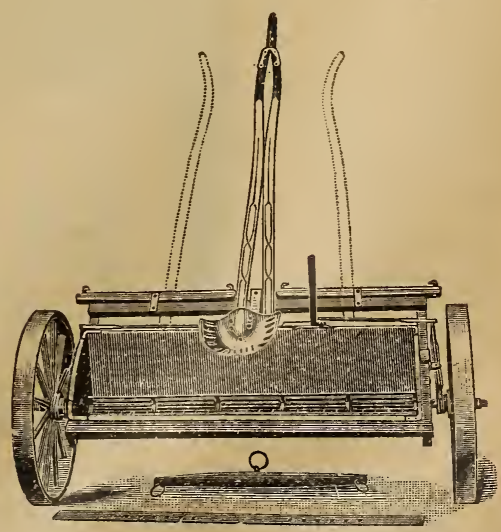




\section{ONTARIO COMBINED (Grain and Fertilizer) BACK-ROLLER HOE DRILL.}

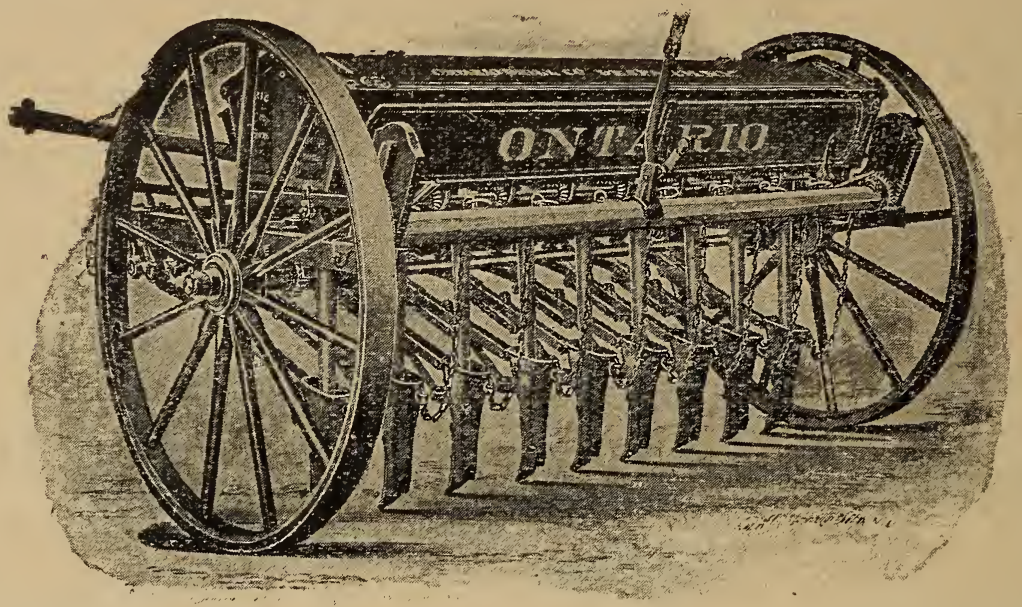

Built in all sizes, both as a combined or plain drill. LIGHT DRAFT-PERFECT BALANCE-EASY LIFT.

The body is made of well-seasoned, kiln-dried lumber, put together in a workmanlike manner. The grain hopper of the smallest drill, holding two bushels, and the fertilizer hopper being of considerably larger capacity.

Price, \$90.00.

\section{ONTARIO COMBINED (Grain and Fertilizer) DOUBLE DISC DRILL.}

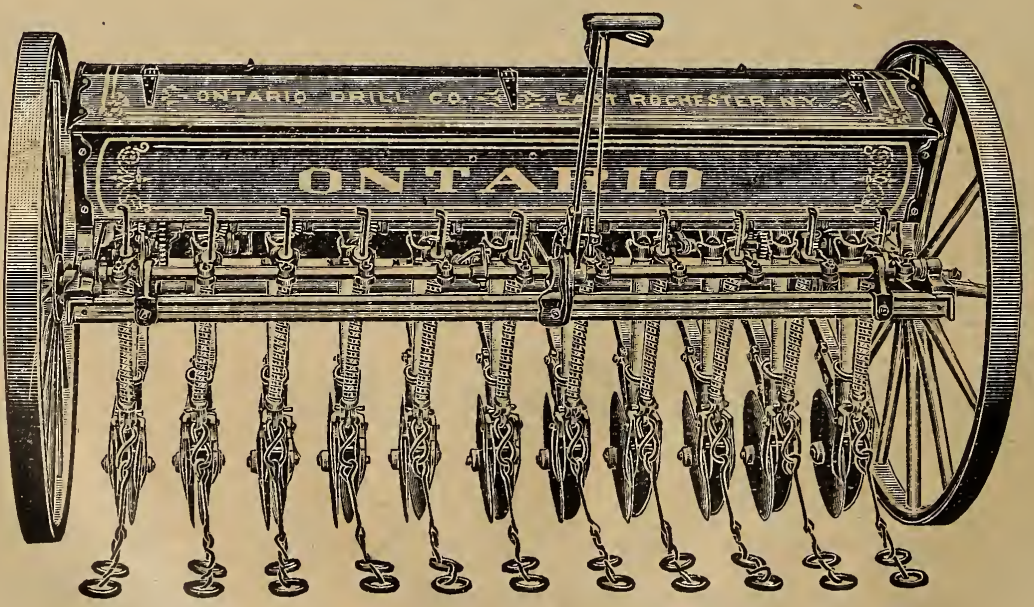

Embodies all the special features of Hoe Drill, excepting discs are used instead of hoes. It has the same broad tread wheels, accurate grain and fertilizer feeds, heavy axle, simple feed devices, accurate grass seeder and land measure, and the same light draft.

Price, $\$ 95.00$ 
CUT SHOWING HAY CARRIER AT WORK.

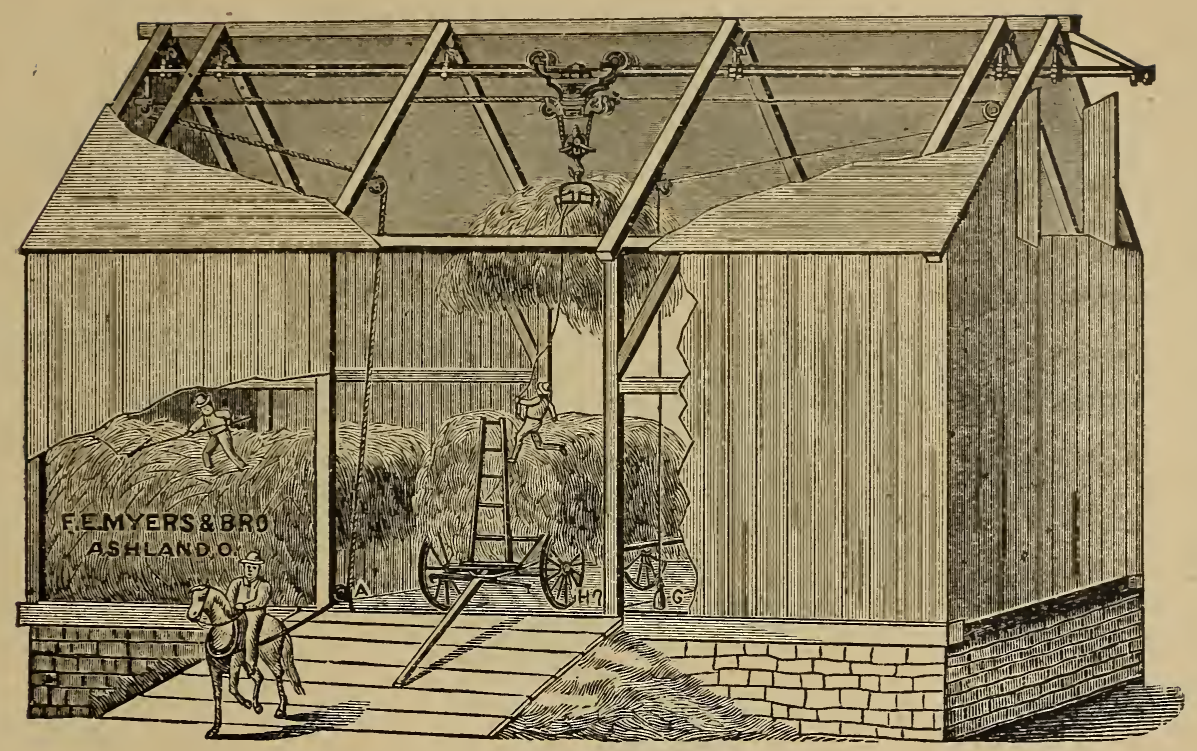

\section{MATERIAL REQUIRED FOR A STEEL TRACK OUTFIT FOR DIFFERENT LENGTH BARNS.}

For A 40-Foot BARN.-One reversible carrier; 40 feet steel track; 21 hanging hooks; 21 rafter brackets; 5 pulleys; 1 D. H. fork; 6 floor hooks; 110 feet 3/4-inch Manila rope; 50 feet 3/8-inch trip rope.

FOR A 50-FOOT BARN.-One reversible carrier; 48 feet steel track; 25 hanging hooks; 25 rafter brackets; 5 pulleys; $1 \mathrm{D}$. H. fork; 6 floor hooks; 130 feet 3/4-inch Manila rope; 55 feet 3/8-inch trip rope.

FOR A 60-FoOT BARN.-One reversible carrier; 60 feet,steel track; 31 hanging hooks; 31 rafter brackets; 5 pulleys; 1 D. H. fork; 6 floor hooks; 160 feet 3/4-inch Nanila rope; 60 feet 3/8-inch trip rope.

Different lengths of barns will use track, hanging hooks and rope in same ratio as above.

Above estimates of rope are for an end hoist. In hoisting from center of barn less rope will be required.

When requesting quotations do not fail to give exact length of barn, whether ridgepole or full rafter, and distance between rafters. Also state whether you expect to hoist from end or center of barn.

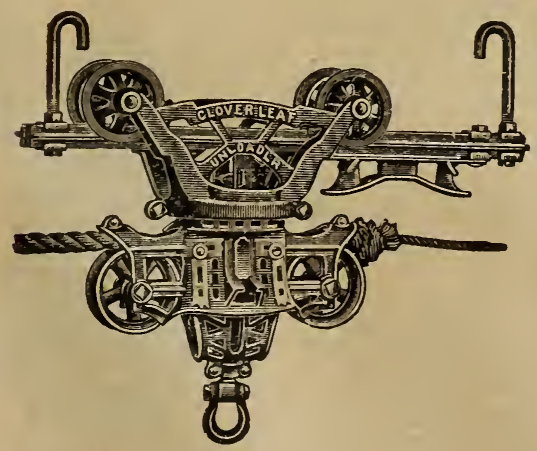

Myers Clover Leaf Steel Track Carrier.

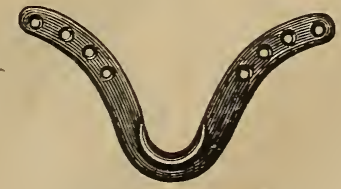

Rafter Bracket.

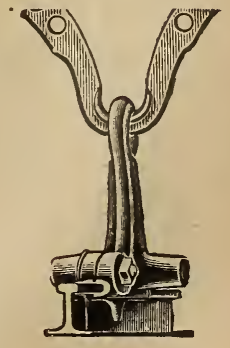

Rafter Bracket with Stop. 
KENDALL \& WHITNEY'S CATALOGUE.

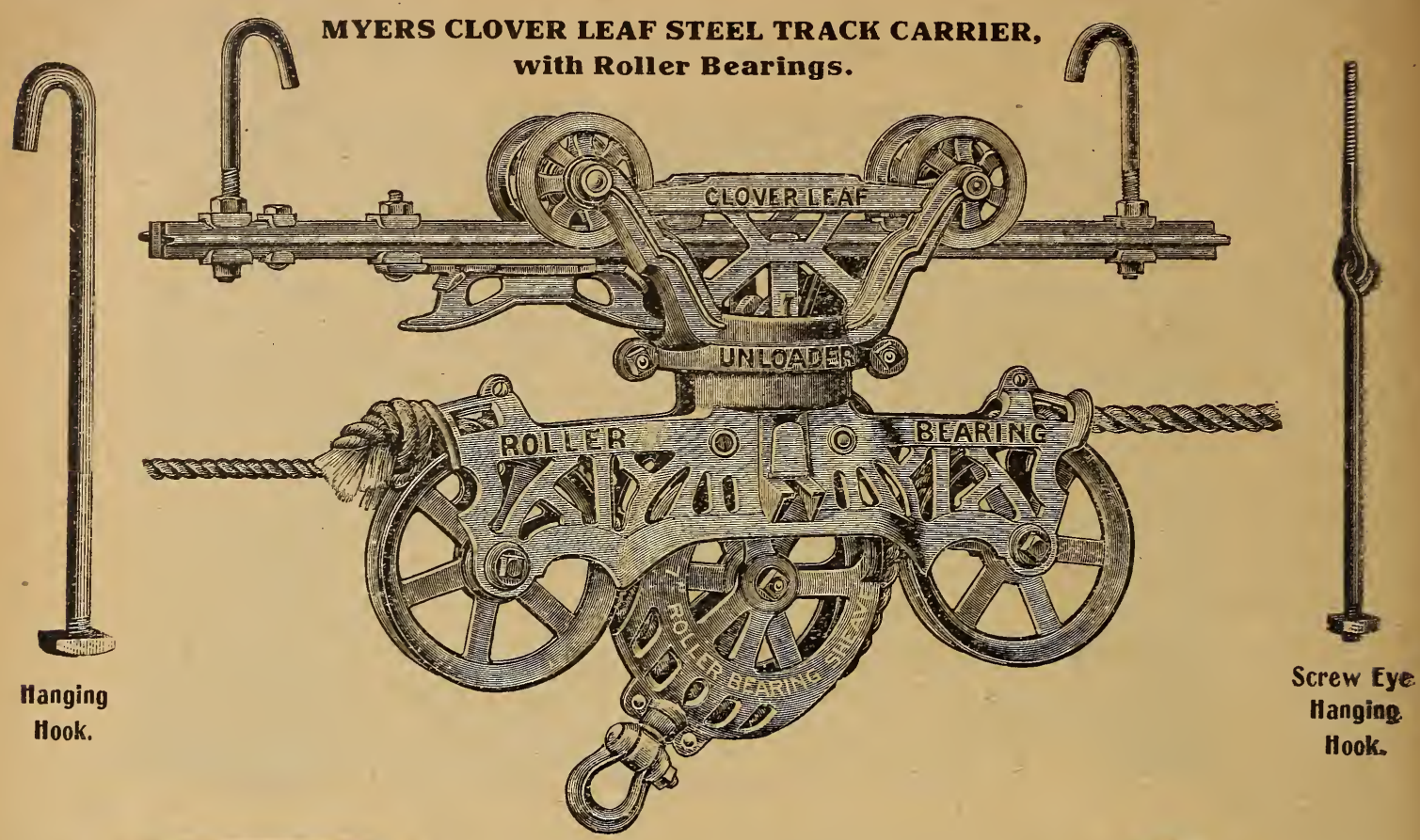

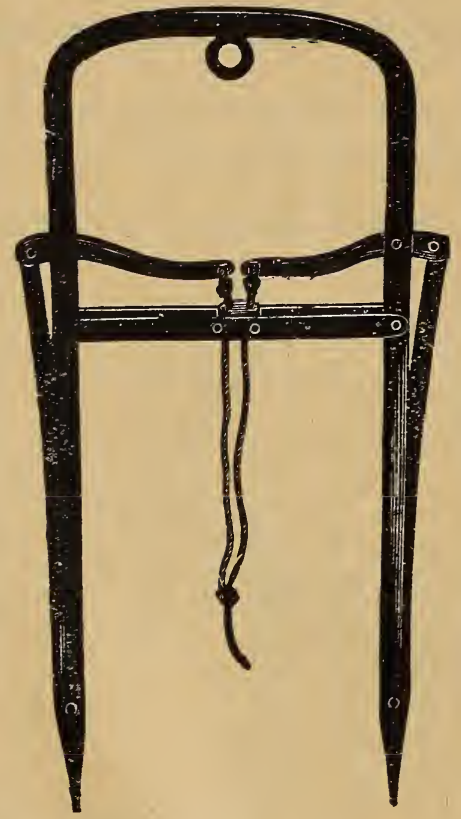

Double Harpoon Fork.

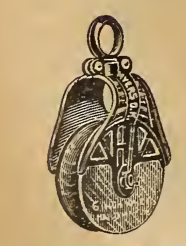

Knot Passing

Pulley.

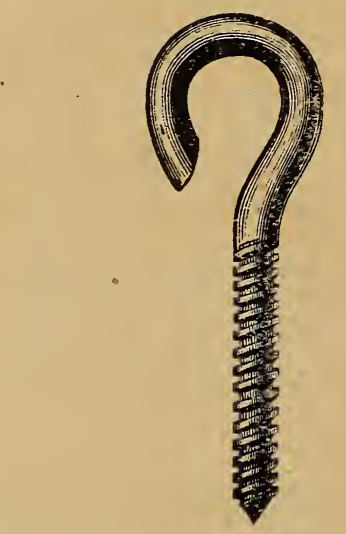

Floor Hook.

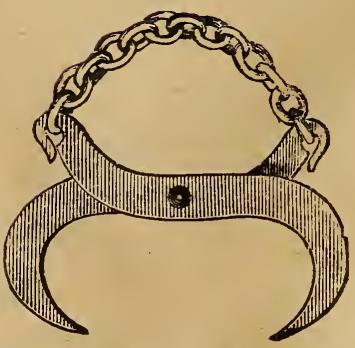

Steel Rafter Grapple.

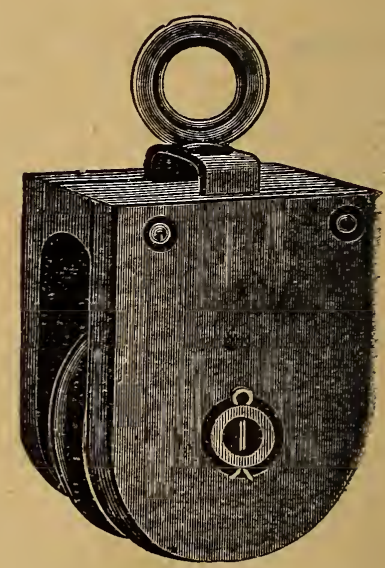

Reed Pulley with Hook or Eye.

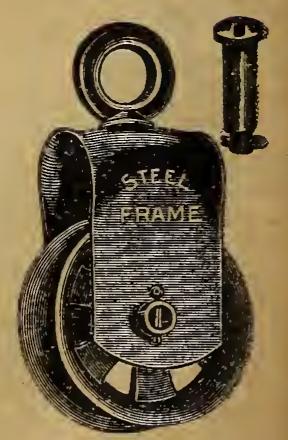

Steel Frame Pulley. 


\section{The Walter A. Wood Line of Machines and Implements for the Farm. ADMIRAL MOWER.}

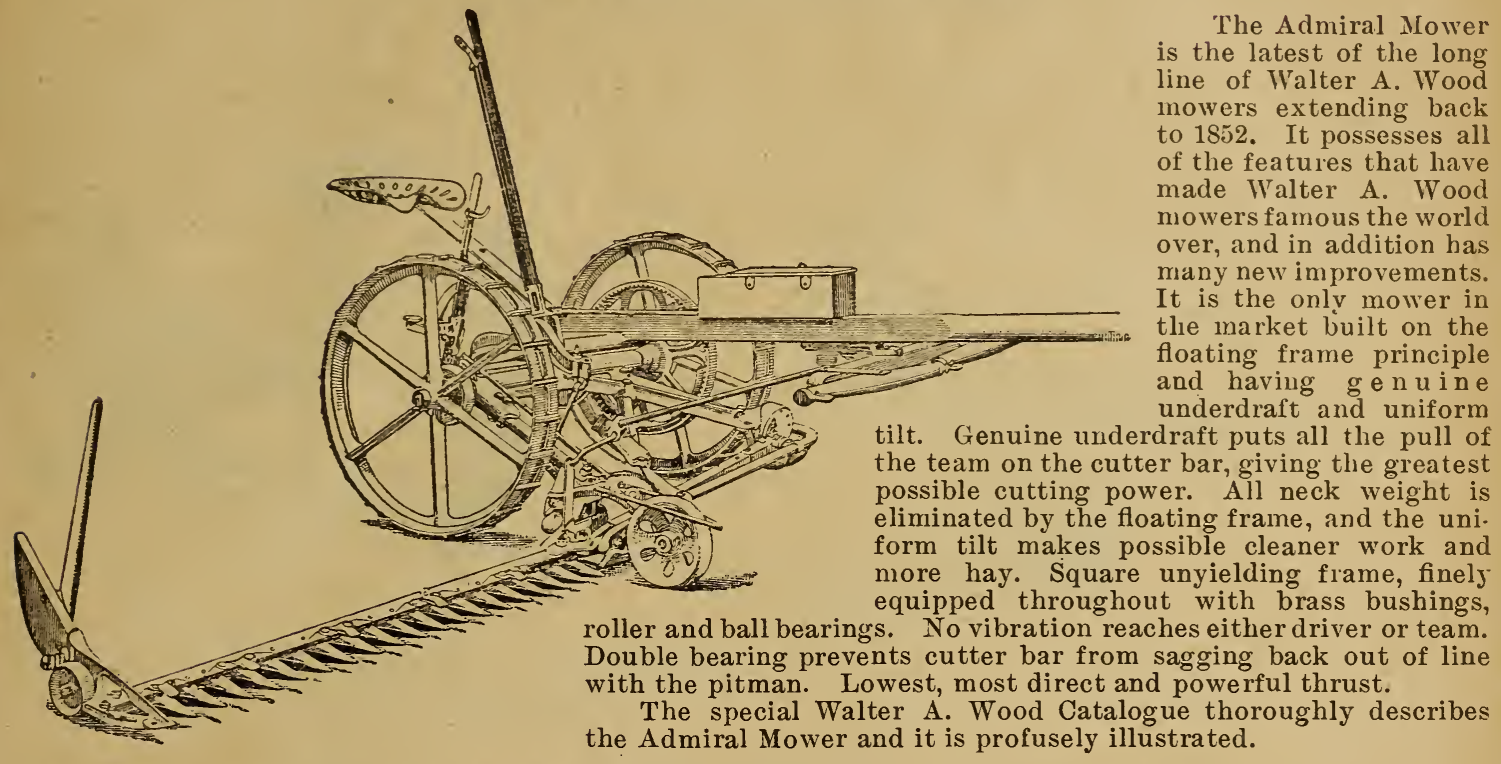

\section{THE WALTER A. WOOD TEDDER.}

The Wood Tedder is built very strongly and substantially. Its construction will withstand all the jar and strain caused by the rapid motion of the fork arms. Strong springs absorb the vibration so that it does not reach either driver or team. Power is transmitted by chain and sprocket from the main axle to the fork arms so that the mechanism works smoothly and evenly. The motion of the forks has been so timed as to toss every bit of hay. Outside forks toss the portion just passed over by the wheels. It is equipped with roller bearings in the places where friction would be most likely to occur.
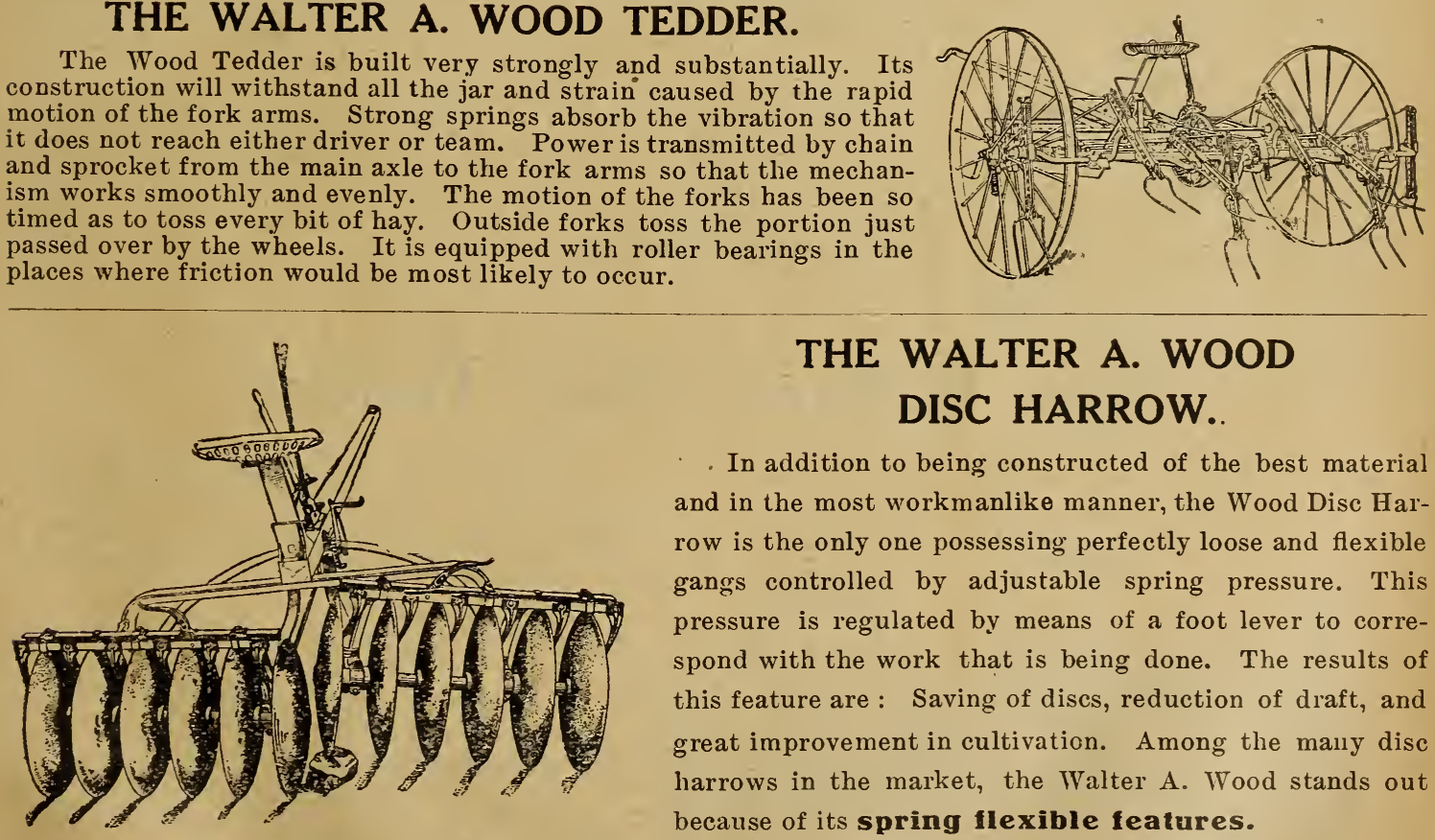

\section{THE WALTER A. WOOD DISC HARROW.}

In addition to being constructed of the best material and in the most workmanlike manner, the Wood Disc Harrow is the only one possessing perfectly loose and flexible gangs controlled by adjustable spring pressure. This pressure is regulated by means of a foot lever to correspond with the work that is being done. The results of this feature are : Saving of discs, reduction of draft, and great improvement in cultivation. Among the mally disc harrows in the market, the Walter A. Wood stands out because of its spring flexible features.

\section{WALTER A. WOOD SPRING TOOTH HARROW.}

Relief Spring-Saves the Team-Prevents Breakage.

Built of the highest quality of material, I-beam frame, U-bar tooth bar. The only harrow equipped with spring which enables the teeth to yield to unusual obstructions when the adjustable lever is locked in position.

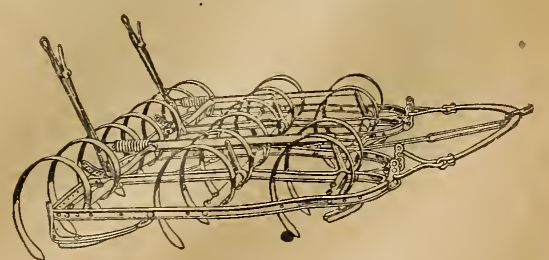




\section{THE WORCESTER BUCKEYE MOWER.}

\section{EASY TO HANDLE}

LIGHT DRAFT

ONE HORSE.

4 foot cut.

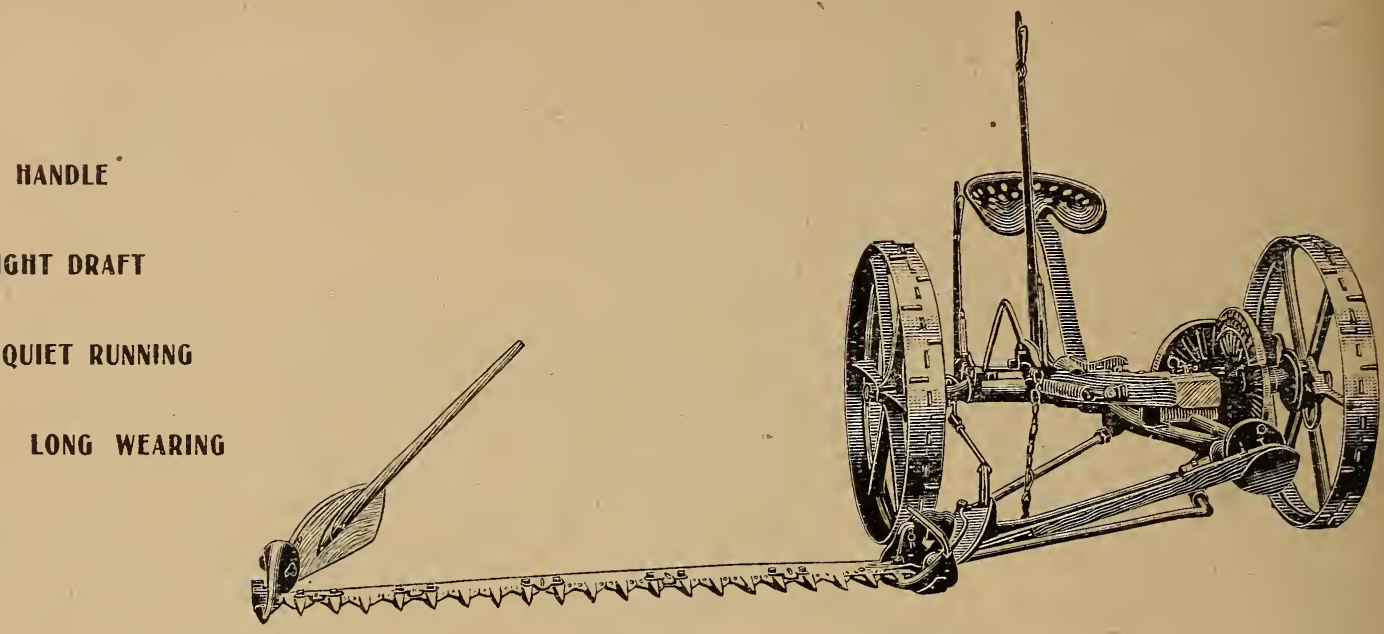

TWO HORSE.

5 foot cut.

6 foot cut.

These mowers are made in three sizes. The one-horse mower is the smallest, but is designed just right to carry a 4 foot cutter bar. The 5 foot is a broad and strong mower, carrying the bar steadily. The 6 foot is a very broad frame, heavier than either of the others, and extra strong.

The Worcester Buckeye is sold everywhere in the east and is popular wherever it is sold, but it was first built for Maine and Massachusetts. It is particularly well made. Try one of the new ones, and you will like it better than any mower you have ever seen. Runs like a watch.

Price on application.

\section{The Bullard Hay Tedder.}

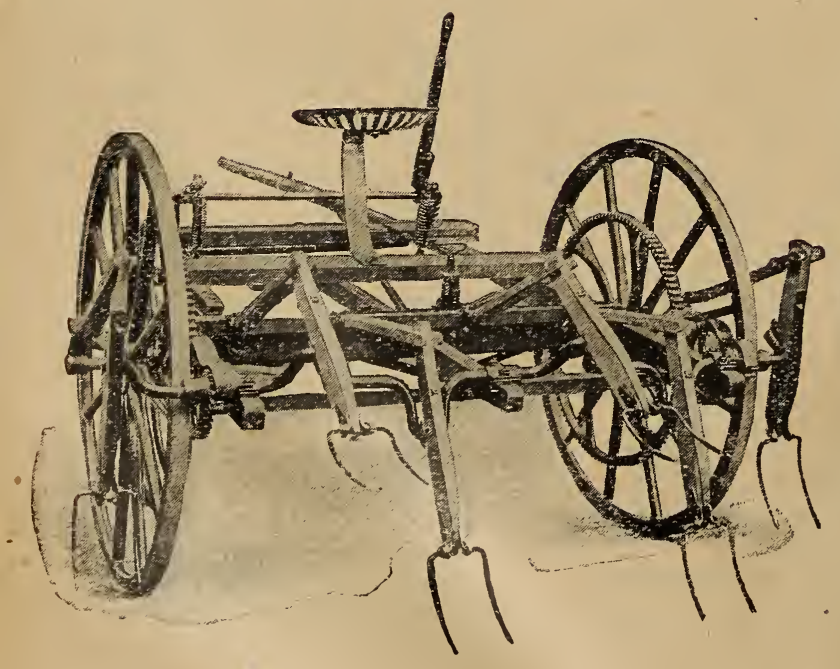

Takes the hay up from the bottom, shakes it in the air and leaves it lightly on the ground for the sun and air to complete the work of haymaking. Does not shake to pieces. Is elastic but tough.

The crank shaft split in the middle makes it easy for the horse to turn.

Two tension springs on the tilting frame, together with the new Mudgett fork springs, prevent breakage of wood arm.

The forks on either side are driven independently by the wheel nearest them, so that this tedder can be turned while it works, without straining the tedder or horse, and do good work all the while.

If you want to get a tedder that will do its work in the right way, with the least fuss and bother, and that gives you the most lasting satisfaction, buy a Bullard. 


\section{The International Harvester Company of America's Line of Osborne Farm Implements.}

\section{THE NEW}

\section{Osborne Mower.}

The new Osborne Mower hasmade a place for itself in the front ranks of grass-cutting machines. Each detail that means much to the farmer has been worked out with care and the been worked out to the farme and the result is a perfect machine in every respect. gears, and a foot-lift that raises the cutter bar high above every obstruc tion, are a few of the valuable fea tures. The draft attachment should not be overlooked when comfort for the team is considered. Made in all sizes, plain and vertical lift.

\section{Osborne Center Drive Tedder.}

The Osborne Tedder is without doubt one of the strongest made and the only tedder that is equipped with roller bearings throughout. This means easy draft and long wear. The full power of both wheels applied to the forks makes the draft light and the forks of both whe draft light, and the forks always in perrect adjustment, whether going straight ahead
or turning a corner. Sizes: 6 and 8 fork.

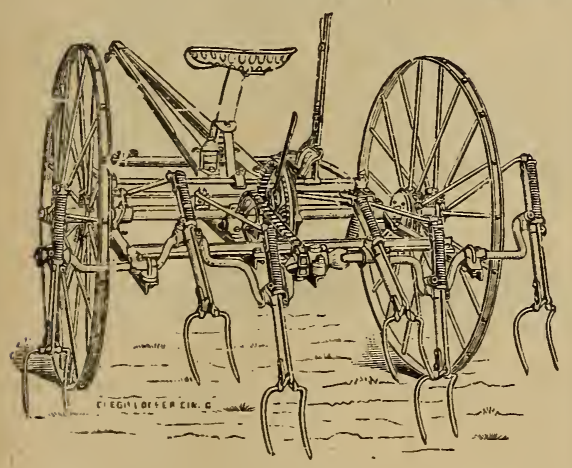

\section{We are very glad to offer our customers the Osborne Disc Harrow, for we know that satisfaction follows every sale. Equipped with weight boxes, center teeth, 3-horse attachment and two levers leaves nothing to be desired. We have it in all sizes, both solid disc and cutaway. Can be furnished with tongue truck if desired.}

Osborne Rival Disc Harrow.

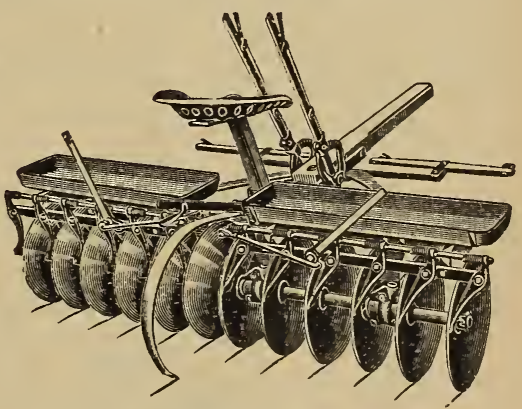

\section{OSBORNE SPRING TOOTH HARROW.}

This harrow is so well known and popular that it needs no description. We simply wish to remind you that we are never without them in stock. Sizes: 9,15 and 17 tooth. We carry the sulky harrow in 15 and 17 tooth.

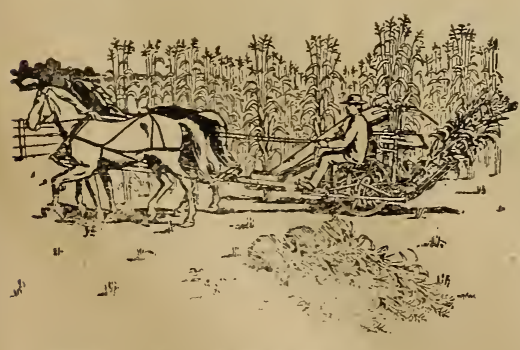

\section{Osborne Corn Harvester.}

The Osborne Corn Binder is a particularly desirable machine for any corn grower to use, because it will handle either short or long corn with equal facility, and pick up, down and tangled corn, delivering it in reasonably good bundles.

Corn is exceedingly hard to cut, and the corn binder that will stand this hard work year after year must have an exceptionally strong main frame. The main frame of the Osborne Corn Binder is made of bar steel, and thoroughly braced to withstand five times the amount of strain that can ever come upon it.

Has binding attachment similar to the grain binder. Knives are shaped to give a long draw cut on the stalk, and two trips make ample provision for long or short corn.

\section{OSBORNE GRAIN BINDER.}

The highest type of modern binder construction. Has best quality steel roller bearings, strongest possible main frame, large elevator capacity, dependable binding attachment, cuts successfully, badly lodged and tangled grain, and binds it with unvarying regularity. 


\section{THE YANKEE HORSE RAKE.}

Some of the Leading Points of Superior Excellence found in the Yankee Horse Rake.

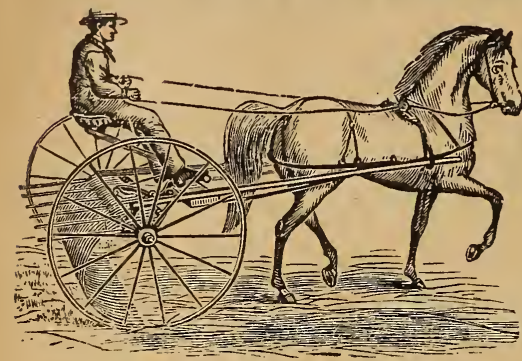

Simplicity in construction and excellent quality of materials.

Adaptability to rake anywhere, whether the fields are rough or smooth or the hay green or dry.

Rake head adjusted so as to balance the weight of the teeth.

This device completely prevents the teeth from dragging heavily and digging into the ground or filling the hay with dirt and dust.

Teeth run level with the ground at their points.

Each tooth is perfectly independent in action and supplied with a yielding spring that will allow it to pass safely over any obstruction that the axle can pass over.

Price on application.

\section{THE "K. \& W." HORSE RAKE.}

THE WAY THE RAKE YOU BUY OUGHT TO BE MADE.

Wood construction, braced at every corner, steel truss rod under the axle bed, highest grade of material used throughout. Light but strong and will outwear any other rake. Sled-runner teeth, with a coil loop near the upper end. Rakes clean everywhere, but does not dig and never injures the grass roots. Not one new tooth furnished in a hundred sales. This rake will not roll hay. Any boy can handle it.

Price on application.

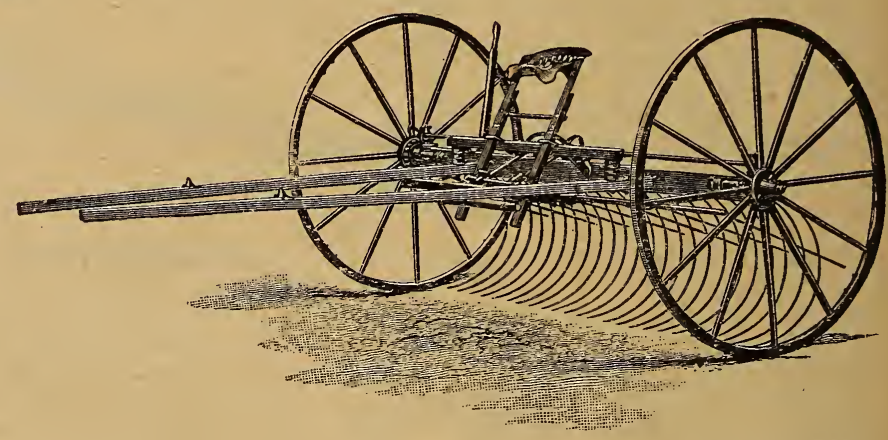

\section{“O. K." CHAMPION POTATO DIGGER.}

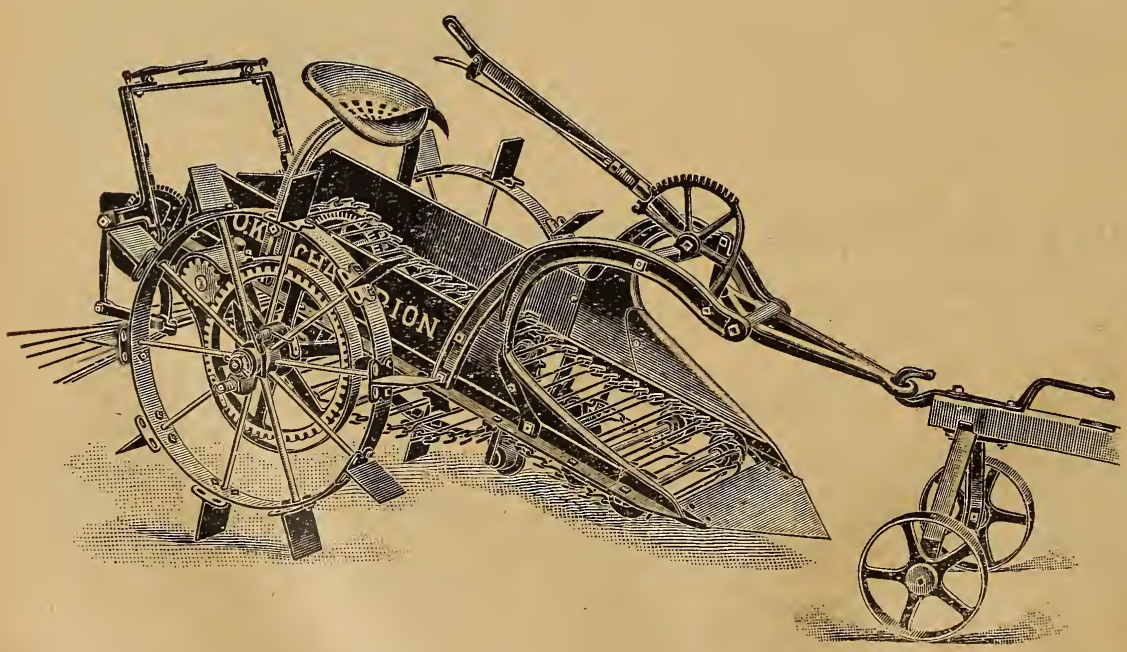

“o. K." CHAMPION DIGGER, NO. 1.

The "O. K." Champion Digger, with its many superior features, commends itself. It is built with a view to simplicity, doing away with all unnecessary wearing parts, which accounts for its easy $\mathrm{draught}$. Two horses will do the work with ease. There is no chain drive to cause friction and wear; only two gear wheels are employed on the entire machine.

Attention is called to the apron, which has alternate high and low links, a feature original with our machine, also the front throat opening being wider than the body of the machine,

allowing the dirt to spread and lose itself more freely when first entering the machine.

The apron at the front moves over special rollers running on stub axles, preventing the catching of stones when leaving the shovel blade. The shaking fork rower over which the potatoes roll after leaving the apron is agitated by an extending arm connected with a frame holding a wheel revolving around three cams on the small pinion, bringing it forward while the rearward movement is accomplished by two heavy springs; this forces the fork to vibrate back and forth vigorously and clcan any remaining dirt that may be carried over the apron, the fork tines being so shaped that it will row the potatoes behind the machine ready for the pickers. 


\section{“O. K.” CHAMPION POTATO DIGGERS-Continued.}

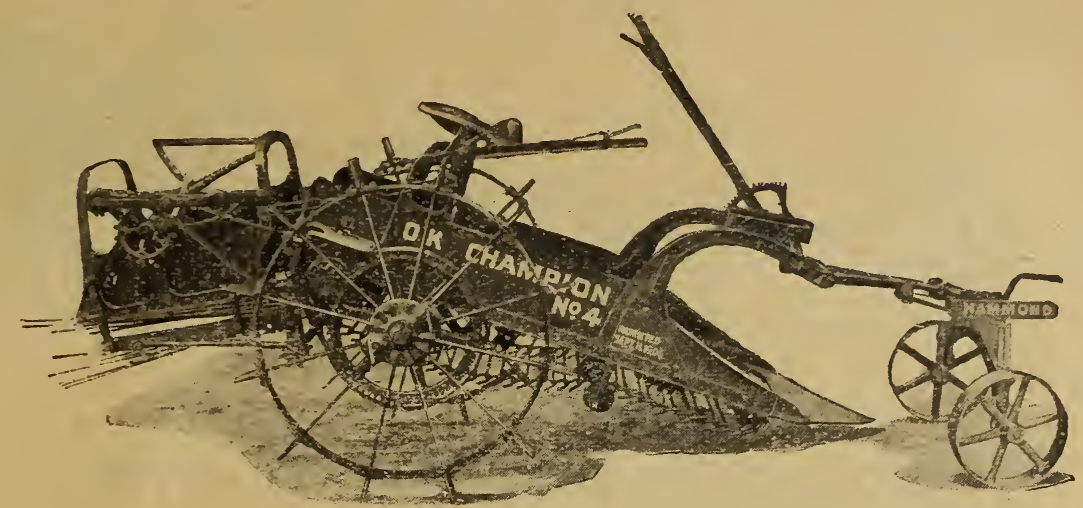

“o. K." CHAMPION DIGGER, NO. 4.

The "O. K." Champion Elevator Potato Digger, No. 4, with vine separating attachment is especially constructed for potato fields where unfavorable conditions are met. It allows the vines and trash to be separated from the tubers and lays them to one side by means of vine kickers while the potatoes are deposited in a row back of the machine.

All parts are of an extra heavy reinforced pattern. The bearings are long and smooth, are well protected and provided with oil cups, thereby insuring easy running. The elevator web and the fork are constructed of a special high carbon crucible spring steel, insuring long wearing qualities.

This digger is 22 inches wide between sides and is equipped with specially constructed front throat sides which allow the dirt to spread when entering the machine, resulting in a quick separation. The truck is of a swivel type pattern and makes turning to any angle or at any distance very easy. The vine separating attachment is constructed of steel and malleable, amply strong to withstand any strain it might be put to in the nost unfavorable field. The shaking fork is hung independently on proper bearings, and is vibrated with a positive shake by means of two pitmans which are operated from an auxiliary shaft, which in turn is driven by means of a heavy sprocket chain direct from the main drive shaft. The entire separating attachment can be raised or lowered to suit the operator, by means of a lever at his right.

\section{"O. K." CHAMPION POTATO DIGGER, NO. 2.}

Designed exactly as No. 1 machine, it varies only in size and dimension, the elevator being two inches wider and ten inches longer, other parts being built proportionately larger. The machine is equipped with our patented front throat sides which allow the dirt to spread twenty-six inches, insuring a very quick separation.

On account of its increased size, the machine has a very large separating capacity, the separating space being approximately fourteen square feet, which makes it especially adapted for heavy soil.

Prices on application.

\section{THE HITCHCOCK}

\section{Potato Digger and Shovel Plow Combined.}

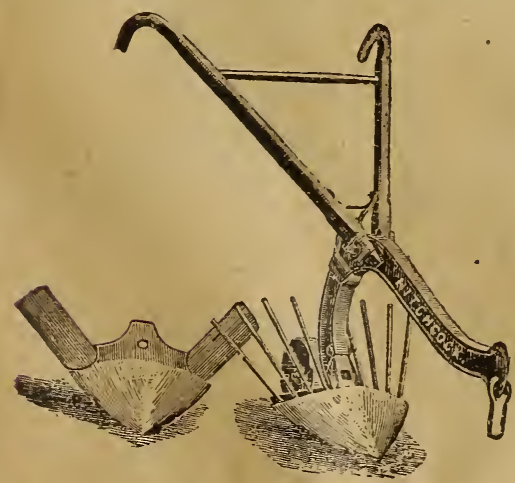

This implement, though very simple in appearance, is the result of much study and many experiments; and it is as near perfect as can be attained and comes within the reach of every farmer. By the changing of one bolt it may be converted either into a Shovel Plow or a Potato Digger. The fingers are adjustable, being held in position by the plow point. Thus, in case of breakage, a new part may be inserted without the expense of whole new head. The fingers, points and wings are made of steel, rendering it light, strong and durable.

Price on application. 


\section{The Hoover Potato Digger.}

A digger built on the right principle to do good work, and with years of experience to prove it.

The shovel, elevator, and vine separator are especially constructed to make the Hoover one of the most perfect working diggers on the market.

Made in one size only, 22-inch.

Price on application.

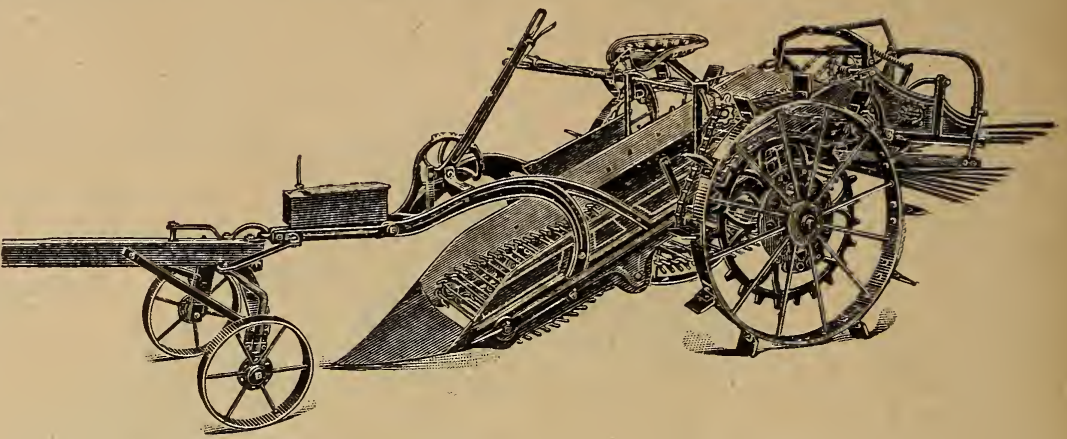

\section{“IRON AGE" POTATO DIGGER.}

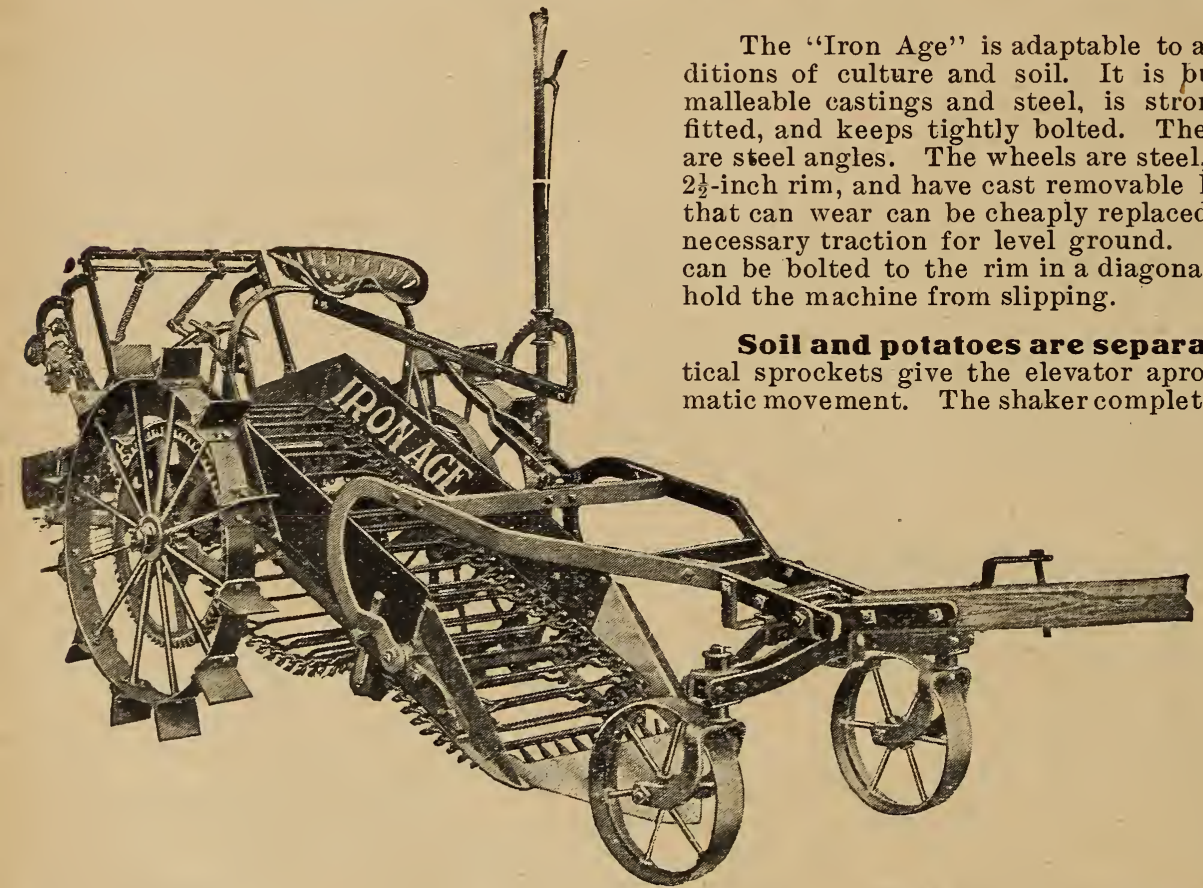

wide diversity of corrstrong entirely of fitted, and keeps tightly bolted. The main frame side bars are steel angles. The wheels are steel, 28 inches in diameter, $2 \frac{1}{2}$-inch rim, and have cast removable hub box - the only part can wear can be cheaply replaced. Steel spurs give the round. For hillside work, they can be bolted to the rim in a diagonal position so they will minging.

separated thoroughly-ellip(hive elevator apron just the right autoelevator chain (apron) consists of interlocking cross bars of steel, has no unnecessary tension, and is driven direct by gearing from both main wheels.

Made in one size only, 22-inch.

\section{Price}

on

application.

\section{THE “DIAMOND” KNIFE GRINDER.}

One of the best machines for its purpose ever put on the market, and the easiest to operate. There are ONLY TWO GEARS in the entire machine, which cannot fail to make it run easily, and it can be quickly attached to a bench, mowing machine wheel, or other suitable support. The castings are all thoroughly japanned.

Price, \$3.50.

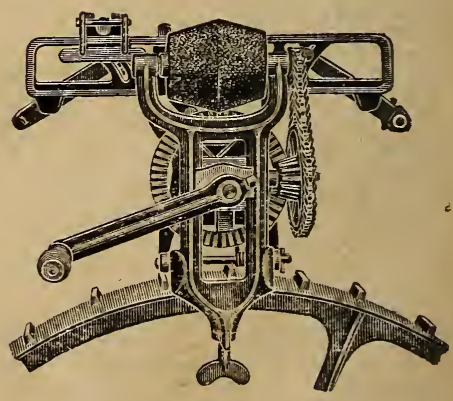

\section{Sections for Mowers and Reapers.}

Farmers can have their orders promptly filled by sending directly to us for sections for all kinds of machines. Sections will be polished on both sides, and stamped with the name of the machine for which they are intended.

ALL KNIVES AND SECTIONS WARRANTED.

In ordering send size of section wanted. 


\section{THE GRAY ENSILAGE CUTTER \\ WITH ELEVATOR AND TRAVELING FEED TABLE.}

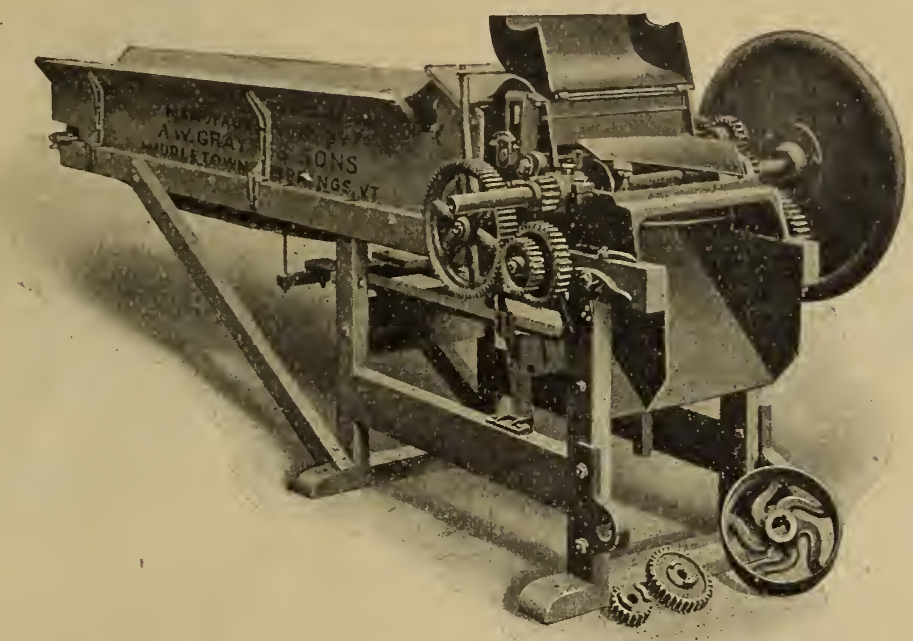

The requirements of a good cutter. Must be rapid. Must not clog or allow leaves and stalks to wind around knives. Must cut or shred green stuff and cut dry fodder as well. Must be convenient. Its gears and knives must be arranged in simple fashion and so reduce wear and prevent frequent repairs. The rollers must grasp the corn stalks and other fodder firmly and feed it accurately to the knives. The moving table must roll on its bearings without twisting or wedging. Above all, it must be strong and durable. It must be light yet strong enough to resist the hard usage naturally given it. It must be elastic enough on its trucks to stand the side rack and straining twists incident to road work.

All these requirements will be found in Gray's Ensilage Cutters.

\section{GRAY'S ENSILAGE CUTTER WITH STATIONARY TABLE.}

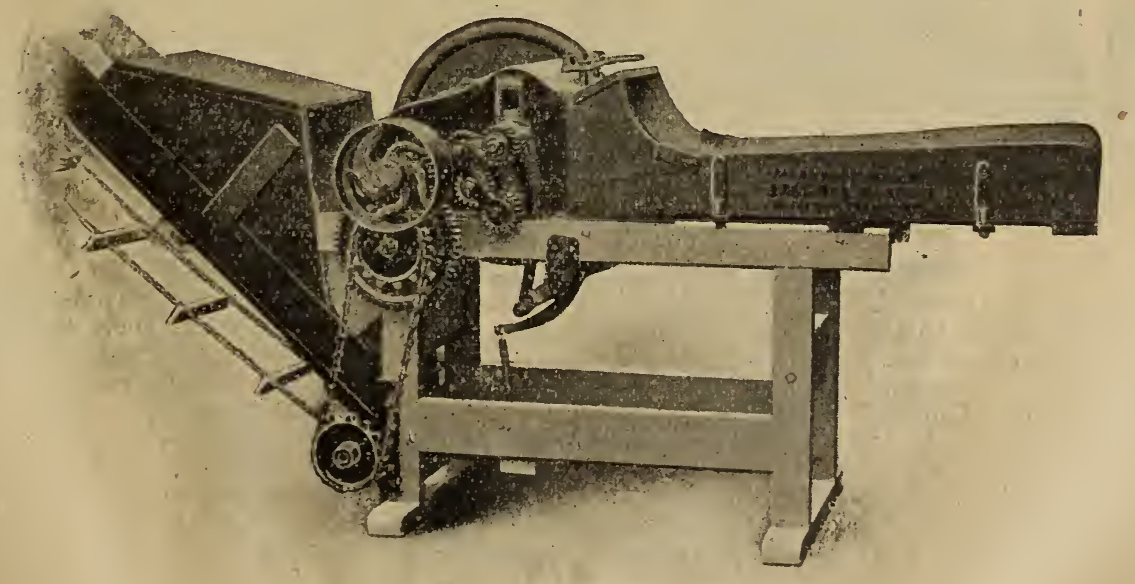

Identical with the traveling feed table, except that the sides of this table, (the table being stationary) are arranged so either or both can be let down by simply lifting a latch.

All cutters are furnished with necessary gears to cut $1 / 4,1 / 2,3 / 4$ and 1 inch lengths. 


\section{“MONEY MAKER" ENSILAGE CUITERS AND BLOWERS.}

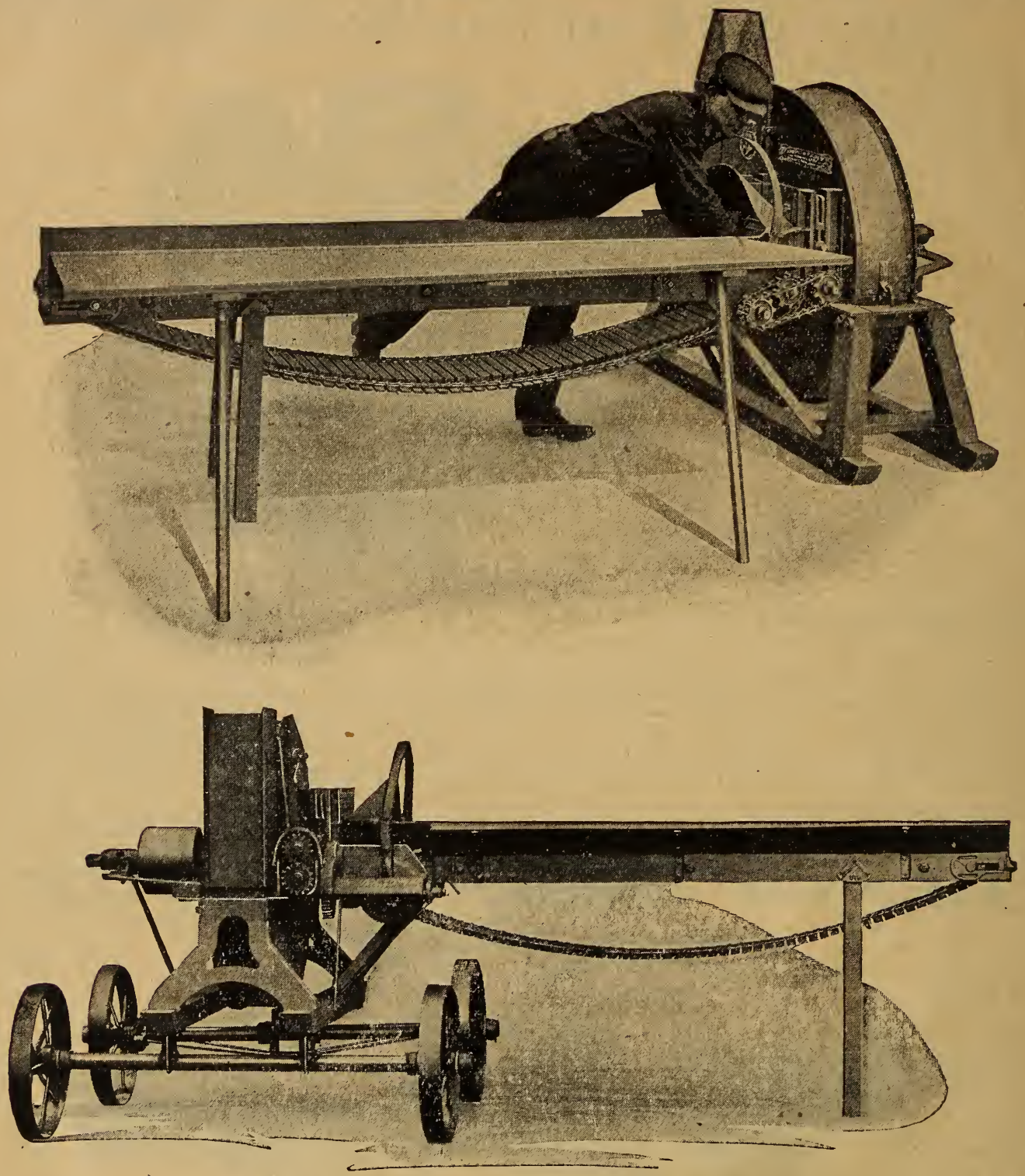

Dises 34 inches in diameter, 1-2 inches thick.

Discs solid, with knives arranged to produce almost no friction. Silage does not pass through the discs, but falls into the face of the fan blades, which force it directly into the delivery tube. Discs revolve at 700 to 900 revolutions per minute.

Cutter knives are straight, the most efficient and strongest type in use. The parts which hold the knives are of malleable iron. Knives are adjusted to cut close and clean like shears blades.

The fan wings are four in number, and are made from malleable iron. Discs, knives and fans are all contained in the fan case.

Feed rolls are ideal. The upper roll is corrugated and the lower is toothed, so that material fed into the cutter is carried along in perfect condition for cutting.

The chain feed carrier is so made that no litter can drop between the slats.

The silage is forced from the fan case, up the delivery tube by means of the fan wings. At the top of the silo, a curved elbow or distributor hood deflects the silage into the silo.

The "Money Maker" Ensilage Cutter can be furnished mounted or unmounted.

An iron safety yoke is placed directly over the hopper, and while it can be used as a starting lever, its chief purpose is to protect the operator from injury, for if a feedér's hand became caught, a touch on the lever will instantly stop the machine. This device is found on no other cutter manufactured.

All gears interchangeable on either sizes of the "Money Maker" Cutters. 


\section{THE GALE-BALDWIN ENSILAGE AND FODDER CUTTER.}

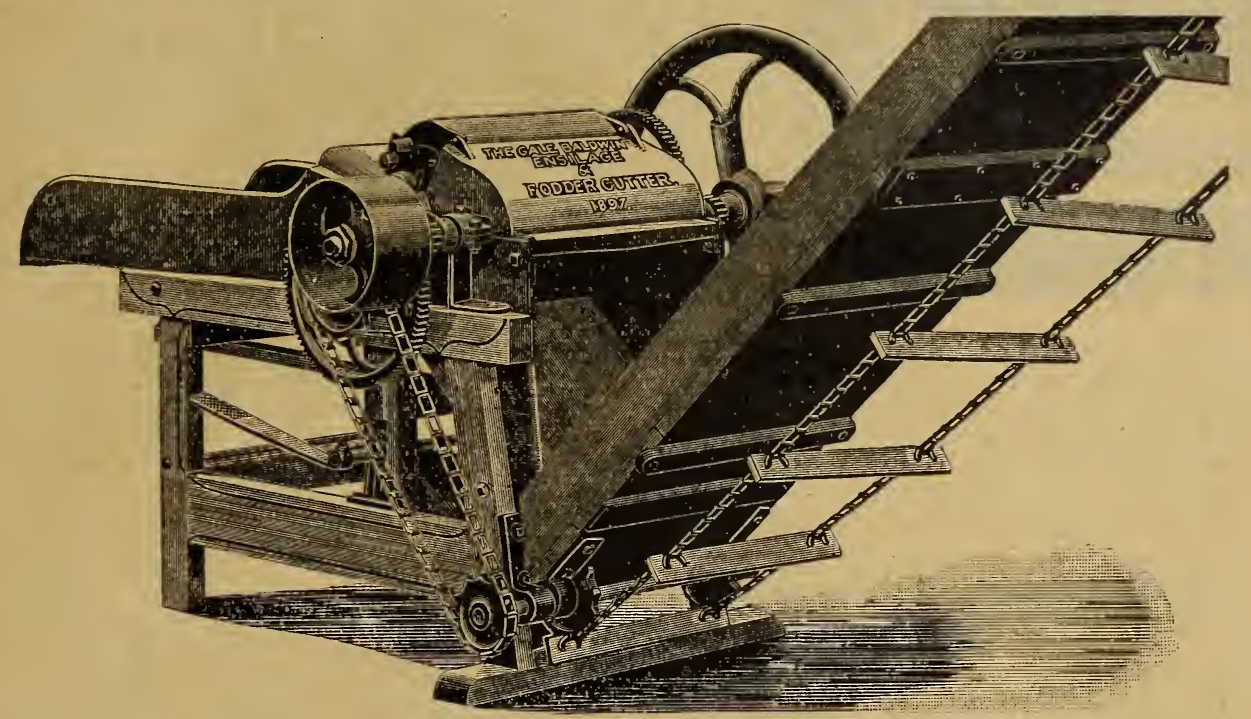

A very successful machine made for light power, and one which is easy to feed, easy to keep in order, and is very durable. Cuts with great rapidity hay, straw, corn stalks, ensilage, etc., and the improvements lately made have proved to be exactly what was needed to make this machine one of the most perfect and easiest working ensilage and fodder cutters.

\section{POWER CUTTERS-WITH TWO KNIVES.}

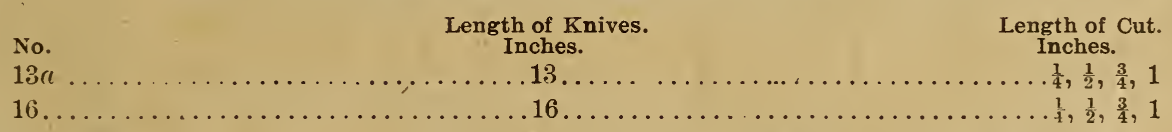

Prices on application.

\section{BLIZZARD ENSILAGE CUTTERS. MOUNTED ON REGULAR TRUCK.}

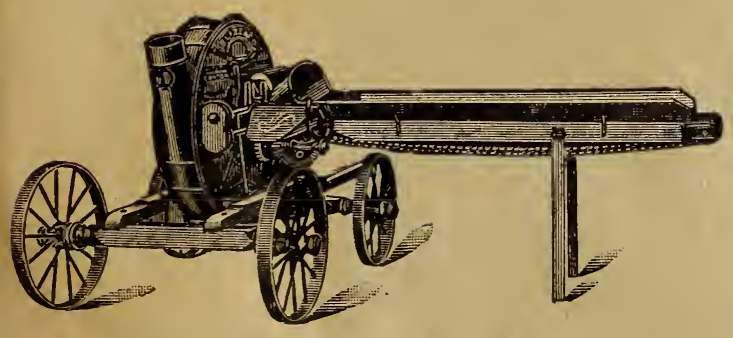

This cut shows the Blizzard ready for attaching belt and pipe and all complete for operation. Aside from strength and simplicity, it has another important feature, namely, the low-down mounting for the machine. The height of the feed table is such that the operator can feed the machine without standing on a platform. The fact that two men can disconnect the feed table and pipe, and load all the parts ready for transportation in from three to five minutes, and can again replace all parts in from five to eight minutes, goes to show the simplicity of this mounting.

The self-feed table enables it to eat up green or dry fodder with astounding rapidity and with very little attention from the operator. It practically runs itself.

The improved wind elevator not only elevates any height and in any direction, but distributes the cut feed evenly inside the silo.

The knives of the Blizzard are extra strong, and the special feature which will appeal to user is that they may be adjusted to or from the shear plate while the machine is running at any speed. 


\section{Papec Pneumatic Ensilage Cutter and Blower.} THE PAPEC IS BUILT OF THE VERY BEST MATERIALS AND IS ONE OF THE STRONGEST, MOST DURABLE CUTTERS IN USE.

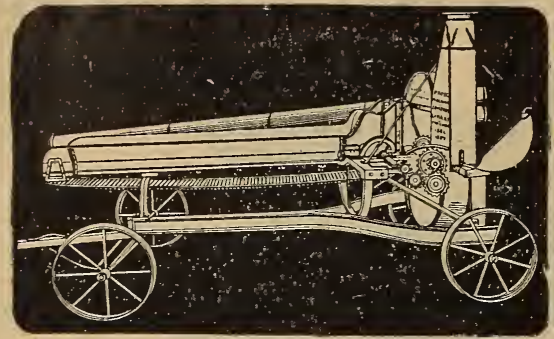

A perfect blower cutter cannot be made with a wooden frame, because it is affected by weather, which will warp the frame and thus throw the lower drum out of position. Besides this, the wood or riveted frames will become more or less diamond shaped by belting continually to a heavy engine. When this occurs it is impossible to keep the knives the proper distance from the shear plate. Since adopting the solid iron frame, all the cutters work alike and can be depended on to give perfect satisfaction under all circumstances.

The feed table is just the right height for the feeder to stand on the ground and feed the corn comfortably. This enables a man to feed faster than when obliged to stand upon a box or a specially constructed sideboard.

The tongue is easily removed, so that the load may be driven up close to the ensilage cutter.

The Papec mounting is strongly constructed of steel channels-no wood to twist and warp.

The Papec is the easiest cutter to set up and take down. Only the pipe has to be put up and removed.

It requires less power to elevate ensilage than a "tied-on blower" machine. The latter requires double the speed of the fan-a waste of power. The Papec is not dependent upon the air blast alone to elevate ensilage. It throws as well as blows. Ensilage is thrown fifteen to twenty feet, then a powerful air blast strikes it while in motion and completes work of elevation.

Price on application.

\section{GREEN MOUNTAIN SILO.}

It is an acknowledged fact that the most successful and the most economical means of producing milk or raising young stock is attributed to the use of the silo. And with the high price of feed it is a safe estimate that the profits from the farm can be increased 25 per cent. by the use of the silo.

This is a round silo, the only shape which will preserve ensilage in perfect condition. The construction is most excellent, the best of spruce and white pine being used. Staves are planed on four sides, and matched and beveled to fit the circle of the silo. The front is strong and rigid, doors are air tight, and heavy hoops and rods insure the silo keeping tight and in shape at all times.

Every silo dipped in creosote preservative unless otherwise ordered. Roofs priced separately. Specifications furnished on any sizes wanted. Let us know your requirements and we will quote you promptly.

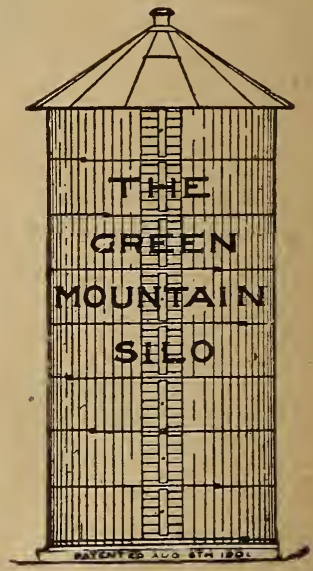

\section{THE CHICOPEE CORN .HUSKER. FOR BOTH STALK AND PICKED CORN.}

This is a most useful and highly desirable machine for the individual farmer. Nothing like it heretofore has ever been placed upon the market, that will approach it for ease and rapidity of doing the work, or in the small amount of power required to operate it.

A two horse tread power, or three to five horse power gasoline engine will run it to its full capacity, which requires that the main driving shaft should have a speed of not more than 300 R.P. M. Stalks fall from the apron at the rear, and can then be taken and rebound the same as when husked by hand. This is a great advantage over the large machines now offered for a like purpose.

This machine has a capacity for husking from 25 to 50 bushels an hour, according to the condition and quality of the corn.

We guarantee the "Chicopee" to husk the corn and separate the ears from the stocks without material injury to the grains of corn.

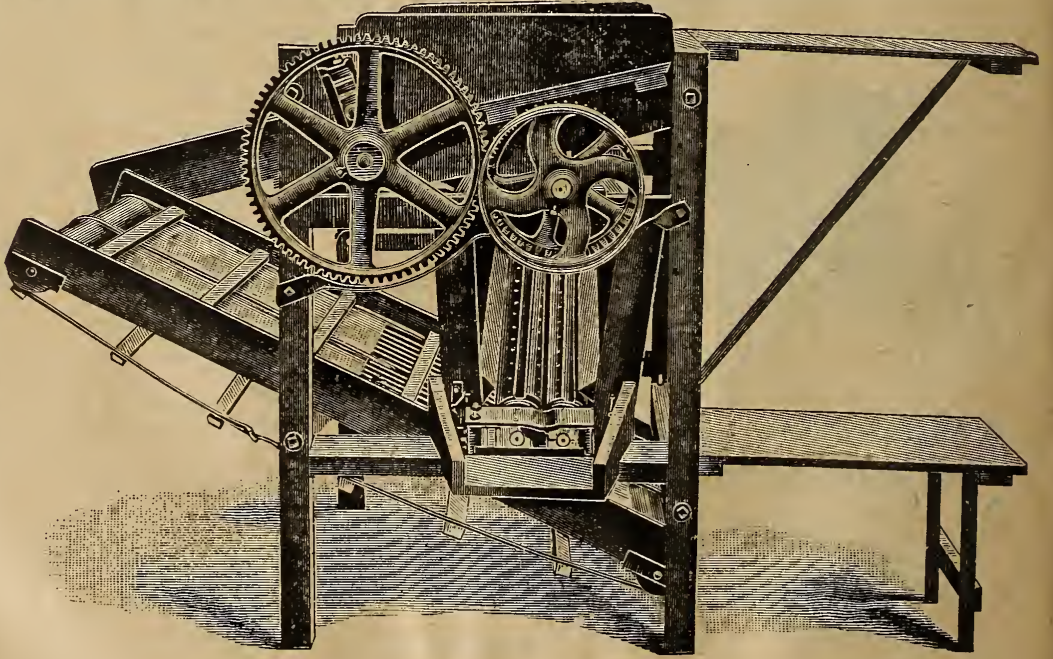

to husk the corn and separate the ears fro
Price on application. 


\section{GRAY'S NEW THRESHER NOS. 305-306,}

WITH POWER BAGGER, STACKER, ETC.

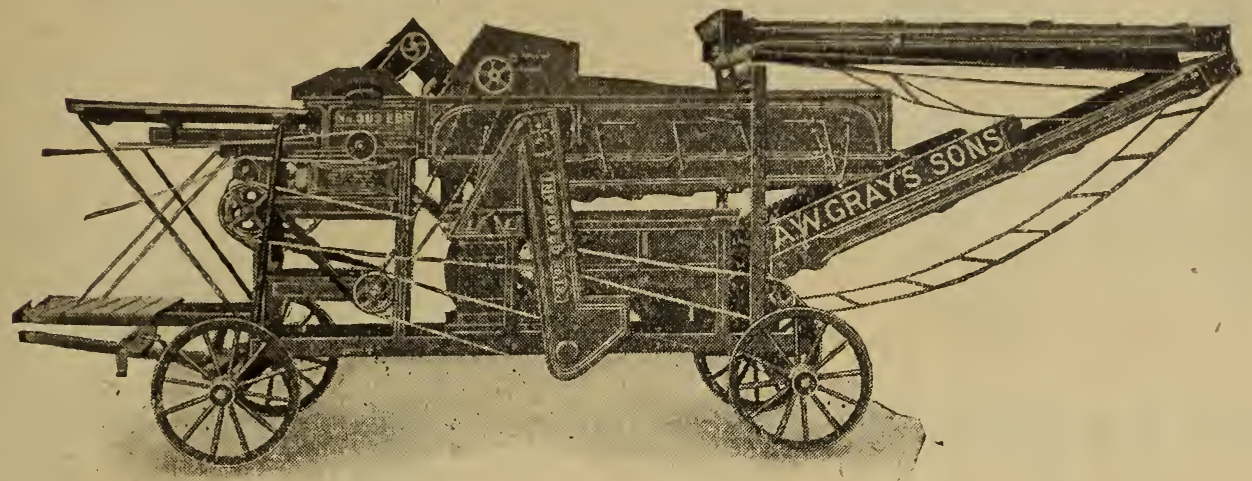

This thresher has been remodeled and reconstructed, and while built along the lines of regular threshers a number of radical changes have been made, one of the principal ones being that it is arranged so that it commences to separate the grain from the straw as soon as it leaves the cylinder, thus meeting the special benefit claimed for the undershot threshers.

It is built especially to meet the demand for use with gasoline engines, is made with $18 \mathrm{x} 30 \mathrm{cylinder}$, but two different sizes of separators have been added to admit using different size engines and are numbered 305 and 306 .

Price on application.

\section{GRAY'S INDEPENDENT DRAG SAW MACHINE.}

FRICTION DRIVE,

to run by Engine or other Power.

This is the latest and best drag sawing machine on the market.

One of the most important points in using the drag saw is to be able to start it slowly, thus removing any danger of breaking or bending the saw, and this is accomplished perfectly by using the friction transmission. Another feature is to be able to stop instantly, and this is arranged for in this ma-

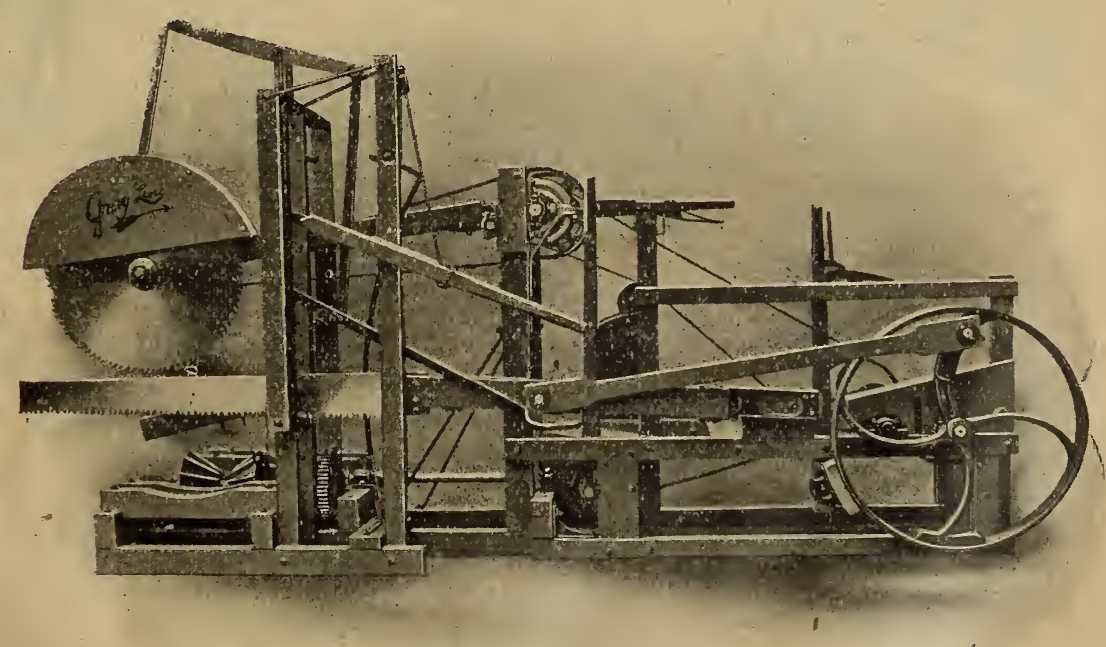
chine as the moving of the brake lever releases the friction pulley, at the same time applies the brake on the balance wheel, thus stopping the machine instantly.

By changing the size of the driving pulley on the counter shaft, these machines may be adapted to almost any style of power. 


\section{Gray's Circular Saw Machine with Extended Table.}

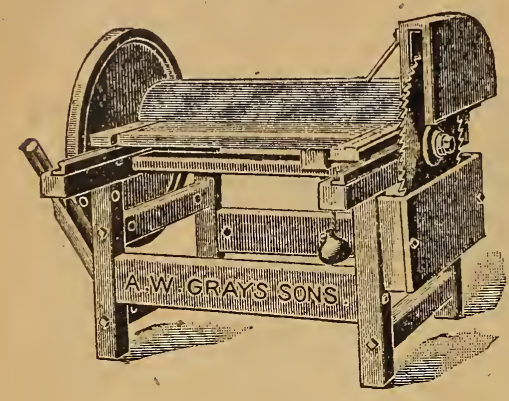

These are made with a table both sides of the saw, which is better adapted for sawing long wood, and can be used for sawing four-foot wood into stove wood. Saw machines made in this way can be used by one person sawing, as there is a rest for the wood both sides of the saw.

Machine equipped with either a 24-inch, 26-inch or 28-inch saw.

If $\mathrm{made}$ for a la rger than 28-inch saw there will be an extra charge for frame, as it has to be made larger.

\section{Gray's Circular Saw Machine with Swing Table.}

To meet the demand for a lower-priced swing table saw we offer the machine as above, except made with swing table.

Price on application.

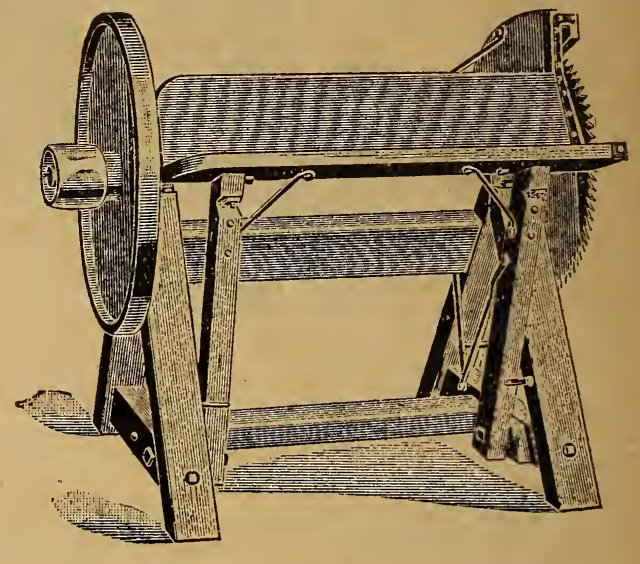

\section{American "Clipper" Wood and Pole Saws.}

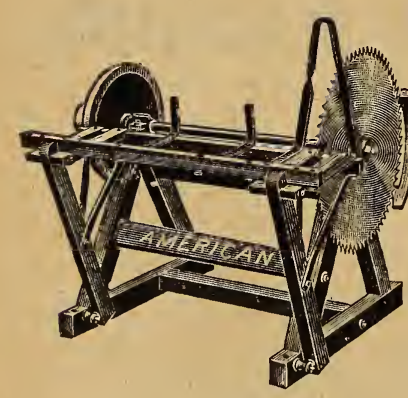

No. 3. Cord Wood Saw.

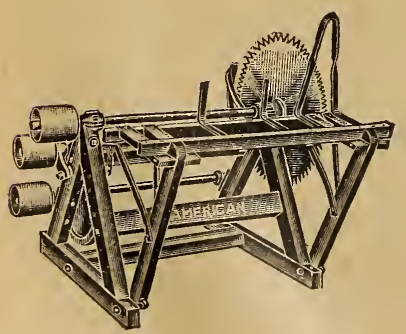

No. 5. Wood or Pole Saw.

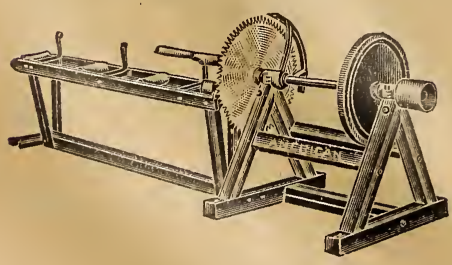

No. 8 .

These saws cover every style of both tilting table and sliding table machines, with balance wheel placed on end of mandrel or on independent shaft under the frame.

The frames are made of selected seasoned hard wood, accurately morticed and tenoned, and securely bolted together by steel rods embedded in the grits and passing through from one side of the frame to the other.

No. 4 has extension table for cutting poles, or four or eight-foot cord wood. By changing the iron guard to the opposite end of the tilting table, this machine can be set up exactly as No. 3 .

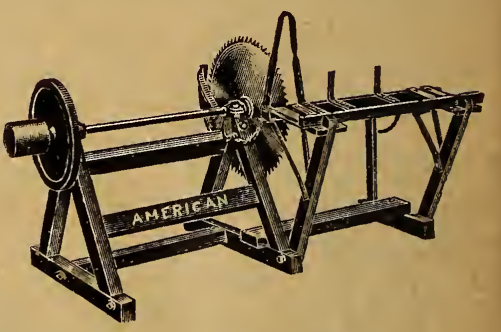

No. 4. Wood or Pole Saw.

No. 5 , is similar to No. 4 , but without extension table.

For those preferring a sliding table wood saw we offer the No. 6 machine. The carriage slides on iron ways with an easy movement and is counter-balanced by weight. When carriage is in forward position the saw is entirely covered by the hood.

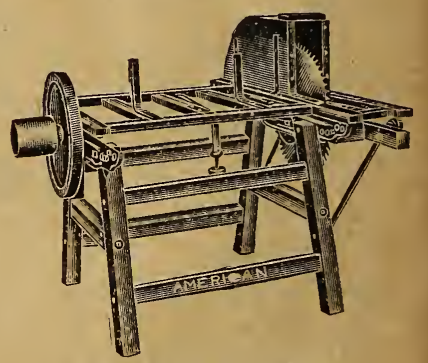

No. 6. Sliding Table Cord Wood Saw.

No. 8 is similar in construction to No. 3 , but with longer table.

The following applies to every saw. Mandrel $1_{16}^{7}$ " diameter, $52^{\prime \prime}$ long. From saw to balance wheel $42^{\prime \prime}$. Mandrel pulley $6^{\prime \prime} \times 6^{\prime \prime}$. Larger pulley at extra cost. Takes saws from $20^{\prime \prime}$ to $30^{\prime \prime}$ with $1 \frac{1}{4} "$ hole. Speed 1000 to 1500 revolutions per minute.

Prices quoted on application. 


\section{GASOLINE ENGINE DEPARTMENT.}

\section{STATIONARY AND PORTABLE ENGINES.}

HORSE POWER SIZES: $3,4,6,8,11,15,20,25,30,40,50,60,75,90$.

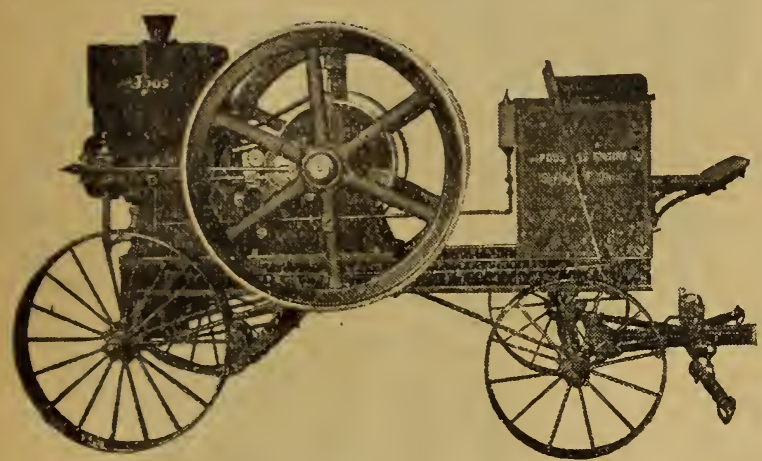

FOOS STANDARD PORTABLE ENGINES. 3 TO 35 HORSE POWER.

The illustration shows the portable and readyfor-mounting type of the Foos Standard Engine. This is the highest quality and inost scientifically designed engine manufactured. It has been used for electric lighting, for industrial purposes and in city water works stations for 27 years. Combined outfits are furnished with this engine for sawing wood, pumping water, etc., and in the regular portable type will furnish the highest grade service for operating threshing machinery, hay presses, filling silos or for any other service. It operates on gasoline or kerosene, and will give constantly satisfactory service.

Special catalogues describing this engine furnished on application.

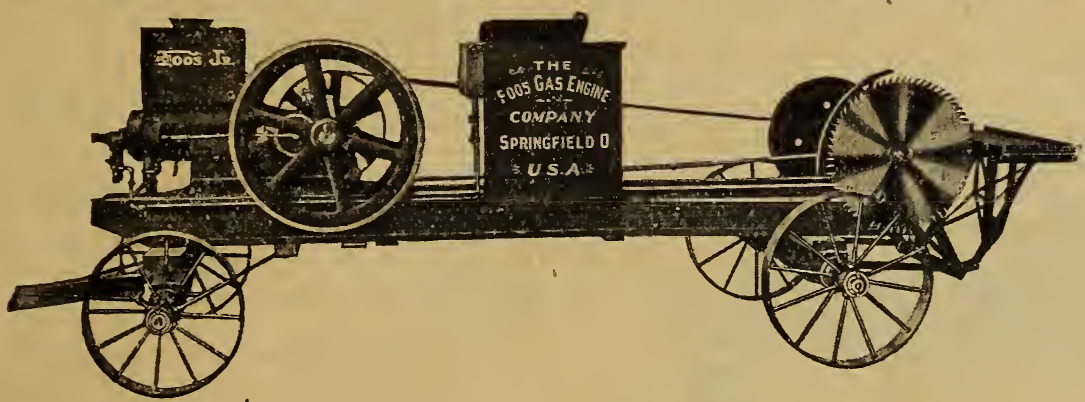

FOOS JUNIOR WOOD SAWING EQUIPMENT, NO. 9.

FURNISHED IN 4, 6 AND 8 HORSE POWER SIZES.

\section{EQUIPMENT A-15.}

Equipment A-15 consisting of a $2 \frac{1}{4}$ horse power Foos Junior engine and pump jack. Can be attached to any ordinary windmill pump standard. The outfit includes the engine, jack and belt. Pumps and skids are not regularly furnished. It is ready to set up with suitable pumps, and will supply from 200 to 2,000 gallons of water an hour, depending upon conditions. The equipment is heavy enough to operate any ordinary pump, but if greater capacity is desired, send for special pumping bulletin.

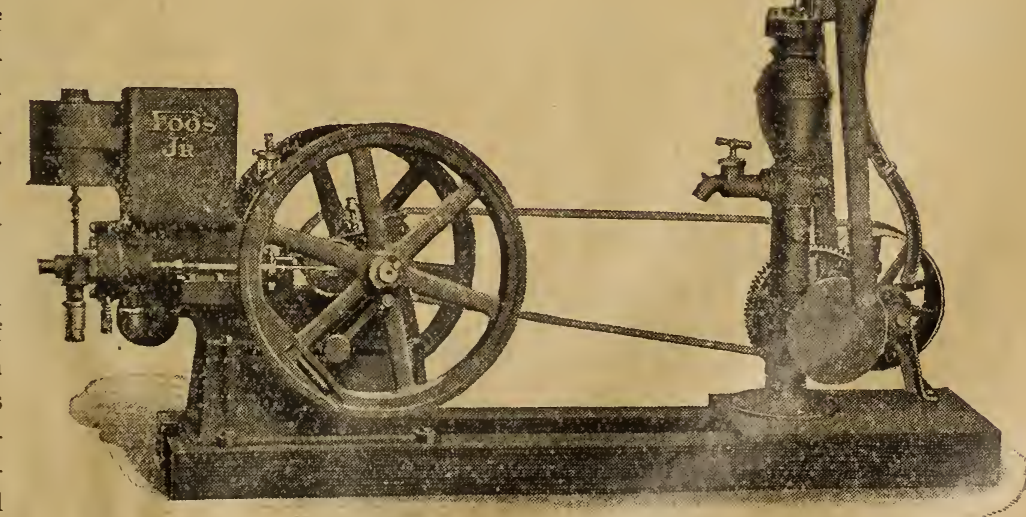

FOOS JUNIOR EQUIPMENT, $A=15$. 


\section{GASOLINE ENGINE DEPARTMENT,--Continued.}

\section{GASOLINE ENGINE EQUIPMENT NO. 3.}

2 1-4 horse power.

In this equipment the engine is mounted on an iron sub-base high enough to make the flywheels clear the floor. It requires only a small amount of cooling water and in every way is convenient and easy to handle. The battery, spark coil, etc., are placed in the base, making an outfit very compact and easy to install on trucks or temporary foundations with other machinery. The No. 3 equipment is also furnished in $1 \frac{1}{2}, 4,6$ and 8 horse power, descriptions of which will be found in the regular catalogue devoted to the Foos Junior line.

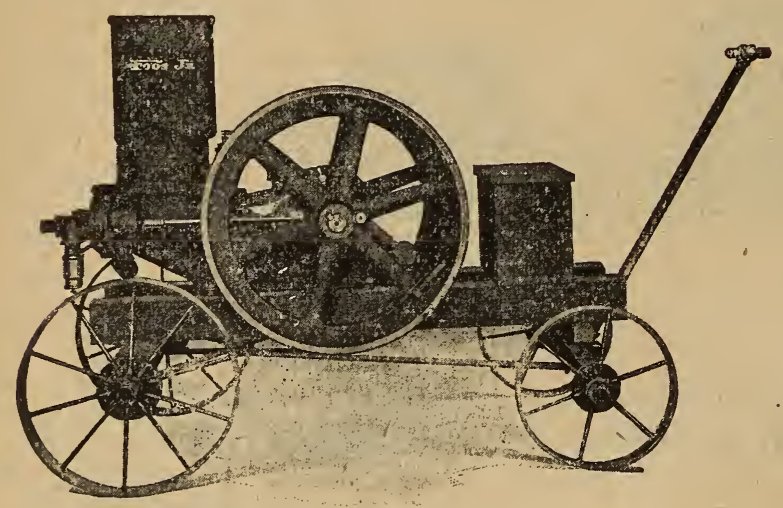

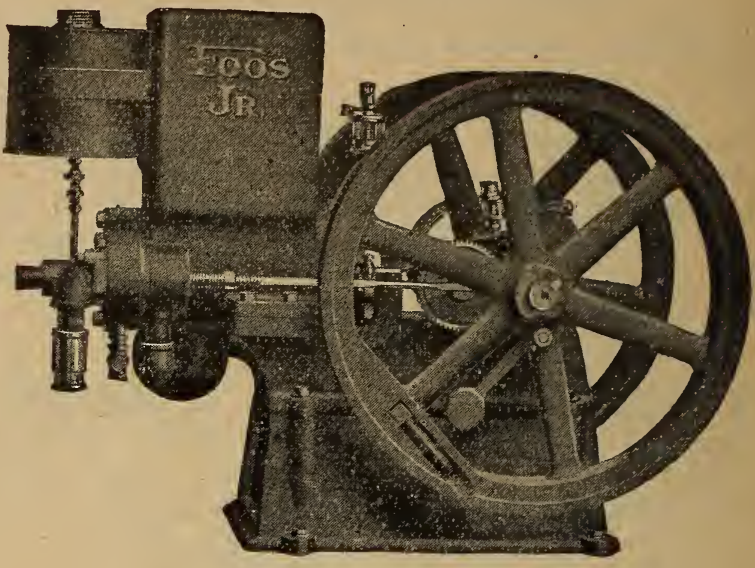

FOOS JUNIOR EQUIPMENT, NO. 3.

\section{GASOLINE ENGINE EQUIPMENT NO. 7.}

\section{$21-4,4,6$ and 8 horse power.}

A Foos Junior engine mounted on a hand truck. This combination is built in four sizes, ready to run when it leaves the factory. Portable outfits are also built in 4,6 and 8 horse power sawing rigs, and in 6 and 8 horse power sizes on two-horse trucks.

\section{Price on application.}

FOOS JUNIOR EQUIPMENT, NO. 7.

\section{DEYO PORTABLE GASOLINE ENGINES.}

\section{TO 16 HORSE POWER.}

$\begin{array}{cccc}\begin{array}{c}\text { SPECIFICATIONS OF DEYO PORTABLE } \\ \text { ENGINES. }\end{array} \\ \begin{array}{c}\text { Size of } \\ \text { Engine. }\end{array} & \text { Speed. } & \text { Weight. } & \begin{array}{c}\text { Clutch } \\ \text { Pulley. }\end{array} \\ 5 & 450 & 1600 & 14 \times 6 \\ 6 \frac{1}{2} & 425 & 2000 & 18 \times 8 \\ 9 & 400 & 2200 & 18 \times 8 \\ 13 & 380 & 3100 & 24 \times 8 \\ 16 & 350 & 3500 & 24 \times 8\end{array}$

EQUIPMENT.

Cover for engine, whiffletrees and neck yoke, spring seat, friction clutch pulley, battery box containing dry cells, coil, two spark plugs and wire, muffler, complete set wrenches, oil cups, oil can, can cylinder oil, box hard grease.

Price on application.

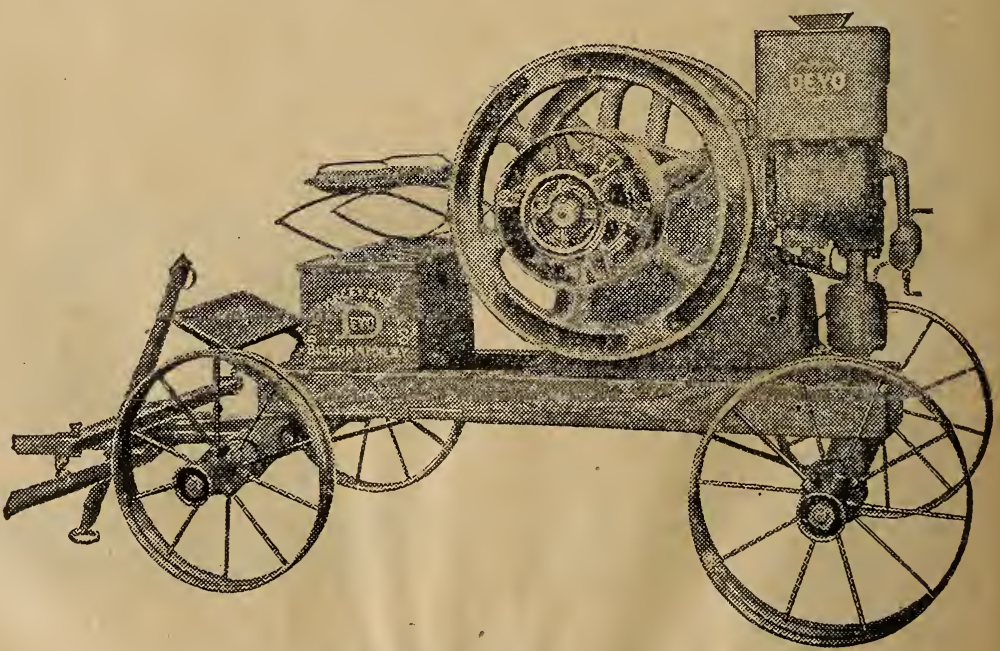

DEYo PORTABLE ENGINE. 


\section{GASOLINE ENGINE DEPARTMENT,-Continued. \\ DEYO STATIONARY GASOLINE ENGINES. \\ 1 1-2 TO 16 MORSE POWER.}

Horizontal type insures perfect lubrication and long wear of piston and cylinder.

Automatic regulation always insures a perfect mixture of air and gasoline and therefore economy.

Centrifugal type fly-wheel governor. Speed may be changed from 100 to 600 revolutions while the engine is running.

Separate and removable cylinder with solid head entirely eliminates packing troubles.

Removable and interchangeable valve cages allow taking out of valves for inspection or cleaning without trouble or changing adjustments.

Exhaust valve positively operated by single lever. Inlet valve automatically locked to seat on idle stroke.

Large exhaust opening allowing burnt gases to escape quickly, saving unnecessary heat and wear.

Ignition by jump spark. Spark plug placed directly in end of the cylinder which gives the spark in the proper place, insuring perfect and rapid combustion.

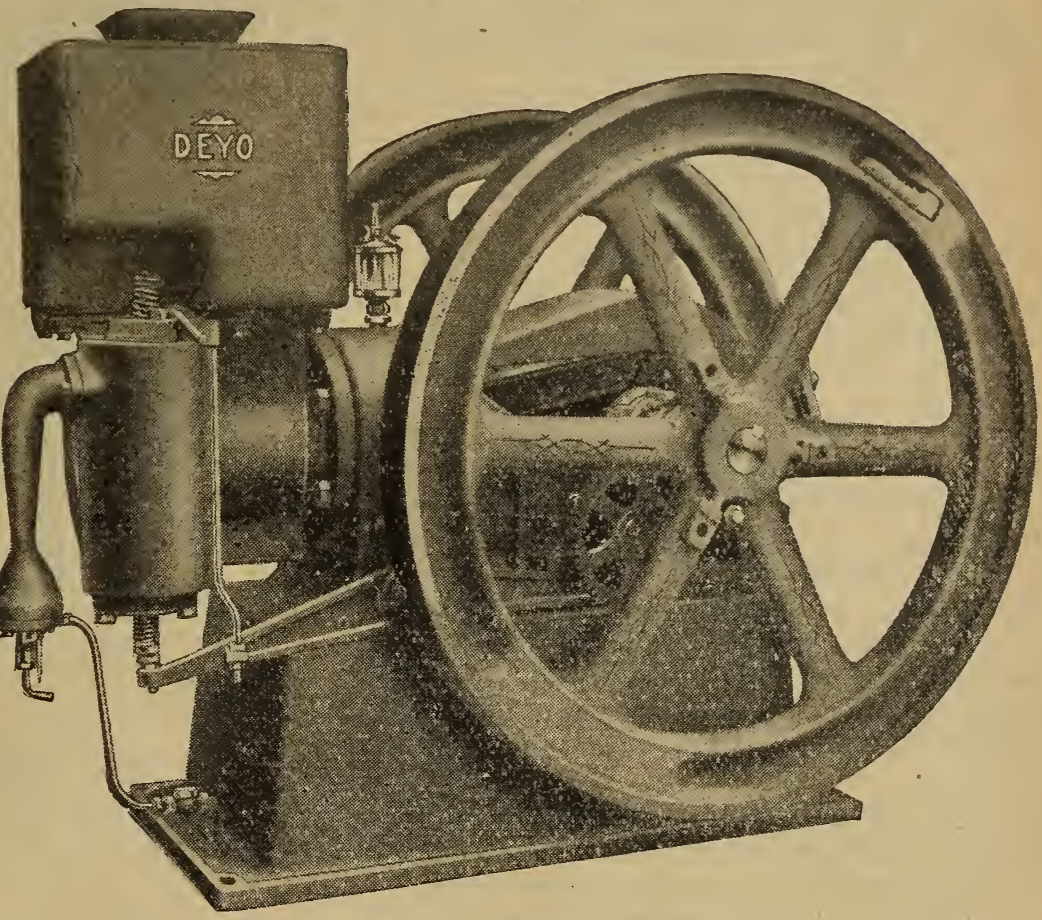

DEYO STATIONARY ENGINE.

Venturi type of suction mixture, doing away with all moving parts as well as gasoline pump. Absolutely no pump to pack, as there is none on the engine.

Large water space around the cylinder and both valves, giving ample protection from excessive heat.

Mixer fitted with air throttle, throttling the air in the throat of the mixer, increasing the air velocity at this point and making the engine exceptionally easy to start, especially in cold weather.

Separate hopper detachable at a point just above cylinder line. A plate may be substituted in place of hopper for gravity or pump circulation. Under side of water jacket fitted with breaking plate to prevent damage to cylinder in case of freezing.

All engines equipped with full set of oilers and wrenches, muffler, exhaust fittings, complete battery belt pulley, repair part price list and instruction sheet. Price on application.

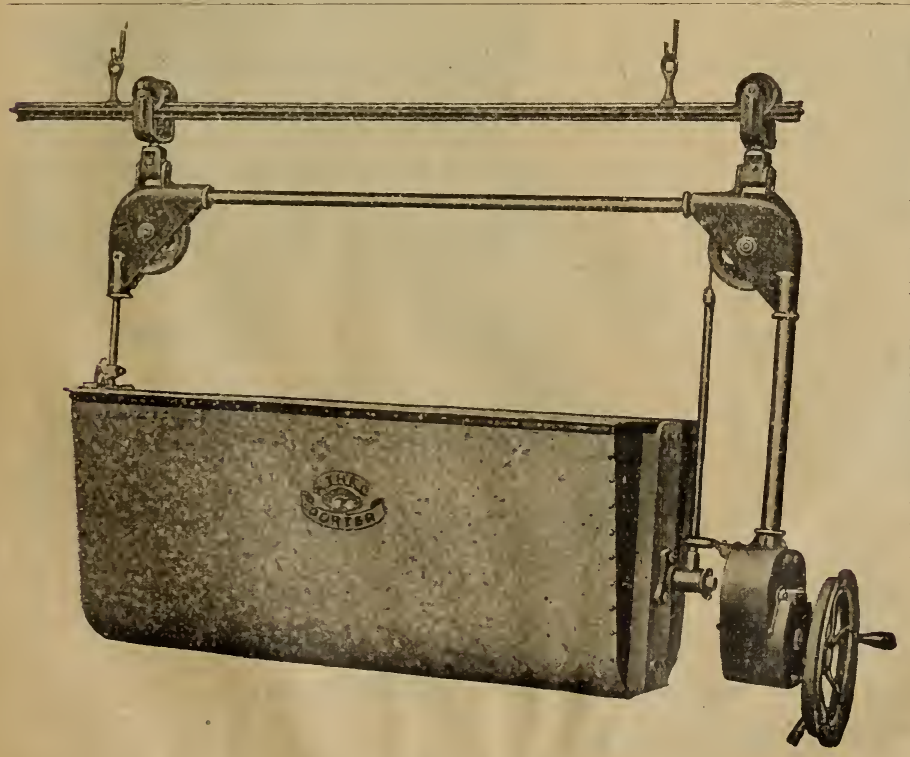

\section{PORTER LITTER CARRIER.}

With it one man can do the work of three, and do it better and easier. It is the handiest and most satisfactory litter carrier on the market. The gear and pinion hoist, with wire cable, gives the biggest lift for the power, and the quickest action. The hopper is made of heavy galvanized steel with capacity of 12 bushels; is held automatically at any height, and is provided with a dumping device, which is tipped at will by the man in the stable. Has one piece steel track, carrier wheels are roller bearing, and are swiveled so carrier will go around the sharpest curves safely. No end motion, no joggling, liquid litter will not slop over-the only litter carrier with a stationary arm.

The Porter Carrier is also made with chain hoist, if desired. 


\section{LETZ GRINDING MILLS.}

Principal features that make the Letz Burrs and Grinders stand forth are:

FINE GRINDING, SILENT RUNNING,

LONG LIFE,

LIGHT DRAFT, SELF-SHARPENING.

PLATES can be changed by anyone in a few minutes.

SEL F - A LI G N M E N T KNUCKLE Burr Holder.

WET, DAMP or OILY GRAIN is a delight to the Letz Grinder.

HARD-OIL GREASE CUPS on every bearing.

FINE GRINDING. The Letz strongest feature is that they are warranted to grind wheat screenings, oat hulls, alfalfa hay after being cut to onehalf inch lengths, also cob and corn, with all the husks, equally as fine as can be done on attrition or French burr grinders. Table meal is a specialty of the Letz Burr.

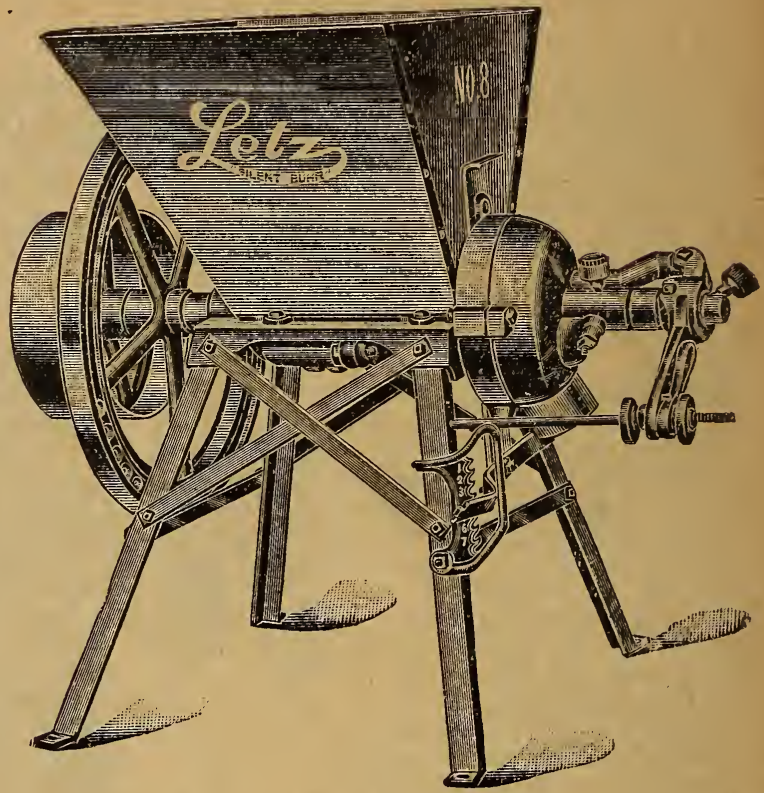

NO. 8 LETZ COMBINE GRINDER.

The Letz Burrs have stood the test for twenty-one years and all their users certify that they cannot be equaled in fine grinding and long life of burrs.

Power required-from 2 to 5 horse power.

Capacity -5 to 25 bushels ear corn per hour.

Plates-8 inches diameter.

Speed-200 to 600 revolutions per minute.

Pulley $-8,10$ or 12 inches diameter, 4 inch face.

Weight-230 pounds.

Price on application.

\section{Peerless Feed Grinding Mills.}

These mills are designed to meet the demand for mills that can be operated with small power, and still have capacity to do a rea. sonable amount of work. They are built of iron and steel excepting the hopper, and have proven great sellers. They are equipped with patented machine cut grinding plates, ball bearing end thrust quick release lever, babbited split boxes, adjustable feed, solid crusher roll
and self lining

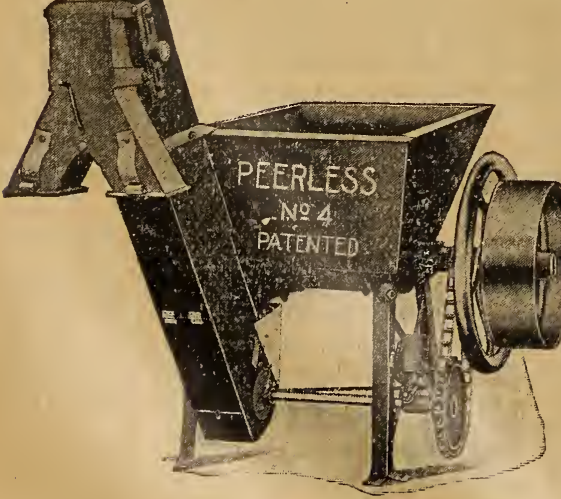
plates.

Power required, from $t w o$ to five horse power.

Capacity, five to twenty-five bushels ear corn per hour.

Speed, 300 to 500 revolutions per minute.

Pulley, $14 \times 4$ inches.

The se mills will also grind shelled corn and smallgrain successfully.

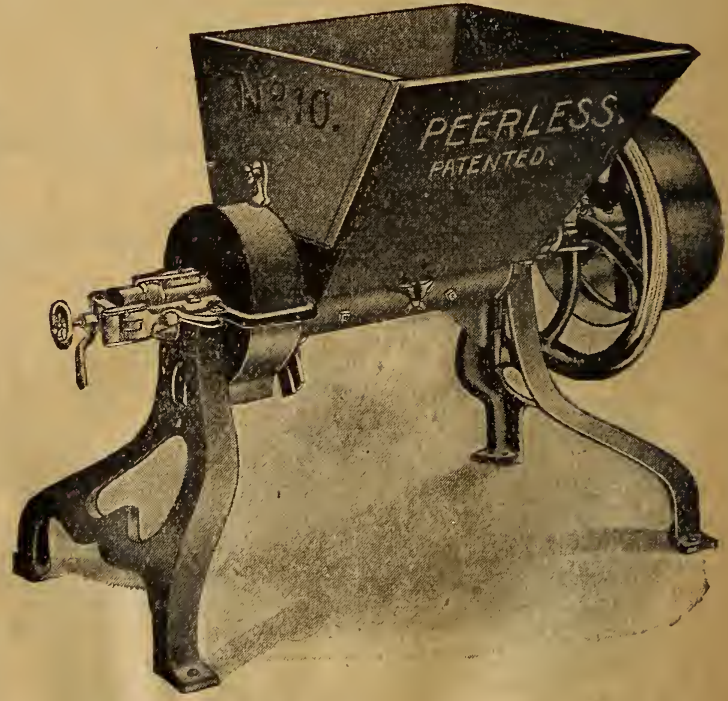

The following sizes, Nos, $4,5,10,40$ and 50 , carried in stock. Price on application. 


\section{BANNER ROOT CUTTERS.}

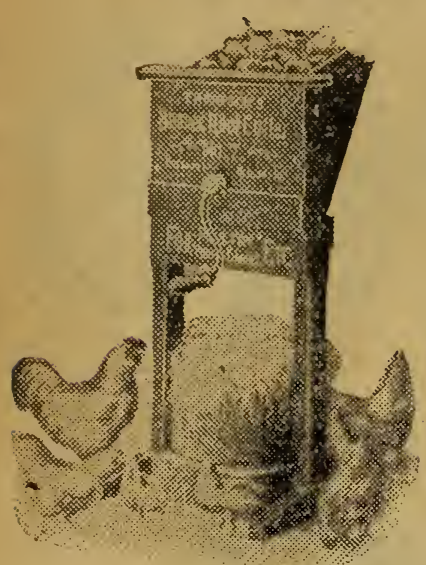

BANNER CUTTER NO. 7 .
Prominent poultrymen all over the country have taken up the matter of green food for their fowls. It is, in fact, a hen's natural food. It is a great egg producer in itself, because it keeps the body of the hen in a good, healthy condition, and healthy hens are the only egg producers, no matter what the breed. Not only do roots make healthy hens, but their economy as food is astonishing.

It cuts fast and is easy running. Leaves the feed in fine ribbon-like strips that make choking impossible. Fowls large or small can safely eat the feed. The knives are adjustable and made of the very best of steel. An iron grate in bottom of hopper lets dirt and gravel escape before reaching the knives. In this cutter we offer the poultrymen a low priced, high grade, nicely finished and mechanically constructed machine, and feel that anyone who desires to feed roots and vegetables to their flocks can well afford to own one. Two to five minutes will cut enough feed for a large flock of fowls.

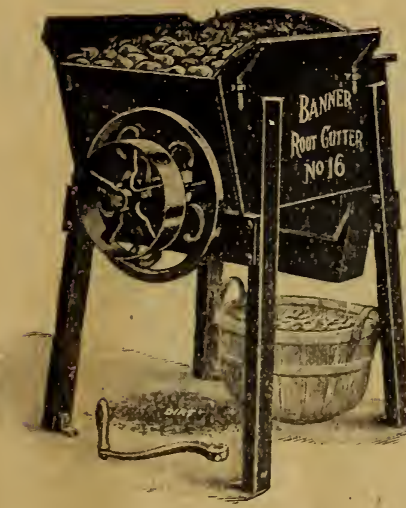

BANNER CUTTER NO. 16.

A grand machine for hand and power use. This machine can be used for hand or power, and it is the only Banner Cutter we offer having" a balance wheel. It is also supplied with a pulley for belt power, and a crank, so it can be used by hand; in fact, it is a small size power cutter, and the best machine made for hand and power use.

The cut is taken from a photograph, so it represents the machine exactly. The condition of the fodder is the same as on all the cutters.

Capacity when run by hand, 30 to 50 bushels per hour. Capacity when run by power, 1 to 3 bushels per minute.

This cutter has the self feeder and dirt separator, same as the other sizes, and is a very desirable size machine for all feeders who do not want the big No. 10 exclusive power machine.

The pulley is 12 inches in diameter, with a 3 -inch face, and fastens to either end of shaft. It has lugs on bottom of legs, so it can be fastened to the floor.

Speed by power, 125 to 150 revolutions.

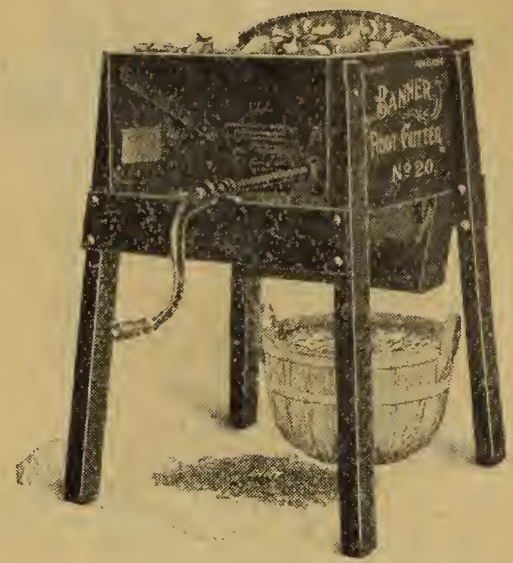

BANNER CUTTER NO. 20.

The No. 20 Banner Root Cutter is made for hand power and is the kind and style that meets with the largest sale, because most of the farmers who feed roots to stock want a machine that is run by hand. It has a capacity of 30 to 50 bushels per hour, although it will cut at the rate of a bushel a minute easily on the test.

It is well built, nicely finished, runs easily, feeds itself, separates the dirt from the cut feed, and, take it all around, it is all that could be desired in the way of a first-class root cutter for all ordinary requirements.

It is supplied with the best steel knives. The condition of the fodder after passing through this machine is left in the same desirable shape, to avoil choking, as comes from all other Banner Root Cutters.

\section{Champion Root Cutter.}

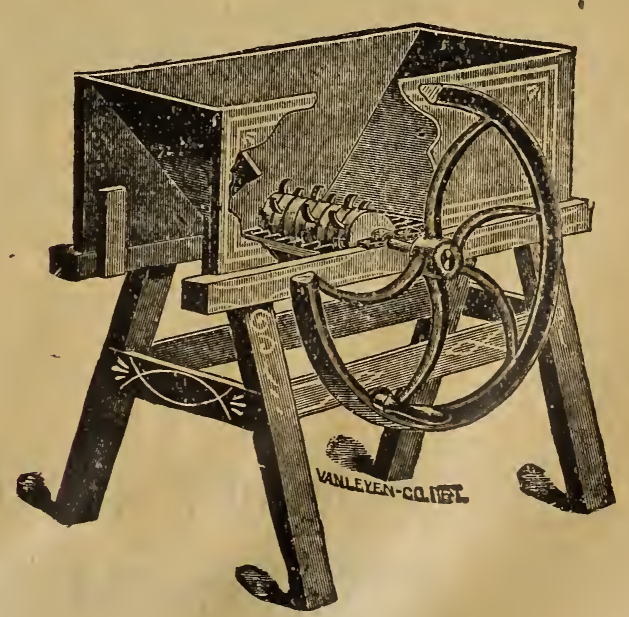

This well-known rout or vegetable cutter has been on the market for many years, and is too well known to need further description. It is well made of good material. 


\section{Derby Feed Cutters.}

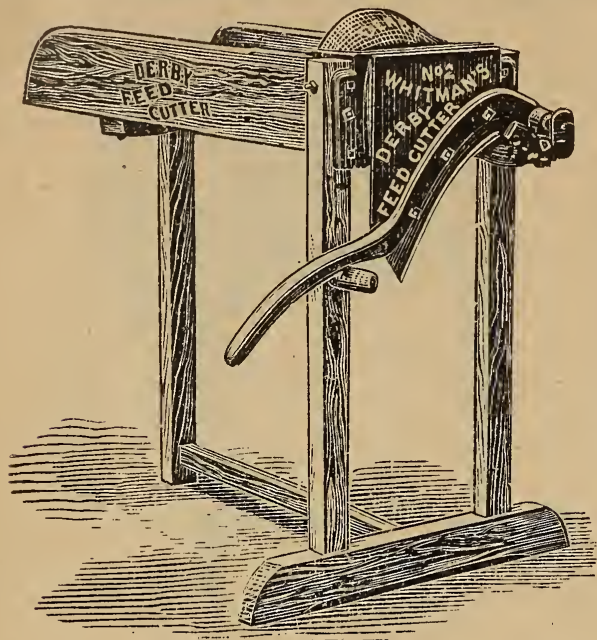

This iron handle level cutter is so simple and easy to work as to commend it to everybody who has but a moderate amount of stock to feed. The knife is easy to adjust, grind and keep in repair.

Price, $\$ 3.50$ to $\$ 6.00$.

\section{Aluminum Cider Mills.}

The very Latest Machines on the Market. The use of aluminum in the s e mills, both in the shredding roll and the hopperparts, gives an absolutely sanitary mill, in which there is no possibility of pollution to the fruit or juice. A l u m inum can be quickly cleansed with water, and furthermoreit is absolutely proof àgainst the action of acids.

Junior, Medium, . Senior,

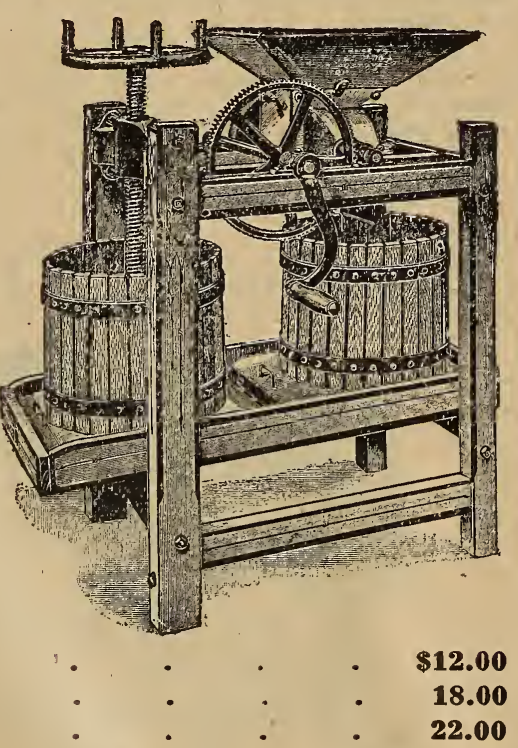

\section{PEABODY'S POTATO AND ROOT CARRIER.}

Cuts 1-4, 7-16 and 3-4 inches. ing beans, peas, etc.

Price, \$2.00.
Chicken Feed Cutter. Invaluable to Poultry Raisers.

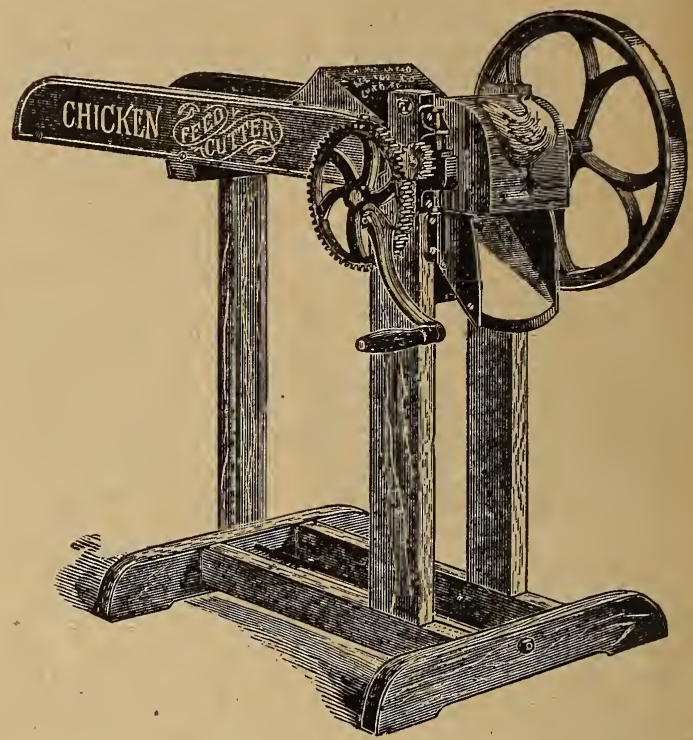

This is a highly efficient machine for cutting clover, hay or other feed into extremely short lengths. It is made with three knives $6 \frac{1}{4}$ inches long, and a self-feeding comb roller, which straightens the feed as it is presented to the knives, making a more uniform length of cut. It cuts very rapidly being one of the fastest machines of its size.

Price, $\$ 15.00$.

\section{CLOUGH'S ADJUSTABLE SIEVE.}

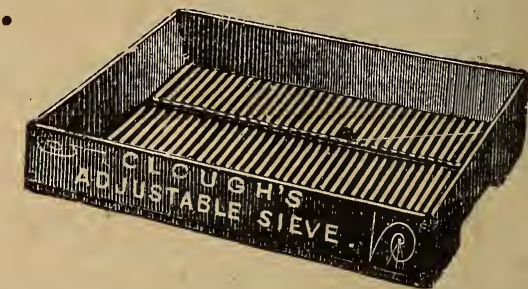

In offering this adjustable sieve to farmers and others, we know that they will find it useful and valuable for separating foul seeds from grain, and sifting out the small grain, thereby getting the most vigorous kernels for seed; also for cleaning and sort-

\section{S.}

Will quickly fill or empty a bin of potatoes without bruising them. Every"farmer needs one. Sizes, from 12 to 22 feet in length. 


\section{PONY CORN SHELLER.}

Has separator, and large, heavy balance wheel. The working parts are held firmly together by solid shaft boxes or bearings. One of the most popular shellers on the market. Made in one size only. Complete with blower attachment.

Price mailed on application.

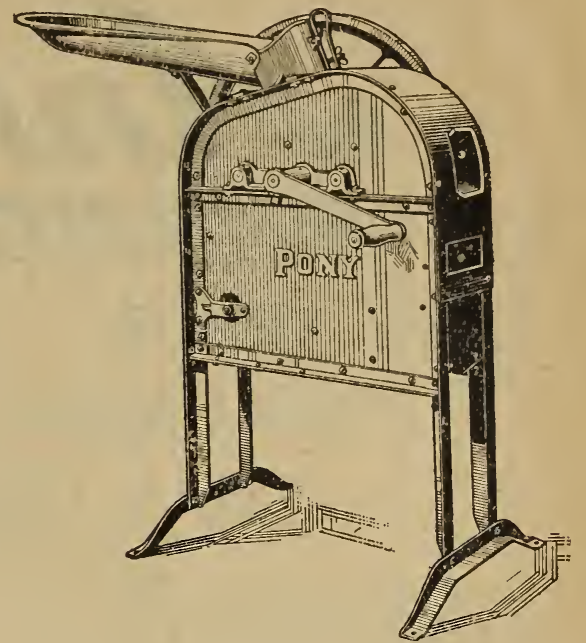

\section{THE CHATHAM MILL.}

\section{THE OWEN'S BEAN THRESHER.}

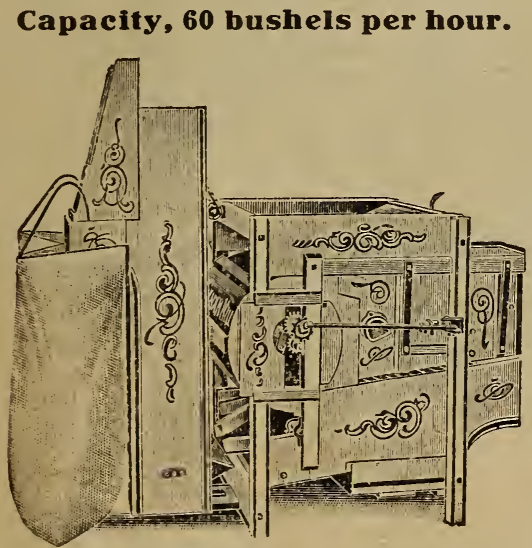

To sow.large, plump grains, such as results from a sensible system of grading with a good mill, results in a direct increase, taking it one year with another, of from 10 to 25 per cent. in the crop.

Grade all the grain in the Chatham Mill, and take out all the foul seeds, dirt, chaff, etc., and thus secure better grain to market and perfectly pure seed for sowing.

\section{Price on application.}

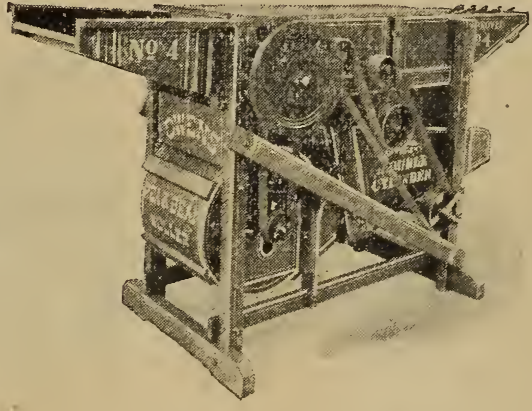

This machine will thresh all varieties of beans (or peas) directly from the rankest growing vines, without splitting the seed. It takes all the seed from the vines and pods in a clean marketable condition, and shreds the vines, making them valuable for fodder. It will also thresh corn in a perfectly satisfactory manner, handling it as nicely as it does beans. All pieces of cob, etc., are removed, and the corn is as well cleaned as when run through the ordinary corn sheller.

Price on application.

\section{JOHNSON FAN MILL.}

The fan mill is indispensable to a well-regulated grain barn. This mill runs the sound, clean grain to one side of the mill, while the sand and small seeds pass out at the other, and the heavy chaff and heads are caught in a receptacle behind the machine. It will not only clean grain, but also grass seed in the best manner.

Price on application.

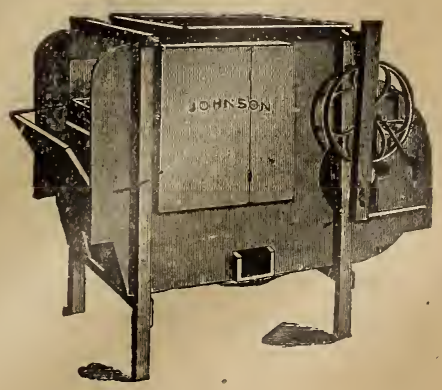




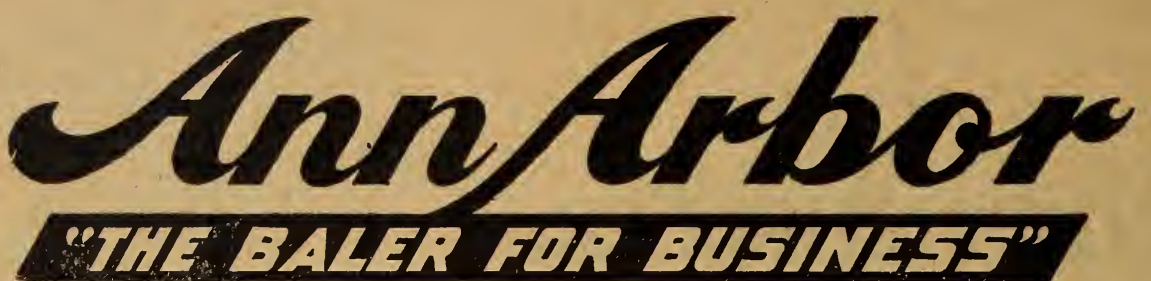

ANN ARBOR

"COLUMBIA"

HAY PRESS.

The capacity of this machine runs from forty to seventy tons per day. It makes bales weighing from 100 to 160 pounds, according to the the operator's wishes, requiring but 8 to 12 horse power to do the work.

The feed hole is but fortytwo inches from the ground. The hay can be pitched directly from the windrow under the automatic self-feeder, thus saving a.man on top of the machine as required by all other belt power presses.

This press is equipped with automatic division block dropper, bale length indicator, etc. It embodies all the latest ideas of steel press construction, and is bound to give the very best satisfaction.

We guarantee the "Ann Arbor" to be capable of baling just as much hay, if not more, under equal conditions as any other press on the market, and to do it with a lower average repair bill. We guarantee it to be well made, of good material, and by good mechanics, and we will furnish free the first season any part defective in workmarıship or material.

\section{No. "35" and Engine Complete on 4 Wheels,}

the handiest, speediest and most economical baling outfit, making bales of one hundred pounds and less. It will bale hay for less money than any other baler on the market. This machine is equipped with the same powerful self-feeder, the same size feed hopper, the same handy, effective block dropper and bale length indicator used on the double geared Ann Arbor "Columbia" and can be run with from 6 to 10 horse power.

\section{No. "20" Combination.}

This press is equipped with the same patented self-feeder that is used on all of the well known and popular "Ann Arbor" belt power balers. Most all self-feeders on horse presses have to be helped by the man feeding if they make any headway, but this belt power press has an absolute self-feeder, the best in the United States without any question. All you have to do is to place the hay over the feed hole. The feeder does the rest at a rate of seventeen to twenty beats per minute.

The block dropper is the same that is used on all these machines, but unlike all other belt power balers, this machine has a long feed hopper opening like a horse press. Makes bales weighing from 85 to 120 pounds, and requires only from $3 \frac{1}{2}$ to 5 horse power. 


\section{STEEL CONSTRUCTED FARM TRUCKS.}

We emphatically recommend these trucks as adapted for all kinds of farm work, being exceptionally well made. and so constructed as to carry any style farm wagon box. Are of especial value in hauling heavy loads, being equipped with tliat end in view.

The frames are solidly put together, and the low, broadtired, well-built steel wheels, with their skein axles, will easily carry any reasonable weight.
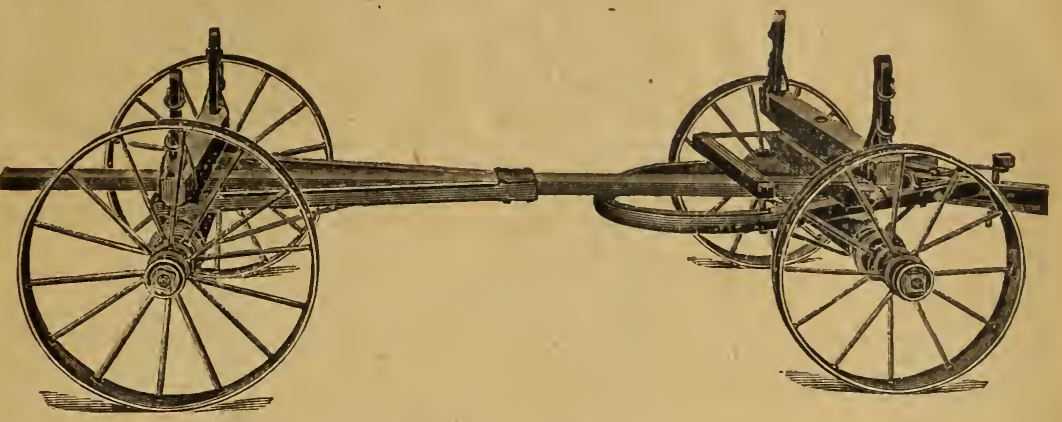

Write for quotations.

\section{EUREKA WAGON JACK.}

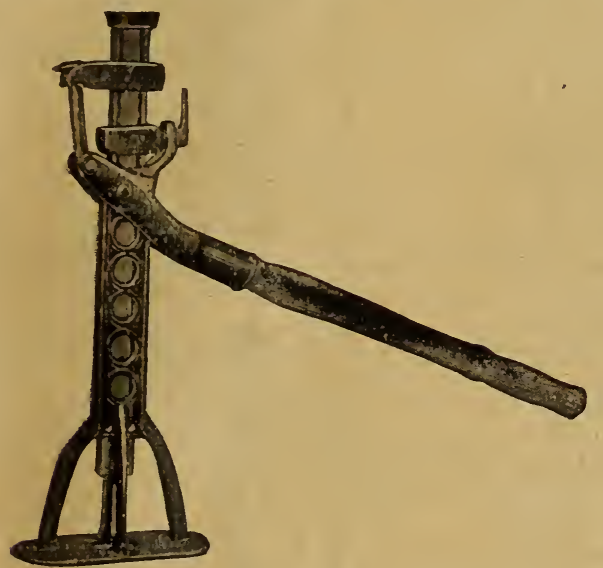

Light in weight but strong in lifting capacity. Small in size but will easily raise a loaded wagon. Is 16 inches in height when lowered. Is lowered by the same handle that raises. Is constructed of steel and malleable iron. Not a bolt, spring, ratchet or rivet used in its construction. Is the most durable and efficient Jack manufactured.
TANK

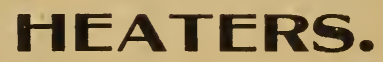

The Arctic cast tank heater, with basket grate, complete with pipe damper and spark arrester.

Diameter, 14 inches.

Height, 24 inches.

Is suitable to use in either wood or steel tank.

$\mathrm{H}$ e a ters are thoroughly tested and warranted not to leak.

Price on application.

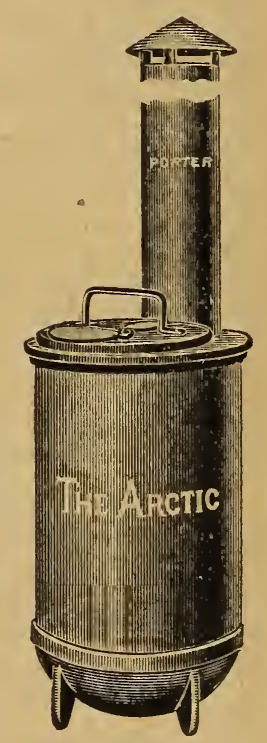

Price on application.

\section{WEBER FARM WAGONS.}

The man who uses weber wagons will use no other.

Weber wagons are made for every purpose and for every clime. They are wagons that will stand unlimited hard usage and will give satisfaction under all conditions. They are constructed of the best oak and hickory only. A practical farmer will instantly realize the enduring, wearresisting qualities of these woods. In addition to the select materials, Weber wagons are protected by the best quality of paint and varnish. The finish not'only looks but wears well, and the purchaser of a Weber wagon can pride himself upon the durability and attractiveness of his wagon.

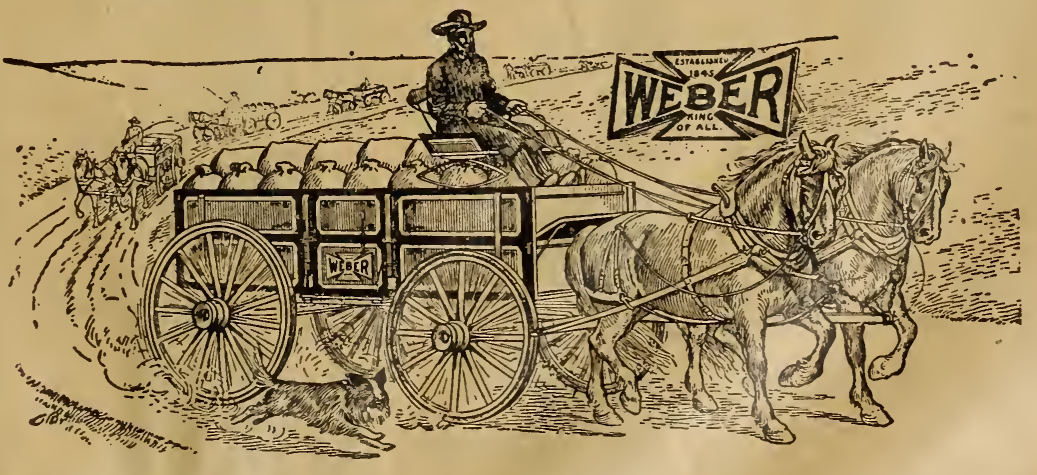

Prices on application. 
Acid, sulphuric,

Aphine,

Arsenate

Atomizers,

Augers, post,

"Auto-Spray,",

Bag Balm,

Bands, poultry leg.

Barrels, galv, iron ash.

Baskets,

Baskets, berry

Baskets, iron,

Bells, cow,

Binders, grain

"Black Leaf 40,"

Blowers, ensilage, 162, 163, 102

Boilers, farmers', $162,163,164$

Boilers, wash,

Bone, ground,

Bone, ground,

Bools, farm, orchard \&

hard \&

$\begin{array}{lr}\text { garden, } & 36 \\ \text { Bordeaux mixture, } \quad 100,101\end{array}$

Bottles, Babcock test, $\quad 90$

Bottles, milk,

Bows, ox,

Bowls, wood,

Boxes, butter,

Boxes, butter shipping.

Boxes, egg shipping.

Boxes, oak bail, 93

Boxes, self-feeding poultry, 73

Brackets, rafter,

Brooders, 69,71

$\begin{array}{lr}\text { Brushes, can \& bottle, } & 88 \\ \text { Buckets, well, } & 59\end{array}$

Bug Death,

Cages, bird,

c

Calf meal

Candìes, sulphur,

Cans, creamery,

Cans, milk

Cans, oil,

Caps, bottle

Carbonol,

Carriers, egg,

Carriers, butter,

Carriers, hay \& supplies,

Carriers, litter,

Carriers, milk bottle,

to \& root.

Cart, water barrel,

Cases, egg,

Catchers, grass,

Charcoal,

Chemicals,

Chisels, grafting,

Choppers, food,

Churns,

Cleaners, pneumatic,

Cleanser and Cleaner.

Clippers, Victor lawn,

Color, butter

Compound, Lawn.

Controller, Jasmin,

Coolers, milk

Creamers, Cooley,

Cultivators, riding, $\quad 140,141$

Cultivators, walking, $\quad 135,139$

Cure, Grange Garget, $\quad 95$

Cutters, bone,

Cutters, chicken feed, 171, 172

Cutters, ensilage,

Cutters, feed,

Cutters, potato

Cutters, root.

Cutworm Killer,

$161,162,163,164$

D

$\begin{array}{lr}\text { Diggers, potato, 158, } & 159,160 \\ \text { Dip, sheep, } & 102 \\ \text { Distributor, fertilizer, } 150,151\end{array}$

Doors, screen,

Drags,

Dragheads

Drills, fertilizer, $\quad 120,151,152$

Drills, grain, $120,151,152$

Drills, seed,

Dryers, clothes,

$53,118,119$

Dryers, wall,

Dusters, Diekey,

Dusters, Acre-an-Hour,

\section{NDEX.}

Electrobator,
Electrohover,
Enulsion, kerosene,
Engines, gasoline, 167, 168, 169
Expander, teat,
Extension, pipe,
Farmogerm,

Feeders, automatic poultry,

Feeders, chick,

Feeders, calf,

Fence, Am. field,

Fence, Am. poultry,

Fence, lawn

Ferment, lactic,

Fertilizers,

Food, fish,

Foods, plant, $\quad 42$

Foods, horse \& cattle, 81,82

Forls, poultry, 79, 80, 81, 82

Forks, wood stable,

Fountains, poultry,

Freezers, ice cream,

Fumigators,

Gates, wire,

Glass ware, creamery,

Gloves, cotton,

Governor pulley,

Graduates,

Grapples,

Grinders, knife,

Grindstones,

Guard, wire flower bed.

Guard, wire tree,

Guns, powder,

Harrows, 130, 131, 132, 133, 134, $136,137,155,157$

Harvester, corn,

Headers, barr

Heads, drag,

Hoders, tan

Hods, Norcross,

Hoes, potato,

Hoes, scuffle,

Hoes, wheel,

Holders, bouquet, 118, 119, 120

Hooks, hanging \& floor, 15

Hoppers, chicken feed, 73,74

Horses, clothes,

Hose, garden.

Hovers, adaptable,

Hovers, portable,

Husker,

Hygrometers,

Ice plows,

Ice tools,

Incubators

Index, horticultur

Index, horticultural, 494

In secticides, $99,100,101,102$ liams,

100

Jacks, wagon,

Jars, fruit,

58, 17 ;

"Kant-Klog,"

Kettles, tea,

Killers, fly.

Killers, lice,

Knives, border,

Knives, hay.

Knives, poultry killing,

Knives, pruning,

Kow Kure,

tree,

Labels, pot

Ladders, step,

Ladles, bu

Lanterns,

Lime.

Lime Sulphur,

Makers, bread \& cake,

Mangers, iron,

Manure, sheep

Manure, shredded cattle.

Markers, poultry

Mattocks,

Mats, hot-bed,
Meal, calf,

Measures, dry,

Measures, acid,

Menders, hose,

Mills, cider

Mills, fan,

Mills, Stover's hand,

Mops, dry,

Moulds, butter,

Mowers, field,

Mulcher,

Muzzles, ox,

Nests, hens',

Netting, poultry,

Norcross Cultivator,

Nozzles, hose,

Nozzles, spray pump,

"O-Cedar,"

Oculum,

Oil, cattle,

Outfit, milk fever

Pails, cream,

Pails, dinner

Pails, galvanized iron,

Pails, garbage, galv. iron, 62

Pails, milk,

Pails, milk strainer,

Pans, feed.

Paper, butter,

Parcel Post rates,

Parers, apple,

Paris Green,

Phosphate.

Picks,

Pickers, blueberry,

Pickers, fruit,

Pipettes,

$\begin{array}{lr}\text { Planters, corn, } & 142-146 \\ \text { Planters, potato, } & 146,147,148\end{array}$

Plants,

Plaster dust,

Plows, bog,

Plows, ice.

Plows, sulky,

Plows, walkin

Points, glazing,

Poppers, corn

Pots, flower,

Powder,K.\&W.sweeping,

Poultry supplies, $\quad 69,89$

Presses, hay,

Probe, teat,

Protectors, plant,

Pruners,

Pruning Compound,

Pulleys, hay fork,

Pumps, spray,

Pumps, wood,

Pumps, vinegar

Pyrox,

R

Racks, feed,

Rafía,

Rakes, garden \& lawn.

Reed, for basketry,

Reels, garden,

Reels, hose.

Relief, cows,

Remedy, garget

Rings, bull,

Rings, fruit jar,

Refrigerators,

Remedies, poultry,

Rollers, land,

Rollers, lawn,

Rollers, towel,

Roup Remedy.

5

Salt, Worcester, see inside last cover.

Sash, hot-bed.

Saws, machine,

Saws, pruning,

Scales, dairy,

Scales, platform

Scrapers, road,

Screens, window,

Seeds, oats \& wheat,

Sections, machine,

Seed drills,

$53,118,119$

Seeds, flower, 4-16

$\begin{array}{ll}\text { Seeds, grain \& forage, } & 34 \\ \text { Seeds, herbs, } & 33\end{array}$

Seeds, herbs,

Seeds, lawn,

Seedlings.

Separators, cream

Sets, caponizing,

Sets, croquet,

Sets, floral,

Settees, lawn, 


\section{WORCESTER SALT}

\section{THE STANDARD OF QUALITY}

Worcester Salt is still the leading brand as it was a generation ago. It is used by everybody who wants the best. Its Purity, Cleanliness, Strength and Flavor have never been equaled. Worcester Salt is unrivaled for butter. Send for our booklet "Butter-Making on the Farm." Free on request.

BEST GROCERS EVERYWHERE SELL WORGESTER SALT

\section{Worcester Salt for Packing Meat}

Worcester Salt turns out better pork, and sweeter hams and bacon than any other salt. A trial will convince you.

Send for our booklet "Curing Meats on the Farm." Contains many valuable receipts.

\section{Ivory Free Running Salt} is the last word for those who prefer a specially prepared salt for use in shakers. It is the saltiest free running salt known, and comes in the best package on the market-a moisture proof carton, with cover and spout. IVORY SALT is always dry and flows freely from either carton or shaker.

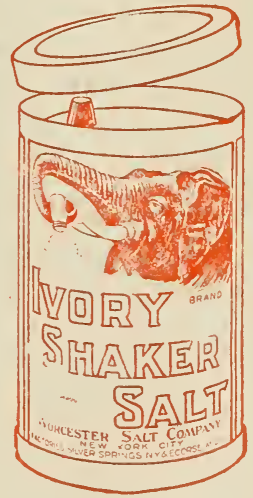

In ordering Salt always specify

\section{WORGESTER SALT்}

Refuse Substitutes

\section{KENDALL \& WHITNEY}

STATE AGENTS

PORTLAND, MAINE 



\section{Since starting to print our Catalogue, the following "CHANGES" in Parcel Post have become effective.}

The limit of weight of parcels of fourth-class mail for delivery within the first and second zones is increased from 20 to 50 pounds, and in the third, fourth, fifth, sixth, seventh and eighth zones from 11 to 20 pounds.

Third Zone: Six cents for the first pound, two cents for each additional pound.

Fourth Zone: Seven cents for the first pound, four cents for each additional pound.

Fifth Zone: Eight cents for the first pound, six cents for each additional pound.

Sixth Zone: Nine cents for the first pound, eight cents for each additional pound.

On and after March 16th, 1914, the classification of articles mailable under the Act authorizing the establishment of the parcel post service shall be extended so as to include "books". The rate of postage on books weighing 8 ounces or less shall be one cent for each 2 ounces or fraction thereof, and on those weighing in excess of 8 ounces the regular zone rate shall apply. 


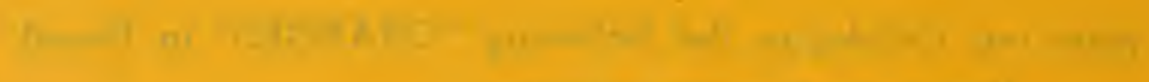

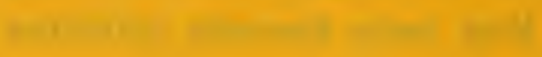

(19)

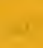





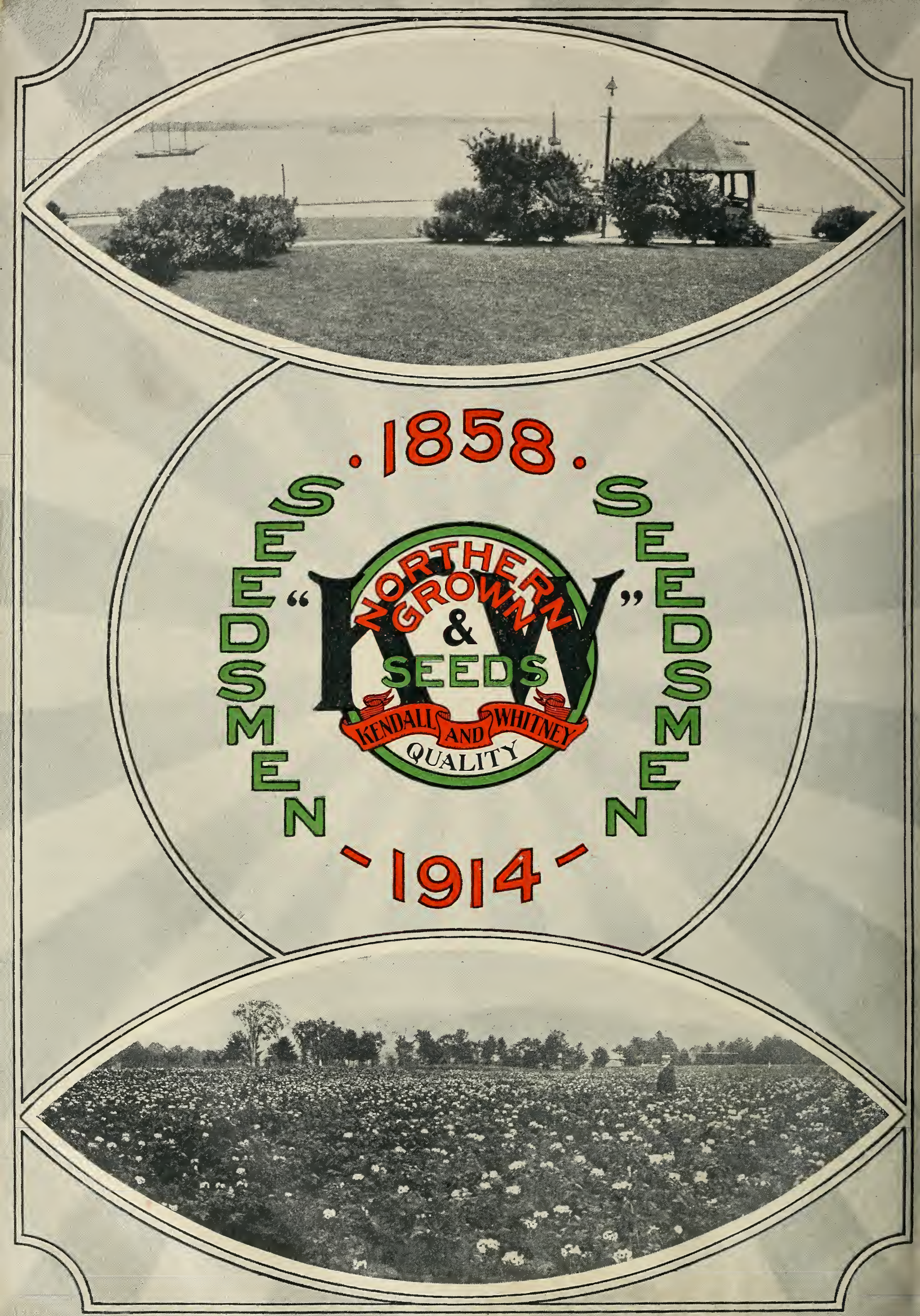

